\title{
COMPORTAMENTO MECÂNICO DE RESÍDUOS SÓLIDOS URBANOS
}

\author{
MIRIAM DE FÁTIMA CARVALHO \\ Tese apresentada à Escola de Engenharia de São Carlos, \\ da Universidade de São Paulo, como parte dos requisitos \\ para obtenção do Título de Doutor em Geotecnia. \\ ORIENTADOR: Prof. Dr. Orencio Monje Vilar
}

São Carlos

1999 


\section{C331c Carvalho, Miriam de Fátima}

Comportamento mecânico de resíduos sólidos urbanos Miriam de Fátima Carvalho - São Carlos, 1999.

Tese (Doutorado) - Escola de Engenharia de São Carlos Universidade de São Paulo, 1999

Orientador: Prof. Dr. Orencio Monje Vilar.

1. Resíduos sólidos urbanos - Aterros sanitários Compressibilidade - Resistência ao cisalhamento

I. Título 


\section{FOLHA DE APROVAÇÃO}

Tese defendida e aprovada em

pela comissão julgadora :

\section{(Assinatura)}

(Nome/Instituição)

(Assinatura)

(Nome/Instituição)

(Assinatura)

(Nome/Instituição)

(Assinatura)

(Nome/Instituição)

Presidente da CPG 


\section{DeDIOATÓRIn}

Aos meus pais, José Maria e Itelvira, exemplo de sabedoria e sacrifício

À Sandro, esposo querido, amigo e companheiro de todos os momentos

À meus irmãos (Cleber, Sandra, Sônia, Edna e Geraldo) pelo incentivo

Aos meus sobrinhos (Raissa, Pedro e Alisson) pela alegria 


\section{AGRADEOIMEnTOS}

Meus sinceros agradecimentos a todas as pessoas e instituições que de uma forma ou de outra contribuíram para a elaboração dessa pesquisa:

Aos professores, funcionários e amigos do Departamento de geotecnia, pelo apoio, amizade e ensinamentos recebidos;

Às firmas Engecorps - Corpo de Engenheiros Consultores Ltda, Ceppolina Engenheiros Consultores, Heleno Fonseca Construtécnica e Limpurb, pelo apoio financeiro e operacional durante os trabalhos de investigação do maciço de RSU e permissão de publicar esses dados nesta pesquisa;

Aos engenheiros Luís Sergio Akira Kaimoto e Silvio Luís de Andrade, por todo apoio dispensado para viabilizar a coleta dos dados de campo;

Aos técnicos do Laboratório de geotecnia da EESC/USP, em especial a Oscar dos Santos, que repetidas vezes me auxiliou na árdua tarefa de montagem dos corpos de prova;

Ao colega Arthur Silva, pelas apreciações e sugestões nas técnicas de caracterização do RSU e à colega Rosana Marília pela ajuda durante os trabalhos de coleta de amostras;

Aos amigos, Bené, Conciani, Paulão, Marção, Floreano, Campelo, Jeselay e outros que me ajudaram no deslocamento da câmara para a prensa de cisalhamento;

À FAPESP - Fundação de Amparo à Pesquisa do Estado de São Paulo, pelo auxílio na forma de um projeto de pesquisa e bolsa concedida;

Ao CNPq pela bolsa de estudos concedida no inicio do programa de pesquisa

Mais do que agradecer, gostaria expressar meu carinho especial a três pessoas que, de formas diferentes, proporcionaram contribuições fundamentais para desenvolvimento deste trabalho.

Engenheiro Afonso Marques, que com seus passos iniciais fincou os alicerces para o desenvolvimento dessa pesquisa e durante todo tempo esteve nos incentivando e nos auxiliando na busca das melhores soluções

Professor $\mathrm{Dr}$ Orencio Monje Vilar, mestre e orientador, pelas valiosas e determinantes orientações, pelo constante apoio e estímulo para prosseguimento deste trabalho e sobretudo pela amizade e compreensão

Sandro Machado, a quem esteve sempre do meu lado, incentivando e ajudando-me a resolver os problemas técnicos. Em meu aprendizado com Sandro, sou testemunha de um estilo de trabalho assentado em equilibrados quinhões de competência, esforço e determinação. 
Pra sê grande, Sê inteiro Nada teu exagera ou exclui, Sê todo em cada coisa Põe o que tu és no mínimo que fazes Assim em cada lago a lua toda brilha Porque alta vive 


\section{SUMÁRIO}

LISTA DE FIGURAS

LISTA DE TABELAS Xiv

LISTA DE SÍMBOLOS Xvi

RESUMO Xix

$\begin{array}{lll}\text { ABSTRACT } & \mathrm{xx}\end{array}$

$\begin{array}{ll}\text { Capítulo 1: INTRODUÇÃO } & 01\end{array}$

Capítulo 2 - REVISÃO BIBLIOGRÁFICA 04

2.1 Aterros sanitários de resíduos sólidos urbanos 04

2.1.1 Introdução 04

2.1.2 Conceituação geral 05

2.1.3 Tipos de aterros 06

2.1.4 Seleção de áreas para implantação de um aterro 08

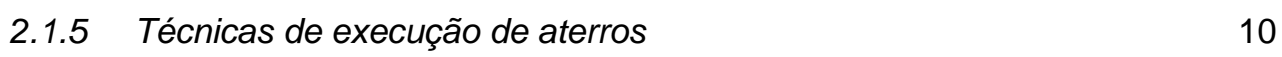

2.1.6 Elementos estruturais básicos de um aterro 14

2.1.6.1 Tratamento de fundação e liner de fundo 14

2.1.6.2 Drenagem de gases e de líquidos percolados 21

2.1.6.3 Drenagem e proteção superficial 23

2.1.6.4 Instrumentação 24

2.2 Propriedades biológicas dos maciços de resíduos sólidos urbanos 27

2.2.1 Introdução $\quad 27$

2.2.2 Biodegradação $\quad 27$

2.2.3 Processos de decomposição dos RSU 28

2.2.4 Fases de estabilização de um aterro sanitário 29

2.3 Propriedades de engenharia dos maciços de resíduos sólidos urbanos $\quad 35$

2.3.1 Introdução 35

2.3.2 Propriedades físicas do resíduo sólido urbano 36

2.3.2.1 Classificação 36

2.3.2.2 Composição 38

2.3.2.3 Distribuição do tamanho das partículas $\quad 40$

2.3.2.4 Teor de umidade 41

2.3.2.5 Temperatura 43

2.3.2.6 Peso específico in situ 44

2.3.2.7 Permeabilidade do RSU 
2.4 Propriedades mecânicas dos resíduos sólidos urbanos

2.4.1 Introdução $\quad 50$

2.4.2 Resistência ao cisalhamento 50

2.4.2.1 Comentários 66

$\begin{array}{lll}2.4 .3 & \text { Compressibilidade } & 70\end{array}$

2.4.3.1 Previsão de recalques 81

2.4.3.2 Comentários 88

Capítulo 3 - MATERIAIS E MÉTODOS 89

$\begin{array}{lll}3.1 & \text { Escolha da área de estudo } & 89\end{array}$

$\begin{array}{lll}3.2 & \text { Investigações e reconhecimento do maciço } & 89\end{array}$

3.2.1 Sondagens de simples reconhecimento com medida de SPT e do torque 91

3.2.2 Ensaio de penetração contínua - CPT 91

3.2.3 Ensaios de infiltração em furos de sondagem 92

3.2.4 Tradagem para coleta de amostras 92

$\begin{array}{ll}\text { 3.2.5 Ensaio cross-hole } & 95\end{array}$

3.2.6 Ensaio de resistividade elétrica 96

3.3 Ensaios de caracterização dos resíduos coletados 98

$\begin{array}{lll}\text { 3.3.1 Teor de umidade } & 98\end{array}$

3.3.2 Composição gravimétrica 99

3.3.3 Tamanho e distribuição dos componentes dos resíduos 100

3.3.4 Sólidos totais voláteis - STV 101

3.3.5 Demanda química de oxigênio - DQO 101

$\begin{array}{ll}\text { 3.3.6 Solubilização, lixiviação e } \mathrm{pH} & 102\end{array}$

$\begin{array}{lll}3.4 & \text { Preparação de amostras representativas } & 103\end{array}$

3.4.1 Critério de escolha 103

$\begin{array}{lll}3.4 .2 & \text { Misturas } & 104\end{array}$

3.4.3 Determinação do peso específico das partículas para as amostras representativas 106

$\begin{array}{lll}3.5 & \text { Ensaios triaxiais } & 106\end{array}$

3.5.1 Aparelhagem utilizada 106

3.5.2 Ensaios triaxiais executados 111

$\begin{array}{ll}3.6 & \text { Ensaio de compressão confinada } \\ \end{array}$ 


\section{Capítulo 4 - APRESENTAÇÃO DOS RESULTADOS}

4.1 Ensaios in siitu

4.1.1 Sondagens de simples reconhecimento com medida de SPT e do torque

4.1.2 Ensaio de penetração contínua - CPT

4.1.3 Ensaio de infiltração em furos de sondagens

4.1.4 Tradagem para coleta de amostras e estimativa do peso específico in situ

4.1.5 Ensaio cross-hole

4.1.6 Ensaio de resistividade elétrica

4.2 Ensaios de caracterização dos resíduos sólidos urbanos coletados

4.2.3 Tamanho e distribuição dos componentes dos resíduos

4.2.4 Sólidos totais voláteis - STV

4.2.5 Demanda química de oxigênio - DQO

4.3 Determinação do peso específico das partículas paras as amostras representativas

4.4 Ensaios de compressão triaxial

4.4.1 Ensaios consolidados drenados (CD)

5.2.1 Sondagens de simples reconhecimento com medida de SPT e do torque

5.2.2 Ensaio de penetração contínua - CPT

5.2.3 Ensaios de infiltração em furos de sondagens

5.2.4 Estimativa do peso específico in situ do resíduo 
5.3 Ensaios de caracterização dos resíduos sólidos urbanos coletados

5.3.1 Teor de umidade 189

5.3.2 Composição gravimétrica 190

5.3.3 Tamanho e distribuição dos componentes dos resíduos 190

5.3.4 Sólidos totais voláteis - STV 191

5.3.5 Demanda química de oxigênio - DQO 191

5.3.6 Lixiviação e solubilização 192

5.4 Ensaios de compressão triaxial 192

5.4.1 Ensaios consolidados drenados (CD) 192

5.4.1.1 Ensaios consolidados drenados com a matriz do resíduo 220

5.4.2 Ensaios consolidados não drenados (CU) 223

5.4.3 Uma avaliação da resistência ao cisalhamento do resíduo sólido urbano estudado 230

5.5 Ensaios de compressão confinada 233

Capítulo 6 - MONITORAMENTO IN SITU DOS RECALQUES 244

6.1 Introdução 244

6.2 Monitoramento in situ dos recalques 244

6.3 Calibração de alguns modelos de recalques da literatura a partir de dados obtidos em campo 249

$\begin{array}{lr}\text { Capítulo } 7 \text { - CONCLUSÕES } & 259\end{array}$

Capítulo 8 - REFERÊNCIAS BIBLIOGRÁFICAS 264

$\begin{array}{ll}\text { ANEXOS } & 279\end{array}$ 


\section{Lista de figuras}

\section{Capítulo 2}

Figura 2.1.1 - Tipos de aterros sanitários (TCHOBANOGLOUS et al. 1993).

Figura 2.1.2 - Estrutura de um aterro sanitário (ENGECOPRS,1996).

Figura 2.1.3 - Componentes do sistema de cobertura final de aterro sanitário, (DANIEL 1998).

Figura 2.1.4 - Sistema de cobertura final mínimo segundo diferentes recomendações e regulamentações (MANASSERO et al. 1996, VAN IMPE 1988b, MANASSERO et al. 1998).

Figura 2.1.5 - Detalhes típicos de drenagem de nascentes (TIVERON et al. 1995).

Figura 2.1.6 - Esquema de aterro para resíduos sólidos urbanos, $L \geq 3,0 m$ e $k \leq$ $10^{-6} \mathrm{~cm} / \mathrm{s}$, (CETESB 1993).

Figura 2.1.7 - Esquema de aterro para resíduos sólidos urbanos, $L \geq 1,50 \mathrm{~m}$ e $k \leq$ $10^{-4} \mathrm{~cm} / \mathrm{s}$ (CETESB, 1993).

Figura 2.1.8 - Detalhes da impermeabilização da fundação, drenagem de nascentes e drenagem interna do aterro sanitário Bandeirantes (TIVERON et al. 1995).

Figura 2.1.9 - Sistemas de liners de base para aterros de resíduos sólidos urbanos segundo recomendações de alguns países (VAN IMPE 1998b e MANASSERO et al. 1998).

Figura 2.1.10 - Sistema de drenagem de líquido percolado (TCHOBANOGLOUS et al. 1993).

Figura 2.1.11 - Drenos verticais dos aterros sanitários, (TIVERON et al. 1995).

Figura 2.1.12 - Drenos de fundação e drenos horizontais (TIVERON et al. 1995).

Figura 2.1.13 - Elementos de drenagem superficial de aterro sanitário (TIVERON et al.1995).

Figura 2.1.14 - Instrumentação (ENGECORPS, 1996).

Figura 2.2.1 - Variação da resistência do resíduo urbano com a idade do aterro em virtude dos processos de degradação, MASSACCl et al. 1993.

Figura 2.2.2 - Evolução típica da degradação dos resíduos e da composição dos gases em aterros sanitários.

Figura 2.2.3 - Variação do teor de sólidos totais voláteis com a idade dos resíduos aterrados (SILVA et al. 1998).

Figura 2.3.1 - Classificação do RSU usando a Carta de Schmertmann (SÁNCHEZ-ALCITURRI, et al. 1993). 
Figura 2.3.2 - Classificação do RSU usando o diagrama triangular (GIRISOLIA et al. 1995).

Figura 2.3.3 - Diâmetros equivalentes dos componentes do RSU, TCHOBANOGLOUS et al. (1993).

Figura 2.3.4 - Distribuição do tamanho das partículas do RSU (modificado de JESSBERGER 1994).

Figura 2.3.5 - Teor de umidade para o resíduo sólido urbano (modificado de KNOCHENMUS et al. 1998).

Figura 2.3.6 - Variação da temperatura do RSU com a profundidade, Aterro Ano Liossia, Atenas (Grécia), (COUMOULOS et al. 1995).

Figura 2.3.7 - Variação da temperatura do RSU com a profundidade, Aterro da Muribeca, Recife (Brasil), (MARIANO \& JUCÁ 1998).

Figura 2.3.8 - Peso específico para o resíduo sólido urbano (modificado de KAVAZANJIAN et al. 1995).

Figura 2.3.9 - Peso específico obtidos através de ensaios em trincheira, furos de sondagem e retro- análise (MATASOVIC \& KAVAZANJIAN 1998).

Figura 2.3.10 - Comparação do coeficiente de permeabilidade do RSU obtido por meio de ensaios de campo e laboratório (LANDVA et al. 1998).

Figura 2.4.1 - Parâmetros de resistência obtidos por retro-análise (SINGH \& MURPHY 1990).

Figura 2.4.2 - Resistência à penetração do SPT para aterros de resíduos sólidos urbanos obtida por vários autores.

Figura 2.4.3 - Resultados típicos de ensaios CPT para aterros de resíduos sólidos urbanos obtidos por diversos autores.

Figura 2.4.4 - Relação tensão - deformação obtida para resíduos sólidos urbanos a partir de ensaios de cisalhamento direto (MANASSERO et al. 1996).

Figura 2.4.5 - Relação tensão cisalhante - tensão normal obtida para resíduos sólidos urbanos a partir de ensaios de cisalhamento direto (VAN IMPE 1998).

Figura 2.4.6 - Resultados de ensaios de cisalhamento direto em resíduos de aterros do Canadá (LANDVA \& CLARK 1990).

Figura 2.4.7 - Curvas tensão - deformação típicas para o resíduo sólido urbano (MANASSERO et al. 1996).

Figura 2.4.8 - Curvas tensão - deformação obtidas de ensaios triaxiais por GRISOLIA et al. (1995b).

Figura 2.4.9 - Diagrama $p-q^{\prime}$ para diferentes níveis de deformações dos RSU (GRISOLIA et al. 1995b).

Figura 2.4.10 - Variação dos parâmetros de resistência com a deformação axial (GRISOLIA et al. 1995b). 
Figura 2.4.11 - Resultados de ensaios de compressão triaxial ( JESSBERGER \& KOCKEL 1993).

Figura 2.4.12- Resistência ao cisalhamento do RSU para diferentes deformações obtidas a partir de ensaios triaxiais (KÖNIG \& JESSBERGER 1997).

Figura 2.4.13 - Modelo esquemático da composição do resíduo sólido urbano proposto por JESSBERGER et al. (1995).

Figura 2.4.14 - Variação do intercepto de coesão com o teor de umidade (GABR \& VALERO, 1995).

Figura 2.4.15 - Ativação do intercepto de coesão e ângulo de atrito com as deformações axiais (KÖNIG \& JESSBERGER 1997).

Figura 2.4.16 - Ruptura do resíduo fresco de 1 a 3 anos de idade, JESSBERGER et al. (1995).

Figura 2.4.17 - Envoltória de resistência para diferentes materiais (MANASSERO et al. 1996).

Figura 2.4.18 - Parâmetros de resistência ao cisalhamento do resíduo sólido urbano estimado por diferentes métodos.

Figura 2.4.19 - Resistência ao cisalhamento do RSU, valores recomendados para projetos por SÁNCHEZ - ALCITURRI et al. (1993).

Figura 2.4.20 - Resultados de resistência ao cisalhamento do RSU obtidas por vários autores (VAN IMPE 1998).

Figura 2.4.21 - Envoltórias de ruptura proposta para o resíduo sólido urbano (VAN IMPE 1998).

Fig. 2.4.22 - Curva teórica de compressibilidade do RSU segundo GRISOLIA \& NAPOLEONI (1996).

Figura 2.4.23 - Recalque total e anual de RSU (GANDOLLA et al. 1994).

Figura 2.4.24 - Resultados obtidos de ensaios de compressão confinada para resíduos do Canadá (LANDVA \& CLARK 1990).

Figura 2.4.25 - Curvas tempo- recalque obtidas de ensaios de compressão confinada por JESSBERGER \& KOCKEL (1993).

Figura 2.4.26 - Parâmetros de compressão primária e secundária em função do índice de vazios

Figura 2.4.27 - Variação do coeficiente de compressão secundária $\left(C^{\prime} \alpha\right)$ com a espessura do aterro (MANASSERO et al. 1996).

Fig. 2.4.28 - Curva teórica de recalque x log t idealizada por Edgers et al. (1992).

Figura 2.4.29 - Medidas de recalques de superfície de diferentes aterros (KÖNIG \& JESSBERGER 1997).

Figura 2.4.30 - Dados de recalque versus o logaritmo tempo para aterros de resíduos sólidos urbanos. 
Figura 2.4.31 - Resultados de ensaios de prova de carga sobre placa (VAN IMPE 1998 e JUCÁ et al. 1997).

Figura 2.4.32 - Variação de módulo de deformação com a tensão vertical obtidos para diferentes resíduos sólidos urbanos (modificado de KNOCHENMUS et al. 1998).

Figura 2.4.33 - Modelo de recalque proposto por Bjarngard \& Edgers (STULGIS et al. 1995).

Figura 2.4.34 - Comportamento de recalque - tempo para resíduos sólidos urbanos idealizado por KÖNIG \& JESSBERGER (1997).

Figura 2.4.35 - Função matemática para cálculo de recalques em aterros sanitários proposta por GOMES et al. (1998).

\section{Capítulo 3}

Figura 3.1 - Localização da área de estudo e disposição em planta das investigações executadas e dos marcos superficiais monitorados.

Figura 3.2 - Tradagem mecânica com trado helicoidal de $40 \mathrm{~cm}$ de diâmetro.

Figura 3.3 - Perfuração e amostragem dos resíduos

Figura 3.4 - Armazenamento das amostras de resíduo sólido urbano coletado em tambores metálicos devidamente lacrados.

Figura 3.5 - Disposição no campo do arranjo dipolo-dipolo - técnica do caminhamento elétrico.

Figura 3.6 - Separação manual dos componentes do resíduo sólido urbano.

Figura 3.7 - Detalhes das amostras da tradagem T2, representativas do horizonte $A(T 2 A)$ e do horizonte $B$ (T2B).

Figura 3.8 - Detalhes da amostra da tradagem $T 1$, representativa do horizonte $B$ (T1B).

Figura 3.9 - Câmara triaxial desenvolvida para a realização de ensaios triaxiais em grandes amostras (150 e 200mm de diâmetro), pedras porosas, colocador de membrana.

Figura 3.10 - Avaliação da deformabilidade da câmara triaxial construída.

Figura 3.11 - Equipamento construído para medida de variação de volume durante a realização de ensaios triaxiais.

Figura 3.12 - Sistema de interface ar-água de aplicação de pressão.

Figura 3.13 - Fluxograma dos ensaios triaxiais executados

Figura 3.14 - Vista de corpos de prova a ser ensaiados, com e sem membrana de revestimento, bem como dispositivos para colocação da membrana, base e corpo da câmara.

Figura 3.15 - Detalhes da composição da matriz T2b, após separação manual de plásticos e materiais maiores que 20mm e após lavagem na peneira $N^{0} .200$. 
Figura 3.16 - Representação esquemática do consolidômetro utilizado para realização dos ensaios de compressão confinada.

\section{Capítulo 4}

Figura 4.1 - Perfil de sondagem SPT-T 01.

Figura 4.2 - Perfil de sondagem SPT-T 02.

Figura 4.3 - Perfil de sondagem SPT-T 03.

Figura 4.4 - Perfil de sondagem SPT-T 04.

Figura 4.5 - Perfil de sondagem SPT-T 05.

Figura 4.6 - Resultado do ensaio de penetração contínua CPT-01 (berma inferior).

Figura 4.7 - Resultado do ensaio de penetração contínua CPT-02 (berma superior).

Figura 4.8 - Coeficientes de permeabilidade do resíduo urbano estudado.

Figura 4.9 - Correções dos pesos dos resíduos sólidos urbanos para as perfurações $T 1$ e $T 2$.

Figura 4.10 - Estimativa do peso específico obtidos através de pesagem do resíduo nas tradagens $T 1$ e $T 2$.

Figura 4.11 - Estimativa da variação do peso específico com a profundidade para RSU, considerando as hipóteses enunciadas no texto.

Figura 4.12 - Perfis de velocidade de propagação da onda cisalhante $\left(v_{s}\right)$ e de compressão $\left(v_{p}\right)$ no resíduo urbano estudado.

Figura 4.13 - Coeficiente de Poisson para o RSU estudado.

Figura 4.14 - Resultados dos módulos cisalhante e de deformação obtidos para o resíduo estudado a partir de ensaios cross-hole.

Figura 4.15 - Localização da linha de caminhamento ensaiada.

Figura 4.16 - Seção (C1) obtida do caminhamento elétrico dipolo-dipolo do aterro sanitário Bandeirantes.

Figura 4.17 - Variação do teor de umidade global do RSU estudado.

Figura 4.18 - Composição do RSU aterrado, tradagem T1.

Figura 4.19 - Composição do RSU aterrado, tradagem T2.

Figura 4.20 - Composição média para o RSU estudado.

Figura 4.21 - Curvas de distribuição do tamanho dos componentes resultantes da tradagem $T 1$.

Figura 4.22 - Curvas de distribuição do tamanho dos componentes resultantes da tradagem $T 2$.

Figura 4.23 - Valores do STV ao longo da profundidade para o RSU estudado. 
diâmetro de $150 \mathrm{~mm}$ e altura de $300 \mathrm{~mm}$, com peso específico inicial de $10 \mathrm{kN} / \mathrm{m}^{3}$ e umidade de moldagem de 63,2\%.

Figura 4.26 - Resultados dos ensaios $C D_{\text {nat }}$ para a amostra T2A (T2a12nat), com diâmetro de $150 \mathrm{~mm}$ e altura de $300 \mathrm{~mm}$, com peso específico inicial de $12 \mathrm{kN} / \mathrm{m}^{3}$ e umidade de moldagem de $66,6 \%$ para corpos de prova com pressão de confinamento de 100 e $200 \mathrm{kPa}$ e umidade $77,4 \%$ para o de $400 \mathrm{kPa}$.

Figura 4.27 - Resultados dos ensaios $C D_{\text {nat }}$ para a amostra T2A (T2a14nat), com diâmetro de $150 \mathrm{~mm}$ e altura de $300 \mathrm{~mm}$, com peso específico inicial de $14 \mathrm{kN} / \mathrm{m}^{3}$ e umidade de moldagem de 65,3\%.

Figura 4.28 - Resultados dos ensaios $C D_{\text {sat }}$ para a amostra T2A (T2a12sat), com diâmetro de $150 \mathrm{~mm}$ e altura de $300 \mathrm{~mm}$, com peso específico inicial de $12 \mathrm{kN} / \mathrm{m}^{3}$ e umidade de moldagem de $68,3 \%$.

Figura 4.29 - Resultados dos ensaios $C D_{\text {nat }}$ para a amostra T1B (T1b12nat), com diâmetro de $150 \mathrm{~mm}$ e altura de $300 \mathrm{~mm}$, com peso específico inicial de $12 \mathrm{kN} / \mathrm{m}^{3}$ e umidade de moldagem de $51,5 \%$.

Figura 4.30 - Resultados dos ensaios $C D_{\text {sat }}$ para a amostra T1B (T1b12sat), com diâmetro de $150 \mathrm{~mm}$ e altura de $300 \mathrm{~mm}$, com peso específico inicial de $12 \mathrm{kN} / \mathrm{m}^{3}$ e umidade de moldagem de 53,7\%.

Figura 4.31 - Resultados dos ensaios $C D_{\text {nat }}$ para a amostra T2B (T2b12nat), com diâmetro de $150 \mathrm{~mm}$ e altura de $300 \mathrm{~mm}$, com peso específico inicial de $12 \mathrm{kN} / \mathrm{m}^{3}$ e umidade de moldagem de $44,4 \%$.

Figura 4.32 - Resultados dos ensaios $C D_{\text {sat }}$ para a amostra T2B (T2b12sat), com diâmetro de $150 \mathrm{~mm}$ e altura de $300 \mathrm{~mm}$, com peso específico inicial de $12 \mathrm{kN} / \mathrm{m}^{3}$ e umidade de moldagem de $44,4 \%$.

Figura 4.33 - Resultados dos ensaios $C D_{\text {nat }}$ para verificação da reprodutibilidade dos resultados triaxiais obtidos. Amostra T2A, com diâmetro de $150 \mathrm{~mm}$ e altura de $300 \mathrm{~mm}$, peso específico inicial de $12 \mathrm{kN} / \mathrm{m}^{3}$ e umidade de $60,7 \%$.

Figura 4.34 - Resultados dos ensaios $C D_{\text {nat }}$ para a amostra $T 1 B$, com diâmetro de $150 \mathrm{~mm}$ e altura de $300 \mathrm{~mm}$, com peso específico inicial de $12 \mathrm{kN} / \mathrm{m}^{3}$.

Figura 4.35 - Resultados dos ensaios $C D_{\text {nat }}$ para a amostra $T 1 B$, com diâmetro de $150 \mathrm{~mm}$ e altura de $300 \mathrm{~mm}$, com peso específico inicial de $12 \mathrm{kN} / \mathrm{m}^{3}$, para determinação do módulo de deformabilidade.

Figura 4.36 - Resultados dos ensaios $C D_{\text {nat }}$ para a amostra T2A (T2a40CDnat), com diâmetro de $200 \mathrm{~mm}$ e altura de $400 \mathrm{~mm}$, peso específico inicial de $12 \mathrm{kN} / \mathrm{m}^{3}$ e umidade de moldagem de 58,0\%.

Figura 4.37 - Resultados dos ensaios $C D_{\text {sat }}$ para a amostra T2A (T2a40CDsat), com diâmetro de $200 \mathrm{~mm}$ e altura de $400 \mathrm{~mm}$, peso específico inicial de $12 \mathrm{kN} / \mathrm{m}^{3}$ e umidade de moldagem de $58,8 \%$ para corpos de prova com pressão de confinamento de 200 e $400 \mathrm{kPa}$ e umidade de $67,7 \%$ para o de $100 \mathrm{kPa}$. 
Figura 4.38 - Resultados dos ensaios $C D_{\text {sat }}$ para a amostra T1B (T1b40CDsat), com diâmetro de $200 \mathrm{~mm}$ e altura de $400 \mathrm{~mm}$, peso específico inicial de $12 \mathrm{kN} / \mathrm{m}^{3}$ e umidade de moldagem de $64 \%$.

Figura 4.39 - Resultados dos ensaios $C D_{\text {sat }}$ para a amostra $T 2 B$ com diâmetro de $200 \mathrm{~mm}$ e altura de $400 \mathrm{~mm}$, com peso específico inicial de $12 \mathrm{kN} / \mathrm{m}^{3}$ e umidade de moldagem de $47,3 \%$.

Figura 4.40 - Resultados dos ensaios $C D_{\text {sat }}$ para a matriz da amostra $T 2 A$ com diâmetro de $100 \mathrm{~mm}$ e altura de $200 \mathrm{~mm}$, peso específico inicial em torno de $16 \mathrm{kN} / \mathrm{m}^{3}$ e umidade de moldagem de $48,2 \%$.

Figura 4.41 - Resultados dos ensaios $C D_{\text {sat }}$ para a matriz da amostra $T 1 B$ com diâmetro de $100 \mathrm{~mm}$ e altura de $200 \mathrm{~mm}$, peso específico inicial em torno de $16 \mathrm{kN} / \mathrm{m}^{3}$ e umidade de moldagem de $58,6 \%$.

Figura 4.42 - Resultados dos ensaios $C D_{\text {sat }}$ para a matriz da amostra $T 2 B$ com diâmetro de $100 \mathrm{~mm}$ e altura de $200 \mathrm{~mm}$, peso específico inicial em torno de $16 \mathrm{kN} / \mathrm{m}^{3}$ e umidade de moldagem em torno de $40,5 \%$.

Figura 4.43 - Resultados dos ensaios $C U_{\text {nat }}$ para a amostra T2A (T2a12CUnat), com diâmetro de $150 \mathrm{~mm}$ e altura $300 \mathrm{~mm}$, na umidade natural e peso esp. de $12 \mathrm{kN} / \mathrm{m}^{3}$.

Figura 4.44 - Resultados dos ensaios $C U_{\text {sat }}$ para a amostra T2A (T2a12Cusat), saturada, com diâmetro de $150 \mathrm{~mm}$ e altura $300 \mathrm{~mm}$ e peso específico de $12 \mathrm{kN} / \mathrm{m}^{3}$.

Figura 4.45 - Resultados dos ensaios $C U_{\text {sat }}$ para a amostra T1B (T1b12CUsat), saturada, com diâmetro de $150 \mathrm{~mm}$ e altura $300 \mathrm{~mm}$ e peso específico de $12 \mathrm{kN} / \mathrm{m}^{3}$.

Figura 4.46 - Resultados dos ensaios $C_{\text {sat }}$ para a amostra T2B (T2b12CUsat), saturada, com diâmetro de $150 \mathrm{~mm}$ e altura $300 \mathrm{~mm}$ e peso específico de $12 \mathrm{kN} / \mathrm{m}^{3}$.

Figura 4.47 - Curva índice de vazios - log da tensão vertical, obtida para a amostra T2A, com peso específico de $8 \mathrm{kN} / \mathrm{m}^{3}$ e umidade de $63,1 \%$.

Figura 4.48 - Curva índice de vazios - log da tensão vertical, obtida para a amostra T2A, com peso específico de $10 \mathrm{kN} / \mathrm{m}^{3}$ e umidade de $59,2 \%$.

Figura 4.49 - Curva índice de vazios - log da tensão vertical, obtida para a amostra T2A, com peso específico de $14 \mathrm{kN} / \mathrm{m}^{3}$ e umidade de $62,4 \%$.

Figura 4.50 - Curva índice de vazios - log da tensão vertical, obtida para a amostra $T 1 B$, com peso específico de $10 \mathrm{kN} / \mathrm{m}^{3}$ e umidade de $95,4 \%$.

Figura 4.51 - Curva índice de vazios - log da tensão vertical, obtida para a amostra $T 1 B$, com peso específico de $10 \mathrm{kN} / \mathrm{m}^{3}$ e na condição saturada.

Figura 4.52 - Curva índice de vazios - log da tensão vertical, obtida para a amostra T2B, com peso específico de $12 \mathrm{kN} / \mathrm{m}^{3}$ e umidade de $67,8 \%$. 
Figura 4.53 - Curvas de leitura do extensômetro x raiz do tempo obtida para a amostra T2A8COM. Peso específico inicial de $8 \mathrm{kN} / \mathrm{m}^{3}$ e umidade inicial de $63,1 \%$.

Figura 4.54 - Curvas de leitura do extensômetro $x \log t$ obtida para a amostra T2A8COM. Peso específico inicial de $8 \mathrm{kN} / \mathrm{m}^{3}$ e umidade inicial de $63,1 \%$.

Figura 4.55 - Curvas de leitura do extensômetro x raiz do tempo obtida para a amostra T2A10COM. Peso específico inicial de $10 \mathrm{kN} / \mathrm{m}^{3}$ e umidade inicial de $59,2 \%$.

Figura 4.56 - Curvas de leitura do extensômetro x log t obtida para a amostra T2A10COM. Peso específico inicial de $10 \mathrm{kN} / \mathrm{m}^{3}$ e umidade inicial de $59,2 \%$.

Figura 4.57 - Curvas de leitura do extensômetro x raiz do tempo obtida para a amostra T2A14COM. Peso específico inicial de $14 \mathrm{kN} / \mathrm{m}^{3}$ e umidade inicial de $62,4 \%$.

Figura 4.58 - Curvas de leitura do extensômetro x log t obtida para a amostra T2A14COM. Peso específico inicial de $14 \mathrm{kN} / \mathrm{m}^{3}$ e umidade inicial de $62,4 \%$.

Figura 4.59 - Curvas leitura do extensômetro $x$ raiz do tempo obtida para a amostra T1B10COM. Peso específico inicial de $10 \mathrm{kN} / \mathrm{m}^{3}$ e umidade inicial de $95,4 \%$.

Figura 4.60- Curvas leitura do extensômetro $x \log t$ obtida para a amostra T1B10COM. Peso específico inicial de $10 \mathrm{kN} / \mathrm{m}^{3}$ e umidade inicial de $95,4 \%$.

Figura 4.61 - Curvas leitura do extensômetro x raiz do tempo obtida para a amostra T1B10COMsat. Peso específico inicial de $10 \mathrm{kN} / \mathrm{m}^{3}$ e com os vazios saturados com água.

Figura 4.62 - Curvas leitura do extensômetro $x \log t$ obtida para a amostra T1B10COMsat. Peso específico inicial de $10 \mathrm{kN} / \mathrm{m}^{3}$ e com os vazios saturados com água.

Figura 4.63- Curvas leitura do extensômetro $x$ raiz do tempo obtida para a amostra T2B12COM. Peso específico inicial de $12 \mathrm{kN} / \mathrm{m}^{3}$ e umidade inicial de $67,8 \%$.

Figura 4.64 - Curvas de leitura do extensômetro x log tobtida para a amostra T2B12COM. Peso específico inicial de $12 \mathrm{kN} / \mathrm{m}^{3}$ e umidade inicial de $67,8 \%$.

\section{Capítulo 5}

Figura 5.1 - Histograma de freqüência dos valores T/N.

Figura 5.2 - Carta de Schmertmann.

Figura 5.3 - Correlação entre qc x N para o resíduo sólido urbano estudado.

Figura 5.4 - Correlação obtida entre $q c x v_{s}$ para o resíduo sólido urbano estudado.

Figura 5.5 - Correlação obtida entre $q c \times v_{p}$ para o resíduo sólido urbano estudado. 
Figura 5.6 - Faixa de variação granulométrica para RSU.

Figura 5.7 - Trajetórias de tensões e envoltórias de resistência num diagrama t-s' obtidas para a amostra T2A, na umidade natural, compactada com peso específico de $10 \mathrm{kN} / \mathrm{m}^{3}$, em corpos de prova de $150 \mathrm{~mm}$ de diâmetro por $300 \mathrm{~mm}$ de altura.

Figura 5.8 - Trajetórias de tensões e envoltórias de resistência num diagrama t-s' obtidas para a amostra $T 2 A$, na umidade natural, compactada com peso específico de $12 \mathrm{kN} / \mathrm{m}^{3}$, em corpos de prova de $150 \mathrm{~mm}$ de diâmetro por $300 \mathrm{~mm}$ de altura.

Figura 5.9 - Trajetórias de tensões e envoltórias de resistência num diagrama t-s' obtidas para a amostra T2A, na umidade natural, compactada com peso específico de $14 \mathrm{kN} / \mathrm{m}^{3}$, em corpos de prova de $150 \mathrm{~mm}$ de diâmetro por $300 \mathrm{~mm}$ de altura.

Figura 5.10 - Envoltórias num diagrama t-s' para a amostra T2A, na umidade natural e peso específico de $10 \mathrm{kN} / \mathrm{m}^{3}$ (T2a10nat), 12 (T2a12nat) e 14 (T2a14nat).

Figura 5.11 - Trajetórias de tensões e envoltórias de resistência num diagrama ts' obtidas para a amostra T2A, saturada e compactada com peso específico de $12 \mathrm{kN} / \mathrm{m}^{3}$, em corpos de prova de $150 \mathrm{~mm}$ de diâmetro por $300 \mathrm{~mm}$ de altura.

Figura 5.12 - Envoltória de resistência para 20\% de deformação obtida de ensaio $C D_{\text {nat }}$ para a amostra $T 2 A$, no teor de umidade natural e compactada com peso específico de $12 \mathrm{kN} / \mathrm{m}^{3}$.

Figura 5.13 - Envoltórias de resistência para 20\% de deformação obtida de ensaio $C D_{\text {sat }}$ para amostra $T 2 A$, saturada e compactada com peso específico de $12 \mathrm{kN} / \mathrm{m}^{3}$.

Figura 5.14 - Envoltórias num diagrama $t$-s' obtidas para a amostra T2A, compactada com $12 \mathrm{kN} / \mathrm{m}^{3}$ e submetida a ensaios $C D_{\text {nat }}$ (T2a12nat) e $C D_{\text {sat }}$ (T2a12sat).

Figura 5.15 - Trajetórias de tensões e envoltórias de resistência num diagrama ts' obtidas para a amostra T1B, na umidade de moldagem, compactada com peso específico de $12 \mathrm{kN} / \mathrm{m}^{3}$, em corpos de prova de $150 \mathrm{~mm}$ de diâmetro e $300 \mathrm{~mm}$ de altura.

Figura 5.16 - Trajetórias de tensões e envoltórias de resistência num diagrama ts' obtidas para a amostra T1B, saturada, compactada com peso específico de 12 $\mathrm{kN} / \mathrm{m}^{3}$, em corpos de prova de $150 \mathrm{~mm}$ de diâmetro e $300 \mathrm{~mm}$ de altura.

Figura 5.17 - Envoltórias num diagrama $t$-s' obtidas para a amostra T1B, compactada com $12 \mathrm{kN} / \mathrm{m}^{3}$ e submetida a ensaios $C D_{\text {nat }}$ (T1b12nat) e $C D_{\text {sat }}$ (T1b12sat).

Figura 5.18 - Trajetórias de tensões e envoltórias de resistência num diagrama ts' obtidas para amostra $T 2 B$, na umidade natural, compactada com peso 
específico de $12 \mathrm{kN} / \mathrm{m}^{3}$, em corpos de prova de $150 \mathrm{~mm}$ de diâmetro e $300 \mathrm{~mm}$ de altura.

Figura 5.19 - Trajetórias de tensões e envoltórias de resistência num diagrama ts' obtidas para amostra T2B, saturada, compactada com peso específico de 12 $\mathrm{kN} / \mathrm{m}^{3}$, em corpos de prova com $150 \mathrm{~mm}$ de diâmetro e $300 \mathrm{~mm}$ de altura.

Figura 5.20 - Envoltórias num diagrama $t$-s' obtidas para a amostra T2B, compactada com $12 \mathrm{kN} / \mathrm{m}^{3}$ e submetida a ensaios $C D_{\text {nat }}$ (T2b12nat) e $C D_{\text {sat }}$ (T2b12sat).

Figura 5.21 - Trajetórias de tensões e envoltórias de resistência num diagrama ts' obtidas de ensaio CD com amostra T2A, na umidade natural, compactada com peso específico de $12 \mathrm{kN} / \mathrm{m}^{3}$, em corpos de prova de $200 \mathrm{~mm}$ de diâmetro e $400 \mathrm{~mm}$ de altura.

Figura 5.22 - Trajetórias de tensões e envoltórias de resistência num diagrama ts' obtidas de ensaio CD com amostra T2A, saturada, compactada com peso específico de $12 \mathrm{kN} / \mathrm{m}^{3}$, em corpos de prova de $200 \mathrm{~mm}$ de diâmetro e $400 \mathrm{~mm}$ de altura.

Figura 5.23 - Trajetórias de tensões e envoltórias de resistência num diagrama t$s^{\prime}$ obtidas de ensaio $C D$ com amostra $T 1 B$, saturada, compactada com peso específico de $12 \mathrm{kN} / \mathrm{m}^{3}$, em corpos de prova de $200 \mathrm{~mm}$ de diâmetro e $400 \mathrm{~mm}$ de altura.

Figura 5.24 - Trajetórias de tensões e envoltórias de resistência num diagrama ts' obtidas de ensaio CD com amostra $T 2 B$, saturada, compactada com peso específico de $12 \mathrm{kN} / \mathrm{m}^{3}$, em corpos de prova de $200 \mathrm{~mm}$ de diâmetro e $400 \mathrm{~mm}$ de altura.

Figura 5.25 - Curvas tensão - deformação obtidas de ensaios CD para amostra T2A, na umidade natural e na condição saturada utilizando corpos de prova com diâmetro de 150 e $200 \mathrm{~mm}$.

Figura 5.26 - Curvas tensão - deformação obtidas de ensaios $C D_{\text {sat }}$ para amostra T1B, em corpos de prova com diâmetro de $150 \mathrm{~mm}$ e $200 \mathrm{~mm}$.

Figura 5.27 - Curvas tensão - deformação obtidas de ensaios $C D_{\text {sat }}$ para amostra T2B, em corpos de prova com diâmetro de $150 \mathrm{~mm}$ e $200 \mathrm{~mm}$.

Figura 5.28 - Relação entre as resistências $\left(\mathrm{s}_{15} / \mathrm{s}_{20}\right)$ obtidas de ensaios $C D$ com amostra T2A, na umidade natural e saturada, compactada com peso específico de $12 \mathrm{kN} / \mathrm{m}^{3}$.

Figura 5.29 - Relação entre as resistências $\left(\mathrm{s}_{15} / \mathrm{s}_{20}\right)$ obtidas de ensaios $C D$ com amostra $T 1 B$, saturada, compactada com peso específico de $12 \mathrm{kN} / \mathrm{m}^{3}$.

Figura 5.30 - Relação entre as resistências $\left(\mathrm{s}_{15} / \mathrm{s}_{20}\right)$ obtidas de ensaios $C D$ com amostra T2B, saturada, compactada com peso específico de $12 \mathrm{kN} / \mathrm{m}^{3}$. 
Figura 5.31 - Parâmetros de resistência ao cisalhamento do resíduo sólido urbano estudado, para deferentes deformações, obtidos de ensaios triaxiais $C D$, em corpos de prova de 150 e $200 \mathrm{~mm}$ de diâmetro por 300 e $400 \mathrm{~mm}$ de altura.

Figura 5.32 - Módulos de elasticidade tangente à origem e secantes, obtidos de ensaios $C D$, em corpos de prova de $150 \mathrm{~mm}$ e $200 \mathrm{~mm}$ de diâmetro para amostra T2A, sob diferentes condições e saturação e peso específico inicial.

Figura 5.33 - Módulos de elasticidade tangente à origem e secantes, obtidos de ensaios CD, em corpos de prova de 150 e $200 \mathrm{~mm}$ de diâmetro, para amostra $T 1 B$, compactada com peso específico de $12 \mathrm{kN} / \mathrm{m}^{3}$, ensaiada na umidade natural e saturada.

Figura 5.34 - Módulos de elasticidade tangente à origem e secantes, obtidos de ensaios CD, em corpos de prova de 150 e $200 \mathrm{~mm}$ de diâmetro, para amostra T2B, compactada com peso específico de $12 \mathrm{kN} / \mathrm{m}^{3}$ e ensaiada na umidade natural e saturada.

Figura 5.35 - Valores de coeficiente de Poisson obtidos de ensaios $C D$, em corpos de prova de 150 e $200 \mathrm{~mm}$ de diâmetro, para a amostra T2A sob diferentes condições de ensaio.

Figura 5.36 - Valores de coeficiente de Poisson obtidos de ensaios $C D$, em corpos de prova de 150 e $200 \mathrm{~mm}$ de diâmetro, para as amostras T1B e T2B, compactadas com peso específico de $12 \mathrm{kN} / \mathrm{m}^{3}$ e ensaiadas na umidade natural e saturadas.

Figura 5.37 - Trajetórias de tensões e envoltórias de resistência num diagrama ts' obtidas de ensaio $C D$, com a matriz da amostra $T 2 A$, saturada, compactada com peso específico em torno de $16 \mathrm{kN} / \mathrm{m}^{3}$, em corpos de prova de $100 \mathrm{~mm}$ de diâmetro e $200 \mathrm{~mm}$ de altura.

Figura 5.38 - Trajetórias de tensões e envoltórias de resistência num diagrama ts' obtidas de ensaio CD, com a matriz da amostra $T 1 B$, saturada, compactada com peso específico em torno de $16 \mathrm{kN} / \mathrm{m}^{3}$, em corpos de prova de $100 \mathrm{~mm}$ de diâmetro e 200mm de altura.

Figura 5.39 - Trajetórias de tensões e envoltórias de resistência num diagrama ts' obtidas de ensaio $C D$, com a matriz da amostra $T 2 B$, saturada, compactada com peso específico em torno de $16 \mathrm{kN} / \mathrm{m}^{3}$, em corpos de prova de $100 \mathrm{~mm}$ de diâmetro e 200mm de altura.

Figura 5.40 - Trajetórias de tensões totais e efetivas e envoltórias de resistência num diagrama $t-s, s^{\prime}$ obtidas de ensaio $C U$, com amostra T2A, na umidade natural, compactada com peso específico de $12 \mathrm{kN} / \mathrm{m}^{3}$, em corpos de prova de $150 \mathrm{~mm}$ de diâmetro e 300mm de altura.

Figura 5.41 - Trajetórias de tensões totais e efetivas e envoltórias de resistência num diagrama $t-s, s^{\prime}$ obtidas de ensaio $C U$, com amostra T2A, saturada, 
compactada com peso específico de $12 \mathrm{kN} / \mathrm{m}^{3}$, em corpos de prova de $150 \mathrm{~mm}$ de diâmetro e 300mm de altura.

Figura 5.42 - Trajetórias de tensões totais e efetivas e envoltórias de resistência num diagrama $t$-s, $s^{\prime}$ obtidas de ensaio $C U$, com amostra $T 1 B$, saturada, compactada com peso específico de $12 \mathrm{kN} / \mathrm{m}^{3}$, em corpos de prova de $150 \mathrm{~mm}$ de diâmetro e $300 \mathrm{~mm}$ de altura.

Figura 5.43 - Trajetórias de tensões totais e efetivas e envoltórias de resistência num diagrama $t$-s, $S^{\prime}$ obtidas de ensaio $C U$, com amostra T2B, saturada, compactada com peso específico de $12 \mathrm{kN} / \mathrm{m}^{3}$, em corpos de prova de $150 \mathrm{~mm}$ de diâmetro e $300 \mathrm{~mm}$ de altura.

Figura 5.44 - Comparação entre os resultados obtidos de ensaios CU e CD para as amostras T1B, T2A e T2B, compactadas com $12 \mathrm{kN} / \mathrm{m}^{3}$ e saturadas.

Figura 5.45 - Resistência não drenada (su) em função de $\sigma_{3}{ }_{3}$ em ensaio CU

Figura 5.46 - Parâmetros de resistência ao cisalhamento de resíduo sólido urbano obtidos de ensaios de laboratório, campo e de retro - análise.

Figura 5.47 - Relação e x log $\sigma$ nos tempos especificados, para a amostra T2A, ensaiada com pesos específicos de 8,10 e $14 \mathrm{kN} / \mathrm{m}^{3}$.

Figura 5.48 - Relação e $x \log \sigma$ nos tempos especificados, para a amostra T1B, ensaiada com pesos específicos de $10 \mathrm{kN} / \mathrm{m}^{3}$.

Figura 5.49 - Relação e x log $\sigma$ nos tempos especificados, para a amostra T2B, ensaiada com pesos específicos de $12 \mathrm{kN} / \mathrm{m}^{3}$.

Figura 5.50 - Comparação do índice de compressão primária em função do índice de vazios para resíduos sólidos urbanos.

Figura 5.51 - Comparação do índice de compressão secundária em função do índice de vazios para resíduos sólidos urbanos.

Figura 5.52 - Módulos de compressão confinada (D) em função da tensão vertical obtidos para a amostra T2A, ensaiada com pesos específicos iniciais de 8 (T2A8COM), 10 (T2A10COM) e $14 \mathrm{kN} / \mathrm{m}^{3}$ (T2A14COM).

Figura 5.53 - Módulos de compressão confinada (D) em função da tensão vertical obtidos para a amostra T2B, ensaiada com peso específico inicial de $12 \mathrm{kN} / \mathrm{m}^{3}$.

Figura 5.54 - Módulos de compressão confinada (D) em função da tensão vertical obtidos para a amostra $T 1 B$, ensaiada com peso específico inicial de $10 \mathrm{kN} / \mathrm{m}^{3}$, na condição de umidade natural e com os vazios saturados com água.

Figura 5.55 - Comparação entre os módulos de elasticidade obtidos de ensaios de compressão confinada e de ensaios triaxiais a $20 \%$ de deformação axial para a amostra T2A.

Figura 5.56- Comparação entre os módulos de elasticidade obtidos de ensaios de compressão confinada e de ensaios triaxiais a $20 \%$ de deformação axial para a amostra T2B. 
Figura 5.57- Comparação entre os módulos de elasticidade obtidos de ensaios de compressão confinada e de ensaios triaxiais a 20\% de deformação axial para a amostra T1B.

Figura 5.58 - Relação entre os módulos de elasticidade obtidos de ensaios em compressão confinada com os obtidos em ensaios triaxiais a $20 \%$ de deformação axial, para todas as amostras estudadas

\section{Capítulo 6}

Figura 6.1 - Medidas de recalque normalizado obtidas para o marco superficial MS-11. Altura inicial de RSU: 28 metros

Figura 6.2 - Medidas de recalque normalizado obtidas para o marco superficial MS-12. Altura inicial de RSU: 37,3 metros

Figura 6.3 - Medidas de recalque normalizado obtidas para o marco superficial MS-13. Altura inicial de RSU: 26,3 metros

Figura 6.4 - Medidas de recalque normalizado obtidas para o marco superficial MS-21. Altura inicial de RSU: 58,6 metros

Figura 6.5 - Curva típica de velocidade de deformação $x$ tempo de monitoramento do aterro.

Figura 6.6 - Taxa de recalque x idade do aterro para o marco MS-11, com altura inicial de RSU de 28,0 metros.

Figura 6.7 - Taxa de recalque x idade do aterro para o marco MS-12, com altura inicial de RSU de 37,3 metros.

Figura 6.8 - Taxa de recalque x idade do aterro para o marco MS-13, com altura inicial de RSU de 26,3 metros.

Figura 6.9 - Taxa de recalque $x$ idade do aterro para o marco MS-21, com altura inicial de RSU de 58,6 metros.

Figura 6.10 - Comparação dos dados observados segundo as propostas de SOWERS (1973).

Figura 6.11 - Ajustes matemáticos a partir de dados de monitoramento de recalques em campo. Marco superficial: MS-11.

Figura 6.12 - Ajustes matemáticos a partir de dados de monitoramento de recalques em campo. Marco superficial: MS-12.

Figura 6.13 - Ajustes matemáticos a partir de dados de monitoramento de recalques em campo. Marco superficial: MS-13.

Figura 6.14 - Ajustes matemáticos a partir de dados de monitoramento de recalques em campo. Marco superficial: MS-21. 


\section{Lista de tabelas}

\section{Capítulo 2}

Tabela 2.1.1- Critérios para avaliação das áreas para instalação de aterro sanitário, (Manual de Gerenciamento Integrado do Lixo Municipal, 1995).

TABELA 2.2.1- Componentes típicos do biogás de aterro de RSU ,TCHOBANOGLOUS et al. (1993).

Tabela 2.2.2 - Composição típica do líquido percolado de aterros sanitários, TOCHOBANOGLOUS et al. (1993).

TABELA 2.3.1 - Porcentagens típicas e principais características dos componentes dos RSU, SOWERS (1973).

TABELA 2.3.2 - Composição do resíduo sólido urbano para diferentes cidades (modificado de MANASSERO et al. 1997).

TABELA 2.3.3- Peso específico do resíduo sólido urbano (OWEIS, 1993).

Tabela 2.3.4 - Coeficientes de permeabilidade para o RSU (modificado de KÖNIG \& JESSBERGER, 1997).

Tabela 2.4.1 - Características de resistência ao cisalhamento do RSU obtidas a partir de retro- análise (VAN IMPE 1998).

\section{Capítulo 3}

Tabela 3.1 - Principais características dos corpos de prova de $150 \mathrm{~mm}$ de diâmetro e $300 \mathrm{~mm}$ de altura.

Tabela 3.2 - Principais características dos corpos de prova de 200mm de diâmetro e $400 \mathrm{~mm}$ de altura.

Tabela 3.3 - Principais características dos corpos de prova utilizados para determinação de módulo de deformabilidade e ensaiados com pressão de confinamento de $25 \mathrm{kPa}$ e sem confinamento.

Tabela 3.4 - Principais características dos corpos de prova de 100mm de diâmetro e $200 \mathrm{~mm}$ de altura.

Tabela 3.5 - Características das amostras submetidas a ensaios de compressão confinada.

\section{Capítulo 4}

Tabela 4.1 - Umidade dos componentes do RSU.

Tabela 4.2 - Resultados de análise química dos extratos lixiviados e solubilizados.

Tabela 4.3 - Peso específico das partículas sólidas para o RSU estudado.

Tabela 4.4 - Principais características, dos corpos de prova de $150 \mathrm{~mm}$ de diâmetro e 
$300 \mathrm{~mm}$ de altura submetidos à ensaios $C D$, após adensamento.

Tabela 4.5 - Principais características, dos corpos de prova de $200 \mathrm{~mm}$ de diâmetro e $400 \mathrm{~mm}$ de altura submetidos à ensaios $C D$, após adensamento.

Tabela 4.6 - Principais características, dos corpos de prova de $150 \mathrm{~mm}$ de diâmetro e $300 \mathrm{~mm}$ de altura submetidos à ensaios CU, após adensamento.

163

\section{Capítulo 5}

Tabela 5.1 - Parâmetros de resistência obtidos para a amostra T2A, em corpos de prova com 150x300mm, compactados com peso específico de 10, 12 e $14 \mathrm{kN} / \mathrm{m}^{3}$.

Tabela 5.2 - Parâmetros de resistência obtidos para a amostra T2A, saturada compactada com peso específico de $12 \mathrm{kN} / \mathrm{m}^{3}$, em corpos de prova de $150 \mathrm{~mm}$ de diâmetro por 300mm de altura.

Tabela 5.3 - Parâmetros de resistência obtidos para a amostra T1B na umidade natural e saturada, compactada com peso específico de $12 \mathrm{kN} / \mathrm{m}^{3}$, em corpos de prova $150 \mathrm{~mm}$ de diâmetro por $300 \mathrm{~mm}$ de altura.

Tabela 5.4 - Parâmetros de resistência obtidos para a amostra T2B, na umidade natural e saturada, compactada com peso específico de $12 \mathrm{kN} / \mathrm{m}^{3}$, em corpos de prova de $150 \mathrm{~mm}$ de diâmetro por $300 \mathrm{~mm}$ de altura.

Tabela 5.5 - Parâmetros de resistência obtidos de ensaios CD em amostra T2A, T2B e $T 1 B$, com peso específico de $12 \mathrm{kN} / \mathrm{m}^{3}$ e em corpos de prova de $200 \mathrm{~mm}$ de diâmetro por $400 \mathrm{~mm}$ de altura.

Tabela 5.6 - Parâmetros de resistência obtidos de ensaios $C D_{\text {sat, }}$ com a matriz das amostras T2A, T2B e T1B, compactada com peso específico em torno de $16 \mathrm{kN} / \mathrm{m}^{3}$ e em corpos de prova de $100 \mathrm{~mm}$ de diâmetro por $200 \mathrm{~mm}$ de altura.

Tabela 5.7 - Parâmetros de resistência obtidos de ensaios CU, em amostras T2A, T2B e T1B, compactadas com peso específico de $12 \mathrm{kN} / \mathrm{m}^{3}$ em corpos de prova $150 \mathrm{~mm}$ de diâmetro x $300 \mathrm{~mm}$ de altura.

Tabela 5.8 - Valores médios de $C_{c}$ e $C_{c}^{\prime}$ para todas as amostras ensaiadas

Tabela 5.9- Valores de $C_{\alpha}$ e $C_{\alpha}^{\prime}$ para todos as amostras estudadas

\section{Capítulo 6}

Tabela 6.1 - Resultados obtidos do ajuste proposto por YEN \& SCANLON (1975).

Tabela 6.2 - Parâmetros obtidos do ajuste de dados de campo, procedimento de Bjarngard \& Edgers (1990).

Tabela 6.3 - Parâmetros empíricos obtidos do ajuste de dados de campo, procedimento de Gibson \& Lo. 


\section{Lista de símbolos}

$\phi=$ ângulo de atrito

$v=$ coeficiente de Poisson

$\varepsilon=$ deformação $(\mathrm{S} / \mathrm{H})$,

$\gamma=$ peso específico $\left(\mathrm{kN} / \mathrm{m}^{3}\right)$

$\lambda=$ taxa de geração de metano, (SOLER et al.. 1995)

$\beta=$ valor médio da atividade biológica para todas as bactérias de um aterro específico (pode variar de 0,1223-1,267 1/ano), (EDGERS et al.. 1992)

$\rho=$ resistividade elétrica aparente (ohm.m)

$\Delta \sigma=$ acréscimo de pressão vertical

$\Delta \sigma=$ tensão compressiva, (EDIL et al.. 1990)

$\left(\Delta \sigma_{1}-\Delta \sigma_{3}\right)=$ tensão desviatória $(\mathrm{kPa})$

$\lambda / \mathrm{b}=$ taxa de compressão secundária, (EDIL et al.. 1990)

$\sigma_{0}{ }_{0}=$ pressão vertical inicial, (SOWERS, 1973)

$\varepsilon_{1}=$ deformações axiais

$\sigma_{3}=$ pressão de confinamento da amostra $(\mathrm{kPa})$

$\gamma_{\mathrm{d} \text { adens }}=$ peso específico seco após adensamento do corpo de prova $\left(\mathrm{kN} / \mathrm{m}^{3}\right)$

$\Delta \mathrm{e}=$ variação do índice de vazios

$\phi_{\mathrm{f}}=$ diâmetro do furo de trado

$\Delta \mathrm{H}=$ recalque total da camada de $\mathrm{RSU}$

$\Delta \mathrm{H} / \mathrm{H}=$ deformação vertical (recalque normalizado)

$\Delta \mathrm{H}_{1}=$ recalque da camada devido a compressão primária, (SOWERS, 1973)

$\Delta \mathrm{H}_{2}=$ recalque da camada devido a compressão secundária, (SOWERS, 1973)

$\gamma_{\text {nat }}=$ peso específico de compactação dos corpos de prova $\left(\mathrm{kN} / \mathrm{m}^{3}\right)$

$\sigma_{\text {oct }}=$ tensões octaédricas

$\Delta \mathrm{P}=$ incremento de tensão vertical média, (BJARNGARD \& EDGERS, 1990)

$\rho_{\mathrm{s}}=$ densidade dos sólidos biodegradáveis; (SOLER et al.. 1995)

$\gamma_{\mathrm{s}}=$ peso específico das partículas sólidas do RSU $\left(\mathrm{kN} / \mathrm{m}^{3}\right)$

$\gamma_{\text {seco }}=$ peso específico seco de compactação do corpo de prova $\left(\mathrm{kN} / \mathrm{m}^{3}\right)$

$\Delta \mathrm{t}=$ acréscimo de tempo

$\phi_{\tan }=$ diâmetro do tanque de bentonita

$\Delta \mathrm{u}=$ variação da pressão neutra $(\mathrm{kPa})$

$\varepsilon_{v}=$ deformações volumétricas

$\Delta \mathrm{V}=$ diferença de potencial entre os eletrodos

$\sigma_{v}=$ tensão vertical de carregamento 
$A=$ parâmetro de pressão neutra

$\mathrm{A}$ e $\mathrm{B}=$ eletrodos

a e b = parâmetro de compressibilidade primária e secundária , (EDIL et al.. 1990)

$\mathrm{a}^{`}$ = constante empírica $\left[\left(\mathrm{a}^{`}=0,00095 \mathrm{H}+0,00985\right)\right]$ que aumenta aproximadamente linear

com a espessura do aterro $(\mathrm{H})$

$\mathrm{B}=$ fator escala relacionando o recalque no aterro devido ao efeito da decomposição com o crescimento cinético das bactérias, (EDGERS et al.. 1992)

$\mathrm{B}=$ parâmetro de Skenpton

b` = constante empírica $[(b `=0,00035 \mathrm{H}+0,00509)]$ que aumenta aproximadamente linear com a espessura do aterro $(\mathrm{H})$.

c = coesão

$\mathrm{C} \alpha=$ índice de compressão secundária

$\mathrm{C} \alpha `$ = coeficiente de compressão secundária

$C^{\prime} \alpha_{1}=$ coeficiente de compressão secundária do primeiro trecho, devido aos fenômeno de creep, deformação lenta

$C^{\prime} \alpha_{2}=$ coeficiente de compressão secundária do segundo trecho, devido aos fenômeno de creep e degradação do resíduo ao longo do tempo

$C^{\prime} \alpha_{(1)}=$ coeficiente de compressão secundária intermediária, (BJARNGARD \& EDGERS, 1990)

$C^{\prime} \alpha_{(2)}=$ coeficiente de compressão secundária a longo prazo, (BJARNGARD \& EDGERS, 1990)

Cc = índice de compressão primária

$\mathrm{CC}^{`}$ = coeficiente de compressão primária

$\mathrm{CD}=$ ensaio triaxial consolidado drenado

$\mathrm{cp}=$ corpo de prova

CPT = ensaio de penetração contínua ou do cone

$\mathrm{CU}=$ ensaio triaxial consolidado não drenado

$\mathrm{D}=$ diâmetro inicial do corpo de prova

$\mathrm{D}=$ módulo de compressão confinada (MPa)

$\mathrm{DQO}=$ demanda química de oxigênio

ds = variação do recalque

$\mathrm{E}=$ módulo de deformabilidade dinâmico (MPa)

$\mathrm{E}=$ módulo de elasticidade secante à origem obtido dos ensaios triaxiais (MPa)

$\mathrm{E}_{0}=$ módulo de elasticidade inicial secante à origem obtido dos ensaios triaxiais(MPa)

$e_{d}$ adens $=$ índice de vazios após adensamento do corpo de prova

$\mathrm{e}_{\mathrm{o}}=$ índice de vazios inicial

$E_{\mathrm{s}}=$ Módulo de deformabilidade secante, segundo KNOCHENMUS et al.. 1998

$\mathrm{f}_{\mathrm{CH} 4}=$ fração de metano no gás gerado, igual a 0,5 (SOLER et al.. 1995)

$\mathrm{G}=$ módulo cisalhante dinâmico (MPa) 
$\mathrm{h}=$ altura inicial do corpo de prova

$\mathrm{H}=$ espessura inicial da camada de RSU, (BJARNGARD \& EDGERS, 1990)

$\mathrm{H}_{0}=$ espessura inicial da camada de RSU

$\mathrm{I}=$ corrente elétrica

$\mathrm{k}$ = coeficiente de permeabilidade a água

$\mathrm{K}=$ fator geométrico que depende do espaçamento entre os quatro eletrodos

$\mathrm{K}_{\mathrm{o}}=$ coeficiente de empuxo em repouso

$\mathrm{m}=$ compressibilidade de referência $\left(\mathrm{m} \cong 2,5 \cdot 10^{-5} 1 / \mathrm{kPa}\right)$, (EDIL et al.. 1990)

$\mathrm{M}(\mathrm{t})$ = parcela biodegradável do resíduo, (SOLER et al.. 1995)

$\mathrm{n}=$ taxa de compressão ( $\mathrm{n} \cong 0,37)$, (EDIL et al.. 1990)

Nat = amostra ensaiada na umidade de moldagem

Po = tensão efetiva vertical média inicial, (BJARNGARD \& EDGERS, 1990)

$\mathrm{qc}=$ resistência de ponta $(\mathrm{MPa})$

$q \mathrm{l}=$ resistência lateral $(\mathrm{MPa})$

RSU = resíduos sólidos urbanos

$S=$ recalque ou deformação volumétrica $\left(s=\Delta H / H_{0}\right)$

$\mathrm{S}_{(\mathrm{t})}=$ recalque no tempo $\mathrm{t}$, (EDIL et al.. 1990)

Sat = amostra ensaiada na condição saturada

SPT = ensaio de penetração padrão

Sro = grau de saturação inicial do corpo de prova

STF = sólidos totais fixos

STV = sólidos totais voláteis

$\mathrm{t}$ = tempo decorrido desde o início da aplicação da carga, (EDIL et al.. 1990)

$\mathrm{t}_{(1)}=$ tempo (dias) para completar a compressão inicial, (BJARNGARD \& EDGERS, 1990)

$\mathrm{t}_{(2)}=$ tempo (dias) para completar a compressão intermediária, (BJARNGARD \& EDGERS, 1990)

$\mathrm{t}_{(3)}=$ período de tempo (dias) para previsão do recalque, (BJARNGARD \& EDGERS, 1990)

$\mathrm{t}_{1}=$ tempo inicial da consolidação secundária, (SOWERS, 1973)

T1 e T2 = tradagem para coleta de amostras referente aos furos de trado 1 e 2 ,

respectivamente

$t_{k}=$ tempo crítico a partir do qual tem-se o aumento da taxa de deformação, (EDGERS et al.. 1992)

$\operatorname{tr}=$ tempo de referência introduzido na equação para tornar o tempo $(t)$ adimensional $(\operatorname{tr}=1)$

$\mathrm{v}=$ taxa de recalque $(\mathrm{v}=\mathrm{ds} / \mathrm{dt}),($ YEN \& SCANLON, 1975)

$\mathrm{V}_{\mathrm{p}}=$ velocidade de propagação da onda de compressão $(\mathrm{m} / \mathrm{s})$

$\mathrm{V}_{\mathrm{s}}=$ velocidade de propagação da onda cisalhante $(\mathrm{m} / \mathrm{s})$

$w=$ teor de umidade de compactação do corpo de prova (\%)

$w=$ umidade calculada em termos de base seca

$w^{`}=$ umidade calculada em termos de base úmida 


\section{RESUMO}

CARVALHO, M. F. Comportamento mecânico de resíduos sólidos urbanos. São Carlos, 1999. 300p. Tese (Doutorado) - Escola de Engenharia de São Carlos, Universidade de São Paulo.

Nesta tese estuda-se o comportamento mecânico de resíduos sólidos urbanos provenientes do Aterro Sanitário Bandeirantes (SP - Brasil) por meio de ensaios de campo e de laboratório, bem como, através de dados de monitoramento de recalques in situ. Os dados são analisados e algumas conclusões a respeito do comportamento do resíduo sólido urbano são apresentadas.

Resultados de ensaios de campo, tais como, sondagens de simples reconhecimento com medida de SPT (Standard Penetration Test), ensaios penetrométricos tipo CPT (Cone Penetration Test), ensaios de infiltração, sondagens a trado para coleta de amostras, ensaio cross-hole e ensaio de resistividade elétrica são apresentados e discutidos, enfatizando as dificuldades de execução e a faixa de valores obtidos.

Os ensaios de laboratório foram executados em amostras remoldadas, coletadas em dois furos de trado $(40 \mathrm{~cm}$ de diâmetro), até cerca de $30 \mathrm{~m}$ de profundidade. O resíduo tem cerca de 15 anos de aterrado e os ensaios físicos e químicos executados mostraram que este é composto de cerca de $50 \%$ de uma fração pastosa com baixos valores de DQO (demanda química de oxigênio) e STV (sólidos totais voláteis), os quais demonstram que o resíduo já atingiu um avançado grau de decomposição.

A resistência ao cisalhamento do resíduo foi avaliada a partir de ensaios triaxiais não drenados (CU) e drenados (CD), utilizando corpos de prova saturados e não saturados de grandes dimensões $(15 \times 30 \mathrm{~cm}$ e $20 \times 40 \mathrm{~cm})$. Desses ensaios obteve-se que os parâmetros de resistência ao cisalhamento do resíduo sólido urbano são largamente dependentes da deformação da amostra, e não foi observado nenhum pico ou valor último nas curvas tensão-deformação. Os valores obtidos estão de acordo com alguns resultados disponíveis na literatura para ensaios de laboratório e retro-análise.

Os ensaios de compressão confinada, executados num consolidômetro de grande diâmetro $(385 \mathrm{~mm})$, mostraram uma rápida compressão inicial e primária e uma grande compressão secundária. As medidas de campo também mostraram deformações dessa natureza, as quais podem ser divididas em duas etapas: a primeira, relacionada à fase inicial do aterro e a segunda, associada, principalmente, à degradação química e biológica do resíduo.

Palavras-chave: Resíduos sólidos urbanos, aterros sanitários, resistência ao cisalhamento de RSU, compressibilidade de RSU 


\begin{abstract}
CARVALHO, M. F. Mechanical behavior of urban solid waste. São Carlos, 1999. 300p. Tese (Doutorado) - Escola de Engenharia de São Carlos, Universidade de São Paulo.
\end{abstract}

This thesis deals with the mechanical behavior of urban solid waste from Bandeirantes Sanitary Landfill (São Paulo, Brazil). Field and laboratory tests, as well as data from field instrumentation (settlement) were obtained and used in the analysis.

Results of in situ tests such as Standard Penetration Test (SPT), Cone Penetration Test (CPT), infiltration tests, auger boring for sampling, cross-hole test and electric resistivity are presented and discussed focusing on the difficulties in performing them as well as their potential as a source of design parameters.

Laboratory tests were performed using remolded samples collected in two boreholes about $30 \mathrm{~m}$ in depth. The waste is about 15 years old and physical and chemical tests showed that about $50 \%$ of it is composed of organic past with low values of COD and TDS, which denote that it is degraded to a large extent.

Shear strength of waste was studied by means of consolidated-drained (CD) and consolidated-undrained (CU) triaxial compression tests on large specimens, tested both at natural water content and saturated. It is shown that shear strength properties are largely dependent on deformation, since no peak or ultimate value was achieved on stress-strain curves. The values obtained are in accordance with some of the few results available in the literature, either from laboratory and back analysis.

Confined compression tests carried out on large samples (385mm diameter) showed quick initial and primary consolidation and large secondary compression. This in accordance with the field behavior, although in this case secondary compression seems to be composed of two parts: the first, related to the early stages of the fill and second one, which seems to be commanded mainly by chemical and biological degradation.

Keywords: Municipal solid waste, sanitary landfill, waste shear strength, waste compressibility 


\section{1 - INTRODUÇÃO}

A industrialização e o crescimento econômico e demográfico das cidades têm aumentado a produção de resíduos sólidos urbanos, agravando o desafio de dispor de maneira segura e adequada a crescente produção de RSU. Face a esse crescimento, as técnicas de disposição utilizadas no passado, como por exemplo, depósito a céu aberto (lixões) ou lançamento em rios e mares tornaram-se intoleráveis sob os aspectos econômico, sanitário e ambiental. Hoje em dia a técnica de disposição de RSU em aterros sanitários, com seus diferentes métodos de operação, é a mundialmente mais empregada. Mesmo nos países mais desenvolvidos essa técnica ainda prepondera, embora o seu uso tenha sido reduzido devido à introdução de leis mais restritivas que procuram aumentar a proteção ao meio ambiente. Já nos países em desenvolvimento, como é o caso do Brasil, os aterros continuam sendo a solução mais adequada sob o ponto de vista técnico e econômico.

No Manual de Gerenciamento Integrado do Lixo Municipal (IPT, 1995), uma estatística bastante sombria, com relação ao saneamento básico do país, destaca que cerca de $76 \%$ do lixo urbano gerado são dispostos a céu aberto e apenas $24 \%$ recebem disposição adequada. Deve-se acrescentar ainda, que a demanda crescente de áreas para disposição dos resíduos e a carência de locais adequados próximos aos centros geradores induzem à exigência de otimizar a capacidade de disposição dos locais disponíveis. Assim, os aterros vem sendo construídos com alturas cada vez maiores, como é o caso do Aterro Bandeirantes (SP) que já supera os 100 metros de altura.

Problemas envolvendo operação, funcionamento, estabilidade e deformabilidade de aterros sanitários são constantes. Por outro lado, é importante frisar, que os projetos e construção de aterros sanitários no Brasil têm sido caracterizados pela adoção de critérios e de parâmetros de projeto baseados na experiência de países do primeiro mundo sem que haja uma confirmação ou validação para as condições de nosso país. Os nossos resíduos têm composição, em termos de matéria orgânica e umidade, bastante diferente dos daqueles países e a simples adoção de parâmetros "geotécnicos" importados para nossos aterros sanitários pode gerar situações críticas de estabilidade, a médio e longo prazo, que poderão criar problemas e zonas de riscos para populações e benfeitorias próximas.

Embora tenha-se usado sistematicamente a disposição de resíduos em aterros sanitários, raros trabalhos experimentais têm sido desenvolvidos com o intuito de estudar o comportamento frente à deformabilidade e resistência desses materiais, bem como de 
procedimentos construtivos adequados. Nesse contexto, tornou-se necessário um conhecimento mais apurado do comportamento geotécnico desses maciços, a fim de caracterizar e determinar os parâmetros a serem empregados nas análises de estabilidade e modelagens, visando permitir a execução de aterros novos ou ampliações dentro de padrões mais seguros e econômicos.

Este trabalho que ora se apresenta, tem por objetivo geral o estudo do comportamento geotécnico dos resíduos sólidos domiciliares, provenientes do Aterro Sanitário Bandeirantes (SP). Constituem objetivos específicos desta pesquisa: A) levantamento do perfil estratigráfico do aterro; B) determinação do perfil de resistência à penetração in situ, através da realização de ensaios SPT-T e ensaios de penetração contínua; C) determinação do coeficiente de permeabilidade in situ; D) determinação dos módulos de deformabilidade através de ensaios cross-hole; E) caracterização do resíduo sólido urbano aterrado (RSU), determinando-se a composição gravimétrica por meio de segregação manual dos componentes (fração pastosa, pedras, metais, papel, vidro, plástico, borracha, têxteis e madeira), determinação das dimensões dos componentes, determinação da umidade, quantificação dos sólidos totais voláteis (STV) e da demanda química de oxigênio (DQO) como indicadores da matéria orgânica na fração pastosa, ensaios de lixiviação e solubilização visando a classificação do resíduo; F) construção de célula triaxial de grandes dimensões, bem como medidor de variação de volume, necessários devido às grandes dimensões dos corpos de prova empregados (150X300 e 200X400mm); G) determinação dos parâmetros de resistência do RSU, através de ensaios de compressão triaxial ( $C D$ e $C U$ ), executados em amostras deformadas de grandes dimensões, compactadas estaticamente em várias densidades; H) determinação dos parâmetros de deformabilidade do RSU, através de ensaios de compressão confinada, utilizando-se os princípios da mecânica dos solos clássica; I) verificação do comportamento dos aterros, através da análise dos ensaios de laboratório e de campo.

Para que fosse possível atender aos objetivos do projeto de pesquisa proposto, fezse uma revisão bibliográfica sobre os temas envolvidos, que é apresentada no Capítulo 2.

No item 2.1 enfocam-se, basicamente, os conceitos gerais, tipos e técnicas empregadas na execução de aterros sanitários, enfatizando os principais elementos estruturais e instrumentos de um aterro e a escolha de áreas para implantação. No item 2.2 aborda-se o processo de degradação do RSU com o tempo, enfatizando as principais fases e fatores envolvidos, bem como os produtos finais gerados. Nos itens 2.3 e 2.4 apresentamse os principais trabalhos encontrados na literatura tratando das propriedades geotécnicas do RSU. Nestes itens são mostradas as principais faixas de variação, tipos de ensaios executados bem como comportamento tensão - deformação do material. No item $2.4 \mathrm{o}$ comportamento de deformabilidade e de resistência do RSU é tratado com bastante ênfase. 
No capítulo 3, apresentam-se os métodos e os equipamentos utilizados na realização dos diversos ensaios, a descrição da área de investigação e os motivos que levaram a escolha do Aterro Sanitário Bandeirantes como o local de desenvolvimento desta pesquisa. Neste capítulo, também é mostrado uma célula triaxial de grande dimensão e um medidor de variação de volume construídos para que fosse possível executar os ensaios triaxiais com RSU.

No capítulo 4, apresentam-se os resultados obtidos a partir da realização dos ensaios de campo e laboratório. No item 4.1 apresentam-se os resultados obtidos das investigações in situ do maciço, valores de SPT, CPT, permeabilidade e velocidade de propagação da onda de compressão e de cisalhamento com a profundidade. Além disso, apresenta-se também, após algumas correções, uma estimativa do peso específico através da pesagem do RSU retirado dos furos de trado para coleta de amostras. No item 4.2 apresentam-se os dados de caracterização físico-química do RSU coletado em termos de teor de umidade, composição gravimétrica, tamanho e distribuição dos componentes dos resíduos, STV, DQO, solubilização e lixiviação. Valores de peso específico das partículas do RSU obtidos de ensaios utilizando um becker de 2 litros devidamente calibrado são apresentados no item 4.3. No item 4.4 são apresentados os resultados dos ensaios triaxiais consolidados drenados e não drenados executados com três amostras representativas, na condição saturada e não saturada, considerando duas dimensões de corpos de prova (150x300 e 200x400mmm). Também neste item são apresentados os resultados de resistência ao cisalhamento obtidos com a matriz básica do resíduo, após a exclusão das fibras. Os resultados dos ensaios de compressão confinada são apresentados no item 4.5.

No capítulo 5, são realizadas as análises dos resultados apresentados no capítulo 4.

No capítulo 6 apresentam-se dados de monitoramento de recalques de 4 marcos superficiais existentes na área de estudo. Neste item fez-se uma comparação dos resultados de compressibilidade obtidos de dados de campo com os obtidos de laboratório. As taxas de recalques obtidas dos dados observados são comparadas com as propostas por alguns pesquisadores, empregando formulações ajustadas a partir de dados de recalque em campo de aterros específicos.

Finalmente, no capítulo 7, as principais conclusões a cerca do trabalho desenvolvido são apresentadas, bem como, algumas sugestões para pesquisa futura. No capitulo 8, são apresentadas as referências bibliográficas citadas ao longo da tese. 


\section{2 - REVISÃO BIBLIOGRÁFICA}

\section{1 - ATERROS SANITÁRIOS DE RESÍDUOS SÓLIDOS URBANOS}

\subsection{1 - Introdução}

Toda atividade humana, seja industrial, domiciliar, comercial e lazer, gera sempre resíduos, que se não forem dispostos adequadamente podem contaminar o solo, as águas e o ar gerando riscos à saúde pública e ao meio ambiente. Nos dias de hoje, face ao desenvolvimento tecnológico e sociocultural decorrente da revolução industrial, a quantidade de resíduo gerado vem aumentando exponencialmente com o tempo e, nota-se, uma redução da capacidade do meio ambiente de assimilá-lo, o que acaba resultando em impactos ambientais.

SCHALCH (1992), com base na NBR 10.004/87 (Resíduos Sólidos - Classificação) classificou os resíduos sólidos quanto à sua origem em: industriais (não perigosos, tóxicos e perigosos), de serviços de saúde ou hospitalares, radioativos (lixo atômico), agrícola e urbanos. É importante destacar a existência de outras classificações para resíduos, as quais estão associadas ao estado físico do resíduo (gasoso, líquido, sólido), grau de periculosidade (classe I, II e III) e fonte geradora.

Os resíduos sólidos urbanos (RSU) são constituídos pelos resíduos domiciliares, comerciais, de varrição e pelos resíduos de serviços de feiras livres, capina e poda. A composição deste resíduo é um reflexo dos hábitos culturais e de consumo da sociedade, do nível de renda e avanços tecnológicos (PRESA, 1982).

Nos últimos anos tem aumentado o interesse no gerenciamento e na disposição dos resíduos sólidos urbanos (RSU). Esforços para minimizar a produção de lixo, bem como para reciclar e reusar alguns materiais são algumas das políticas de gerenciamento do lixo adotadas hoje por todo o mundo. Mesmo com o desenvolvimento de novas tecnologias de tratamento, ainda assim, o aterramento continua sendo o método de disposição mais usado nas diferentes partes do mundo. No Brasil, segundo o Manual de Gerenciamento Integrado do Lixo Municipal (1995), cerca de 76\% das 242.000 toneladas diárias de resíduos sólidos urbanos produzidas são dispostas a céu aberto (lixões) e, apenas $24 \%$ restantes, recebem uma disposição mais adequada. Destas, 13\% vão para os aterros controlados, 10\% para aterros sanitários, 0,9\% para as usinas de compostagem e 0,1\% para as usinas de incineração. 
O projeto e a operação dos aterros sanitários envolvem uma variedade de problemas geotécnicos o que torna necessário o conhecimento das propriedades mecânicas dos resíduos na busca de soluções de projetos mais econômicos e seguros. A quantificação dessas propriedades é difícil devido à heterogeneidade do material, o qual apresenta diferentes tipos, formas e dimensões de constituintes e componentes que podem degradar com o tempo, gerando gases e lixívia. A biodegradação da fração orgânica do RSU contribui significativamente para modificar o comportamento mecânico dos aterros de RSU. Além disso, existem dificuldades relacionadas com a amostragem, tipos de ensaios e tamanhos de amostras mais indicados para os testes.

Neste capítulo, faz-se uma revisão bibliográfica sobre o tema "Aterros sanitários de resíduos sólidos", apresentando-se os conceitos gerais, tipos e técnicas de execução, bem como os cuidados a serem observados na escolha de locais para implantação de aterros. São apresentados, também, os elementos básicos da estrutura de um aterro sanitário e os principais instrumentos utilizados no monitoramento das deformações e das pressões neutras geradas e também considerações sobre propriedades físicas, biológicas e geotécnicas dos resíduos sólidos urbanos.

\subsection{2 - Conceituação geral}

Historicamente, a disposição de resíduos sólidos no solo se deu desde os primórdios da civilização humana. Atualmente, apesar das inovações em novas tecnologias de tratamento e disposição (incineração, compostagem, reciclagem, compactação e alternativas como trituração e enfardamento), que visam reduzir previamente o volume de resíduos, os aterros continuam sendo o método de disposição mais usado mas diferentes partes do mundo.

Segundo LEITE (1995), o aterro sanitário é o método de disposição mais difundido em todo o mundo visto que é a solução mais econômica quando comparada com os processos de compostagem e de incineração. $O$ aterro sanitário é o principal sistema de destino final dos resíduos sólidos domésticos hoje no Brasil.

Segundo ABNT, NBR 8419, "Aterro Sanitário é um método de disposição de resíduos sólidos no solo, sem provocar prejuízos ou ameaças à saúde e à segurança, utilizando-se princípios de engenharia, de tal modo, a confinar o lixo no menor volume possível, cobrindo-o com uma camada de terra, ao fim do trabalho de cada dia, ou mais freqüentemente, conforme o necessário".

É comum equívocos em relação aos termos aterros sanitários, lixões ou depósitos de resíduos. Segundo LEITE (1991), nos lixões ou depósitos estão ausentes os critérios científicos ou ecológicos de disposição do resíduo e, por isso são criticados pelo ponto de 
vista sanitário. Já o aterro sanitário, deve ser executado de tal forma que não comprometa a qualidade das águas subsuperficiais e do solo, assim, deve conter:

- conjunto de células recobertas, diariamente, por uma camada de solo para evitar a proliferação de vetores e espalhamento de papéis e poeira, pelo vento,

- sistema de drenagem de gás e de líquido percolado,

- sistema de tratamento dos líquidos percolados,

- sistema de drenagem de águas superficiais e nascentes,

- liner de fundo, etc.

Os resíduos destinados aos aterros sanitários, geralmente, são constituídos por uma parcela considerável de materiais facilmente e/ou moderadamente degradáveis que sofrem processos de transformações físico-químicas e biológicas decorrentes da decomposição da matéria orgânica, da qual resulta a produção de chorume e gás. Os principais gases gerados são o metano e o dióxido de carbono, sendo o metano correspondente de $60 \%$ do total produzido e este é inflamável quando misturado com oxigênio na proporção de 10 a 15\%. O líquido percolado de aterro sanitário, freqüentemente denominados de chorume, apresentam elevadas concentrações de espécies químicas que podem infiltrar-se no solo e vir a poluir e contaminar as águas subterrâneas e superficiais.

É importante ressaltar, que esse comportamento peculiar de degradação dos resíduos sólidos urbanos, em condições ambientais propícias, gerando gás e líquido percolado, exerce influência preponderante na escolha do local de implantação e nos elementos básicos da estrutura do aterro, bem como nas características geotécnicas do maciço a curto e longo prazo.

\subsection{3 - Tipos de aterros}

Atualmente, a disposição de RSU em aterros tem se modificado devido às mudanças das características do resíduo a dispor, como também por novos costumes de descarte, novas exigências ambientais, novos sistemas de coleta, separação e transformação. A concepção dos aterros vem se modificando, mas pode-se classificar os aterros sob duas formas, quais sejam: quanto ao tipo de aterro e quanto ao método de aterramento.

a) Quanto ao tipo de aterro: destacam-se os aterros sanitários convencionais para resíduos sólidos, para resíduos sólidos triturados e para resíduos especiais.

Os aterros convencionais são aqueles usados para disposição de resíduos sólidos urbanos e materiais inertes, empregando os processos de compactação. Já os aterros de resíduos sólidos triturados, recebem resíduos previamente triturados, perdendo muitas características consideradas insatisfatórias num aterro convencional. Assim podem atingir 
altas densidades, cerca de 35\% maior que em aterros convencionais. Além disso, dependendo da legislação local, os resíduos podem ser dispostos sem recobrimento diário, o que acarreta um aumento de vida útil do aterro. Os aterros de resíduos específicos são aterros conhecidos como monoaterros, pois são exclusivos para um tipo de material (cinzas, amianto e outros).

b) Quanto às formas construtivas e operacionais adotadas na disposição (método de aterramento): os aterros podem ser classificados em aterros de trincheiras, de superfície e de depressão (Figura 2.1.1).

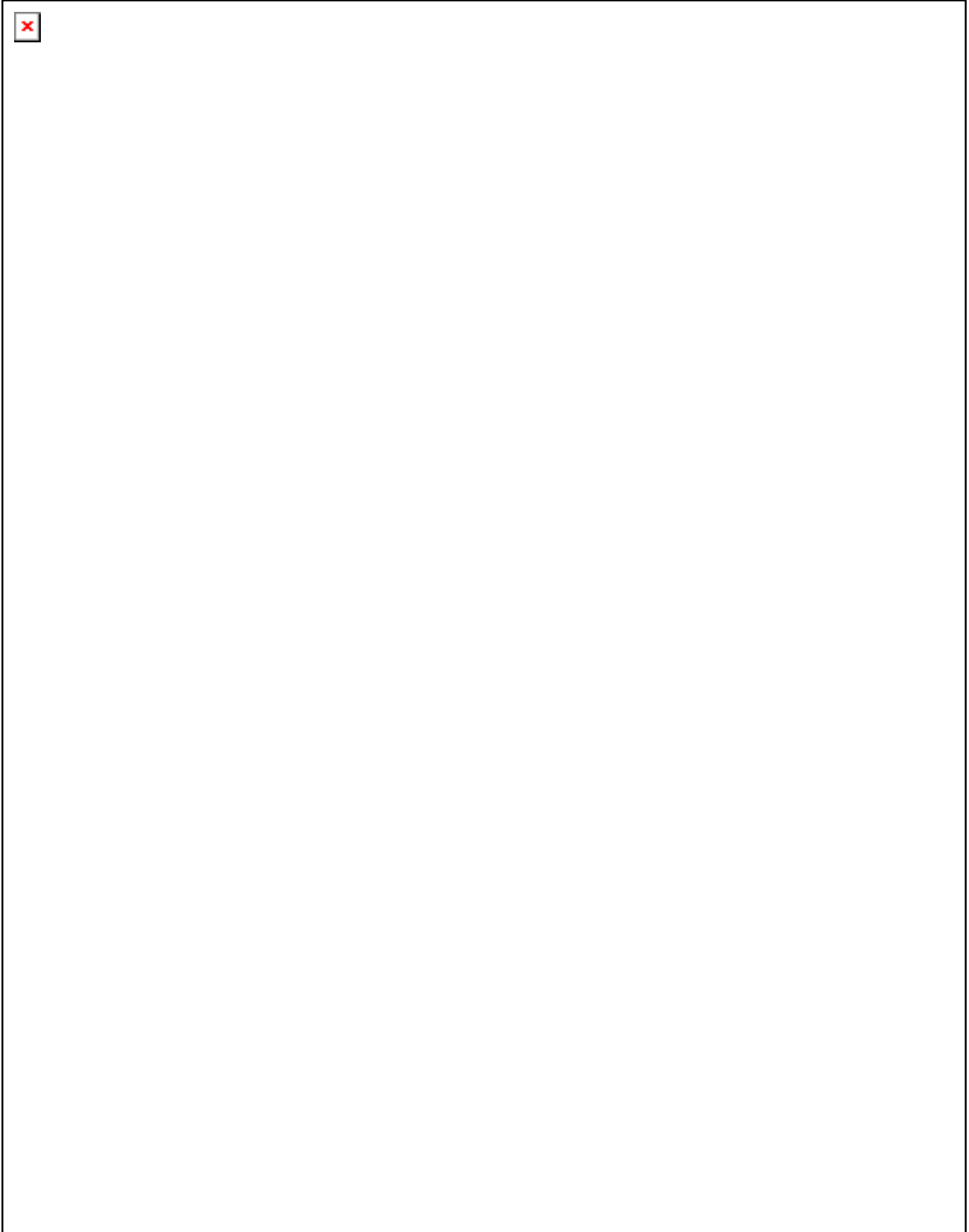

Figura 2.1.1 - Tipos de aterros sanitários (TCHOBANOGLOUS et al. 1993). 
$O$ aterro em trincheira deve ser usado para comunidades que geram baixa quantidade de resíduos ou em casos onde a composição química ou biológica do resíduo for duvidosa e trazer riscos à saúde pública ou ao meio ambiente. Para esse tipo de aterro, o lençol freático não deve estar próximo da superfície e as dimensões da trincheira são função da quantidade de resíduos a ser aterrada e da vida útil requerida. Os resíduos são dispostos em células ou trincheiras escavadas no solo com taludes 1,5:1; 2:1, (H:V), compactados e recobertos, diariamente, por uma camada de solo. O fundo da escavação deve ser impermeabilizado com membrana sintética e/ou solo compactado.

$\mathrm{O}$ aterro de superfície é usado em locais de topografia plana impróprios para a execução de trincheiras e células, onde os desníveis para disposição dos resíduos são obtidos com um dique de terra ou do próprio resíduo. Esse método é bastante oneroso, pois requer cuidados especiais, como por exemplo construção de diques, etc.

Por último, os aterros de depressão (canyons) são empregados em regiões de topografias acidentadas, como grotas, fundos de vale, pedreiras extintas e encostas. As técnicas de disposição e compactação do resíduo, nesse tipo de aterro, variam com a geometria, com a hidrologia e geologia do local e com a disponibilidade de material para cobertura (TCHOBANOGLOUS et al. 1993).

\subsection{4 - Seleção de áreas para implantação de um aterro}

A seleção do local para instalação de um aterro sanitário envolve não só fatores ambientais, mas também, técnicos, econômicos, legais e sociais. Devem ser investigados os condicionantes topográficos, hidrogeológicos e geotécnicos da área, distância de transporte dos centros geradores dos RSU, capacidade de disposição, condições de acesso e trafegabilidade, susceptibilidade de contaminação do lençol freático e disponibilidade de solos para recobrimento e proteção, dentre outros fatores.

Informações climáticas como precipitação pluviométrica, evaporação, direção dos ventos predominantes e regime de chuvas devem ser considerados na escolha do local de implantação de um aterro sanitário, pois esses dados influem no projeto, no planejamento e na operação do sistema. A geologia, hidrogeologia e geotecnia são os fatores mais importantes na análise ambiental da área, pois a partir desses dados estabelecem-se as medidas de projeto e monitoramento do aterro. Os dados geológicos e geotécnicos referemse aos parâmetros de resistência, deformabilidade e condutividade hidráulica dos terrenos de fundação e, os de higrogeologia, referem-se ao comportamento das águas subterrâneas, dentre outros.

A estimativa da capacidade de disposição do local na avaliação do custo - benefício do projeto é determinante na seleção da área. Segundo BENVENUTO (1995) a avaliação da capacidade de disposição deve ser realizada com base nos volumes futuros de resíduos 
a serem dispostos e de acordo com um projeto geométrico para utilização da área por um período de pelo menos por 10 anos para áreas já em utilização e, 20 anos, para áreas novas.

Os locais de disposição devem estar o mais afastado possível dos centros geradores, mas que não seja tão longe a ponto de inviabilizar o empreendimento. É desejável que o acesso ao local seja de preferência por vias pavimentadas de trânsito rápido, evitando-se as de transito intenso e congestionadas.

A CETESB (1993) preconiza algumas restrições na escolha do local de implantação de um aterro sanitário, a saber:

- distância mínima de 500m de residências, condicionada à direção dos ventos,

- distância mínima de $200 \mathrm{~m}$ de corpos d'água superficiais,

- condutividade hidráulica do subsolo inferior a $10^{-5} \mathrm{~cm} / \mathrm{s}$,

- lençol freático no mínimo a 1,5 metros da cota de fundo do aterro.

Segundo TIVERON et al. (1995), a escolha de áreas para a implantação de aterros sanitários, quase sempre, recai sobre regiões encaixadas, em que as redes de águas superficiais e subterrâneas convergem para um único ponto, o qual pode ser perfeitamente monitorado e tratado, podendo com isso ser evitado a eventual contaminação do lençol freático. Já o Manual de Gerenciamento Integrado do Lixo Municipal (1995) recomenda a utilização dos critérios apresentados na Tabela 2.1.1 para avaliação de possíveis áreas para instalação de aterros sanitários.

MELLO \& VAL (1994) comentam a existência de três linhas na concepção das áreas de disposição, que são: a) áreas impermeabilizadas ou totalmente drenadas de forma a evitar qualquer contato do líquidos percolados com as águas subterrâneas. b) áreas em que se admite certa infiltração do percolado, impondo fatores limitantes como a profundidade do lençol freático e as características hidráulicas dos solos de fundação. c) áreas em que se impõe o contato entre o percolado e o lençol freático, condicionando que o lençol freático não atinja cotas inferiores a um determinado valor. Os autores argumentam ainda, que a escolha da área de disposição a utilizar, em cada caso, deve ser baseada no tipo do resíduo a dispor e sua inter-relação com o meio físico.

ZUQUETTE et al. (1995) propuseram uma metodologia para classificar áreas frente a utilização como aterros sanitários, considerando um grupo de 32 atributos do meio físico. Esses atributos são analisados com objeto de classificar cada unidade da região como favorável, moderada, severa ou restrita. Esta classificação visa orientar o profissional no sentido de melhor selecionar os possíveis locais, bem como conhecer as zonas de maiores impactos ambientais, para as quais serão necessários investimentos mais significativos em estudos específicos e em recursos tecnológicos. 
Tabela 2.1.1- Critérios para avaliação das áreas para instalação de aterro sanitário, (Manual de Gerenciamento Integrado do Lixo Municipal, 1995).

\begin{tabular}{|c|c|c|c|}
\hline \multirow{2}{*}{$\begin{array}{c}\text { Dados } \\
\text { Necessários }\end{array}$} & \multicolumn{3}{|c|}{ Classificação das Áreas } \\
\hline & Recomendada & $\begin{array}{l}\text { Recomendada com } \\
\text { Restrições }\end{array}$ & $\begin{array}{c}\text { Não - } \\
\text { Recomendada }\end{array}$ \\
\hline Vida útil & $>10$ anos & \multicolumn{2}{|c|}{ (10 anos, a critério do órgão ambiental) } \\
\hline $\begin{array}{l}\text { Distância do centro } \\
\text { atendido }\end{array}$ & $>10 \mathrm{~km}$ & $10-20 \mathrm{~km}$ & $>20 \mathrm{~km}$ \\
\hline Zoneamento ambiental & \multicolumn{2}{|c|}{ Áreas sem restrições no zoneamento ambiental } & $\begin{array}{c}\text { unidades de } \\
\text { conservação ambiental } \\
\text { e correlatas }\end{array}$ \\
\hline Zoneamento urbano & Crescimento mínimo & $\begin{array}{l}\text { Crescimento } \\
\text { intermediário }\end{array}$ & crescimento máximo \\
\hline $\begin{array}{c}\text { Densidade } \\
\text { populacional }\end{array}$ & baixa & Média & alta \\
\hline $\begin{array}{l}\text { Uso e ocupação das } \\
\text { terras }\end{array}$ & \multicolumn{2}{|c|}{ áreas devolutas ou pouco utilizadas } & ocupação intensa \\
\hline Valorização das terras & boa & Média & alta \\
\hline $\begin{array}{c}\text { Aceitação da } \\
\text { população e de } \\
\text { entidades ambientais e } \\
\text { não-governamentais }\end{array}$ & boa & Razoável & inaceitável \\
\hline $\begin{array}{l}\text { Distância dos cursos } \\
\text { d'água }\end{array}$ & $>200 m$ & \multicolumn{2}{|c|}{$\begin{array}{l}<200 m \text {, com aprovação do órgão ambiental } \\
\text { responsável }\end{array}$} \\
\hline
\end{tabular}

\subsection{5 - Técnicas de execução de aterros}

A técnica de execução de um aterro sanitário, segundo TIVERON et al. (1995), consiste basicamente, na compactação do resíduo em células com altura variando de 2 a 4 metros e inclinação máxima do talude de 1:2. O resíduo deve ser espalhado e compactado pelo talude de baixo para cima, com 3 a 5 passadas do trator de esteira (SCHALCH et al. 1990), de modo a obter um peso específico mínimo de $10 \mathrm{kN} / \mathrm{m}^{3}$ (TIVERON et al. 1995). A compactação, muitas vezes, é também realizada pelo próprio tráfego dos equipamentos de transporte. O processo de compactação, além de aumentar a vida útil do aterro face ao maior volume disposto, auxilia na redução da compressibilidade, na migração de percolados e gases, podendo reduzir os riscos de incêndio.

Após a compactação, o resíduo deverá ser recoberto, diariamente, por uma camada que pode ser de solo, de materiais inertes processados ou não, de materiais processados de aterros antigos e materiais selecionados e triturados. A espessura dessa camada é função do tipo de aterro em execução e da própria composição dos resíduos e deve apresentar espessura mínima de $15 \mathrm{~cm}$. Esse recobrimento visa evitar o arraste de detritos pelo vento, bem como evitar o aparecimento de moscas, insetos, pequenos animais (aves e ratos) e outros vetores que possam provocar problemas de saúde pública.

Após o encerramento de uma parcela do aterro, complementa-se essa cobertura até atingir uma espessura de $40 \mathrm{~cm}$. Essa camada intermediária é importante na implantação final do sistema de drenagem superficial e de proteção dos taludes, etc. A 
estrutura final do aterro é constituída por um conjunto de células adjacentes e sobrepostas, como pode observar na Figura 2.1.2.

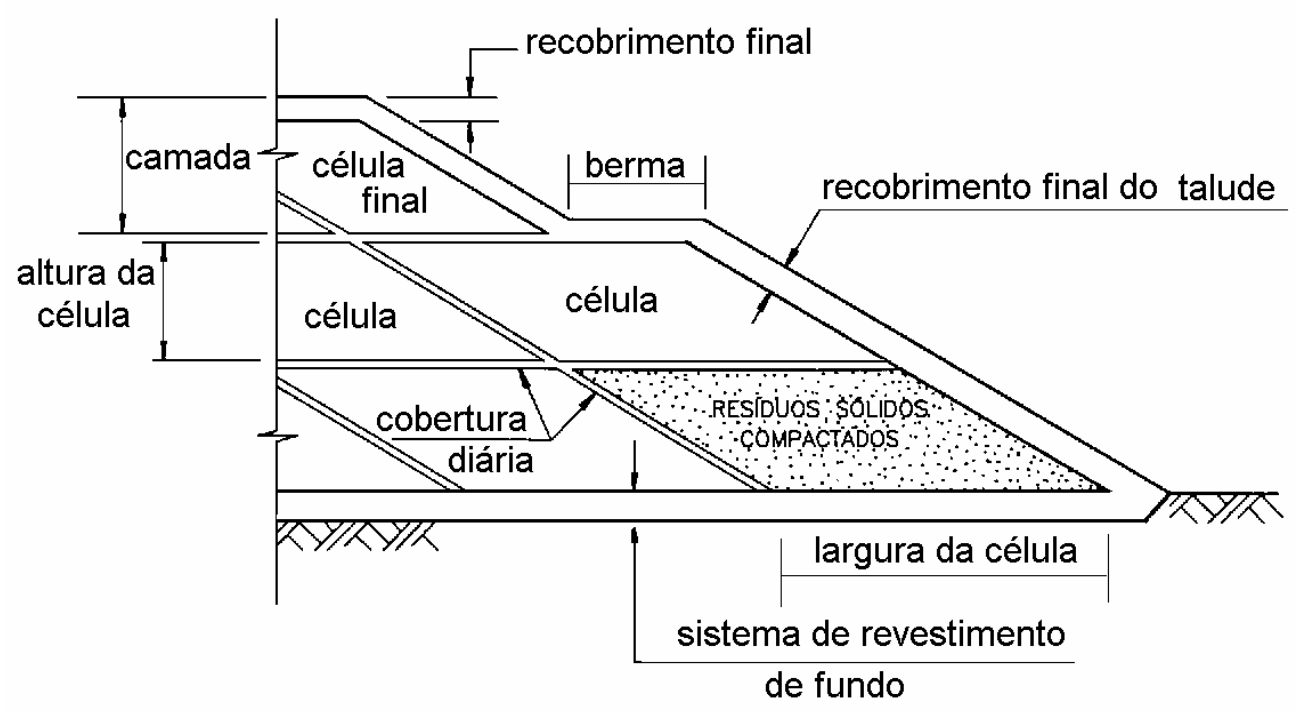

Figura 2.1.2 - Estrutura de um aterro sanitário (ENGECORPS, 1996).

A necessidade do emprego de recobrimentos diários é freqüentemente debatida, pois o volume perdido do aterro em virtude dessas camadas é bastante significativo. Este chega a representar entre 10 e $20 \%$ do volume total do aterro, constituindo um custo de implantação de cerca de 20 a 30\% do custo global do aterro (ENGECORPS, 1996). Outro aspecto importante, diz respeito a interferência provocada pelas camadas de recobrimento na permeabilidade vertical do aterro, podendo condicionar o aparecimento de lençóis suspensos de líquidos percolados e bolsões de gás.

QUERIO \& LUNDELL (1992) defende a utilização de geossintéticos para o recobrimento diário, onde os painéis são abertos no final dos trabalhos de cada dia e no dia seguinte são removidos para a continuação do procedimento de disposição. Segundo os autores acima, os painéis de geotêxteis podem ser usados aproximadamente 5 vezes no inverno e mais de 15 vezes em dias ensolarados. Já as lonas impermeáveis ("tarpaulins") apresentam um tempo de vida maior que os geotêxteis.

Após a conclusão dos trabalhos de disposição no aterro, uma camada final de recobrimento de argila compactada de no mínimo $60 \mathrm{~cm}$, deve ser executada, tendo como função, além das já citadas para a cobertura diária, a de diminuir a taxa de formação de percolado através da impermeabilização, controlar a saída de gases e a de servir de camada suporte para algum tipo de empreendimento que porventura venha ser construído no local, (Figura 2.1.3). Segundo BENSON et al. (1994) e DANIEL (1998), camadas adicionais, também, podem ser incorporadas na camada final, constituindo sistemas sofisticados com presença de camada de drenagem, camada para extração de gás, camada 
de solo vegetal etc (Figura 2.1.3). A camada superficial é tipicamente composta de solo vegetal não compactado, com espessura variando de 15 a $60 \mathrm{~cm}$, para permitir o desenvolvimento da vegetação na superfície e recuperação da área. Em seguida, vem uma camada de proteção constituída de mistura de solos e uma camada de drenagem, a qual pode ser constituída por areia, pedregulho, geotêxteis ou georede. Segundo VAN IMPE (1998b), a camada de drenagem é opcional, sendo necessária somente em locais onde existir um grande fluxo de água ou altas forças de percolação através da camada de proteção. A camada de impermeabilização (liner) é composta de camadas de solo compactado com baixa permeabilidade, geomembrana, geossínteticos ou combinações desses materiais (BENSON et al. 1994; VAN IMPE 1998b, DANIEL 1998), sendo que a espessura da barreira depende do material utilizado. Essa camada tem a função de minimizar a infiltração de água e saída de gases da camada de RSU. A camada de coleta de gases permite conduzir os gases para pontos de coleta e remoção e, em geral, é constituída por materiais como areia, geotêxteis e georede.

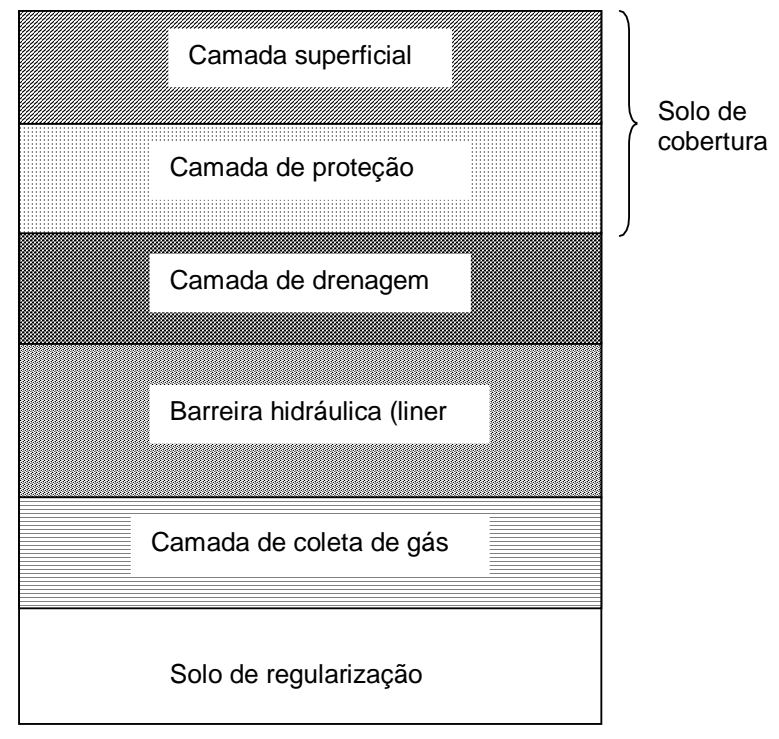

Figura 2.1.3 - Componentes do sistema de cobertura final de aterro sanitário, (DANIEL 1998).

A Figura 2.1.4 apresenta os diferentes tipos de sistemas de cobertura final mínimo propostos segundo recomendações e regulamentações de alguns países (MANASSERO et al. 1996; VAN IMPE 1998b e MANASSERO et al. 1998).

No Brasil, ainda são raros os aterros que recebem esquemas de recobrimento sofisticados, como os citados anteriormente. Em geral, os recobrimentos aqui adotados caracterizam-se por uma camada de solo argiloso pouco erodível, de espessura variando de 
0,60 a 1,5m e sobre esta é feito o plantio de grama (ENGECORPS, 1996). Este tipo de revestimento final representa cerca de $5 \%$ do custo total do aterro.

Itália

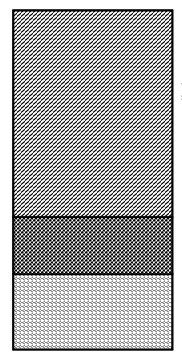

Classe I

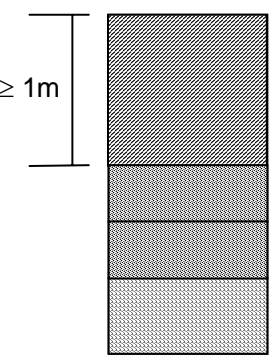

Classe II
Alemanha

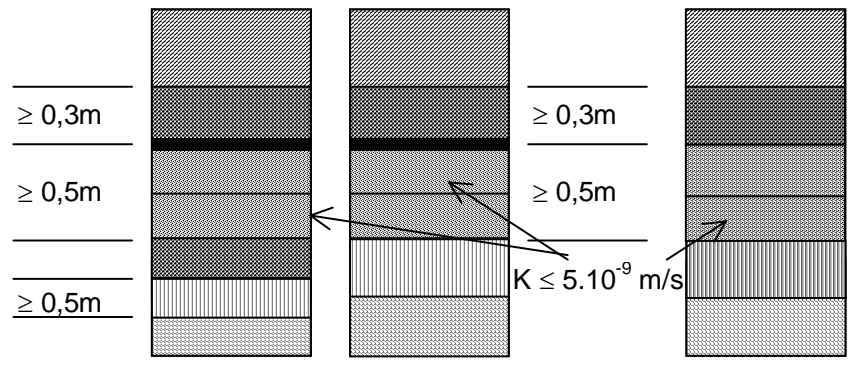

Resíduo Perigoso

Classe II

Classe I
USA (EPA)

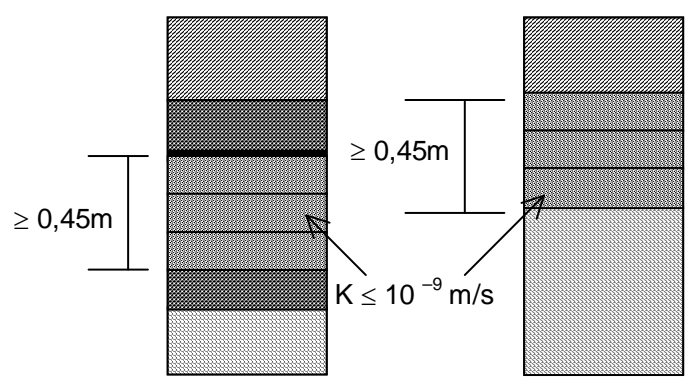

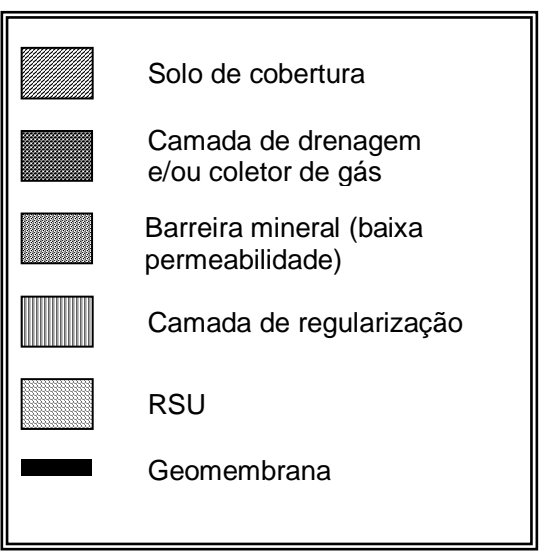

Figura 2.1.4 - Sistema de cobertura final mínimo segundo diferentes recomendações e regulamentações (MANASSERO et al. 1996, VAN IMPE 1988b, MANASSERO et al. 1998).

A escassez cada vez maior de áreas para disposição de resíduos sólidos tem motivado o desenvolvimento de processos e tecnologias que permitam reduzir o volume lançado nos aterros, aumentando assim a vida útil desses. Disso resulta, além da compactação convencional dos resíduos no aterro, a adoção de tecnologias como trituração ("shredding") e enfardamento ("balling") dos RSU.

A compactação dinâmica do RSU é um fator importante no processo de operação dos aterros, pois além de reduzir volume, melhora as características mecânicas dessas estruturas no que refere-se ao aumento de densidade e redução de recalques (VAN IMPE \& BOUAZZA, 1996).

A trituração consiste no processamento dos resíduos em equipamentos trituradores antes de serem dispostos no aterro sanitário. Uma das vantagens dessa técnica é a 
obtenção de maiores densidades após compactação, a aceleração dos processos de degradação bioquímica e a necessidade de menor quantidade de material de recobrimento (DEZEEUW et al. 1976).

Os equipamentos para trituração são muito variáveis face a diversos fatores, dos quais pode destacar-se, dimensões que se deseja obter após trituração, produção diária, sistema de alimentação e descarga, tipo de resíduo a ser processado, etc. Informações mais detalhadas do processo de trituração, equipamento e custo $\mathrm{x}$ produtividade podem ser encontradas em ENGECORPS (1996).

O processo de enfardamento dos resíduos caracteriza-se pela compactação e prensagem prévia dos materiais em câmaras apropriadas, gerando fardos auto-sustentáveis e amarrados, os quais são transportados e dispostos no aterro sanitário. As dimensões dos fardos são função do equipamento empregado, podendo, no entanto, terem dimensões

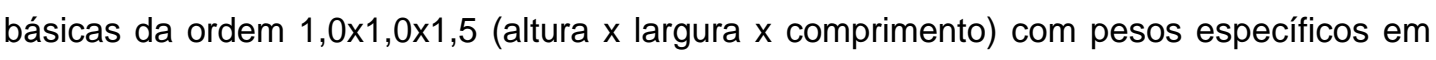
torno de $12 \mathrm{kN} / \mathrm{m}^{3}$. Esse processo permite uma redução na geração do líquido percolado e gases, redução da dispersão de papéis e odores, maior facilidade de transporte, descarga e empilhamento e redução dos recobrimentos diários em cerca de $65 \%$.

\subsection{6 - Elementos estruturais básicos de um aterro}

A seguir apresentam-se os elementos básicos que devem ser considerados no projeto e na operação de aterros sanitários de resíduos sólidos urbanos.

\subsubsection{1 - Tratamento de fundação e liner de fundo}

O tratamento de fundação de um aterro sanitário depende das condições geológicogeotécnicas e hidrogeológicas da área selecionada e da capacidade prevista para o mesmo, as quais são determinadas durante o projeto básico.

Em geral, os subsolos dos aterros e de suas adjacências, necessitam de tratamento devido às características geotécnicas insatisfatórias de suas camadas. Muitas vezes, ocorrem solos moles de baixa capacidade de carga, que devem ser removidos e substituídos. Tratamentos de trincas e fraturas em rochas do subsolo e de encostas adjacentes, também são recomendados dependendo das condições das descontinuidades (dimensões, características dos materiais de preenchimento, etc).

O tratamento de fundação de aterros sanitários, de acordo com TIVERON et al. (1995), envolve a captação e drenagem de todas as nascentes e cursos d'água que porventura existam na área e a impermeabilização ("liner") do terreno de fundação do aterro. 
A drenagem de nascentes é feita a partir da execução de drenos constituídos por valas preenchidas por areia e brita, envoltas ou não em manta-geotêxtil, complementada, em alguns casos, por tubos perfurados de concreto armado. Em geral, esses drenos são iniciados junto às nascentes e instalados em valas escavadas ao longo das linhas de drenagem natural (Figura 2.1.5), TIVERON et al. (1995).

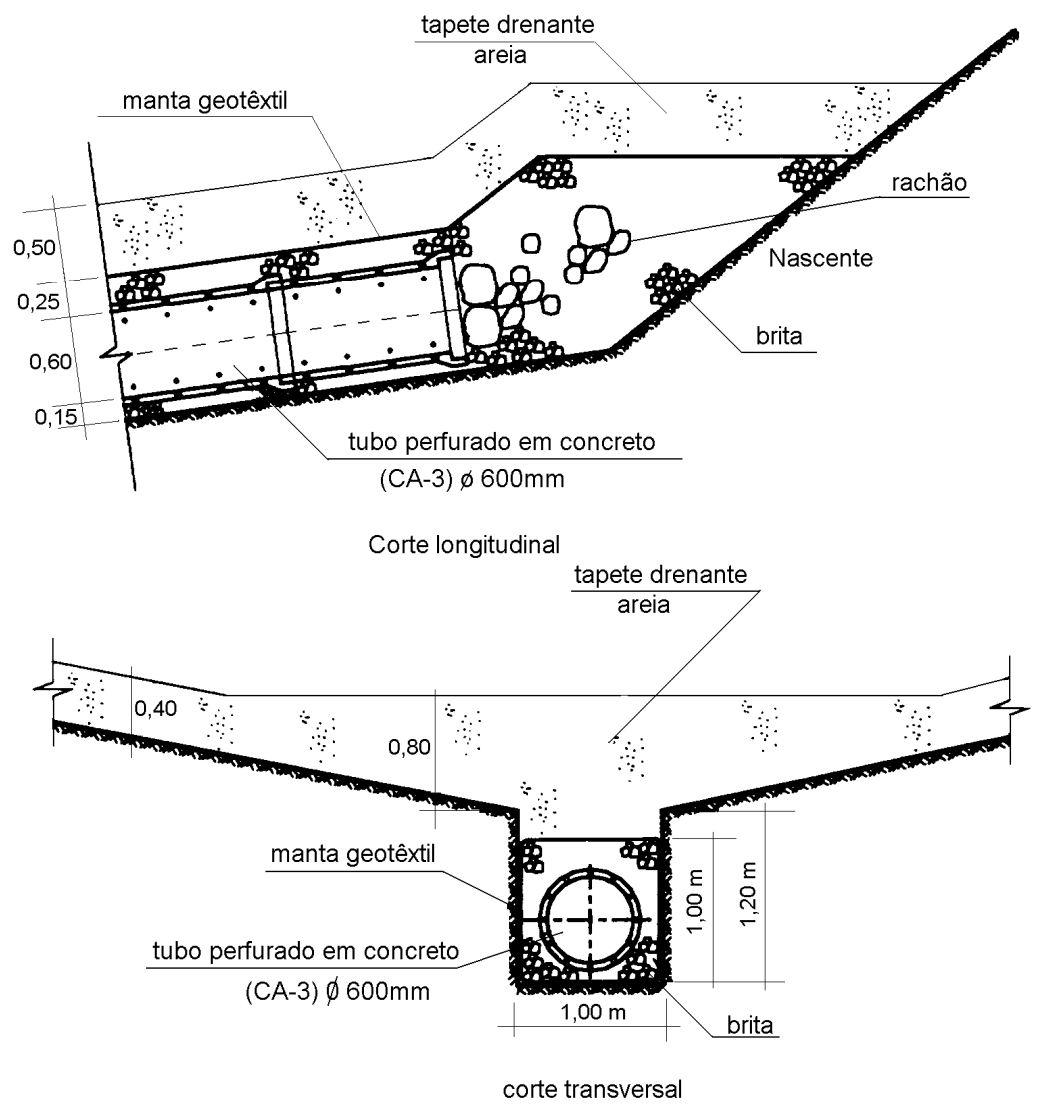

Figura 2.1.5 - Detalhes típicos de drenagem de nascentes (TIVERON et al. 1995).

A CETESB (1993), levando em consideração as particularidades do local previsto para implantação de aterro sanitário, apresenta algumas condições mínimas a serem observadas para áreas de disposição de resíduos classe II, na qual enquadra o resíduo sólido urbano, (Figuras 2.1.6 e 2.1.7).

Para terrenos de fundação que apresentam permeabilidade inferior a $10^{-6} \mathrm{~cm} / \mathrm{s}$ e nível de água a uma profundidade igual ou superior a 3,0m, não há necessidade de impermeabilização da superfície do terreno natural. Por outro lado, para subsolos mais permeáveis, com $\mathrm{K} \leq 10^{-4} \mathrm{~cm} / \mathrm{s}$ e posição do nível de água igual ou superior a 1,5m, há a necessidade de impermeabilização da fundação do aterro. A ABNT (Projeto de norma PN 1:603.06 - 006) exige que o liner de base das células, apresente permeabilidade inferior a $10^{-7} \mathrm{~cm} / \mathrm{s}$ e espessura mínima igual a $1,0 \mathrm{~m}$. 


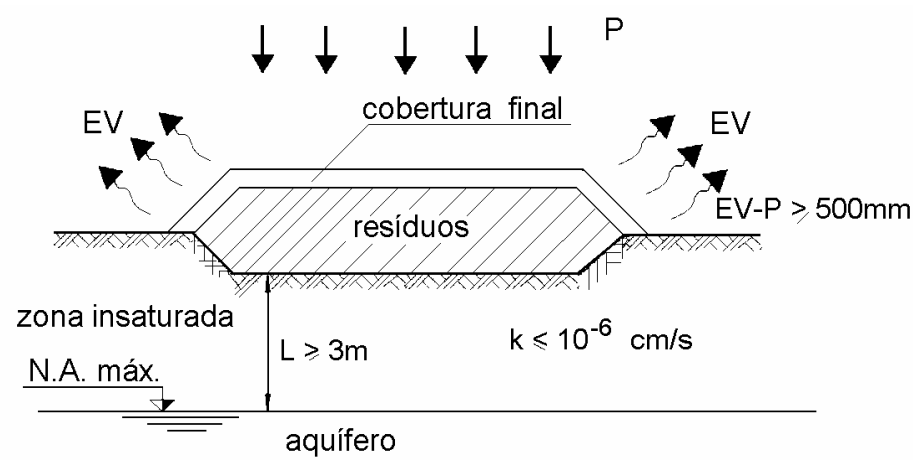

a) Condições climáticas e hidrológicas favoráveis

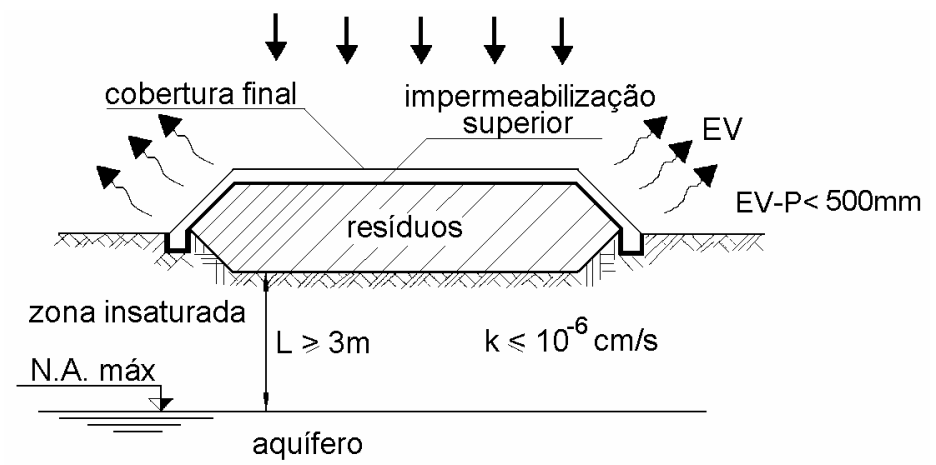

b) Condições climáticas insatisfatórias e hidrológicas favoráveis

Figura 2.1.6 - Esquema de aterro para resíduos sólidos urbanos, $L \geq 3,0 \mathrm{~m}$ e $k \leq 10^{-6} \mathrm{~cm} / \mathrm{s}$, (CETESB 1993).

Segundo TIVERON et al. (1995), o sistema de liner da fundação de aterros sanitários, em São Paulo, é executado após a drenagem das nascentes, sendo utilizado para tal fim uma camada de solo argiloso compactado, com $0,60 \mathrm{~m}$ de espessura. A compactação desta camada é controlada através de ensaios específicos, visando obter um grau de compactação mínimo de $95 \%$ e teor de umidade dentro da faixa de $0 \pm 2 \%$ da umidade ótima do proctor normal. Acima da camada de solo argiloso, emprega-se uma geomembrana de polietileno (HDPE) com espessura de $2 \mathrm{~mm}$ e sobre esta, é executada uma outra camada de solo argiloso com objetivo de recobrir e proteger a manta. Essa camada possui espessura mínima de 0,60m , sendo compactada levemente pelo próprio trânsito dos equipamentos. A Figura 2.1.8 apresenta um esquema geral da impermeabilização da fundação, drenagem de nascentes, bem como a drenagem interna adotada para o aterro sanitário Bandeirantes, localizado na cidade de São Paulo. 


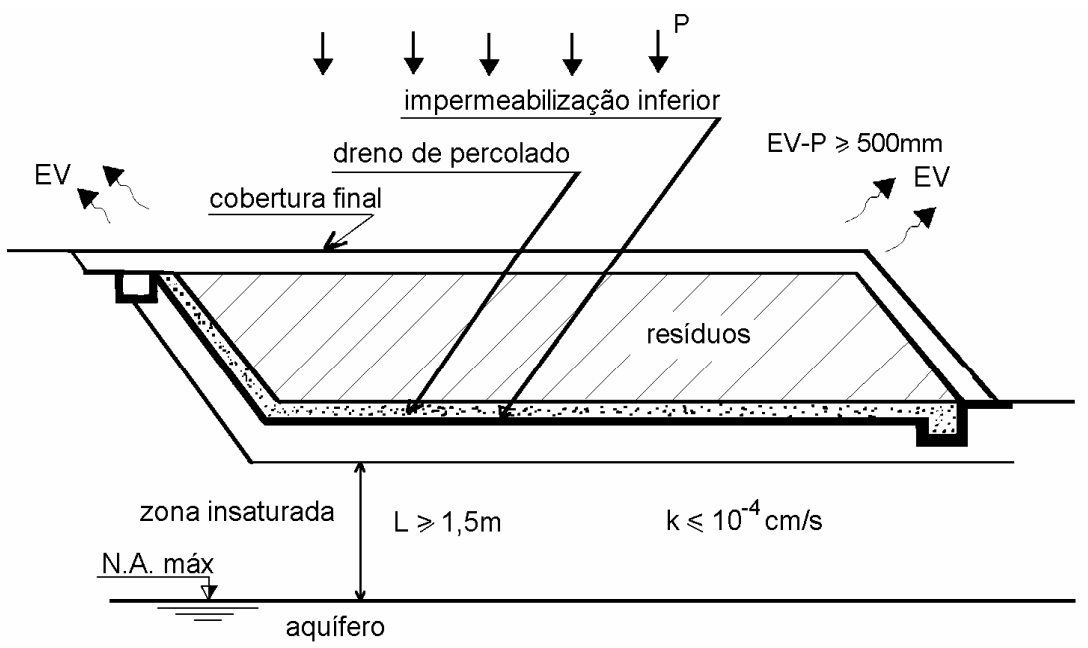

a) Condições climáticas favoráveis e hidrológicas insatisfatórias

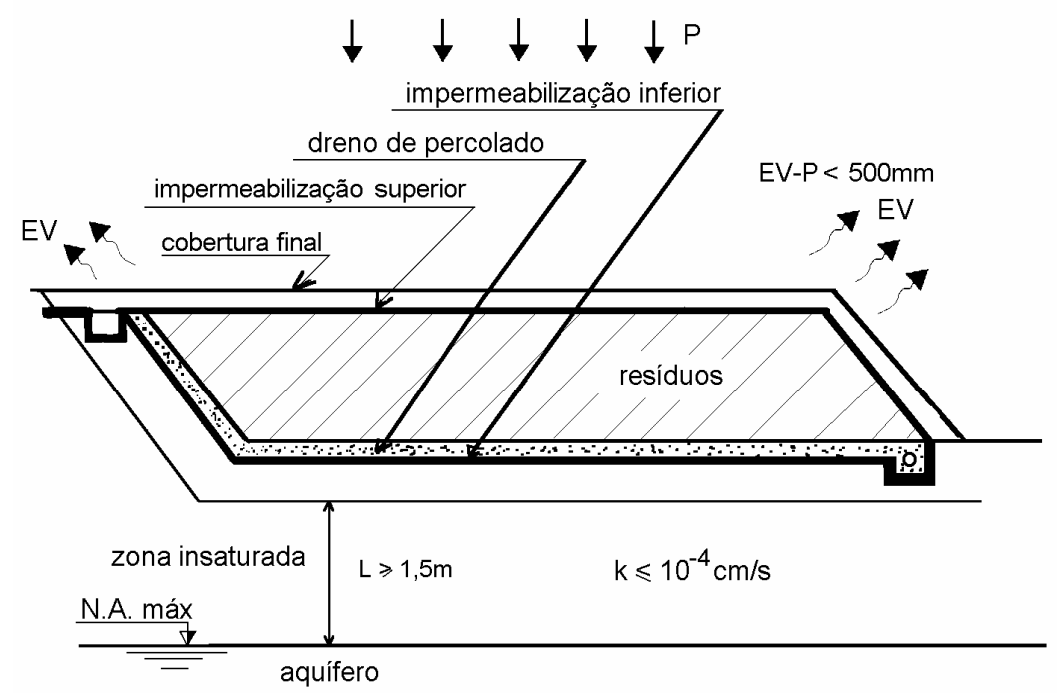

b) Condições climáticas e hidrológicas insatisfatórias

Figura 2.1.7 - Esquema de aterro para resíduos sólidos urbanos, $L \geq 1,50 \mathrm{~m} e$ $k \leq 10^{-4} \mathrm{~cm} / \mathrm{s}$ (CETESB, 1993).

Os liners são dispositivos utilizados quando se deseja reter ao máximo possível a percolação de um líquido, de forma que ele não atinja as águas e solo natural. Assim, devem apresentar estanqueidade, durabilidade, resistência mecânica, resistência a intempéries e compatibilidade com os resíduos a serem aterrados.

Existem vários tipos de liners, dentre eles destacam-se os naturais, os de argila compactada e as geomembranas (polietileno, PVC, asfáltica). A escolha de um ou de outro tipo é influenciada pelo uso a que se destina, pelo ambiente físico, pela química do percolado e pela taxa de infiltração. 


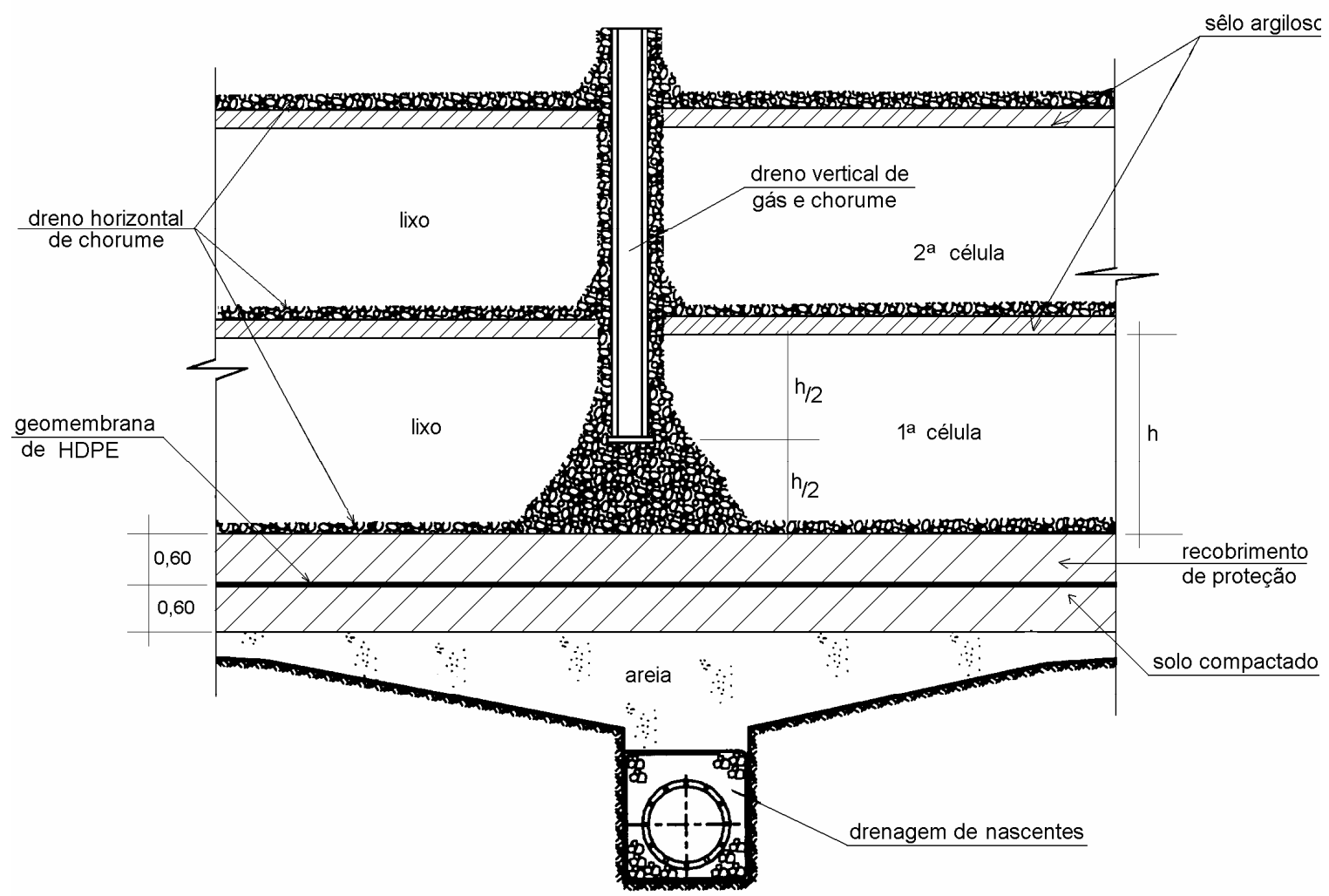

Figura 2.1.8 - Detalhes da impermeabilização da fundação, drenagem de nascentes e drenagem interna do aterro sanitário Bandeirantes (TIVERON et al. 1995).

Os liners naturais são formações de solos argilosos de baixa condutividade hidráulica, a qual deve situar-se entre $10^{-6}$ a $10^{-7} \mathrm{~cm} / \mathrm{s}$ (DANIEL, 1993). Esses solos fornecem a base protetora quase ideal para algumas situações, onde a argila pode atenuar alguns contaminantes, por processos de sorção e precipitação (LEITE, 1995).

Os liners simples de argila compactada podem apresentar condutividade hidráulica adequada, quando executados empregando boa prática de engenharia geotécnica e bom controle de qualidade. Esses liners são considerados resistentes a longo prazo com respeito às influências químicas dos percolados e podem apresentar alto potencial de retenção do contaminante. Por outro lado, a contração das camadas de argila pode resultar em trincas de contração que pode diminuir a eficiência da barreira (ABARZUA \& NAREA 1992; JESSBERGER, 1995; DANIEL, 1998).

A baixa condutividade hidráulica de laboratório, é condição necessária para o bom funcionamento da barreira, mas não é a condição suficiente, visto que as condições de campo, em geral, não são as mesmas que as determinadas em laboratório. Outros fatores que deverão ser considerados referem-se a compatibilidade química entre o percolado e a capa de argila e o transporte por difusão molecular (MANASSERO 1997 e MANASSERO et al. 1998). 
Autores como JESSBERGER (1995) e GRAY (1995) dentre outros, têm-se preocupado em estudar os mecanismos de transporte em barreiras hidráulicas. Em casos de barreiras com condutividade hidráulica muito baixa (menor que $10^{-9} \mathrm{~cm} / \mathrm{s}$ ), o processo de transporte dominante é por difusão molecular (GRAY, 1995). Já o processo de advecção torna-se dominante para condutividade hidráulica maior que $10^{-6} \mathrm{~cm} / \mathrm{s}$ e para condutividade entre $10^{-6}-10^{-9} \mathrm{~cm} / \mathrm{s}$ atuam tanto a difusão como a advecção.

Segundo a CETESB (1993) o solo argiloso usado para a confecção de liner deve apresentar as seguintes características:

- classificação $\mathrm{CL}, \mathrm{CH}, \mathrm{SC}$ ou OH

- condutividade hidráulica menor que $10^{-7} \mathrm{~cm} / \mathrm{s}$

- porcentagem de material fino, passando na peneira \#200 maior que $30 \%$

- $L P \geq 30 \%$ e IP $\geq 15 \%$

- $\mathrm{pH} \geq 7$

De uma forma cada vez mais constante, tem-se empregado os liners sintéticos compostos (solo/ geomembrana) para impermeabilização das bases dos aterros sanitários. Esses liners são constituídos por geomembrana intercalada nas camadas de argila compactada formando estruturas compostas, onde cada camada tem uma finalidade (drenagem, proteção, impermeabilização) (TCHOBANOGLOUS et al. 1993; BONAPARTE, 1995; DANIEL \& BOWDERS, 1996). A Figura 2.1.9 apresenta alguns sistemas de liners de base para aterros de resíduos sólidos urbanos propostos segundo regulamentações e recomendações de diferentes países (MANASSERO 1997, VAN IMPE, 1998b; MANASSERO et al. 1998). Nesta figura pode ser observado que os diversos países adotam diferentes sistemas de liners de fundo para aterros sanitários e pode-se observar também uma clara tendência de emprego de liners compostos (argila compactada/ geomembrana). A regulamentação francesa considera a possibilidade de uso de uma simples geomembrana se o terreno natural apresentar uma permeabilidade menor $10^{-6} \mathrm{~m} / \mathrm{s}$ e espessura maior que $5 \mathrm{~m}$. Similarmente, as exigências mínimas propostas pela Bélgica e Reino Unido referem-se a uma camada de argila compactada com espessura maior ou igual a $1 \mathrm{~m}$.

Segundo VAN IMPE (1998b) e AREIAS et al. (1998), os sistemas de impermeabilização de base de aterros nos Estados Unidos, em geral, são definidos independentemente das condições do terreno natural, ao passo que em alguns países europeus essas características são observadas. Os autores argumentam ainda que, embora os sistemas de liners prescrito por normas sejam importantes por promover um nível mínimo de proteção para o meio ambiente, eles podem não serem suficientes para assegurar o impacto ambiental mínimo em alguns casos. Portanto, deve-se atentar para os padrões de funcionamento e qualidade de execução dos liners. 

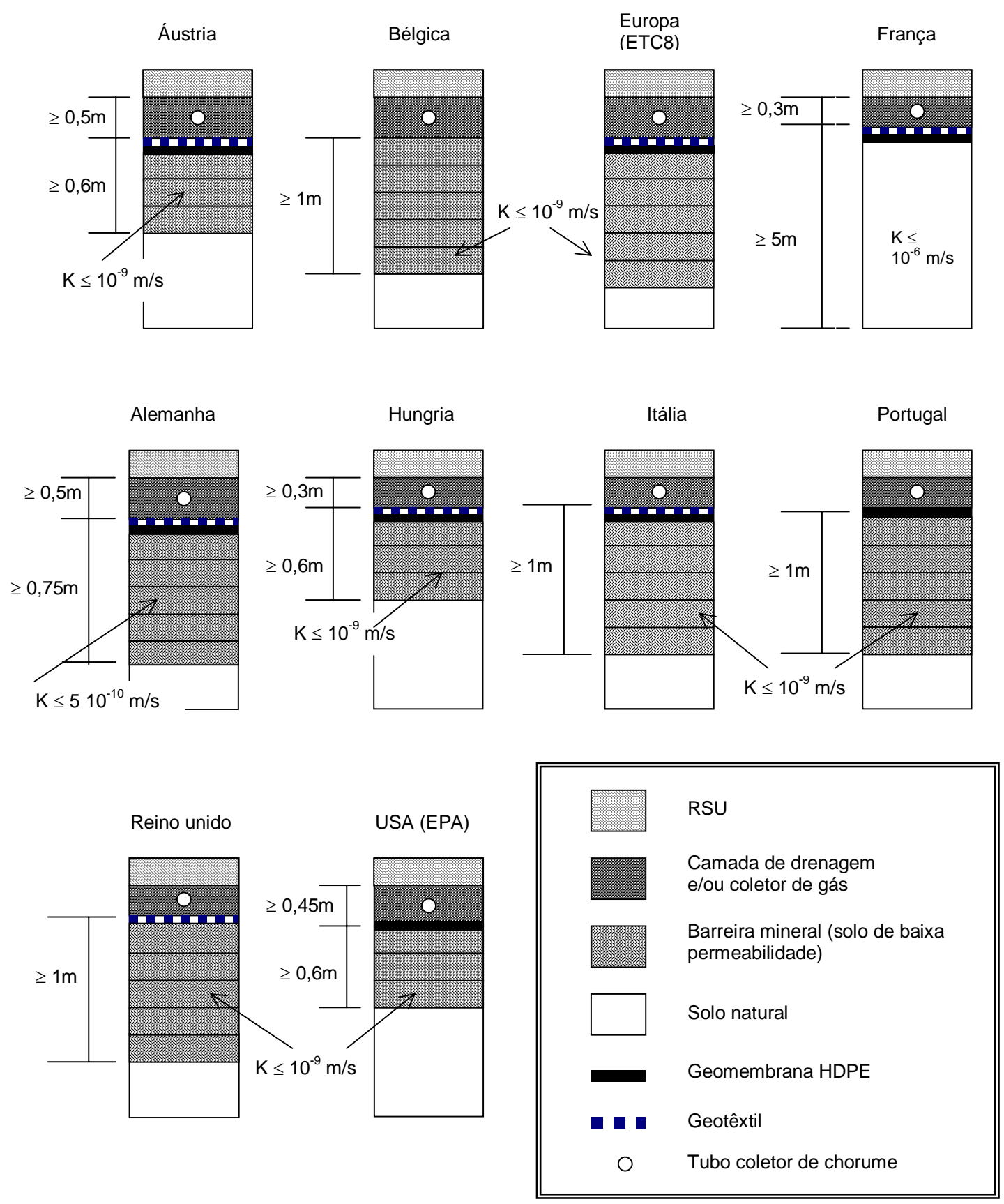

Figura 2.1.9 - Sistemas de liners de base para aterros de resíduos sólidos urbanos segundo recomendações de alguns países (VAN IMPE 1998b e MANASSERO et al. 1998).

A idéia de combinar os revestimentos, leva em conta, além dos aspectos construtivos e operacionais, os relacionados com a alteração das características das camadas de solo devido à infiltração do líquido percolado e às altas temperaturas no interior do aterro (GOURC et al. 1998). As geomembranas por sua vez, estão sujeitas a danos 
(furos e rasgos) durante a instalação e início da operação do aterro. Além disso, certos tipos de mantas estão sujeitas ao ataque dos líquidos percolados, como as de PVC e asfáltica. Já as de polietileno apresentam maior resistência à degradação química, à hidrólise, à degradação biológica e baixa resistência à termo-oxidação (VIDAL et al. 1994; ABRAMENTO, 1995 e SIMPSON, 1995).

De acordo com PEGGS (1992), as geomembranas de PVC têm se mostrado eficientes em aterros de resíduos sólidos municipais e perigosos, sendo capazes de conterem a lixívia sem sinais de degradação. $O$ autor argumenta ainda que, enquanto as geomembranas de HDPE possuem resistência ao puncionamento maior que as de PVC, esta última é muito mais maleável, podendo moldar-se às superfícies não uniformes.

MELLO \& VAL (1994) enfocam a necessidade de conhecer o comportamento dos materiais sintéticos a longo prazo, enfatizando a compatibilidade química dos materiais e o transporte por difusão molecular.

Ressalta-se, também, que as superfícies de contato entre os geossintéticos e outros materiais, na maioria das vezes, constituem uma superfície potencial de deslizamento. Pesquisadores como DEL-GRECO \& OGGERI (1993), PASQUALINI et al. (1993), MASADA et al. (1994); BIENER et al. (1995) e MANASSERO et al. (1996) têm procurado levantar os parâmetros de resistência das interfaces de diversos materiais com os geossintéticos, onde geralmente são usados os ensaios de cisalhamento direto. De acordo com CARROLL \& CHOUERY-CURTIS (1991) o ângulo na interface geossintético-solo ou geossintéticogeossintético varia entre 8 a $25^{\circ}$.

\subsubsection{2 - Drenagem de gases e de líquidos percolados}

Os aterros sanitários devem possuir um sistema de drenagem interna eficiente para permitir a dissipação dos gases e remoção, captação e condução dos líquidos percolados aos sistemas de reservação e tratamento. Os dispositivos utilizados são os drenos de fundação, drenos horizontais e drenos verticais.

O sistema de drenagem de fundação deve coletar e conduzir os líquidos percolados, através de drenos internos de brita com tubos perfurados, até o local de acumulação, de onde serão enviados a um tratamento adequado. Segundo TCHOBANOGLOUS et al. (1993), a coleta de líquidos percolados envolve um sistema de liner para impermeabilização da base do aterro e uma rede de canais e tubos interligados, localizados na base de planos inclinados de modo a formar divisores de água, que conduzem os líquidos percolados às canaletas e, posteriormente, aos tubos de drenagem, (Figura 2.1.10). 

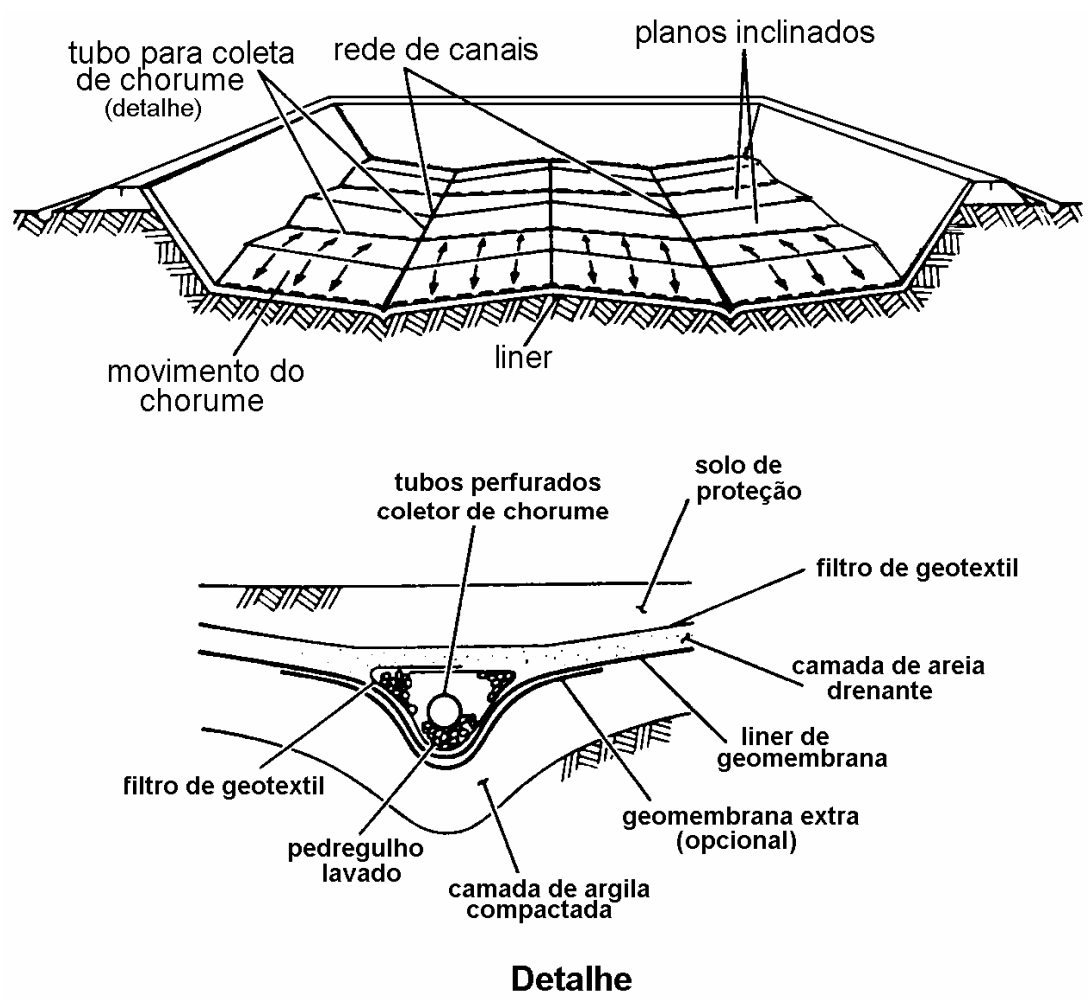

Figura 2.1.10 - Sistema de drenagem de líquidos percolados (TCHOBANOGLOUS et al. 1993).

Os drenos verticais devem ser dispostos em diferentes pontos no aterro, geralmente distanciados de 50 a 100m um dos outros, sendo construídos pela superposição de tubos de concreto ou PVC perfurados e revestidos com brita, que vão desde a camada de cobertura superficial até o fundo do aterro (LEITE 1991; TIVERON et al. 1995).

Face a elevada deformabilidade dos aterros sanitários, TIVERON et al. (1995) exibem soluções adotadas em aterros na cidade de São Paulo, buscando garantir a integridade e continuidade destes elementos ao longo do aterro. São apresentadas duas soluções: os drenos de concreto com 1,20m de diâmetro e os denominados drenos tipo "Ranzini" (Figura 2.1.11). Os drenos de 1,20m de diâmetro são executados com tubos perfurados de concreto armado, sendo os mesmos envolvidos por uma camada de rachão com espessura mínima de $20 \mathrm{~cm}$ para sua proteção. Já os drenos tipos "Ranzini" apresentam diâmetro externo de 2,0m, compostos por um tubo de concreto armado perfurado de 0,60m, envolto por uma camada anelar de rachão de 0,70m de espessura, a qual é confinada por uma tela metálica. Em muitos locais na extremidade superior desses drenos e após a conclusão do aterro ou parte dele, são instalados queimadores de gases, que se situam a uma altura mínima de 3,0m acima da superfície do terreno.

Associados aos drenos verticais devem ser adotados os drenos horizontais os quais facilitam a drenagem da massa do resíduo. Estes drenos deverão ser implantados junto ao topo da camada de solo da célula subjacente a partir da escavação de valas que as interligam aos drenos verticais. As valas devem ser preenchidas com rachão até uma altura 
de cerca de 1,20 m, sendo o trecho restante recomposto com RSU compactado. A Figura 2.1.12 apresenta, de forma esquemática esses drenos, bem como os drenos de fundação.

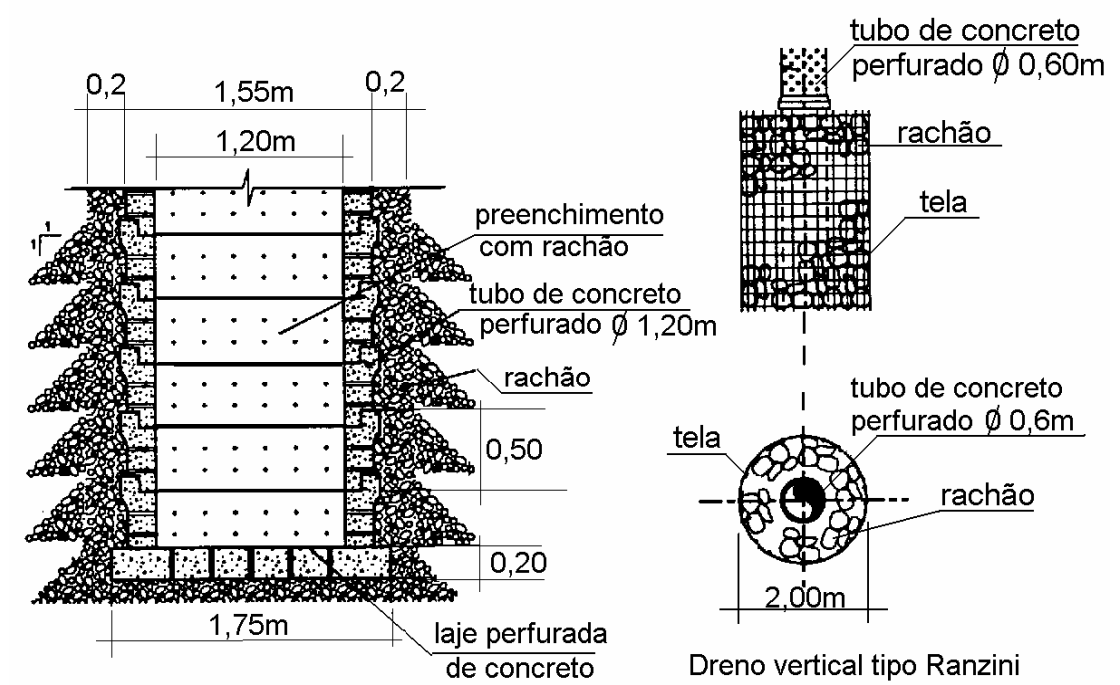

Dreno vertical de gás e chorume

Figura 2.1.11 - Drenos verticais dos aterros sanitários, (TIVERON et al. 1995).
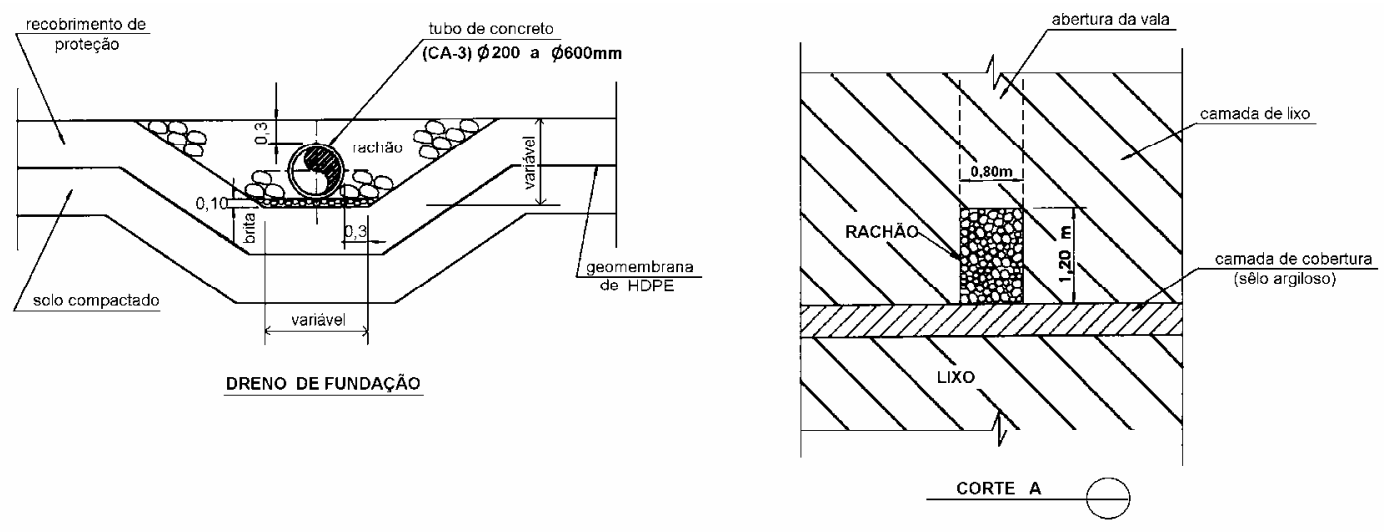

DRENOS HORIZONTAIS DE CHORUME

Figura 2.1.12 - Drenos de fundação e drenos horizontais (TIVERON et al. 1995).

Os materiais usados na construção dos sistemas de drenagem devem manter suas características e funcionalidade ao longo da vida do aterro. Considerações particulares deverão ser dadas para a possível formação de filmes biológicos que aderindo na superfície dos grãos podem obstruir total ou parcialmente os poros, dificultando a drenagem (MASSACCl et al. 1993).

\subsubsection{3 - Drenagem e proteção superficial}

As águas provenientes da precipitação direta sobre o aterro, bem como as do escoamento superficial das áreas adjacentes, tendem a percolar através da massa do RSU. 
Isso pode causar erosões e carreamento de poluentes que, juntamente com os líquidos de decomposição do RSU, constituem material de alta carga poluidora. Assim, os aterros devem ser dotados de sistemas de drenagem superficial, os quais visam interceptar e desviar o escoamento das águas pluviais para fora da área do aterro, diminuindo desta forma, o volume de líquidos percolados, (LEITE, 1991). Esse sistema é geralmente constituído por canaletas de berma, descidas d'água no talude, que de acordo com TIVERON et al. (1995), devem ser constituídos por elementos flexíveis, tais como mantasgabião, brita, rachão, etc, separadas das camadas de recobrimento por mantas-geotêxtil (Figura 2.1.13). Nas regiões de contorno e adjacências dos aterros são executados dispositivos convencionais de drenagem em concreto armado, como canaletas, escadas hidráulicas, etc.
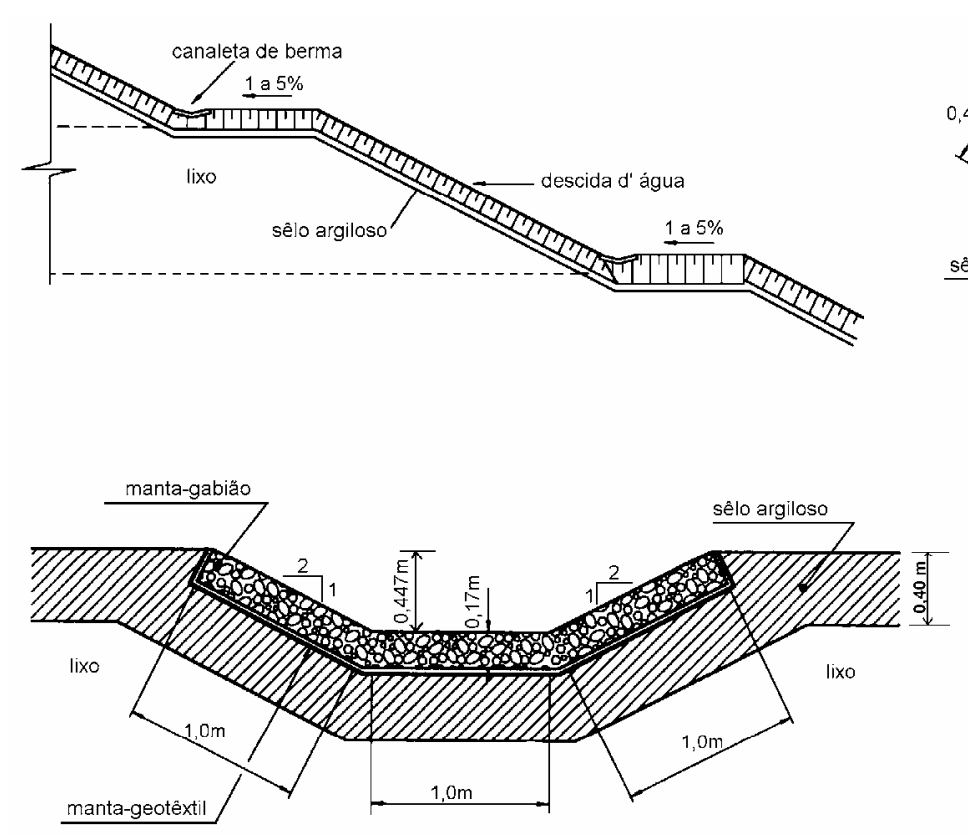

DESCIDA DE ÁGUA NO TALUDE

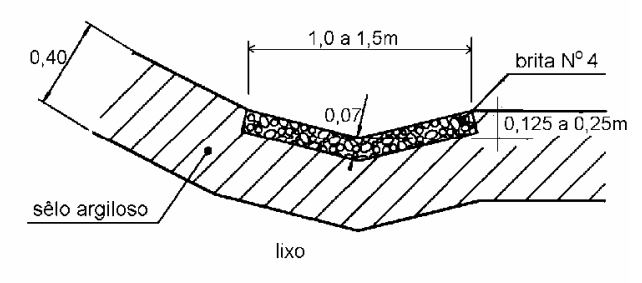

CANALETA DE BERMA

Figura 2.1.13 - Elementos de drenagem superficial de aterro sanitário (TIVERON et al.1995).

A proteção superficial dos taludes e bermas dos aterros sanitários é feita através do plantio de grama, o qual pode ser por meio de placas, semeadura direta ou hidrosemeadura, ou de arbustos de pequeno porte.

\subsubsection{4 - Instrumentação}

O monitoramento de um aterro de resíduo sólido urbano é fundamental pois permite conhecer o modelo de comportamento e o funcionamento do maciço, bem como levantar os parâmetros para idealização de projetos mais econômicos e seguros. 
Segundo CEPOLLINA et al. (1994), o monitoramento de aterros sanitários em geral, restringe-se às observações topográficas dos recalques $\mathrm{e}$, eventualmente, no monitoramento ambiental. Atualmente, frente às grandes alturas dos aterros sanitários e à ocorrência de alguns casos de deslizamentos, tornou-se imprescindível o maior conhecimento dos fatores condicionantes do comportamento desses aterros. Dessa forma, vários parâmetros são constantemente observados, como pressões internas, deslocamentos horizontais e verticais, nível de água, pressões de gás, movimento do solo de fundação, temperatura, etc.

De forma geral, os instrumentos comumente utilizados no monitoramento dos aterros sanitários estão apresentados na Figura 2.1.14 e são:

- marcos superficiais: permitem avaliar os deslocamentos horizontais e verticais do aterro através do controle topográfico .

- medidores de recalque (placas): permitem avaliar os recalques das camadas a diversas profundidades, a partir do terreno de superfície.

- piezômetros: permitem avaliar as pressões internas do maciço devido a presença dos gases e percolados (líquido percolado).

- termopares: permitem medir a temperatura em profundidade.

Os piezômetros tipo Casagrande, em geral, apresentam problemas de operação em decorrência da presença de gás, que gera borbulhamento e/ou elevação do volume de líquidos percolados falseando as medidas de pressão líquida (CEPOLLINA et al. 1994). Diante do desempenho insatisfatório, esses piezômetros são substituídos por piezômetros tipo Vector, os quais permitem medir as pressões de gás e de líquidos percolados, separadamente, por um processo de sifão, (Figura 2.1.14). A descrição e detalhes do instrumento podem ser encontrados em VAL et al. (1994) e ANTONIUTTI NETTO et al. (1995).

Segundo CODUTO \& HUITRIC (1990), inclinômetros com conecção Sondex (fabricado pela "Slope Indicator Company) também tem sido utilizados para monitorar os movimentos horizontais em aterros sanitários, os quais permitem medir maiores deslocamentos em virtude da maior flexibilidade do tubo de revestimento em plástico corrugado. A grande problemática no uso desses instrumentos reside na obstrução dos furos de inspeção devido aos grandes deslocamentos do maciço.

De acordo com a ENGECORPS (1996) as leituras dos instrumentos, em situações normais de controle e acompanhamento, devem ser realizadas em períodos de 15 a 30 dias. Em casos onde as condições de estabilidade estão comprometidas ou ocorrem períodos de intensas precipitações as leituras deverão ser tomadas em períodos mais curtos (semanais, diárias). Os dados do monitoramento deverão ser correlacionados com a estabilidade do maciço, sendo importante subsídio para a análise de segurança e identificação de níveis de alerta quanto a integridade dos aterros sanitários. 


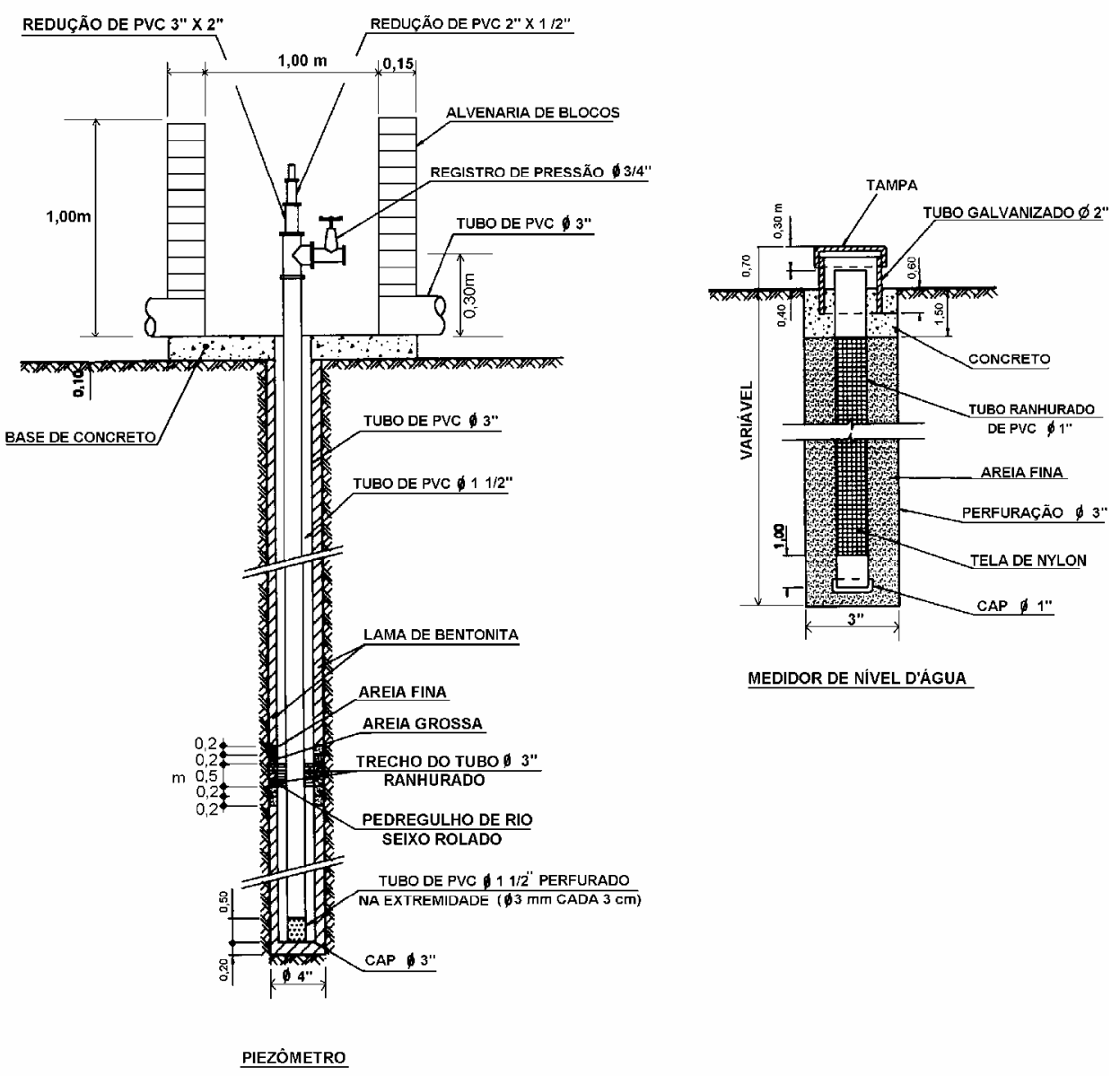

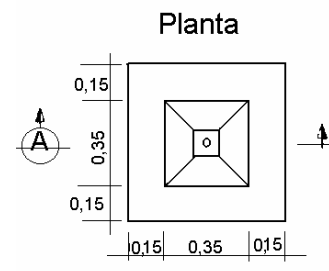

Escala 1:10

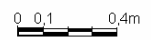

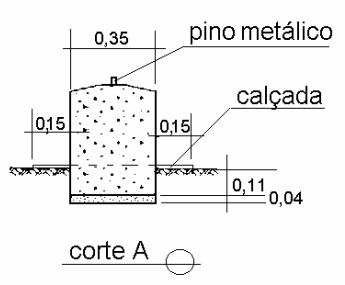

Marco superficial

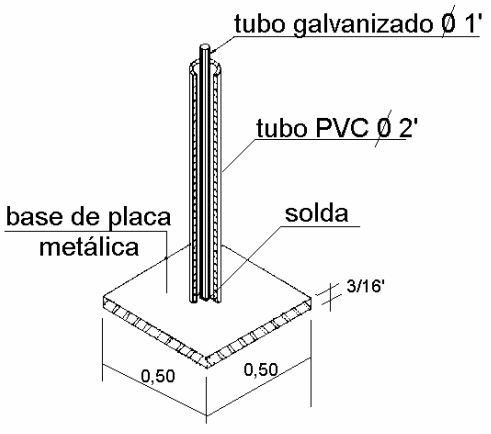

Medidor de recalque

Figura 2.1.14 - Instrumentação (ENGECORPS, 1996). 


\section{2 - PROPRIEDADES BIOLÓGICAS DOS MACIÇOS DE RESÍDUOS SÓLIDOS URBANOS}

\subsection{1 - Introdução}

Os aterros de resíduos sólidos urbanos, ao contrário dos maciços de solos compactados, são constituídos por diferentes tipos de componentes (metais, plásticos, papéis, vidros, madeiras, têxteis, resíduos orgânicos, pedras e solos) que, quando depositados, interagem formando um maciço heterogêneo e poroso com comportamento peculiar. Além da composição heterogênea dos constituintes, a degradação dos mesmos com o passar do tempo é considerada um ponto relevante no comportamento desses materiais.

Os resíduos transformam-se, ao longo do tempo, por fenômenos físicos, químicos e biológicos. As transformações biológicas promovem modificações de muitos componentes sólidos, em biogás e em líquidos, acarretando uma redução no volume do material depositado e variações em suas propriedades geotécnicas ao longo do tempo.

\subsection{2. - Biodegradação}

A biodegradação é a propriedade biológica mais importante da fração orgânica dos resíduos sólidos urbanos domiciliares, a qual consiste na transformação dos componentes orgânicos complexos, com o tempo e em condições de anaerobiose, em biogás (metano, dióxido de carbono e outros), em líquidos, em matéria orgânica mineralizada e em compostos orgânicos mais simples (TCHOBANOGLOUS et al. 1993).

No aterro, os componentes orgânicos são utilizados como substrato por um número de diferentes microrganismos capazes de estabilizar e de converter a matéria orgânica facilmente degradável em subprodutos (MILLER et al. 1991; EDGERS et al. 1992 e FANG 1993).

Do ponto de vista geotécnico, a degradação dos resíduos altera o comportamento dos aterros sanitários. Por exemplo, como resultado da contínua perda de massa da fase sólida do RSU, tem-se o aumento de densidade e a conseqüente diminuição da permeabilidade e da compressibilidade do aterro (EDGERS et al. 1992; WALL \& ZEISS, 1995 e SIMÕES et al. 1996). Além disso, a degradação pode modificar a resistência ao 
cisalhamento do resíduo através do enfraquecimento do efeito "reforço" dado pela presença de materiais plásticos, têxteis e fibras. Na Figura 2.2.1, apresenta-se um gráfico da possível redução da resistência ao cisalhamento e, em particular, do ângulo de atrito $(\phi)$ com o tempo, para vários resíduos domiciliares com diferentes idades. Segundo MASSACCI et al. (1993) a variação da resistência com o tempo, provavelmente, é resultante dos processos de degradação físico-químicos e biológicos que ocorrem nos RSU.

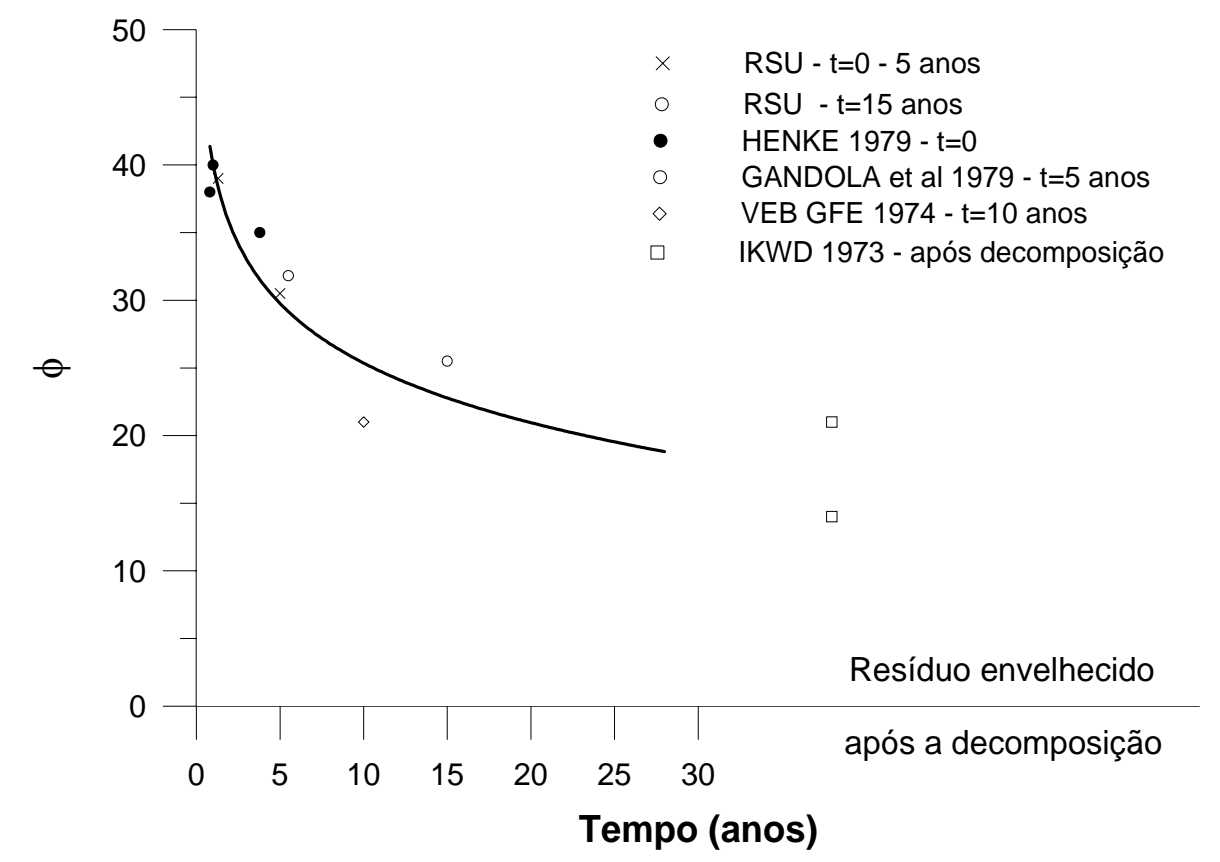

Figura 2.2.1 - Variação da resistência do resíduo urbano com a idade do aterro em virtude dos processos de degradação, MASSACCI et al. 1993.

\subsection{3 - Processos de decomposição biológica dos RSU}

A decomposição biológica dos RSU aterrados ocorre inicialmente por processos aeróbios e predominantemente por processos anaeróbios. Os processos anaeróbios, aqueles que ocorrem na ausência de oxigênio molecular $\left(\mathrm{O}_{2}\right)$, são os mais efetivos.

Quando o resíduo é disposto no aterro desenvolvem-se alguns processos de decomposição aeróbia até que todo o oxigênio adsorvido no resíduo seja consumido. Esta fase aeróbia tem curta duração, em média algumas semanas. Em seguida, um grupo de bactérias hidrolíticas fermentativas hidrolizam compostos orgânicos de cadeias complexas e os transformam em compostos moleculares de cadeias simples. Estes últimos são fermentados resultando em uma variedade de produtos como etanol, butiratos, acetatos e propionatos. As condições de crescimento, a fisiologia e o metabolismo desses microrganismos não estão completamente conhecidos. Outro grupo de microrganismos essencial à degradação anaeróbia é o grupo das bactérias acetogênicas produtoras de 
hidrogênio, as quais fermentam ácidos voláteis de cadeia maior que o metanol transformando-os em hidrogênio e acetato. Igualmente importantes, nas fases iniciais de decomposição anaeróbia são as bactérias acetogênicas consumidoras de hidrogênio, pois fermentam um amplo espectro de compostos de um carbono e ácido acético, precursor do metano. Quanto aos aspectos relacionados às necessidades nutricionais e fisiologia das bactérias acetogênicas pouco se conhece. Os produtos metabólicos das bactérias acetogênicas são utilizados pelas bactérias metanogênicas de várias espécies com diferentes formas celulares. Os principais produtos do metabolismo das bactérias metanogênicas é o gás metano e dióxido de carbono obtidos a partir de ácidos orgânicos voláteis (FARQUHAR 1989, MILLER et al. 1991). Paralelamente, bactérias redutoras de sulfato produzem acetato $\left(\mathrm{CH}_{3} \mathrm{COO}\right)$, hidrogênio $\left(\mathrm{H}_{2}\right)$ e sulfitos $\left(\mathrm{S}^{2-}\right)$ que serão utilizados pelas metanogênicas (BIDONE \& POVINELLI, 1999).

Segundo SILVA et al. (1998), os processos de degradação dos resíduos sólidos urbanos têm sido estudados, geralmente, em escala laboratorial utilizando-se de equipamentos denominados lisímetros ou bio-reatores operados com altas concentrações de sólidos, nos quais são simuladas as condições ambientais de um aterro sanitário ou, em outros casos, as condições de reatores biológicos convencionais. Entretanto, ainda são poucos os dados disponíveis sobre estudos desenvolvidos em larga escala.

Uma série de fatores influencia os processos de biodegradação, dentre eles podese citar, teor de umidade, composição do resíduo, temperatura, tamanho de partículas e grau de compactação do RSU, disponibilidade de nutrientes, detalhes de projeto e de operação do aterro (compactação, existência da cobertura diária, drenagem) e condições climáticas favoráveis (VAN MEERTEN et al. 1995).

O teor de umidade do RSU é um dos principais fatores no controle do processo de degradação. Segundo MILLER et al. (1991) a umidade ótima deve estar entre 50 a 70\% (base úmida) para aterros de RSU fresco e, entre 30 a 80\% (base úmida), para aterros mais antigos. Segundo EL-FADEL et al. (1997) o teor de umidade é a variável que mais afeta os processos de biodegradação pois promove um ambiente aquoso que facilita o transporte de nutrientes e de microrganismos, além de diluir os constituintes inibidores do processo. A decomposição anaeróbia, a qual é dominante nos aterros sanitários, ocorre em temperaturas que variam de 20 a $44^{\circ} \mathrm{C}$.

\subsection{4 - Fases de estabilização de um aterro sanitário}

Farquhar \& Rovers $^{1}$ (citado por SCHALCH, 1992) foram os pioneiros nos estudos de degradação do RSU em aterros. Segundo esses autores, a estabilização em aterros

\footnotetext{
${ }^{1}$ FARQUHAR, G. J. \& ROVERS, F. A. (1973). Gás production during refuse decomposition. Water, Air and Soil Pollution, no 2, p.483-495.
} 
sanitários ocorre dentro de quatro fases distintas, as quais apresentam, em linhas gerais, a alteração da composição do biogás ao longo do tempo.

De acordo com BIDONE \& POVINELLI (1999) a transformação anaeróbia do material orgânico bruto em bioestabilizado nos aterros sanitários, com a geração do gás metano (denominada metonogênese), é assumida conceitual e atualmente como um processo de cinco fases. São elas:

Fase I - Ajustamento inicial: disposição dos resíduos, acúmulo de umidade. Subsidência inicial e cobertura da área. Inicio do processo de estabilização detectado por mudanças nos parâmetros ambientais.

Fase II - Transição: formação de chorume, transição da fase aeróbia para a anaeróbia. Estabelecimento das condições de óxido-redução e aparecimento de compostos intermediários (ácidos voláteis)

Fase III - Formação de ácidos: predominância de ácidos orgânicos voláteis de cadeia longa. Decréscimo do pH com conseqüentes mobilização e possível complexação de espécies metálicas. Liberação de nutrientes com $\mathrm{N}$ e $\mathrm{P}$ que serão utilizados como suporte para o crescimento da biomassa. O hidrogênio é detectado e sua presença afeta a natureza e o tipo de produtos intermediários em formação

Fase IV - Fermentação metânica: produtos intermediários que aparecem durante a fase de formação de ácidos são convertidos em $\mathrm{CH}_{4}$ e $\mathrm{CO}_{2}$. Retorno do $\mathrm{pH}$ à condição de tampão, controlado pelos ácidos voláteis. Potenciais redóx nos valores mais baixos. Precipitação e complexação de metais. Drástica redução de DQO (medida no lixiviado) com correspondente aumento na produção de gás.

Fase $\boldsymbol{V}$ - Maturação final: estabilização da atividade biológica, com relativa inatividade. Escassez de nutrientes e paralisação da produção de gás. Predominância de condições ambientais naturais. Aumento do valor do potencial redóx com o aparecimento de O2 e espécies oxidadas. Conversão lenta dos materiais orgânicos resistentes aos microrganismos em substâncias húmicas complexadas com metais.

Além da $5^{a}$ fase que é atribuída à intrusão de ar no aterro, Christensen \& Kjeldsen ${ }^{1}$ (apud SILVA et al. 1998) consideram a existência de mais duas fases atribuídas a oxidação biológica do metano produzindo dióxido de carbono e, uma última fase, na qual o ar circula pelo aterro.

A Figura 2.2.2 apresenta o modelo gráfico de evolução típica da degradação dos resíduos e da composição dos gases do aterro.

A duração de cada fase é algo muito polêmico e depende de fatores como pH, Eh, alcalinidade, nutrientes, infiltração de água no aterro, temperatura, composição e grau de compactação do resíduo, disposição e cobertura final, etc. Segundo GRISOLIA et al. (1993),

\footnotetext{
${ }^{1}$ CHISTENSEN, T.H. \& KJELDSEN (1995). Landfill emissions and environmental impact: an introdution. In Proc. Of Fifth International Landfill Symposium, Caligari, vol3, pp.3-12.
} 
experimentos de laboratório comparados com observações diretas em aterros permitem fazer algumas inferências quanto a qualidade e quantidade do biogás produzido em relação ao tempo. Assim, a fase I tem duração de aproximadamente uma semana, a fase II de uma semana a 6 meses, a fase III de 3 meses a 3 anos e a fase IV de 8 a 40 anos e finalmente, a fase $V$, uma duração que pode variar de 1 ano a 80 anos.

No processo de degradação, além do metano e dióxido de carbono são gerados, em menor quantidade, outros gases, como: amônia, monóxido de carbono, hidrogênio, ácido sulfídrico (Tabela 2.2.1).

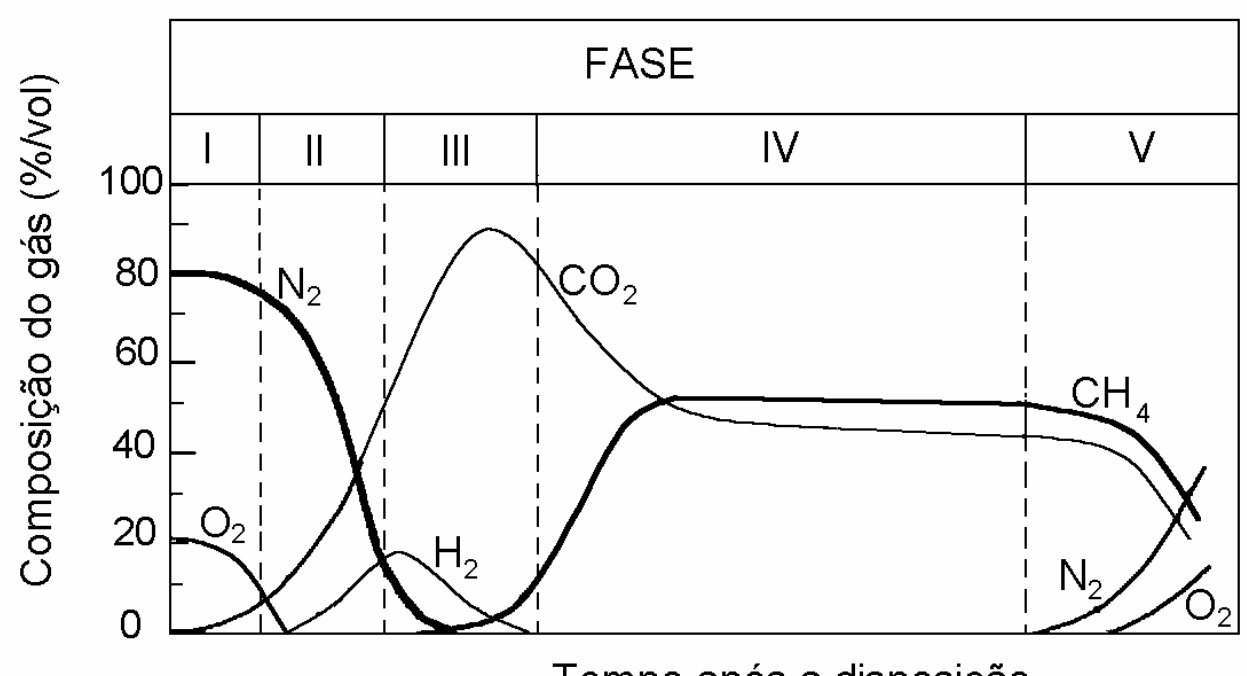

Tempo após a disposição

Figura 2.2.2 - Evolução típica da degradação dos resíduos e da composição dos gases em aterros sanitários (SCHALCH, 1992).

TABELA 2.2.1- Componentes típicos do biogás de aterro de RSU segundo TCHOBANOGLOUS et al. (1993).

\begin{tabular}{l|c}
\hline \multicolumn{1}{c|}{ Componentes } & \% (a base de peso seco) \\
\hline Metano $\left(\mathrm{CH}_{4}\right)$ & $45-60$ \\
Dióxido de carbono $\left(\mathrm{CO}_{2}\right)$ & $40-60$ \\
Nitrogênio $\left(\mathrm{N}_{2}\right)$ & $2-5$ \\
Oxigênio $\left(\mathrm{O}_{2}\right)$ & $0,1-1,0$ \\
Ácido sulfídrico $\left(\mathrm{H}_{2} \mathrm{~S}\right)$ & $0-1.0$ \\
Amônia $\left(\mathrm{NH}_{3}\right)$ & $0,1-1,0$ \\
Hidrogênio $\left(\mathrm{H}_{2}\right)$ & $0-0,2$ \\
Monóxido de carbono $(\mathrm{CO})$ & $0-0,2$ \\
Traços de gases & $0,01-0,6$ \\
\hline
\end{tabular}

De acordo com PORTEOUS (1993), em geral o pico de produção de biogás ocorre por volta dos primeiros 10 anos após a disposição do resíduo, prolongando-se até os 40 
anos. O período principal de utilização corresponde aos 4 a 19 anos após a deposição, onde cerca de $35 \%$ do total produzido pode ser coletado e utilizado.

O dióxido de carbono sendo 1,5 vezes mais denso do que o ar e 2,7 vezes mais denso que o metano, move-se para o fundo do aterro e por ser solúvel em água, mistura-se com o chorume que é drenado do aterro ou com a água do subsolo, alterando inadequadamente suas características.

O metano pode ser reaproveitado como fonte energética (produção de vapor, energia elétrica, combustível). Na maioria das vezes, o reaproveitamento é antieconômico face ao baixo poder calorífico do metano, à presença de $\mathrm{H}_{2} \mathrm{~S}$ causando problemas de corrosão nos equipamentos e umidade provocando danos nos motores de combustão e devido aos altos investimentos em instalações para a recuperação. Dessa forma, o procedimento mais empregado no tratamento dos gases consiste na queima, transformando-o em gás carbônico, óxido de nitrogênio, dióxido de enxofre e outros gases.

O processo da decomposição predominantemente anaeróbio em aterros sanitários gera, como subproduto da atividade bacteriana, o chorume (líquido negro, ácido e com odor forte). Esse líquido possui um alto potencial poluente, composição química extremamente complexa e variável. A produção de chorume decorrente do processo de degradação é normalmente reduzida. O problema maior reside nas águas pluviais que infiltram nos aterros e aumentam a quantidade de líquido percolado.

Segundo VAN IMPE (1995), a taxa de produção de percolado em aterros localizados em regiões de clima árido com precipitação inferior a $300 \mathrm{~mm}$ é muito pequena. Já em climas úmidos, a taxa de produção de percolado é alta, tornando-se relevante o emprego de geomembranas na camada de cobertura final do aterro.

As características do líquido percolado de aterros sanitários variam caso a caso, em função da idade do aterro e da fase em que a amostra foi coletada. A faixa de variação das concentrações é grande, principalmente para aterros novos. TOCHOBONOGLOUS et al. (1993) apresentam valores típicos da composição do líquido percolado de aterros sanitários novos e antigos (Tabela 2.2.2).

Devido a grande variação das características do líquido percolado, os sistemas de tratamentos são complexos, podendo ser diferentes em função do tempo de vida do aterro e, até mesmo, diferentes para pontos distintos do aterro. Vários métodos de tratamento podem ser usados, dentre os quais destacam-se, os tratamentos biológicos (lodos ativados, lagoas de estabilização aeradas, lagoas anaeróbias), os físicos (sedimentação/ flotação, filtração, adsorsão, osmose reversa), os químicos (oxidação, precipitação e neutralização) (LEMA et al. 1988).

Há autores que recomendam a pulverização do líquido percolado no solo. No entanto, LEMA et al. (1988) enfatizam que essa prática não deve ser usada, visto que esse percolado apresenta, em geral, alta concentração de elementos tóxicos que contaminam o solo. Segundo SCHALCH (1984), o líquido percolado apresenta alta concentração de sólidos totais, dificultando e tornando oneroso o tratamento por processos químicos. Já a 
presença de grande porcentagem de matéria orgânica biodegradável de difícil decantação permite a utilização de tratamentos biológicos. Informações detalhadas sobre cada método de tratamento podem ser encontradas em LEMA et al. (1988).

Tabela 2.2.2 - Composição típica do líquido percolado de aterros sanitários, TOCHOBANOGLOUS et al. (1993).

\begin{tabular}{|c|c|c|c|}
\hline \multirow[t]{2}{*}{ Constituintes } & \multicolumn{2}{|c|}{ Aterros novos (<2 anos) } & \multirow{2}{*}{$\begin{array}{c}\text { Aterros antigos } \\
\text { (>10 anos) }\end{array}$} \\
\hline & Faixa & Típico & \\
\hline DBO (mg/L) & $2000-30000$ & 10000 & $100-200$ \\
\hline COT (mg/L) & $1500-20000$ & 6000 & $80-160$ \\
\hline $\mathrm{DQO}(\mathrm{mg} / \mathrm{L})$ & $3000-60000$ & 18000 & $100-500$ \\
\hline SST (mg/L) & $200-2000$ & 500 & $100-400$ \\
\hline N (orgânico) (mg/L) & $10-800$ & 200 & $80-120$ \\
\hline $\mathrm{N}$ (amoniacal) (mg/L) & $10-800$ & 200 & $20-40$ \\
\hline Nitratos (mg/L) & $5-40$ & 25 & $5-10$ \\
\hline $\mathrm{P}$ (total) (mg/L) & $5-100$ & 30 & $5-10$ \\
\hline Orto-P (mg/L) & $4-80$ & 20 & $4-8$ \\
\hline Alcalinidade $\left(\mathrm{CaCO}_{3}\right)(\mathrm{mg} / \mathrm{L})$ & $1000-10000$ & 3000 & $200-1000$ \\
\hline $\mathrm{pH}$ & $4,5-7,5$ & 6 & $6,5-7,5$ \\
\hline Dureza $\left(\mathrm{CaCO}_{3}\right)(\mathrm{mg} / \mathrm{L})$ & $300-10000$ & 3500 & $200-500$ \\
\hline $\mathrm{Ca}(\mathrm{mg} / \mathrm{L})$ & $200-3000$ & 1000 & $100-400$ \\
\hline $\mathrm{Mg}(\mathrm{mg} / \mathrm{L})$ & $50-1500$ & 250 & $50-200$ \\
\hline $\mathrm{K}(\mathrm{mg} / \mathrm{L})$ & $200-1000$ & 300 & $50-400$ \\
\hline $\mathrm{Na}(\mathrm{mg} / \mathrm{L})$ & $200-2500$ & 500 & $100-200$ \\
\hline Cloretos (mg/L) & $200-3000$ & 500 & $100-400$ \\
\hline Sulfatos (mg/L) & $50-1000$ & 300 & $20-50$ \\
\hline $\mathrm{Fe}$ (total) (mg/L) & $50-1200$ & 60 & $20-200$ \\
\hline
\end{tabular}

É importante ressaltar que a biodegradabilidade da fração orgânica do RSU pode ser avaliada pela demanda química de oxigênio (DQO), pelo conteúdo de sólidos totais voláteis (STV) e pelo conteúdo de lignina e de celulose. Durante a decomposição do RSU aterrado, ocorre, por um lado, uma redução na taxa de sólidos totais voláteis e na taxa de celulose e, por outro lado, um aumento da taxa de lignina, sendo que a relação entre essas duas ultimas substâncias (celulose/ lignina) muda com o tempo. BOOKTER \& HAM (1982) pesquisando resíduos novos e resíduos aterrados com várias idades obtiveram que a taxa celulose/ lignina é de aproximadamente 4,0 para resíduos frescos, 0,9-1,20 para resíduos de aterros ativos e parcialmente estabilizados e 0,2 para resíduos de aterros relativamente bem estabilizados. Segundo os autores, a relação celulose/lignina é um bom índice para estimativa da degradabilidade do resíduo ao longo do tempo. A Figura 2.2.3 apresenta resultados de teor de STV com a idade dos resíduos aterrados, obtidos por SILVA et al. (1998). Os resultados demonstram uma redução na taxa de sólidos totais voláteis ao longo do tempo, quando comparadas aos teores de voláteis presentes nos resíduos domiciliares 
frescos. Os valores obtidos indicam reduções de cerca de $80 \%$ a partir do $4^{\circ}$ ano de aterramento, a qual é atribuída à conversão da matéria orgânica para gases e ao carreamento de compostos orgânicos pelos líquidos percolados.

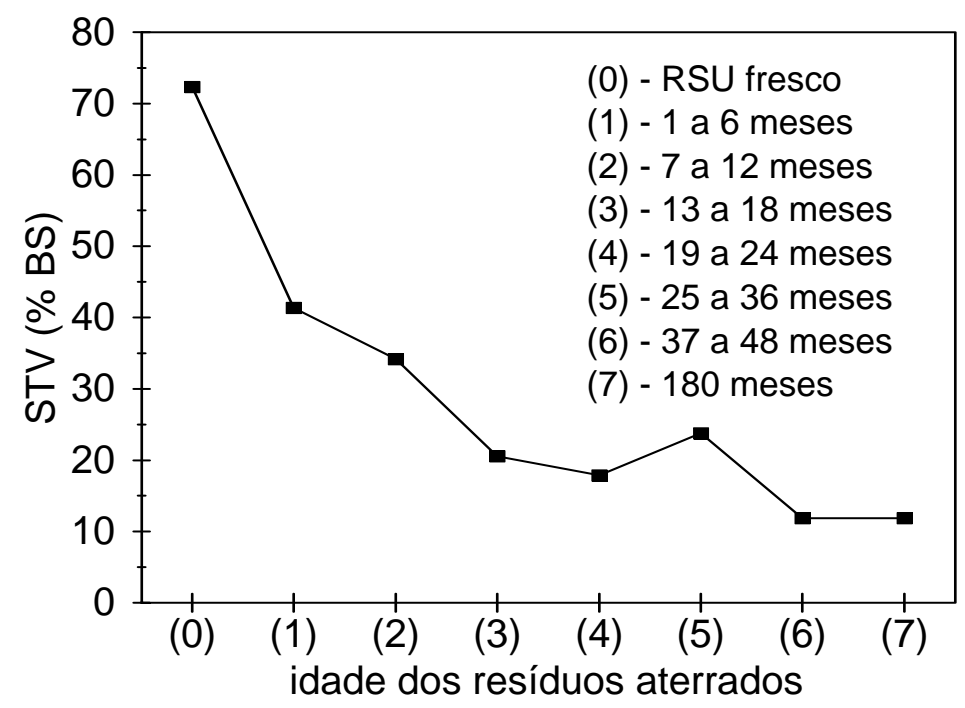

Figura 2.2.3 - Variação do teor de sólidos totais voláteis com a idade dos resíduos aterrados (SILVA et al. 1998). 


\section{3 - PROPRIEDADES DE ENGENHARIA DOS MACIÇOS DE RESÍDUOS SÓLIDOS URBANOS}

\subsection{1 - Introdução}

Os aterros sanitários devem ser vistos como estruturas de engenharia, onde devem ser satisfeitas as exigências usuais de segurança, no que se referem à estabilidade a ruptura, às deformações, às tensões impostas no solo de fundação, etc. Em geral, o projeto e a operação de aterros sanitários envolvem uma variedade de problemas geotécnicos, que para serem solucionados exigem o conhecimento adequado das propriedades físicas e mecânicas do resíduo sólido domiciliar (peso específico, resistência ao cisalhamento, permeabilidade, compressibilidade, dentre outras). A quantificação dessas propriedades é complexa, pois o resíduo sólido urbano é constituído por componentes de diferentes tipos, formas e dimensões. Cada um desses componentes possui natureza e comportamento mecânico significativamente diferente. Além disso, tem-se as dificuldades relacionadas com o tamanho e a obtenção de amostras representativas das condições in situ, dificuldades quanto a técnica e procedimento de ensaio, bem como a mudança das propriedades do RSU com tempo devido aos processos de degradação (VAN IMPE, 1998; KNOCHENMUS et al. 1998; MANASSERO et al. 1996 e KÖNIG \& JESSBERGER, 1997).

Segundo KNOCHENMUS et al (1998), as informações relativas às propriedades físicas e mecânicas do resíduo são limitadas, e ocasionalmente, os dados reportados são contraditórios. Usualmente, as propriedades físicas e mecânicas dos resíduos sólidos urbanos são estudadas estendendo-se para esses materiais os mesmos conceitos desenvolvidos na mecânica dos solos. Existem algumas limitações no uso dessa aproximação, pois esse tipo de resíduo tem algumas diferenças importantes em relação aos solos. Como comentado acima, o resíduo sólido urbano é altamente heterogêneo, apresentando tanto componentes inertes como os degradáveis (matéria orgânica), os quais passam por processos de degradação gerando gás e chorume. A degradação pode provocar alterações significativas nas propriedades mecânicas desses materiais.

Nos próximos capítulos será apresentada uma revisão sobre o tema "propriedades geotécnicas dos resíduos sólidos urbanos", mostrando as principais faixas de variação apresentadas por diversos autores. Neste capítulo, serão abordadas as propriedades físicas dos resíduos sólidos urbanos (peso específico, umidade, composição, tamanho de 
componentes, etc). No próximo, mostrar-se-á, a partir de resultados de ensaios de laboratório e campo, que o comportamento geotécnico do RSU em termos de resistência e compressibilidade, é fortemente condicionado pelas grandes deformações sofridas pelo material e transformações resultantes do processo de degradação bioquímica. Apresenta-se também uma breve discussão sobre alguns modelos para previsão de recalques em aterros sanitários.

\subsection{2 - Propriedades físicas do resíduo sólido urbano}

As principais propriedades físicas dos resíduos sólidos urbanos incluem teor de umidade, peso específico, composição e conteúdo orgânico, tamanho de partícula, classificação e permeabilidade, as quais serão comentadas a seguir.

\subsubsection{1 - Classificação}

De acordo com as recomendações do GLR - Recommendations "Geotechnic of Landfill (KNOCHENMUS et al. 1998 e KÖNIG \& JESSBERGER 1997) os resíduos podem ser classificados em materiais como solos e materiais diferente de solos. No primeiro caso, o resíduo tem comportamento similar aos solos e, portanto, os princípios da mecânica dos solos são aplicáveis. Já para o caso de resíduos classificados como materiais diferente de solos, os princípios da mecânica dos solos somente tem aplicações limitada ou não são aplicáveis. De acordo com os autores acima, o resíduo sólido urbano se inclui nesta última categoria.

A classificação do RSU é geralmente feita com base na avaliação dos seguintes parâmetros: teor de umidade, distribuição do tamanho das partículas e identificação das diferentes categorias de materiais contido em uma amostra representativa (composição gravimétrica ou volumétrica) (KNOCHENMUS et al. 1998). Outra aproximação para classificação do RSU, é o emprego da Carta de Schmertmann (SÁNCHEZ-ALCITURRI et al. 1993). Nesta carta são plotados os resultados médios obtidos dos ensaios de penetração do cone, excluindo os picos de resistência causados pela presença de objetos rígidos do lixo. Resultados de ensaios de penetração contínua (CPT) obtidos para RSU, por vários autores, (JESSBERGER 1990, HINKLE 1990, SIEGEL et al. 1990 e SÁNCHEZ-ALCITURRI et al. 1993) e plotados na carta de Schmertmann, permitem classificar o RSU dentro de uma variação de areia fofa a argila siltosa e arenosa (Figura 2.3.1).

GRISOLIA et al. (1995) propuseram uma sistemática de classificação para o resíduo usando um diagrama triangular formado por três classes de materiais, que são materiais 
inertes, materiais muito deformáveis e materiais orgânicos biodegradáveis. Essa classificação consiste em plotar os dados de composição de cada classe do RSU no diagrama triangular e a partir da determinação da posição de cada amostra no diagrama, pode-se avaliar as propriedades mecânicas esperadas para o material. Para ilustrar, na Figura 2.3.2 apresenta-se um diagrama triangular contendo dados obtidos em diversos países (GRISOLIA et al. 1995). Segundo os autores, pode-se observar no diagrama, para as diferentes regiões, zonas delimitadas que refletem a origem geográfica do RSU.

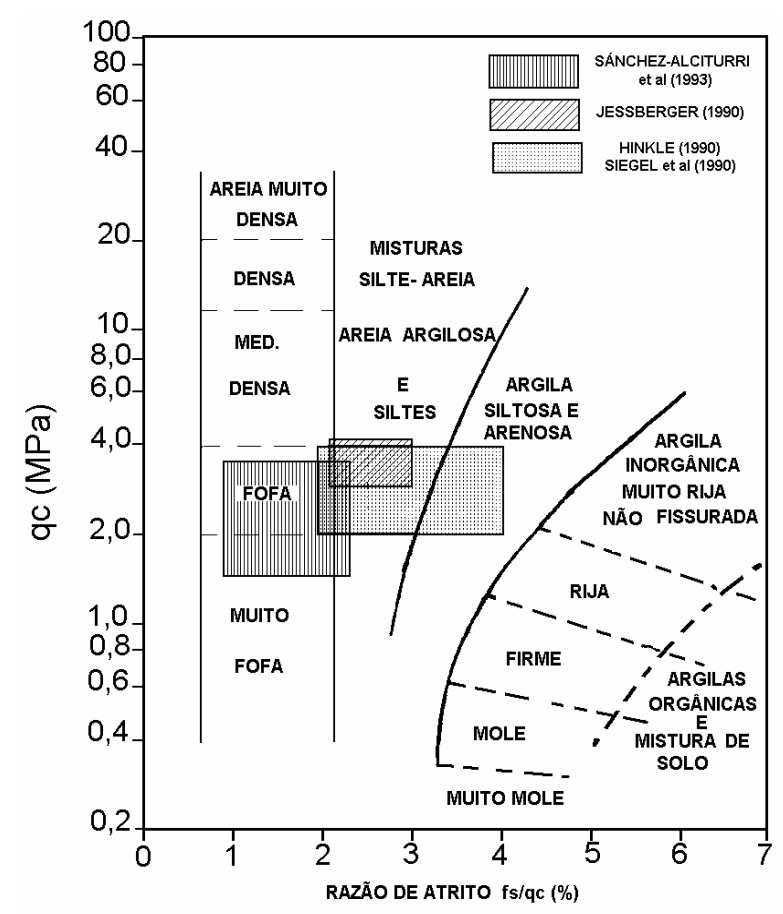

Figura 2.3.1 - Classificação do RSU usando a Carta de Schmertmann (SÁNCHEZ-ALCITURRI, et al. 1993).

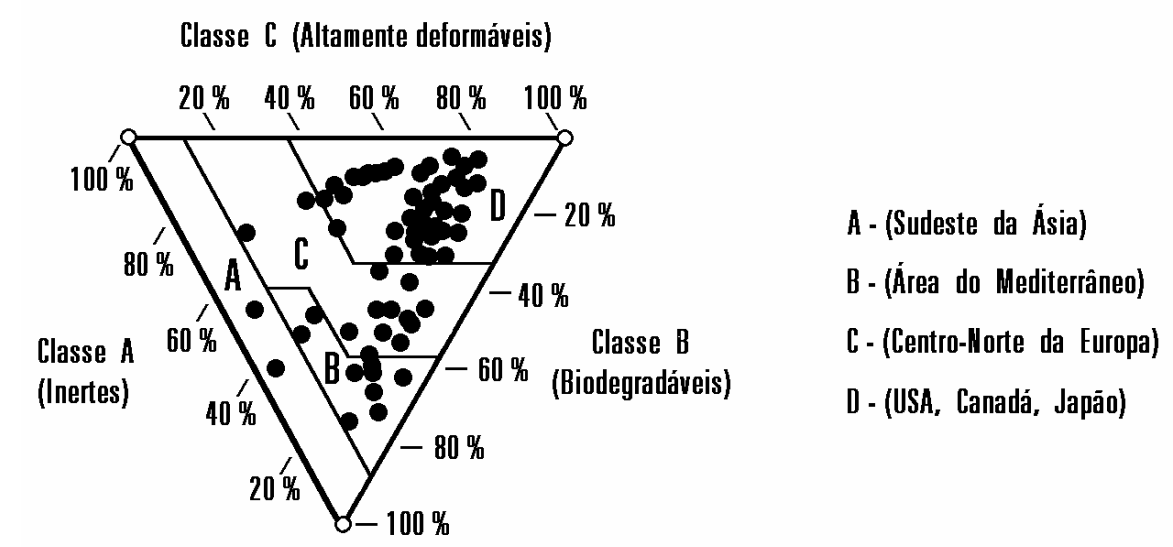

Figura 2.3.2 - Classificação do RSU usando o diagrama triangular (GIRISOLIA et al. 1995). 


\subsubsection{2 - Composição}

Os resíduos sólidos urbanos, assim como os solos naturais, são meios multifásicos constituídos pelas fases sólida, líquida e gasosa. Num primeiro momento, tem-se o predomínio da parte sólida (os resíduos propriamente dito), após algum tempo, devido aos processos de biodegradação, surgem as fases líquida (chorume) e gasosa (gás metano e outros). Essas duas últimas fases estão relacionadas aos processos de decomposição do resíduo ao longo do tempo, os quais estão diretamente associados ao teor de umidade, conteúdo orgânico do RSU e condições climáticas (GRISOLIA \& NAPOLEONI 1996; CARTIER \& BALDIT, 1983). A fase sólida, por sua vez, apresenta diversos constituintes, os quais formam um arranjo poroso que pode estar ou não preenchido por líquido percolado e/ou biogás e pode, ainda, estar em processo constante de decomposição. Dessa forma, parece consenso geral, que o ponto básico para a compreensão do comportamento dos maciços de RSU é o conhecimento das interações existentes entre as três fases e as alterações destas com o tempo, ou seja, sua biodegradabilidade.

Segundo GRISOLIA \& NAPOLEONI (1996) e MASSACCI et al. (1993) a fase sólida dos RSU pode ser dividida em três categorias quais sejam: materiais inertes estáveis, materiais altamente deformáveis e materiais orgânicos biodegradáveis.

A categoria dos inertes (vidros, metais, cerâmicas, solos, cinzas, resto de demolição) apresentam comportamento mecânico semelhante aos solos granulares, os quais desenvolvem forças de atrito entre as partículas. A segunda categoria inclui os materiais como plásticos, papéis, têxteis e borracha, os quais apresentam alta deformabilidade e possibilidade de absorver ou incorporar fluidos no interior de sua estrutura. Quando submetidos a um carregamento, esses materiais sofrem grandes deformações iniciais com mudança de sua forma original, além disso, a longo prazo podem apresentar deformações de natureza viscosa. Finalmente, a categoria dos materiais orgânicos biodegradáveis constituída por resíduos de poda e alimentares passam por significantes transformações físico-químicas a curto-prazo, acompanhadas pela produção de líquidos e gases.

Neste contexto, a fase sólida dos RSU é constituída por uma mistura de materiais de diferentes tipos, formas e dimensões, tais como, papel, plástico, papelão, tecidos, borracha, madeira, vidro, metais, resíduos alimentares e de feiras, entulho e outros. SOWERS (1973) apresenta as principais características e porcentagens típicas de cada constituinte do resíduo, (Tabela 2.3.1).

A composição do RSU é muito heterogênea e pode variar de pequenos materiais orgânicos até grandes materiais inorgânicos. Além disso, existe uma variação significante na porcentagem dos principais componentes do lixo urbano de uma região para outra, a qual, geralmente, está relacionada com os níveis de desenvolvimento econômico, tecnológico, sanitário e cultural dessas regiões (CARTIER \& BALDIT, 1983) e com as 
práticas de reciclagem, incineração e os hábitos de desperdícios da sociedade (COWLAND \& KOOR, 1995). Em geral, a composição do RSU em locais menos desenvolvidos socioeconomicamente apresenta-se com maior porcentagem de matéria orgânica quando comparada com locais mais desenvolvidos. Isso pode ser visto na Tabela 2.3.2, onde apresenta-se valores médios ilustrativos da variabilidade da composição citada para alguns países. Os dados apresentados nesta tabela foram compilados de MANASSERO et al. (1996), MARQUES et al. (1998) e JUCÁ et al. (1997).

TABELA 2.3.1 - Porcentagens típicas e principais características dos componentes dos RSU, SOWERS (1973).

\begin{tabular}{lcll}
\hline \multicolumn{1}{c}{ Material } & $\begin{array}{c}\text { Porcentagem } \\
\text { (em peso) }\end{array}$ & \multicolumn{1}{c}{ Característica } \\
\hline Resíduos orgânicos & $10-20$ & $\begin{array}{l}\text { úmido, fermenta e degrada rapidamente, } \\
\text { compressível, fraco }\end{array}$ \\
\hline Papel e pano & $10-40$ & seco a úmido, degrada e queima, compressível \\
\hline Resíduos de poda & $10-20$ & úmido, fermenta, degrada e queima \\
\hline Plásticos & $1-2$ & $\begin{array}{l}\text { seco, compressível, resistente a degradação mas } \\
\text { pode queimar }\end{array}$ \\
\hline Instrumento de Metal & $5-15$ & seco, corrosível e triturável & \\
\hline Metal maciço & 1 & seco, levemente corrosível e rígido \\
\hline Borracha & $5-10$ & $\begin{array}{l}\text { seco, elástico, queimável, compressível, } \\
\text { resistente à degradação }\end{array}$ \\
\hline Vidro & $5-15$ & $\begin{array}{l}\text { seco, triturável e compressível, resistente à } \\
\text { degradação }\end{array}$ \\
\hline Madeira de demolição & $0-5$ & seco, triturável, compressível, degrada e queima \\
\hline Entulho & $0-10$ & $\begin{array}{l}\text { úmido, triturável, erodivel, resistente à } \\
\text { degradação }\end{array}$ \\
\hline Cinzas e escória & $0-5$ & $\begin{array}{l}\text { úmido, compressível, quimicamente ativo e } \\
\text { parcialmente solúvel. }\end{array}$ \\
\hline
\end{tabular}

TABELA 2.3.2 - Composição do resíduo sólido urbano para diferentes cidades (modificado de MANASSERO et al. 1997).

\begin{tabular}{|c|c|c|c|c|c|c|c|c|c|c|}
\hline \multirow{3}{*}{ Componentes } & \multicolumn{10}{|c|}{ Cidade / País } \\
\hline & \multirow{2}{*}{\begin{tabular}{|l|} 
Bangkok \\
Tailândia
\end{tabular}} & \multirow{2}{*}{$\begin{array}{l}\text { Pekin } \\
\text { China }\end{array}$} & \multirow{2}{*}{$\begin{array}{l}\text { Nairobi } \\
\text { Kenia }\end{array}$} & \multirow{2}{*}{ Hong kong } & \multirow{2}{*}{$\begin{array}{c}\text { New York } \\
\text { USA }\end{array}$} & \multirow{2}{*}{$\begin{array}{l}\text { Istanbul } \\
\text { Truquia }\end{array}$} & \multirow{2}{*}{$\begin{array}{l}\text { Atenas } \\
\text { Grecia }\end{array}$} & \multirow{2}{*}{$\begin{array}{c}\text { Cochabamba } \\
\text { Bolívia }\end{array}$} & \multicolumn{2}{|c|}{ Brasil } \\
\hline & & & & & & & & & São Paulo & Recife \\
\hline Metal & 1 & 1 & 3 & 3 & 5 & 2 & 4 & 1 & 5 & 2 \\
\hline Papel & 25 & 5 & 12 & 3 & 22 & 10 & 19 & 2 & 14 & 15 \\
\hline Plástico & - & 1 & 5 & - & - & 3 & 7 & 3 & 14 & 8 \\
\hline $\begin{array}{c}\text { Borracha, couro } \\
\text { e madeira }\end{array}$ & 7 & 1 & - & 7 & 3 & 6 & 4 & 1 & 7 & - \\
\hline Têxteis & 3 & - & - & 10 & - & 3 & - & - & 3 & - \\
\hline Materiais org. & 44 & 45 & 74 & 15 & 20 & 61 & 59 & 71 & 51 & 60 \\
\hline Vidro & 1 & 1 & 4 & 10 & 6 & 1 & 2 & 1 & 1 & 2 \\
\hline Outros & 19 & 46 & 2 & 22 & 46 & 14 & 5 & 21 & 5 & 13 \\
\hline
\end{tabular}




\subsubsection{3 - Distribuição do tamanho das partículas}

A sistemática de determinação da dimensão e distribuição das partículas do resíduo sólido urbano é limitada, face a grande heterogeneidade e variedade desses resíduos. Não existe um método padronizado para análise (SANTOS \& PRESA, 1995). Para uma primeira aproximação, tem-se procurado correlacionar os componentes individuais do resíduo a diâmetros equivalentes, definidos no estudo de TCHONOBANOGLOUS et al. (1993) que se mostram na Figura 2.3.3. Outra forma de determinação do tamanho dos componentes do RSU é usar a análise clássica de peneiramento e traçar a curva de distribuição do tamanho dos grãos (JESSBERGER 1994 e JESSBERGER 1994b). A Figura 2.3.4 mostra as curvas do tamanho das partículas para resíduos sólidos urbanos com diferentes idades (MANASSERO et al. 1996) e a faixa de variação típica para distribuição granulométrica do RSU sugerida por JESSBERGER (1994). A grande faixa de variação da distribuição do tamanho das partículas é o resultado da composição muito heterogênea desses resíduos. $O$ tamanho típico das partículas varia entre pedregulho a uma fração menor que $20 \%$ de partículas finas $(<0,075 \mathrm{~mm})$ (KNOCHENMUS et al. 1998). Segundo os autores existe uma tendência da fração mais fina do RSU aumentar com o aumento da idade do lixo, como resultado da biodegradação do material orgânico.

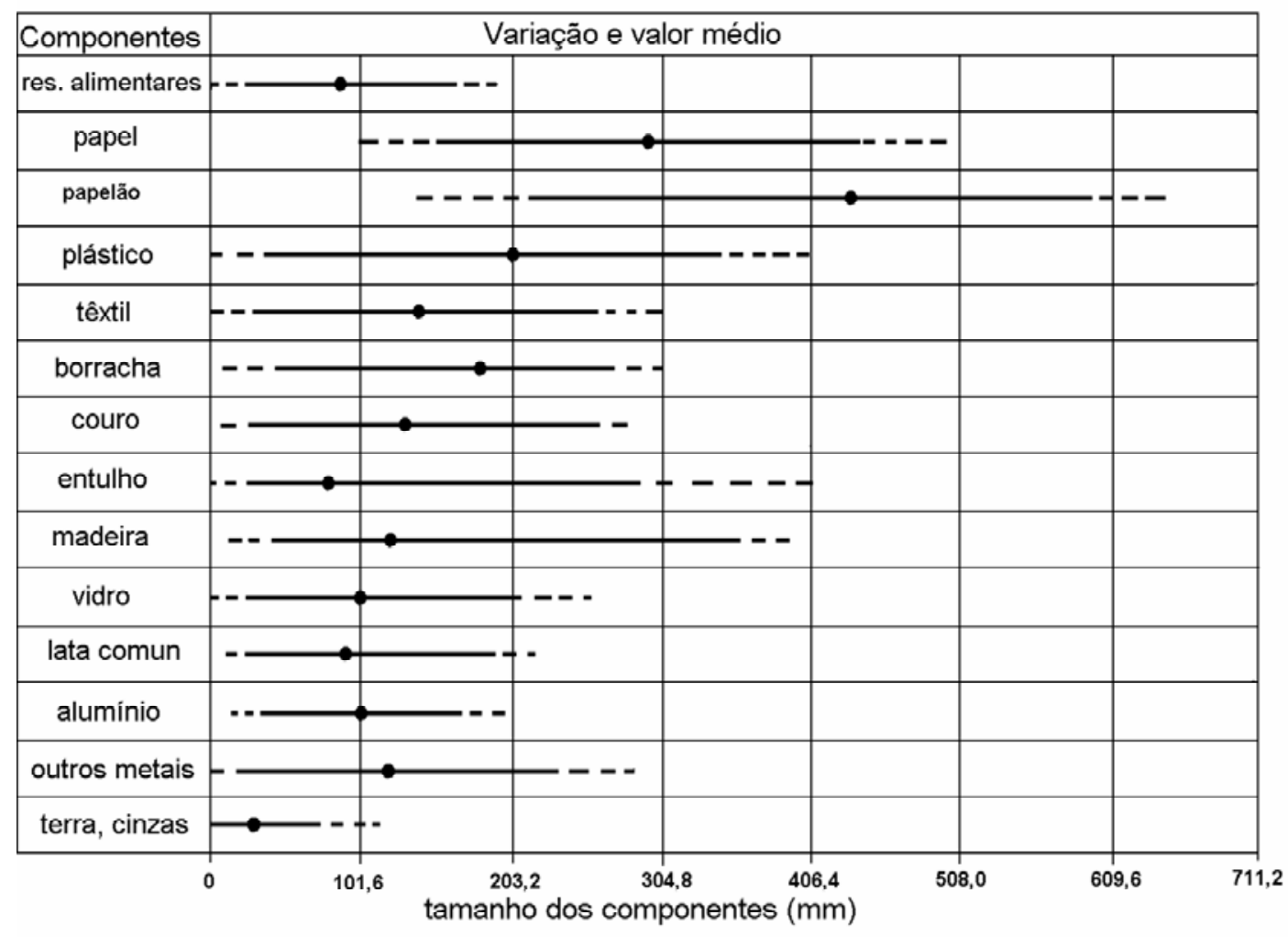

Figura 2.3.3 - Diâmetros equivalentes dos componentes do RSU, TCHOBANOGLOUS et al. (1993). 
Para representação da distribuição granulométrica de RSU da Alemanha, KÖLSCH (1995) adotou a separação dos constituintes em porcentagem por peso através de peneiras com abertura 8,40 e $120 \mathrm{~mm}$. Acima de $120 \mathrm{~mm}$, os materiais foram separados visualmente em 500 e $1000 \mathrm{~mm}$. Ensaios de distribuição do tamanho das partículas para o RSU do aterro de Pioneer Crossing, Pensilvania, executados por GABR \& VALERO (1995) foram feitos utilizando a fração do RSU menor que $9,5 \mathrm{~mm}$ e, portanto, não podem ser considerados representativos da amostra total de RSU.

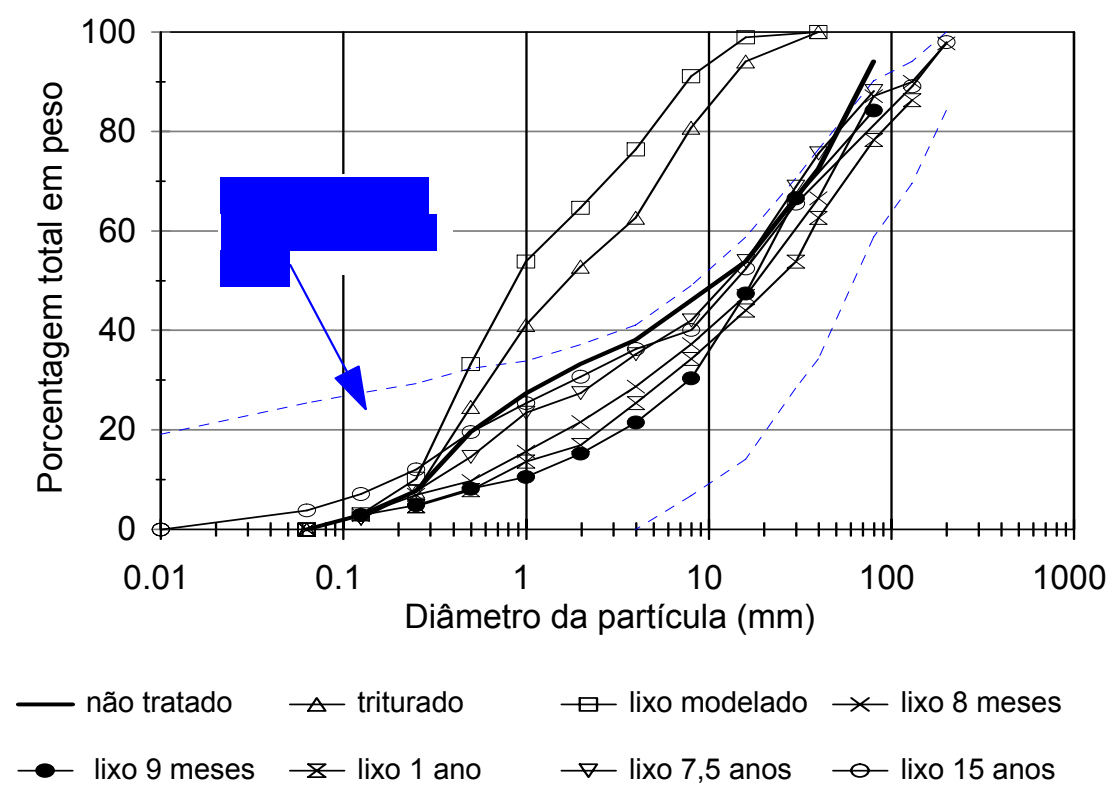

Figura 2.3.4 - Distribuição do tamanho das partículas do RSU (modificado de JESSBERGER 1994).

\subsubsection{4 - Teor de umidade}

O teor de umidade do RSU depende da composição inicial do material, das condições climáticas locais, do processo de operação dos aterros, da taxa de decomposição biológica, da capacidade e funcionamento dos sistemas de coleta de líquidos percolados e do sistema de liner de recobrimento. No aterro sanitário, o teor de umidade pode variar significativamente entre um ponto e outro, tornando-se relevante a obtenção do perfil de umidade com a profundidade, o qual pode ser obtido através de sonda de neutrons ou secagem de amostras representativas em estufa. Segundo KÖNIG \& JESSBERGER (1997) pode-se usar estufa com temperatura de $70^{\circ} \mathrm{C}$ e $105^{\circ} \mathrm{C}$ e o teor de umidade do RSU pode ser definido analogamente como em mecânica dos solos ( $w$ =massa de água / massa seca). Para TCHONOBANOGLOUS et al. (1993) a umidade pode ser determinada tanto em base seca como em base úmida.

SIEGEL et al. (1990) encontraram valores de umidade entre 10 a $45 \%$ para resíduos do aterro de Monterey Park, Califórnia. Já GIFFORD et al. (1990) apresentaram 
valores entre 14 a 68\%, para resíduos do aterro de Albany, New York. Estudos executados em aterros de resíduos sólidos municipais dos Estados Unidos por Huitric ${ }^{1}$ apud MANASSERO et al. (1996) e por TCHOBANOGLOUS et al. (1993) mostraram que o teor de umidade do RSU, usualmente, varia entre $15 \%$ a $40 \%$, com um valor típico de aproximadamente $25 \%$, onde a evapotranspiração excede a precipitação. Medidas feitas por GABR \& VALERO (1995) no aterro de Pioneer Crossing, Pensilvania (USA) mostraram um aumento do teor de umidade com a profundidade, o qual varia de cerca de $30 \%$, próximo da superfície, até $130 \%$ para maiores profundidades. Comportamento oposto foi obtido por COUMOULOS et al. (1995), para o aterro de Ano Liossia em Atenas (Grécia). De acordo com COUMOULOS et al. (1995), o teor de umidade decresce com a profundidade, variando de $80 \%$ para 5 metros de profundidade, até cerca de $40 \%$ para profundidade de 30metros (Figura 2.3.5). Nessa figura também estão apresentados os resultados publicados por Blight et al ${ }^{2}$ apud KÖNIG \& JESSBERGER (1997) obtidos para o aterro de Linbro (África do Sul) em duas épocas diferentes (outubro 1988 e novembro 1990, esta última após uma chuva sazonal) e os resultados de JUCÁ et al. (1997), para o aterro da Muribeca em Recife (Brasil).

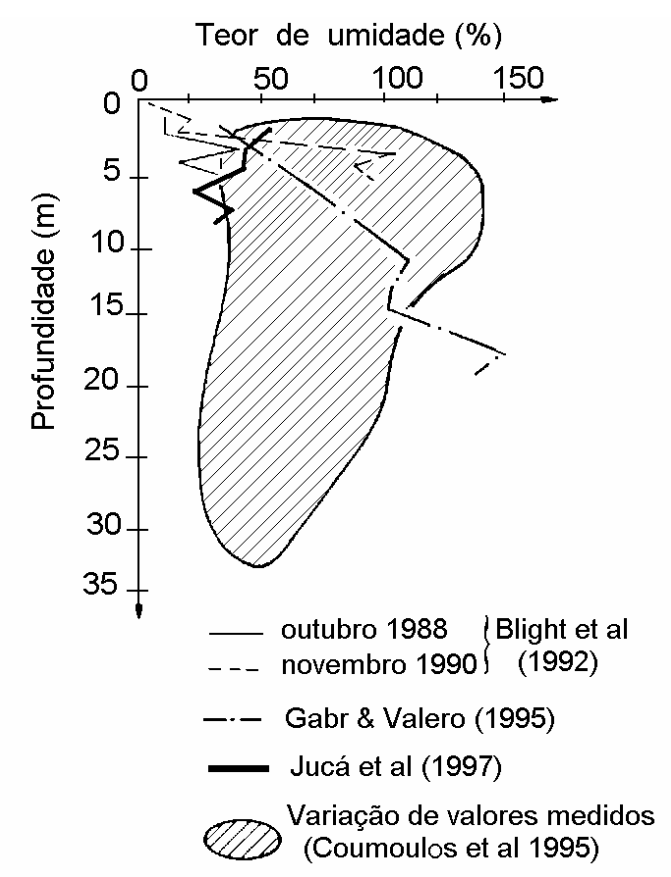

Figura 2.3.5 - Teor de umidade para o resíduo sólido urbano (modificado de KNOCHENMUS et al. 1998).

Segundo KNOCHENMUS et al. (1998), o teor de umidade do RSU é basicamente o resultado de altas porcentagens de lixo orgânico (resíduos alimentares, de jardim e poda).

\footnotetext{
${ }_{1}^{1}$ HUITRIC, R. (1981). Sanitary landfill settlement rates. Technical university of Berlin.

2 BLIGHT, G. E.; BALL, J. M. \& BLIGHT, J.J. (1992). Moisture and suction in sanitary landfills in semiarid areas. ASCE Journal Environmrntal Engineering, v. 118(6).
} 
Os componentes inorgânicos, tais como, papéis e produtos plásticos, geralmente, têm um teor de umidade abaixo de $10 \%$. Assim, o teor de umidade tende a aumentar com o aumento do conteúdo orgânico do material. Esse comportamento foi também observado por LANDVA \& CLARK (1990) para aterros do Canadá.

\subsubsection{5. - Temperatura}

Da literatura consultada obteve-se poucas referências constando resultados de variação de temperatura do RSU com a profundidade. COUMOULOS et al. (1995) apresentam dados de temperatura para o aterro de Ano Liossia em Atenas (Grécia)(Figura 2.3.6) e MARIANO \& JUCÁ (1998) apresentam resultados de temperatura para o aterro da Muribeca em Recife (Figura 2.3.7). Segundo COUMOULOS et al. (1995) as temperaturas do RSU flutuam em $40^{\circ} \mathrm{C}$ a $60^{\circ} \mathrm{C}$ e estas não foram afetadas pelas variações sazonais da temperatura ambiente.
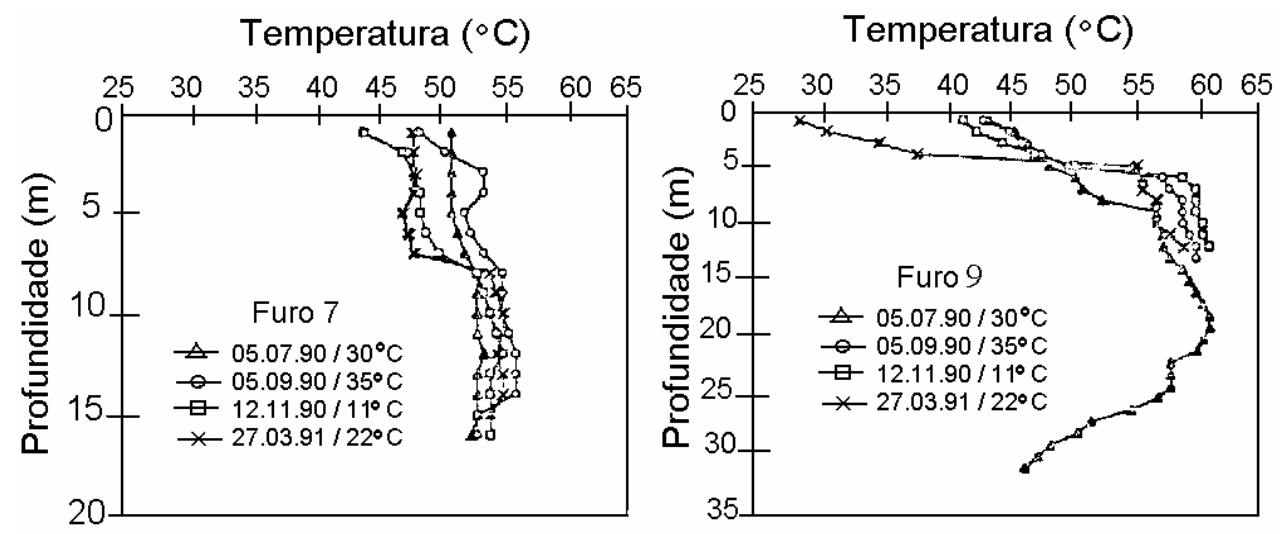

Figura 2.3.6 - Variação da temperatura do RSU com a profundidade, Aterro Ano Liossia, Atenas (Grécia), (COUMOULOS et al. 1995).

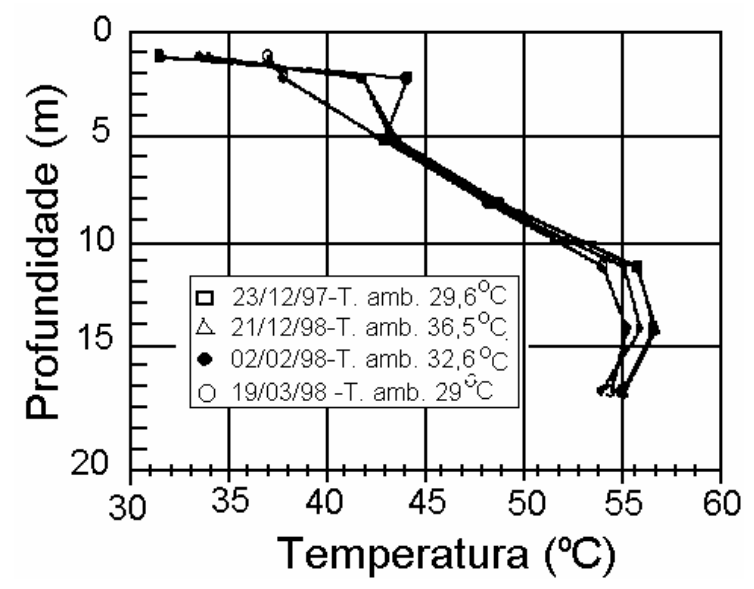

Figura 2.3.7 - Variação da temperatura do RSU com a profundidade, Aterro da Muribeca, Recife (Brasil), (MARIANO \& JUCÁ 1998). 


\subsubsection{6 - Peso específico in situ}

O peso específico in situ do RSU aterrado é especialmente influenciado pela composição e umidade do RSU, pelas camadas de cobertura diária, pela compactação e pela decomposição e consolidação do resíduo com o tempo (COWLAND et al. 1993; MITCHELL et al. 1995, LING et al. 1998). Em aterros mais antigos, o peso específico depende do grau de decomposição, fatores ambientais e profundidade da amostra e este, geralmente, aumenta com a profundidade como resultado do processo de compressão e bioconsolidação do RSU (KÖNIG \& JESSBERGER 1997). Como o RSU é composto de vários constituintes, o seu peso específico total médio depende do peso específico, porosidade, grau de saturação e porcentagem de cada componente individual.

Vários autores como CARTIER \& BALDIT 1983; LANDVA \& CLARK 1990; SINGH \& MURPHY 1990; EDIL et al. 1990; WATTS \& CHARLES 1990; OWEIS 1993; GOTTELAND et al. 1995; WITHIAN et al. 1995; KAVAZANJIAN et al. 1995; MANASSERO et al. $1996 \mathrm{e}$ KNOCHENMUS et al. 1998, têm publicado dados de peso específico in situ para o resíduo sólido urbano. Por exemplo, LANDVA \& CLARK (1990), apresentaram uma faixa de variação do peso específico in situ, determinados em poços escavados, entre 7 e $14 \mathrm{kN} / \mathrm{m}^{3}$, para aterros no Canadá, os quais apresentam um elevado conteúdo orgânico (tipicamente superior a 50\%). Na tabela 2.3.3 apresentam-se alguns valores de pesos específicos publicados por OWEIS (1993), os quais foram obtidos de comunidades com programas mínimos de reciclagem. Fassett et al ${ }^{1}$ apud MANASSERO et al. (1996) apresentaram valores de pesos específicos variando de 3 a $9 \mathrm{kN} / \mathrm{m}^{3}$ para aterros mal compactados, de 5 a $8 \mathrm{kN} / \mathrm{m}^{3}$ para moderadamente compactados e de 9 a $10,5 \mathrm{kN} / \mathrm{m}^{3}$ para aterros bem compactados. WITHIAN et al. (1995) encontraram valores entre 11 a $13 \mathrm{kN} / \mathrm{m}^{3}$, para o aterro de Dekorte Park (New Jersey).

KAVAZANJIAN et al. (1995) elaboraram um perfil de variação do peso específico com a profundidade desenvolvido a partir dos dados publicados pelo Earth Technology ${ }^{2} \mathrm{e}$ Fassett et al (Figura 2.3.8). Os dados do Earth Technology (1988) são resultantes de estudos de campo e de laboratório executados para o aterro Puente Hills, próximo de Los Angeles. Para esse caso, o perfil do peso específico está apresentado na figura 2.3.8, onde obteve-se peso específico variando de $3,3 \mathrm{kN} / \mathrm{m}^{3}$ na superfície, até $12,8 \mathrm{kN} / \mathrm{m}^{3}$ para profundidades maiores que 60metros. Nesta figura também estão mostradas as envoltórias de valor máximo e mínimo obtidas por Fassett et al (1994), bem como os resultados de

\footnotetext{
${ }^{1}$ FASSETT, J. B., LEONARDS, G. A \& REPETTO, P. C. (1994). Geotechnical properties of municipal solid wastes and their use in landfill design. Proc. Waste Tchnical Conference, Charleston, SC, USA.

2 EARTH TECHNOLOGY (1988). In-place stability of landfill slopes, puente hills landfill, Los Angeles, California. Repot no. 88-614-1, prepared for the sanitation districts of Los Angeles county, the Earth Technology Corp., Long Beach, CA.
} 
Weimer (1982). Segundo KAVAZANJIAN et al. (1995), o peso específico in situ médio varia tipicamente entre 8,6 a $10,2 \mathrm{kN} / \mathrm{m}^{3}$ e, geralmente, aumenta com a profundidade devido à bioconsolidação do RSU com o tempo e à compressão devido à sobrecarga. A partir de profundidades superiores a 40 - 45 metros tem-se um pequeno aumento do peso específico com a profundidade.

TABELA 2.3.3- Peso específico do resíduo sólido urbano (OWEIS, 1993).

\begin{tabular}{l|c}
\hline Forma do resíduo sólido urbano (RSU) & Peso específico $\left(\mathbf{k N / \mathbf { m } ^ { 3 }}\right)$ \\
\hline RSU - compactação moderada a boa & $4,7-6,3$ \\
RSU - compactação boa a excelente & $8,6-9,4$ \\
RSU - fardo de lixo & 8,6 - 14,1 \\
RSU - aterro ativo com líquido percolado & 6,6 \\
RSU - aterro antigo & 9,7 \\
RSU - ensaio em poço & $8,9-16,2$ \\
RSU - após recalque e degradação & $9,9-11,0$ \\
Resíduo de incinerador & $7,2-12,7$ \\
Resíduo de incinerador (compactado na $\rho_{\text {dmáx, wót) }}$ & 13,5 \\
Resíduo de incinerador recente e antigo (in situ) & $14,9-16,6$ \\
Pedaço de madeira (seca) & 2,3 \\
Pedaço de madeira (com 64\% de umidade) & 3,8 \\
Composto de folha & 2,6 \\
Compostagem (40\% de umidade) & 5,2 \\
Produto final & 3,5 \\
\hline
\end{tabular}

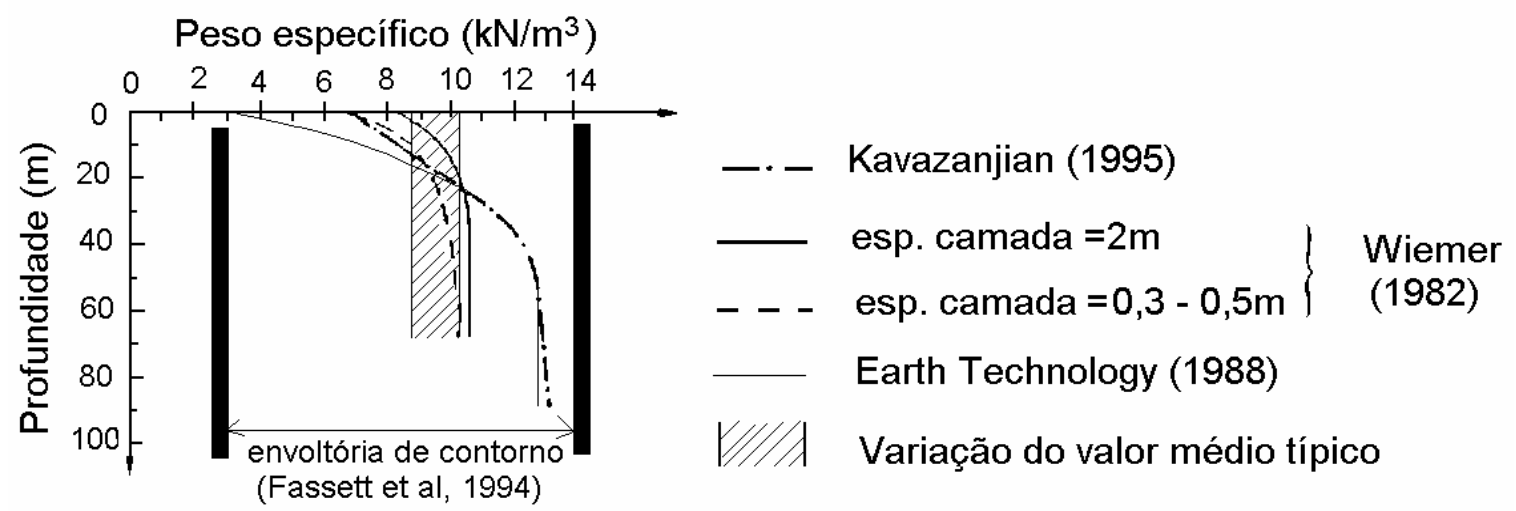

Figura 2.3.8 - Peso específico para o resíduo sólido urbano (modificado de KAVAZANJIAN et al. 1995). 
Segundo KÖNIG \& JESSBERGER (1997) os pesos específicos obtidos para os resíduos sólidos urbanos aterrados apresentam uma ampla faixa de variação, indo deste baixos valores como $3 \mathrm{kN} / \mathrm{m}^{3}$, para aterros não compactados a pobremente compactados, até valores como $17 \mathrm{kN} / \mathrm{m}^{3}$, para aterros com alto grau de compactação. Mas em geral, os valores médios situam-se entre $9-12 \mathrm{kN} / \mathrm{m}^{3}$. É importante ressaltar que inclusive valores acima de $18 \mathrm{kN} / \mathrm{m}^{3}$ já foram medidos por GOTTELAND et al. (1995), para um aterro francês e por MATASOVIC \& KAVAZANJIAN (1998) para um aterro da Califórnia. Na Figura 2.3.9 apresenta-se medidas de pesos específicos obtidos por MATASOVIC \& KAVAZANJIAN (1998) para o aterro Oll (Califórnia) empregando diferentes métodos de ensaios (em trincheiras, furo de sondagem e retro-análise). Os resultados indicam que o peso específico do RSU variou de uma forma não sistemática entre $12 \mathrm{kN} / \mathrm{m}^{3}$ e $21 \mathrm{kN} / \mathrm{m}^{3}$, com a maioria dos valores entre 14 e $18 \mathrm{kN} / \mathrm{m}^{3}$.

Segundo GOTTELAND et al. (1995), várias técnicas são usadas para determinar o peso específico in situ, dentre elas destacam-se os ensaios em poços escavados (2 a $4 \mathrm{~m}$ de profundidade) ou trincheira e aqueles empregando radiação gama. Os ensaios em poços consistem na pesagem do material e determinação do volume a partir do preenchimento da cava devidamente impermeabilizada com manta sintética. Para os autores acima, nenhum dos métodos é realmente preciso e adequado para o RSU, sendo portanto, obtido um grau de incerteza nas medidas, o qual está entre 10 a $20 \%$.

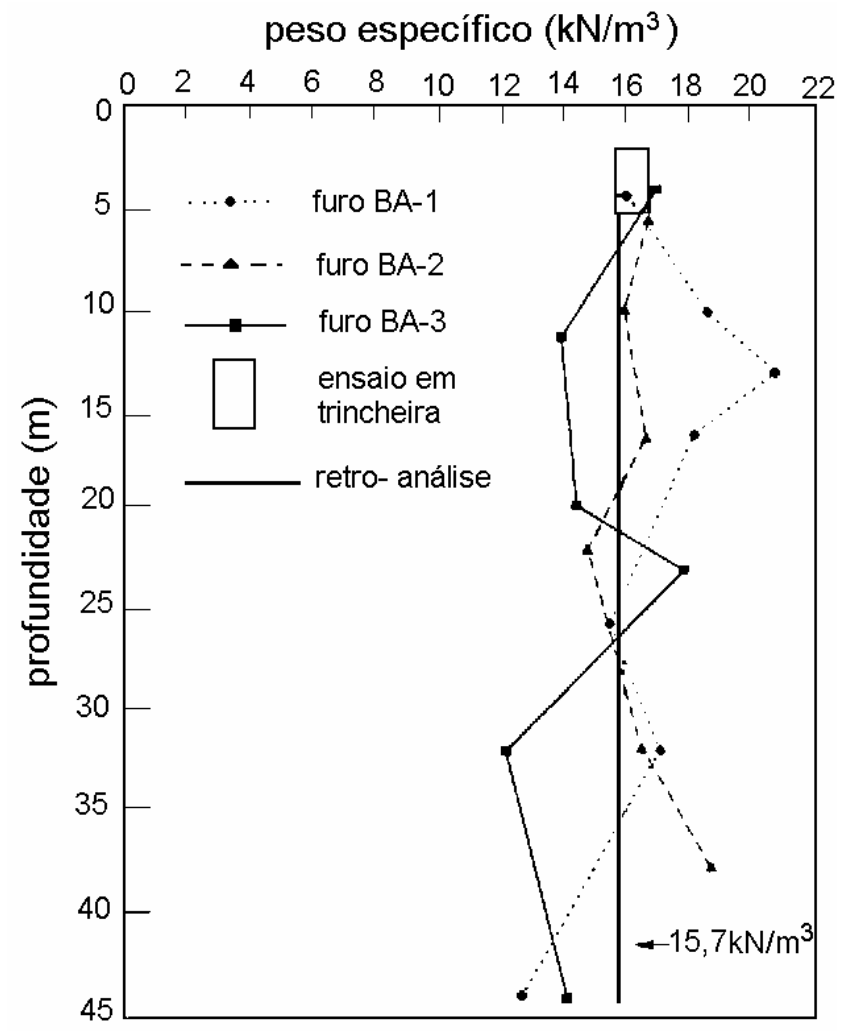

Figura 2.3.9 - Peso específico in situ obtidos através de ensaios em trincheira, furos de sondagem e retro- análise (MATASOVIC \& KAVAZANJIAN 1998). 


\subsubsection{7 - Permeabilidade do RSU}

O coeficiente de permeabilidade do resíduo é um importante parâmetro de projeto e operação de aterros sanitários, particularmente nos casos de problemas de estabilidade e migração não controlada de líquido percolado.

A permeabilidade é normalmente avaliada por meio de ensaios de laboratório e ensaios in situ, executados em trincheiras e poços escavados de grande diâmetro ou em furos de sondagem.

A Tabela 2.3.4 apresenta dados de condutividade hidráulica de RSU publicados por vários autores e compilados por KÖNIG \& JESSBERGER (1997). Também foram incluídos nesta tabela os resultados obtidos por SANTOS et al. (1998) para o aterro da Muribeca em Recife e por BLENGINO et al. (1996) para o aterro de Scarpino na Itália. Os valores mostram que o coeficiente de permeabilidade, geralmente, varia de $10^{-4} \mathrm{~m} / \mathrm{s}$ a $10^{-6} \mathrm{~m} / \mathrm{s}$, o qual é compatível com os valores obtidos para areias finas e limpas.

A permeabilidade é altamente dependente do procedimento de aterramento, grau de compactação, pressão de sobrecarga, idade e composição do RSU (KNOCHENMUS et al. 1998). Portanto, deve ser determinada de caso para caso. MANASSERO et al. (1996) sugere o uso de um coeficiente de permeabilidade de $10^{-5} \mathrm{~m} / \mathrm{s}$ como uma primeira aproximação. Segundo McCREANOR \& REINHART (1997), a literatura apresenta valores de permeabilidade para lixo urbano variando de várias ordens de magnitude, os quais são em função dos procedimentos de disposição bem como da característica do material.

LANDVA et al. (1998) apresentaram dados de ensaios de permeabilidade executados em laboratório, em duas amostras de RSU do Canadá, usando equipamento especializado para medida de permeabilidade vertical e horizontal, sob incremento de tensão vertical. Os resultados obtidos estão apresentados na Figura 2.3.10. Nesta figura também estão plotados os resultados de permeabilidade in situ obtidos de poços escavados para vários aterros do Canadá (Calgary, Edmonton, Mississanga, Waterloo) publicados por LANDVA \& CLARK (1990) e os resultados de Rowe \& Nadarajah ${ }^{1}$ apud LANDVA et al. (1998). A figura mostra uma considerável variação na permeabilidade in situ com a profundidade, mas segundo LANDVA et al. (1998), excluindo os resultados de ensaios SL21 , os quais parecem estar influenciados pela presença de camadas com muitos plásticos e caixas, inibindo o fluxo e resultando, portanto, em um menor valor de $k$, os dados obtidos estão razoavelmente próximos da linha média ajustada por Rowe \& Nadarajah a partir de medidas de permeabilidade no campo $\left(k=0,00018 \mathrm{e}^{-0,269 \cdot z}\right)$.

\footnotetext{
${ }^{1}$ ROWE, R.K. \& NADARAJAH, P. (1996). Estimating leachate drawdown due to pumping wells in landfiils. Canadian Geotechenical Journal, vol. 33, no. 1, pp1-10
} 
Tabela 2.3.4 - Coeficientes de permeabilidade para o RSU (modificado de KÖNIG \& JESSBERGER, 1997).

\begin{tabular}{|c|c|c|c|}
\hline Referência & $\begin{array}{c}\text { Peso } \\
\text { específico } \\
\left(\mathrm{kN} / \mathrm{m}^{3}\right) \\
\end{array}$ & $\begin{array}{c}\text { Coeficiente de } \\
\text { permeabilidade } \\
(\mathrm{m} / \mathrm{s})\end{array}$ & Método de ensaio \\
\hline Fungaroli et al (1979) & $1,1-4$ & $1 \times 10^{-5}-2,0 \times 10^{-4}$ & Determinação em lisímeros \\
\hline Koriates et al (1983) & 8,6 & $3,15 \times 10^{-5}-5,1 \times 10^{-5}$ & Ensaio de laboratório \\
\hline Oweis \& Khera (1986) & 6,45 & $1 \times 10^{-5}$ & Estimativa de dados de campo \\
\hline Oweis et al (1990) & $\begin{array}{c}6,45 \\
9,4-14 \\
6,3-9,4\end{array}$ & $\begin{array}{c}1 \times 10^{-5} \\
1,5 \times 10^{-6} \\
1,1 \times 10^{-5} \\
\end{array}$ & $\begin{array}{l}\text { Ensaio de bombeamento } \\
\text { Ensaio de campo com carga } \\
\text { variável } \\
\text { Ensaio em poço } \\
\end{array}$ \\
\hline Landva \& Clark (1990) & $10,1-14,4$ & $1 \times 10^{-5}-4 \times 10^{-4}$ & Ensaio em poço \\
\hline Gabr \& Valero (1995) & - & $1 \times 10^{-7}-1 \times 10^{-5}$ & Ensaio de laboratório \\
\hline Blengino et al (1996) & $9-11$ & $3 \times 10^{-7}-3 \times 10^{-6}$ & $\begin{array}{l}\text { Ensaio de campo em furos } \\
\text { profundos }(30-40 \mathrm{~m}) \text { e com carga } \\
\text { variável }\end{array}$ \\
\hline Manassero et al (1990) & $8-10$ & $1,5 \times 10^{-5}-2,6 \times 10^{-4}$ & $\begin{array}{l}\text { Ensaio de bombeamento (15-20m } \\
\text { em profundidade) }\end{array}$ \\
\hline Beaven \& Powrie (1995) & $5-13$ & $1 \times 10^{-7}-1 \times 10^{-4}$ & $\begin{array}{l}\text { Ensaios de laboratório com } \\
\text { pressão conf. de } 0-600 \mathrm{kPa}\end{array}$ \\
\hline Brandl (1990) & $\begin{array}{l}11-14 \\
13-16\end{array}$ & $\begin{array}{c}7 \times 10^{-6}-2 \times 10^{-5} \\
\text { (comp. rolo) } \\
5 \times 10^{-6}-3 \times 10^{-7} \\
\text { (comp. dinâmica) }\end{array}$ & $\begin{array}{l}\text { Ensaio de campo com carga } \\
\text { variável } \\
\text { Ensaio em poço }\end{array}$ \\
\hline Brandl (1994) & $\begin{array}{l}9-12 \\
9-12 \\
13-17\end{array}$ & $\begin{array}{c}2 \times 10^{-5}-1 \times 10^{-6} \\
5 \times 10^{-4}-3 \times 10^{-5} \\
\text { (pre-tratado) } \\
2 \times 10^{-6}-3 \times 10^{-5} \\
\text { (muito compactado) }\end{array}$ & Ensaio de laboratório \\
\hline Jessberger (1984) & $\begin{array}{l}\text { RSU mist. } \\
\text { com entulho } \\
\text { (ensaio I) }\end{array}$ & $\begin{array}{c}1 \times 10^{-8}-10^{-3} \\
3 \times 10^{-8}-1 \times 10^{-5}\end{array}$ & $\begin{array}{l}\text { Antes da comp. dinâmica } \\
\text { Depois da comp. dinâmica }\end{array}$ \\
\hline Jessberger (1984) & $\begin{array}{l}\text { RSU mist. } \\
\text { com entulho } \\
\text { (ensaio I) } \\
\end{array}$ & $\begin{array}{l}4 \times 10^{-6}-4 \times 10^{-3} \\
1 \times 10^{-7}-1 \times 10^{-4}\end{array}$ & $\begin{array}{l}\text { Antes da comp. dinâmica } \\
\text { Depois da comp. dinâmica }\end{array}$ \\
\hline Santos et al (1998) & $14-19$ & $1 \times 10^{-7}$ & $\begin{array}{l}\text { Ensaio in situ em furo de } \\
\text { sondagem }\end{array}$ \\
\hline Blengino et al. (1996) & - & $3 \times 10^{-7}-2,5 \times 10^{-6}$ & $\begin{array}{l}\text { Ensaio in situ em furo de } \\
\text { sondagem }\end{array}$ \\
\hline
\end{tabular}




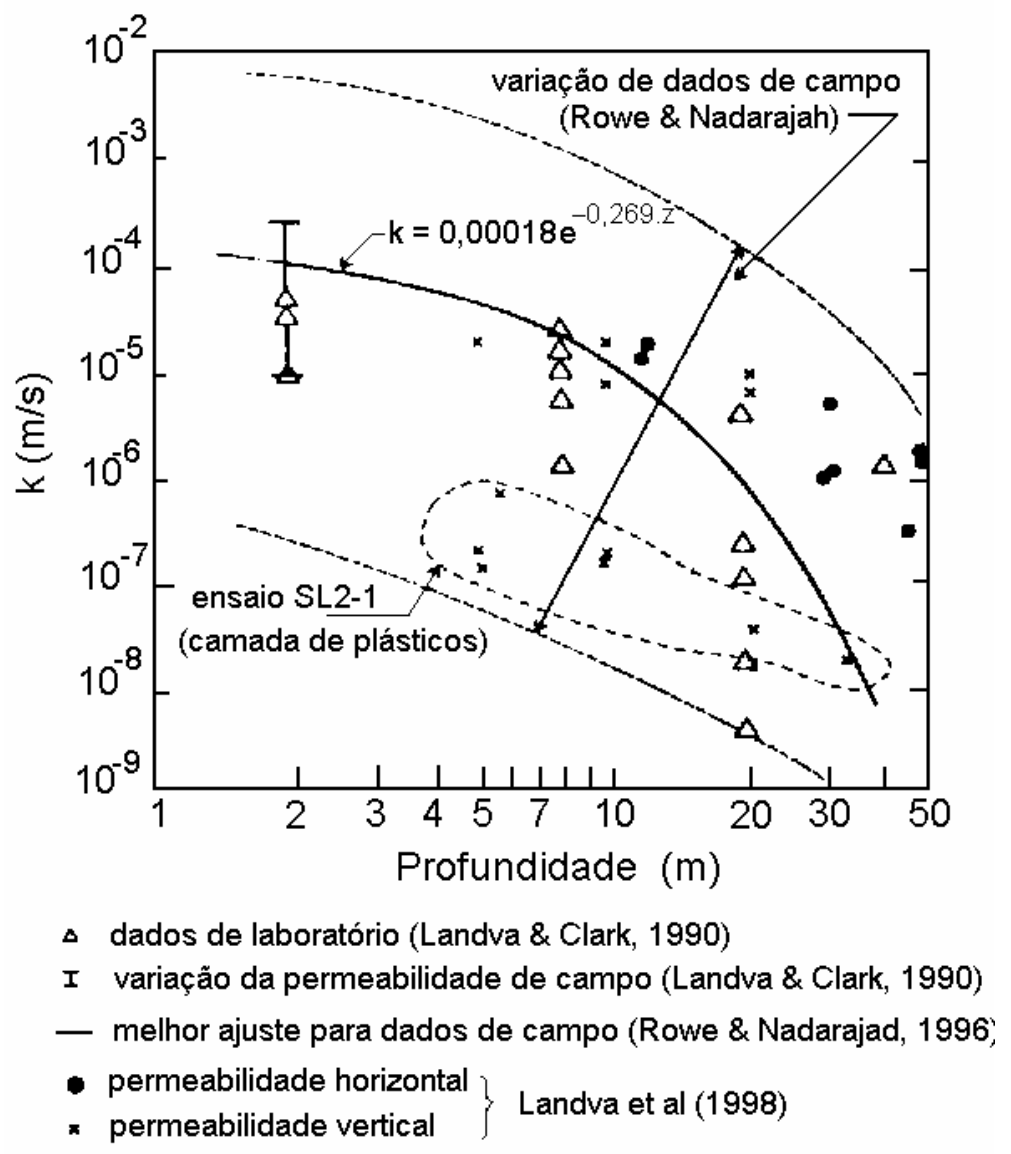

Figura 2.3.10 - Comparação do coeficiente de permeabilidade do RSU obtido por meio de ensaios de campo e laboratório (LANDVA et al. 1998). 


\section{4 - PROPRIEDADES MECÂNICAS DOS RESÍDUOS SÓLIDOS URBANOS}

\subsection{1 - Introdução}

As principais propriedades mecânicas dos resíduos sólidos urbanos (resistência ao cisalhamento e compressibilidade) são fortemente influenciadas pela composição e estado de alteração do resíduo bem como pelo comportamento mecânico de cada componente. As informações sobre essas propriedades do RSU são escassas e, em alguns casos, os dados publicados são contraditórios (KNOCHENMUS et al. 1998).

A quantificação das propriedades mecânicas desses materiais é uma tarefa difícil dada a influência da composição heterogênea do RSU, presença de componentes com diferentes formas e dimensões que dificulta, sobremaneira, a obtenção de amostras de boa qualidade, definição do tamanho das amostras e tipos de ensaios mais adequados para serem utilizados.

Em geral, as propriedades mecânicas dos resíduos sólidos urbanos são avaliadas empregando, para esses materiais, os métodos convencionais de ensaios desenvolvidos para solos, ambos de campo e laboratório. Porém autores como SÁNCHEZ-ALCITURRI et al. (1993), MANASSERO et al. (1996), KÖNIG \& JESSBERGER (1997) dentre outros, chamam a atenção quanto ao cuidado que deve ser tomado quando estender para o RSU os conceitos e as teorias clássicas da mecânica dos solos, pois existem significantes diferenças entre estes dois materiais. O RSU apresenta um alto índice de vazios e portanto uma grande compressibilidade, apresenta partículas de natureza muito diferente sendo que algumas delas são muito deformáveis e podem degradar, provocando uma autoconsolidação e variação das propriedades com o tempo.

\subsection{2 - Resistência ao cisalhamento}

A resistência ao cisalhamento do RSU é usualmente determinada por meio de ensaios in situ, ensaios de laboratório (triaxiais, cisalhamento direto) e retro-análise de dados de campo. 


\section{a) Retro-análise de dados de campo}

Segundo KÖNIG \& JESSBERGER (1997) e MANASSERO et al. (1996) deve-se tomar um cuidado especial com o emprego de parâmetros de resistência obtidos de retro análise, pois existe um número infinito de combinações de resistência ao cisalhamento o qual satisfaz a equação de equilíbrio (uma equação e duas incógnitas) e portanto, a solução não pode ser obtida precisamente.

A definição dos parâmetros de resistência a partir de retro-análise do comportamento do maciço limitam-se apenas a alguns poucos casos (COWLAND et al. 1993). SINGH \& MURPHY (1990) apresentaram uma coletânea dos vários parâmetros de resistência, obtidos de retro-análise de aterros sanitários de resíduos sólidos urbanos, (Figura 2.4.1), porém não se obteve nenhum tipo de informação das considerações adotadas no cálculo.

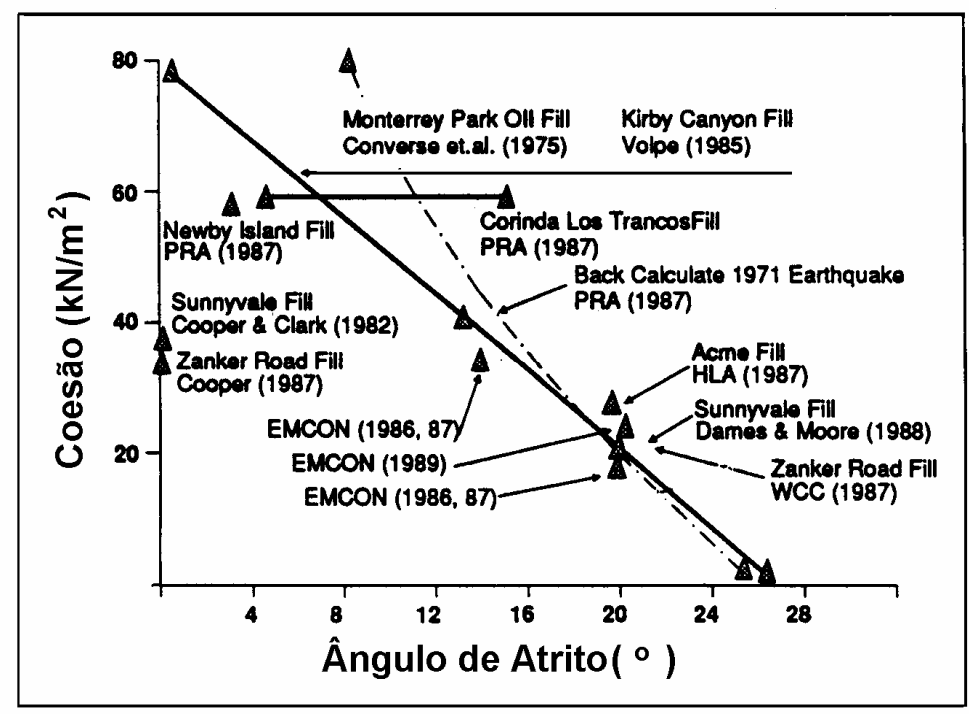

Figura 2.4.1 - Parâmetros de resistência obtidos por retro-análise (SINGH \& MURPHY 1990).

A Tabela 2.4.1 apresenta alguns parâmetros de resistência ao cisalhamento resultantes de retro-análise publicados por VAN IMPE (1998). Nesta tabela, também estão incluídos os parâmetros de resistência obtidos por BENVENUTO \& CUNHA (1991) a partir do escorregamento ocorrido no sub-aterro AS-1 do aterro sanitário Bandeirantes (SP). 
Tabela 2.4.1 - Características de resistência ao cisalhamento do RSU obtidas a partir de retro- análise (VAN IMPE 1998).

\begin{tabular}{|l|c|c|l|}
\hline \multirow{2}{*}{\multicolumn{1}{c|}{ Referência }} & \multicolumn{2}{|c|}{ Parâmetros de resistência } & \multicolumn{1}{c|}{ Comentários } \\
\cline { 2 - 4 } & $\boldsymbol{C}^{\prime}(\mathbf{k P a})$ & $\phi^{\prime}(\mathrm{q})$ & \multicolumn{1}{|c|}{} \\
\hline Cowland et al (1993) & 10 & 25 & Corte no RSU em trincheira profunda \\
\hline Kavazanjian et al (1995) & - & $25-34$ & $45 \mathrm{kPa}<\sigma<180 \mathrm{kPa}$ \\
\hline Van Impe et al (1996) & 20 & 0 & sobrecarga $\leq 20 \mathrm{kPa}$ \\
\hline Van Impe et al (1996) & 0 & 38 & $20 \mathrm{kPa}<$ sobrecarga $\leq 60 \mathrm{kPa}$ \\
\hline Van Impe et al (1996) & 20 & 30 & sobrecarga $>60 \mathrm{kPa}$ \\
\hline Benvenuto \& Cunha (1991) & 13,5 & 22 & Peso específico $10-13 \mathrm{kN} / \mathrm{m}^{3}$ \\
\hline
\end{tabular}

\section{b) Ensaios in situ}

Vários autores (SIEGEL et al. 1990, SÁNCHEZ-ALCITURRI et al. 1993, COUMOULOS et al. 1995 e JUCÁ et al. 1997) têm avaliado a resistência do RSU por meio de ensaios in situ, tais como CPT, SPT e vane test. Na maioria dos casos, esses ensaios são difíceis de serem executados devido à presença de materiais resistentes como madeira, pedra, metal e outros, os quais provocam grandes picos na resistência medida, desvio das haste dos equipamentos e avarias nos amostradores, paletas e ponteiras.

Segundo SINGH \& MURPHY (1990) e MANASSERO et al. (1996), os resultados obtidos dos ensaios de vane não são representativos da resistência do RSU, pois as paletas usadas neste ensaio são muito pequenas comparadas com as dimensões dos componentes do RSU.

A Figura 2.4.2 apresenta resultados típicos de ensaios de SPT executados em vários aterros sanitários. Nesta figura estão apresentados os resultados obtidos por COUMOULOS et al. (1995) para o aterro de Ano Liossia, em Atenas (Grécia), os resultados obtidos por SÁNCHEZ-ALCITURRI et al. (1993) para o aterro de Meruelo (Espanha), bem como, os resultados obtidos por JUCÁ et al. (1997), para o aterro da Muribeca (Recife) e resultados obtidos por SOWERS (1968) para aterros não controlados da Georgia (USA).

Segundo SOWERS (1968) e JUCÁ et al. (1997), os valores de penetração do amostrador ( $\left.\mathrm{N}_{\mathrm{SPT}}\right)$, raramente, ultrapassam 10 golpes. Já COUMOULOS et al. (1995) e SÁNCHEZ-ALCITURRI et al. (1993) encontraram valores de $\mathrm{N}_{\mathrm{SPT}}$ crescentes com a profundidade, sendo que os resultados obtidos por COUMOULOS et al. (1995), para o aterro Ano Liossia, apresentaram-se bem maiores, com $\mathrm{N}_{\mathrm{SPT}}$ variando de cerca de 25 golpes para a profundidade de $5 \mathrm{~m}$ até cerca de 65 golpes para a profundidade de $25 \mathrm{~m}$. Esses ensaios apresentam um alto grau de dispersão nos resultados o que torna difícil sua interpretação e obtenção das propriedades de resistência do RSU através de correlações com o número de golpes (KNOCHENMUS et al. 1998). 


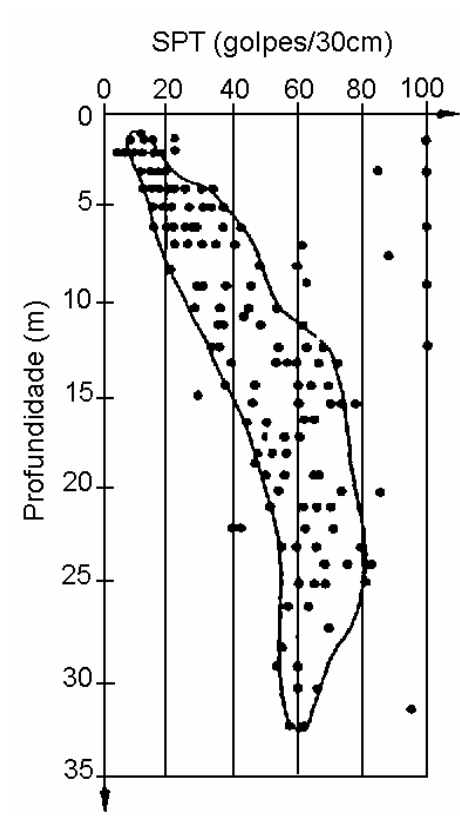

N SPT
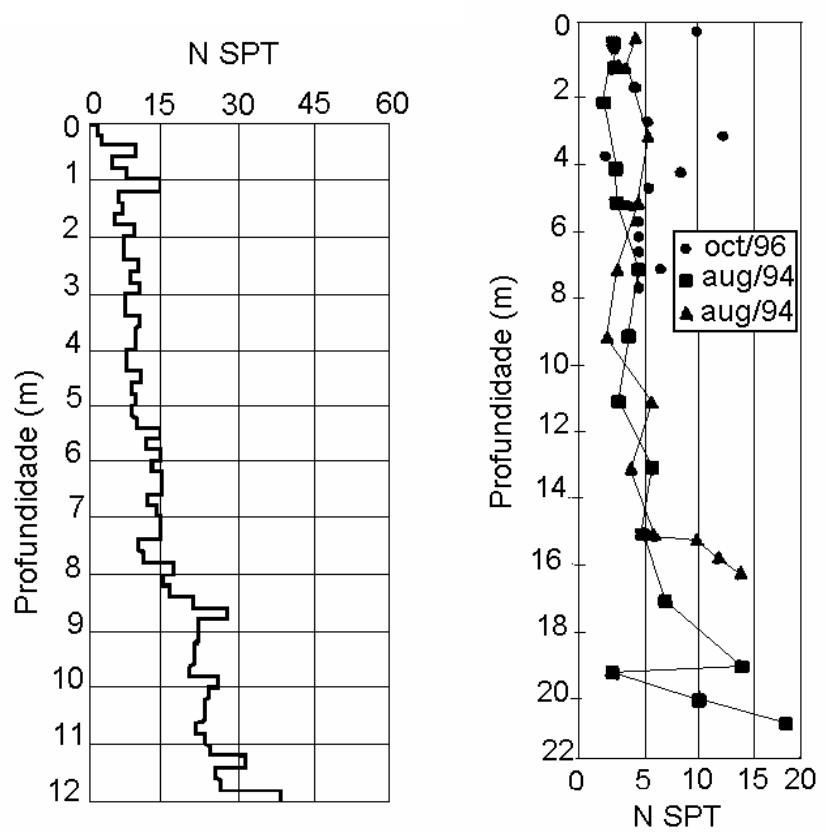

COUMOULOS et al. (1995)

SÁNCHEZ-ALCITURRI et al. (1993)

JUCÁ et al. (1997)
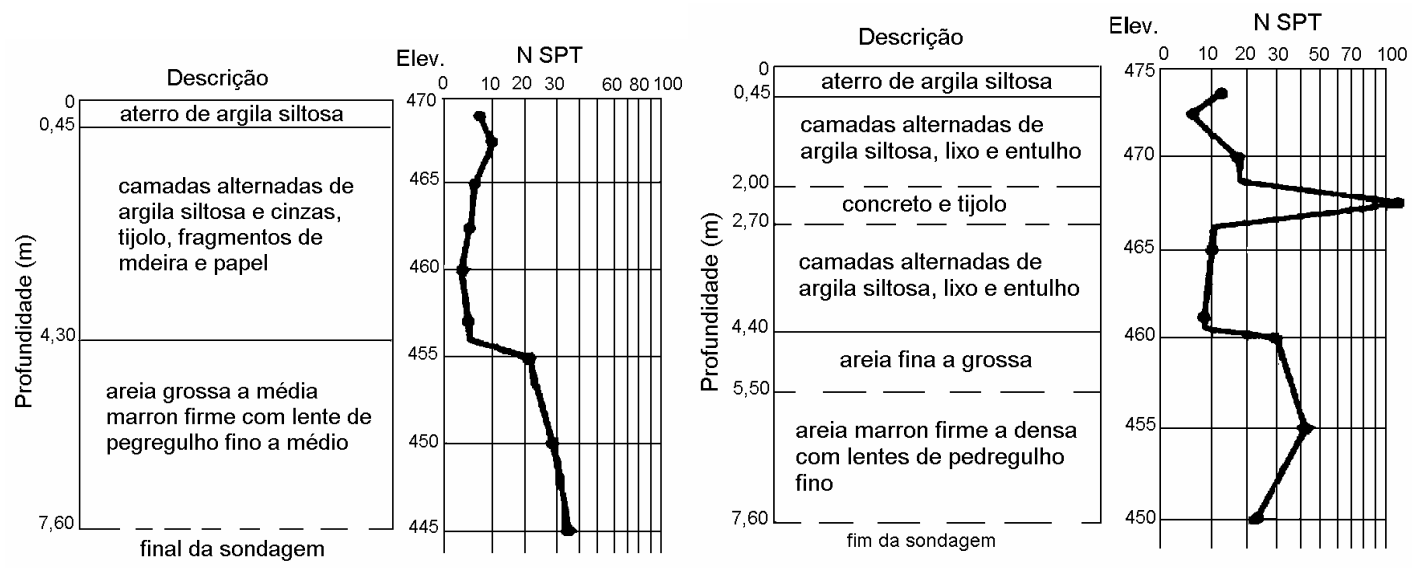

\section{SOWERS (1968)}

Figura 2.4.2 - Resistência à penetração do SPT para aterros de resíduos sólidos urbanos obtida por vários autores.

Os ensaios de penetração contínua (CPT) podem ser usados para localizar áreas de menor resistência no interior do aterro e avaliar a variação da resistência com o tempo (SIEGEL et al. 1990, MANASSERO et al. 1996, KNOCHENMUS et al. 1998). A Figura 2.4.3 apresenta resultados típicos de ensaios de CPT realizados em vários aterros sanitários (CARTIER \& BALDIT 1983, SIEGEL et al 1990, BOUAZZA et al. 1996). 


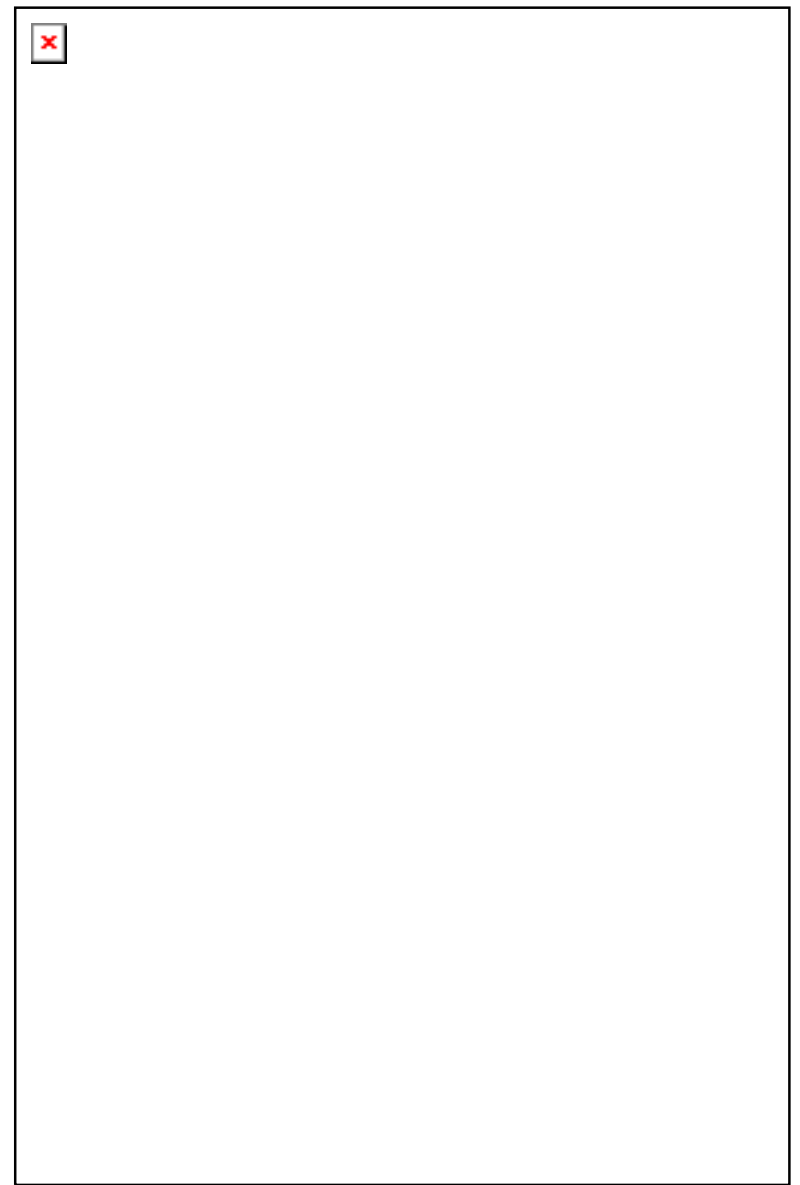

SIEGEL et al. (1990)
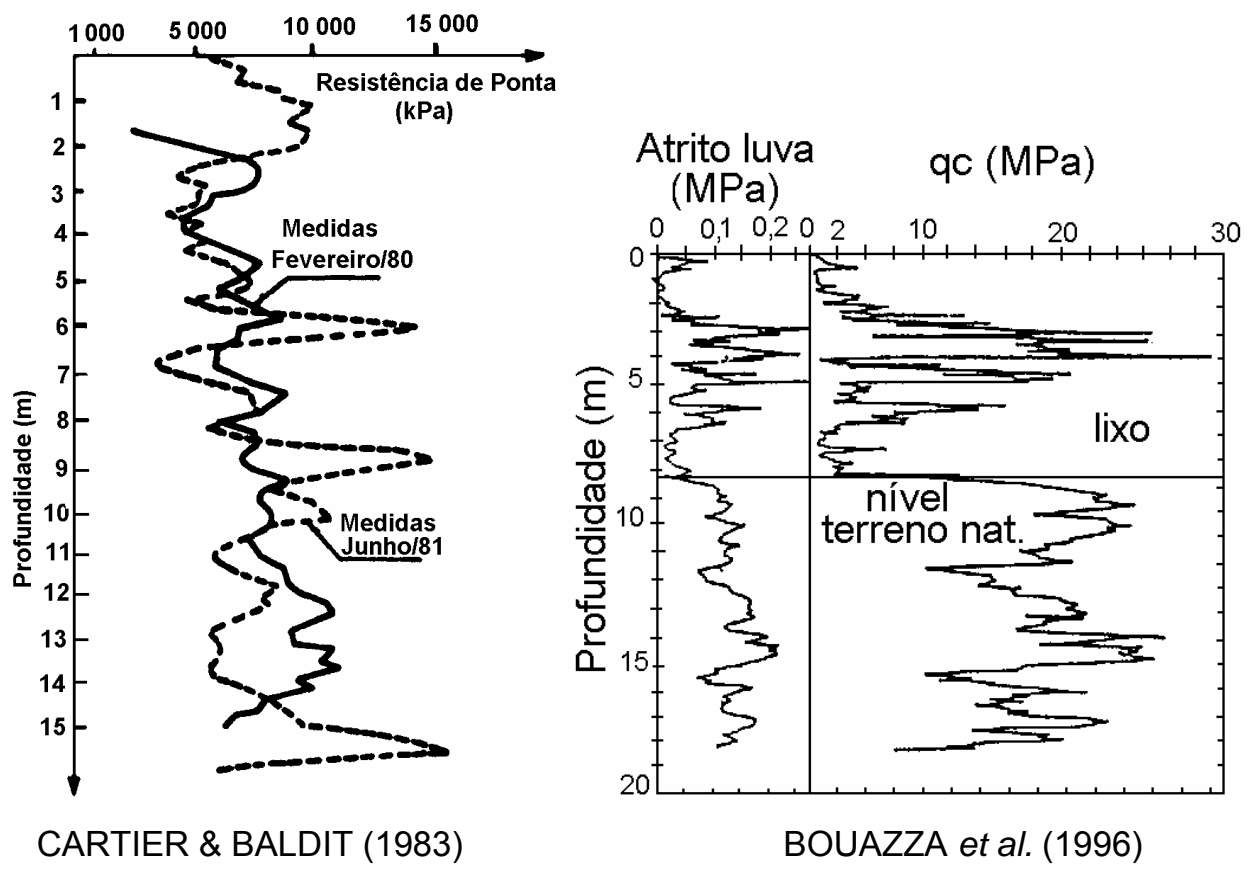

Figura 2.4.3 - Resultados típicos de ensaios CPT para aterros de resíduos sólidos urbanos obtidos por diversos autores. 
Embora as medidas do CPT apresentam picos de resistência, indicando que o cone freqüentemente encontra objetos rígidos (madeira, metal, pedras, etc), pode-se observar uma tendência geral onde, na maioria dos casos, a resistência de ponta aumenta com profundidade (MANASSERO et al. 1996).

SÁNCHEZ-ALCITURRI et al. (1993) obteve para o aterro de Meruelo (Espanha) resistência de ponta variando de 1 - 3MPa e relação de atrito (atrito na luva / resistência de ponta) variando de $1-2 \%$. Com esses resultados e empregando correlações existentes para areias entre qc e $\phi$, os autores acima estimaram um ângulo de atrito para o resíduo sólido urbano variando entre $28^{\circ}-35^{\circ}$. Outro aspecto importante, é que com esses resultados plotados na carta Shemertamann pôde-se obter uma classificação para o resíduo variando de areias fofas a areia argilosa e siltes (ver figura 2.3.1).

Além dos ensaios de SPT e CPT, alguns autores tem avaliado a resistência do resíduo por meio de ensaios de cisalhamento direto in situ, em grandes blocos de RSU (DEL-GRECO \& OGGERI 1993, WITHIAN et al. 1995).

WITHIAM et al. (1995) executaram, no aterro de Dekorte Park (New Jersey),

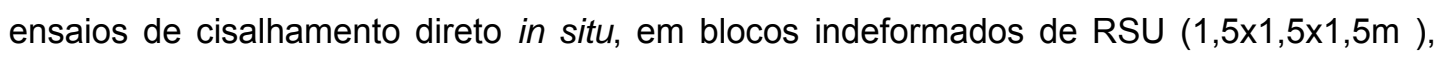
empregando um equipamento de grande dimensão, onde a seção inferior da caixa foi ancorada num aterro de argila compactada e a parte superior foi presa por um sistema de cabos à uma retro - escavadeira, pelo qual se aplicava a força horizontal. A força normal foi obtida através do uso de blocos de madeira e pesos de concreto. Foram executados 5 ensaios de cisalhamento direto em múltiplo estágio e variando as tensões normais de 0$21 \mathrm{kPa}$. A técnica do múltiplo estágio permitiu eliminar o efeito da variabilidade dos resultados associados ao uso de diferentes amostras para cada ensaio. A envoltória de ruptura foi definida por um intercepto de coesão de cerca de $10 \mathrm{kPa}$ e ângulo de atrito de $30^{\circ}$. Segundo os autores, os valores obtidos são coerentes com aqueles apresentados por SINGH \& MURPHY (1990).

Richardson \&Reynolds ${ }^{1}$ apud KAVAZANJIAN et al. (1995) também apresentaram, a partir de ensaios de cisalhamento direto in situ de grandes dimensões $(1,5 \times 1,5 \mathrm{~m})$, valores de coesão de $10 \mathrm{kPa}$ e ângulo de atrito variando de 18 a $43^{\circ}$, para um RSU com peso específico em torno de $15 \mathrm{kN} / \mathrm{m}^{3}$ e submetido à tensão normal variando entre $14-38 \mathrm{kPa}$, a qual foi aplicada por blocos de concreto.

Os resultados de ensaios de cisalhamento direto in situ realizados por GOTTELAND et al. (1995) em aterros de RSU do sul da França, apresentaram a mesma ordem de grandeza dos reportados por COWLAND et al. (1993) (c=10kPa e $\left.\phi=25^{\circ}\right)$. Foi empregado uma caixa de cisalhamento de $1 \mathrm{~m}^{2}$ de área por $35 \mathrm{~cm}$ de altura para cada seção da caixa, e amostras deformadas e não deformadas, as quais apresentaram resultados coerentes. Os

\footnotetext{
${ }^{1}$ RICHARDSON, G. \& REYNOLDS, D. (1991). Geosynthetic considerations in a landfill on compressible clays. Proc. of Geosynthetics' 91 , vol.2, Athanta, GA.
} 
autores comentaram ainda que, mesmo para grandes deslocamentos, como por exemplo $35 \%$, as curvas tensão- deformação não apresentaram pico de ruptura. Isso está coerente com resultados de ensaios triaxiais publicados por JESSBERGER \& KOCKEL, (1993); GRISOLIA et al. (1993) e COWLAND et al. (1993).

\section{c) Ensaios de laboratório}

Os ensaios de laboratório (triaxial e cisalhamento direto) tem sido os mais usados na avaliação da resistência do resíduo sólido urbano, os quais vêm sendo executados em amostras construídas em laboratório e amostras deformadas coletadas de aterros sanitários. A maior limitação desses ensaios reside na dificuldade de obter amostras de boa qualidade no que se refere à distribuição do tamanho dos grãos e à composição representativa do total, bem como no emprego de equipamentos de grandes dimensões (KÖNIG \& JESSBERGER 1997 e KNOCHENMUS et al. 1998).

Conforme expõe MANASSERO et al. (1996), a interpretação dos ensaios com RSU usando os conceitos teóricos derivados do comportamento de solos, é bastante útil no atual estado de conhecimento. Dessa forma, os conceitos de ângulo de atrito e intercepto de coesão são normalmente utilizados.

Os ensaios de cisalhamento direto vem sendo executados por alguns pesquisadores para obter os parâmetros de resistência do RSU e, em alguns casos, para obter os parâmetros de resistência na superfície de contato entre o RSU e geossintéticos (DEL - GRECO \& OGGERI 1993). Segundo SIEGEL et al. (1990) e MANASSERO et al. (1996), esse tipo de ensaio não reproduz o real comportamento do resíduo no aterro, mas serve como uma aproximação inicial para procedimentos mais exatos.

Curvas tensão - deformação típica obtida de ensaios de cisalhamento direto com RSU, apresentadas por vários autores, são mostradas na Figura 2.4.4 (MANASSERO et al. 1996). As curvas exibem ganho contínuo de resistência com a deformação medida e nenhuma delas apresentou pico de resistência. Nesse caso, similarmente aos ensaios triaxiais, os parâmetros de resistência serão determinados a partir de uma deformação considerada admissível. Para esses ensaios, em geral, tem-se empregado deformações de $10 \%$ e $15 \%$. Na Figura 2.4 .5 mostra-se a variação da tensão cisalhante $(\tau)$ com tensão normal $(\sigma)$ resultante de ensaios de cisalhamento direto obtidos por vários autores, para níveis de deformação de 10 e 15\%. Segundo VAN IMPE et al. (1998) os resíduos apresentam alguns aspectos similares ao comportamento de materiais convencionais tais como solo. No caso de fardo de RSU compactado, os maiores valores de ângulo de atrito são conseguidos para valores de tensão normal mais baixa, enquanto que o melhor entrosamento entre as partículas e o reforço das fibras é revelado para tensões verticais mais altas. No caso de resíduos antigos, o maior ângulo de atrito e intercepto de coesão são 
obtidos devido à matriz composta do material (solo - RSU) e também devido à variação do nível de tensão. Uma envoltória de ruptura linear curvada pode ser ajustada através dos dados para avaliar o nível de tensões (MANASERRO et al. 1996).

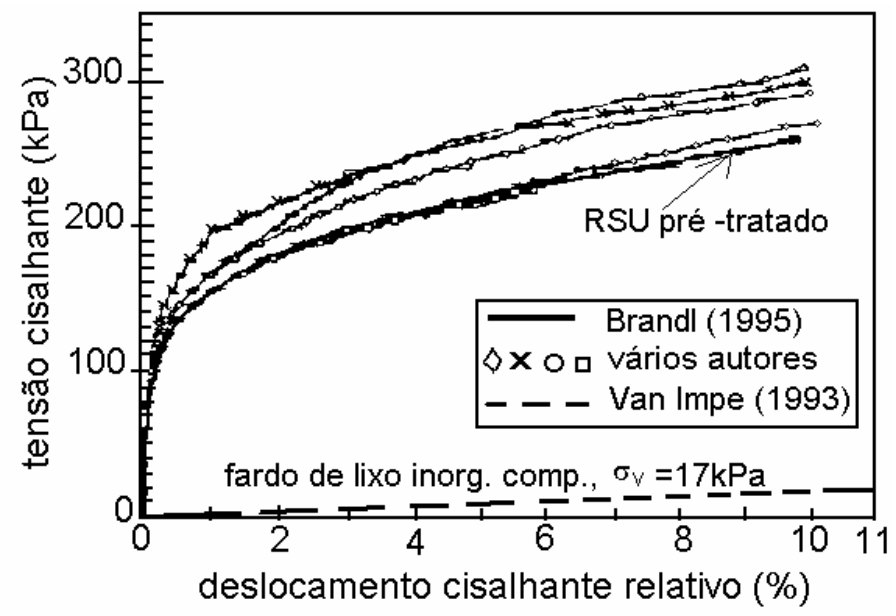

Figura 2.4.4 - Relação tensão - deformação obtida para resíduos sólidos urbanos a partir de ensaios de cisalhamento direto (MANASSERO et al. 1996).

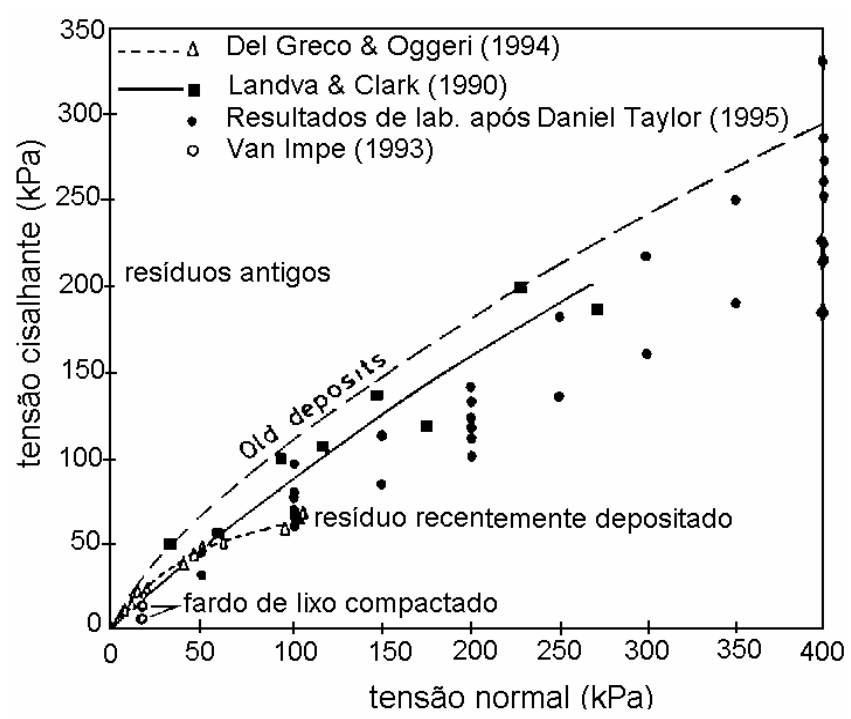

Figura 2.4.5 - Relação tensão cisalhante - tensão normal obtida para resíduos sólidos urbanos a partir de ensaios de cisalhamento direto (VAN IMPE 1998).

A Figura 2.4.6 apresenta os resultados de ensaios de cisalhamento direto executados por LANDVA \& CLARK (1990) em amostras de grandes dimensões $(434 \times 287 \mathrm{~mm})$ de resíduos provenientes de aterros do Canadá. As amostras foram cisalhadas com velocidade de $1,5 \mathrm{~mm} / \mathrm{min}$. Os autores obtiveram que a resistência ao cisalhamento do RSU é altamente variável dependendo do tipo de material. Para os casos 
ensaiados, a coesão variou entre $0-23 \mathrm{kPa}$ e o ângulo de atrito entre $24-41^{\circ}$. Não se identificou nenhuma evidência direta de que a resistência ao cisalhamento muda significativamente com o tempo.

SIEGEL et al. (1990), excluindo os resultados de ensaios obtidos para amostras com conteúdo de solo relativamente alto apresentaram, para o RSU do Monterey Park (Califórnia), um ângulo de atrito médio de $39^{\circ}$ e de $53^{\circ}$ se, na interpretação, forem considerados todos os dados obtidos. Este valor é significativamente superior aos obtidos por outros autores. Os ensaios de cisalhamento direto foram executados em amostras com 7,6 a $10,2 \mathrm{~cm}$ de altura e $13 \mathrm{~cm}$ de diâmetro.
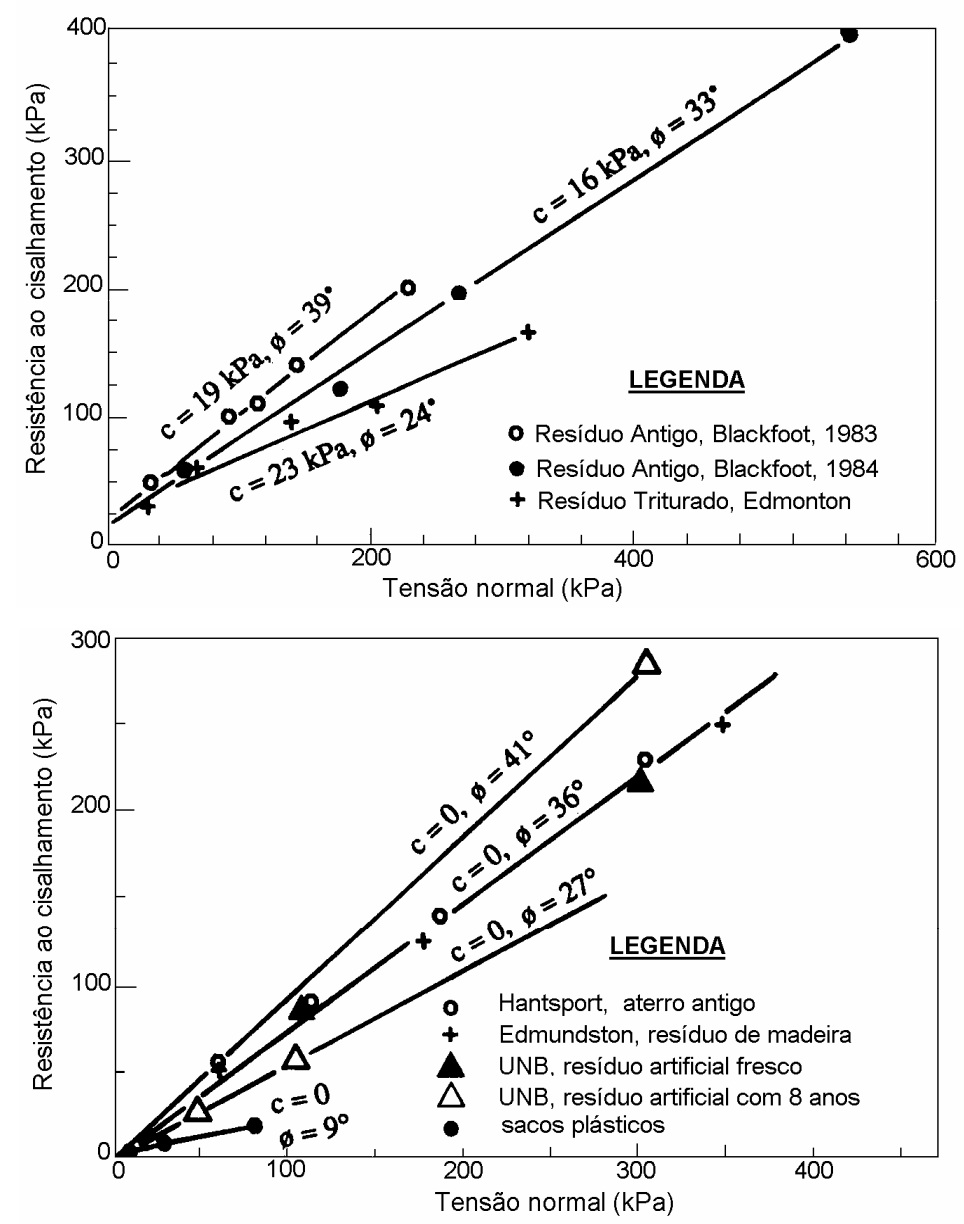

Figura 2.4.6 - Resultados de ensaios de cisalhamento direto em resíduos de aterros do Canadá (LANDVA \& CLARK 1990).

GABR \& VALERO (1995) apresentaram resultados de ensaios de cisalhamento direto executados em resíduo antigo (15 a 30 anos de aterrado) do aterro de Pioneer Crossing (Pennsylvania), compactado diretamente em uma caixa de cisalhamento de $63,5 \mathrm{~mm}$ de diâmetro e $23 \mathrm{~mm}$ de espessura e cisalhado com baixa velocidade de deslocamento (por exemplo, para tensão normal de $69 \mathrm{kPa}$ usou 0,024 $\mathrm{mm} / \mathrm{min}$ ), visando a dissipação da pressão neutra durante o cisalhamento. Os resíduos testados apresentaram, 
para vários níveis de deformação axial (5 e 10\%), um aumento do ângulo de atrito com o deslocamento enquanto que a coesão permaneceu essencialmente constante. Segundo GABR \& VALERO (1995) o ângulo de atrito varia de 20,5 a $39^{\circ}$ e a coesão varia de 0 a $27,5 \mathrm{kPa}$, sendo essas variações provenientes da diferença de idade, composição, tamanho e densidade das amostras.

A resistência ao cisalhamento do RSU obtida a partir de ensaios triaxiais tem sido apresentada por diversos pesquisadores (SINGH \& MURPHY 1990, GRISOLIA et al. 1995b, JESSBERGER \& KOCKEL 1993, JESSBERGER et al. 1995, GABR \& VALERO 1995, GRISOLIA \& NAPOLEONI 1996, MANASERRO et al. 1996, KÖNIG \& JESSBERGER 1997, KNOCHENMUS et al. 1998, VAN IMPE 1998 e WOJNAROWICZ et al. 1998). Resultados típicos de curva tensão -deformação, obtidos desses ensaios, demonstram que o RSU pode sofrer grandes deformações, excedendo 15 a $20 \%$, sem mobilizar a tensão cisalhante de pico (Figura 2.4.7). Para alguns casos, onde as deformações axiais são muito altas, a curva tensão - deformação pode inclusive apresentar uma inflexão para cima, sugerindo um endurecimento do material (MANASSERO et al. 1996 e KNOCHENMUS et al. 1998).

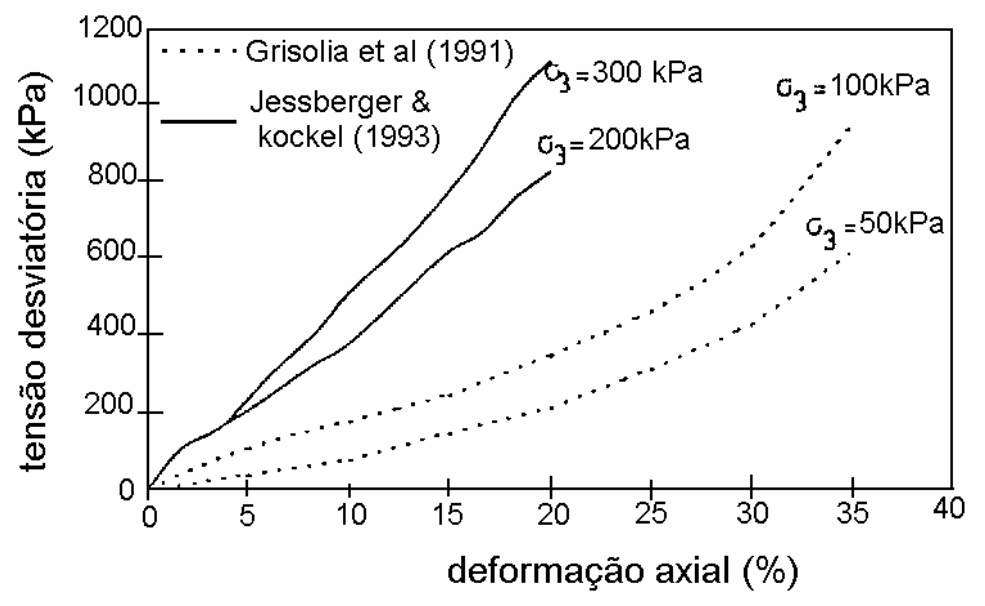

Figura 2.4.7 - Curvas tensão - deformação típicas para o resíduo sólido urbano (MANASSERO et al. 1996).

Com base nos resultados dos ensaios triaxiais de RSU não se pode definir com facilidade as condições de ruptura. Dessa forma, os parâmetros de resistência (c e $\phi$ ) devem ser determinados para níveis de deformação, sendo os valores de 10 a $20 \%$, os mais usados. Segundo GRISOLIA et al (1995b) e KÖNIG \& JESSBERGER (1997) uma forma interessante de apresentar os resultados de ensaios triaxiais de RSU é o emprego das trajetórias de tensões, pois estas facilitam a visualização dos resultados. Pode-se traçar diversas envoltórias de resistência, para diferentes deformações, através dos pontos obtidos das trajetórias. 
Os parâmetros de resistência de RSU da Itália foram avaliados por meio de ensaios triaxiais em células de grandes dimensões ( $D=25 \mathrm{~cm}, h=65 \mathrm{~cm}$ ), (GRISOLIA et al. 1995b). Foram ensaiadas amostras de lixo fabricadas artificialmente em laboratório, com a seguinte composição: pano e madeira $6 \%$, papel $32 \%$, plástico $8 \%$, cascalho $32 \%$, matéria orgânica $22 \%$; e teor de umidade médio de $40 \%$. Os corpos de prova foram dinamicamente compactados por meio de um soquete de $46 \mathrm{~N}$ caindo 25 vezes de uma altura de $46 \mathrm{~cm}$ e apresentaram peso específico entre $6,0 \mathrm{kN} / \mathrm{m}^{3}$ a $7,4 \mathrm{kN} / \mathrm{m}^{3}$. Os ensaios triaxiais foram executados empregando três tensões de confinamento $(50,100$ e $300 \mathrm{kPa})$ e as curvas tensão deformação obtidas estão apresentadas na Figura 2.4.8. GRISOLIA et al. (1995b) apresentam os resultados obtidos num digrama qxp", para diferentes deformações axiais $(10-40 \%)$ e apresentam, também para cada caso, a reta de melhor ajuste para a envoltória de resistência (Figura 2.4.9).

Em síntese, os parâmetros de resistência obtidos são apresentados em função das deformações axiais na Figura 2.4.10. Quando a deformação axial aumenta de 10 para 15\%, o ângulo de atrito aumenta de 15 para $25^{\circ}$ e, quando a deformação passa de 20 para 35\%, o ângulo de atrito aumenta de 30 para $40^{\circ}$. A coesão, também, mostra uma significativa variação com as deformações axiais, apresentado valores entre 2 e $3 \mathrm{kPa}$ para $10 \%$ de deformação, mas esta aumenta rapidamente para $10 \mathrm{kPa}$, quando as deformações axiais atingem $20 \%$ e chegando a $50 \mathrm{kPa}$ para deformações axiais da ordem de $35 \%$.

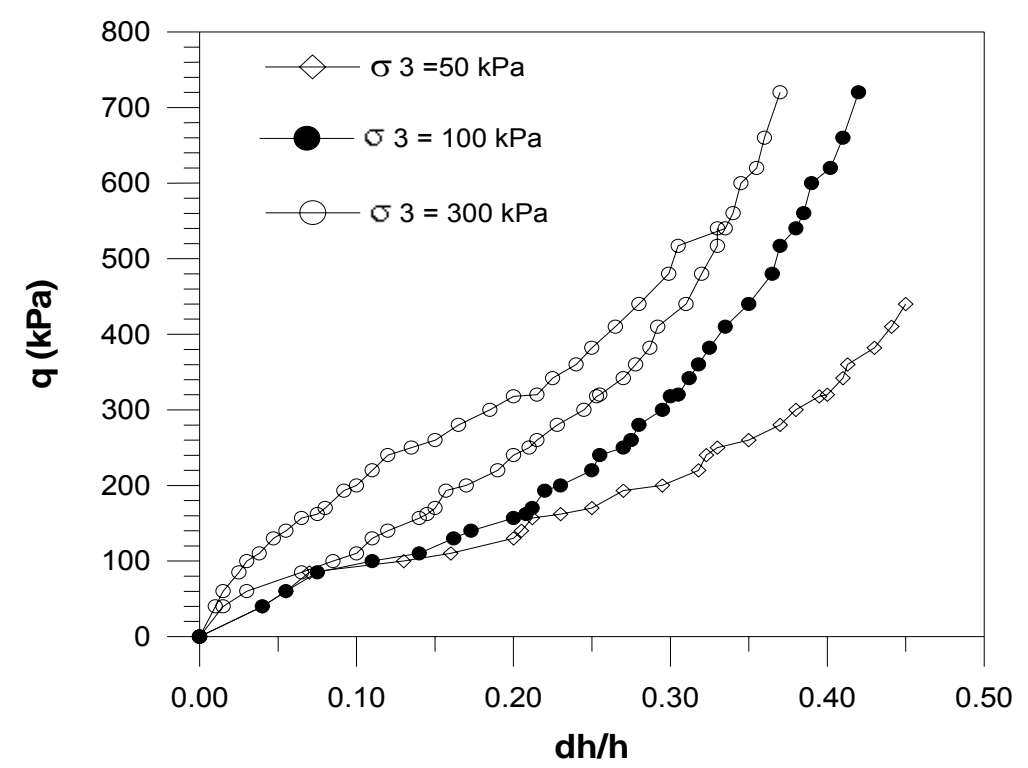

Figura 2.4.8 - Curvas tensão - deformação obtidas de ensaios triaxiais por GRISOLIA et al. (1995b). 

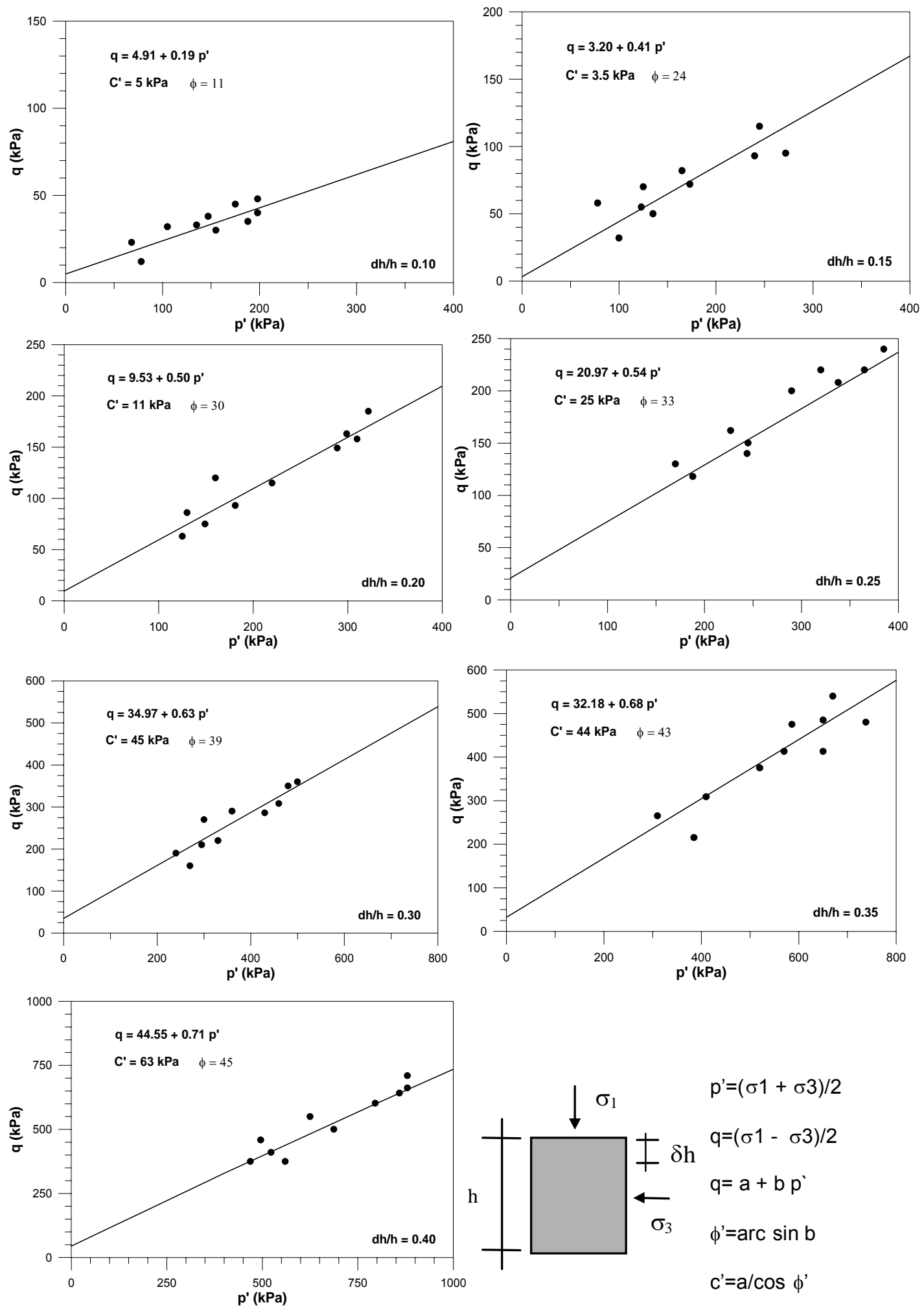

Figura 2.4.9 - Diagrama q-p' para diferentes níveis de deformações dos RSU (GRISOLIA et al. 1995b). 

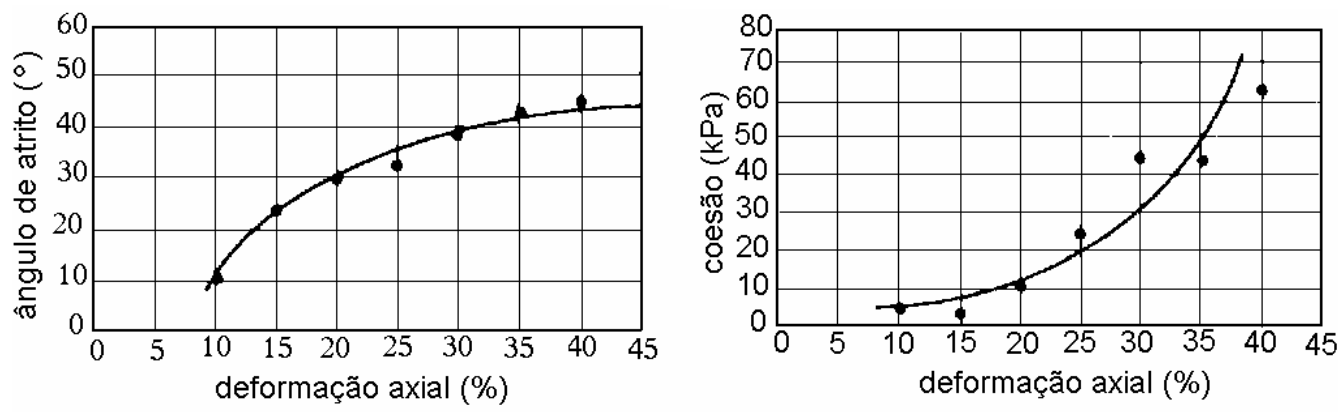

Figura 2.4.10 - Variação dos parâmetros de resistência com a deformação axial (GRISOLIA et al. 1995b).

JESSBERGER \& KOCKEL (1993) empregando células de grandes $(D=30 \mathrm{~cm}$, $h=60 \mathrm{~cm})$ e pequenas dimensões $(D=10 \mathrm{~cm}, h=20 \mathrm{~cm})$ executaram ensaios de compressão triaxial em amostras de RSU triturado e não triturado, com idade de 1 a 3 anos. Foram executados ensaios drenados (CD) com velocidade de deformação de $1 \% / \mathrm{min}$, onde mediuse $\sigma_{1}, \sigma_{3}, \varepsilon_{1}$ (deformação vertical) e $\varepsilon_{v}$ (deformação volumétrica). A Figura 2.4.11 apresenta as curvas tensão-deformação para o RSU triturado, onde pode-se verificar que a ruptura não ocorre, mesmo para grandes deformações da amostra. Esse comportamento, segundo JESSBERGER \& KOCKEL (1993), é decorrente da alta compressibilidade do RSU, que no início do ensaio apresenta poros relativamente grandes e superfície de contato efetiva partícula-partícula relativamente pequena. Com o incremento de tensão desviatória $\left(\sigma_{1}-\sigma_{3}\right)$, ocorre a compressão vertical $\left(\varepsilon_{1}\right)$ e volumétrica $\left(\varepsilon_{v}\right)$ da amostra (Figura 2.4.11), resultando em um incremento da superfície de contato efetiva entre as partículas, mas tendendo a conservar o estado de tensões.

A Figura 2.4.11, apresenta, ainda, a variação do coeficiente de Poisson $\left(v=\Delta \varepsilon_{3} / \Delta \varepsilon_{1}\right)$ com a deformação vertical, definido para o ensaio de compressão triaxial com pressão de confinamento constante. O coeficiente de Poisson não variou com a pressão de confinamento, o desvio para a curva de $\sigma_{3}=100 \mathrm{kN} / \mathrm{m}^{2}$, segundo os autores acima é, provavelmente, devido à problemas com a preparação da amostra.

JESSBERGER et al. (1995) e KÖNIG \& JESSBERGER (1997) apresentaram parâmetros de resistência para os RSU com diferentes idades. Os dados referem-se a ensaios de compressão triaxial, em câmaras de grandes dimensões $(D=30 \mathrm{~cm}, h=60 \mathrm{~cm})$, com RSU triturado e com idade variando de 9 meses, 1-3, 7-10, 15-20 anos (Figura 2.4.12). 

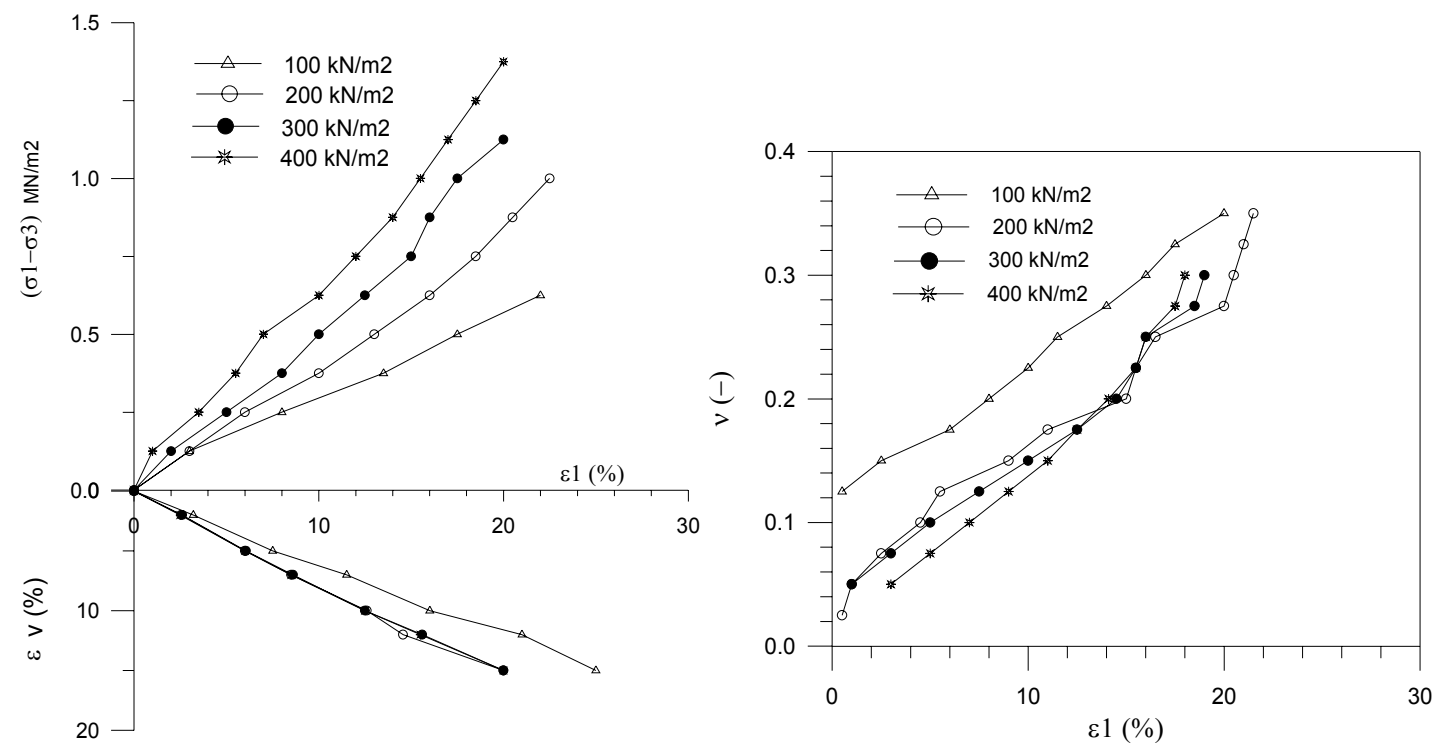

Figura 2.4.11 - Resultados de ensaios de compressão triaxial ( JESSBERGER \& KOCKEL 1993).
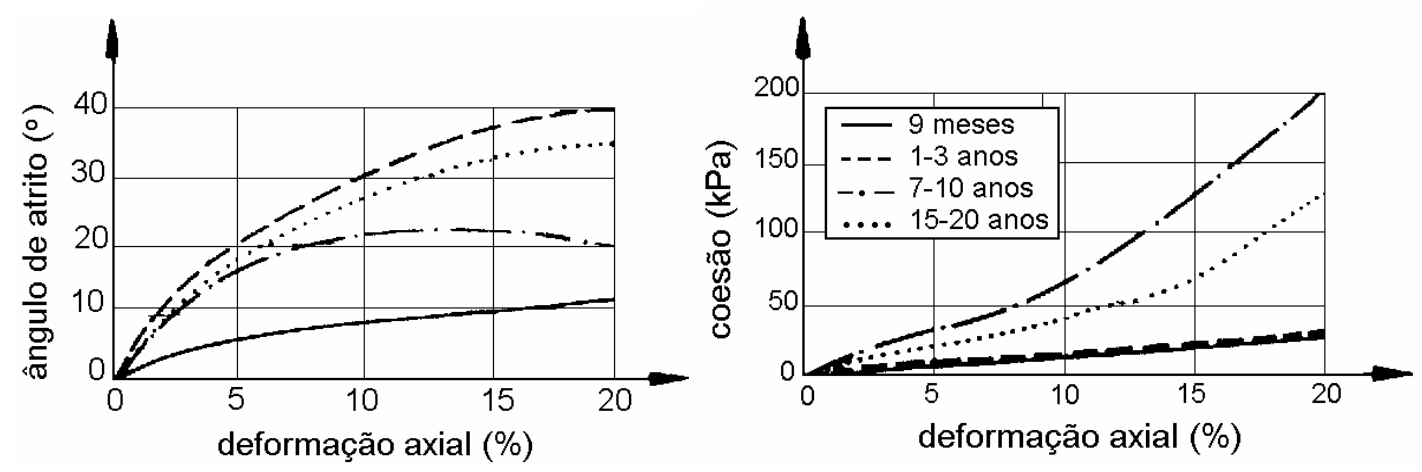

Figura 2.4.12- Resistência ao cisalhamento do RSU para diferentes deformações obtidas a partir de ensaios triaxiais (KÖNIG \& JESSBERGER 1997).

De acordo com os autores acima, a variação dos parâmetros de resistência para os diferentes resíduos estudados é grande. Considerando a deformação axial de 20\%, o ângulo de atrito variou de $10-40^{\circ}$ e a coesão de 25 a $200 \mathrm{kPa}$. E não foi evidenciada, claramente, a redução da resistência com idade do RSU depositado. Além disso, JESSBERGER et al. (1995) e KÖNIG \& JESSBERGER (1997) comentaram que o valor limite do ângulo de atrito é usualmente mobilizado para deformações axiais menores que $20 \%$ e, por outro lado, não se pode observar nenhum valor limite para a coesão, mesmo para grandes deformações.

Segundo JESSBERGER et al. (1995) e KÖNIG \& JESSBERGER (1997) o comportamento de resistência que o resíduo sólido urbano apresenta, para grandes deformações, pode ser comparado ao comportamento de solo reforçado. Os componentes fibrosos do RSU, como plásticos, têxteis, papel e papelão podem agir como reforço da 
mistura de lixo e, nesse caso, contribuir para o ganho de intercepto de coesão ou de resistência, como acontece em solo - reforçado. Dessa maneira, o RSU pode ser considerado como um material composto, constituído por duas componentes: uma matriz básica compreendida pelas partículas de granulação fina a média que apresentam comportamento de atrito e a outra, a matriz de reforço, é constituída pelos componentes fibrosos do RSU. A Figura 2.4.13 apresenta o modelo esquemático da composição do RSU.

Vários autores (GABR \& VALERO 1995 , KÖNIG \& JESSBERGER 1997 e MANASSERO et al. 1996) afirmaram que quando o efeito reforço deixa de existir ou tornase menos intenso, o conteúdo de umidade passa a desempenhar um papel predominante no comportamento de resistência do RSU (Figura 2.4.14). Nesta figura estão apresentados os resultados de ensaios triaxiais de GABR \& VALERO (1995) executados para um resíduo com alto grau de decomposição, coletado do aterro Pioneer Crossing (Pensilvania), com 15 a 30 anos de aterrado. Esta figura demonstra a redução da coesão para um aumento do teor de umidade.

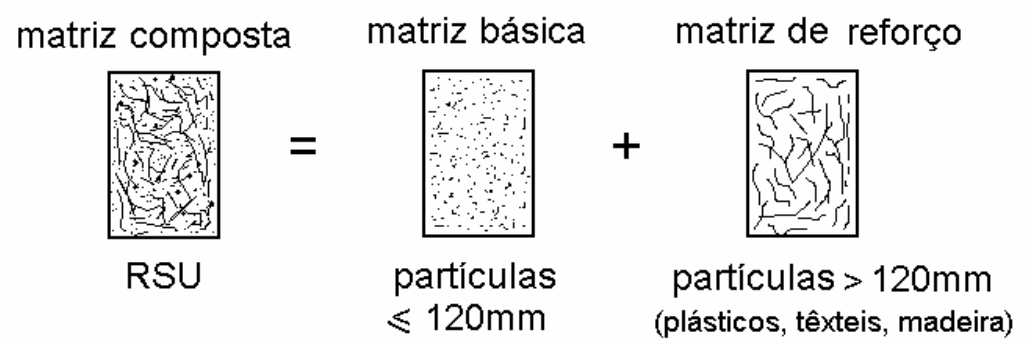

Figura 2.4.13 - Modelo esquemático da composição do resíduo sólido urbano proposto por JESSBERGER et al. (1995).

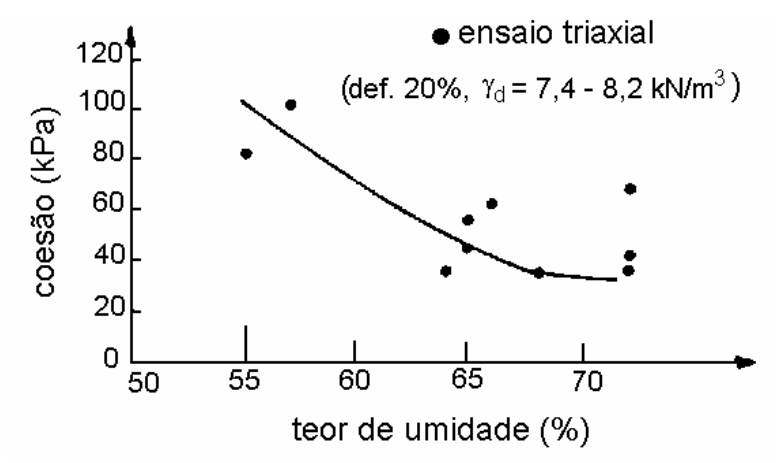

Figura 2.4.14 - Variação do intercepto de coesão com o teor de umidade (GABR \& VALERO, 1995).

Fundamentados em ensaios triaxiais de RSU com diferentes conteúdos de fibras (reforço), JESSBERGER et al. (1995) mostraram que a resistência ao cisalhamento da matriz básica, que corresponde ao RSU sem fibras é, fundamentalmente do tipo atrito, sendo que o seu valor limite $\left(42-45^{\circ}\right)$ é somente ativado para deformações muito altas e levemente influenciado pelos materiais de reforço (plásticos). O intercepto de coesão, por sua vez, é particularmente dependente da matriz de reforço e pode ser definido como a 
coesão devido à resistência a tração dos componente de reforço. A ativação da coesão requer, contudo, grandes deformações, a qual inicia próximo dos $20 \%$ de deformação axial e quando o atrito está quase mobilizado totalmente (Figura 2.4.15). Dessa forma, a matriz fibrosa não tem influência significativa nas propriedades de atrito do resíduo, mas promove um significativo aumento do intercepto de coesão.
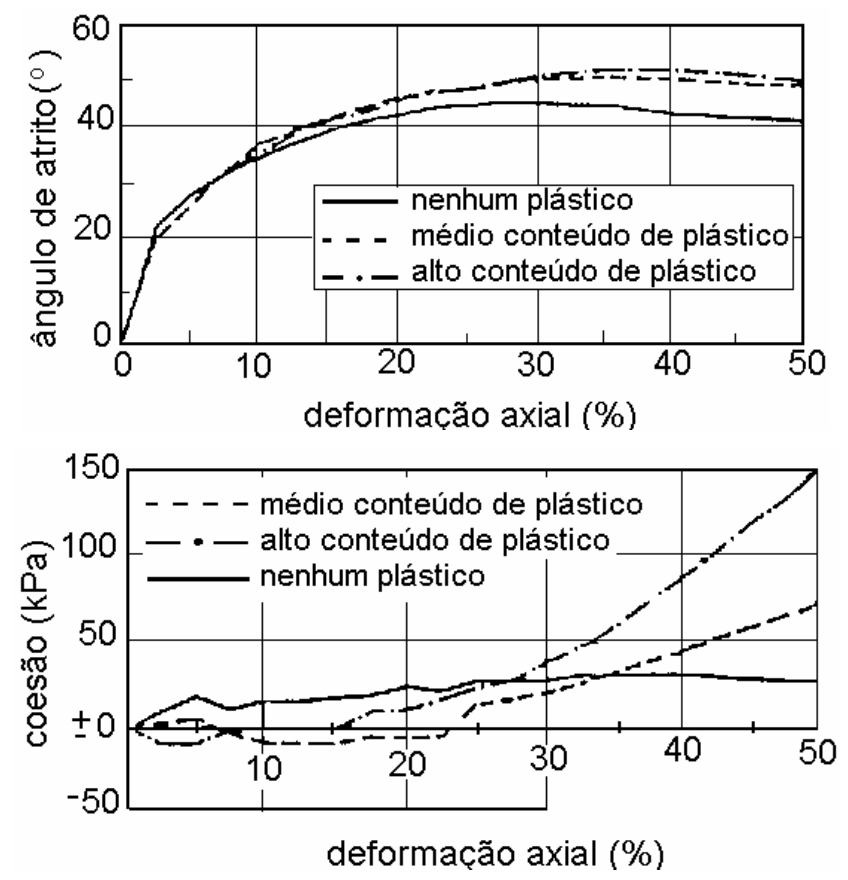

Figura 2.4.15 - Ativação do intercepto de coesão e ângulo de atrito com as deformações axiais (KÖNIG \& JESSBERGER 1997).

O ganho de coesão proveniente da presença da matriz fibrosa pode ser mais facilmente observado na Figura 2.4.16 onde, num diagrama $p-q^{\prime}$, a resistência ao cisalhamento do resíduo propriamente dito (matriz básica + fibras) apresentou um intercepto de coesão e um movimento da linha de ruptura aproximadamente paralelo em relação ao resíduo da matriz básica (JESSBERGER et al. 1995). Para o caso, a resistência ao cisalhamento máxima do RSU com 1-3 anos de idade foi de $\phi=42^{\circ}$ a $49^{\circ}$ e C=51 a $41 \mathrm{kPa}$.
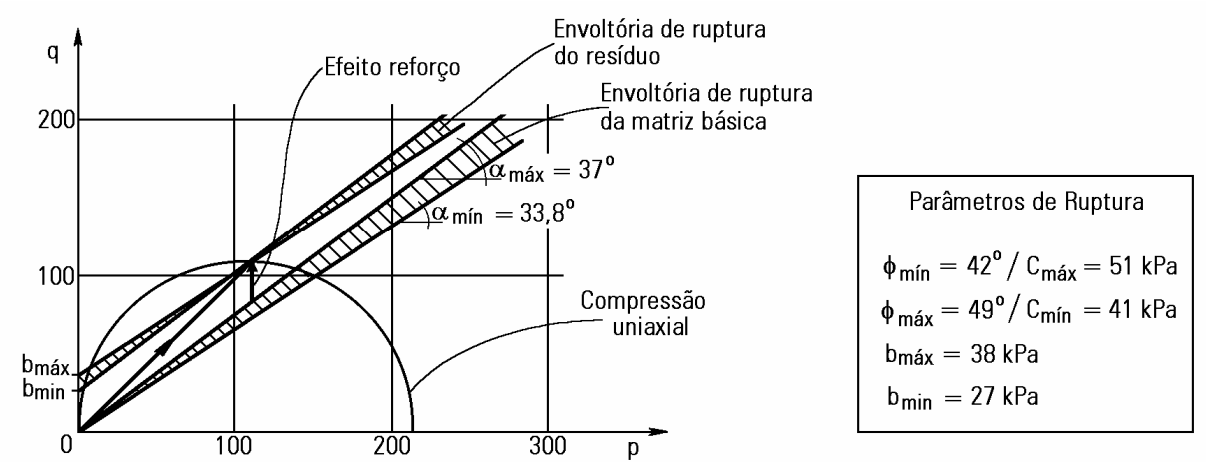

Figura 2.4.16 - Ruptura do resíduo fresco de 1 a 3 anos de idade, JESSBERGER et al. (1995). 
A Figura 2.4.17 apresenta, conjuntamente, os resultados de ensaios obtidos com o RSU triturado, matriz básica e mistura de solo - fibra. KÖNIG \& JESSBERGER (1997), MANASSERO et al. (1996) dentre outros autores, chamam a atenção para o fato de que o RSU não apresenta uma envoltória de ruptura significativamente bilinear, como acontece para solos reforçados. De acordo com os autores acima, isto pode ser explicado pelo fato de que o RSU é reforçado por plásticos com tamanhos e com propriedades tensão deformação diferentes. A figura 2.4.17 também mostra que a envoltória obtida para o resíduo triturado é paralela à envoltória da matriz básica do RSU, sugerindo que o "reforço" não afeta as propriedades de atrito do RSU triturado, mas aumenta o intercepto de coesão.

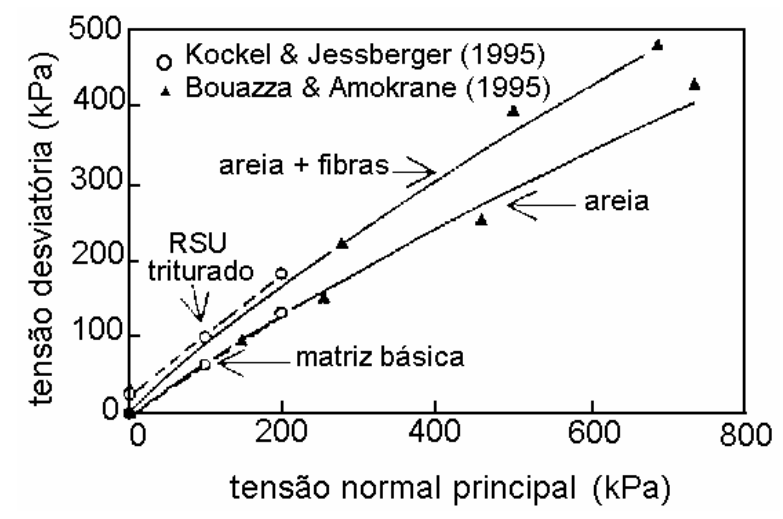

Figura 2.4.17 - Envoltória de resistência para diferentes materiais (MANASSERO et al. 1996).

\subsubsection{1 - Comentários}

Vários autores têm apresentado valores para os parâmetros de resistência ao cisalhamento do resíduo sólido urbano, obtidos a partir de ensaios de campo, de laboratório e de retro - análise (LANDVA \& CLARK 1990, GABR \& VALERO 1990, GRISOLIA et al. 1995b, KAVAZANJIAN et al 1995, JESSBERGER \& KOCKEL 1993 e JESSBERGER et al. 1995). Os valores apresentados para cada caso variam consideravelmente em virtude das características do próprio material, tipo de ensaio adotado e condições de tensões aplicadas, etc. Em geral, tem-se encontrado valores para ângulo de atrito variando entre $10^{\circ}$ a $53^{\circ}$, enquanto a coesão pode variar de 0 a $67 \mathrm{kPa}$ (KÖNIG \& JESSBERGER 1997, KNOCHENMUS et al. 1998).

Tornou-se usual apresentar os parâmetros de resistência obtidos para o resíduo urbano num diagrama coesão versus ângulo de atrito, tal como mostra a Figura 2.4.18. SINGH \& MURPHY (1990) foram os primeiros a usar essa representação. Baseados em resultados de ensaios de campo, laboratório e de retro- análise até então disponíveis, os autores acima, traçaram uma faixa recomendada para projetos. A partir de então muitos 
pontos tem sido acrescentados nesse diagrama, inclusive com novas sugestões para a faixa recomendada, como se mostrará mais adiante.

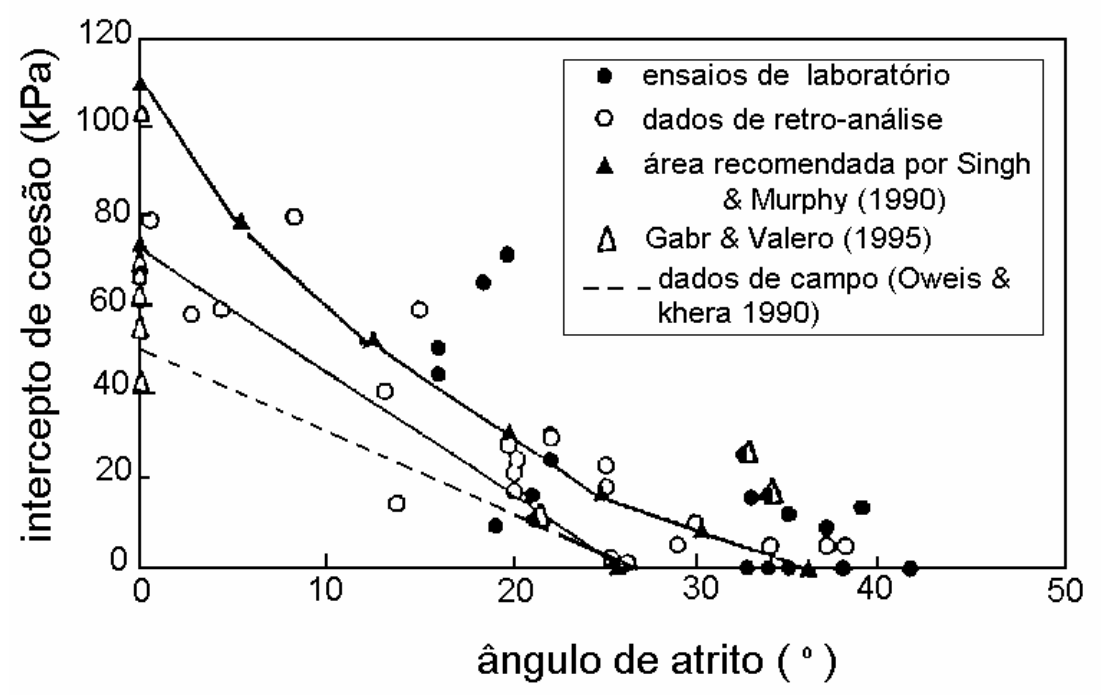

Figura 2.4.18 - Parâmetros de resistência ao cisalhamento do resíduo sólido urbano estimado por diferentes métodos.

Pode-se observar na figura 2.4.18 que existe uma grande dispersão nos resultados, tornando difícil estimar corretamente a resistência para o resíduo sólido urbano. Mesmo assim, de acordo com SÁNCHEZ - ALCITURRI et al. (1993) algumas tendências são observadas:

- os resultados de ensaios de laboratório indicam que um significante ângulo de atrito é mobilizado, o qual varia entre $25^{\circ}$ e $35^{\circ}$. Não foi medido nenhum valor inferior a $17^{\circ}$ (os valores compilados de SINGH \& MURPHY 1990 e GABR \& VALERO 1995 que apresentam $\phi=0$ referem-se a ensaios UU). O intercepto de coesão é variável, mas para ensaios de laboratório, a grande concentração dos valores estão abaixo de $60 \mathrm{kPa}$. Os dados mostram valores de $\mathrm{s}_{\mathrm{u}}$ variando de $20 \mathrm{kPa}$ até valores acima de $100 \mathrm{kPa}$.

A partir dessas observações, SÁNCHEZ - ALCITURRI et al. (1993) apresentaram um novo diagrama para a obtenção de parâmetros de projeto, sendo a área hachurada a recomendada (Figura 2.4.19). De acordo com os autores, esta área, grosseiramente, coincide com a faixa proposta por SINGH \& MURPHY (1990). 


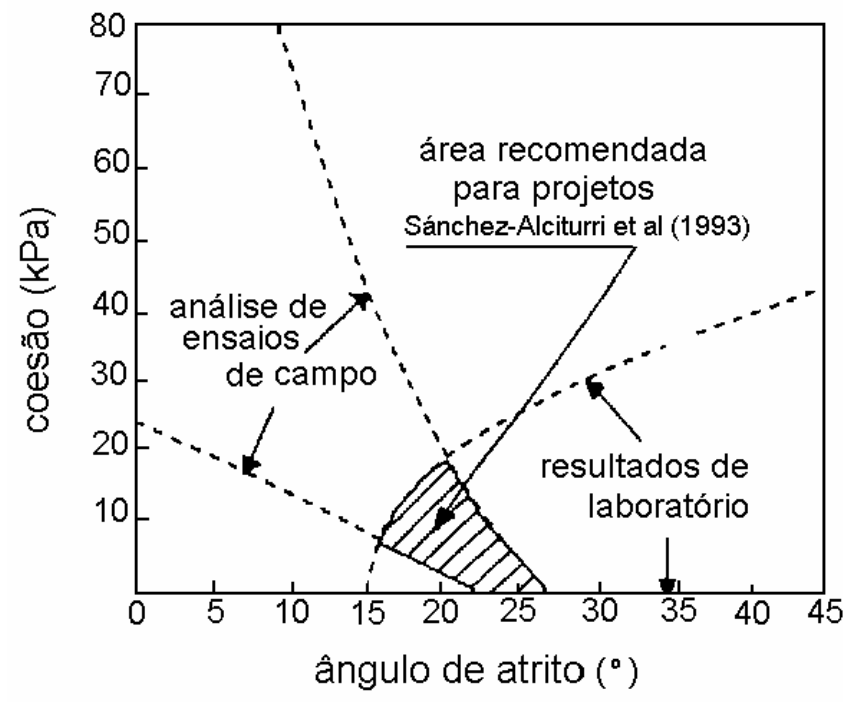

Figura 2.4.19 - Resistência ao cisalhamento do RSU, valores recomendados para projetos por SÁNCHEZ - ALCITURRI et al. (1993).

Autores como SÁNCHEZ - ALCITURRI et al. (1993), KÖNIG \& JESSBERGER (1997), MANASSERO et al. (1996) e KNOCHENMUS et al. (1998) ressaltam que deve-se tomar muito cuidado com os diagramas apresentados nas figuras 2.4 .18 e 2.4.19. Neles estão plotados, juntos, tanto resultados de ensaios de campo, laboratório (cisalhamento direto e triaxial) bem como dados de retro- análise. Segundo esses autores, no caso de ensaios de laboratório os pares de valores c e $\phi$ são determinados, no entanto, para os ensaios in situ e reto- análise, existem infinitos pares de valores $\mathrm{c}$ e $\phi$ que satisfazem as condições de equilíbrio (uma equação e duas incógnitas). Nos casos de ensaios de campo, geralmente, são feitas suposições de valores individuais para c e $\phi$ do RSU, sendo usual considerar o resíduo puramente coesivo $(\phi=0)$ ou puramente não coesivo $(C=0)$. Segundo SÁNCHEZ-ALCITURRI et al. (1993), esse procedimento é válido para solos, onde existem bases para essas suposições. No entanto, para o resíduo sólido urbano não existem bases firmes para essa tomada de decisão e a análise em termos de c e $\phi$ é a mais adequada.

Baseados em dados de resistência ao cisalhamento disponíveis incluindo resultados de ensaios de cisalhamento direto in situ e em laboratório, ensaios em placas carregadas e dados de retro- análise, KAVAZANJIAN et al. (1995) ajustou uma envoltória de ruptura linear curvada para o resíduo sólido urbano, como mostra a Figura 2.4.20. Por questão de simplicidade o mesmo autor propõe o uso da envoltória bi- linear (Figura 2.4.21), onde duas zonas distintas podem ser distinguidas: 1) zona $A$ corresponde a baixos níveis de tensões, onde tem-se valores maiores para $\phi$ e valores menores para a coesão. 2) zona B corresponde a altos níveis de tensões, onde tem-se menores valores de $\phi$ e maiores valores de c. Nesta proposta, o material de lixo é considerado puramente coesivo $(\mathrm{c}=24 \mathrm{kPa})$ para 
tensão normal abaixo de $30 \mathrm{kPa}$ e para tensão acima deste valor, o RSU foi considerado não coesivo, $\operatorname{com} \phi=33^{\circ}$.

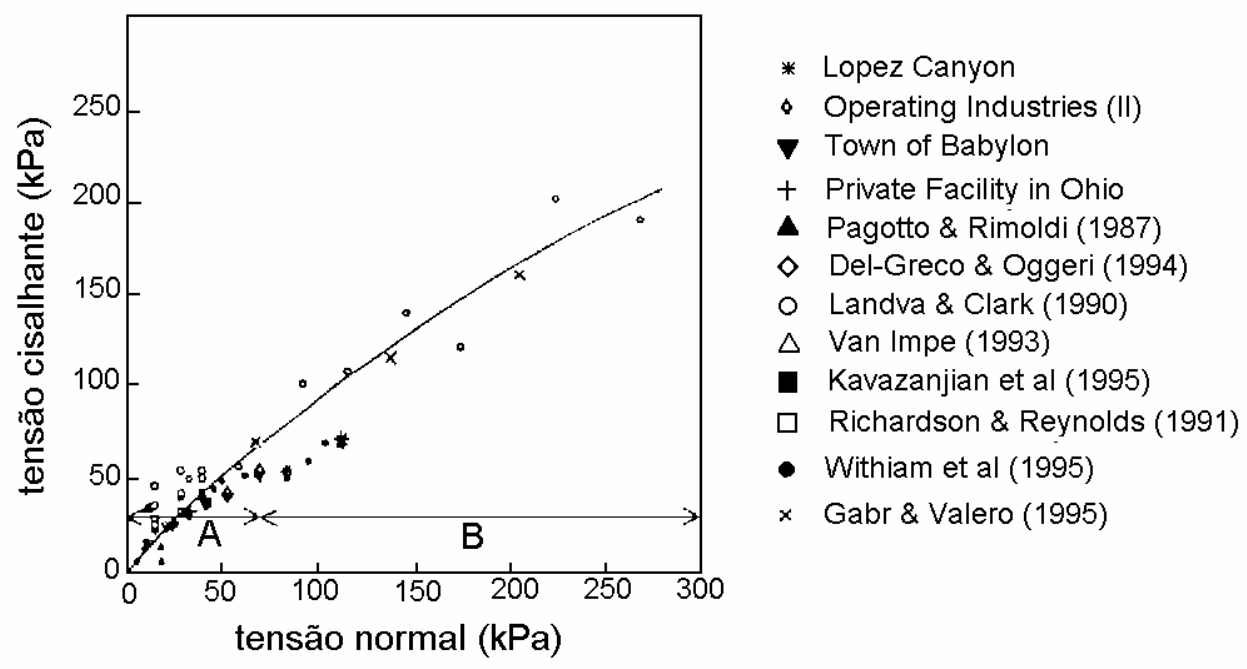

Figura 2.4.20 - Resultados de resistência ao cisalhamento do RSU obtidas por vários autores (VAN IMPE 1998).

Para os dados da Figura 2.4.20, VAN IMPE (1998) e MANASSERO et al. (1996) propuseram uma envoltória de ruptura com três partes (Figura 2.4.21), sendo a zona $A$ correspondente a baixas tensões $\left(0 \leq \sigma_{v}<20 \mathrm{kPa}\right)$, onde o comportamento do resíduo é puramente coesivo $(\mathrm{c}=20 \mathrm{kPa})$. A zona $\mathrm{B}$, corresponde a tensão normal baixa a moderada $\left(20 \mathrm{kPa} \leq \sigma_{\mathrm{v}}<60 \mathrm{kPa}\right)$, nesse caso tem-se $\mathrm{c}=0$ e $\phi \cong 38^{\circ}$. Finalmente a zona $\mathrm{C}$, corresponde a altas tensões $\left(\sigma_{v} \geq 60 \mathrm{kPa}\right)$, onde tem-se $\mathrm{c} \geq 20 \mathrm{kPa}$ e $\phi \cong 30^{\circ}$.

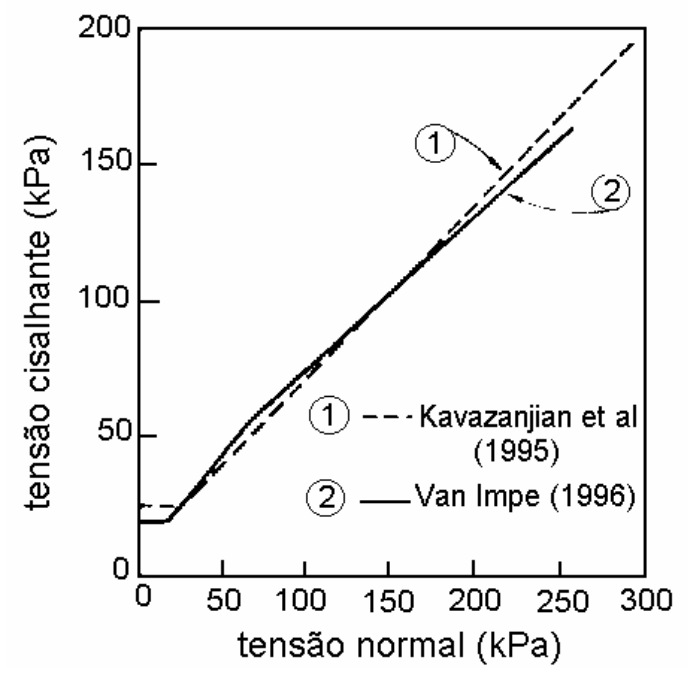

\begin{tabular}{|c|c|c|c|c|}
\hline Autor & Parte & $\sigma(\mathrm{kPa})$ & $\mathrm{C}(\mathrm{kPa})$ & $\emptyset(9)$ \\
\hline \multirow{2}{*}{1} & A & $<30$ & 24 & 0 \\
& B & $\geqslant 30$ & 0 & 33 \\
\hline \multirow{4}{*}{2} & A & $<20$ & 20 & 0 \\
& B & $20 \leq \sigma<60$ & 0 & 38 \\
& C & $\geqslant 60$ & $\geqslant 20$ & 30 \\
\hline
\end{tabular}

Figura 2.4.21 - Envoltórias de ruptura proposta para o resíduo sólido urbano (VAN IMPE 1998). 


\subsection{3 - Compressibilidade}

Os aterros de resíduos sólidos urbanos, ao contrário dos maciços de solos compactados, são constituídos por diferentes tipos de resíduos (metais, plásticos, papéis, vidros, madeiras, têxteis, resíduos orgânicos, pedras e solos) que, quando depositados, interagem formando um maciço heterogêneo e poroso com comportamento peculiar.

Além da composição heterogênea dos constituintes, a degradação dos mesmos com o passar do tempo e a compressibilidade devido à sobrecarga, são considerados pontos relevantes no comportamento peculiar dos resíduos sólidos urbanos.

Os depósitos se transformam, ao longo do tempo, por fenômenos físico-químicos e biológicos. Esses fenômenos são influenciados por fatores como, composição e umidade do resíduo, disponibilidade de nutrientes para crescimento microbiológico, detalhes de projeto e de operação do aterro (compactação, existência da cobertura diária, drenagem) e condições climáticas favoráveis (VAN MEERTEN et al. 1995). As transformações biológicas constituem-se nas modificações de muitos componentes sólidos do RSU, com o tempo e em condições ambientais propícias, em gases, líquidos e sólidos inorgânicos e orgânicos relativamente inertes (TCHOBANOGLOUS et al. 1993). Assim, ocorre uma redução no volume do material depositado.

Conforme exposto acima, os mecanismos que governam os recalques em aterros de resíduos sólidos urbanos são complexos e numerosos devido à heterogeneidade do RSU, deformabilidade das partículas, natureza degradável do material e presença de grandes vazios. Esses mecanismos tem sido apresentados e discutidos por vários autores (SOWERS (1973), YEN \& SCONLON (1975), CODUTO \& HUITRIC (1990), MASSACCI et al. (1993), DUNN (1995), MANASSERO et al. (1996), BOUAZZA et al. (1996), VAN IMPE (1998), dentre outros).

MANASSERO et al. (1996) propuseram que o mecanismo de recalque em aterros sanitários pode ser representado pelas seguintes fases:

1) Compressão mecânica resultante do re-arranjo e da quebra de elementos sólidos devido ao peso próprio do RSU e peso dos materiais de cobertura,

2) Variação de volume causada pela migração de pequenas partículas para os vazios maiores (erosão e ravinamentos internos),

3) Comportamento viscoso e fenômeno de consolidação envolvendo o esqueleto sólido e as partículas individuais ou seja os componentes,

4) Recalques causados pela biodegradação do material orgânico,

5) Colapso dos componentes devido as alterações físico-químicas processadas através da corrosão, oxidação e degradação dos componentes inorgânicos.

6) Dissipação da pressão neutra de líquidos e gases 
Essa proposta de subdivisão dos mecanismos de recalque é comparável com a curva teórica de compressibilidade proposta por GRISOLIA \& NAPOLEONI (1996) (Figura 2.4.22). Segundo GRISOLIA \& NAPOLEONI (1996), os resíduos, assim como os solos, são meios multifásicos constituídos de elementos sólidos, líquidos e gasosos. Mas, existem diferenças essenciais entre esses dois materiais. $\mathrm{Na}$ fase sólida do RSU, pode-se distinguir três classes de materiais:

1) Materiais inertes estáveis (metais, vidros, entulho), cujo comportamento pode ser assumido como o de um solo heterogêneo de granulação grossa.

2) Materiais altamente deformáveis (fragmentos e caixas de papel, plásticos e têxteis), que apresentam grandes recalques e comportamento anisotrópico.

3) Materiais facilmente degradáveis (materiais orgânicos, vegetais, restos alimentares), os quais passam por transformações físico-químicas, em um curto espaço de tempo, causando redução de volume e gerando gases e líquidos.

Após o lançamento, são poucos os contatos entre os materiais inertes estáveis e o RSU apresenta uma estrutura porosa que pode variar de forma e volume. Sob carga, ocorre uma acentuada redução de volume dos materiais altamente deformáveis e deslocamento dos inertes estáveis (Fase II). Mantendo a carga constante, ocorrem deformações do tipo "creep" e transformações da matéria orgânica (Fase III), até que estabeleçam, no fim do processo, contatos diretos entre os elementos inertes estáveis.

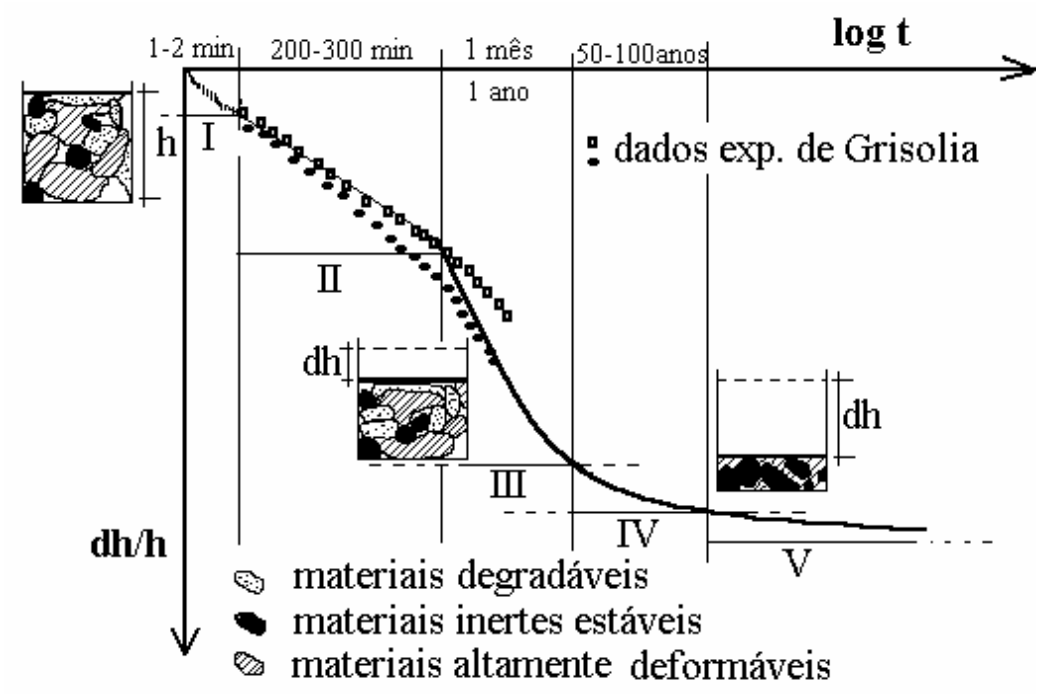

Fase I: def. inicial, redução da macroporosidade

Fase II: recalque residual dos mat. altamente deformáveis

Fase III: deformação lenta e decomposição dos orgânicos

Fase $\Gamma$ : deformação concluída

Fase V: deformação residual

Fig. 2.4.22 - Curva teórica de compressibilidade do RSU segundo GRISOLIA \& NAPOLEONI (1996). 
O recalque dos RSU, segundo CODUTO \& HUITRIC (1990), pode ser definido por três mecanismos: consolidação (mudança da tensão efetiva), "shrinkage" (decomposição da matéria orgânica) e compactação (sobrecarga). O termo consolidação, refere-se ao recalque resultante da drenagem dos materiais saturados depositados sob aplicação da sobrecarga. "Shrinkage" é o processo pelo qual os sólidos orgânicos e úmidos são gradualmente decompostos e convertidos em metano e dióxido de carbono, resultando num correspondente decréscimo de volume do aterro. A compactação é definida como a reorientação dos sólidos em uma configuração mais densa em decorrência dos fenômenos de creep devido a sobrecarga aplicada e ou decomposição.

Conforme EDIL et al. (1990), SÁNCHEZ-ALCITURRI et al. (1993), KNOCHENMUS et al. (1998) e SIMÕES \& CAMPOS (1998), a magnitude dos recalques em aterros sanitários, devido ao peso próprio do RSU e à atuação de sobrecargas, é influenciada por diversos fatores incluindo: peso específico e índice de vazios iniciais do resíduo, conteúdo orgânico, altura do aterro e sobrecargas adicionais, história de tensões durante a operação e após o fechamento do aterro, nível e flutuação dos líquidos percolados no interior da massa do aterro, fatores ambientais como umidade, temperatura e gases, presentes ou gerados no interior do aterro.

A elevada compressibilidade dos aterros sanitários, apesar de ser, por um lado, problemática, por outro, prolonga a vida útil do aterro, possibilitando deposições adicionais (Edil et al. 1990). Em geral, os recalques nos aterros municipais são normalmente irregulares, sendo, no período inicial ( 1 a 2 meses após finalizada a construção), bastante intensos. Em seguida, continuam a ocorrer por um longo período, porém com velocidade menor. O maciço de RSU recalca, sob peso próprio, entre 10 a $40 \%$ da altura original do aterro e a maioria dos recalques ocorre nos primeiros anos após a disposição do resíduo (SOWERS 1968, EDIL et al. 1990, GRISOLIA \& NAPOLEONI 1996). Esse fato foi confirmado por resultados de ensaios em colunas drenadas de grande diâmetro executados por GANDOLLA et al. (1994), como mostra na Figura 2.4.23.

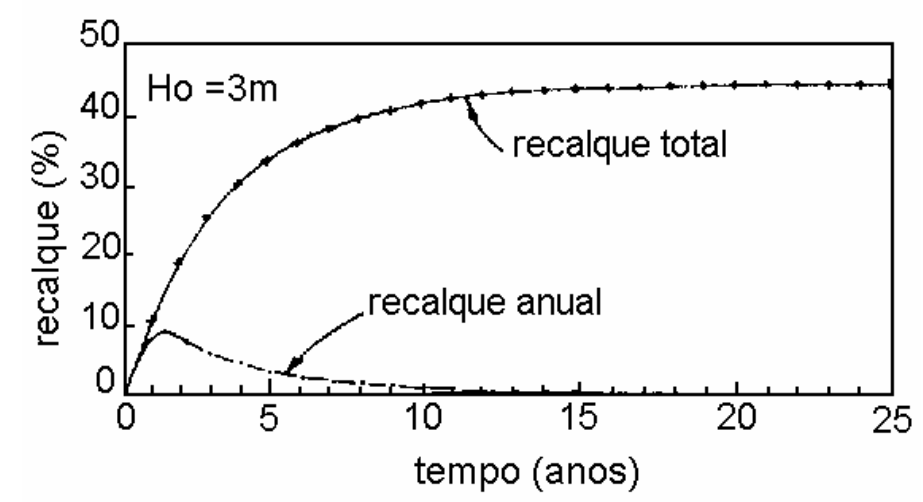

Figura 2.4.23 - Recalque total e anual de RSU (GANDOLLA et al. 1994). 
A compressão para o RSU é comumente estimada usando-se a teoria da consolidação unidirecional, onde a compressão total, semelhante ao que se faz em solos, é dividida em compressão inicial, primária e secundária (SOWERS 1973, SIMÕES et al. 1996). A compressão inicial ou imediata, a qual é quantificada pela teoria da elasticidade, está associada à compressão dos vazios e dos constituintes por ação das cargas impostas e pelo processo de operação dos aterros. Já a compressão primária, analisada através da teoria clássica de Terzaghi, é devida à drenagem dos líquidos existentes no interior do aterro. Por último, a compressão secundária é, em parte, proveniente da degradação físicoquímica e biológica que ocorre no aterro. Os recalques nesta fase seguem uma relação linear com o logaritmo do tempo, de modo similar ao fenômeno de compressão secundária observado em solos. Segundo GRISOLIA \& NAPOLEONI (1996), a compressão imediata depende da composição do resíduo e da forma de disposição e sua avaliação é, no entanto, difícil, pois durante a construção dos aterros sanitários é muito difícil acompanhar e interpretar os dados obtidos. Segundo os autores, a interpretação das medidas torna-se possível após a conclusão do aterro. Já o recalque a longo prazo depende, principalmente, da taxa de biodegradação e do comportamento viscoso dos resíduos. A taxa de decomposição depende de inúmeros parâmetros incluindo o grau de compactação dos resíduos no aterro (KNOCHENMUS et al. 1998). A compactação efetiva do RSU pode reduzir significativamente o recalque. Por outro lado, o decréscimo da porosidade pode reduzir o potencial das reações biológicas, e desse modo reduzir a taxa de recalque no tempo.

De acordo com SOWERS (1973) o recalque do RSU é similar aos das turfas, em que após um rápido e imediato recalque, ocorre um recalque adicional acompanhado por um pequeno ou nenhum desenvolvimento de poro- pressão. Entretanto, de maneira diferente dos depósitos de turfas, a compressão secundária do RSU inclui uma significante componente de decomposição biológica.

Como pode-se observar, a previsão de recalques em maciços de resíduos municipais é complexa e envolve variáveis de difícil quantificação. Apesar disso, tem-se utilizado os conceitos da teoria clássica de adensamento, para avaliar o comportamento dos resíduos sólidos domiciliares. A dificuldade no emprego dessa teoria está em determinar os parâmetros $\mathrm{C}_{c}, \mathrm{C}_{\alpha}, \mathrm{e}_{0}$, requeridos na análise, visto que os resíduos apresentam grande heterogeneidade e presença de materiais de grandes dimensões, necessitando equipamentos de ensaios de dimensões maiores e que contemplem esses aspectos particulares.

Até o presente, os dados publicados relativos às propriedades de compressibilidade de resíduos sólidos urbanos são bastante limitados (KNOCHENMUS et al. 1998). A compressibilidade pode ser determinada a partir de ensaios de laboratório, ensaios in situ e através de monitoramento de aterros existentes. A grande limitação dos ensaios de laboratório e in situ está relacionada com o tempo de duração dos ensaios e com a 
incapacidade de contemplar todos os aspectos relativos aos mecanismos de compressão. Em geral, esses ensaios apenas descrevem o recalque mecânico (mudança da tensão efetiva e sobrecarga) e os recalques devidos à degradação do RSU não são considerados ou são apenas, parcialmente considerados (KÖNIG \& JESSBERGER 1997).

Em laboratório, o processo de compressão do resíduo resultante da degradação dos componentes com o tempo é difícil de ser esquematizado e previsto, visto que é governado por fatores biológicos, físico-químicos que para ocorrerem necessitam de condições ideais e propícias, além de um tempo muito longo, superior aos necessários para completar esses ensaios (GRISOLIA \& NAPOLEONI 1996). Dessa forma, o monitoramento in situ do recalque torna-se a maneira mais realista e mais representativa para estudar $\mathrm{o}$ processo de compressibilidade dos resíduos sólidos urbanos, pois as medidas em campo incluem todos os fatores e interações dominantes nesse comportamento.

As medidas de laboratório para o recalque do lixo urbano são muito escassas, somente alguns casos foram reportados recentemente (LANDVA \& CLARK, 1990; MANASSERO et al.,1996; KÖNIG \& JESSBERGER, 1997 e VAN IMPE, 1998). Os ensaios de laboratório são geralmente executados em células de consolidação de grande diâmetro (LANDVA \& CLARK 1990, JESSBERGER \& KOCKEL 1993) e apenas GABR \& VALERO (1995) empregou uma célula de consolidação convencional.

A compressibilidade de resíduos sólidos urbanos antigos (idade desconhecida) de vários aterros do Canadá foi avaliada por LANDVA \& CLARK (1990) a partir de ensaios de compressão confinada em célula de grande dimensão (diâmetro $=0,45 \mathrm{~m}$ ) e os resultados estão apresentados na Figura 2.4.24. Os resíduos apresentaram alta compressibilidade com valores de coeficiente de compressão primária $\left(C c^{\prime}=C c /\left(1+e_{0}\right)\right)$ variando de 0,2 a 0,5 e coeficiente de compressão secundária $\left(C \alpha /\left(1+e_{0}\right)\right)$ variando entre 0,03 a 0,002 , onde este último, segundo os autores, parece aumentar com o aumento do conteúdo orgânico.

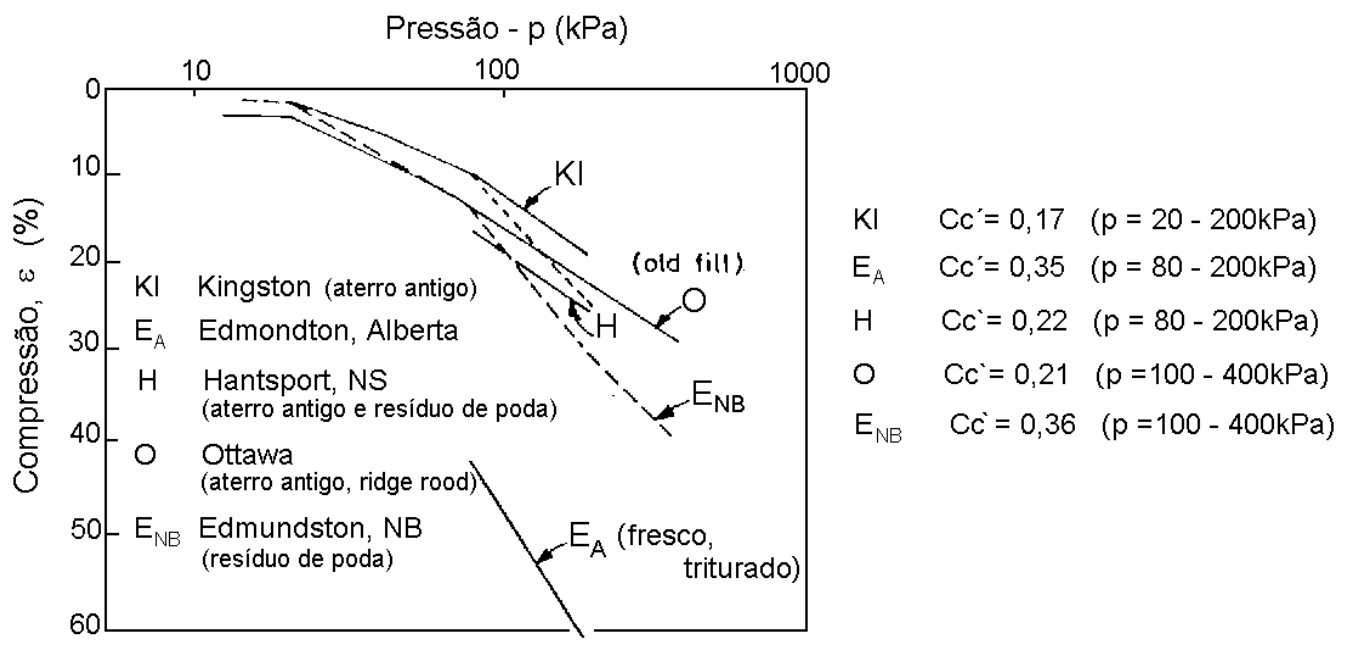

Figura 2.4.24 - Resultados obtidos de ensaios de compressão confinada para resíduos do Canadá (LANDVA \& CLARK 1990). 
JESSBERGER \& KOCKEL (1993) utilizando uma célula de compressão confinada de grande dimensão $(D=1 \mathrm{~m})$ ensaiou amostras de RSU da Alemanha com 15 anos de idade. As amostras foram compactadas com peso específico seco variando de 7 a $10 \mathrm{kN} / \mathrm{m}^{3}$ e foram, inicialmente, pré-carregadas com $25 \mathrm{kN} / \mathrm{m}^{2}$. Posteriormente, aplicaram-se, por vários dias, as cargas de $50,100,200,400$ e $650 \mathrm{kN} / \mathrm{m}^{2}$. As curvas tempo- recalque são mostradas na Figura 2.4.25. Uma compressão inicial pode ser identificada durante os primeiros 10 a 30 segundos após a aplicação das cargas, seguida por um aumento mais lento da compressão da amostra.
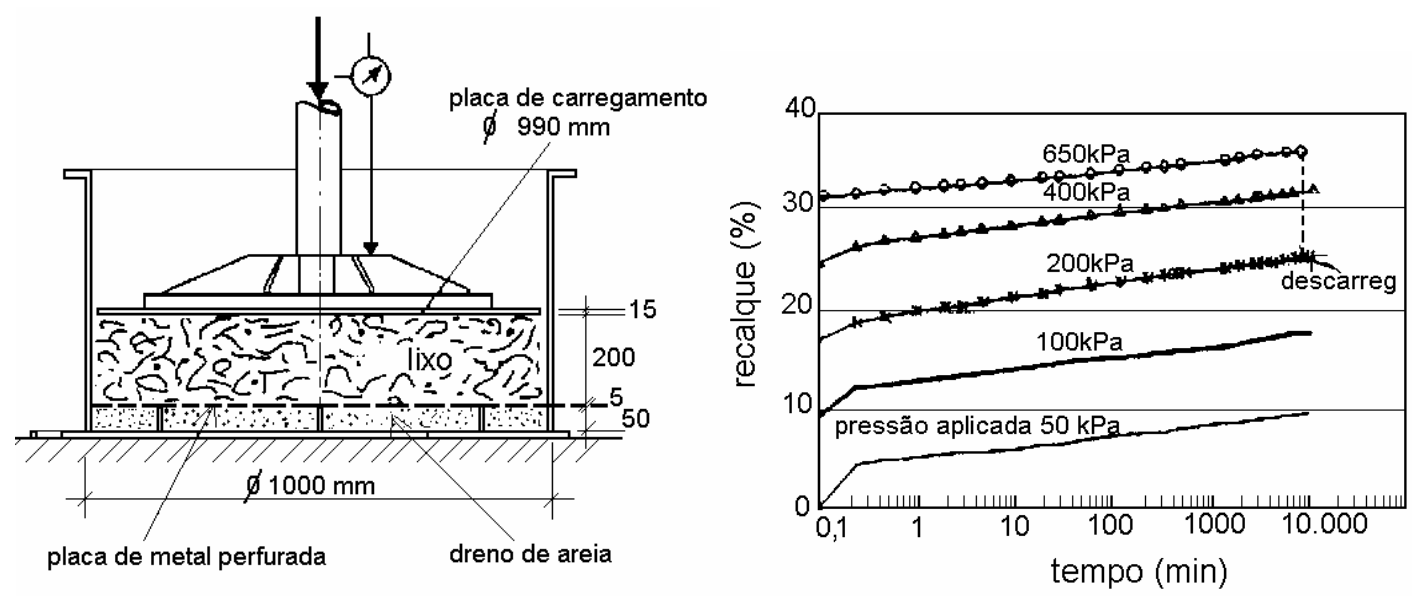

Figura 2.4.25 - Curvas tempo- recalque obtidas de ensaios de compressão confinada por JESSBERGER \& KOCKEL (1993).

GABR \& VALERO (1995) executaram ensaios de compressão confinada em células convencionais de pequeno diâmetro $(63,5 \mathrm{~mm})$ utilizando amostras de resíduos com 15 a 30 anos após aterramento e compactadas no teor de umidade natural. Obtiveram um índice de compressão (Cc) variando de 0,4 a 0,9 para índices de vazios entre 1 e 3 , e índice de compressão secundária $(\mathrm{C} \alpha)$ variando de 0,009 a 0,03 para a mesma faixa de índice de vazios. De acordo com os autores o $\mathrm{C} \alpha$ parece ser mais dependente das condições favoráveis à degradação que do índice de vazios. A Figura 2.4.26 apresenta alguns resultados para o índice de compressão primária e secundária obtidos de ensaios de laboratório (GABR \& VALERO 1995), de dados de monitoramento de células experimentais (WALL \& ZEISS 1995), bem como, as envoltórias superior e inferior propostas por SOWERS (1973), a partir de dados de monitoramento de aterros existentes. SOWERS (1973) argumenta que o índice de compressão primária (Cc) pode variar de $0,15 . e_{0}$ até 0,55. $e_{0}$, com o limite superior correspondendo ao resíduo com maior conteúdo orgânico. O índice de compressão secundária $(C \alpha)$ pode variar de 0,03. $e_{0}$, para condições anaeróbias até $0,09 . e_{0}$ sob condições aeróbias. Tanto os resultados obtidos por GABR \& VALERO (1995), que são provenientes de células convencionais, como os de WALL \& ZEISS (1995) compararam relativamente bem com as envoltórias teóricas de SOWERS (1973). No 
entanto, os índices de vazios iniciais apresentados por WALL \& ZEISS (1995) e SOWERS (1973) são significativamente maiores que os estimados para o caso de laboratório. BOUTWELL \& FIORE (1995) encontraram, para o resíduo urbano, uma relação (C $\alpha / C c)$ variando de 0,058 - 0,073. Esses valores estão relativamente próximos dos apresentados para turfas $(0,075-0,085)$ por MESRI \& GODLEWSKI (1977).
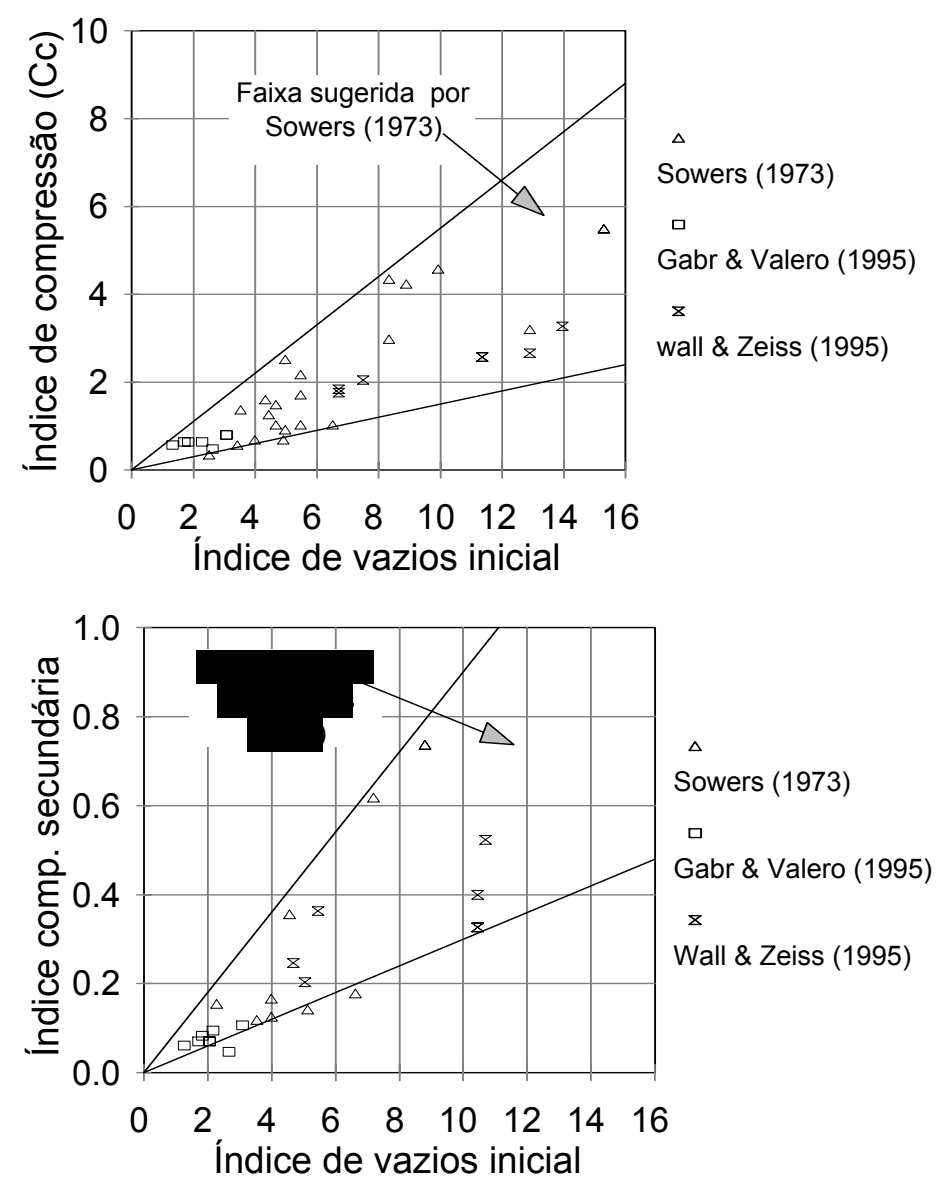

Figura 2.4.26 - Parâmetros de compressão primária e secundária em função do índice de vazios

A Figura 2.4.27 apresenta uma proposta para estimar o coeficiente de compressão secundária do resíduo sólido urbano em função da espessura do aterro, elaborada por MANASSERO et al. (1996), a partir de uma compilação de resultados apresentados por diversos autores.

Os recalques dependentes do tempo são difíceis de serem contemplados nas determinações de laboratório (MANASSERO et al 1996 e KÖNIG \& JESSBERGER 1997), o que torna o monitoramento de aterros existentes, por um longo período, uma atividade importante no estudo e compreensão do comportamento de compressibilidade do resíduo urbano. De acordo com EDGERS et al. (1992), as curvas recalque- logaritmo do tempo 
obtidas para resíduos sólidos urbanos são caracterizadas por duas partes aproximadamente lineares e com inclinações diferentes ( $\mathrm{C} \alpha_{\text {min. }}$ e $\left.\mathrm{C} \alpha_{\text {máx. }}\right)$ (Figura 2.4.28). Segundo esses autores, a mudança das deformações com o logaritmo do tempo pode ser atribuída aos processos de degradação físico-química e biodegradação dos resíduos, os quais efetivamente começam a ocorrer após algum tempo de disposição. Assim, as deformações no primeiro trecho são atribuídas às interações mecânicas e aos fenômenos de creep e no segundo trecho, tem-se a ação conjunta das deformações devido aos fenômenos de creep e às resultantes dos processos de degradação do resíduo.

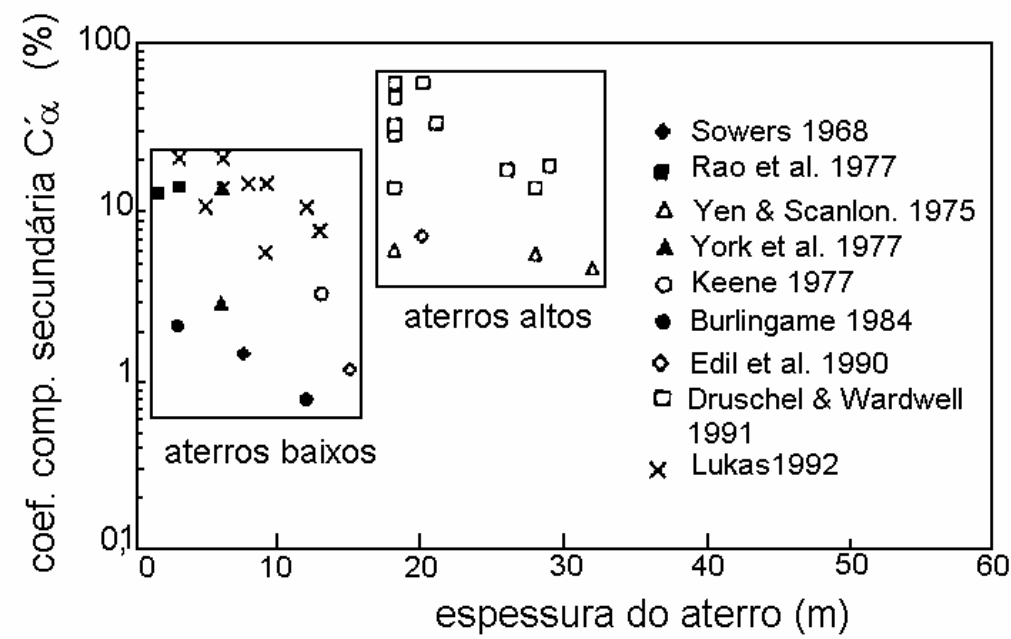

Figura 2.4.27 - Variação do coeficiente de compressão secundária (C' $\alpha$ ) com a espessura do aterro (MANASSERO et al. 1996).

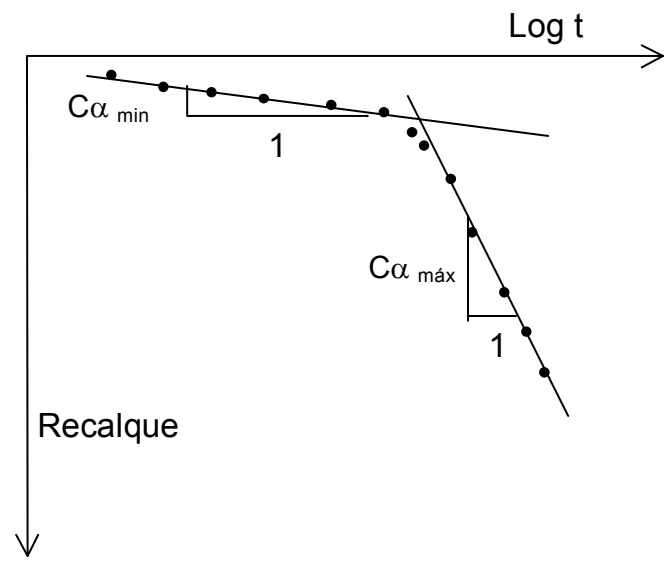

Fig. 2.4.28 - Curva teórica de recalque $x \log t$ idealizada por Edgers et al. (1992).

$\mathrm{Na}$ Figura 2.4.29 mostra-se uma compilação de resultados de recalques de superfície de diferentes aterros com o tempo, apresentada por KÖNIG \& JESSBERGER 1997. As medidas referem-se à aterros com resíduos sólidos urbanos de diferentes 
composições e idades da Europa e da América do Norte. O tempo zero corresponde ao final do período de operação do aterro e os recalques foram definidos como relações adimensionais entre os recalques medidos e a altura do aterro no final do período de operação. As curvas indicam uma mudança da taxa de recalque com o logaritmo do tempo. Segundo os autores, a taxa de recalque muda aproximadamente entre 200 a 650 dias após o final do processo de operação do aterro e não se observou para estágios finais de observação (10.000 dias) nenhuma mudança da taxa de recalque. A mudança da taxa de recalque relacionada com o logaritmo do tempo foi atribuída aos processos de biodegradação e degradação físico-química do resíduo (KÖNIG \& JESSBERGER 1997; MANASSERO et al. 1996). Tais processos necessitam de algum tempo para começarem efetivamente a ocorrer, o que está em acordo com o fato de que a produção de gás no aterro se inicia após algum tempo de disposição.

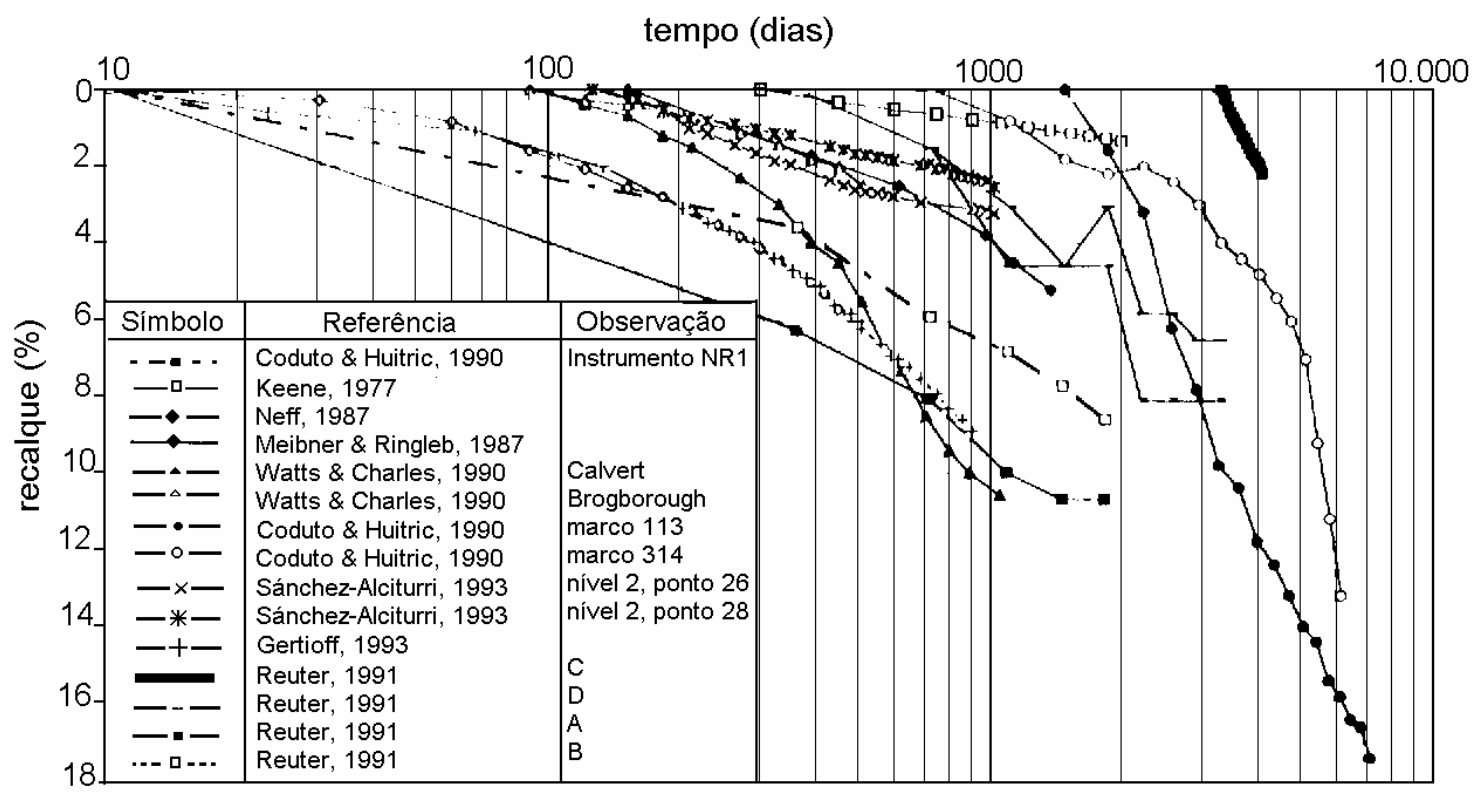

Figura 2.4.29 - Medidas de recalques de superfície de diferentes aterros (KÖNIG \& JESSBERGER 1997).

Recentemente BOUTWELL \& FIORE (1995) descreveram um estudo de caso onde um aterro experimental foi totalmente monitorado, isto é, mediram-se os recalques mesmo durante o processo de construção e 13 meses após o término do aterro. Os dados obtidos estão apresentados na Figura 2.4.30. Nesta figura apresenta-se também as medidas de recalques de um aterro experimental em Massachusetts publicadas por STULGIS et al. (1995). Os dados apresentados por esses autores indicam que existe uma componente de recalque que ocorre rapidamente após a aplicação da sobrecarga no aterro, uma segunda componente que exibe comportamento linear com log $t e$, possivelmente, uma terceira 
componente que inicia-se, aproximadamente, aos 200 dias de carregamento e que também exibe comportamento linear, mas com uma inclinação diferente da anterior. Esta última componente leva-se em consideração os recalques resultantes dos processos de degradação do RSU. É interessante observar que os dados de monitoramento de aterros obtidos por BOUTWELL \& FIORE (1995) e STULGIS et al. (1995) estão de acordo com a curva teórica de recalques $x \log t$ idealizada por EDGERS et al. (1992), (ver fig 2.4.28).

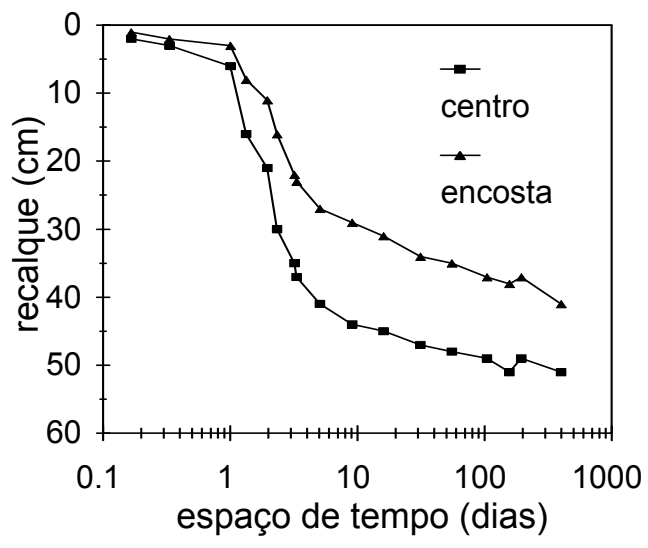

BOUTWELL \& FIORE (1995)

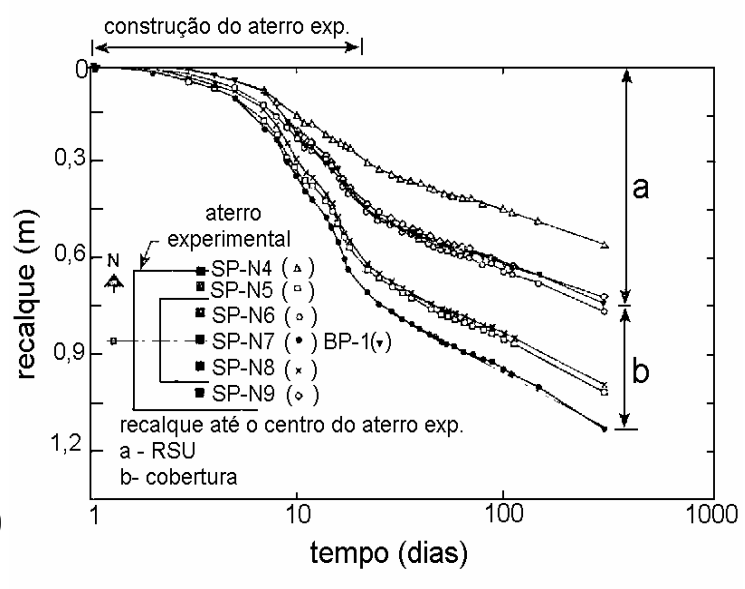

STULGIS et al. (1995)

Figura 2.4.30 - Dados de recalque versus o logaritmo tempo para aterros de resíduos sólidos urbanos.

A compressão em aterros sanitários também pode ser avaliada por meio de ensaios de campo, tais como prova de carga sobre placa (usadas em camadas mais superficiais), ensaios pressiométricos (usados em profundidade maiores) e técnicas de geofísica mais avançadas como por exemplo SASW (spectral analysis of surface waves) (MANASSERO et al. 1996; VAN IMPE 1998b). Segundo KNOCHENMUS et al. (1998), os resultados de ensaios in situ bem como suas correlações podem não ser diretamente aplicáveis para o resíduo sólido urbano, podendo inclusive gerar valores não representativos da compressibilidade do material de lixo.

Os ensaios de prova de carga sobre placa são, geralmente, executados nas camadas de cobertura do RSU (topo do aterro) ou em camadas superficiais após a remoção da camada de recobrimento e são usados para avaliar a capacidade de carga de aterros para possível aproveitamento da área e deformabilidade dos mesmos. De acordo com KNOCHENMUS et al. (1998), SÁNCHEZ-ALCITURRI et al. (1993c) e SÁNCHEZALCITURRI et al. (1994), a limitação dos ensaios de prova de carga sobre placa é que a zona de influência é pequena, atingindo, em geral, somente a parte superior da camada de RSU, podendo dessa forma, dar resultados não representativos do conjunto. LANDVA \& CLARK (1990) e SÁNCHEZ-ALCITURRI et al. (1993b) recomendam, para aterros sanitários, o uso de provas de carga lenta sobre placa de maiores dimensões (da ordem de $1 \mathrm{~m}$ ), dada a grande deformabilidade e heterogeneidade do RSU. O aumento do tamanho da placa 
permite atingir uma zona maior de influência, abrangendo uma maior profundidade na camada de resíduo. Já a aplicação lenta da carga permite desenvolver as deformações de creep (compressão secundária), as quais são mais significativas para esse tipo de material.

A Figura 2.4.31 apresenta resultados típicos de prova de carga sobre placa $(\phi=$ 0,6m) executados no aterro de Apples (Bélgica) por VAN IMPE et al. (1998). A figura também, mostra os resultados de prova de carga obtidos por JUCÁ et al. (1997) e SANTOS et al. (1998b) no aterro da Muribeca (Recife). JUCÁ et al. (1997) variaram a situação de embutimento da placa no terreno conservando o diâmetro da placa. Os ensaios de número $\mathrm{N}^{\circ}$. 1, 2 e 3 foram executados na camada de recobrimento do RSU com espessura de 80 , 60 e $80 \mathrm{~cm}$, respectivamente e, apenas, o ensaio de $\mathrm{N}^{\circ} 4$ foi executado diretamente sobre o RSU. Observa-se desta figura que não existe nenhuma evidencia de ruptura para o RSU.

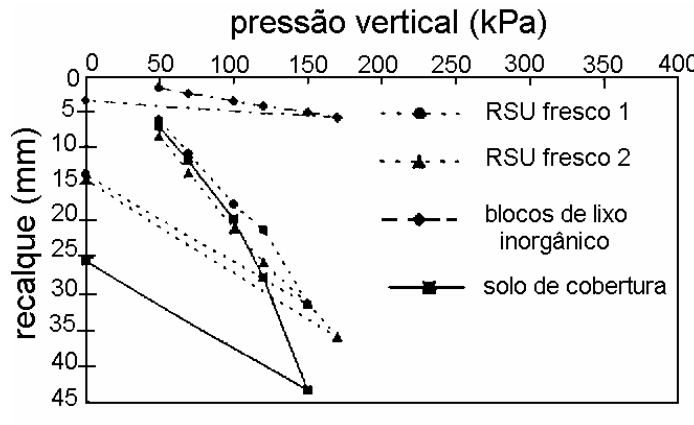

VAN IMPE (1998)

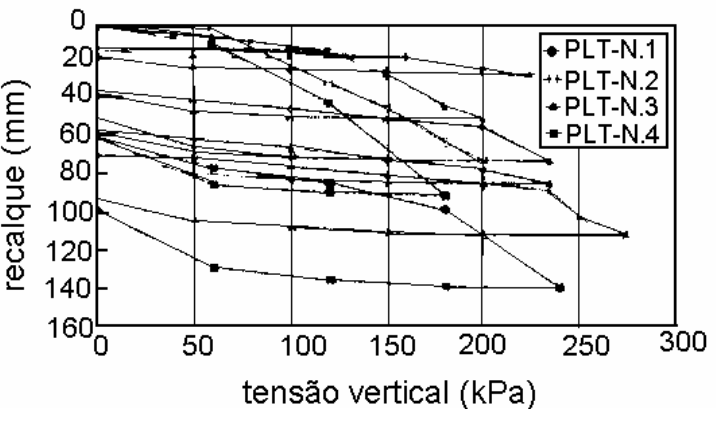

JUCÁ et al. (1997).

Figura 2.4.31 - Resultados de ensaios de prova de carga sobre placa (VAN IMPE 1998 e JUCÁ et al. 1997).

A Figura 2.4.32 apresenta alguns resultados de módulo de deformabilidade para o resíduo sólido urbano obtidos por vários autores utilizando diferentes métodos de ensaios, bem como as envoltórias superior e inferior propostas por MANASSERO et al. (1996) e as relações obtidas por KÖNIG \& JESSBERGER (1997) a partir de resultados de 21 ensaios de compressão confinada de grandes dimensões. KÖNIG \& JESSBERGER (1997) encontraram uma relação linear entre tensão vertical e módulo de deformabilidade, salientando que, para ensaios de laboratório, o módulo é derivado da linha de compressão virgem e portanto somente dá informações de recalque para RSU que não tenha sido submetido a cargas maiores que aquelas aplicadas no ensaio. A variação do módulo de deformabilidade depende de vários fatores, tais como composição do RSU, estado de compactação, presença da cobertura de solo, diâmetro da placa (em alguns casos), tipo de ensaio e idade do resíduo (MANASSERO et al. 1996; VAN IMPE 1998). Segundo KNOCHENMUS et al. (1998), o módulo de deformabilidade para o resíduo urbano varia entre 0,5 a 3MPa e, em virtude da duração limitada dos ensaios de campo e laboratório, os 
resultados não levam em conta as variações do módulo com o tempo e com as mudanças físico-químicas e biológicas do resíduo.

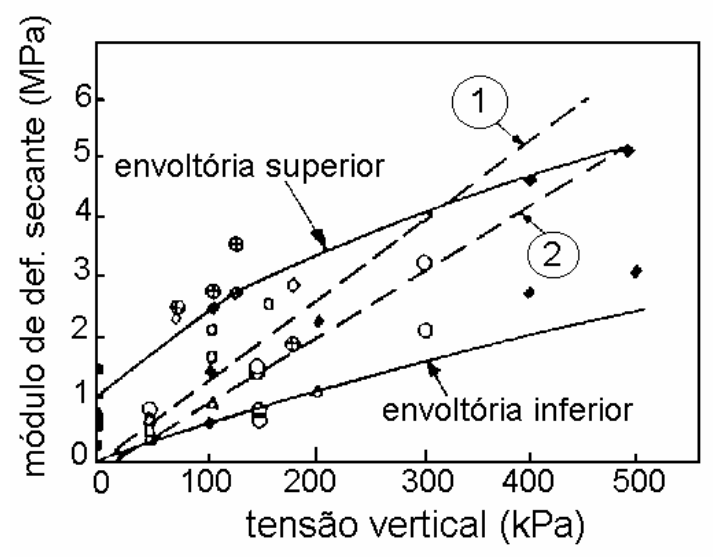

- Jessberger \& Kockel (1993)

- Landva \& Clark (1990)

$\triangle \quad$ Wiemer (1982)

a Palma - Gonzalez (1995)

- RSU 1, Apples Landfill

(7) RSU 2, Apples Landfill

- SASW tests (Van Impe, 1993)

Envoltória de Manassero et al. 1996)

- - - Relações de König \& Jessberger (1997)

(1) $E_{S}(\mathrm{MPa})=-0,106+10,9 \sigma$

(2) $E_{S}(\mathrm{MPa})=-0,294+12,5 \sigma$

Figura 2.4.32 - Variação de módulo de deformação com a tensão vertical obtidos para diferentes resíduos sólidos urbanos (modificado de KNOCHENMUS et al. 1998).

\subsubsection{1 - Previsão de recalques}

A avaliação dos recalques de um aterro sanitário tem sido feita, na maior parte dos casos relatados na literatura, através da teoria da consolidação unidirecional ou através de expressões empíricas resultantes de dados de monitoramento de campo (RAO et al. 1987, GOURC et al. 1998b, LING et al. 1998, SIMÕES et al. 1996 e WALL \& ZEISS 1995).

Como comentado anteriormente, o recalque de um aterro sanitário com o tempo é dividido em recalque inicial (devido a ação de cargas externas), primário (dissipação da água dos poros) e secundário (creep e degradação biológica). Conforme salienta ELFADEL et al. (1997), o recalque inicial tem sido ignorado para as propostas de modelagem e os recalques primários e secundários tem sido modelados como processos independentes (formulações propostas por Sowers 1973, Bjarngard \& Edgers 1990), ou combinados (YEN \& SCANLON 1975, exponencial de creep, etc).

SOWERS (1973) foi o primeiro a avaliar os recalques num aterro sanitário por meio de aproximação da mecânica dos solos. A partir de dados de monitoramento de campo, o autor acima, concluiu que, desde que não ocorram mudanças significativas no interior das células, ou seja, desde que os diversos fatores que influenciam o processo de degradação (temperatura, umidade e $\mathrm{pH}$ ) permaneçam constantes, a relação recalque vs logaritmo do tempo é aproximadamente linear. Assim, SOWERS (1973) admitiu que os recalques totais 
de um aterro podem ser divididos em duas parcelas: uma gerada por solicitações mecânicas e, a outra, gerada pela decomposição físico-química e biológica do RSU ao longo do tempo.

A parcela resultante das solicitações mecânicas é decorrente do peso próprio das camadas de RSU e das sobrecargas (camada de recobrimento, estrutura rígida, etc). Os recalques provenientes destas solicitações podem ser analisados à luz da teoria da consolidação dos solos, como compressão primária, e são determinados pela equação:

$$
\Delta H_{1}=\frac{H_{o}}{1+e_{o}} C c \log \frac{\sigma_{0}^{\prime}+\Delta \sigma}{\sigma_{o}^{\prime}}
$$

onde: $\Delta \mathrm{H}_{1}=$ recalque da camada devido a compressão primária, $\mathrm{H}_{\mathrm{o}}=$ espessura inicial da camada, $e_{o}=$ índice de vazios inicial, $\mathrm{Cc}=$ índice compressão, $\sigma^{\circ}{ }_{\circ}=$ pressão vertical inicial, $\Delta \sigma=$ acréscimo de pressão vertical.

Os recalques devido às solicitações mecânicas ocorrem por um período de cerca de um a dois meses após a aplicação das solicitações. Considera-se que a partir daí inicia-se a segunda parcela dos recalques, desenvolvida pela decomposição física, química e biológica do RSU e correspondente à compressão secundária. Os recalques, devido à compressão secundária, expressam a redução de volume provocada pelas transformações do material e às perdas de massa resultante da fuga de gases e de líquidos. Eles seguem uma relação linear com o logaritmo do tempo, de modo similar ao fenômeno de compressão secundária observado em solos, e podem ser expressos por:

$$
\Delta H_{2}=\frac{H_{o}}{1+e_{o}} \mathrm{C} \alpha \cdot \log \frac{\mathrm{t}_{1}+\Delta t}{\mathrm{t}_{1}}
$$

onde: $\Delta \mathrm{H}_{2}=$ recalque da camada devido a compressão secundária, $\mathrm{H}_{\mathrm{o}}=$ espessura inicial da camada, $\mathrm{e}_{\mathrm{o}}=$ índice de vazios inicial, $\mathrm{C} \alpha=$ índice de compressão secundária, $\mathrm{t}_{1}=$ tempo inicial da consolidação secundária, $\Delta \mathrm{t}=$ acréscimo de tempo.

Dentro desta mesma linha, dois estudos similares publicados mais recentemente são os de Bjarngard \& Edgers ${ }^{1}$ e de Fasset et al. ${ }^{2}$ apud STULGIS et al. (1995), os quais foram baseados em dados de monitoramento de aterros. Bjarngard \& Edgers consideram a existência de dois índices de compressão secundária, um intermediário e outro a longo

\footnotetext{
'BJARNGARD, A. \& EDGERS, L. (1990). Settlements of municipal solid waste landfill. Proceedings of the Thirteenth Annual Madison, sept.

${ }^{2}$ FASSETT, J. B., LEONARDS, G. A., \& REPETTO, P. C. (1994). Geotechnical Properties of municipal solid wastes and their use in landfill design. Proceedings of the Waste Tech. Conference, Charleston, Sc, January.
} 
prazo( Figura 2.4.33) enquanto que Fasset et al. consideram a existência de apenas um índice de compressão secundária. A equação para cálculo de recalque de Fasset et al. é similar à de SOWERS (1973) e a de Bjarngard \& Edgers ganha mais um termo, ficando da seguinte forma:

$$
\frac{\Delta \mathrm{H}}{\mathrm{H}}=\mathrm{C}^{\prime} \mathrm{C} \cdot \log \frac{\overline{\mathrm{Po}}+\Delta \mathrm{P}}{\overline{\mathrm{Po}}}+\mathrm{C}^{\prime} \alpha_{(1)} \log \frac{\mathrm{t}(2)}{\mathrm{t}(1)}+\mathrm{C}^{\prime} \alpha_{(2)} \log \frac{\mathrm{t}_{(3)}}{\mathrm{t}_{(2)}}
$$

onde: $\Delta H=$ recalque, $H=$ espessura inicial da camada de $R S U, \Delta H / H=$ deformação vertical (recalque normalizado), $\mathrm{Po}=$ tensão efetiva vertical média inicial, $\Delta \mathrm{P}=$ incremento de tensão vertical média, $t_{(1)}=$ tempo (dias) para completar a compressão inicial, $t_{(2)}=$ tempo (dias) para completar a compressão intermediária, $t_{(3)}=$ período de tempo (dias) para previsão do recalque, $\mathrm{Cc}^{\prime}=$ coeficiente de compressão primária, $C^{\prime} \alpha_{(1)}=$ coeficiente de compressão secundária intermediária, $C^{\prime} \alpha_{(2)}=$ coeficiente de compressão secundária a longo prazo.

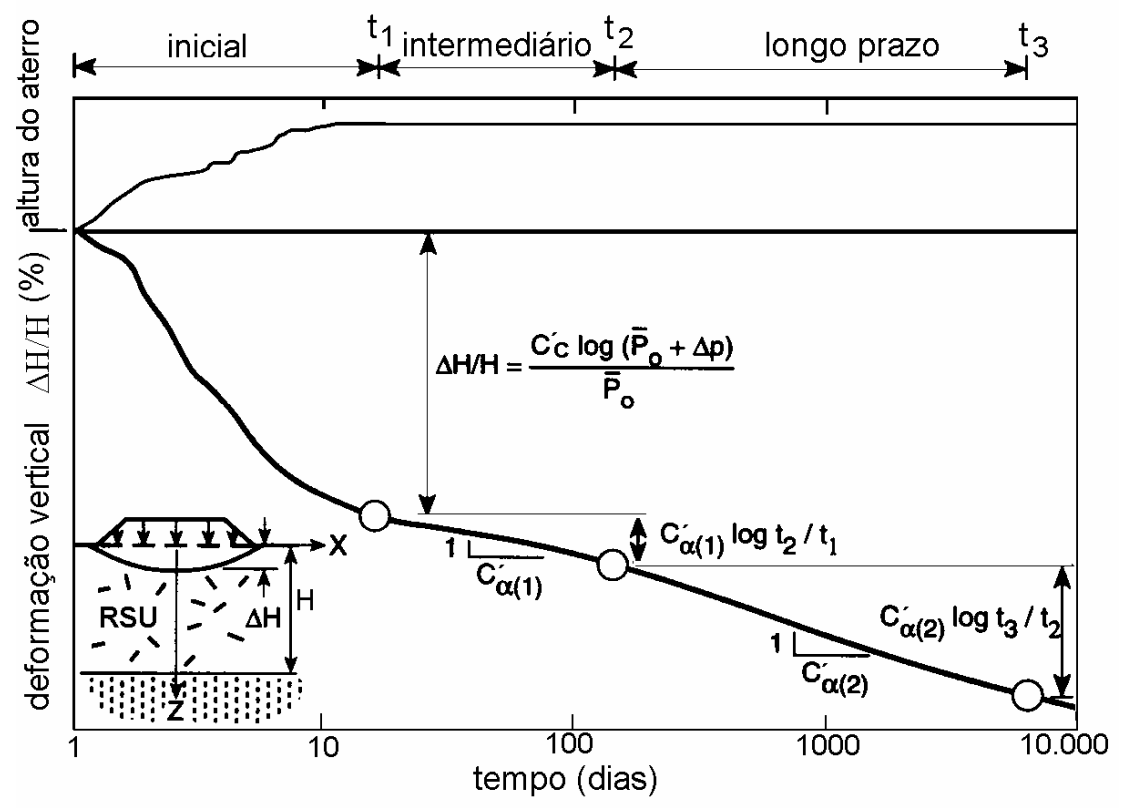

Figura 2.4.33 - Modelo de recalque proposto por Bjarngard \& Edgers (STULGIS et al. 1995).

Os modelos propostos por Bjarngard \& Edgers e Fassett et al. pressupõem que, a curto prazo, a relação entre a deformação vertical $(\Delta \mathrm{H} / \mathrm{H})$ e log $(\mathrm{Po}+\Delta \mathrm{P} / \mathrm{Po})$ é linear. Bjarngard $^{1}$ apud MANASSERO et al. (1996), a partir de resultados de ensaios de compressão confinada em amostras preparadas em laboratório (papel e areia) e de dados de monitoramento de cinco diferentes aterros de RSU, obtiveram um comportamento de

\footnotetext{
${ }^{1}$ Bjarngard, A, (1989). The compression characteristics of landfill. M. Sc. Thesis, Tufts University, Medford (USA).
} 
recalque razoavelmente linear para uma dada variação de tensões verticais. Por outro lado, Fasset et al. (1994) apud MANASSERO et al. (1996) têm indicado que a relação $(\Delta \mathrm{H} / \mathrm{H})$ vs log tensão vertical é, geralmente, não linear e o coeficiente de compressão primária decresce com o aumento da tensão vertical.

KÖNIG \& JESSBERGER (1997) idealizaram o comportamento de recalque - tempo de um aterro de resíduo sólido como mostrado na Figura 2.4.34. A curva recalque - tempo é dividido em três partes, uma devido ao recalque induzido por cargas, o qual ocorre em um período de aproximadamente 10 dias após a finalização do aterro e pode ser descrito pela relação linear entre as tensões e módulo de deformabilidade. As outras duas partes referem-se aos recalques dependentes do tempo e podem ser descritos pelos parâmetros $\mathrm{C}_{\alpha, \mathrm{k}}, \mathrm{C}_{\alpha, \mathrm{t}}$ e $\mathrm{t}_{2, \mathrm{k}}=\mathrm{t}_{1, \mathrm{t}}$. Caso não exista dados disponíveis, o módulo de deformação dependente da tensão, pode ser estimado pelas relações apresentadas na figura 2.4.32, e os parâmetros $C_{\alpha, k}, C_{\alpha, t}$ e $t_{2, k}=t_{1, t}$, em uma primeira aproximação, podem ser obtidos da figura 2.4.29. Caso exista algum dado, deve-se traçar a curva deformação vs log $t$ e prever os parâmetros conforme mostra a figura 2.4.34. KÖNIG \& JESSBERGER (1997) apresentam ainda valores médios de 0,03 para o $C_{\alpha, k}$, de 0,102 para o $C_{\alpha, t}$ e de 425 para o $t_{2, k}$.
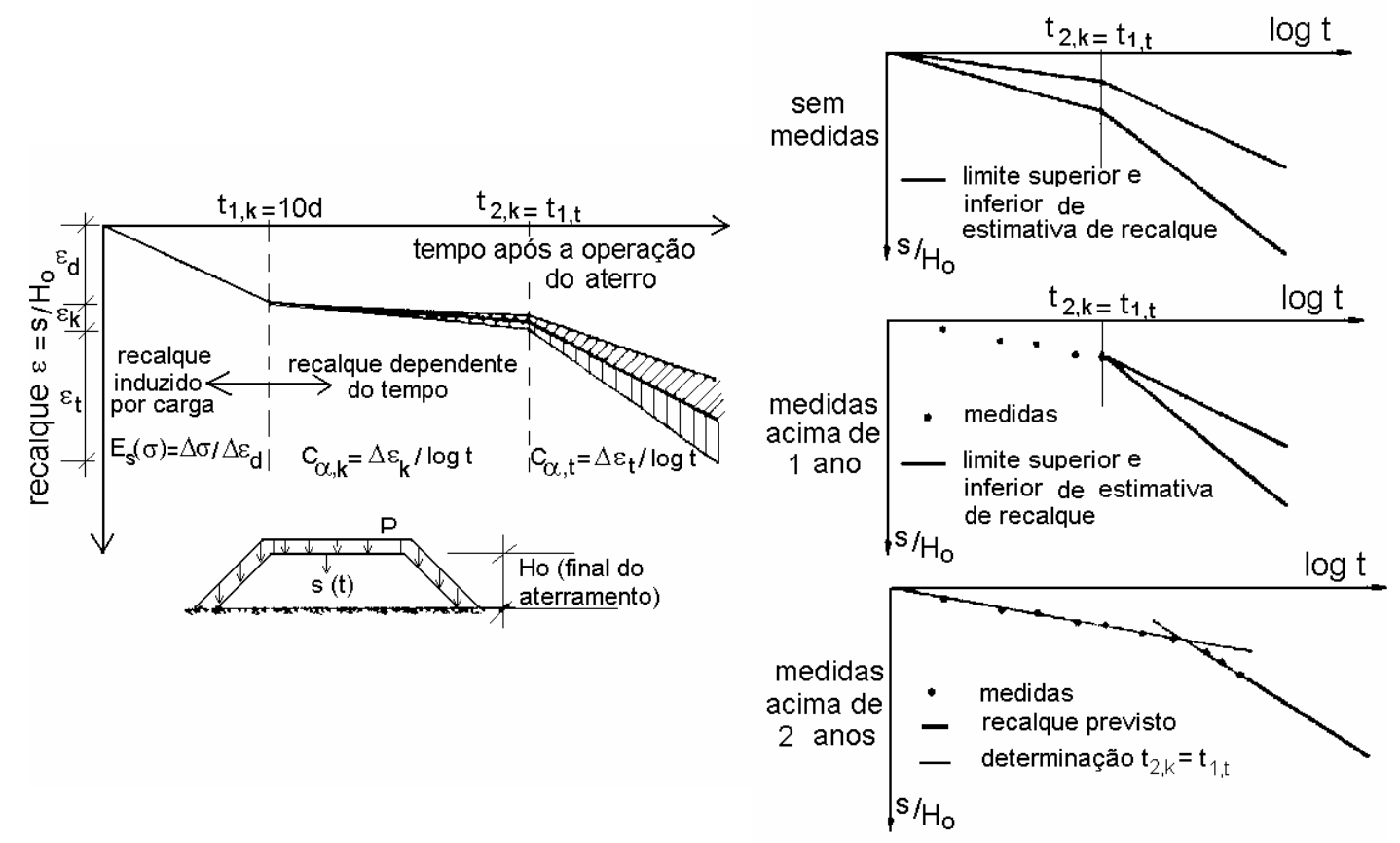

Figura 2.4.34 - Comportamento de recalque - tempo para resíduos sólidos urbanos idealizado por KÖNIG \& JESSBERGER (1997). 
YEN \& SCANLON (1975), a partir de medidas de taxa de recalque obtidas de três aterros sanitários na Califórnia, com altura entre 12 -30m durante aproximadamente 10 anos, sugeriram uma variação logarítmica para a taxa de recalque $(v=d h / d t)$ :

$$
v=\frac{d h}{d t}=a^{`}-b^{`} \cdot \log t
$$

onde: $v=$ taxa de recalque, $d h=$ variação de altura, $t=$ tempo, $a^{\prime}$ e $b^{\prime}=$ constantes empíricas. Os autores sugerem valores para os parâmetros $a^{`}$ e b` $\left[\left(a^{\prime}=0,00095 \mathrm{H}+0,00985\right)\right.$, $\left.\left(b^{`}=0,00035 \mathrm{H}+0,00509\right)\right]$ aumentando aproximadamente linear com a espessura do aterro $(\mathrm{H})$.

YEN \& SCANLON (1975) observaram que a taxa de recalque decresce linearmente com o logaritmo do tempo, tornando-se zero para 200- 300 meses (25 anos). Entretanto, observações feitas em aterros mais antigos demonstraram que os recalques continuam a ocorrer sobre longos períodos de tempo (MANASSERO et al. 1996). Medidas de recalques feitas por SÁNCHEZ-ALCITURRI et al. (1993b) no aterro de Meruelo mostraram que a taxa de recalque não é linear com log $t$, quando consideram-se períodos de tempos inferiores a 2 anos e, no entanto, quando são considerados tempos superiores a este valor, as taxas de recalques ajustam razoavelmente bem com os resultados obtidos empregando as proposições de YEN \& SCANLON (1973).

Alguns modelos empíricos, desenvolvidos para aplicações em outros materiais, tem sido utilizados com relativo sucesso na previsão de recalques em aterros sanitários. Dentre eles, destacam-se o modelo de Gibson \& Lo e o modelo exponencial de creep (Power creep law) (EDIL et al. 1990).

O modelo reológico de Gibson \& Lo, de acordo com EDIL et al. (1990), apresenta uma boa previsão de recalques para as turfas, as quais apresentam mecanismos de compressão semelhantes aos dos RSU. Tanto as turfas, como os RSU, apresentam grandes vazios que se comprimem ligeiramente no inicio (compressão primária) e que continuam comprimindo mais lentamente por um longo tempo (compressão secundária), onde inicia-se um processo de quebra de estrutura das partículas. Por esse modelo, o recalque dependente do tempo é dado por:

$$
S_{(t)}=H \varepsilon_{(t)}=H \Delta \sigma\left[a+b\left(1-e^{-\frac{\lambda}{b} \cdot t}\right)\right]
$$

onde: $S_{(t)}=$ recalque, $H=$ altura inicial do resíduo, $\varepsilon=$ deformação $(S / H), \Delta \sigma=$ tensão compressiva, $\mathrm{a}$ e $\mathrm{b}=$ parâmetros de compressibilidade primária e secundária 
respectivamente, $\lambda / \mathrm{b}=$ taxa de compressão secundária, $\mathrm{t}=$ tempo decorrido desde $\mathrm{o}$ início da aplicação da carga.

EDIL et al. (1990) utilizaram registros de recalques em aterros sanitários e concluíram ser satisfatória a aplicação deste modelo na previsão de recalques em aterros de resíduos sólidos urbanos. Os desvios apresentados entre recalques previstos e medidos em campo situaram-se na faixa de 0 a $21 \%$.

O modelo exponencial de creep tem sido extensivamente usado para representar o comportamento de creep transiente de inúmeros materiais da engenharia EDIL et al. (1990), e o recalque dependente do tempo é expresso pela equação:

$$
S_{(t)}=H \varepsilon_{(\mathrm{t})}=\mathrm{H} \Delta \sigma \mathrm{m}(\mathrm{t} / \mathrm{tr})^{\mathrm{n}}
$$

onde: $\mathrm{S}_{(\mathrm{t})}=$ recalque no tempo $\mathrm{t}, \mathrm{H}=$ altura inicial do resíduo, $\Delta \sigma=$ tensão compressiva, $\mathrm{m}=$ compressibilidade de referência, $\mathrm{n}=$ taxa de compressão, $\operatorname{tr}=$ tempo de referência introduzido na equação para tornar o tempo $(t)$ adimensional $(t r=1)$.

EDIL et al. (1990) estimaram valores médios para os parâmetros $\mathrm{m}\left(2,5.10^{-5} 1 / \mathrm{kPa}\right)$ e $n(0,37)$ realizando ajustes de curvas a partir de registros de monitoramento de recalque em aterros sanitários. Eles mencionam que apesar do reduzido número de registros, os desvios entre os recalques previstos e os medidos foram de $0-14 \%$. Embora o modelo exponencial de creep tenha apresentado, para este caso, resultados um pouco mais precisos que os obtidos com o modelo de Gibson \& Lo, esse modelo se baseia em parâmetros que não tem significado físico.

GOMES et al. (1998) apresentam uma função ajustada para cálculo de recalque, obtida a partir de medidas variação de altura de 3 células reatoras com $1 \mathrm{~m}$ de diâmetro, tomadas num período de 448 dias e sem adição de sobrecarga. As células foram preenchidas com resíduos sólidos urbanos compactados, sendo que uma foi monitorada com recirculação de chorume sem tratamento, e as outras duas sem recirculação. Como não foi observado nenhum acréscimo significativo nos recalques devido à recirculação de chorume, os autores acima propuseram uma função matemática única, do tipo $Y=1 E^{-6} x^{3}-$ $0,0009 x^{2}+0,2738$ (Figura 2.4.35) para previsão de recalques em aterros sanitários de resíduos sólidos urbanos.

EDGERS et al. (1992) propuseram um modelo matemático para calcular o recalque devido aos processos de creep e biodegradação do resíduo ao longo do tempo. Segundo os autores, os efeitos da decomposição são pequenos até um tempo crítico, $t_{k}$, a partir do qual a taxa de deformação aumenta. O tempo crítico ou de ajuste corresponde ao tempo 
necessário para as bactérias começarem a se multiplicar exponencialmente. Assim, as deformações devido à decomposição são diretamente proporcionais à mudança do número de bactérias e pode ser expresso por:

$$
\varepsilon_{\text {bio }}=B\left(e^{\beta\left(t-t_{k}\right)}-1\right)
$$

onde: $\mathrm{B}$ = fator escala relacionando o recalque no aterro devido ao efeito da decomposição com o crescimento cinético das bactérias, $t=$ tempo, $t_{k}=$ tempo crítico a partir do qual temse $\circ$ aumento da taxa de deformação, $\beta=$ valor médio da atividade biológica para todas as bactérias de um aterro específico (pode variar de 0,1223 - 1,267 1/ano).

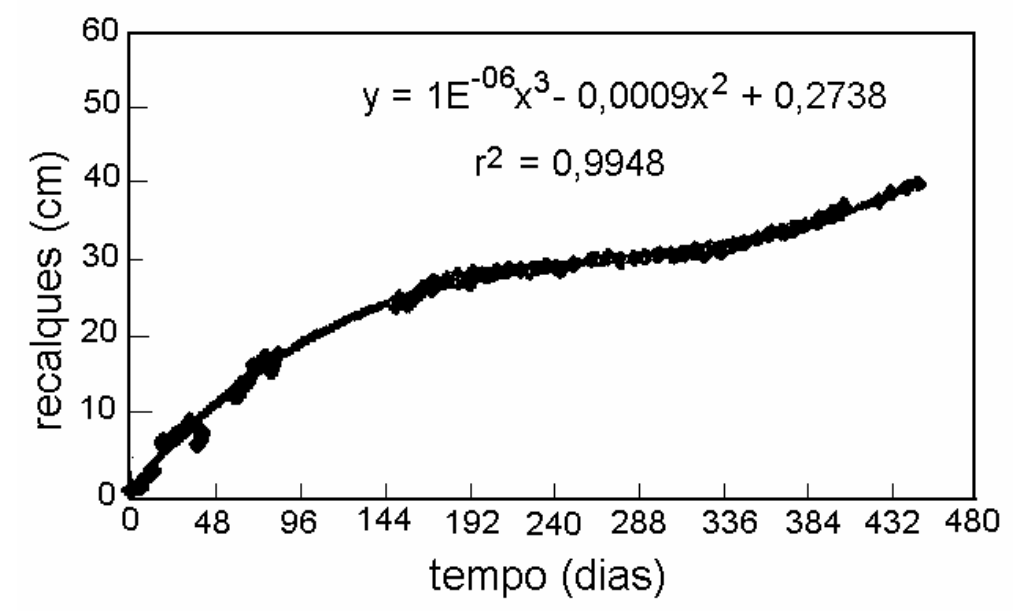

Figura 2.4.35 - Função matemática para cálculo de recalques em aterros sanitários proposta por GOMES et al. (1998).

Outro modelo que leva em conta os processos de bioconsolidação do resíduo é o de SOLER et al. (1995). Segundo os autores, a modelagem da bioconsolidação requer o estabelecimento de modelos de geração de gases, uma vez que a perda de massa e a conseqüente redução de volume ao longo do tempo, são função da taxa de produção de gases no interior do aterro sanitário. SOLER et al. (1995), a partir da equação de geração de metano no aterro (modelo Scholl Canyon), determinaram a perda de volume de sólidos devida à biodegradação $\left(\Delta \mathrm{V}_{\mathrm{s}}(\mathrm{t})\right)$ através da equação:

$$
\Delta V_{s}(t)=\frac{\lambda}{f_{C H 4} \cdot \rho_{s}} \cdot \int_{t=0}^{t_{i}} M(t) \cdot e^{-\lambda t} \cdot d t
$$

onde: $\rho_{\mathrm{s}}=$ densidade dos sólidos biodegradáveis; $\mathrm{f}_{\mathrm{CH} 4}=$ fração de metano no gás gerado, igual a 0,$5 ; \lambda=$ taxa de geração de metano, $M(t)=$ parcela biodegradável do resíduo. 


\subsubsection{2 - Comentários}

Embora os recalques no aterro sejam freqüentemente avaliados usando a teoria da consolidação unidirecional (aproximação elástica ou relações e-log $\sigma$ ) o uso dessa aproximação é complicada pelas seguintes razões:

- os índices de compressão primária e secundária são uma função do índice de vazios inicial ou altura inicial do aterro, os quais são difíceis de serem conhecidos, principalmente em aterros mais antigos.

- as relações e-log $\sigma$ ou e-logt são muitas vezes não lineares e consequentemente, os índices de compressão Cc e $\mathrm{C}_{\alpha}$ podem significativamente variar com as tensões geradas no aterro, as quais podem variar com tempo (Fasset et al. ${ }^{1}$ apud MANASSERO et al. 1996).

- os recalques primários dependem das tensões efetivas, as quais são função do peso específico do resíduo e do nível de lixívia e dissipação dos gases no aterro e esses parâmetros são difíceis de serem avaliados, além disso eles podem mudar com o tempo.

Além das razões apresentadas acima, as hipóteses básicas da teoria de adensamento de Terzaghi não são satisfeitas (MASSACCl et al.,1993; WALL \& ZEISS, 1995; SOLER et al., 1995; SIMÕES \& CAMPOS, 1998). As deformações nos aterros são bastante grandes e o material encontra-se não saturado. O próprio processo de operação do aterro, com células sendo cobertas diariamente, minimizando as infiltrações e a existência de sistemas de drenagem impedem que a condição de saturação seja atingida na maior parte do aterro, ao longo de sua vida útil. Associada a isso as partículas de muitos dos componentes são compressíveis e a lei de Darcy não é satisfeita (FANG, 1993). Portanto muitas incertezas são envolvidas na avaliação da compressibilidade de resíduos sólidos municipais e a validade dos resultados calculados usando a aproximação da consolidação clássica são bastante questionáveis (MORRIS \& WOODS 1990, MANASSERO et al., 1996 e VAN IMPE 1998b). Ressalta-se a necessidade de desenvolver modelos mais avançados que contemplem as particularidades do material em análise.

\footnotetext{
${ }^{1}$ FASSETT, J. B., LEONARDS, G. A., \& REPETTO, P. C. (1994). Geotechnical Properties of municipal solid wastes and their use in landfill design. Proceedings of the Waste Tech. Conference, Charleston, Sc, January.
} 


\section{3 - MATERIAIS E MÉTODOS}

\section{1 - ESCOLHA DA ÁREA DE ESTUDO}

A área escolhida para o desenvolvimento desta pesquisa foi o Aterro Sanitário Bandeirantes localizado no município de São Paulo, próximo à Rodovia dos Bandeirantes (km 26,5 - Zona Norte). Este aterro é uma das principais áreas de disposição de resíduos sólidos urbanos da cidade de São Paulo, recebendo hoje cerca de 8000 t/dia. Sua utilização começou em meados de 1979 e possui hoje uma área aproximada de 100 hectares e uma altura de RSU estocado variando de 30 a 100m. É constituído por cinco áreas operacionais, das quais três encontram-se esgotadas (AS-1, AS-2, AS-3), e duas em fase de operação (AS-4 e AS-5).

A área de estudo pré-selecionada, de aproximadamente $450 \mathrm{~m}^{2}$, localiza-se no subaterro AS-2 e tem cerca de 15 anos de execução. Tal área foi selecionada por apresentar resíduos mais antigos, logística operacional adequada e instrumentação próxima (marcos superficiais e piezômetros), cujas leituras poderão ser utilizadas na interpretação dos dados obtidos. A locação esquemática da área selecionada e dos ensaios in situ segue disposição apresentada na Figura 3.1.

\section{2 - INVESTIGAÇÕES E RECONHECIMENTO DO MACIÇO}

Com o objetivo de caracterizar a área escolhida foram executadas as seguintes investigações in situ:

- cinco sondagens de simples reconhecimento com medida de SPT e do torque (SPT-T),

- dois ensaios penetrométricos tipo CPT,

- dois ensaios de infiltração utilizando dois furos da sondagem,

-duas tradagens para coleta de amostras com trado de 40cm de diâmetro T1 e T2

- ensaios geofísicos (cross-hole),

- ensaio de resistividade elétrica, 

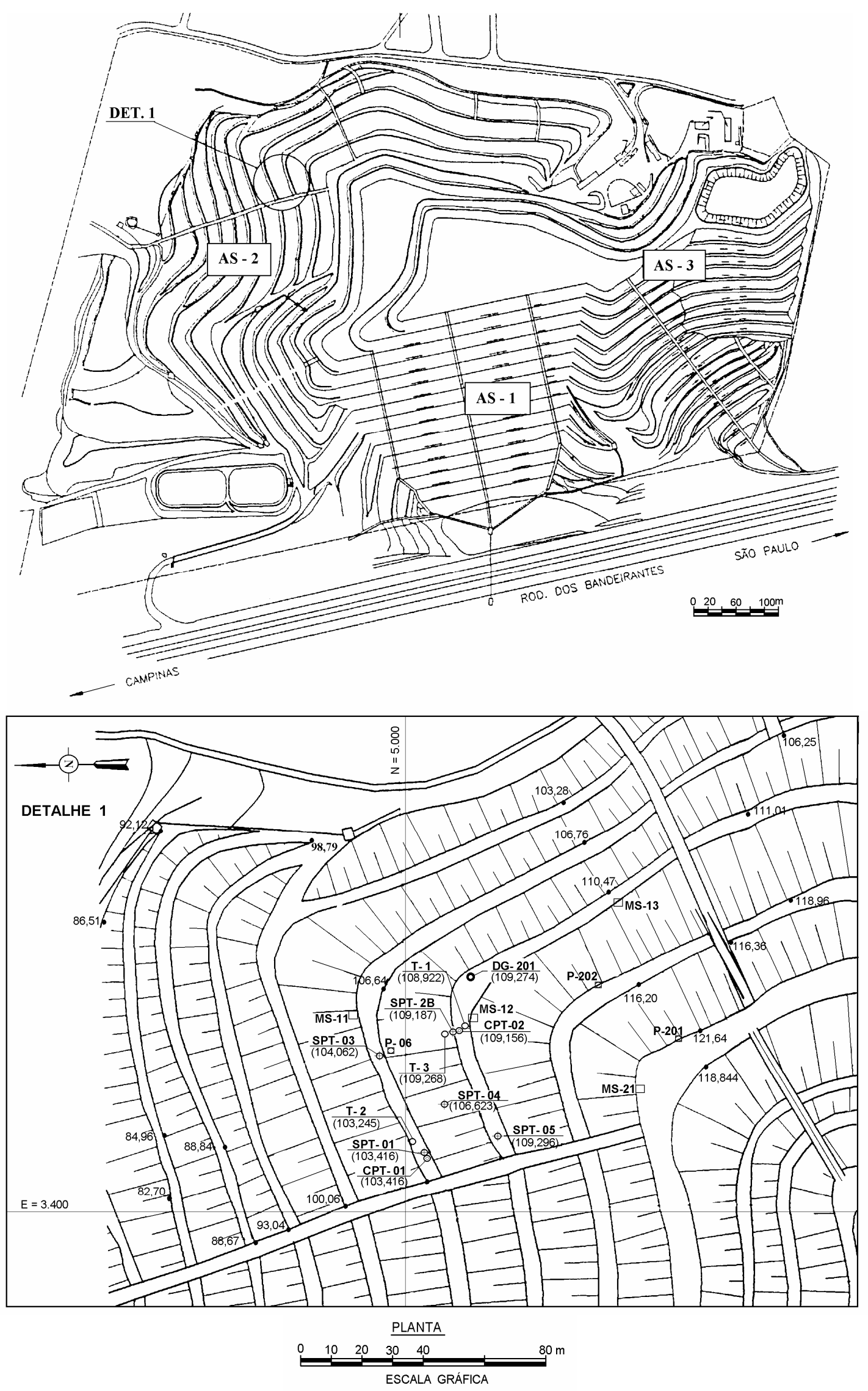

Figura 3.1 - Localização da área de estudo e disposição em planta das investigações executadas e dos marcos superficiais monitorados. 


\subsection{1 - Sondagens de simples reconhecimento com medida de SPT e do torque}

As sondagens a percussão foram executadas segundo prescrição da norma NBR 6484, utilizando amostrador padrão Terzaghi de diâmetros nominais, interno e externo de 1 3/8" e 2", respectivamente. Os ensaios SPT-T, bem como os de infiltração foram executados pela Empresa Engesolos - Engenharia de Solos e Fundações S/A.

As sondagens a percussão, realizadas para verificação das características mecânicas do aterro, atingiram em geral a profundidade de 30 metros, exceto em duas delas, onde foi encontrado terreno natural a 27 metros. Após as medidas da penetração do amostrador em intervalo de um metro, obtiveram-se as medidas do torque, o qual consiste na aplicação de um momento, expresso em kgf.m, necessário para provocar o giro do amostrador cravado no comprimento padrão de 45cm (RANZINI, 1988 e 1994).

É importante destacar, que as dificuldades de execução do ensaio SPT estão sempre presentes, sendo necessário algumas vezes, a relocação da sondagem em virtude da presença de materiais mais resistentes como enrocamento ("rachão") que constitui o sistema de drenagem interno do aterro. A utilização de tubo de revestimento, lavagem por circulação de água e inúmeras manobras com o trado foram utilizadas para permitir a limpeza do furo e o avanço da perfuração. As dificuldades encontradas para realização do ensaio podem ser reproduzidas pelo tempo gasto para avanço de um metro da sondagem, o qual variou entre 1 e 10 horas.

Foi possível uma razoável recuperação de amostra de RSU, viabilizada pela utilização de um trado constituído por cortes (dentes) ao longo do corpo espiral. Assim, materiais como plásticos e têxteis se entrelaçavam nas saliências, permitindo a remoção e limpeza do furo. Ainda neste ensaio vale ressaltar a grande dificuldade na extração dos tubos de revestimento, os quais tiveram que ser sacados com macacos a óleo e equipamento tipo "munck". Mesmo assim, alguns trechos de tubo ficaram perdidos no maciço.

Apesar das dificuldades encontradas, todas dentro do esperado, e do baixo rendimento da perfuração foi possível executar os trabalhos de investigação no maciço sanitário empregando as técnicas consagradas pela mecânica de solos.

\subsection{2 - Ensaio de penetração contínua - CPT}

Os ensaios de penetração do cone (Deep Sounding) foram executados de acordo com a norma NBR 3406 e consistiram na determinação da resistência de ponta oferecida pelo resíduo à cravação de um cone de $10 \mathrm{~cm}^{2}$ de área, com aresta formando com a horizontal um ângulo de $60^{\circ}$. A penetração da luva acoplada à ponteira permite a medida do 
atrito local (luva de Begeman). Os ensaios CPT foram executados pela Empresa Engesolos - Engenharia de Solos e Fundações S/A.

Foram executados dois ensaios penetrométricos, sendo um até a profundidade de 26 metros e o outro, por problemas de deflexão das hastes, até a profundidade de 19 metros.

As dificuldades encontradas no ensaio CPT dizem respeito a profundidade do furo e a presença de materiais de elevada resistência. Tais fatores implicaram em deflexões das hastes e reações superiores à capacidade do equipamento (10t), impossibilitando a continuidade do ensaio.

\subsection{3 - Ensaios de infiltração em furos de sondagem}

Os ensaios de infiltração foram realizados em dois furos de sondagem SPT (SPT03, SPT-05) com carga constante, em sub-trechos de 3 em 3 metros, sendo o trecho ensaiado (distância entre a extremidade do revestimento e o fundo do furo) igual a 1 metro.

O ensaio consiste na medida da vazão de água necessária para manter o nível de água constante no tubo de revestimento, após estabilização da infiltração (ABGE, 1981). Com as medidas de vazão e de configuração do ensaio, no que se refere-se à altura da coluna d'água, dimensões do furo, posição do nível de água e comprimento do trecho ensaiado, calculou-se os coeficientes de permeabilidade (k) utilizando as formulações propostas por Zangar, 1953, as quais podem ser encontradas em ABGE, (1981).

\subsection{4 - Tradagem para coleta de amostras}

Para que fosse possível a investigação do comportamento geotécnico do resíduo aterrado, por meio de ensaios de laboratório, foi realizada a coleta de amostras a partir de dois furos de trado mecânico de grande diâmetro $(D=0,40 m)$. As tradagens foram realizadas pela Empresa Perfurasolos - Empreiteira de construções Ltda.

As amostras de resíduo sólido urbano foram retiradas a cada intervalo de aproximadamente 2 metros e pesadas na tentativa de estimar o peso específico do resíduo. Em seguida, as amostras foram acondicionadas em tambores metálicos e mantidas para futuros ensaios. Também foram retiradas de cada avanço do trado, em sacos plásticos devidamente lacrados, resíduos destinados à determinação da umidade natural (in situ).

A determinação do peso específico foi problemática devido à técnica de amostragem adotada. Infelizmente, durante as sucessivas operações de descida e subida do trado, ocorreu uma tendência de fechamento do furo. Assim, uma quantidade maior de material de lixo era extraída do furo, o que resultava em medidas errôneas de pesos e 
volumes. Na tentativa de sanar esses problemas, fez-se uma nova perfuração com 10,50 metros de profundidade total, utilizando apenas um suplemento do trado com diâmetro de $0,30 \mathrm{~m}$. Todo o resíduo foi pesado e o volume foi obtido preenchendo o furo com pasta de bentonita. O uso de pasta de bentonita para melhor medir o volume do furo apresentou a mesma deficiência comentada acima. Assim as estimativas do peso específico ficaram comprometidas.

Durante os trabalhos de coleta e estimativa do peso específico, tomou-se muito cuidado no controle de avanço da haste do trado e na identificação das camadas de solo utilizadas para cobertura das camadas de RSU, a fim de que esse não contaminasse as amostras coletadas. A profundidade foi controlada através de marcas (pichações) na torre da perfuratriz. Empregou-se, também, uma lona plástica estendida ao redor do furo para evitar a contaminação do resíduo com o solo de cobertura. É importante abordar, também, que para proteção individual do pessoal envolvido na coleta de amostra, bem como, durante todos os trabalhos envolvendo contato com o RSU, foram utilizados luvas impermeáveis, mascaras de gás, botas, etc.

As Figuras 3.2 a 3.4 ilustram as operações de execução do furo de tradagem, retirada das amostras e armazenamento.

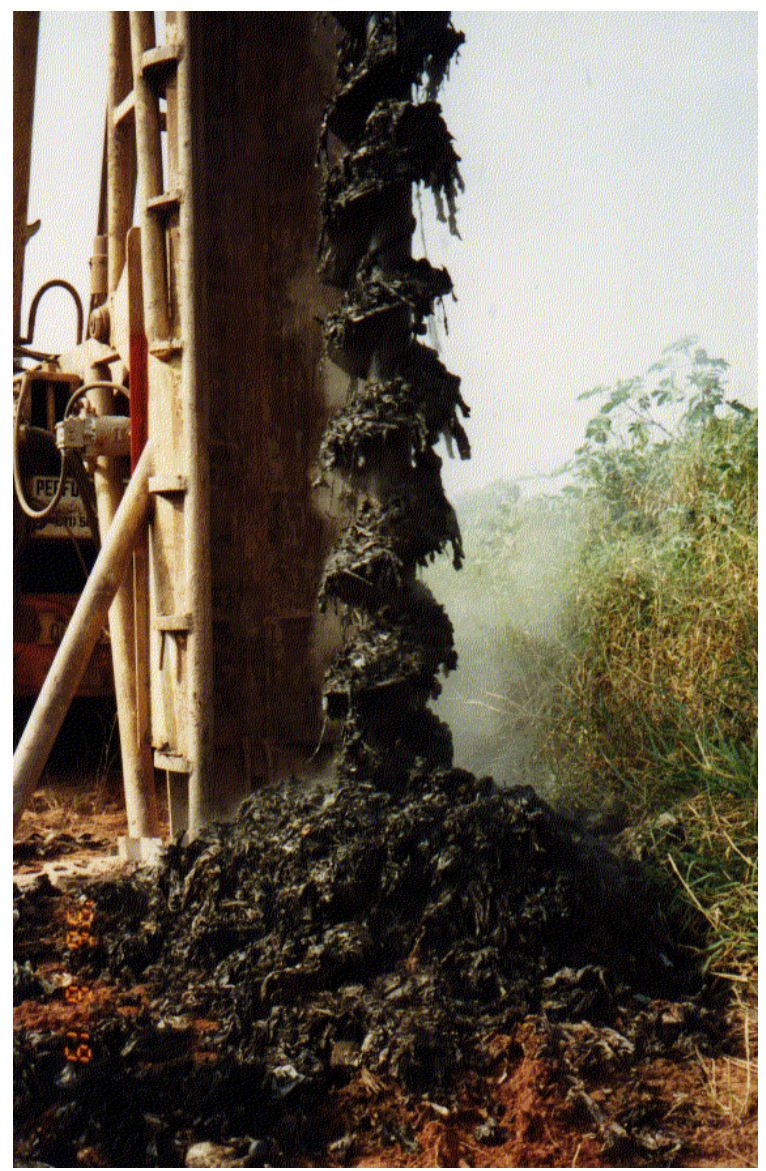

Figura 3.2 - Tradagem mecânica com trado helicoidal de $40 \mathrm{~cm}$ de diâmetro. 


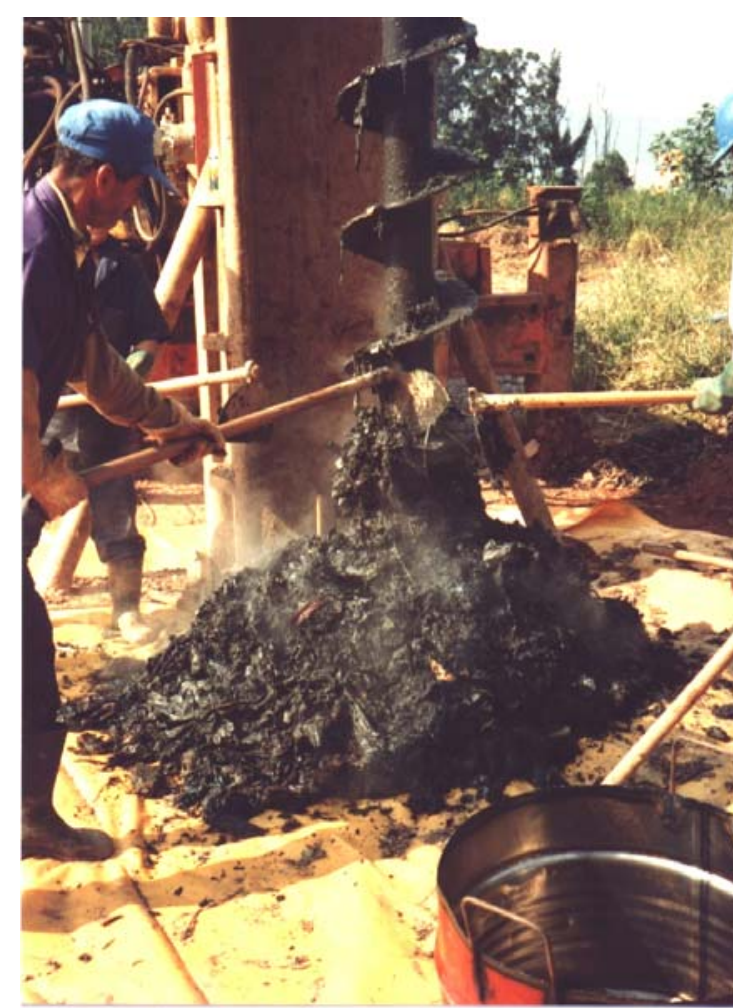

Figura 3.3 - Perfuração e amostragem de resíduos sólidos urbanos do Aterro sanitário Bandeirantes.

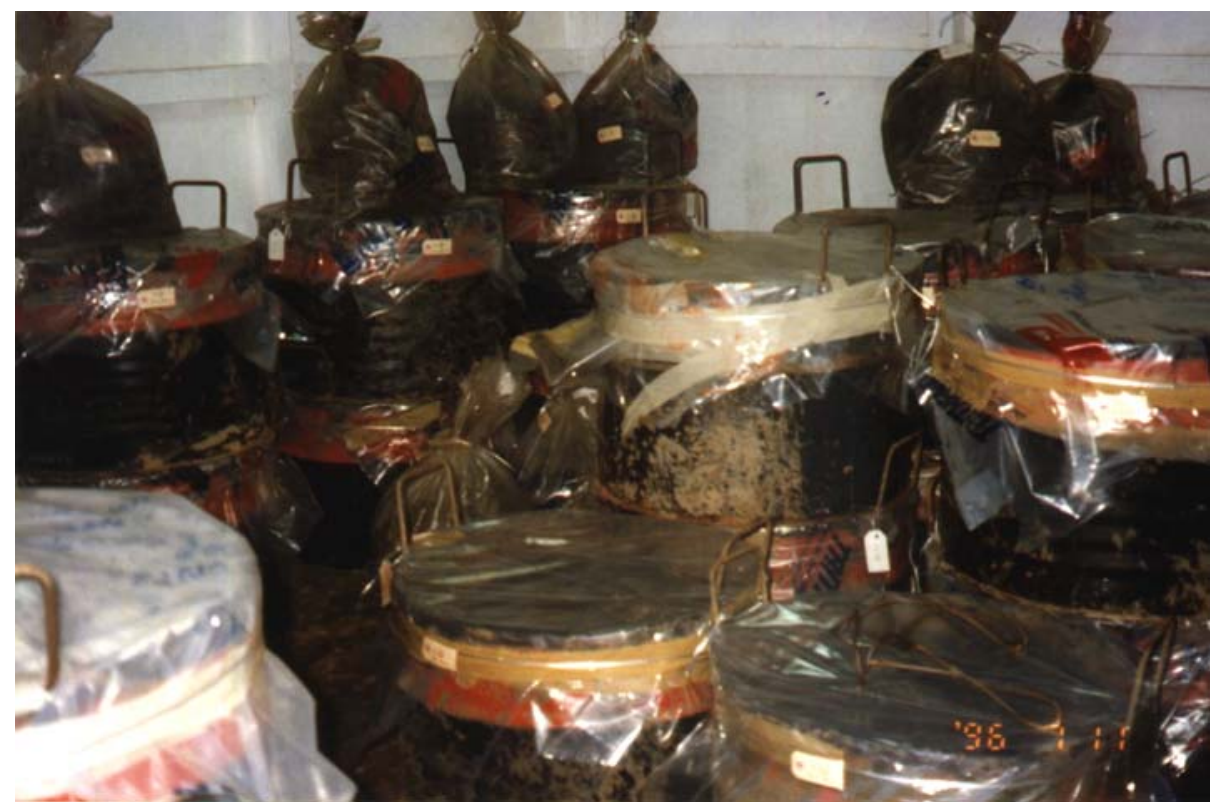

Figura 3.4 - Armazenamento das amostras de resíduo sólido urbano coletado em tambores metálicos devidamente lacrados.

Da tradagem T1 (na berma superior, distanciada a 8m do dreno de gás) coletaramse 13 amostras, sendo a primeira (T1-1) e a última (T1-13) bastante contaminadas com solo de cobertura das células. Inicialmente, mediu-se a temperatura em 3 pontos, durante a 
perfuração. Danos no termômetro, impediram a obtenção da temperatura com mais freqüência.

A tradagem T1 foi finalizada na profundidade de 29 metros, onde instalou-se um tubo de PVC (classe 15) com 3 polegadas e com ponta fechada para realização do ensaio cross-hole. A tradagem T2 foi finalizada na profundidade 32 metros e as amostras foram coletadas até 27 metros, a partir daí o resíduo apresentou-se totalmente saturado por líquido percolado impedindo a coleta. Esta tradagem foi inicialmente deslocada, pois na primeira tentativa de perfuração (próximo do pé do talude), já aos 5 metros de profundidade, o material apresentava-se totalmente saturado por líquido percolado impedindo a coleta .

Executaram-se, também, na berma de cima, próxima ao furo T1, uma tradagem extra sem coleta de material (T3), para instalação do tubo de PVC (classe 15, com 3") para realização do ensaio cross-hole, uma vez que seria difícil aproveitar o dreno de gás para tal.

As amostras foram devidamente acondicionadas em tambores e depois conduzidas ao laboratório de campo para execução de ensaios de caracterização físico-química (umidade natural, composição gravimétrica, distribuição do tamanho dos componentes, STV, DQO, pH, lixiviação e solubilização). Com estas amostras foram realizados também ensaios de resistência ao cisalhamento e compressibilidade para avaliação do comportamento mecânico do RSU.

\subsection{5 - Ensaio Cross-hole}

O ensaio cross-hole foi usado para estimar os parâmetros dinâmicos (módulo de deformação e de cisalhamento e coeficiente de Poisson's) do resíduo sólido urbano.

A técnica sísmica do cross-hole, ou transmissão direta entre furos, tem como principal objetivo a medida, em profundidade, das velocidades de propagação das ondas de compressão (p) e cisalhante (s) de um furo de sondagem equipado com um martelo, a outro equipado com um geofone (GIACHETI, 1991). Este ensaio encontra-se normalizado pela ASTM (D4428/ D4428M - 84). O equipamento utilizado é composto de sismógrafo registrador com sistema de gravação (marca Bison, modelo 1580-2), fonte mecânica geradora de ondas elásticas, geofones para captação das ondas.

As velocidades das ondas de compressão e cisalhante foram determinadas através da medida do tempo requerido para o impacto percorrer a massa de RSU e ser captado pelo geofone colocado a uma distância de 7,6 metros da fonte. Assim, a partir da obtenção das velocidades de propagação das ondas e do peso específico estimado para o resíduo foi possível determinar os módulos cisalhante e de deformabilidade segundo as formulações abaixo:

$$
\begin{aligned}
& \mathrm{G}=\mathrm{V}_{\mathrm{S}}^{2} \gamma \\
& \mathrm{E}=2 \mathrm{~V}_{\mathrm{S}}^{2} \gamma(1+v)
\end{aligned}
$$




$$
v=\frac{\left(\mathrm{V}_{\mathrm{p}}^{2}-2 \mathrm{~V}_{\mathrm{S}}^{2}\right)}{2\left(\mathrm{~V}_{\mathrm{p}}^{2}-\mathrm{V}_{\mathrm{S}}^{2}\right)}
$$

onde:

$\mathrm{G}=$ módulo cisalhante dinâmico (MPa)

$\mathrm{E}=$ módulo de deformabilidade dinâmico (MPa)

$v=$ coeficiente de Poisson

$\mathrm{V}_{\mathrm{s}}=$ velocidade de propagação da onda cisalhante $(\mathrm{m} / \mathrm{s})$

$\mathrm{V}_{\mathrm{p}}=$ velocidade de propagação da onda de compressão $(\mathrm{m} / \mathrm{s})$

$\gamma=$ peso específico $\left(\mathrm{kN} / \mathrm{m}^{3}\right)$.

Para a realização do ensaio cross-hole foi aproveitado um dos furos de tradagem utilizado para coleta de amostras e outro furo, distanciado deste de 7,6 metros, foi executado. Tubo de PVC de 3"(classe 15) com ponta fechada foi instalado no centro de cada furo e o espaço vazio preenchido com brita 2 .

O ensaio cross-hole foi executado pelo Instituto de Pesquisas Tecnológicas do Estado de São Paulo (IPT). Até a profundidade de 10m, o ensaio foi executado em camadas, ou seja geofone e martelo na mesma profundidade. A partir daí variaram-se as posições do geofone até 28 metros, mantendo-se o martelo fixo na profundidade de 10 metros, profundidade esta que corresponde ao tamanho máximo do cabo do martelo utilizado.

\subsection{6 - Ensaio de resistividade elétrica}

A técnica de caminhamento elétrico dipolo-dipolo (resistividade elétrica), executada utilizando um resistivímetro (marca Bison, modelo 2390 Signal Enhancement Earth Resistivity System) de corrente alternada máxima de $5 \mathrm{~Hz}$ e potência de saída de $500 \mathrm{~W}$, foi empregada numa seção do aterro Bandeirantes com o objetivo de mapear a presença de resíduos e líquidos percolados na área em estudo e de testar a eficiência dessa técnica em aterros altos. Essa técnica de caminhamento foi estudada por ELIS (1998).

"A técnica de caminhamento elétrico consiste em observar a variação lateral de resistividade a profundidades aproximadamente constantes. Isso é obtido fixando-se o espaçamento dos eletrodos e caminhando-se com os mesmos ao longo de perfis, efetuando as medidas de resistividade aparente. Com o dispositivo eletródico dipolo-dipolo, os eletrodos $A B$ de injeção de corrente e $M N$ de potencial são dispostos segundo um mesmo perfil e $o$ arranjo é definido pelos espaçamentos $X=A B=M N$. A profundidade de investigação cresce com o espaçamento (R), e teoricamente corresponde a R/2 (Figura 3.5), as medidas 
são efetuadas em várias profundidades de investigação, permitindo assim a construção de uma seção de resistividade aparente (ELIS \& ZUQUETTE 1996)".

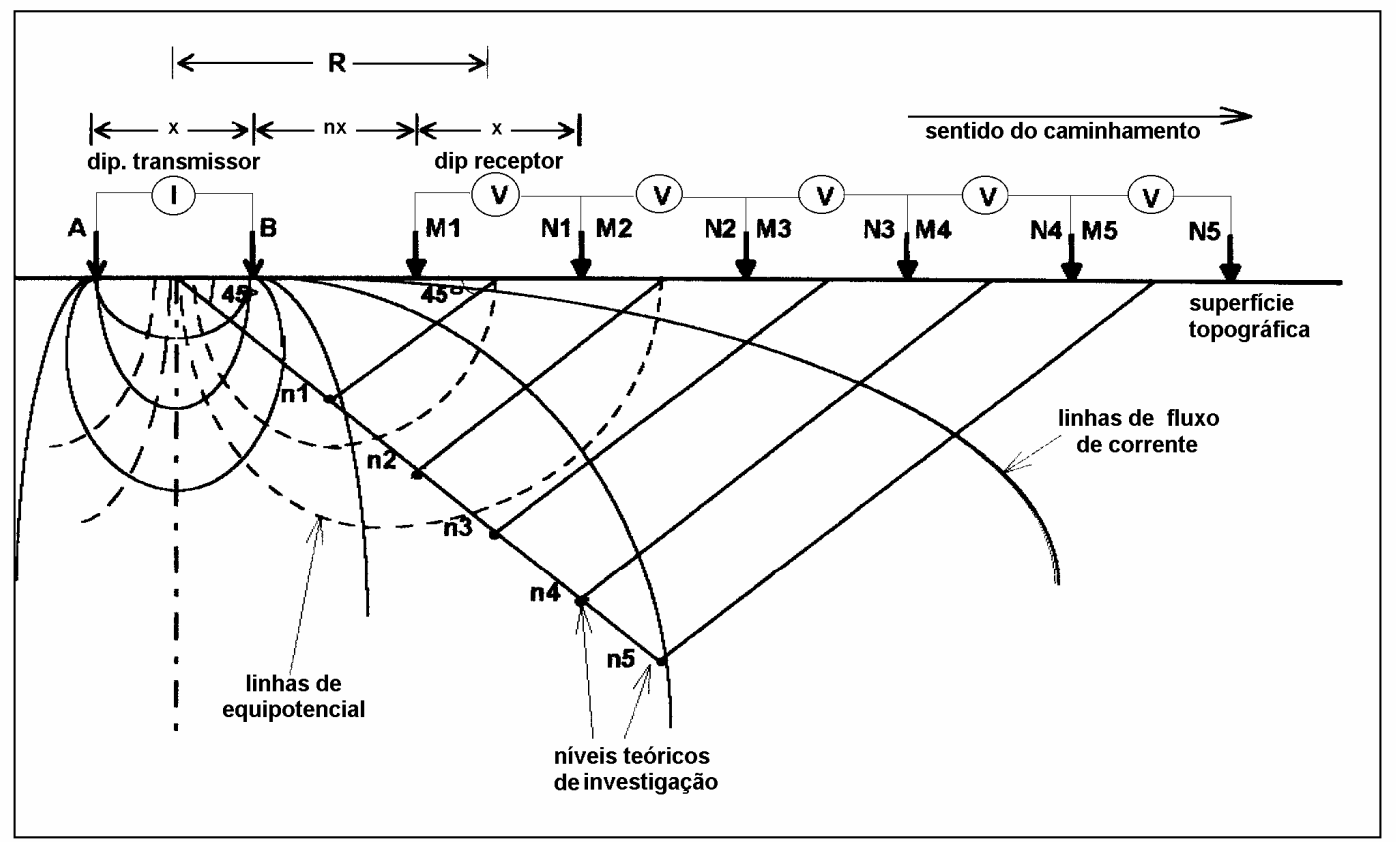

Figura 3.5 - Disposição no campo do arranjo dipolo-dipolo - técnica do caminhamento elétrico.

Ao passar uma corrente elétrica (I) através dos eletrodos A e B, e medir a diferença de potencial $(\Delta \mathrm{V})$ criada entre os eletrodos $\mathrm{M}$ e $\mathrm{N}$, obtém-se a resistividade através da fórmula:

$$
\rho=\mathrm{K} \frac{\Delta V}{\mathrm{I}}
$$

sendo $\mathrm{K}$, um fator geométrico que depende do espaçamento entre os quatro eletrodos e é calculado por:

$$
\mathrm{K}=\pi \frac{\mathrm{AM} \cdot \mathrm{AN}}{\mathrm{MN}}
$$

A resistividade ( $\rho$ ) pode ser definida como sendo a maior ou menor facilidade com que uma corrente elétrica se propaga por um material. Os valores de resistividade são afetados pela presença de água, pela natureza dos sais dissolvidos e pela porosidade total do meio. Maiores informações acerca deste ensaio poderão ser obtidas em ELIS (1998).

As investigações de caminhamento elétrico foram realizadas ao longo de uma seção transversal previamente estaqueada, com espaçamento constante de $40 \mathrm{~m}$, definido em função das profundidades de investigação requerida para abranger toda a espessura do 
resíduo em campo, no caso 120 metros. A seção levantada (setembro de 1997, no final do período de estiagem) atravessou toda a área onde se realizaram os ensaios de campo. Após a disposição do arranjo no aterro e fixados os níveis de investigações, obtiveram-se as leituras para a primeira estaca, daí deslocou-se todo o arranjo para a estaca seguinte e novamente foram tomadas as leituras. Este procedimento foi executado até atingir o final da seção a ser levantada. Os dados foram tratados com ajuda do software SURFE.

\section{3 - ENSAIOS DE CARACTERIZAÇÃO DOS RESÍDUOS COLETADOS}

Com intuito de caracterizar os resíduos sólidos urbanos amostrados, quanto a sua composição físico-química, foram realizados ensaios de:

- teor de umidade natural

- composição gravimétrica

- estimativa do tamanho das partículas

- DQO (demanda química de oxigênio)

- STV (sólidos totais voláteis)

- solubilização, lixiviação e pH

$\mathrm{Na}$ falta de normas específicas para realização de ensaios com resíduos sólidos urbanos, adotaram-se as normas vigentes para resíduos sólidos (NBR 10.004/87, NBR 10.005/87, NBR 10.006/87) e também a metodologia apresenta por GOMES (1989) no caso da determinação da demanda química de oxigênio e sólidos totais voláteis.

Os ensaios de caracterização física (teor de umidade, composição e tamanho dos componentes do resíduo) foram realizados no laboratório de campo no Aterro Sanitário Bandeirantes (SP). Já os ensaios de caracterização química (STV, pH, DQO, lixiviação e solubilização) foram realizados no laboratório de Hidráulica e Saneamento da USP de São Carlos.

\subsection{1 - Teor de umidade}

O resíduo sólido urbano é constituído por uma grande quantidade de componentes, tais como matéria orgânica, plásticos, papéis, metais, vidros, têxteis, madeiras, borrachas, etc. Cada um desses componentes pode apresentar maior ou menor capacidade de retenção de fluido em seus vazios, o que torna a umidade extremamente variável para cada constituinte. 
Neste contexto, determinou-se tanto a umidade global do RSU, constituído de todas as frações, como a umidade de cada componente resultante da segregação manual (composição gravimétrica).

As amostras destinadas à determinação da umidade in situ foram retiradas concomitantemente aos trabalhos de amostragem, separando-se uma porção de cerca de 7 a $8 \mathrm{~kg}$ de resíduo, descartando-se materiais de dimensões muito avantajadas. Esse resíduo foi colocado em saco plástico devidamente lacrado e encaminhado ao laboratório. Dessa amostra do resíduo, devidamente homogeneizada e quarteada, separaram-se três porções de mais ou menos $1000 \mathrm{~g}$ que foram mantidas em estufa a $70^{\circ} \mathrm{C}$, até que se observasse a constância de peso das mesmas.

Para a determinação da umidade de cada componente utilizaram-se as amostras resultantes do ensaio de composição obtidas da segregação manual de cada constituinte. A umidade foi obtida através da diferença de peso entre a fração úmida segregada e a fração seca em estufa a $70^{\circ} \mathrm{C}$ até a constância de peso.

\subsection{2 - Composição gravimétrica}

A composição dos resíduos coletados, a cada trecho de 2 metros, foi obtida por meio de ensaios de caracterização física, o qual consistiu na separação manual e quantificação de cada um dos constituintes do resíduo, dentre eles podemos destacar, papeis, plásticos, madeiras, metais, vidros, pedras, têxteis, borrachas e fração pastosa, a qual é constituída por uma mistura de matéria orgânica, solo e outros.

Inicialmente, cerca de $40 \mathrm{~kg}$ de cada amostra do resíduo, obtida durante o processo de amostragem e acondicionada em sacos plásticos, foi devidamente homogeneizada sobre uma laje de concreto com auxílio de pá e enxada, até a obtenção de uma massa visualmente uniforme. A partir daí, fez-se o quarteamento do material de forma a reduzir a quantidade inicialmente coletada para cerca de 6 a $8 \mathrm{~kg}$. O procedimento obedecido no quarteamento consistiu na separação do total em quatro partes de aproximadamente mesmo peso. Em seguida, desprezando duas partes vis a vis, as outras duas partes restantes eram então novamente misturadas e homogeneizadas para novo quarteamento. Esse processo foi repetido até obter-se a quantidade necessária para a realização do ensaio de composição.

Uma vez obtida a amostra de ensaio procedeu-se à separação manual de cada um dos componentes do resíduo, obedecendo os seguintes grupos (Figura 3.6):

- plásticos (inclui todos os tipos de materiais plásticos, tais como, sacos de lixo, sacolinhas, embalagens, etc)

- $\quad$ vidros (frascos e cacos de vidro) 
- metais (todas as sucatas de alumínio, ferro, aço, latas, pregos, moedas e outros)

- papéis (jornal, papelão, embalagens e outros)

- borrachas (tiras de chinelo e de pneu e outros)

- têxteis (tecido, trapo e couro)

- madeiras

- pedras

- fração pastosa (matéria orgânica, solos e outros materiais não possíveis de separação)

Para cada um desses componentes foram determinados os pesos e o teor de umidade (base seca e base úmida).

A determinação da composição física do resíduo sólido urbano bem como a montagem de corpos de prova para ensaios de laboratório, apesar de serem tarefas simples, que não necessitam de nenhum equipamento especial, foram as etapas mais trabalhosas desta pesquisa, necessitando grande dedicação e determinação por parte do pessoal nela envolvido.

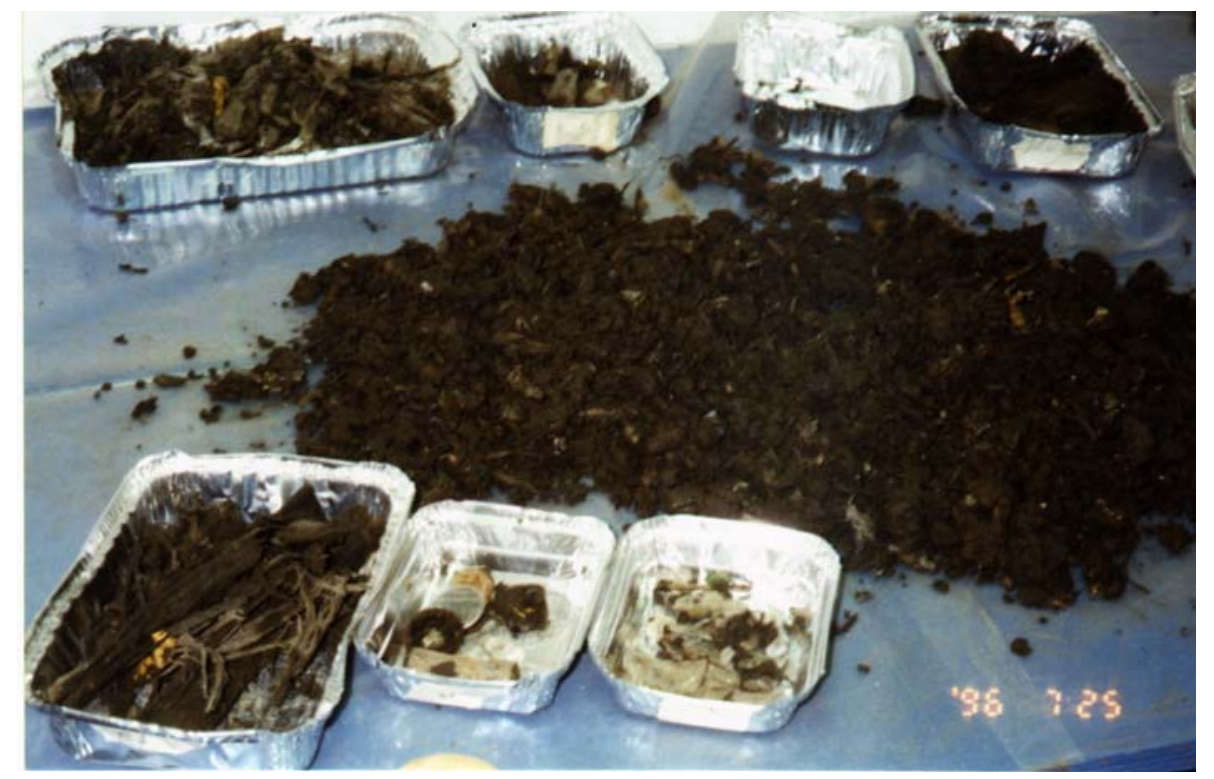

Figura 3.6 - Separação manual dos componentes do resíduo sólido urbano.

\subsection{3 - Tamanho e distribuição dos componentes dos resíduos}

Na tentativa de caracterizar o tamanho dos componentes do resíduo procedeu-se a passagem do resíduo seco (sob temperatura de $70^{\circ} \mathrm{C}$ ) através de uma série de peneiras pré-selecionadas (2", $1^{1 / 2}$ ", 1 ", 5/8", 3/8", 4,76mm, 2,0mm e $0,59 \mathrm{~mm}$ ) e a medida direta de componentes com dimensões maiores que 2". Assim, obteve-se a porcentagem das 
partículas que passa em cada peneira, possibilitando o traçado da curva representativa dos diâmetros dos componentes.

Para a realização desse ensaio utilizaram-se as amostras, secas em estufa, resultantes do ensaio de determinação da composição física. No processo de peneiramento, materiais como plásticos e têxteis que entrelaçavam-se nas malhas das peneiras foram excluídos. Esses materiais representam aproximadamente $20 \%$ em peso da amostra total. É importante frisar que materiais excessivamente grandes como algumas pedras, pedaços de madeira e metais foram inicialmente excluídos, no processo de quarteamento.

\subsection{4 - Sólidos totais voláteis - STV}

Os ensaios de caracterização química tais como sólidos totais voláteis, demanda química de oxigênio foram realizados com a fração pastosa triturada, resultante da segregação manual. $O$ processo de trituração constitui-se na passagem dessa pasta no liqüidificador, até a obtenção de um pó fino.

O ensaio consistiu na secagem de três porções de cada amostra da fração pastosa triturada, em estufa a $70^{\circ} \mathrm{C}$ por 1 hora e calcinação em mufla a $600^{\circ} \mathrm{C}$ por duas horas. $\mathrm{O}$ valor do STV é a diferença de pesos da amostra após secagem na estufa (material inerte + não inerte) e na mufla (material inerte). Assim o que queima na mufla é a matéria não inerte e a sobra (resíduo) é a matéria inerte (cinzas).

Segundo GOMES (1989) através da determinação dos sólidos totais voláteis (STV) determina-se a porcentagem de cinzas e a quantidade de matéria orgânica existente no resíduo. Portanto esse parâmetro pode ser um indicador da degradação do RSU ao longo do tempo. Um alto percentual de STV indica presença de muita matéria orgânica para ser degradada (RSU novo) e baixos valores indicam que o resíduo já passou por um acentuado processo de degradação.

\subsection{5 - Demanda química de oxigênio - DQO}

A análise de demanda química de oxigênio (DQO) mede a quantidade de matéria orgânica existente no RSU que pode ser oxidada quimicamente. Esse parâmetro é um indicador da degradação do resíduo ao longo do tempo, onde altos valores DQO são encontrados em resíduo fresco e baixos valores em resíduo que já passou por um considerável processo de degradação.

Empregou-se na execução desse ensaio, a metodologia apresentada por GOMES (1989) e exposta a seguir:

- tomar $1 \mathrm{~g}$ da fração pastosa triturada e seca em estufa $\left(70^{\circ} \mathrm{C}\right)$ 
- adicionar $5 \mathrm{~mL}$ de água destilada e adicionar $20 \mathrm{~mL}$ de ácido sulfúrico

- mexer com bastão de vidro até que a reação se esfrie

- colocar a mistura em um balão volumétrico de $250 \mathrm{ml}$ e completar o volume com água destilada

- filtrar a amostra, o extrato será colocado em contato com $20 \mathrm{ml}$ de dicromato de potássio (dependendo da coloração, deve diluir o extrato até que este fique com uma cor aproximadamente semelhante ao padrão de referência "branco").

- colocar a solução por 2 horas no digestor (marca Hach) à $150^{\circ} \mathrm{C}$ e, em seguida, fazer as leituras de DQO no espectrofotômetro de leitura direta DR/2000 (marca Hach).

\subsection{7 - Solubilização, lixiviação e pH}

A fim de que se possa efetuar a classificação do resíduo aterrado segundo a norma NBR 10.004/87 (Resíduos Sólidos - Classificação) foram executados os ensaios de lixiviação e de solubilização.

Os processos de lixiviação e solubilização são operações de separação de certas substâncias contidas no resíduo que permitem classificá-lo, quanto aos seus riscos potenciais ao meio ambiente e à saúde pública, em três classes, quais sejam:

- Resíduos Classe I - perigosos

- Resíduos Classe II - não inertes

- Resíduos Classe III- inertes

Resíduos Classe I: "são classificados como resíduos perigosos ou classe I, os resíduos sólidos ou misturas de resíduos que, em função de suas características de inflamabilidade, corrosividade, reatividade, toxicidade e patogenicidade, podem apresentar riscos à saúde pública, provocando ou contribuindo para um aumento de mortalidade ou incidência de doenças e/ou apresentar efeitos adversos ao meio ambiente, quando manuseado ou disposto de forma inadequada.

Os resíduos que submetidos ao ensaio de lixiviação (NBR 10005/87 - Lixiviação de Resíduos - Procedimento) apresentarem no extrato lixiviado teores de poluentes em concentração superior ao limite máximo dado na norma (listagem 7), são classificados como perigosos".

Resíduos Classe II: "são classificados como não inertes ou classe II, os resíduos ou misturas de resíduos sólidos que não se enquadram na classe I (perigosos) ou classe III (inertes). Estes resíduos podem ter propriedades tais como combustibilidade, biodegradabilidade ou solubilidade em água".

Resíduos Classe III: "são classificados como classe III ou resíduos inertes, os resíduos sólidos ou misturas de resíduos sólidos, que submetidos ao ensaio de 
solubilização (NBR10006/87 - Solubilização de resíduos - Procedimento) não tenham nenhum de seus componentes solubilizados, em concentrações superiores aos padrões definidos na norma (listagem 8)".

Os extratos solubilizados e lixiviados destinados à determinação da concentração de metais foram obtidos segundo os procedimentos das normas NBR 10.006/87 e NBR 10.005/87, respectivamente. Para a realização destes dois ensaios utilizaram-se a fração pastosa resultante do ensaio de composição gravimétrica. A seguir descrever-se-á, resumidamente, os procedimentos adotados para obtenção de cada extrato:

- Extrato solubilizado: tomou-se uma amostra de $250 \mathrm{~g}$ da fração pastosa (em base seca), adicionou-se $1000 \mathrm{~mL}$ de água destilada e agitou-se por 5 minutos utilizando um equipamento do tipo jar-test. Após 7 dias em contato, o extrato foi filtrado, acidificado ( $\mathrm{pH} \pm$ 2) e preservado para determinação dos metais.

- Extrato lixiviado: tomou-se $100 \mathrm{~g}$ da fração pastosa (massa seca), adicionou-se 1600ml de água destilada (16:1). Após agitação por cinco minutos, mediu-se o pH e foi ajustando-o para um valor de 5,0 0,2 mediante adição de ácido acético $0,5 \mathrm{~N}$. A mistura foi agitada por um período mínimo de 24 horas, durante o qual corrigiu-se o $\mathrm{pH}$. Se no final da agitação, a quantidade de ácido acético acrescentado for inferior a $400 \mathrm{ml}$, acrescentar à solução, o valor correspondente de água destilada que complete os $400 \mathrm{ml}$. O extrato foi então filtrado e acidificado para posterior análise química de verificação da periculosidade do resíduo. É importante acrescentar que a utilização de ácido acético é para simular as condições presentes num aterro sanitário de resíduo sólido urbano.

Após a obtenção dos extratos lixiviados e solubilizados prosseguiram-se as análises de metais utilizando um espectrofotômetro de absorção atômica (AA - 1275) com lâmpadas de cátodo oco.

As determinações do $\mathrm{pH}$ foram obtidas por meio de um potenciômetro Orion (modelo 310) usando eletrodo combinado. Para essas medidas utilizaram-se as mesmas amostras do ensaio de lixiviação.

\section{4 - PREPARAÇÃO DE AMOSTRAS REPRESENTATIVAS}

\subsection{1 - Critério de escolha}

Em virtude da grande quantidade de material resultante da coleta em sub -trechos de aproximadamente 2 em 2 metros ao longo das tradagens, optaram-se por preparar amostras representativas do total para a realização dos ensaios de laboratório (resistência ao cisalhamento e compressibilidade).

Com base na caracterização físico-química de todas as amostras coletadas, procurou-se separar amostras semelhantes no que se refere a curva de tamanho dos 
componentes, uma vez que os outros parâmetros como DQO (demanda química de oxigênio), STV (sólidos totais voláteis) não apresentaram nenhuma tendência de variação em função de fatores como profundidade e extratos de aterramento.

Algumas amostras, apesar de possuírem curvas de tamanho dos componentes semelhantes, foram excluídas por apresentarem grande quantidade de solo proveniente das coberturas das camadas de RSU.

Além disso, identificou-se no campo a existência de dois horizontes, onde os materiais aparecem com características de degradação diferenciada, sendo o primeiro horizonte de $0-18 \mathrm{~m}$, constituído de materiais visualmente menos degradados, com presença de grandes embalagens e sacos plásticos. O segundo horizonte de $18-30 \mathrm{~m}$, constituído por um resíduo visualmente mais degradado, de cor escura e odor forte. Essa diferenciação não foi possível de ser detectada na caracterização físico-química. A partir das observações efetuadas em campo e supondo ser a degradação um fator potencial na influência do comportamento mecânico do resíduo sólido urbano aterrado, optaram-se por misturar apenas amostras com curvas "granulométricas" semelhantes e que pertencesse ao mesmo horizonte.

\subsection{2 - Misturas}

As amostras representativas constituem-se de misturas de amostras semelhantes no que se refere a curva de tamanho dos componentes e identificação visual de degradação. Assim, foi possível compor 4 amostras representativas, sendo:

T1A: (horizonte superficial e menos degradado): constituída das misturas das amostras T1-2, T1-3, T1 - 6 e T1-7

T1B: (horizonte profundo e mais degradado): constituída das misturas das amostras T1-9, T1-10 e T1-11

T2A: (horizonte superficial e menos degradado): constituída das misturas das amostras T2-2, T2-3, T2-4 e T2-5

T2B: (horizonte profundo e mais degradado): constituída das misturas das amostras T2-7, T2-8, e T2-9

As nomenclaturas T1 e T2 são referentes às tradagens 1 e 2, A, refere-se ao horizonte mais superficial, entre 0-18 metros e B, ao horizonte mais profundo, entre 18-30 metros.

$\mathrm{Na}$ Figura 3.7 pode-se observar diferenças visuais de degradação entre os dois horizontes A e B, para as amostras da tradagem T2 (T2A e T2B) e na Figura 3.8 apresentase uma vista da amostra representativa T1B. Na Figura 3.7 observa-se que o material da amostra T2A, aparentemente, apresenta-se com uma massa mais heterogênea e com maior 
quantidade de plásticos, já a amostra T2B, apresenta-se mais homogênea e com partículas com menores dimensões.

No laboratório de campo, foi feita a mistura e homogeneização das amostras selecionadas. A homogeneização foi feita exaustivamente por processo manual, utilizandose enxada e lona plástica. As amostras representativas foram colocadas em tambores metálicos devidamente fechados e armazenadas no laboratório de campo (Aterro Bandeirantes) para futuro envio para o laboratório de geotecnia da EESC/USP, onde foram ensaiadas.
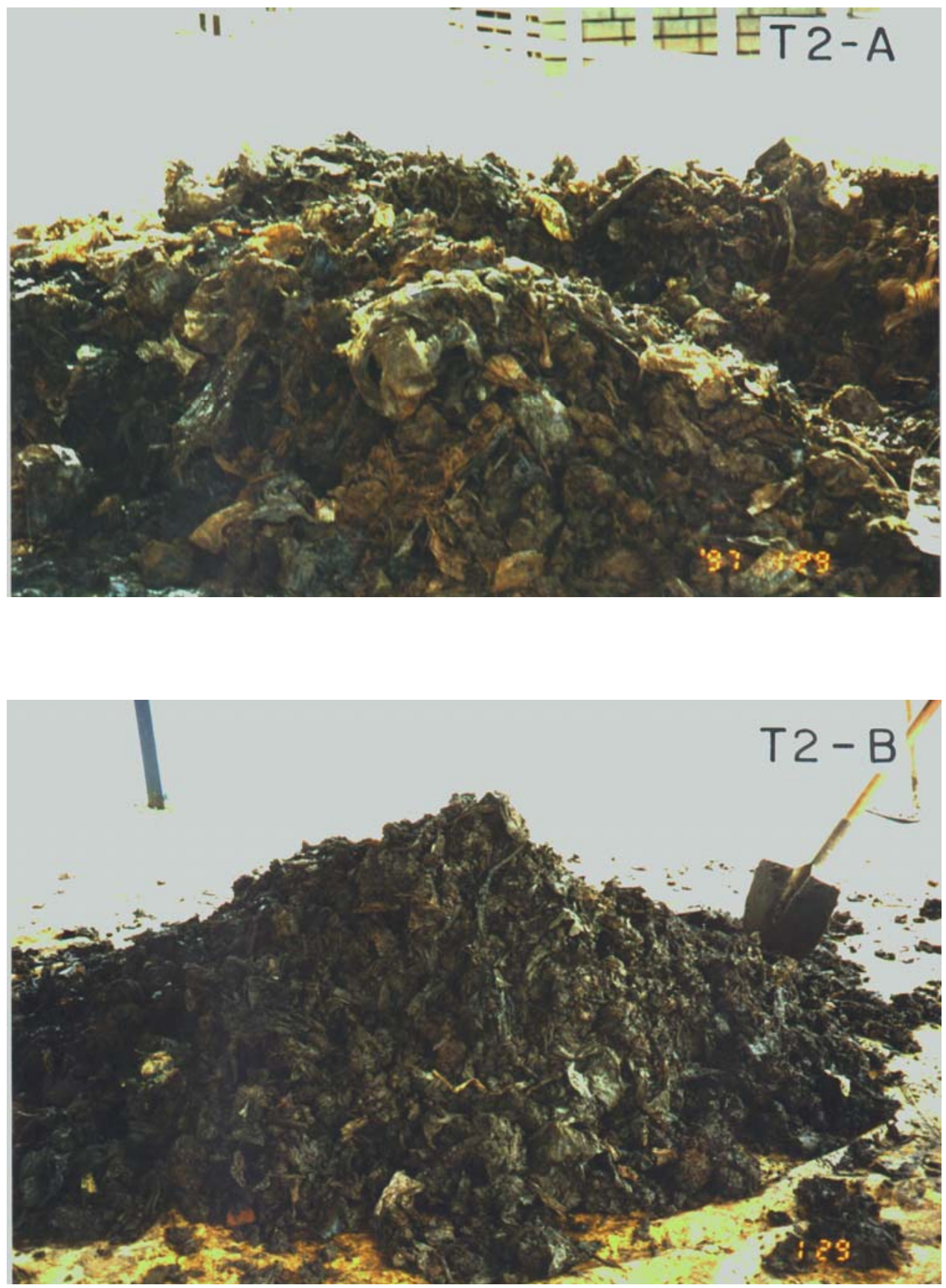

Figura 3.7 - Detalhes das amostras da tradagem T2, representativas do horizonte $A$ (T2A) e do horizonte $B$ (T2B). 


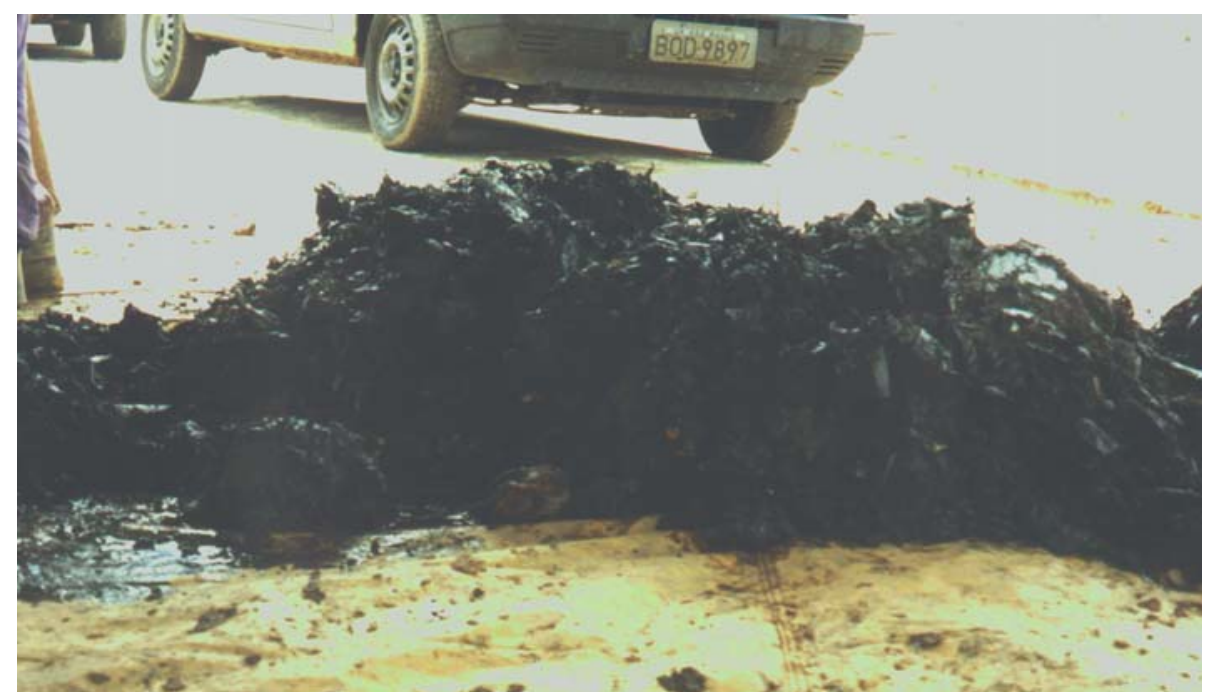

Figura 3.8 - Detalhes da amostra da tradagem T1, representativa do horizonte $B$ (T1B).

\subsection{3 - Determinação do peso específico das partículas para as amostras representativas}

Para determinação dos índices físicos das amostras representativas, houve necessidade de determinar o peso específico médio das partículas sólidas de cada amostra. Para isso, tomaram-se cerca de $800 \mathrm{~g}$ de resíduo devidamente quarteado e executou-se o ensaio de determinação do peso específico das partículas sólidas utilizando a norma empregada para solo (NBR 6508/84), substituindo apenas o picnômetro por um becker de 2 litros, devidamente calibrado para um intervalo de temperatura de 15 a $40^{\circ} \mathrm{C}$. Foram feitas várias determinações adotando-se os valores médios.

\section{5. - ENSAIOS TRIAXIAIS}

\subsection{1 - Aparelhagem utilizada}

Para que fosse possível a realização de ensaios triaxiais em amostras de RSU houve a necessidade de construir equipamentos com grandes dimensões que permitissem executar ensaios em que as dimensões dos componentes pudessem estar melhor representadas. O tamanho dos corpos de prova utilizados na realização de ensaios em materiais heterogêneos, deformáveis e com presença de partículas de grandes dimensões, como no caso do RSU, desempenha um papel fundamental. 
Na Figura 3.9 é mostrada a câmara de compressão triaxial construída para a realização de ensaios em amostras de grandes dimensões, com diâmetros de 150 e 200 $\mathrm{mm}$ e alturas de 300 e 400mm. O corpo da câmara é constituído de tubo RPVC com diâmetro de 300mm e capacidade de suporte 1MPa de pressão. A base, o topo da câmara e os cabeçotes dos corpos de prova são constituídos de duralumínio, sendo o pistão de aço inoxidável. A vedação entre o pistão e o topo da câmara foi obtida por intermédio do uso de o'rings. O conjunto possui uma altura de $700 \mathrm{~mm}$ e um diâmetro externo de $400 \mathrm{~mm}$, de modo que esta possa ser usada em uma prensa, existente no laboratório de geotecnia, da Wykeham Farrance, modelo WF 11.000, com capacidade de no máximo 10 toneladas. Também foram construídos moldes para compactação dos corpos de prova, dispositivos que permitem colocar a membrana de revestimento no corpo de prova e testar as membranas quanto à presença de furos e também pedras porosas para o topo e a base da câmara. Na Figura 3.9 pode-se observar detalhes desses dispositivos. No topo do cabeçote foi adaptado um guia de bronze para o pistão, permitindo a centralização do mesmo no início do ensaio. A centralização e o ajuste do pistão ficava comprometida em virtude do corpo da câmara ser constituído por um tubo de RPVC não transparente.

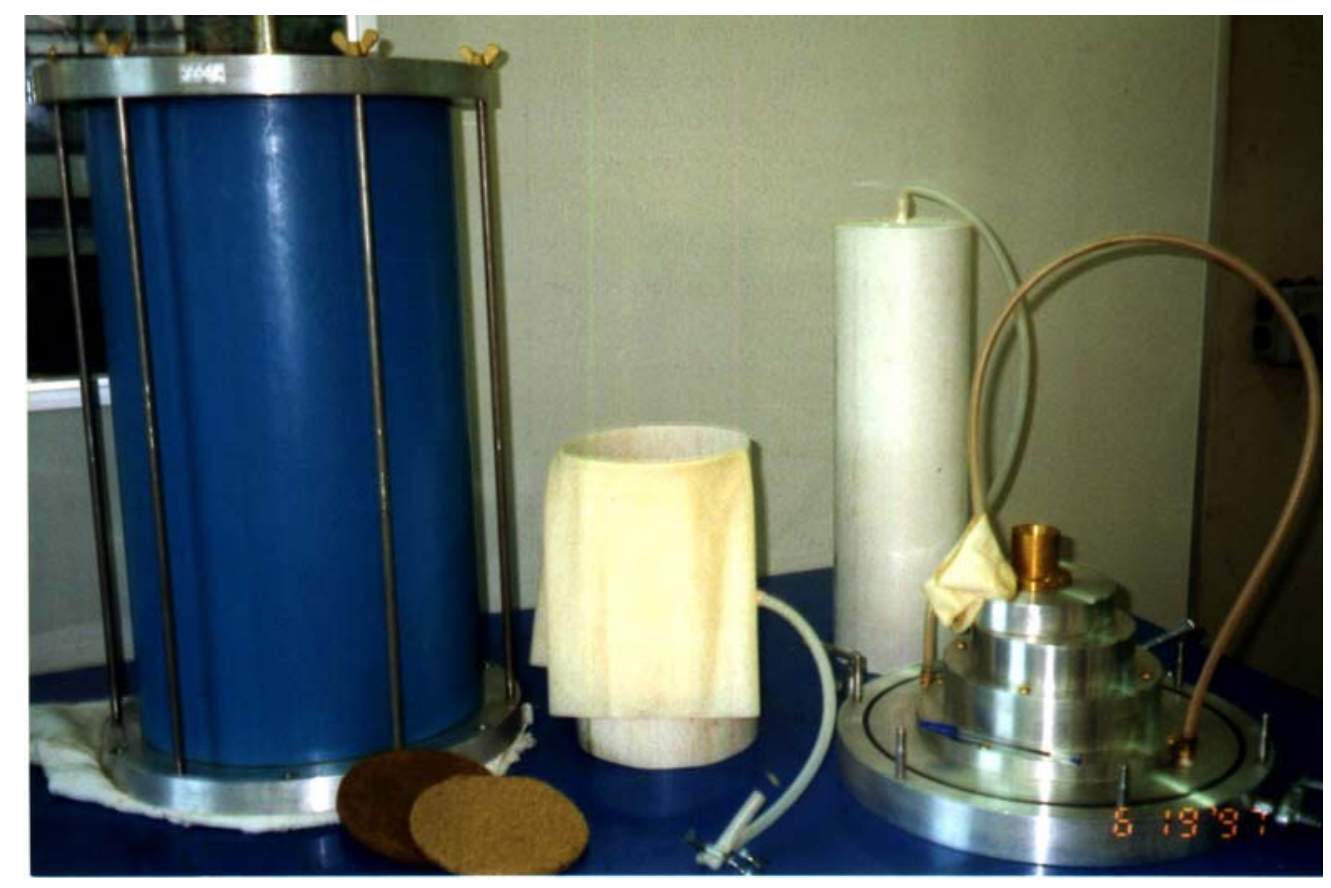

Figura 3.9 - Câmara triaxial desenvolvida para a realização de ensaios triaxiais em grandes amostras (150 e 200mm de diâmetro), pedras porosas, colocador de membrana.

Após a confecção da câmara triaxial foram realizados testes para a averiguação de sua deformabilidade (variação volumétrica com as pressões aplicadas) e estanqueidade. 
A deformabilidade foi avaliada submetendo-se a câmara preenchida com água, à vários estágios de pressão e medindo-se a variação de volume ocorrida. Na Figura 3.10 são mostrados os resultados obtidos, tanto no sentido de aplicação como alívio de pressão. Obtiveram-se uma constante de variação volumétrica de $0,56 \mathrm{~cm}^{3} / \mathrm{kPa}$, valor considerado pequeno frente às dimensões das amostras a serem utilizadas nos ensaios (12 litros para o corpo de prova de $20 \times 40 \mathrm{~cm}$ e 7 litros para o corpo de prova de $15 \times 30 \mathrm{~cm}$ ).

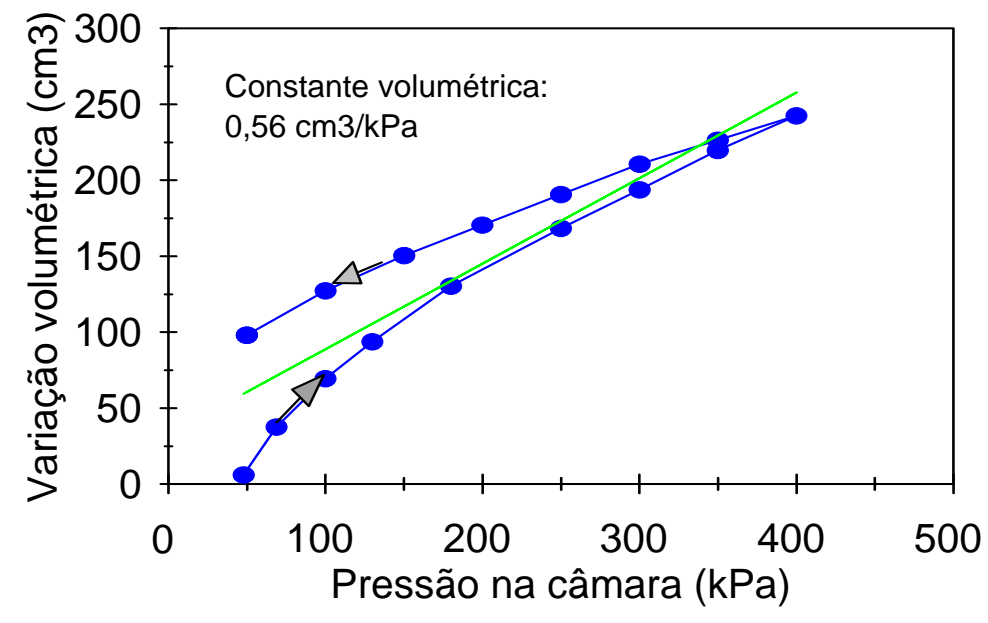

\section{- Pontos medidos - Regressão}

Figura 3.10 - Avaliação da deformabilidade da câmara triaxial construída.

Quanto à estanqueidade à água, o equipamento quando testado à pressões na água de até $800 \mathrm{kPa}$, não apresentou vazamentos. Para avaliar a estanqueidade da base e conexões, a mesma foi imergida em água, sendo então injetado ar comprimido em seu interior, verificando-se a ocorrência ou não de bolhas de ar, em função de eventuais vazamentos.

Em virtude da grande deformabilidade do corpo de prova de RSU, os medidores de variação de volume, existente no laboratório, com capacidade máxima de $80 \mathrm{~cm}^{3}$ apresentavam dificuldades operacionais durante a execução do ensaio, uma vez que várias reversões deveriam ser feitas para medidas das deformações volumétricas dos corpos de prova. Face a essa dificuldade, houve necessidade de se construir um medidor com maior capacidade de medida, no caso com $500 \mathrm{~cm}^{3}$.

O medidor de variação de volume construído é constituído de duralumínio e possui uma altura interna útil de $50 \mathrm{~mm}$ e diâmetro interno de $11,284 \mathrm{~cm}$, o qual fornece uma área exata de $100 \mathrm{~cm}^{2}$ e volume de $500 \mathrm{~cm}^{3}$. Foi calibrado um transdutor de deslocamento (modelo WF) para monitorar os deslocamentos que, multiplicados pela constante de 
calibração do medidor de volume (constante 0,1 ) fornecem a variação volumétrica do corpo de prova. A Figura 3.11 mostra o medidor de volume construído.

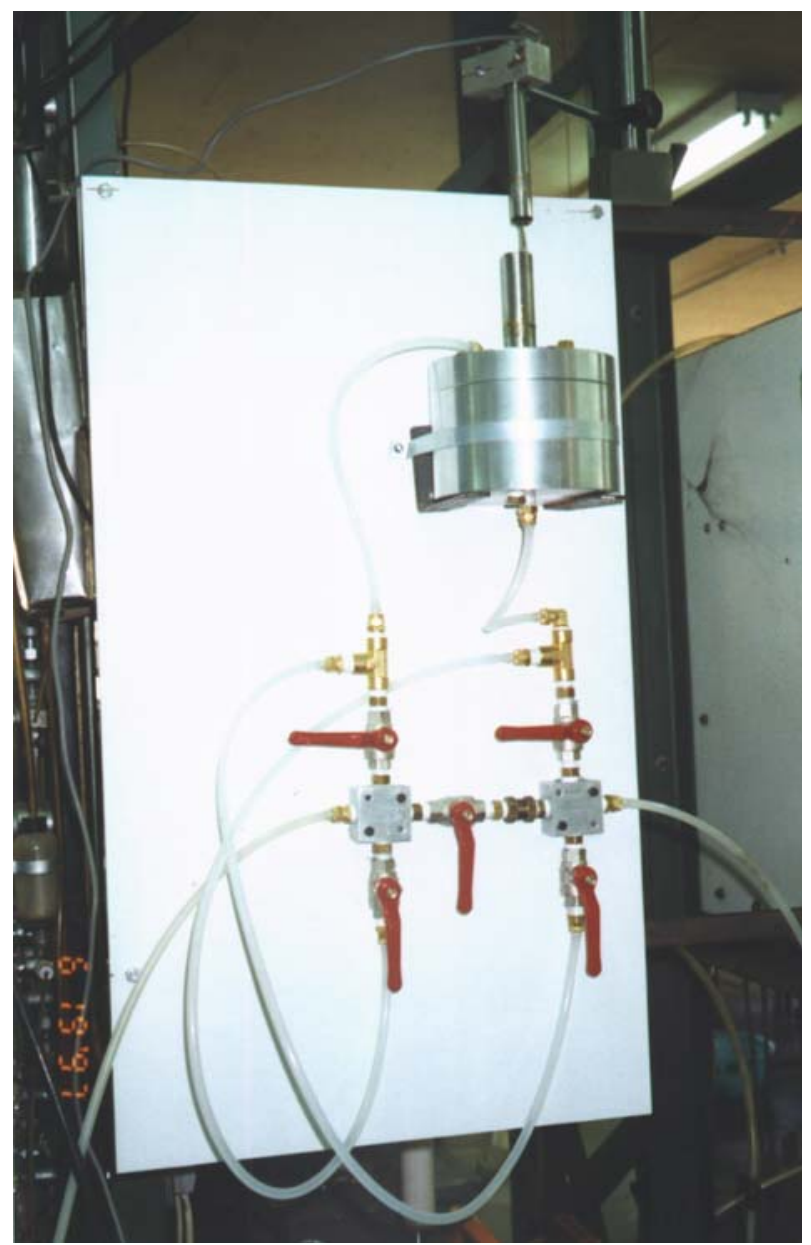

Figura 3.11 - Equipamento construído para medida de variação de volume durante a realização de ensaios triaxiais.

Os dispositivos de canecas de mercúrio para aplicação da pressão de confinamento e contra pressão não garantiam o funcionamento do sistema sem interrupções, uma vez que mediante as grandes variações de volume sofridas pelo corpo de prova seriam necessárias manobras de encher, repetidas vezes, as canecas de mercúrio durante o ensaio. Assim foi elaborado um sistema de interface ar-água para aplicação da pressão (Figura 3.12).

As interfaces de pressão ar-água foram elaboradas aproveitando-se duas câmaras triaxiais sobressalentes, existentes no Laboratório de Geotecnia. Na base de cada câmara foi instalada uma interface de borracha, de modo que a pressão de ar comprimido aplicada na base das câmaras pôde ser transmitida à água utilizada na aplicação das pressões de confinamento e contra-pressão. Devido à grande deformabilidade da interface de borracha, 
as pressões na água podem ser mantidas, mesmo com grandes variações volumétricas do corpo de prova.

No sistema de aplicação da pressão de confinamento, à medida que se comprime o corpo de prova, a interface de borracha vai abrindo, ou melhor enchendo de ar, devido ao deslocamento de água do sistema de pressão para a câmara de ensaio. Daí há a necessidade de esvaziar a interface, mas sempre com as torneiras de saída da câmara fechadas. Já no sistema de aplicação de contra pressão, a interface deve permanecer aberta ou seja cheia de ar, para que a água drenada do corpo de prova comprime a interface fazendo-a reduzir de volume para reservar o líquido drenado.

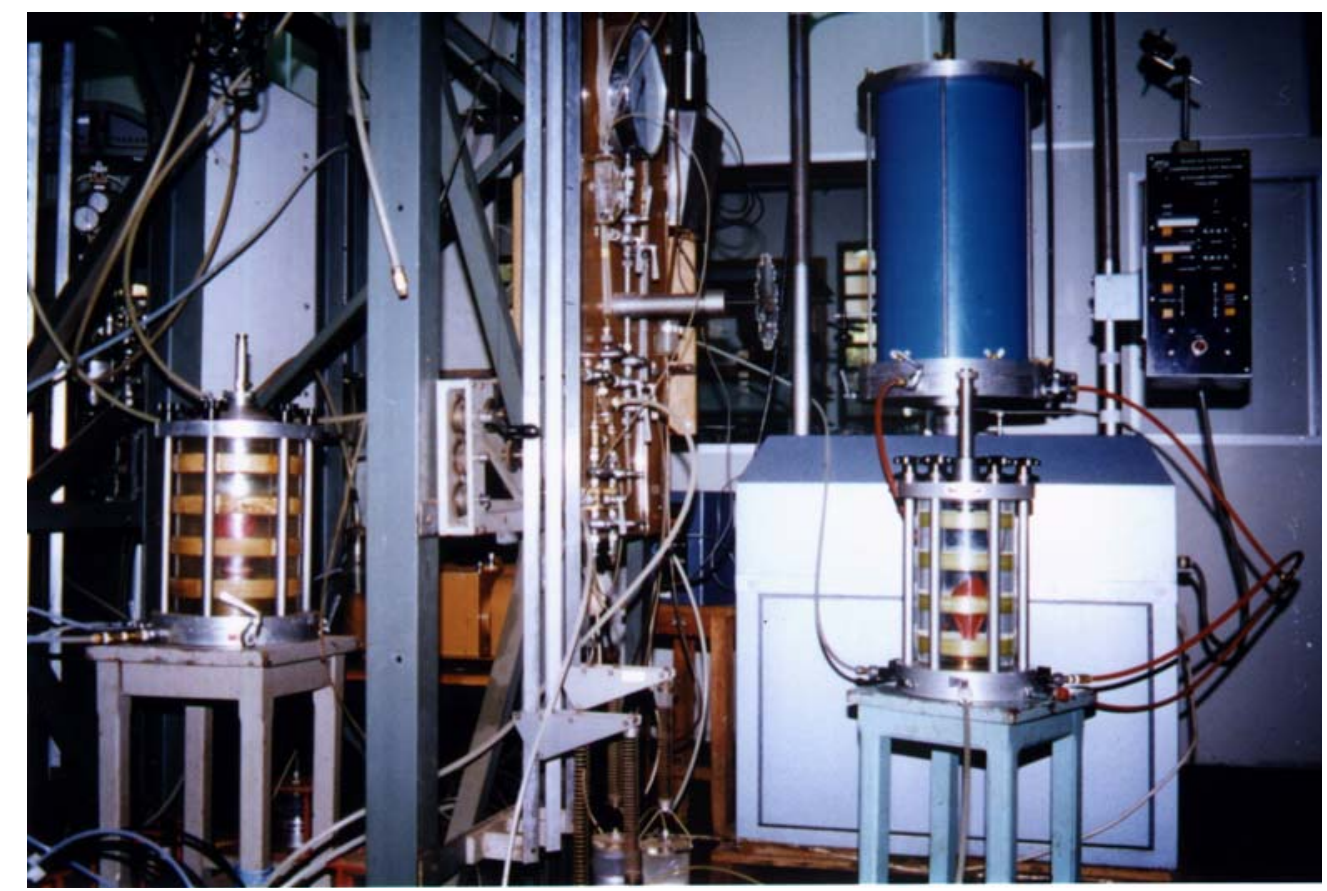

Figura 3.12 - Sistema de interface ar-água de aplicação de pressão.

Para a medida dos principais parâmetros de ensaio foram utilizados:

- uma célula de carga (já existente) com capacidade de 5 toneladas para medidas das tensões desviatórias;

- um transdutor de pressão (modelo WF 17021) da Wykeham Farrance com capacidade máxima de leitura de $1700 \mathrm{kPa}$, para medida das pressões desenvolvidas;

- um medidor de variação de volume, com capacidade de medida de $500 \mathrm{~cm}^{3}$ e resolução de $0,5 \mathrm{~cm}^{3}$, acoplado a um sistema de reversão (desenvolvido como parte integrante deste projeto de pesquisa). As variações volumétricas foram controladas por meio de um transdutor de deslocamento posicionado na parte superior do êmbolo do medidor de variação de volume. As medidas de variação de volume foram realizadas com base na quantidade de água entrando ou 
saindo da câmara triaxial levando em conta a curva de calibração da câmara triaxial, volume deslocado pela entrada do pistão durante a fase de cisalhamento;

- dois extensômetros com curso de $50 \mathrm{~mm}$ foram usados para medida do deslocamento axial. Os extensômetros eram instalados na estrutura da prensa e na base da câmara e quando o curso de um deles estava próximo do fim, o outro era imediatamente posicionado para obtenção das leituras.

O monitoramento das medidas fornecidas pelos transdutores e célula de carga foi realizado por meio de um indicador de medida, de fabricação da Wykeham Farrance com quatro canais para leituras simultâneas. Essas medidas foram realizadas de forma manual uma vez que operações de esvaziamento da interface água-ar bem como a reversão do sentido de fluxo do medidor de variação de volume, necessárias durante a realização dos ensaios, não eram previstas pelo programa de aquisição de dados. Todos esses instrumentos foram devidamente calibrados sob tensões compatíveis às que foram aplicadas nos ensaios.

\subsection{2 - Ensaios triaxiais executados}

Para avaliação da resistência ao cisalhamento do resíduo foram realizados ensaios triaxiais convencionais, do tipo consolidados drenados (CD) e consolidados não drenados (CU), em amostras deformadas saturadas e não saturadas. Esses ensaios foram realizados com as amostras deformadas representativas do resíduo coletado, T1B, T2A e T2B (ver item 3.4). $A$ amostra $T 1 A$, que apresenta constituição semelhante à amostra $T 2 A$ com materiais menos degradados, não foi ensaiada pois o comportamento desse horizonte foi bem investigado por um razoável número de ensaios executados para a amostra T2A. Foram adotadas algumas variações no peso específico e condições de saturação das amostras compactadas bem como variações nas dimensões dos corpos de prova com o objetivo de avaliar a influência desses parâmetros na resistência ao cisalhamento do resíduo. Foram ensaiados corpos de prova com 150mm de diâmetro e $300 \mathrm{~mm}$ de altura e corpos de prova com $200 \mathrm{~mm}$ de diâmetro e $400 \mathrm{~mm}$ de altura. Para a amostra T2A, compactaram-se corpos de prova com peso específico de 10, 12 e $14 \mathrm{kN} / \mathrm{m}^{3}$. Para as demais amostras, o peso específico de $12 \mathrm{kN} / \mathrm{m}^{3}$ foi escolhido, primeiro por produzir corpos de prova mais estáveis e segundo, pela maior facilidade de compactação e manuseio.

O fluxograma apresentado na Figura 3.13 mostra todas as situações adotadas para a execução dos ensaios triaxiais. 


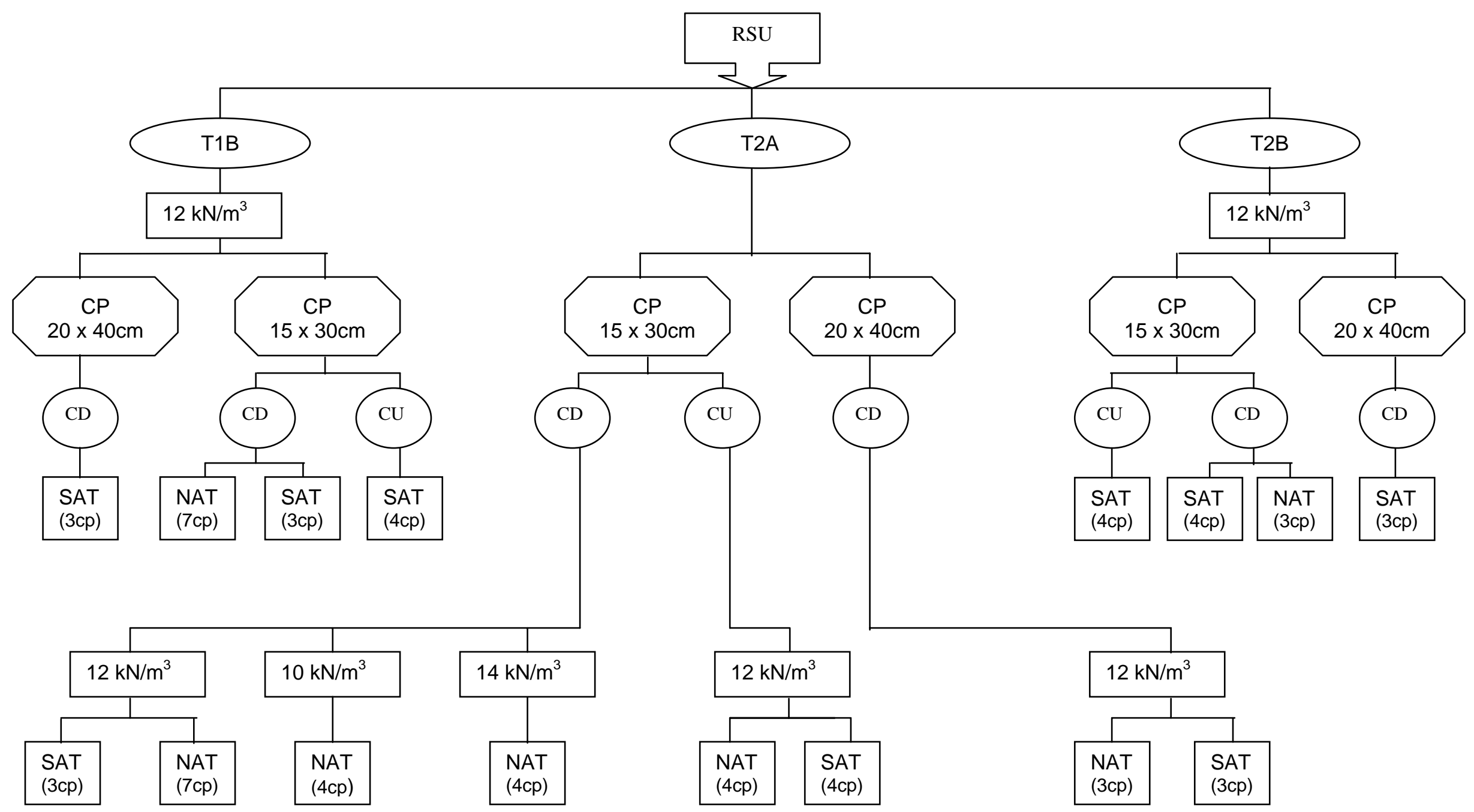

Figura 3.13 - Fluxograma dos ensaios de compressão triaxial executados. 
No total, foram realizados 47 ensaios triaxiais consolidados drenados (CD) e 16 ensaios consolidados não drenados (CU) com medida de pressão neutra. Dos ensaios $C D$ realizados, 28 são com amostras na condição de umidade de moldagem (nat) e 19 com amostras saturadas (sat). Dos ensaios CD, na condição de umidade de moldagem, quatro ensaios foram executados sob as mesmas condições (mesma amostra e pressão de confinamento) para verificação da reprodutibilidade dos resultados obtidos e três foram executados para determinação do módulo de deformabilidade. A maioria dos ensaios CU foram executados na condição saturada.

Além desses ensaios, foram também executados 9 ensaios consolidados drenados, com amostra da matriz do resíduo na condição saturada. A matriz foi obtida excluindo, manualmente, do resíduo todos os materiais plásticos, têxteis e componentes com dimensões superiores a $20 \mathrm{~mm}$. Foram utilizados corpos de prova de $100 \mathrm{~mm}$ de diâmetro por $200 \mathrm{~mm}$ de altura, compactados estaticamente com pesos específicos de $16 \mathrm{kN} / \mathrm{m}^{3}$. Esses ensaios foram realizados com objetivo de avaliar a resistência do material sem o reforço dado pelos materiais plásticos e têxteis.

Todos os corpos de prova utilizados na realização dos ensaios triaxiais foram compactados estaticamente, em 5 camadas $(6 \mathrm{~cm}$ de espessura para corpo de prova de $30 \mathrm{~cm}$ e $8 \mathrm{~cm}$ para o de $40 \mathrm{~cm}$ ) com o auxílio de uma prensa hidráulica, a qual permitiu aplicar um esforço uniforme necessário para a compactação. As amostras foram compactadas dentro de membranas de látex e protegidas por um tubo de PVC, possuindo uma geratriz secionada de modo a permitir sua instalação e retirada sem causar danos nos corpos de prova. O tubo de PVC era ajustado por braçadeiras e era usado um tarugo de madeira revestida com um filme plástico para apoiar o corpo de prova. Também era colocado no topo do corpo de prova outro tarugo de madeira com um peso para evitar qualquer expansão da amostra. Alguns materiais e plásticos muito grandes em relação às dimensões dos corpos de prova foram excluídos durante o processo de compactação.

Os corpos de prova de uma mesma série de ensaio foram compactados juntos e armazenados em local adequado até serem ensaiados.

Os corpos de prova de amostras com menor umidade, como a T2A, foram extremamente difíceis de serem compactados, pois após a retirada do esforço aplicado, os corpos de prova aumentavam de volume. A amostra T2A foi utilizada na umidade natural. Por outro lado, as amostras T1B e T2B, para serem manuseadas, foram colocadas ao ar livre sobre uma lona plástica, para perda de umidade. Esses materiais, mesmo depois da coleta, apresentaram geração de grande quantidade de líquido e odor extremamente desagradável. As amostras compactadas com peso específico de $10 \mathrm{kN} / \mathrm{m}^{3}$ resultavam em corpos de prova pouco estáveis e com várias depressões, dificultando o manuseio. As amostras compactadas com peso específico de 12,14 e $16 \mathrm{kN} / \mathrm{m}^{3}$ produziam corpos de prova mais estáveis e de melhor qualidade (Figura 3.14), porém para esses dois últimos era necessário um maior esforço na compactação. Os corpos de prova compactados com $14 \mathrm{e}$ 
$16 \mathrm{kN} / \mathrm{m}^{3}$, durante o processo de compactação, perdiam grande quantidade de líquido, ficando com densidade final inferior ao valor estipulado.

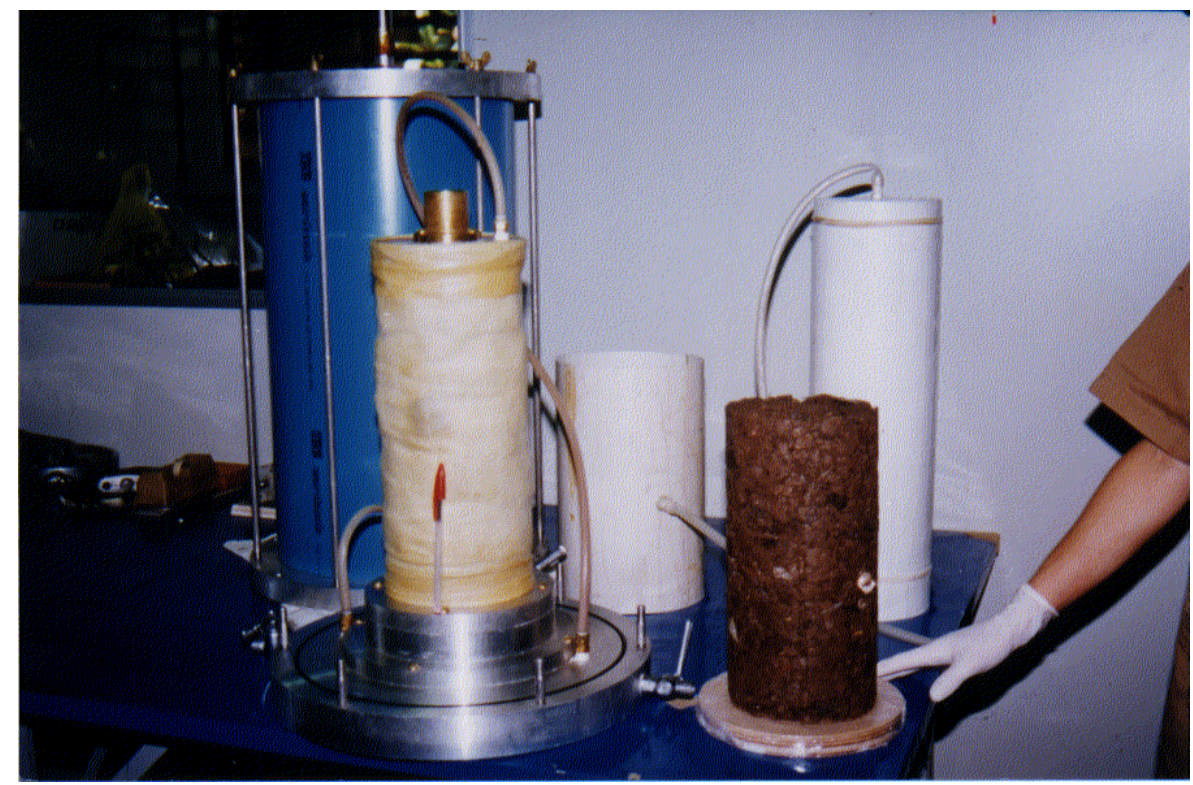

Figura 3.14 - Vista de corpos de prova a ser ensaiados, com e sem membrana de revestimento, bem como dispositivos para colocação da membrana, base e corpo da câmara.

Os corpos de prova de RSU foram consolidados, em geral, com pressões de confinamento efetiva de 100, 200 e $400 \mathrm{kPa}$. A pressão de confinamento foi aplicada em estágios de $50 \mathrm{kPa}$, pois, devido à grande compressão da amostra no início do confinamento, foram necessárias constantes operações de drenagem do ar da interface de aplicação de pressão na câmara.

A velocidade de cisalhamento adotada foi $0,7 \mathrm{~mm} / \mathrm{min}$. Este valor é inferior aos calculados tendo-se como base os valores $t_{90}$ obtidos durante a fase de adensamento das amostras, utilizando-se o procedimento proposto por HEAD (1984). A velocidade de cisalhamento adotada foi um pouco inferior a empregada por JESSBERGER \& KOCKEL (1993) para ensaios triaxiais com resíduos sólidos da Alemanha (1 $\mathrm{mm} / \mathrm{min})$.

No caso dos ensaios realizados com amostras saturadas, a saturação foi obtida por percolação de água de torneira da base para o topo da amostra e por aplicação de contra pressão. Devido às grandes dimensões dos corpos de prova utilizaram-se água da rede de abastecimento para a percolação da amostra, cuja pressão de saída era em torno de $70 \mathrm{kPa}$. Anteriormente à percolação de água através da amostra, foi aplicado uma pressão na câmara de $80 \mathrm{kPa}$ com as torneiras de drenagens fechadas. Em seguida, permitia-se a percolação de água da base para o topo, por um bom tempo, normalmente até que não se observasse mais bolhas de ar na saída. Em seguida, a torneira do topo era fechada, 
mantendo-se aberta a entrada de água pela base da câmara. Esse estágio, em geral, era mantido de um dia para outro (período da noite). No dia seguinte, aplicava-se a contra pressão e fazia-se as medidas do parâmetro B de Skempton. Obtiveram-se valores de B variáveis entre 0,84 a 0,98.

Alguns problemas ocorreram durante a execução dos ensaios, como perfurações nas membranas de látex, excentricidade e entortamento do pistão de aplicação de carga, perfurações na interface de ar-água e perda de pedras porosas.

Inicialmente, no estágio de adensamento das amostras, vários corpos de prova foram perdidos devido à perfurações da membrana de látex que envolve a amostra. Para impedir o contato de materiais pontiagudos do lixo com a membrana foi usado um filme plástico (magipak) envolvendo toda a amostra. Observou-se que esse filme plástico era muito resistente e impedia a deformação do corpo de prova. Assim, a alternativa adotada foi compactar os corpos de prova dentro de membranas usadas e/ou furadas e cobrir as saliências e depressões com geotêxtil e só depois foram colocadas as duas membranas de ensaio para proteger a amostra. Esse procedimento permitiu a realização com sucesso dos ensaios triaxiais. Para evitar problemas de excentricidade, foi utilizado um guia de latão para o pistão de aplicação de carga, fixado ao cabeçote. Durante o adensamento, a trava da prensa de cisalhamento era constantemente ajustada e nivelada para impedir a subida e a saída do pistão do eixo devido a compressão da amostra. As pedras porosas de topo e base confeccionadas de areia lavada, com diâmetro compreendido no intervalo de malhas de peneiras $\# 50<\phi<\# 30$, misturada com $3 \%$ de seu peso com araldite pega lenta, não suportaram as pressões aplicadas no ensaio e foram substituídas por geotêxtil.

Para que fosse possível executar os ensaios em corpos de prova com $200 \mathrm{~mm}$ de diâmetro e $400 \mathrm{~mm}$ de altura foi necessário confeccionar membranas de látex que apresentasse diâmetro mínimo de $200 \mathrm{~mm}$ e altura de $500 \mathrm{~mm}$. As membranas com essas dimensões não são comercialmente oferecidas pelo mercado.

Inicialmente, tentamos fabricar as membranas através do processo de imersão, que consistia basicamente em impregnar a superfície do molde com uma mistura de látex e vulcanizar em altas temperaturas. Mas o processo de fabricação resultou em membranas com espessuras não uniformes e com furos devido à presença de bolhas de ar na massa de látex. Também deve-se ressaltar a grande dificuldade de manuseio do molde devido suas grandes dimensões e peso, bem como, odor extremamente desagradável da massa de látex. Assim as membranas foram fabricadas pela empresa Big Balões (SP) e o molde de aço inoxidável foi por nós confeccionado.

As Tabelas 3.1 e 3.2 apresentam as condições e as principais características dos corpos de prova submetidos a ensaios triaxiais convencionais com $150 \mathrm{~mm}$ de diâmetro por $300 \mathrm{~mm}$ de altura, $200 \mathrm{~mm}$ de diâmetro por $400 \mathrm{~mm}$ de altura, respectivamente. 
Tabela 3.1 - Principais características dos corpos de prova de $150 \mathrm{~mm}$ de diâmetro e 300mm de altura.

\begin{tabular}{|c|c|c|c|c|c|c|c|c|}
\hline Amostra & Ensaio & $\mathbf{N}^{\mathbf{0}}$ & $\begin{array}{c}\sigma_{3} \\
(\mathrm{kPa})\end{array}$ & $\begin{array}{l}\text { W } \\
(\%)\end{array}$ & $\begin{array}{c}\gamma_{\text {nat }} \\
\left(\mathrm{kN} / \mathrm{m}^{3}\right)\end{array}$ & $\begin{array}{c}\gamma_{\text {seco }} \\
\left(\mathrm{kN} / \mathrm{m}^{3}\right)\end{array}$ & eo & $\begin{array}{l}\text { Sro } \\
(\%)\end{array}$ \\
\hline \multirow{26}{*}{ T2A } & \multirow{2}{*}{$C D_{\text {nat }}$} & 1 & 100 & 66,6 & 12,0 & 7,20 & 2,110 & 70,7 \\
\hline & & 2 & 200 & 66,6 & 12,2 & 7,32 & 2,061 & 72,4 \\
\hline & T2a12nat & 3 & 400 & 77,4 & 12,2 & 6,88 & 2,257 & 76,8 \\
\hline & \multirow{2}{*}{$\mathrm{CD}_{\text {sat }}$} & 1 & 100 & 68,3 & 12,2 & 7,24 & 2,069 & 74,0 \\
\hline & & 2 & 200 & 68,3 & 12,2 & 7,24 & 2,112 & 72,5 \\
\hline & T2a12sat & 3 & 400 & 68,3 & 12,1 & 7,19 & 2,112 & 72,5 \\
\hline & \multirow{3}{*}{$C D_{\text {nat }}$} & 1 & 100 & 63,2 & 10,14 & 6,21 & 2,609 & 54,3 \\
\hline & & 2 & 200 & 63,2 & 10,18 & 6,24 & 2,591 & 54,7 \\
\hline & & 3 & 400 & 63,2 & 10,17 & 6,23 & 2,597 & 54,5 \\
\hline & T2a10nat & 4 & 100 & 63,2 & 10,16 & 6,22 & 2,603 & 54,4 \\
\hline & \multirow{3}{*}{$C D_{\text {nat }}$} & 1 & 100 & 65,3 & 13,60 & 8,22 & 1,726 & 84,8 \\
\hline & & 2 & 200 & 65,3 & 13,51 & 8,17 & 1,743 & 84,0 \\
\hline & & 3 & 400 & 65,3 & 13,33 & 8,07 & 1,777 & 82,4 \\
\hline & T2a14nat & 4 & 400 & 65,3 & 13,75 & 8,32 & 1,693 & 86,4 \\
\hline & \multirow{3}{*}{$C D_{\text {nat }}$} & 1 & 400 & 60,7 & 12,22 & 7,60 & 1,948 & 69,8 \\
\hline & & 2 & 400 & 60,7 & 12,15 & 7,56 & 1,963 & 69,3 \\
\hline & & 3 & 400 & 60,7 & 12,29 & 7,64 & 1,931 & 70,5 \\
\hline & * & 4 & 400 & 60,7 & 11,94 & 7,43 & 2,017 & 67,4 \\
\hline & \multirow{3}{*}{$\mathrm{CU}_{\text {nat }}$} & 1 & 98 & 58,2 & 12,20 & 7,71 & 1,910 & 68,3 \\
\hline & & 2 & 208 & 58,2 & 12,20 & 7,71 & 1,910 & 68,3 \\
\hline & & 3 & 416 & 58,2 & 12,50 & 7,90 & 1,837 & 71,0 \\
\hline & T2a12Cunat & 4 & 408 & 79,6 & 12,38 & 6,89 & 2,253 & 79,2 \\
\hline & \multirow{3}{*}{$\mathrm{CU}_{\text {sat }}$} & 1 & 110 & 67,6 & 12,40 & 7,40 & 2,028 & 74,7 \\
\hline & & 2 & 226 & 67,6 & 12,35 & 7,37 & 2,040 & 74,3 \\
\hline & & 3 & 308 & 67,6 & 12,33 & 7,36 & 2,045 & 74,0 \\
\hline & T2a12Cusat & 4 & 216 & 70,4 & 12,35 & 7,25 & 2,091 & 75,5 \\
\hline \multirow{10}{*}{ T1B } & \multirow[t]{2}{*}{$C D_{\text {nat }}$} & 1 & 100 & 51,5 & 11,95 & 7,89 & 1,959 & 61,4 \\
\hline & & 2 & 200 & 51,5 & 12,08 & 7,97 & 1,930 & 62,3 \\
\hline & T1b12nat & 3 & 400 & 51,5 & 12,12 & 8,00 & 1,919 & 62,7 \\
\hline & $\mathrm{CD}_{\text {sat }}$ & 1 & 100 & 53,7 & 11,92 & 7,76 & 2,009 & 62,4 \\
\hline & & 2 & 200 & 53,7 & 11,99 & 7,80 & 1,994 & 62,9 \\
\hline & T1b12sat & 3 & 400 & 53,7 & 12,01 & 7,81 & 1,990 & 63,0 \\
\hline & & 1 & 108 & 58,6 & 12,24 & 7,72 & 2,025 & 67,6 \\
\hline & $\mathrm{CU}_{\text {sat }}$ & 2 & 208 & 58,6 & 12,12 & 7,64 & 2,056 & 66,6 \\
\hline & & 3 & 408 & 58,6 & 12,25 & 7,72 & 2,013 & 67,9 \\
\hline & T1b12Cusat & 4 & 408 & 58,6 & 11,99 & 7,56 & 2,089 & 65,5 \\
\hline & $C D_{\text {nat }}$ & 1 & 100 & 44,4 & 12,12 & 8,39 & 1,988 & 56,0 \\
\hline & Sal & 2 & 200 & 44,4 & 12,35 & 8,55 & 1,932 & 57,6 \\
\hline & T2b12nat & 3 & 400 & 44,4 & 12,31 & 8,52 & 1,942 & 57,3 \\
\hline & & 1 & 100 & 44,4 & 12,45 & 8,62 & 1,908 & 58,3 \\
\hline & $C_{\text {sat }}$ & 2 & 200 & 44,4 & 12,59 & 8,72 & 1,875 & 59,4 \\
\hline T2B & & 3 & 400 & 44,4 & 12,45 & 8,62 & 1,908 & 58,3 \\
\hline & T2b12sat & 4 & 200 & 44,4 & 12,47 & 8,64 & 1,901 & 58,6 \\
\hline & & 1 & 108 & 43,1 & 12,12 & 8,47 & 1,960 & 55,1 \\
\hline & $\mathrm{CU}_{\text {sat }}$ & 2 & 208 & 43,1 & 12,25 & 8,57 & 1,925 & 56,1 \\
\hline & & 3 & 408 & 43,1 & 12,26 & 8,57 & 1,925 & 56,1 \\
\hline & T2b12Cusat & 4 & 308 & 43,1 & 12,25 & 8,56 & 1,929 & 56,0 \\
\hline
\end{tabular}

mesmo peso específico) para verificação da reprodutibilidade dos resultados 
Tabela 3.2 - Principais características dos corpos de prova de $200 \mathrm{~mm}$ de diâmetro e 400mm de altura.

\begin{tabular}{|c|c|c|c|c|c|c|c|c|}
\hline \multirow{2}{*}{ Amostra } & Ensaio & $\mathbf{N}^{\mathbf{0}}$ & $\begin{array}{c}\sigma_{3} \\
(\mathrm{kPa})\end{array}$ & $\begin{array}{c}\mathbf{W} \\
(\%)\end{array}$ & $\begin{array}{c}\gamma_{\text {nat }} \\
\left(\mathrm{kN} / \mathrm{m}^{3}\right)\end{array}$ & $\begin{array}{c}\gamma_{\text {seco }} \\
\left(\mathrm{kN} / \mathrm{m}^{3}\right)\end{array}$ & eo & $\begin{array}{c}\text { Sro } \\
(\%)\end{array}$ \\
\hline \multirow{4}{*}{ T2A } & $\mathrm{CD}_{\text {nat }}$ & 1 & 100 & 58,0 & 11,97 & 7,57 & 1,956 & 66,4 \\
& & 2 & 200 & 58,0 & 12,08 & 7,65 & 1,929 & 67,4 \\
& T2a40CDnat & 3 & 400 & 58,0 & 12,03 & 7,61 & 1,943 & 66,9 \\
\cline { 2 - 9 } & CD $_{\text {sat }}$ & 1 & 100 & 67,7 & 12,00 & 7,16 & 2,130 & 71,2 \\
& & 2 & 200 & 58,0 & 12,16 & 7,69 & 1,910 & 68,0 \\
& T2a40CDsat & 3 & 400 & 58,0 & 12,15 & 7,69 & 1,913 & 67,9 \\
\hline \multirow{2}{*}{ T1B } & CD $_{\text {sat }}$ & 1 & 100 & 63,7 & 11,95 & 7,32 & 2,192 & 67,8 \\
& & 2 & 200 & 63,7 & 12,12 & 7,41 & 2,153 & 69,0 \\
& T1b40CDsat & 3 & 400 & 64,0 & 12,16 & 7,42 & 2,147 & 69,6 \\
\hline \multirow{2}{*}{ T2B } & CD $_{\text {sat }}$ & 1 & 100 & 47,3 & 12,06 & 8,19 & 2,061 & 57,5 \\
& & 2 & 200 & 47,3 & 11,99 & 8,14 & 2,080 & 57,0 \\
& T2b40CDsat & 3 & 400 & 47,3 & 12,12 & 8,23 & 2,048 & 57,9 \\
\hline
\end{tabular}

A nomenclatura utilizada para representação de cada série de ensaio está indicada na própria tabela (3.1 e 3.2) e consta de letras e números. No caso dos corpos de prova de $150 \mathrm{~mm}$ de diâmetro por $300 \mathrm{~mm}$ de altura (Tabela 3.1) tem-se, primeiramente, a identificação da amostra representativa, depois o peso específico de compactação dos corpos de prova e finalmente as condições de realização do ensaio (T2a12nat). Já para os corpos de prova com $200 \mathrm{~mm}$ de diâmetro por $400 \mathrm{~mm}$ de altura (Tabela 3.2), como todos os corpos de prova foram compactados com $12 \mathrm{kN} / \mathrm{m}^{3}$, no lugar do peso específico está indicado a altura do corpo de prova em centímetros (T2a40CDnat).

A Tabela 3.3 apresenta as características dos corpos de prova utilizados para determinação do módulo de deformabilidade, bem como, daqueles ensaiados com uma baixa pressão de confinamento $(25 \mathrm{kPa})$ e sem confinamento (compressão simples). $\mathrm{O}$ ensaio sem confinamento foi cisalhado com a mesma velocidade adotada para os ensaios triaxiais convencionais $(0,7 \mathrm{~mm} / \mathrm{min})$. Esses ensaios foram executados com a amostra T1B, na umidade natural, utilizando corpos de prova de $150 \mathrm{~mm}$ de diâmetro.

Tabela 3.3 - Principais características dos corpos de prova utilizados para determinação de módulo de deformabilidade e ensaiados com pressão de confinamento de $25 \mathrm{kPa}$ e sem confinamento.

\begin{tabular}{|c|c|c|c|c|c|c|c|c|}
\hline \multirow{2}{*}{ Amostra } & Ensaio & $\mathbf{N}^{\mathbf{0}}$ & $\begin{array}{c}\sigma_{3} \\
(\mathrm{kPa})\end{array}$ & $\begin{array}{c}\mathbf{W} \\
(\%)\end{array}$ & $\begin{array}{c}\gamma_{\text {nat }} \\
\left(\mathrm{kN} / \mathrm{m}^{3}\right)\end{array}$ & $\begin{array}{c}\gamma_{\text {seco }} \\
\left(\mathrm{kN} / \mathrm{m}^{3}\right)\end{array}$ & eo & $\begin{array}{c}\text { Sro } \\
(\%)\end{array}$ \\
\hline \multirow{4}{*}{ T1B } & Det. do & 1 & 50 & 73,5 & 12,58 & 7,25 & 2,219 & 77,3 \\
& módulo & 2 & 200 & 73,5 & 12,32 & 7,10 & 2,287 & 75,0 \\
& & 3 & 400 & 73,5 & 12,49 & 7,19 & 2,244 & 76,5 \\
\cline { 2 - 9 } & T1B12 & 1 & - & 60,2 & 12,61 & 7,87 & 1,966 & 71,5 \\
& natural & 2 & 25 & 73,5 & 12,37 & 7,13 & 2,274 & 75,4 \\
\hline
\end{tabular}


Para ensaiar a matriz do resíduo foi utilizado corpos de prova de $100 \mathrm{~mm}$ de diâmetro por 200mm de altura, compactados estaticamente em 5 camadas por meio de uma prensa hidráulica. Os corpos de prova foram compactados com peso específico em torno de $16 \mathrm{kN} / \mathrm{m}^{3}$, mas durante a prensagem, perdiam grande quantidade de líquido ficando, em geral, com peso específico abaixo deste valor. Não foi possível obter corpos de prova de boa qualidade para menores valores de peso específico, pois os corpos de prova danificavam-se quando extraídos do molde de aço por meio do extrator. Assim teve-se que aumentar o peso específico dos corpos de prova, o que comprometeu e dificultou bastante as análises de comparação dos resultados.

Como comentado anteriormente, a matriz de cada amostra representativa foi obtida por meio de separação manual de plásticos e materiais com partículas maiores que $20 \mathrm{~mm}$, sobrando uma fração pastosa, constituída de boa parte de solo e outras partículas. É importante frisar, também, que mesmo após a exclusão das fibras, essas amostras apresentaram uma quantidade razoável de pequenos fragmentos plásticos, somente perceptíveis após lavagem do material na peneira $\mathrm{N}^{0} .200$ (Figura 3.15).

Após a execução dos ensaios triaxiais com a matriz do resíduo, parte dos corpos de prova foram submetidas à lavagem na peneira \# 200, onde pôde-se observar a presença de pequenas tiras de plásticos e outros materiais. Na Figura 3.15 pode-se verificar as características da matriz antes do ensaio triaxial e depois do ensaio e da lavagem na peneira \# 200. Após a lavagem, esses materiais foram secados em estufa e fez-se o peneiramento. Obtiveram-se para a matriz T2A e T1B, que no máximo $40 \%$ do material passou na peneira \#200, e em torno de $40 \%$ apresentou diâmetro entre $0,075 \mathrm{~mm}$ e $2 \mathrm{~mm}$. Para a matriz T2B, cerca de $49 \%$ do material passou na peneira $\# 200$ e $45 \%$ apresentou diâmetro entre $0,075 \mathrm{~mm}$ e $2 \mathrm{~mm}$.

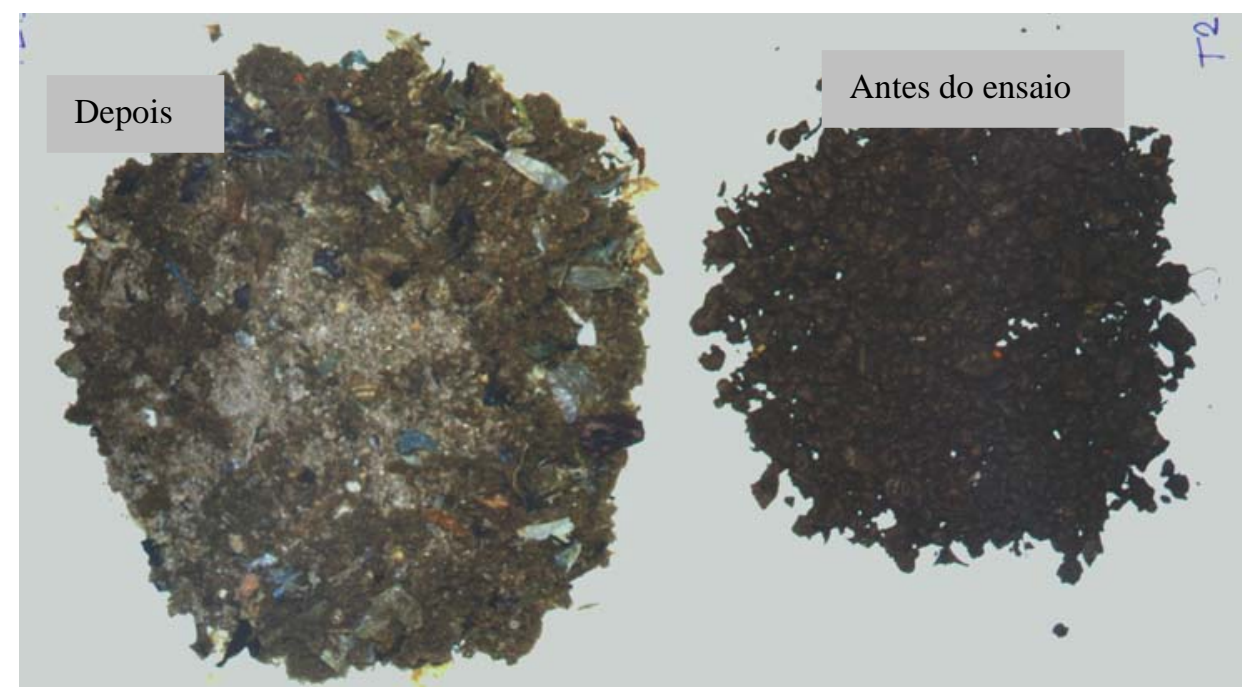

Figura 3.15 - Detalhes da composição da matriz T2b, após separação manual de plásticos e materiais com partículas maiores que $20 \mathrm{~mm}$ e após lavagem na peneira $N^{\circ} .200$. 
Na Tabela 3.4 estão apresentadas as características dos corpos de prova da matriz do resíduo, com dimensões de $100 \mathrm{~mm}$ de diâmetro por 200mm de altura.

Tabela 3.4 - Principais características dos corpos de prova de $100 \mathrm{~mm}$ de diâmetro e $200 \mathrm{~mm}$ de altura.

\begin{tabular}{|c|c|c|c|c|c|c|c|c|}
\hline Amostra & Ensaio & $\mathbf{N}^{\mathbf{0}}$ & $\begin{array}{c}\sigma_{3} \\
(\mathrm{kPa})\end{array}$ & $\begin{array}{c}\mathbf{W} \\
(\%)\end{array}$ & $\begin{array}{c}\gamma_{\text {nat }} \\
\left(\mathrm{kN} / \mathrm{m}^{3}\right)\end{array}$ & $\begin{array}{c}\gamma_{\text {seco }} \\
\left(\mathrm{kN} / \mathrm{m}^{3}\right)\end{array}$ & eo & $\begin{array}{c}\text { Sro } \\
(\%)\end{array}$ \\
\hline \multirow{2}{*}{$\mathrm{T} 2 \mathrm{~A}$} & $\mathrm{CD}_{\text {sat }}$ & 1 & 100 & 48,2 & 15,31 & 10,33 & 1,170 & 92,3 \\
& Matriz T2a & 3 & 200 & 48,2 & 15,35 & 10,36 & 1,163 & 92,9 \\
& $\mathrm{CD}_{\text {sat }}$ & 1 & 100 & 58,6 & 15,62 & 9,85 & 1,371 & 99,8 \\
T1B & & 2 & 200 & 58,6 & 14,90 & 9,40 & 1,485 & 92,0 \\
& Matriz T1b & 3 & 400 & 58,6 & 15,28 & 9,63 & 1,424 & 96,0 \\
\hline \multirow{2}{*}{ T2B } & CD $_{\text {sat }}$ & 1 & 100 & 42,1 & 16,06 & 11,30 & 1,218 & 86,6 \\
& & 2 & 200 & 38,2 & 16,01 & 11,59 & 1,164 & 82,3 \\
& Matriz T2b & 3 & 400 & 41,2 & 15,99 & 11,32 & 1,214 & 86,9 \\
\hline
\end{tabular}

Os ensaios da matriz foram executados utilizando os equipamentos convencionais de laboratório. Os corpos de prova foram saturados por percolação de água da base para o topo da amostra e por aplicação de contra pressão. Obtiveram-se baixos valores do parâmetro $B$, que situaram-se entre 0,84-0,93. Empregaram-se pressões de confinamento efetiva de 100, 200 e $400 \mathrm{kPa}$ e velocidade de cisalhamento de $0,08 \mathrm{~mm} / \mathrm{min}$.

\section{6 - ENSAIO DE COMPRESSÃO CONFINADA}

Para estudo da compressibilidade do resíduo sólido urbano foram realizados ensaios de compressão confinada, utilizando um consolidômetro de grandes dimensões existente no Laboratório de Geotecnia da EESC/USP.

O consolidômetro possui diâmetro interno de $365 \mathrm{~mm}$ e altura de $385 \mathrm{~mm}$ e é constituído de aço inoxidável. A Figura 3.16 apresenta, de modo esquemático, o consolidômetro utilizado, bem como suas principais partes, como câmara para aplicação de pressão, pedras porosas, pistão, disco-tampa, etc.

O equipamento possui uma câmara de pressão, pedras porosas de topo e base para drenagem. A pressão é transmitida ao resíduo sólido através da aplicação de ar comprimido na câmara de pressão formada pelo espaço entre o êmbolo e o disco-tampa. O êmbolo possui dois o' rings para vedar a passagem de ar para o RSU.

Pedras porosas posicionadas no topo e na base do consolidômetro permitem a drenagem de lixívia resultante do processo de adensamento. As pedras porosas, inicialmente, foram confeccionadas no laboratório, visto que devido as suas dimensões especiais (diâmetro de $360 \mathrm{~mm}$ ), apresentavam elevado custo e dificuldade no fornecimento 
por parte dos fabricantes. O maior inconveniente de uso destas pedras foi a fragilidade $\mathrm{e}$ necessidade de serem renovadas a cada término de ensaio.
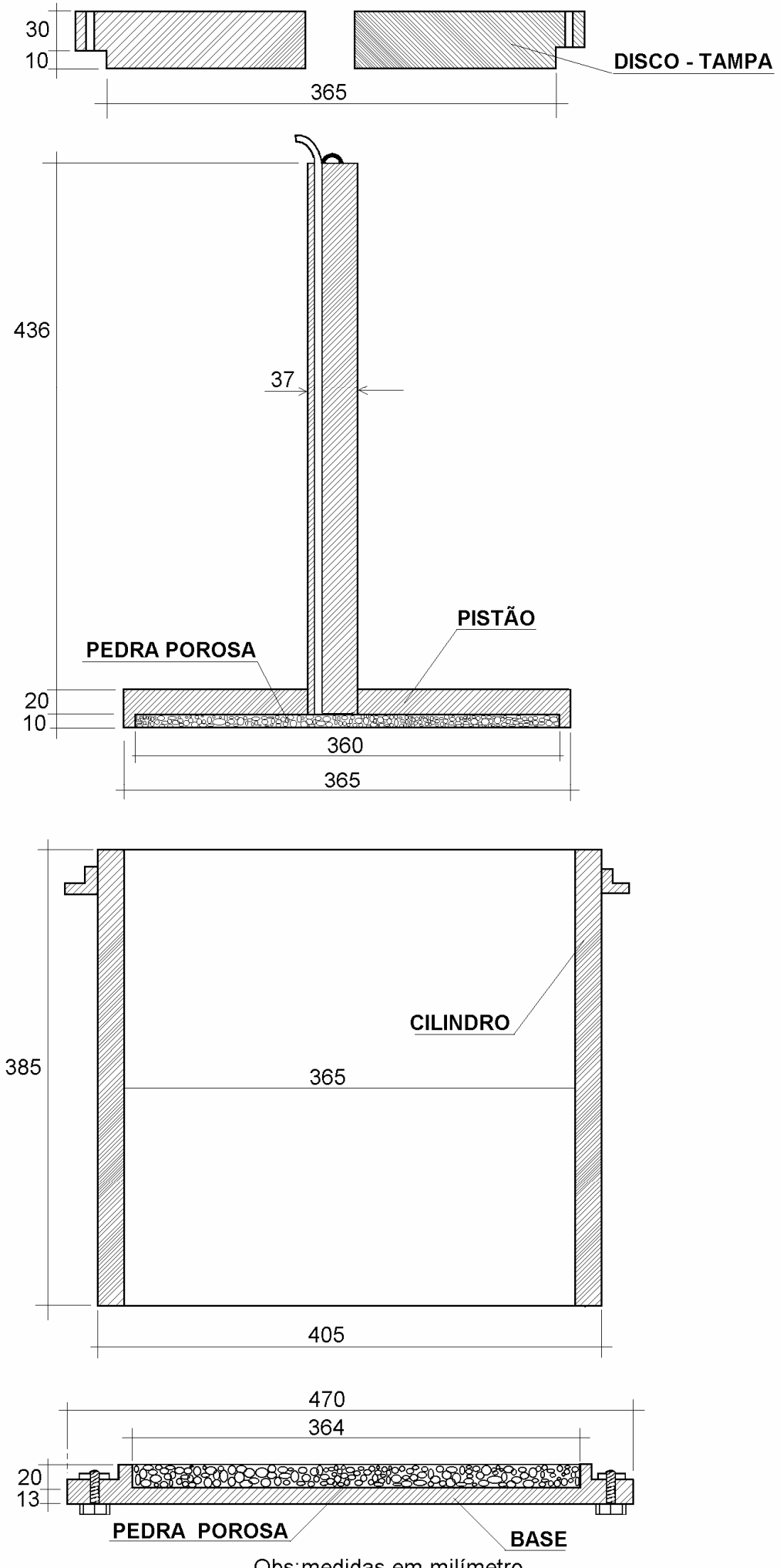

Obs:medidas em milímetro

Figura 3.16 - Representação esquemática do consolidômetro utilizado para realização dos ensaios de compressão confinada. 
As pedras foram confeccionadas de areia lavada com diâmetro compreendido no intervalo de malha de peneiras $\# 50<\phi<\# 30$, misturada com $3 \%$ de seu peso com araldite pega lenta. Feita a mistura, colocava-se no molde e comprimia-se levemente, rasando a superfície (STANCATI, 1991). As pedras devem ficar expostas a luz de infra vermelho por um tempo de mais ou menos 12 horas, para acelerar o endurecimento do araldite. Deve-se também promover o revezamento das faces expostas à luz para que o adesivo distribua melhor nos vazios da pedra. Essas pedras de areia lavada foram substituídas por pastilhas de bronze (60 a 200 micros) de fabricação da Filbronsi - Filtros de Bronze Sinterizados S/A.

O consolidômetro possibilita ainda o monitoramento das tensões laterais resultantes das pressões verticais aplicadas, através de uma célula de carga com capacidade $0,5 \mathrm{MPa}$ (modelo TLT-0,5) e sensibilidade 0,5\%, posicionada na parede do cilindro. Durante a execução dos ensaios de compressão confinada, infelizmente as duas células utilizadas para as medidas de tensões laterais não tiveram um comportamento satisfatório. Inclusive com queda de energia, essas células perdiam a indicação do display e com a volta da energia, não conseguiam recuperar suas leituras. Como esses ensaios tiveram longa duração, em geral quase 4 meses, incidentes como esses eram inevitáveis. Assim as leituras das pressões laterais foram desconsideradas por não serem confiáveis.

Foram executados ensaios de compressão confinada com as três amostras representativas T1B, T2A e T2B, sendo que para a amostra T2A variaram-se o peso específico inicial do resíduo, a fim de verificar a influência desse parâmetro nos coeficientes de compressibilidade.

Em todos os ensaios de compressão confinada foram utilizadas amostras deformadas e no teor de umidade natural e somente uma amostra foi ensaiada sob condição saturada (T1B10COMSAT). O resíduo foi colocado manualmente no consolidômetro até a uma altura de $285 \mathrm{~mm}$, em 6 camadas e levemente comprimido. Para o caso da amostra T1B que se apresentou bastante úmida, apenas rasou-se a superfície do material, de modo a obter o peso específico úmido estipulado.

Durante o processo de montagem do ensaio executado em condições saturadas, da amostra T1B (T1B10COMSAT), cada camada era saturada com água da rede de abastecimento até preencher todos os vazios e se acumular na superfície da amostra. Foram colocados um total de 7,2 litros de água. Durante a execução do ensaio mediram-se toda a lixívia drenada. Para essa amostra coletaram-se 16,9 litros de lixívia e para a amostra T1B10COM, ensaiada na condição de umidade natural coletaram-se 8,7 litros.

Aplicaram-se vários estágios de carregamento vertical na amostra, sempre dobrando a carga anterior $(10,20,40,80,160$ e 320 e $640 \mathrm{kPa})$ e as deformações e as tensões laterais foram medidas. Cada estágio de carregamento durou em média 15 dias ou até a definição da reta deformação $x \log \mathrm{t}$. Em média, cada ensaio de consolidação levou cerca de 4 meses para ser executado. Para medida de deformação utilizaram-se um extensômetro de $50 \mathrm{~mm}$, com sensibilidade de 0,01, posicionado no topo do pistão. 
Após a aplicação do último estágio de pressão, no caso $640 \mathrm{kPa}$ (carga máxima que pôde ser usada com segurança), a amostra era descarregada segundo a ordem decrescente do sentido de carregamento. Após isso, o consolidômetro era desmontado e determinava-se o peso e o teor de umidade do corpo de prova no final do ensaio. As amostras apresentavam um odor forte e desagradável após abertura do consolidômetro.

A Tabela 3.5 apresenta as características das amostras antes e depois dos ensaios de consolidação.

Tabela 3.5 - Características das amostras submetidas a ensaios de compressão confinada.

\begin{tabular}{|c|c|c|c|c|c|c|c|c|c|c|c|c|c|}
\hline \multirow{2}{*}{ ÍNDICES } & \multicolumn{9}{|c|}{ T2A } & \multicolumn{3}{c|}{ T2B } & \multicolumn{5}{c|}{ T1B } \\
\cline { 2 - 15 } & T2A8COM & T2A10COM & T2A14COM & T2B12COM & \multicolumn{1}{|c|}{ T1B10COM } & T1B10COMsat \\
\hline & antes & dep. & antes & Dep. & antes & dep. & Antes & dep. & antes & dep. & antes & dep. \\
\hline & & & & & & & & & & & & \\
\hline $\mathrm{w}(\%)$ & 63,1 & 40,4 & 59,2 & 37,8 & 62,4 & 41,4 & 67,8 & 33,1 & 95,4 & 42,4 & 91,0 & 37,4 \\
\hline $\begin{array}{c}\gamma \\
\left(\mathrm{kN} / \mathrm{m}^{3}\right)\end{array}$ & 8,0 & 13,62 & 10,0 & 15,40 & 14,03 & 15,89 & 12,30 & 16,57 & 10,48 & 14,93 & 10,73 & 16,12 \\
\hline $\begin{array}{c}\gamma_{\mathrm{d}} \\
\left(\mathrm{kN} / \mathrm{m}^{3}\right)\end{array}$ & 4,89 & 9,70 & 6,28 & 11,17 & 8,64 & 11,24 & 7,33 & 12,45 & 5,36 & 10,48 & 5,63 & 11,74 \\
\hline $\begin{array}{c}\gamma_{\mathrm{s}} \\
\left(\mathrm{kN} / \mathrm{m}^{3}\right)\end{array}$ & 22,41 & 22,41 & 22,41 & 22,41 & 22,41 & 22,41 & 25,07 & 25,07 & 23,35 & 23,35 & 23,35 & 23,35 \\
\hline eo & 3,582 & 1,310 & 2,568 & 1,006 & 1,702 & 0,994 & 2,420 & 1,014 & 3,353 & 1,228 & 3,157 & 0,990 \\
\hline Sro $(\%)$ & 39,5 & 69,1 & 51,7 & 84,3 & 82,1 & 93,3 & 70,2 & 81,8 & 66,4 & 80,7 & 67,3 & - \\
\hline
\end{tabular}

Obs: $\mathrm{T} 1, \mathrm{~T} 2$ = tradagem 1 e 2 ;

$\mathrm{A}$ e $\mathrm{B}=$ horizonte superficial e profundo respectivamente;

$8,10,12$ e $14=$ peso específico úmido no início do ensaio $\mathrm{COM}=$ ensaio de compressão confinada sat $=$ saturação dos vazios com água 


\section{4 - APRESENTAÇÃO DOS RESULTADOS}

\section{1 - ENSAIOS IN SITU}

\subsection{1 - Sondagens de simples reconhecimento com medida de}

SPT e do torque

As figuras 4.1 a 4.5 apresentam os perfis de sondagens obtidos para cada ponto investigado. Nestes perfis podem ser evidenciados os valores de resistência a penetração (N) e as medidas do torque com a profundidade, bem como as espessuras das camadas do resíduo, solo de cobertura e posição do nível de água.

No Anexo 01 estão apresentadas algumas seções transversais traçadas entre os diversos perfis de sondagens obtidos.

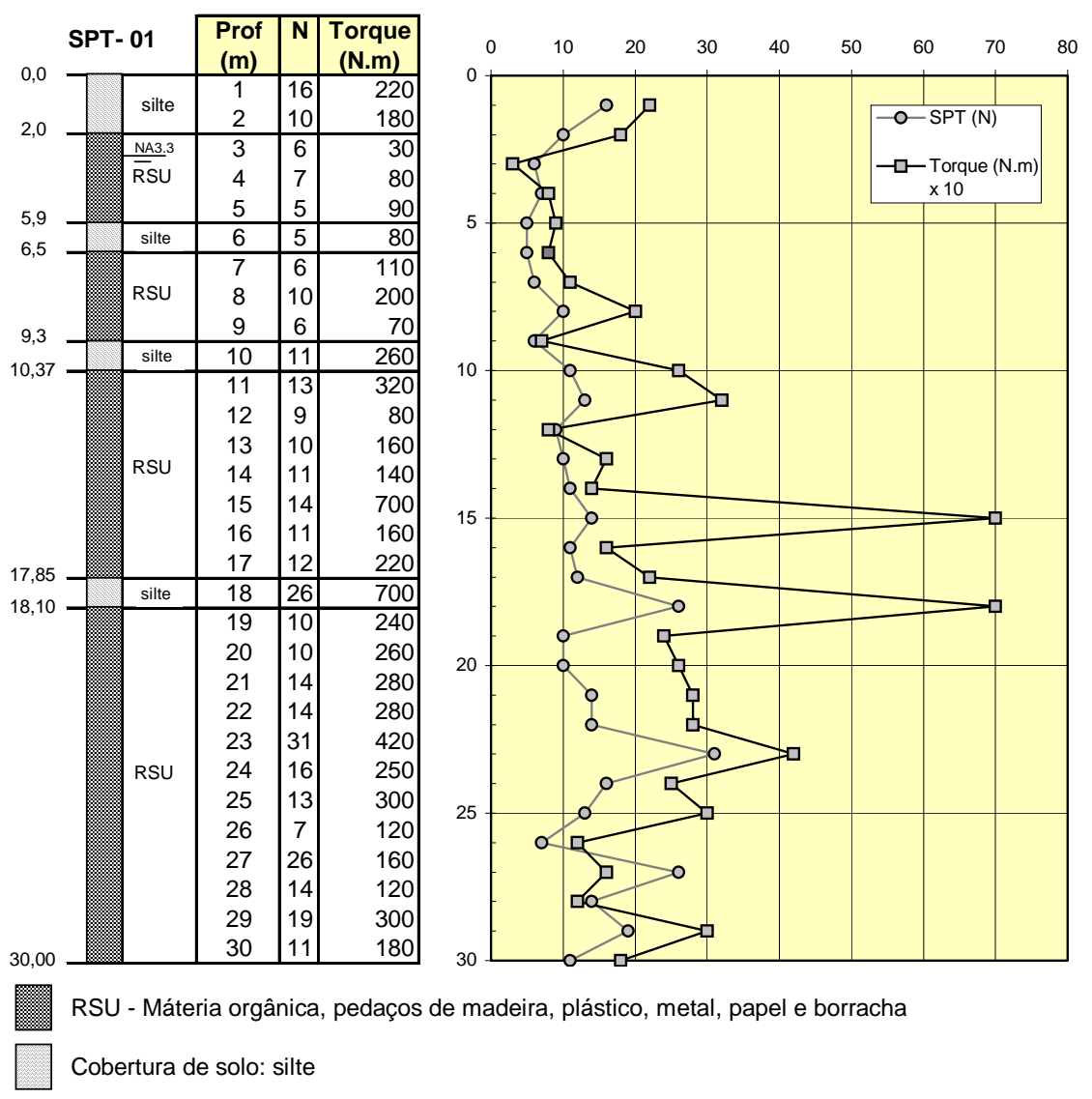

Figura 4.1 - Perfil de sondagem SPT-T 01. 


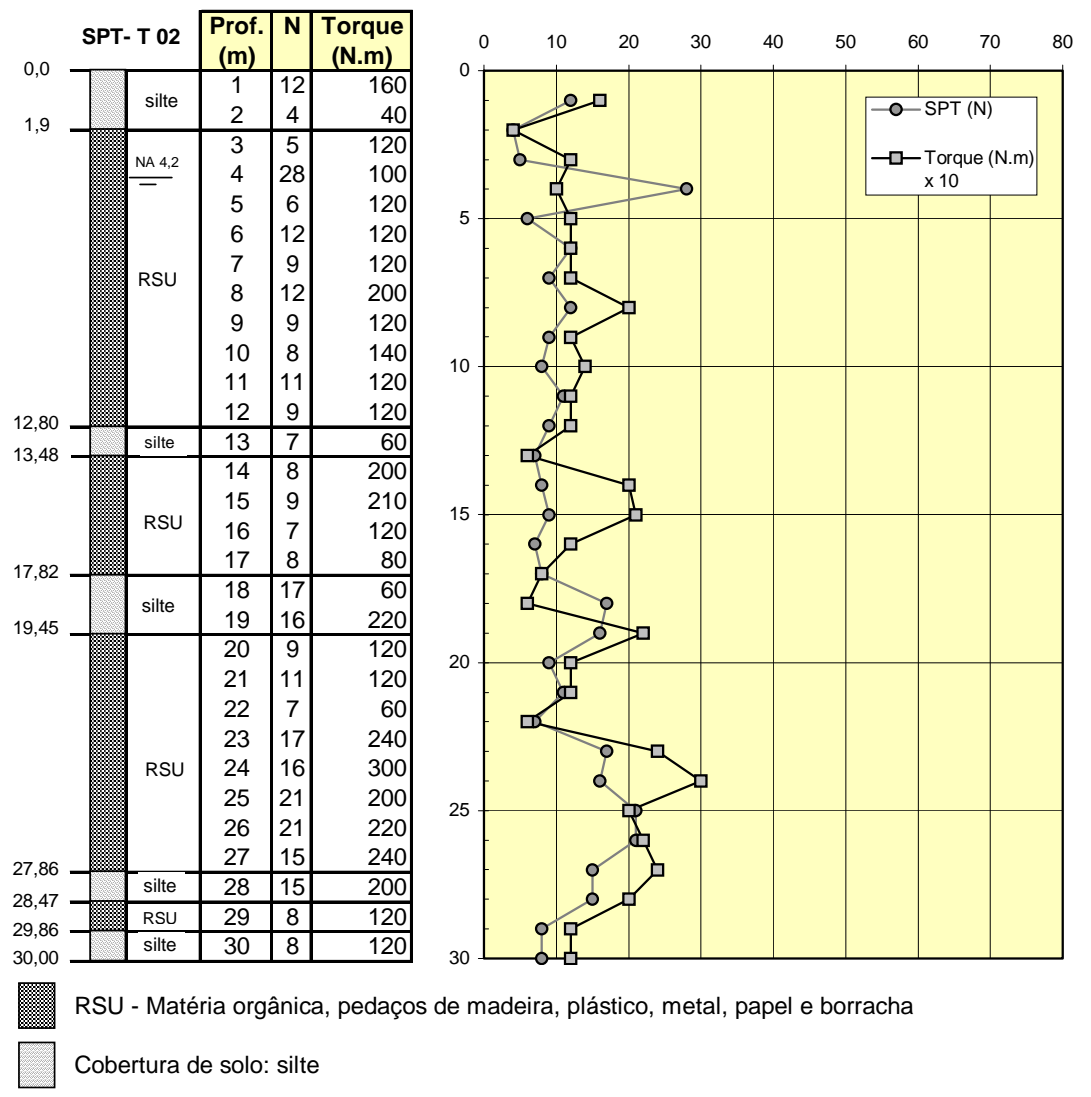

Figura 4.2 - Perfil de sondagem SPT-T 02.

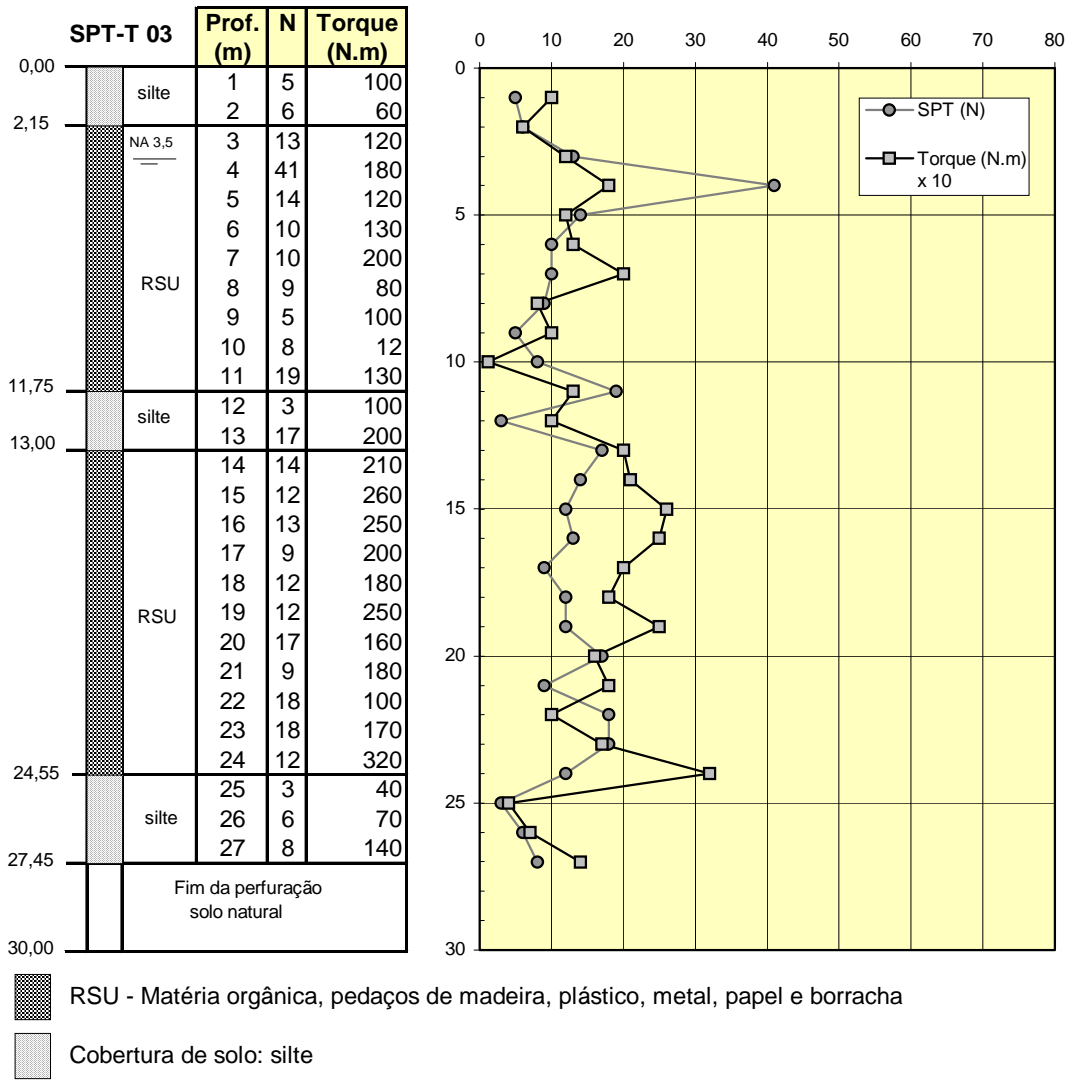

Figura 4.3 - Perfil de sondagem SPT-T 03. 

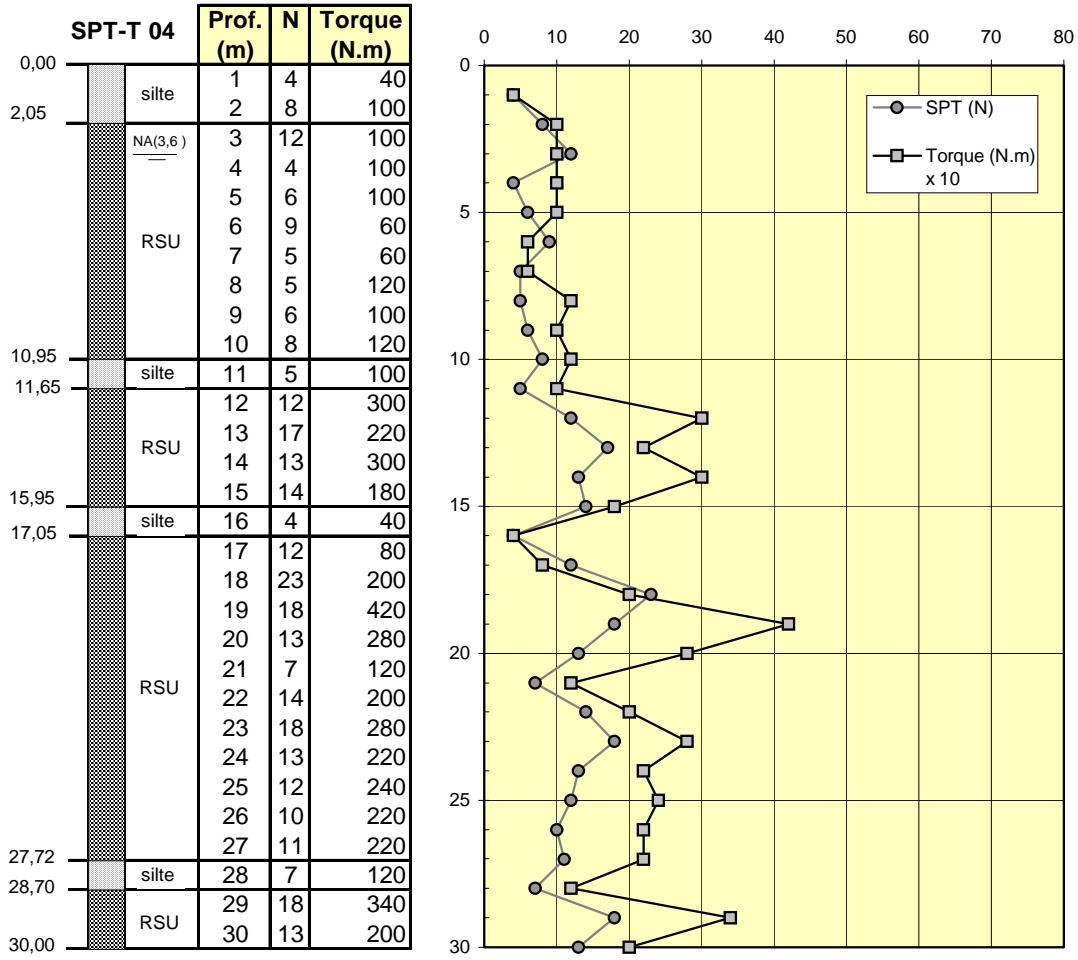

RSU - Matéria orgânica, pedaços de madeira, plástico, metal, papel e borracha

Cobertura de solo: silte

Figura 4.4 - Perfil de sondagem SPT-T 04.

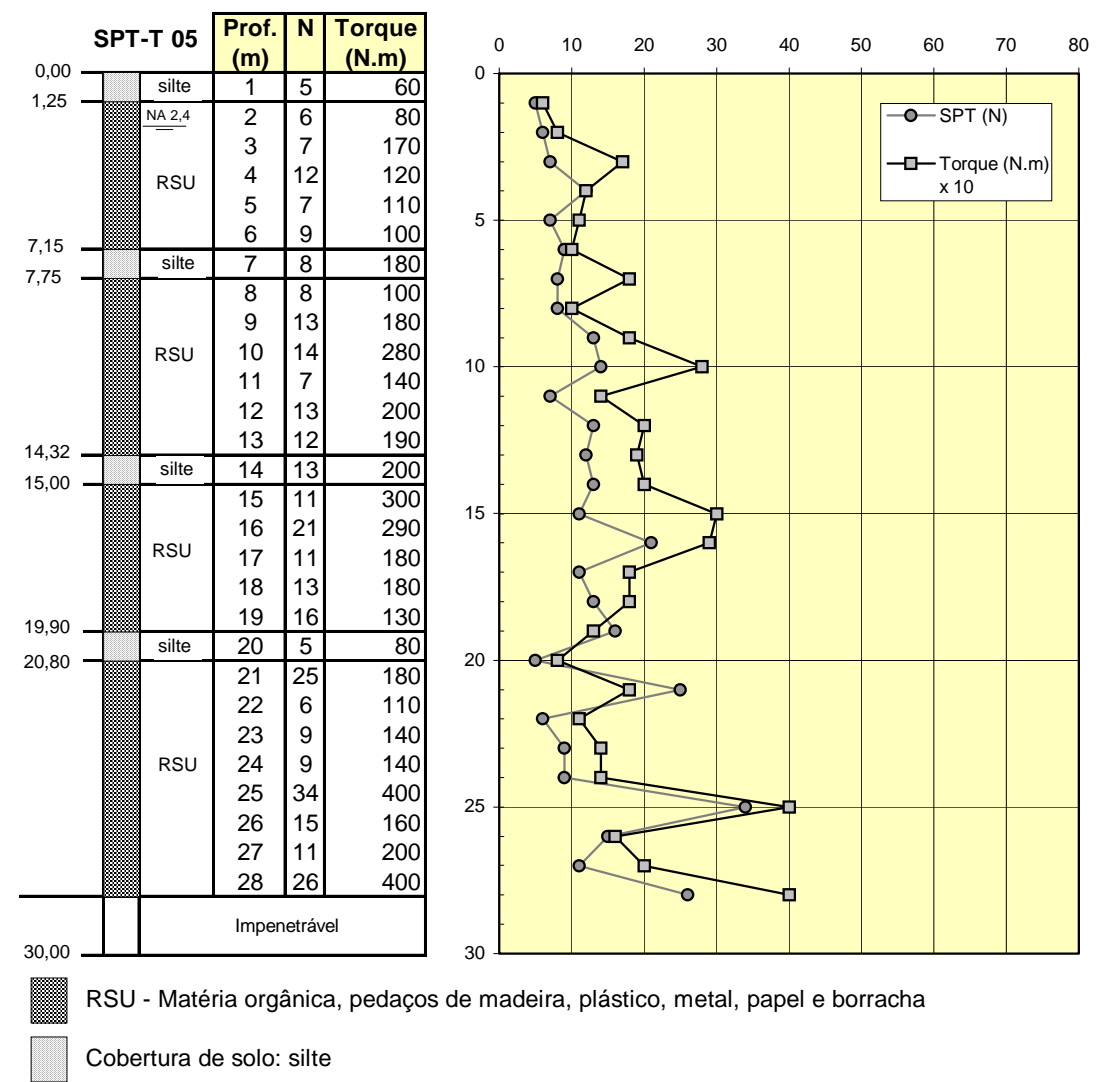

Figura 4.5 - Perfil de sondagem SPT-T 05. 
Pôde-se identificar nos materiais retirados dos furos de sondagem, moedas, plásticos e até mesmo pedaço de jornal datado de 1989 a 17 metros de profundidade em bom estado de conservação, podendo ser facilmente lido.

O nível de líquido percolado foi encontrado nas primeiras células, variando de 2,40 a 4,2 metros abaixo da boca do furo. Após a identificação do nível freático adotou-se o procedimento de lavagem por circulação de água, pois esta técnica permitiu o avanço e a limpeza do furo com maior facilidade. Porém em função desse processo executivo adotado não pôde ser verificada a ocorrência de lençóis empoleirados de percolados.

\subsection{2 - Ensaio de penetração contínua - CPT}

As Figuras 4.6 e 4.7 apresentam as resistências de ponta e lateral obtidas dos ensaios de penetração contínua CPT em dois pontos investigados.

É importante comentar, que apesar das dificuldades relacionadas com a ultrapassagem de materiais de elevada resistência e deflexão das hastes, bem como o baixo rendimento da perfuração, foi possível executar, em maciços sanitários, tanto os ensaios de sondagem de simples reconhecimento (SPT) como os ensaios de penetração contínua (CPT) empregando as técnicas consagradas pela mecânica dos solos.
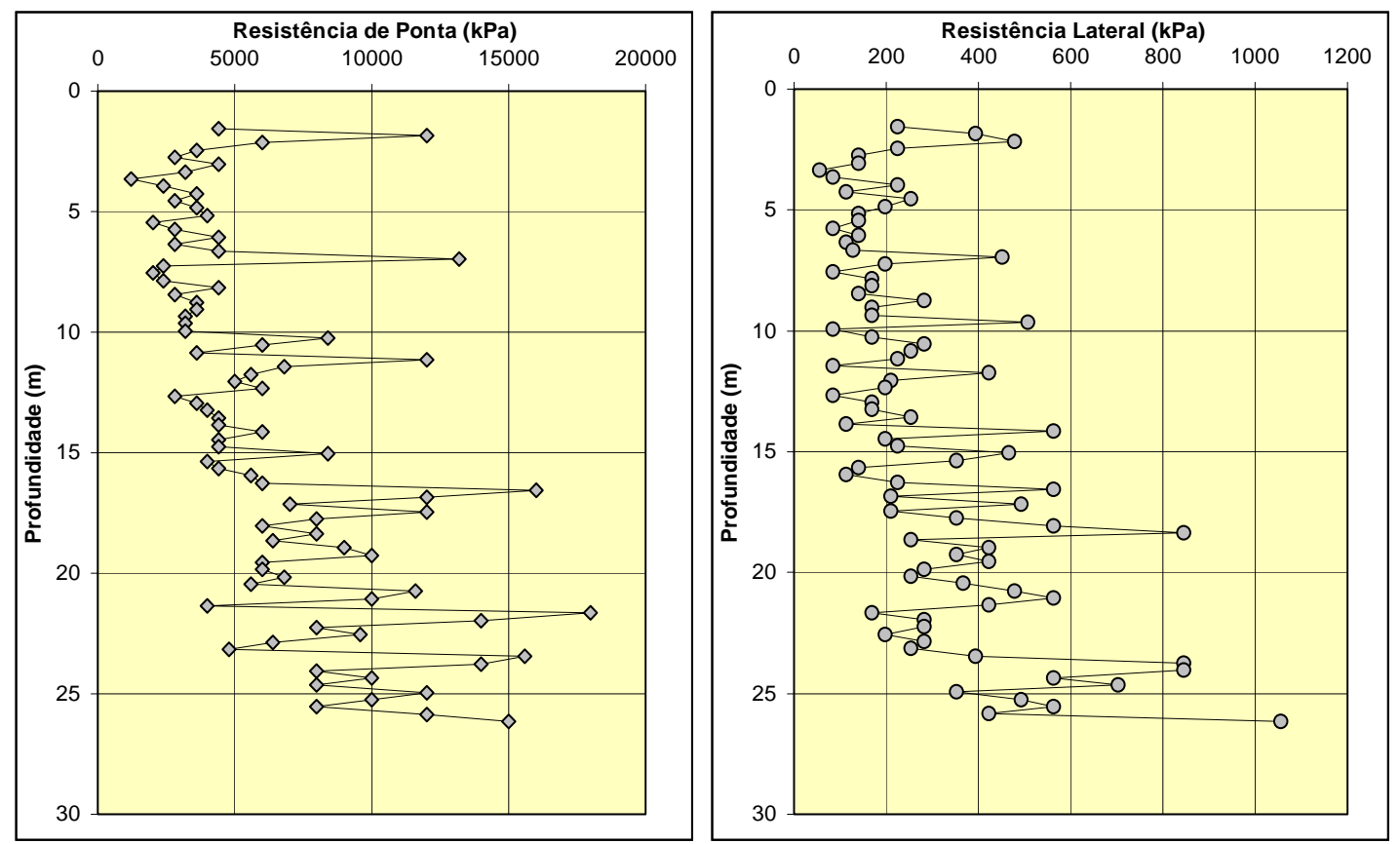

Figura 4.6 - Resultado do ensaio de penetração contínua CPT-01 (berma inferior). 

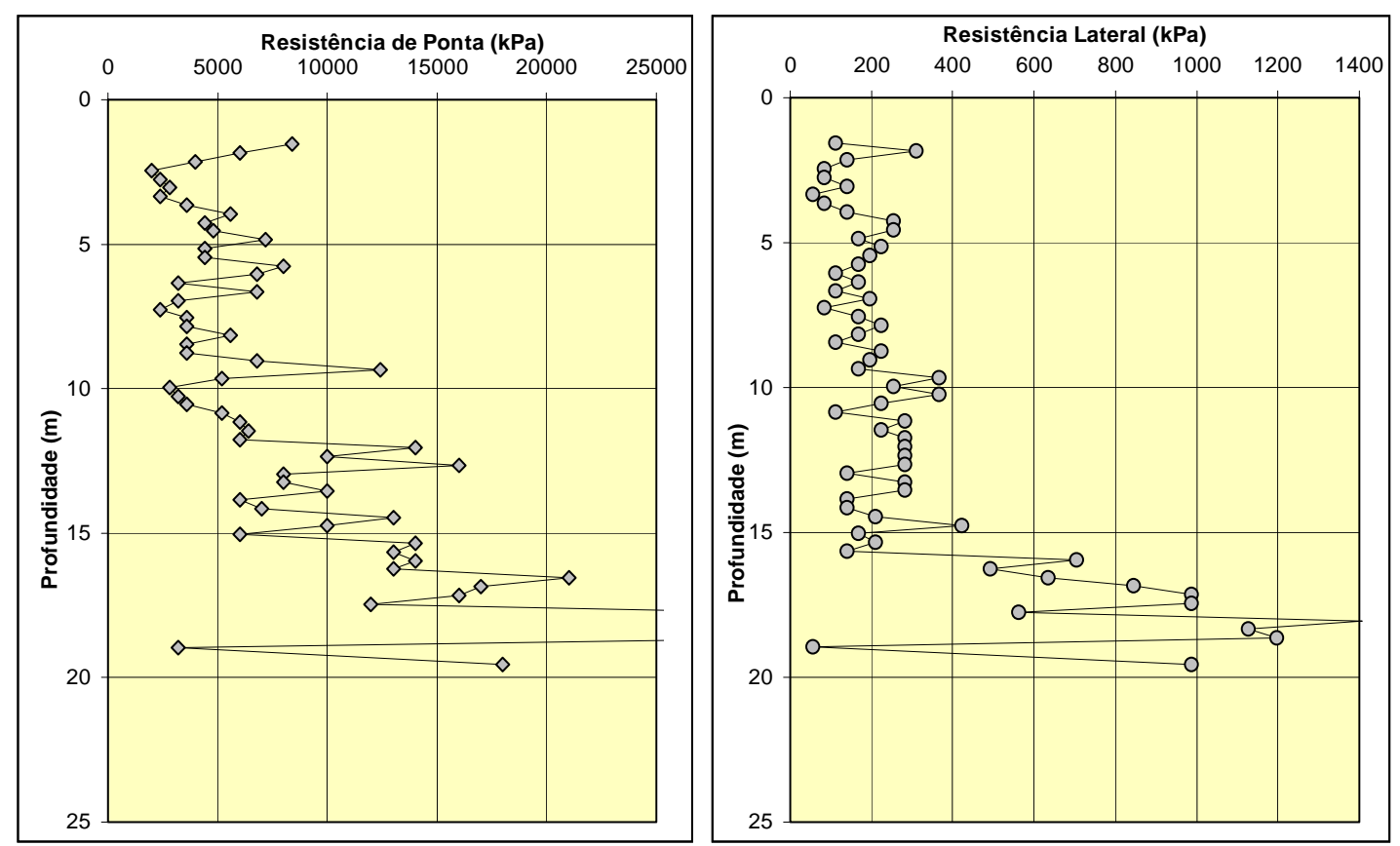

Figura 4.7 - Resultado do ensaio de penetração contínua CPT-02 (berma superior).

\subsection{3 - Ensaio de infiltração em furos de sondagens}

Os resultados dos ensaios de infiltração executados em dois furos de sondagem apresentaram grandes variações nas vazões de água infiltradas, as quais podem ser, em princípio, justificadas pela heterogeneidade dos materiais ensaiados. Os coeficientes de permeabilidade do resíduo, calculados utilizando as especificações da ABGE (1981), estão apresentados na Figura 4.8 e variaram entre $8 \times 10^{-4}$ a $5 \times 10^{-6} \mathrm{~cm} / \mathrm{seg}$.

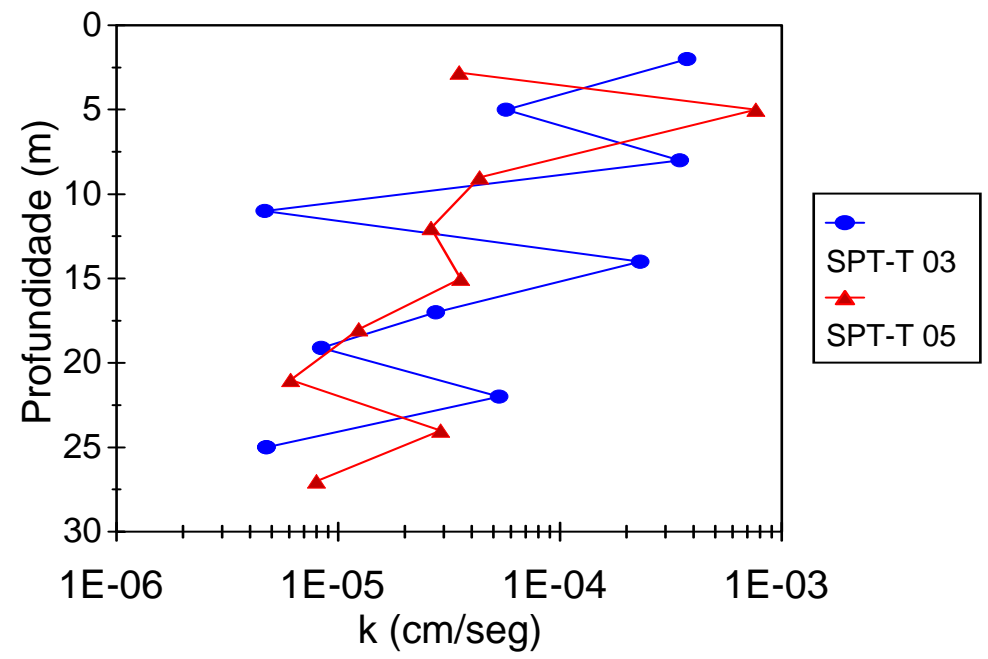

Figura 4.8 - Coeficientes de permeabilidade do resíduo urbano estudado. 


\subsection{4 - Tradagem para coleta de amostras e estimativa do peso específico in situ}

Como mencionado no item 3.2.4, foram executados dois furos para a coleta de amostras, utilizando trado mecânico helicoidal com $40 \mathrm{~cm}$ de diâmetro. Todo o material retirado foi pesado para estimativa do peso específico. No Anexo 02 apresentam-se as descrições das características dos resíduos coletados ao longo do perfil.

Numa tentativa inicial de cálculo do peso específico, determinou-se primeiramente o peso do resíduo correspondente ao avanço do trado nos diferentes trechos de coleta (em geral, a cada 2 metros). Conhecendo o comprimento de avanço do trado e o seu diâmetro nominal pôde-se determinar o volume e, portanto, pôde-se inferir o peso específico do resíduo coletado. No entanto, observou-se que ao longo da perfuração, o peso do resíduo aumentava com a profundidade, indicando uma deformação (fechamento) das paredes do furo e o conseqüente arraste de material. Face a essas observações, o peso do resíduo ao longo da profundidade foi corrigido empregando a análise de regressão linear através das medidas de peso obtidas em campo. Assim, pôde-se determinar o acréscimo médio em peso para cada trecho de 2 metros. Os valores dos pesos corrigidos foram obtidos subtraindo-se do peso medido, o acréscimo médio calculado. A Figura 4.9 apresenta os dados dos pesos medidos e dos corrigidos para as duas perfurações. Para o cálculo da regressão do peso corrigido do resíduo na perfuração T1, não foram considerados os dois últimos pontos, visto que estes apresentavam valores menores. A partir dos pesos corrigidos e do volume de cada trecho determinaram-se os pesos específicos in stu, os quais estão apresentados na Figura 4.10. Tais pesos específicos são para valores de umidade em campo apresentados na Figura 4.17 (calculados em base seca).

$\mathrm{Na}$ tentativa de minimizar os erros devido ao arraste de material foi feita uma nova tradagem (T4) com 10,50m de profundidade total, utilizando apenas um suplemento do trado, com diâmetro $0,30 \mathrm{~m}$. Todo o resíduo foi pesado e o volume foi obtido preenchendo o furo com pasta de bentonita. O solo de cobertura apresentava uma espessura de 4,0m, assim a camada de RSU era apenas de $6,50 \mathrm{~m}$ e pesava $658,80 \mathrm{~kg}$. A variação da altura de bentonita no tanque $\left(\phi_{\mathrm{tan}}=1,98 \mathrm{~m}\right)$ foi de $9 \mathrm{~cm}$, a qual preencheu uma altura de $8,75 \mathrm{~m}$ da perfuração. $\mathrm{O}$ volume de bentonita gasto para preencher apenas o trecho com resíduos $(6,50 \mathrm{~m})$ foi de $0,20586 \mathrm{~m}^{3}$.

Da relação de volumes pôde-se determinar o diâmetro médio do furo de trado, como apresentado a seguir:

$$
\left(\frac{\phi_{\mathrm{f}}}{\phi_{\tan }}\right)^{2}=\frac{0,09}{8,75} \Rightarrow \phi_{\mathrm{f}}=0,20 \mathrm{~m}
$$

Observa-se das considerações acima, um fechamento do diâmetro do furo, o qual atinge um valor médio de $0,20 \mathrm{~m}$. Assim, se o peso específico estimado fosse calculado com 
base no volume de bentonita, este apresentaria um valor bastante alto e irreal $\left(32 \mathrm{kN} / \mathrm{m}^{3}\right)$. Se se considerar o diâmetro nominal do furo de trado $(0,30 \mathrm{~m})$, obtém-se um valor de $14,4 \mathrm{kN} / \mathrm{m}^{3}$ para o peso específico. É importante frisar que o valor considerando o diâmetro nominal é o limite superior, visto que durante o giro da haste do trado, este pode promover o arraste de materiais das paredes e o alargamento do diâmetro da perfuração e com isso, um aumento de volume, levando à conseqüente diminuição dos valores do peso específico.
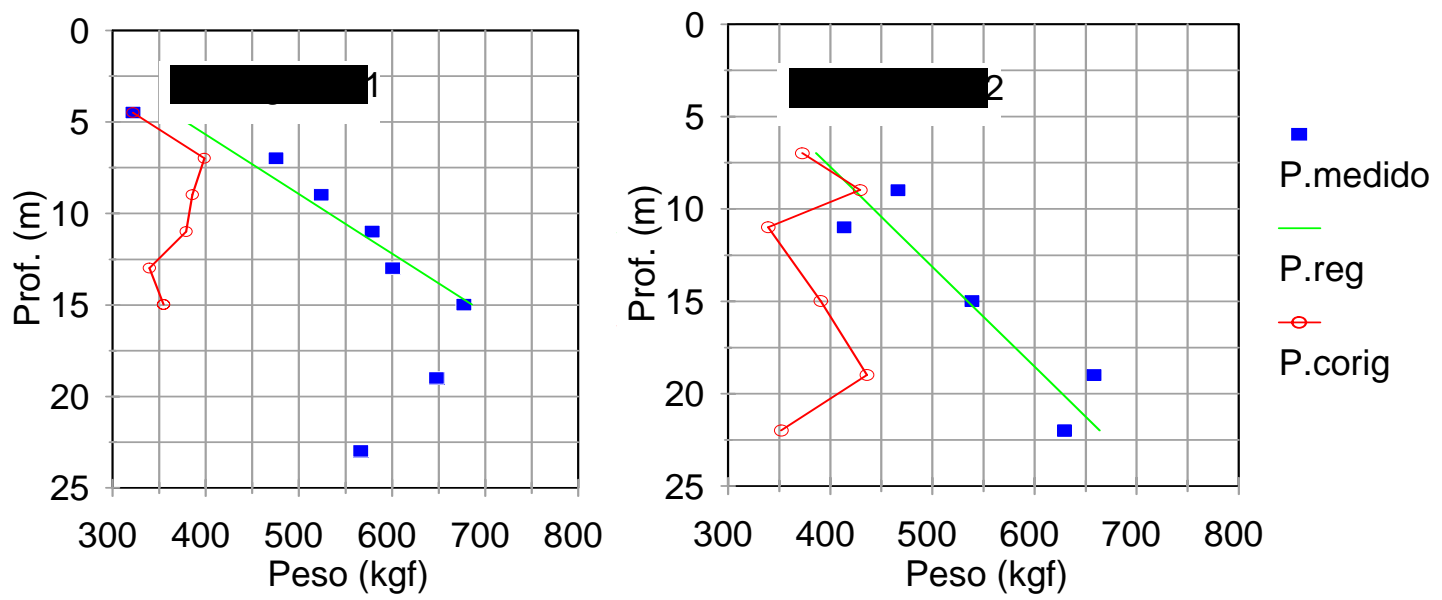

Figura 4.9 - Correções dos pesos dos resíduos sólidos urbanos para as perfurações T1 e T2

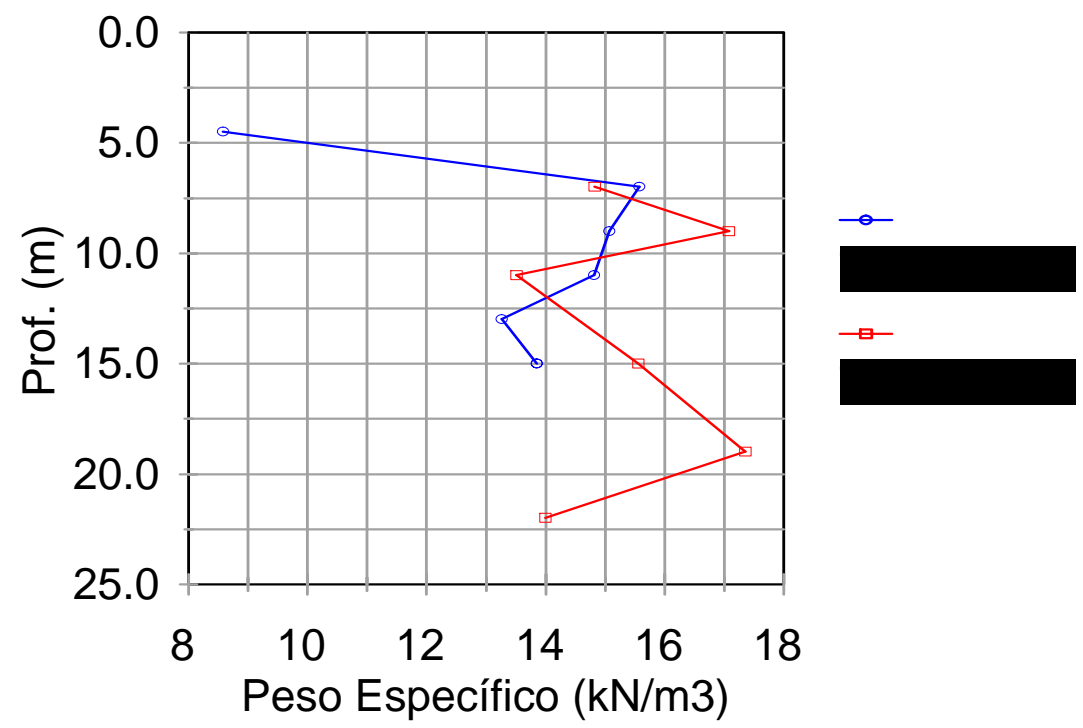

Figura 4.10 - Estimativa do peso específico in situ obtidos através de pesagem do resíduo nas tradagens $T 1$ e $T 2$.

A Figura 4.11 apresenta curvas de limite superior e inferior para a uma estimativa imprecisa da variação do peso específico com a profundidade. O limite superior é a média 
dos valores obtidos nas perfurações T1 e T2, os quais foram apresentados e discutidos nas Fig. 4.9 e 4.10. Já a curva limite inferior do peso específico é resultante da relação entre o peso dos resíduos amostrados e acondicionados nos tambores metálicos e o volume ocupado por ele no respectivo tambor. Essa última curva foi considerada como limite inferior, uma vez que o material já sofreu um fator de empolamento com o processo de amostragem.

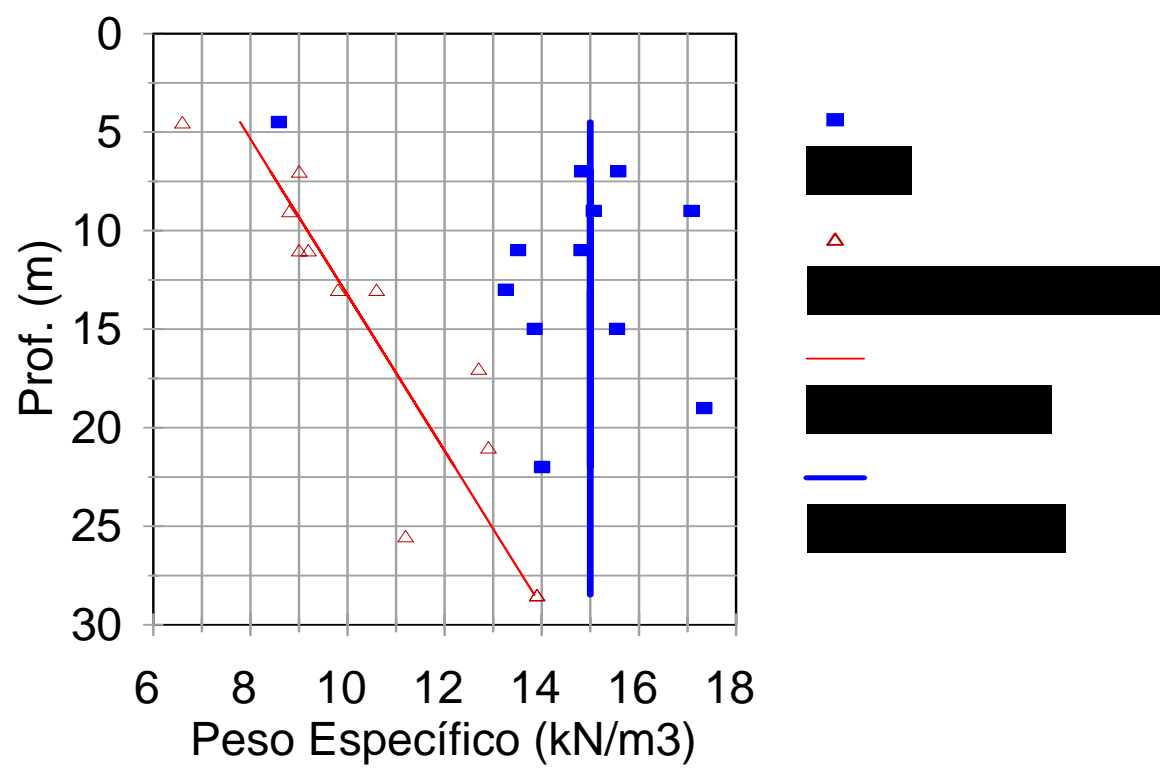

Figura 4.11 - Estimativa da variação do peso específico com a profundidade para RSU, considerando as hipóteses enunciadas no texto.

\subsection{5 - Ensaio cross-hole}

Os perfis de velocidade de propagação das ondas cisalhante $\left(v_{s}\right)$ e de compressão $\left(v_{p}\right)$ obtidos para o resíduo estudado estão apresentados na Figura 4.12.

É importante mencionar que até a profundidade de 10 metros, foi utilizado o geofone e o martelo na mesma posição, a partir daí, mantiveram-se o martelo fixo a 10 metros de profundidade e deslocaram-se o geofone de 2 em 2 metros. Assim, as medidas de velocidades das ondas nesse trecho, não correspondem as medidas em camadas e sim, de uma seção que vai de um ponto a outro entre os dois furos. Obtiveram-se valores crescentes de velocidades das ondas com a profundidade. Os valores de velocidade de onda, principalmente da onda de compressão, tenderam a aumentar bastante a partir dos 10 metros, deixando uma margem à dúvida se esse é o real comportamento do material ou esses valores foram afetados pela maneira de execução do ensaio.

Valores de coeficiente de Poisson, calculados a partir das velocidades de propagação das ondas de compressão e cisalhante medidas, estão apresentados na Figura 4.13. Já a Figura 4.14 apresenta resultados obtidos para os módulos cisalhante e de 
deformação com a profundidade, para valores de pesos específicos máximos e mínimos estimados para área em estudo.
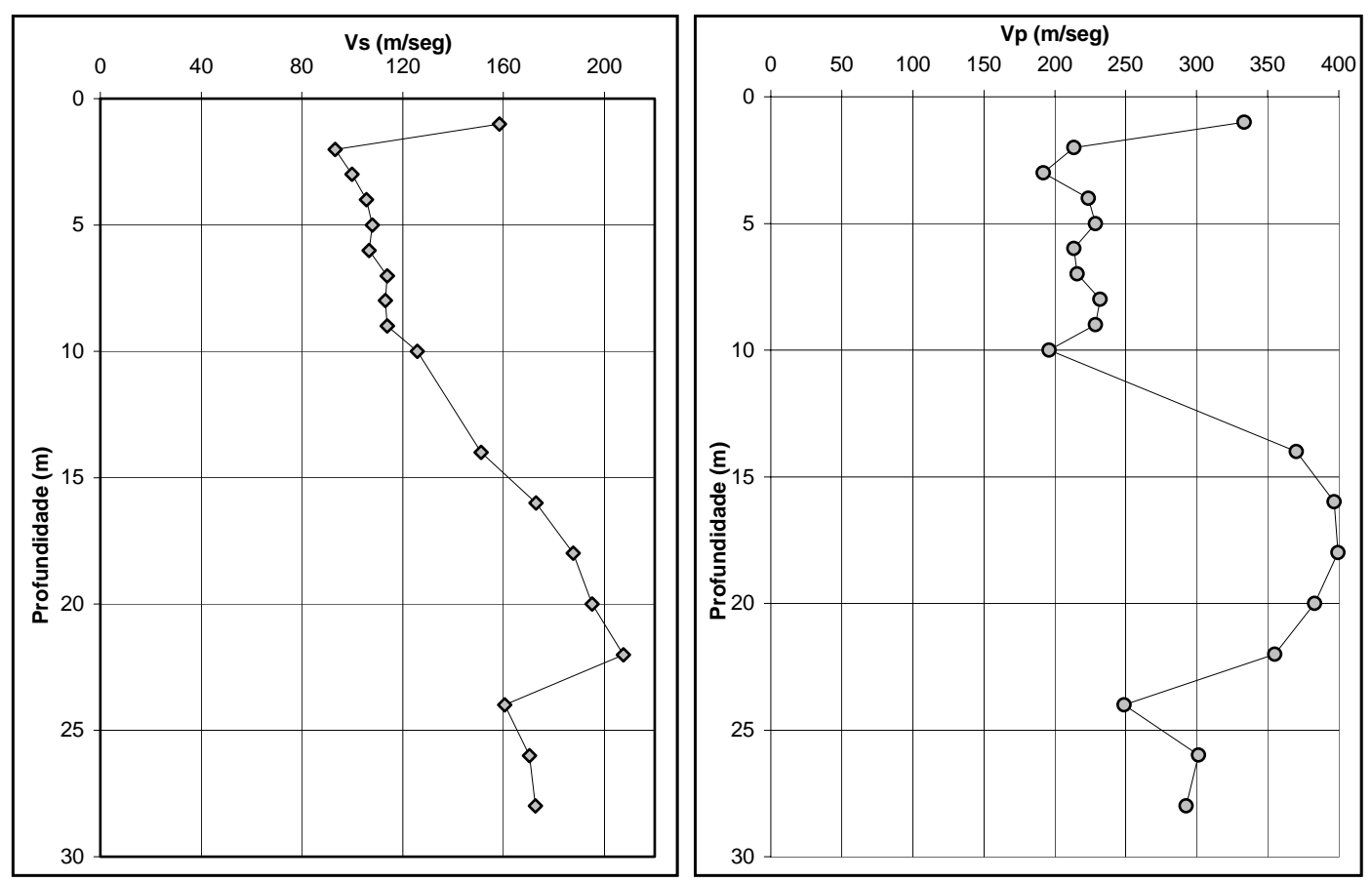

Figura 4.12 - Perfis de velocidade de propagação da onda cisalhante $\left(v_{s}\right)$ e de compressão $\left(v_{p}\right)$ no resíduo urbano estudado.

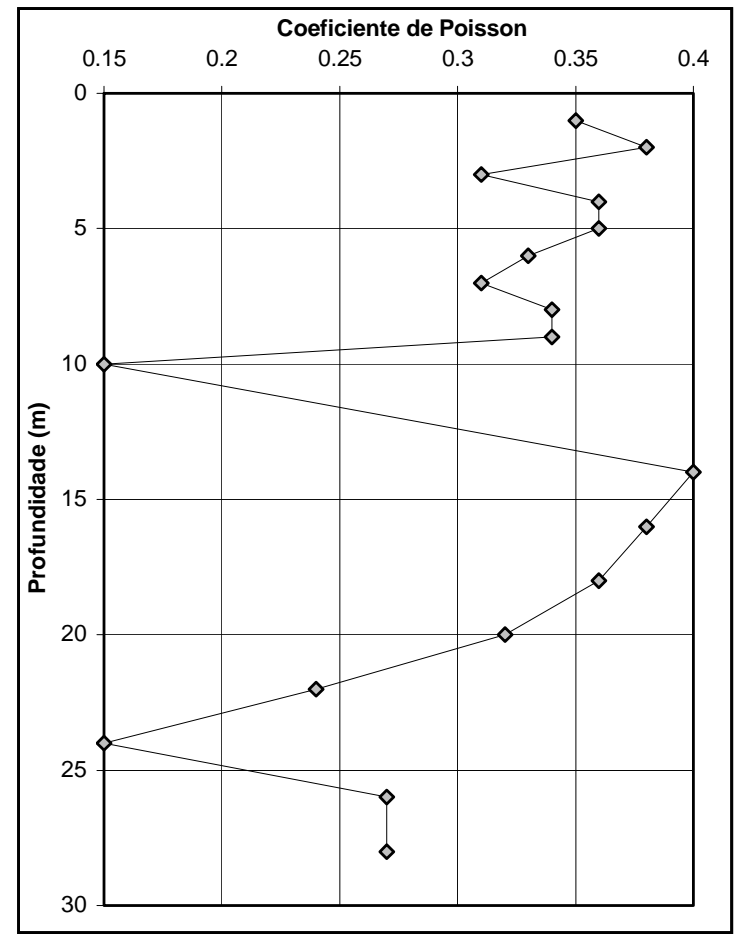

Figura 4.13 - Coeficiente de Poisson para o RSU estudado. 

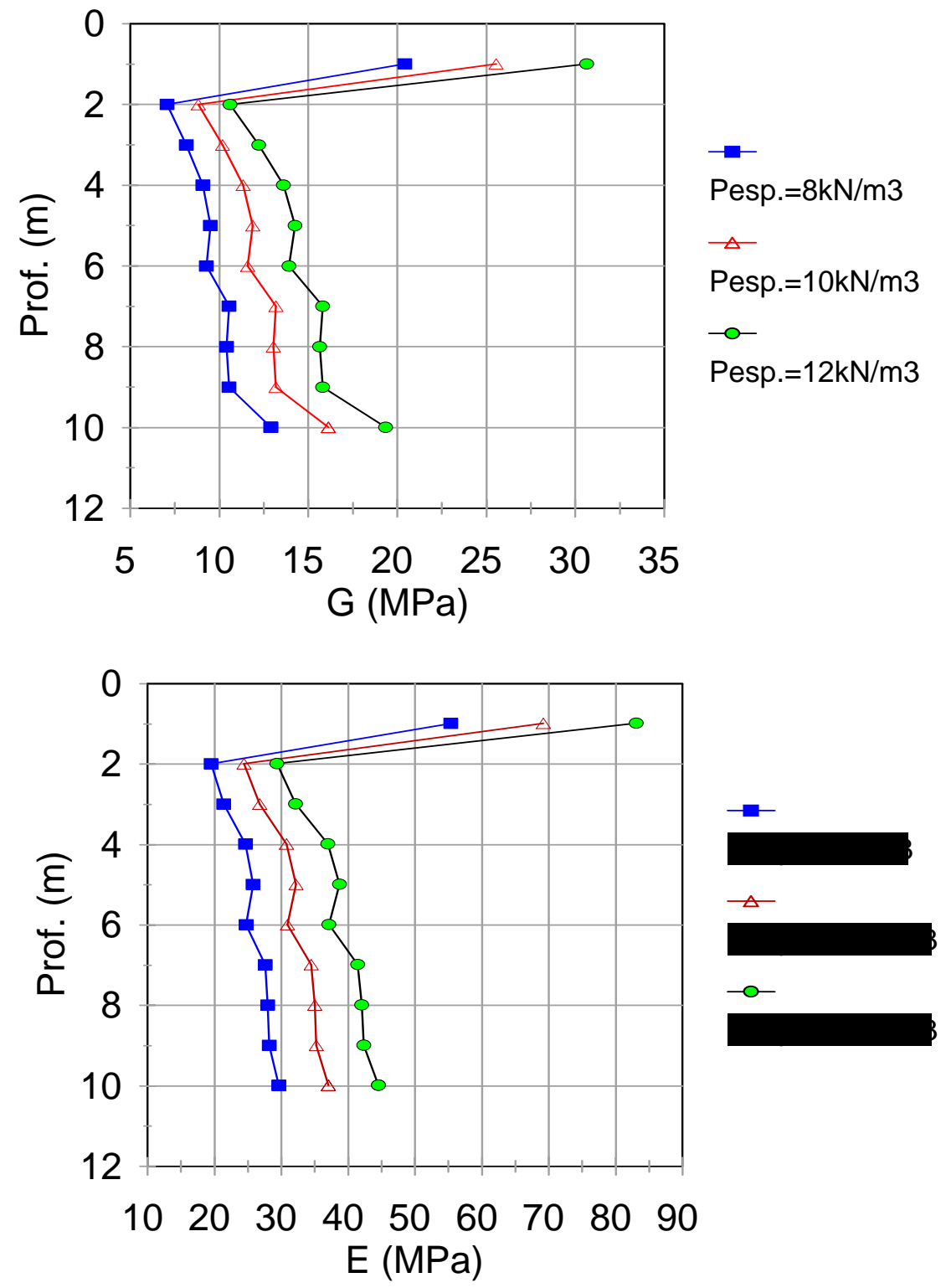

Figura 4.14 - Resultados dos módulos cisalhante e de deformação obtidos para o resíduo estudado a partir de ensaios cross-hole.

\subsection{6 - Ensaio de resistividade elétrica}

A Figura 4.15 apresenta a planta de localização da linha de caminhamento dipolodipolo realizado no Aterro Sanitário Bandeirantes. Os dados obtidos das medidas de resistividade no campo foram tratados com ajuda do software SURFE e a seção C1 obtida está apresentada na Figura 4.16. Em geral, os valores de resistividade são baixos na porção superior do aterro e apresentam um pequeno aumento em direção a base do mesmo. Nesta figura, através da diferença de resistividade foi possível estimar a localização da base do aterro. Os valores baixos de resistividade, em torno de 4ohm.m, referem-se à massa de RSU e acima deste valor tem-se o solo de fundação. 

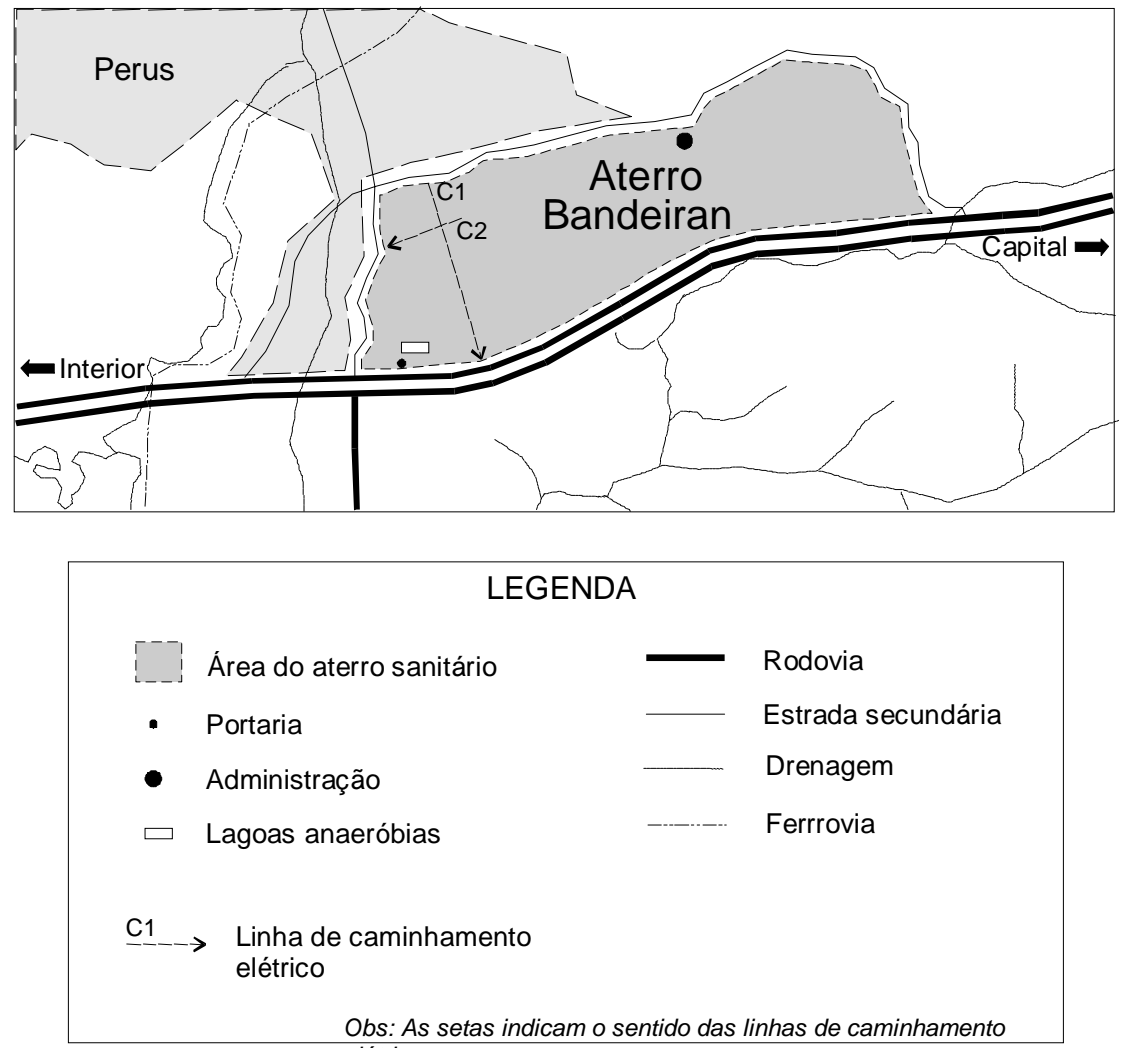

$\mathrm{N}$

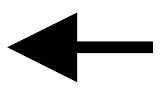

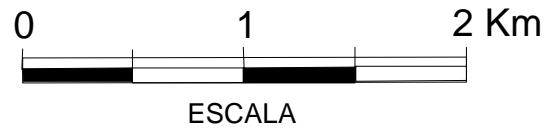

Figura 4.15 - Localização da linha de caminhamento ensaiada.

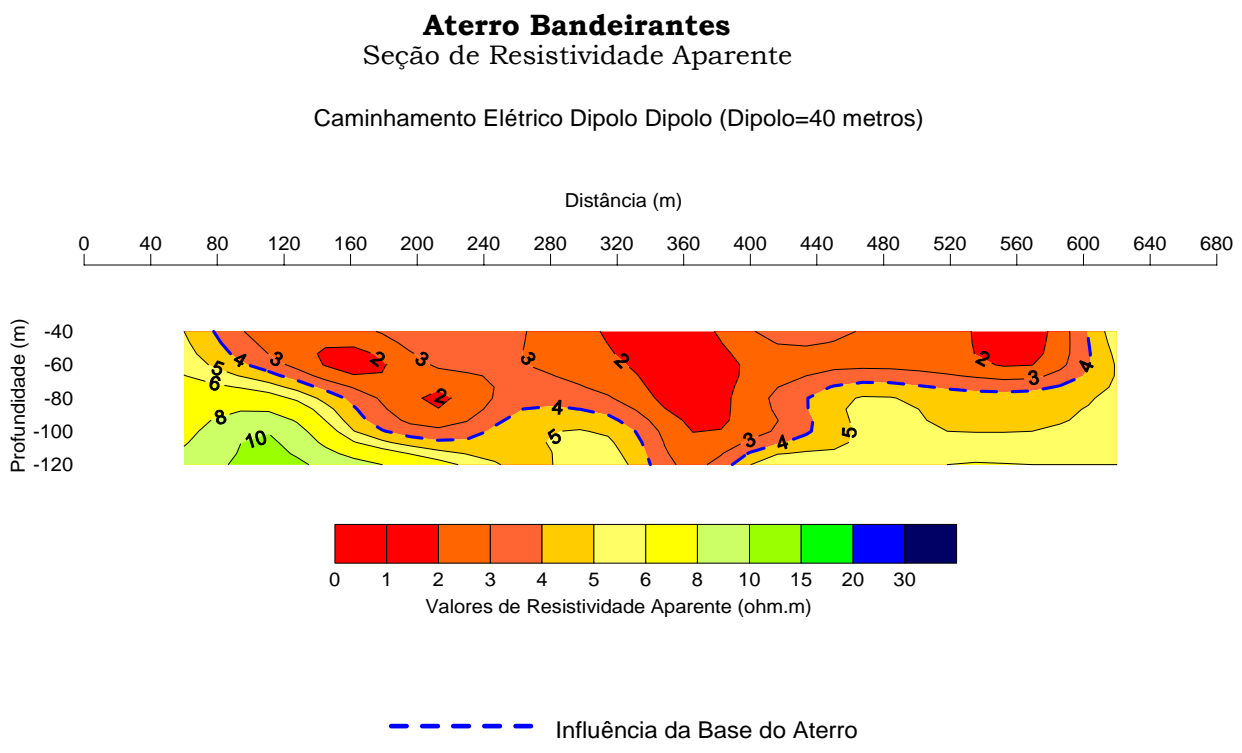

Figura 4.16 - Seção (C1) obtida do caminhamento elétrico dipolo-dipolo do aterro sanitário Bandeirantes. 


\section{2 - ENSAIOS DE CARACTERIZAÇÃO DOS RESÍDUOS SÓLIDOS URBANOS COLETADOS}

\subsection{1 - Teor de umidade}

A Figura 4.17 apresenta as variações do teor de umidade em campo com a profundidade para as duas tradagens (T1 e T2), calculado em termos de base seca. 亡̀ importante esclarecer que estes valores podem também ser expressos em base úmida, sendo dado por: $w^{`}=w^{\prime} /(1+w)$, onde $w^{`}=$ umidade em base úmida, $w=$ umidade em base seca.

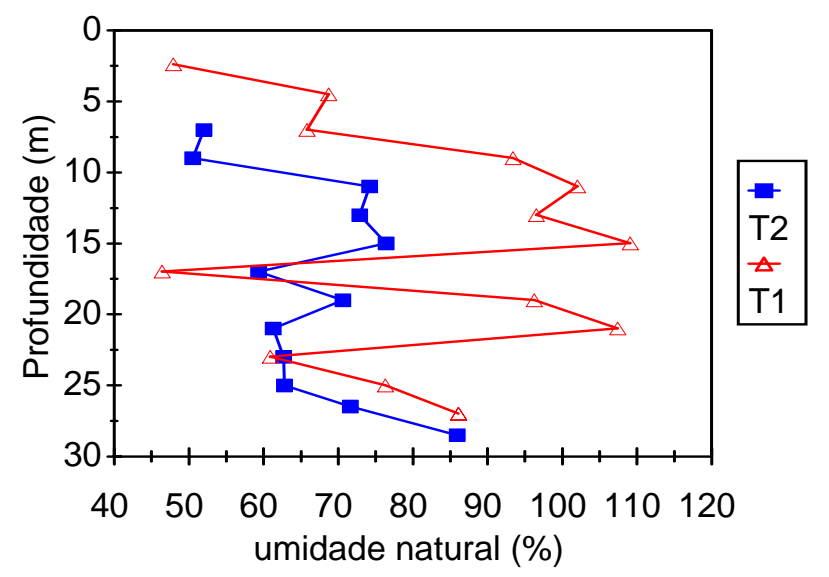

Figura 4.17 - Variação do teor de umidade in situ do RSU estudado, valores em base seca.

O teor de umidade de cada componente do resíduo, determinado através da diferença em peso entre a fração úmida segregada e a fração seca em estufa a $70^{\circ} \mathrm{C}$, está apresentado na Tabela 4.1. Nesta tabela pode-se observar diferenças marcantes no teor de umidade entre os diversos constituintes.

Tabela 4.1 - Umidade dos componentes do RSU.

\begin{tabular}{c|cc}
\hline COMPONENTES & $\begin{array}{c}\text { UMIDADE (\%) } \\
\text { Base seca }\end{array}$ & $\begin{array}{c}\text { UMIDADE (\%) } \\
\text { Base úmida }\end{array}$ \\
\hline Metais & 19,6 & 16,4 \\
Papel & 74,8 & 42,8 \\
Vidro & 5,9 & 5,57 \\
Plástico & 41,5 & 29,3 \\
Borracha & 24,5 & 19,6 \\
Têxteis & 55,0 & 35,5 \\
Pedra & 12,6 & 11,2 \\
Madeira & 69,8 & 41,1 \\
Pasta Orgânica & 47,0 & 32,0 \\
\hline
\end{tabular}




\subsection{2 - Composição gravimétrica}

As Figuras 4.18 e 4.19 apresentam a composição física dos resíduos coletados em sub-trechos de mais ou menos 2 metros ao longo do perfil. A composição apresentada para cada material está em termos de peso seco. Nestas figuras, nenhuma tendência de variação da composição do resíduo, com a profundidade foi observada mas pôde-se observar a ocorrência de grande quantidade de fração pastosa, composta por matéria orgânica e inertes e uma considerável quantidade de plástico, madeira e pedra.

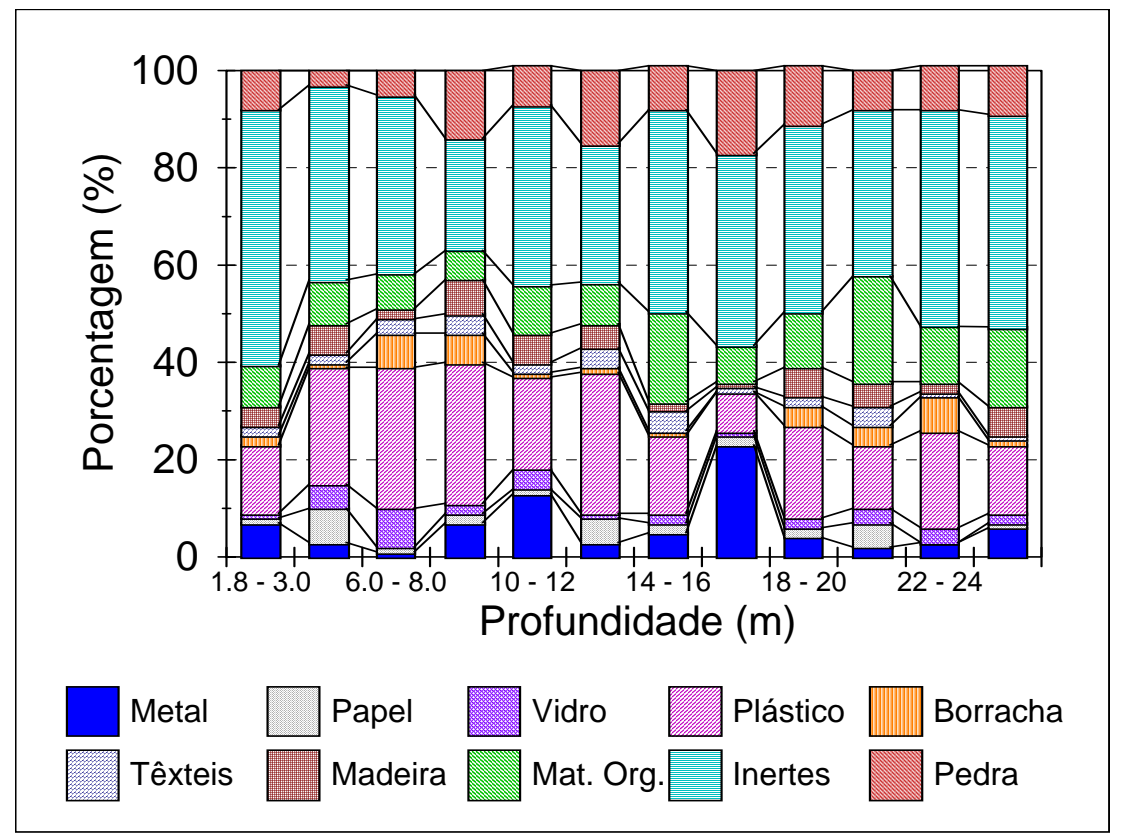

Figura 4.18 - Composição do RSU aterrado, tradagem T1.

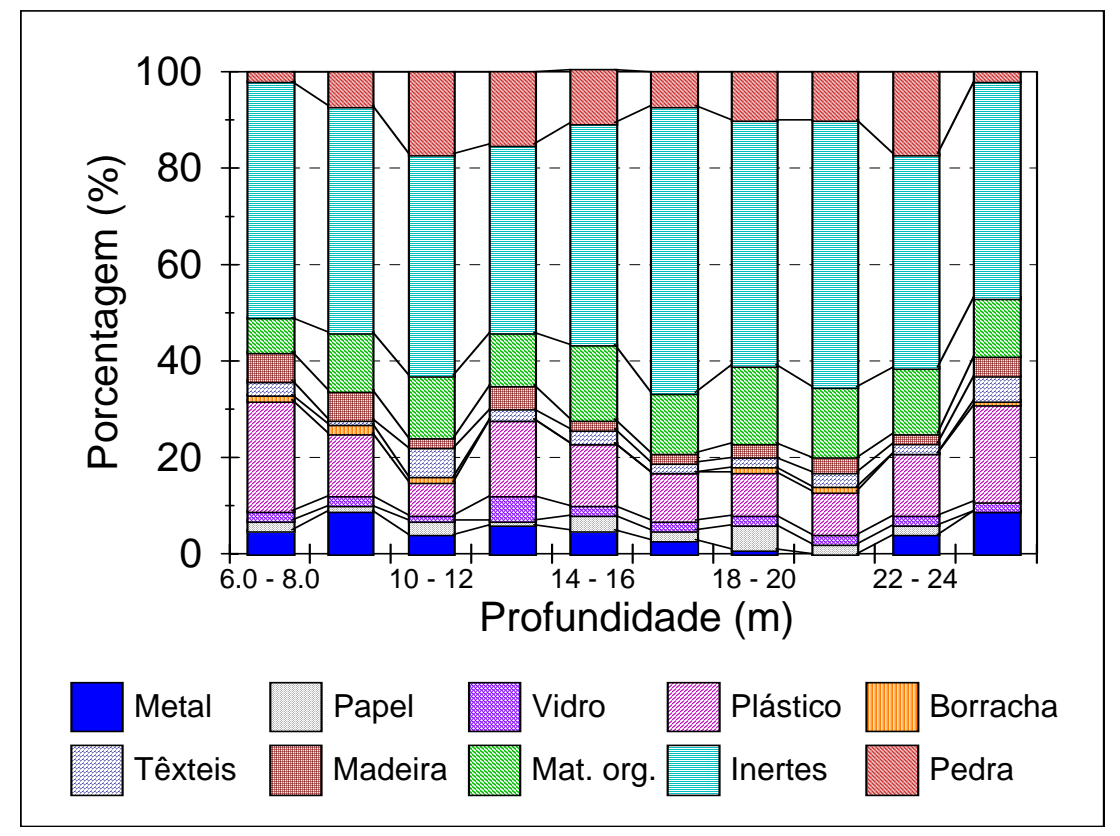

Figura 4.19 - Composição do RSU aterrado, tradagem T2. 
A partir da execução dos ensaios de STV realizados e apresentados no próximo item, foi possível dividir a fração pastosa em inertes e matéria orgânica quimicamente oxidável, isto é, matéria orgânica ainda passível de sofrer decomposição. As figuras 4.18 e 4.19 apresentam um reduzido valor de matéria orgânica em relação aos inertes, mostrando que RSU está num estágio avançado de degradação, mas ainda com presença de materiais de grandes dimensões como plásticos, madeiras, metais, etc.

A composição física média para os resíduos domiciliares aterrados estudados, obtida por meio de análise estatística da ocorrência em peso seco dos materiais em cada profundidade, está apresentada na Figura 4.20 e consta de 55\% de fração pastosa (12\% de matéria orgânica quimicamente oxidável e $43 \%$ de inertes), $4 \%$ de madeira, 10\% de pedra, $3 \%$ de têxteis, $2 \%$ de borracha, $17 \%$ de plástico, $2 \%$ de vidro, $2 \%$ de papel e $5 \%$ de metal.

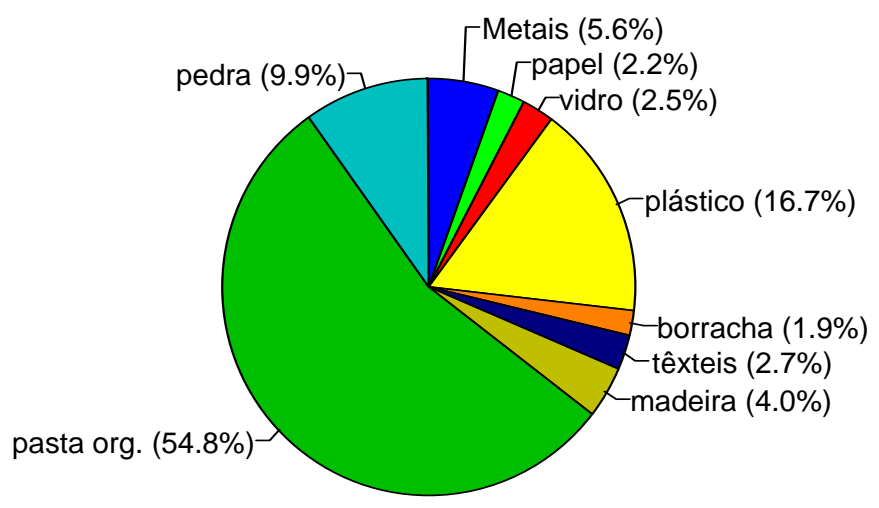

Figura 4.20 - Composição média para o RSU estudado.

\subsection{3 - Tamanho e distribuição dos componentes dos resíduos.}

As Figuras 4.21 a 4.22 apresentam as curvas de distribuição do tamanho dos componentes do resíduo estudado. No processo de peneiramento foram excluídos os materiais plásticos e têxteis, os quais representam aproximadamente $20 \%$ em peso da amostra total.

\subsection{4 - Sólidos totais voláteis}

A Figura 4.23 apresenta os valores de STV para as duas tradagens com a profundidade. O STV encontrado varia entre 120 a 270mg/g. Observa-se para a profundidade de $22 \mathrm{~m}$, um aumento no valor do STV. Essa variação pode ser devido à ocorrência do selo de cobertura nesta profundidade e ou heterogeneidade das amostras.

O STV médio, em porcentagem, está em torno de $22 \%$ para os dois perfis no final dos 15 anos de aterramento do RSU. Para a fração orgânica dos resíduos sólidos 
domiciliares urbanos frescos, SILVA et al. (1998) obtiveram uma porcentagem de STV próxima a $75 \%$.

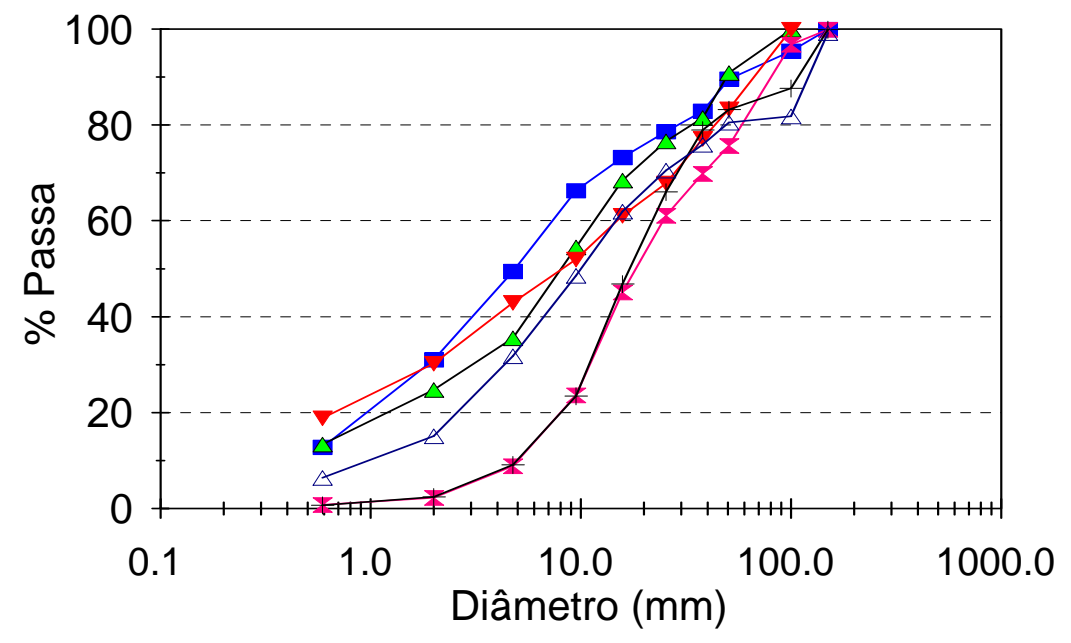

$-\mathrm{T} 1-1 \triangleleft \mathrm{T} 1-2 \rightarrow \mathrm{T} 1-3 \approx \mathrm{T} 1-4+\mathrm{T} 1-5 \triangle \mathrm{T} 1-6$

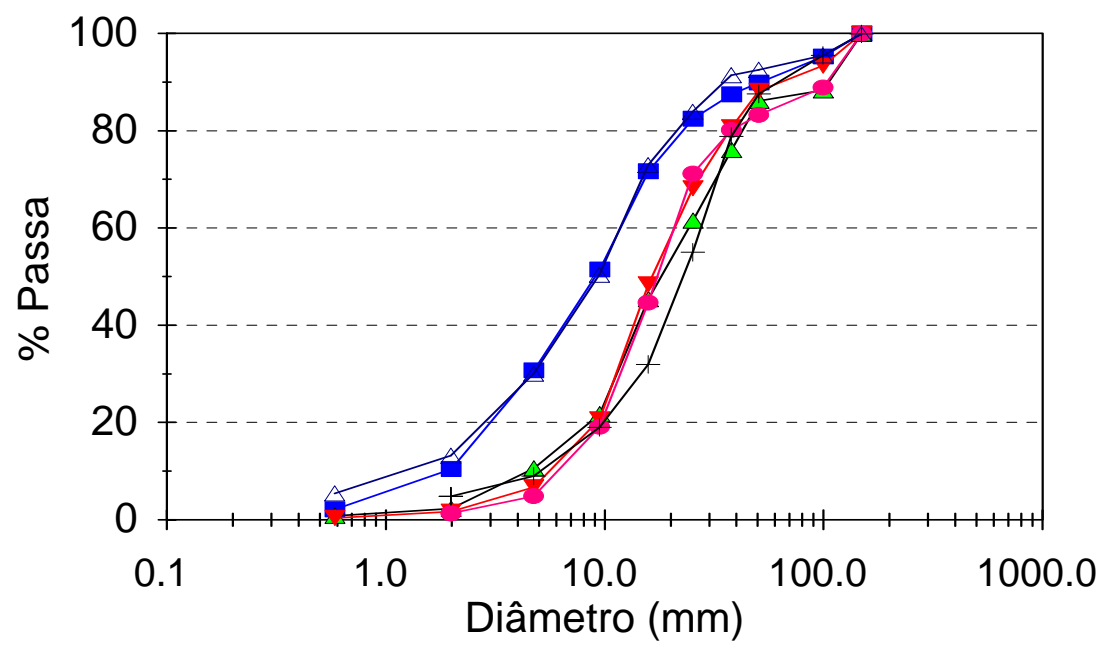

$\mathrm{T} 1-7 \rightarrow \mathrm{T} 1-8 \rightarrow \mathrm{T} 1-9 \multimap \mathrm{T} 1-10+\mathrm{T} 1-11 \triangle \mathrm{T} 1-12$

Figura 4.21 - Curvas de distribuição do tamanho dos componentes resultantes da tradagem $T 1$. 


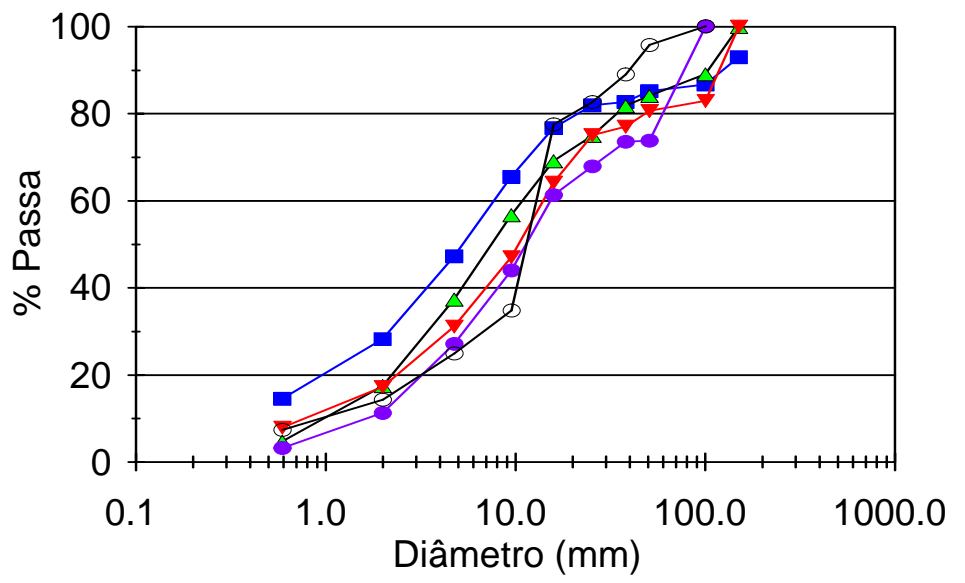

$-\mathrm{T} 2-1 \triangle \mathrm{T} 2-2-\mathrm{T} 2-3-\mathrm{T} 2-4-\mathrm{T} 2-5$

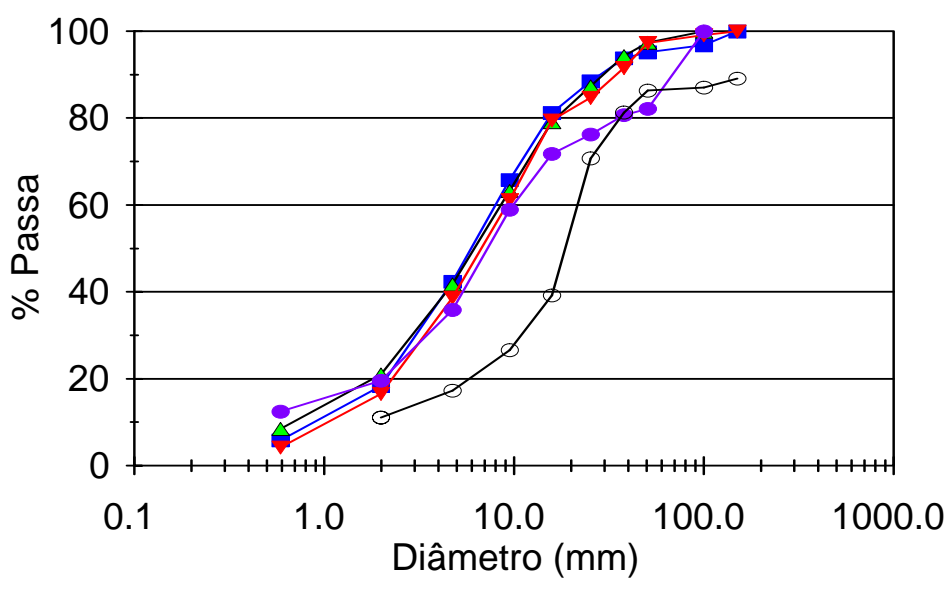

$\mathrm{T} 2-6 \rightarrow \mathrm{T} 2-7 \rightarrow \mathrm{T} 2-8 \bullet \mathrm{T} 2-9 \bullet \mathrm{T} 2-10$

Figura 4.22 - Curvas de distribuição do tamanho dos componentes resultantes da tradagem $T 2$.

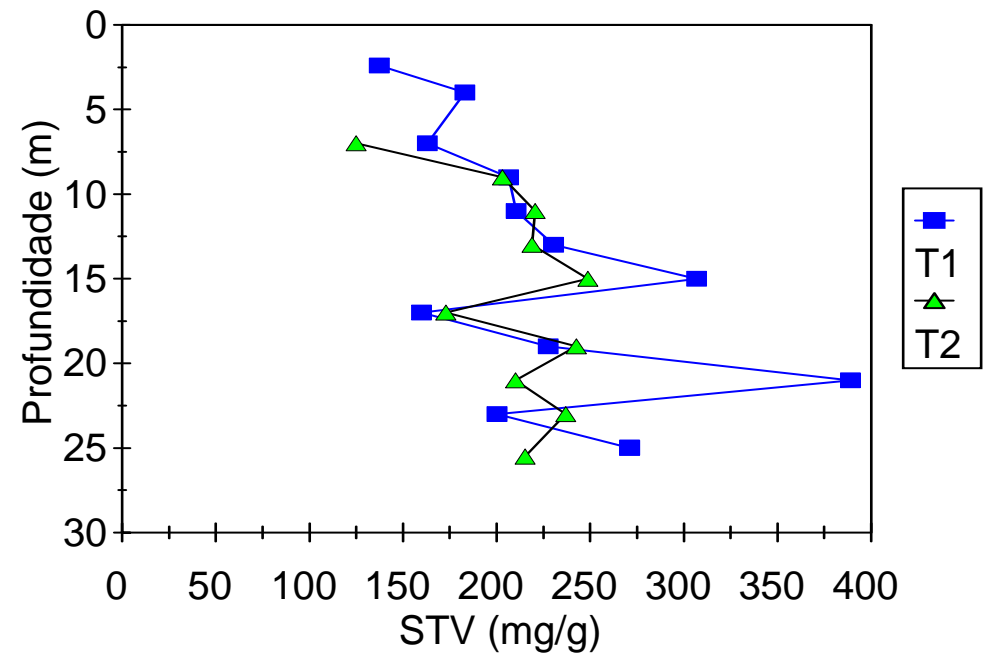

Figura 4.23 - Valores do STV ao longo da profundidade para o RSU estudado. 


\subsection{5 - Demanda química de oxigênio - DQO}

A Figura 4.24 apresenta os resultados de DQO $(\mathrm{mg} / \mathrm{g})$ obtidos para as duas tradagens, os quais variaram em torno de $100-175 \mathrm{mg} / \mathrm{g}$. A DQO média encontrada, em porcentagem é da ordem de $13 \%$. Para a amostra na profundidade de $22 \mathrm{~m}$ obteve-se um aumento significante tanto no valor de DQO como no do STV. È provável que isso seja em função da ocorrência de uma camada de solo de cobertura da células nesta profundidade.

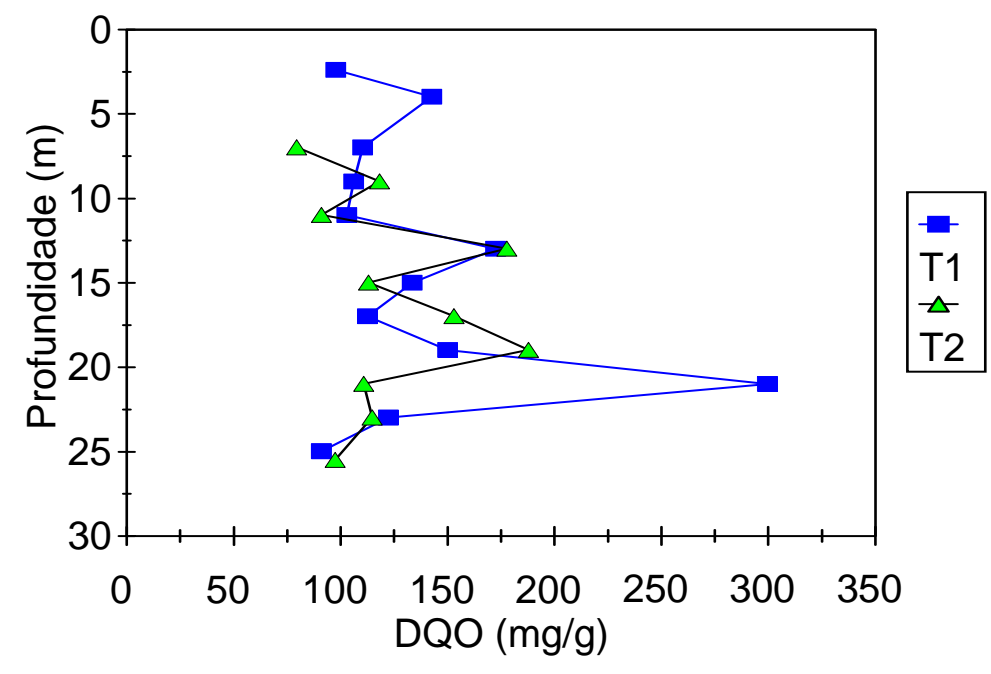

Figura 4.24 - Valores DQO ao longo da profundidade para RSU estudado.

\subsection{6 - Lixiviação e solubilização}

A Tabela 4.2 apresenta os resultados das análises químicas, para os extratos solubilizados e lixiviados, para diversas amostras do RSU coletado.

De acordo com NBR 10.004/87, para o resíduo ser classificado como classe III (inerte), nenhum dos constituintes solubilizados e lixiviados deve apresentar concentrações superiores aos padrões de potabilidade de água. Como pode ser visto na Tabela 4.2, os resíduos estudados apresentaram concentrações de ferro, manganês e cromo acima dos padrões, além de propriedades como combustibilidade, degradabilidade e solubilidade em água. Dessa forma são classificados, de acordo com NBR 10.004/87, como Classe II (não inertes). A Tabela 4.2, também, apresenta os valores de $\mathrm{pH}$ para cada amostra. $\mathrm{O} \mathrm{pH}$ das amostras da tradagem T1 variou entre 7,60 a 8,0, já as amostras da tradagem T2 apresentaram valores um pouco menores, na faixa de 6,9 a 7,8 . 
Tabela 4.2 - Resultados de análise química dos extratos lixiviados solubilizados do RSU estudado.

\begin{tabular}{|c|c|c|c|c|c|c|c|c|}
\hline \multicolumn{9}{|c|}{ ENSAIO DE LIXIVIAÇÃO } \\
\hline PARÂMETROS & Limite máx & T1-1 & T1-4 & T1-5 & T1-7 & T1-9 & T1-11 & T1-12 \\
\hline Zinco (mg/L) & & 6.50 & 22.0 & 6.00 & 11.0 & 6.00 & 7.00 & 7.40 \\
\hline Chumbo (mg/L) & 5.0 & nd & nd & nd & nd & nd & nd & nd \\
\hline Cádmio (mg/L) & 0.5 & nd & nd & nd & nd & nd & nd & nd \\
\hline Níquel (mg/L) & & 0.05 & 0.58 & 0.16 & 0.55 & 0.25 & 0.25 & 0.30 \\
\hline Ferro (mg/L) & & 9.50 & 25.00 & 11.0 & 11.20 & 14.50 & 24.60 & 13.00 \\
\hline Manganês (mg/l) & & 3.42 & 7.00 & 2.13 & 4.57 & 3.12 & 3.18 & 2.43 \\
\hline Cobre (mg/l) & & 0.04 & 0.26 & 0.05 & 0.36 & 0.15 & 0.20 & 0.21 \\
\hline Cromo (mg/L) & & 0.04 & 0.06 & 0.01 & 0.07 & 0.07 & 0.02 & 0.06 \\
\hline pH inicial & & 7,60 & 8,46 & 7,98 & 8.00 & 7,70 & 8.00 & 8.12 \\
\hline pH final & & 5,03 & 4,98 & 5,01 & 5,05 & 5,07 & 4,95 & 4,96 \\
\hline $\begin{array}{l}\text { Volume de ácido } \\
\text { acético }(\mathrm{mL})\end{array}$ & & 101,5 & 211,0 & 171,0 & 265,0 & 190,0 & 210,5 & 188,5 \\
\hline \multicolumn{9}{|c|}{ ENSAIO DE SOLUBILIZAÇÃO } \\
\hline PARÂMETROS & Limite máx. & T1-1 & T1-4 & T1-5 & T1-7 & T1-9 & T1-11 & T1-12 \\
\hline Zinco (mg/L) & 5.0 & 0.10 & 0.33 & 0.18 & 0.33 & 0.21 & 0.32 & 0.30 \\
\hline Chumbo (mg/L) & 0.05 & $\mathrm{nd}$ & $\mathrm{nd}$ & nd & nd & nd & $\mathrm{nd}$ & nd \\
\hline Cádmio (mg/L) & 0.005 & nd & nd & nd & nd & nd & nd & nd \\
\hline Níquel (mg/L) & & nd & 0.21 & 0.14 & 0.24 & 0.16 & 0.10 & 0.15 \\
\hline Ferro $(\mathrm{mg} / \mathrm{L})$ & 0.3 & 0.83 & 1.48 & 1.40 & 4.50 & 3.32 & 2.72 & 3.20 \\
\hline Manganês (mg/L) & 0.1 & 0.12 & 0.18 & 0.13 & 0.23 & 0.21 & 0.09 & 0.12 \\
\hline Cobre $(\mathrm{mg} / \mathrm{L})$ & 1.0 & 0.05 & 0.16 & 0.07 & 0.14 & 0.02 & 0.14 & 0.20 \\
\hline Cromo (mg/L) & 0.05 & $\mathrm{nd}$ & 0.09 & 0.01 & 0.04 & 0.02 & 0.01 & 0.07 \\
\hline
\end{tabular}

* nd = não detectado

\begin{tabular}{|c|c|c|c|c|c|c|c|c|}
\hline \multicolumn{9}{|c|}{ ENSAIO DE LIXIVIAÇÃO } \\
\hline PARÂMETROS & Limite máx. & T2-1 & T2-3 & T2-5 & T2-6 & T2-8 & T2-9 & T2-10 \\
\hline Zinco (mg/L) & & 3,90 & 7,90 & 4,00 & 7,60 & 6,80 & 6,00 & 3,00 \\
\hline Chumbo (mg/L) & 5.0 & nd & nd & $\mathrm{Nd}$ & nd & nd & nd & nd \\
\hline Cádmio (mg/L) & 0.5 & nd & nd & nd & nd & nd & nd & nd \\
\hline Níquel (mg/L) & & nd & 0,07 & 0,02 & 0.03 & 0,47 & 0,27 & 0,14 \\
\hline Ferro (mg/L) & & 5,95 & 16,70 & 7,90 & 12,00 & 19,50 & 13,60 & 15,20 \\
\hline Manganês (mg/L) & & 1,58 & 1,54 & 2,14 & 2,06 & 1,90 & 2,40 & 1,65 \\
\hline Cobre (mg/L) & & 0,11 & 0,03 & 0,13 & 0,14 & 0,48 & 0,32 & 0,07 \\
\hline Cromo (mg/L) & & 0,02 & 0,17 & 0,05 & 0,14 & 0,12 & 0,14 & 0,08 \\
\hline pH inicial & & 7,89 & 7,40 & 6,96 & 7,43 & 7,03 & 6,96 & 7,47 \\
\hline pH final & & 5,00 & 5,02 & 5,01 & 5,00 & 5,00 & 4,97 & 4,95 \\
\hline $\begin{array}{l}\text { Volume de ácido } \\
\text { acético }(\mathrm{mL})\end{array}$ & & 117,5 & 181,0 & 187,0 & 193,0 & 174,0 & 210,0 & 143,0 \\
\hline \multicolumn{9}{|c|}{ ENSAIO DE SOLUBILIZAÇÃO } \\
\hline PARÂMETROS & Limite máx. & T2-1 & T2-3 & T2-5 & T2-6 & T2-8 & T2-9 & T2-10 \\
\hline Zinco $(\mathrm{mg} / \mathrm{L})$ & 5.0 & 0.12 & 0.23 & 0.22 & 0.15 & 0.43 & 0.33 & 0.23 \\
\hline Chumbo (mg/L) & 0.05 & nd & nd & nd & nd & nd & nd & nd \\
\hline Cádmio (mg/L) & 0.005 & nd & nd & nd & nd & nd & nd & nd \\
\hline Níquel (mg/L) & & 0.13 & 0.23 & 0.29 & 0.07 & 0.54 & 0.38 & 0.26 \\
\hline Ferro (mg/L) & 0.3 & 2.32 & 7.80 & 21.50 & 7.86 & 14.00 & 11.0 & 7.10 \\
\hline Manganês (mg/L) & 0.1 & 0.16 & 0.23 & 0.56 & 0.35 & 0.70 & 0.77 & 0.39 \\
\hline Cobre $(\mathrm{mg} / \mathrm{L})$ & 1.0 & 0.04 & 0.04 & 0.07 & 0.04 & 0.33 & 0.12 & 0.08 \\
\hline Cromo (mg/L) & 0.05 & 0.12 & 0.15 & 0.10 & 0.25 & 0.30 & 0.26 & 0.26 \\
\hline
\end{tabular}




\section{3 - DETERMINAÇÃO DO PESO ESPECÍFICO DAS PARTÍCULAS PARA AS AMOSTRAS REPRESENTATIVAS}

A Tabela 4.3 apresenta os pesos específicos das partículas sólidas obtidas para as três amostras estudadas. Os valores na Tabela 4.3 são valores médios resultantes de vários ensaios executados para cada amostra.

Tabela 4.3 - Peso específico das partículas sólidas para o RSU estudado.

\begin{tabular}{c|c}
\hline Amostras & $\gamma \mathbf{s}\left(\mathbf{k N} / \mathbf{m}^{\mathbf{3}}\right)$ \\
\hline T1B & 23,35 \\
T2A & 22,41 \\
T2B & 25,07 \\
\hline
\end{tabular}

A amostra T2B possui um peso específico bem maior que as outras duas. Isso pode ser devido ao fato desta apresentar em sua constituição uma maior quantidade de solo. $\mathrm{O}$ método de amostragem utilizado não permitiu evitar a contaminação de algumas amostras com solo de cobertura das células.

É importante frisar que, apesar de todo cuidado na obtenção das amostras para execução dos ensaios, os resultados podem ser afetados pela heterogeneidade inerente do material, pelas variações na composição e alteração da amostra. Assim, os valores dos pesos específicos das partículas sólidas, encontradas para o resíduo em questão, não devem ser usados indiscriminadamente para resíduo de outro local e com constituição diferente, pois este depende do estado de alteração dos componentes e da composição do material.

\section{4 - ENSAIOS DE COMPRESSÃO TRIAXIAL}

\subsection{1 - Ensaios consolidados drenados (CD)}

As Figuras 4.25 a 4.27 apresentam os resultados obtidos a partir dos ensaios triaxiais convencionais, com diâmetro de $150 \mathrm{~mm}$ e altura de $300 \mathrm{~mm}$, consolidados isotropicamente e cisalhados em condições drenadas (CD), para a amostra T2A, na umidade natural e com diferentes pesos específicos iniciais. Para cada peso específico, são apresentados os gráficos de diferença de tensões principais e de deformação volumétrica durante a fase de cisalhamento, em função da deformação axial.

É interessante notar nos gráficos tensão - deformação, que o RSU exibe um comportamento onde a diferença de tensões principais aumenta continuamente com as 
deformações axiais, sem atingir qualquer pico na curva tensão - deformação ou sem atingir um valor último.

Para os corpos de prova da amostra T2A compactados com pesos específicos de 10, 12 e $14 \mathrm{kN} / \mathrm{m}^{3}$ obtiveram-se, na fase de cisalhamento, deformações volumétricas de compressão no cisalhamento em torno de 8,11 e 14\%, para pressões de confinamento de 400, 200 e $100 \mathrm{kPa}$, respectivamente.

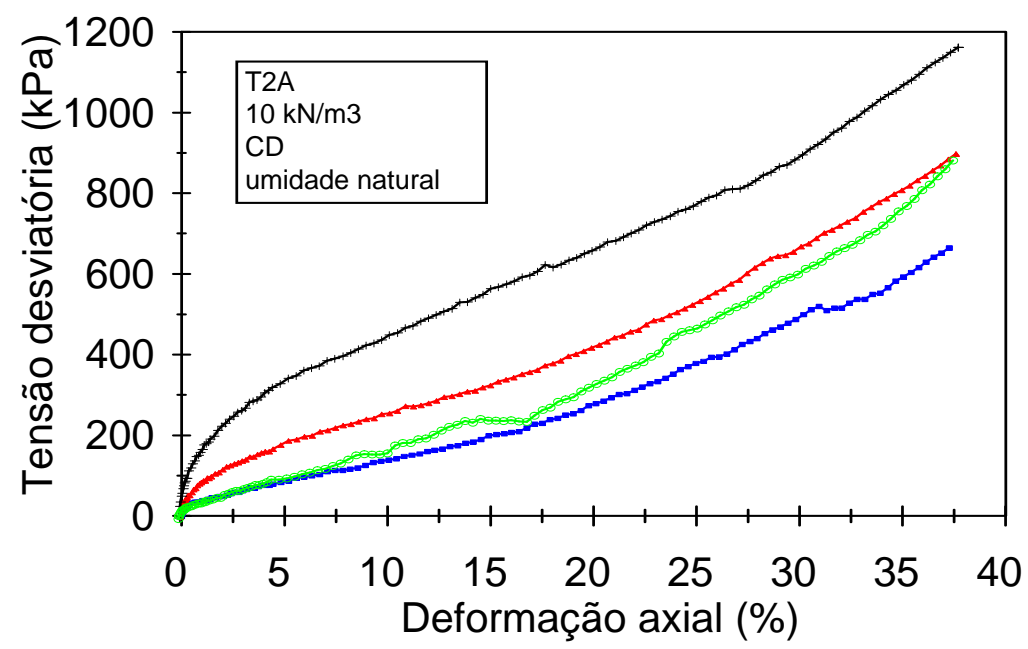

$$
\rightarrow 100 \mathrm{kPa} \rightarrow 200 \mathrm{kPa}+400 \mathrm{kPa} \rightarrow-100 \mathrm{kPa}
$$

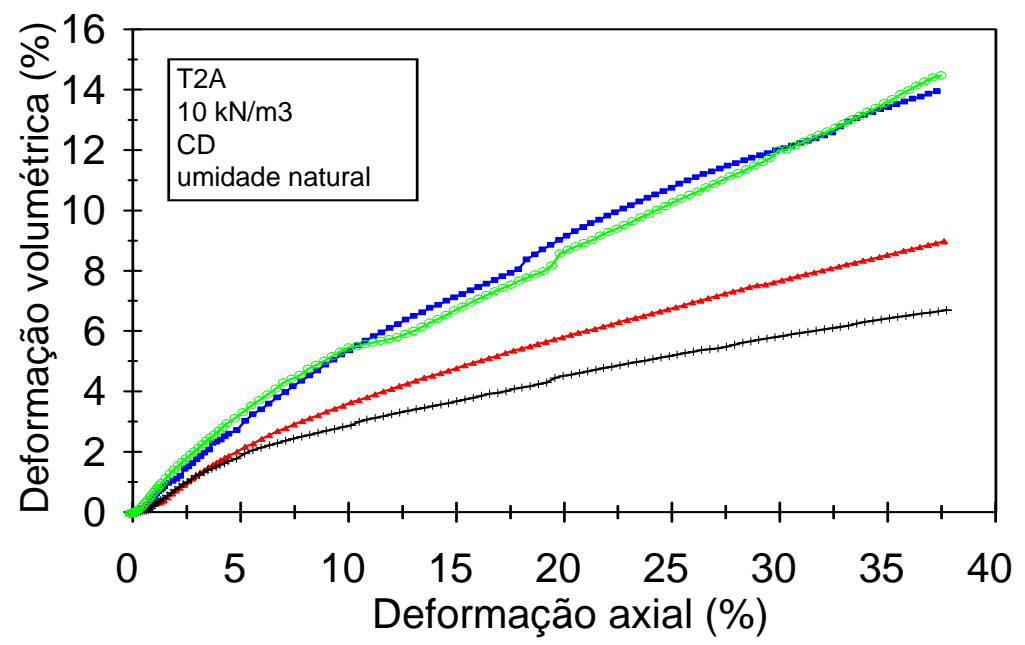

$$
\rightarrow-100 \mathrm{kPa} \rightarrow 200 \mathrm{kPa}+400 \mathrm{kPa}-100 \mathrm{kPa}
$$

Figura 4.25 - Resultados dos ensaios $C D_{\text {nat }}$ para a amostra T2A, (T2a10nat), com diâmetro de $150 \mathrm{~mm}$ e altura de $300 \mathrm{~mm}$, com peso específico inicial de $10 \mathrm{kN} / \mathrm{m}^{3}$ e umidade de moldagem de $63,2 \%$. 
As deformações volumétricas resultantes do processo de consolidação isotrópica, apesar de não terem sido apresentadas aqui, foram consideradas na correção da área transversal do corpo de prova no final do adensamento e, em geral, variaram entre 15 a $36 \%$ para pressão de confinamento de 100 a $400 \mathrm{kPa}$.

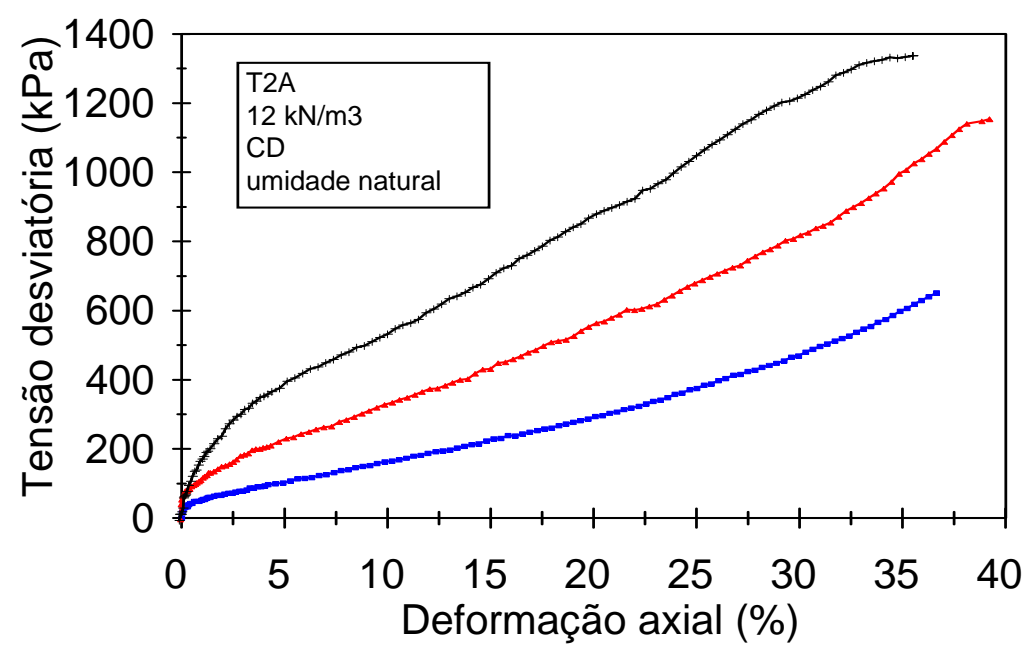

$-100 \mathrm{kPa}-200 \mathrm{kPa}+400 \mathrm{kPa}$

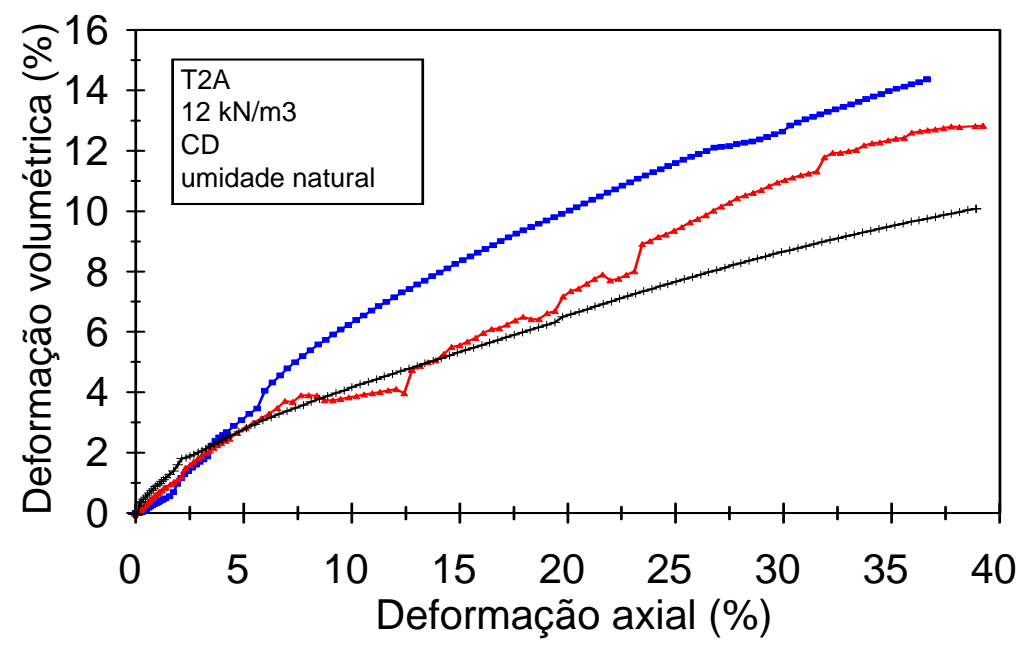

$$
-100 \mathrm{kPa} \rightarrow 200 \mathrm{kPa}+400 \mathrm{kPa}
$$

Figura 4.26 - Resultados dos ensaios $C D_{\text {nat }}$ para a amostra T2A (T2a12nat), com diâmetro de $150 \mathrm{~mm}$ e altura de $300 \mathrm{~mm}$, com peso específico inicial de $12 \mathrm{kN} / \mathrm{m}^{3}$ e umidade de moldagem de $66,6 \%$ para corpos de prova com pressão de confinamento de 100 e $200 \mathrm{kPa}$ e umidade $77,4 \%$ para o de $400 \mathrm{kPa}$. 


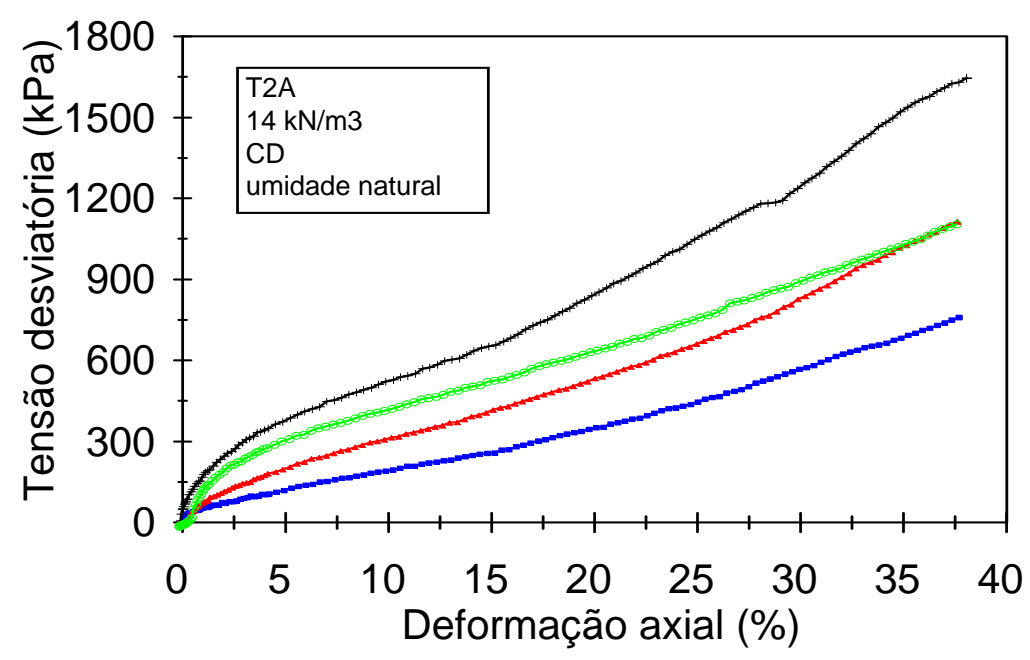

$\rightarrow 100 \mathrm{kPa} \rightarrow 200 \mathrm{kPa}+400 \mathrm{kPa}-400 \mathrm{kPa}$

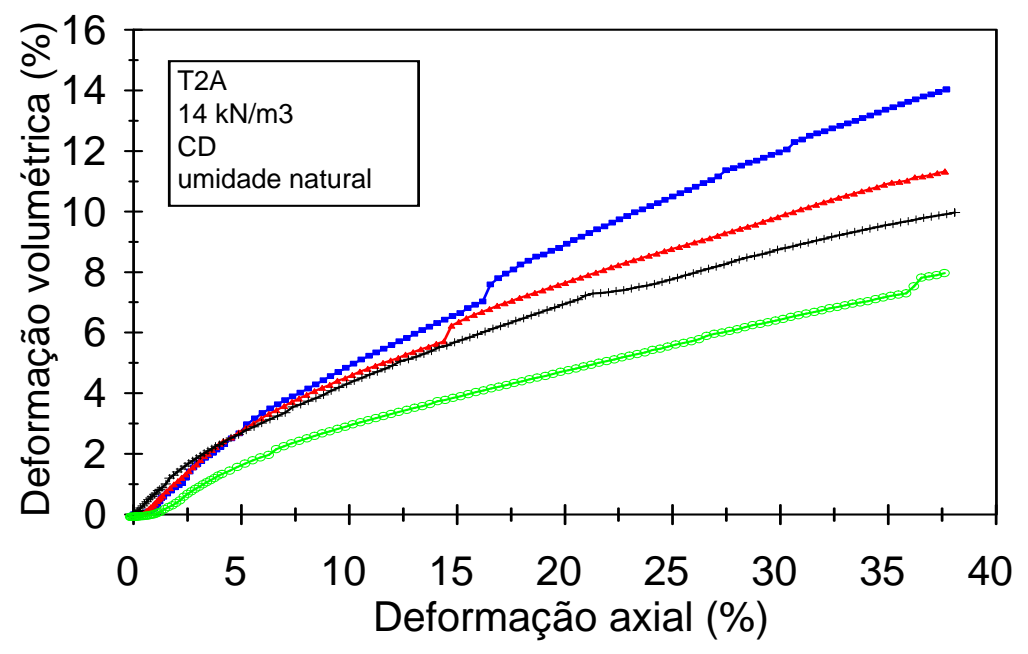

$$
-100 \mathrm{kPa}-200 \mathrm{kPa}+400 \mathrm{kPa}-400 \mathrm{kPa}
$$

Figura 4.27 - Resultados dos ensaios $C D_{\text {nat }}$ para a amostra T2A (T2a14nat), com diâmetro de $150 \mathrm{~mm}$ e altura de $300 \mathrm{~mm}$, com peso específico inicial de $14 \mathrm{kN} / \mathrm{m}^{3}$ e umidade de moldagem de $65,3 \%$.

A Tabela 4.4 apresenta as características dos corpos de prova no final do adensamento para os ensaios triaxiais executados. Para os ensaios saturados, não foi possível coletar o liquido drenado, pois este fluiu para a interface de ar-água de aplicação da contra pressão. Para esse caso, consideraram-se a deformação volumétrica e o teor de umidade no final do ensaio, após cisalhamento, como ponto de partida para obtenção das características do corpo de prova no fim do adensamento. 
Tabela 4.4 - Principais características, dos corpos de prova de $150 \mathrm{~mm}$ de diâmetro e $300 \mathrm{~mm}$ de altura submetidos à ensaios $C D$, após adensamento.

\begin{tabular}{|c|c|c|c|c|c|c|c|c|}
\hline \multirow{2}{*}{ Amostra } & \multirow{2}{*}{ Ensaio } & \multirow{2}{*}{$\mathrm{N}^{\circ}$} & \multirow{2}{*}{$\begin{array}{c}\sigma_{3} \\
(\mathrm{kPa})\end{array}$} & \multirow{2}{*}{$\begin{array}{c}\gamma_{\text {nat }} \\
\left(\mathrm{kN} / \mathrm{m}^{3}\right)\end{array}$} & \multicolumn{2}{|c|}{ Adensamento } & \multirow{2}{*}{$\begin{array}{l}\gamma_{\mathrm{d} \text { adens }} \\
\left(\mathrm{kN} / \mathrm{m}^{3}\right)\end{array}$} & \multirow{2}{*}{$\mathbf{e}_{\text {aden }}$} \\
\hline & & & & & h (cm) & $D(\mathrm{~cm})$ & & \\
\hline \multirow{18}{*}{$\mathrm{T} 2 \mathrm{~A}$} & $\mathrm{CD}_{\text {nat }}$ & 1 & 100 & 12,0 & 28.3 & 14.27 & 8,43 & 1,657 \\
\hline & & 2 & 200 & 12,2 & 27.12 & 13.29 & 10,10 & 1,217 \\
\hline & T2a12nat & 3 & 400 & 12,2 & 26.52 & 13.16 & 10,04 & 1,233 \\
\hline & $\mathrm{CD}_{\text {sat }}$ & 1 & 100 & 12,2 & 27,50 & 13,98 & 8,84 & 1,536 \\
\hline & & 2 & 200 & 12,2 & 26,89 & 13,67 & 9,78 & 1,291 \\
\hline & T2a12sat & 3 & 400 & 12,1 & 26,28 & 13,32 & 10,50 & 1,133 \\
\hline & & 1 & 100 & 10,14 & 26,41 & 13,27 & 8,92 & 1,510 \\
\hline & $C D_{\text {nat }}$ & 2 & 200 & 10,18 & 26,44 & 13,20 & 9,03 & 1,482 \\
\hline & & 3 & 400 & 10,17 & 26,30 & 13,15 & 9,16 & 1,445 \\
\hline & T2a10nat & 4 & 100 & 10,16 & 26,75 & 13,30 & 8,59 & 1,608 \\
\hline & & 1 & 100 & 13,60 & 28,3 & 14,34 & 9,61 & 1,331 \\
\hline & $C D_{\text {nat }}$ & 2 & 200 & 13,51 & 28,27 & 13,95 & 10,16 & 1,205 \\
\hline & & 3 & 400 & 13,33 & 27,87 & 13,53 & 10,98 & 1,039 \\
\hline & T2a14nat & 4 & 400 & 13,75 & 26,47 & 13,69 & 11,16 & 1,008 \\
\hline & & 1 & 400 & 12,22 & 27,16 & 13,53 & 10,23 & 1,190 \\
\hline & $C D_{\text {nat }}$ & 2 & 400 & 12,15 & 27,20 & 13,51 & 10,27 & 1,181 \\
\hline & & 3 & 400 & 12,29 & 27,21 & 13,53 & 10,25 & 1,186 \\
\hline & * & 4 & 400 & 11,94 & 26,73 & 13,36 & 10,62 & 1,111 \\
\hline \multirow{6}{*}{ T1B } & $C D_{\text {nat }}$ & 1 & 100 & 11,95 & 28,53 & 14,35 & 9,17 & 1,546 \\
\hline & & 2 & 200 & 12,08 & 27,48 & 13,73 & 10,39 & 1,246 \\
\hline & T1b12nat & 3 & 400 & 12,12 & 27,22 & 13,48 & 10,89 & 1,143 \\
\hline & $\mathrm{CD}_{\text {sat }}$ & 1 & 100 & 11,92 & 28,39 & 14,13 & 9.41 & 1,481 \\
\hline & & 2 & 200 & 11,99 & 28,02 & 13,89 & 9,83 & 1,376 \\
\hline & T1b12sat & 3 & 400 & 12,01 & 27,44 & 13,65 & 10,37 & 1,252 \\
\hline \multirow{7}{*}{$\mathrm{T} 2 \mathrm{~B}$} & $C D_{\text {nat }}$ & 1 & 100 & 12,12 & 27,40 & 13,93 & 10,65 & 1,354 \\
\hline & & 2 & 200 & 12,35 & 27,17 & 13,73 & 11,07 & 1,265 \\
\hline & T2b12nat & 3 & 400 & 12,31 & 26,49 & 13,41 & 11,90 & 1,106 \\
\hline & $\mathrm{CD}_{\text {sat }}$ & 1 & 100 & 12,45 & 27,49 & 13,75 & 10,91 & 1,298 \\
\hline & & 2 & 200 & 12,47 & 27,06 & 13,35 & 11,22 & 1,232 \\
\hline & T2b12sat & 3 & 400 & 12,59 & 26,77 & 13,28 & 12,01 & 1,088 \\
\hline & & 4 & 200 & 12,47 & 26,88 & 13,49 & 11,57 & 1,166 \\
\hline
\end{tabular}

* - ensaios de verificação da reprodutibilidade dos resultados

Na Figura 4.28 apresentam-se as curvas tensão - deformação e deformação volumétrica - deformação axial, durante o cisalhamento, para amostra de lixo T2A, sob condições saturadas, em corpos de prova de $150 \times 300 \mathrm{~mm}$ de diâmetro/altura e peso específico de $12 \mathrm{kN} / \mathrm{m}^{3}$. Para essa amostra, as deformações volumétricas encontradas, tanto da fase de compressão isotrópica como de cisalhamento, estão próximas dos valores anteriormente apresentados, exceto para a amostra ensaiada com pressão de confinamento de $100 \mathrm{kPa}$, onde obtiveram-se deformação volumétrica máxima, durante o cisalhamento, de $12 \%$. 


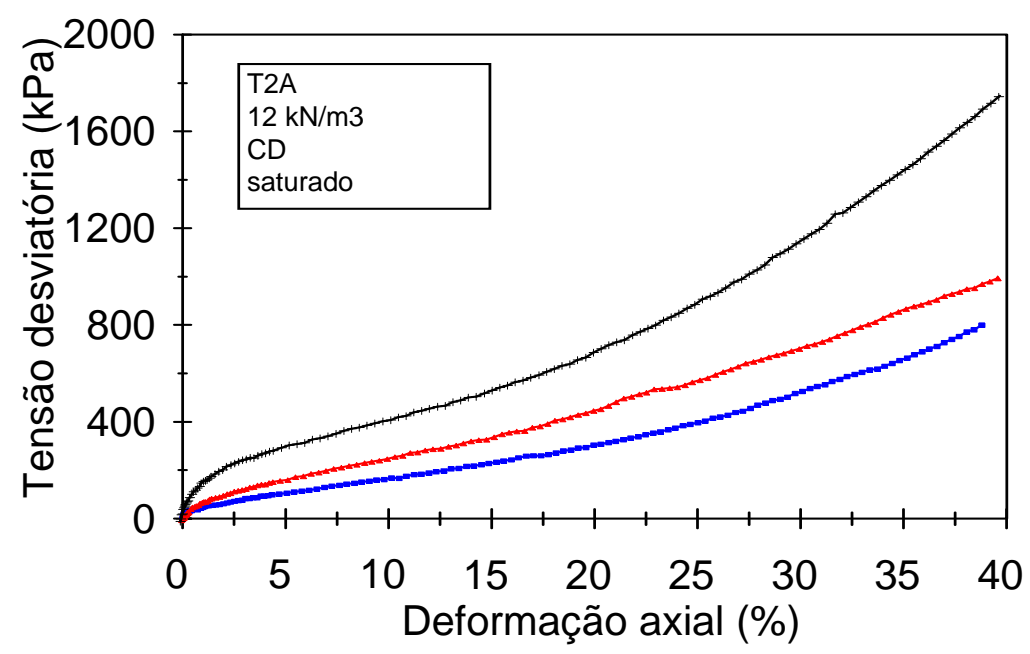

$-100 \mathrm{kPa}-200 \mathrm{kPa}-400 \mathrm{kPa}$

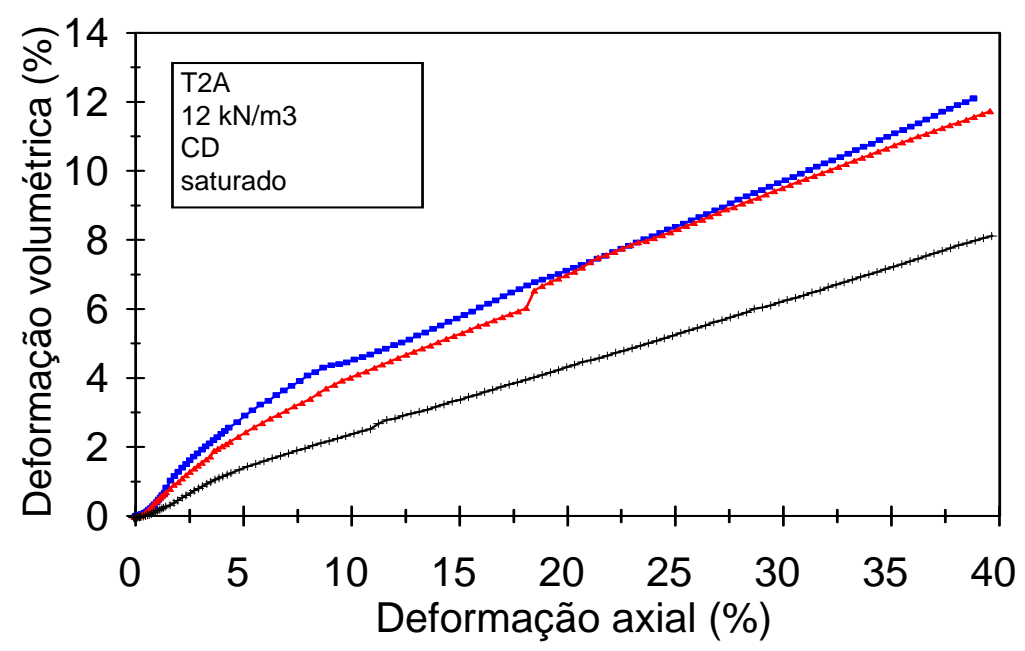

$-100 \mathrm{kPa} \rightarrow 200 \mathrm{kPa}+400 \mathrm{kPa}$

Figura 4.28 - Resultados dos ensaios $C D_{\text {sat }}$ para a amostra T2A (T2a12sat), com diâmetro de $150 \mathrm{~mm}$ e altura de $300 \mathrm{~mm}$, com peso específico inicial de $12 \mathrm{kN} / \mathrm{m}^{3}$ e umidade de moldagem de $68,3 \%$.

As figuras 4.29 a 4.32 apresentam os resultados obtidos a partir dos ensaios triaxiais em corpos de prova de $150 \mathrm{~mm}$ de diâmetro por $300 \mathrm{~mm}$ de altura, para as amostras de RSU T1B e T2B, sob condições saturadas e na umidade de moldagem após terem sido deixadas ao ar livre para perda de umidade, de modo que pudessem ser 
manuseadas. Pode-se observar nestas figuras, que a amostra de lixo T2B apresenta menor deformação volumétrica no cisalhamento em relação às outras duas amostras, cujo valor está em torno de $5 \%$ para corpos de prova confinados com $100 \mathrm{kPa}$ e 3,5\% para corpos de prova confinados com $400 \mathrm{kPa}$. Já na fase de compressão isotrópica, as deformações volumétricas variaram entre $22,5 \%$ a $31,5 \%$, para pressões de confinamento de 100 e 400 $\mathrm{kPa}$, respectivamente.

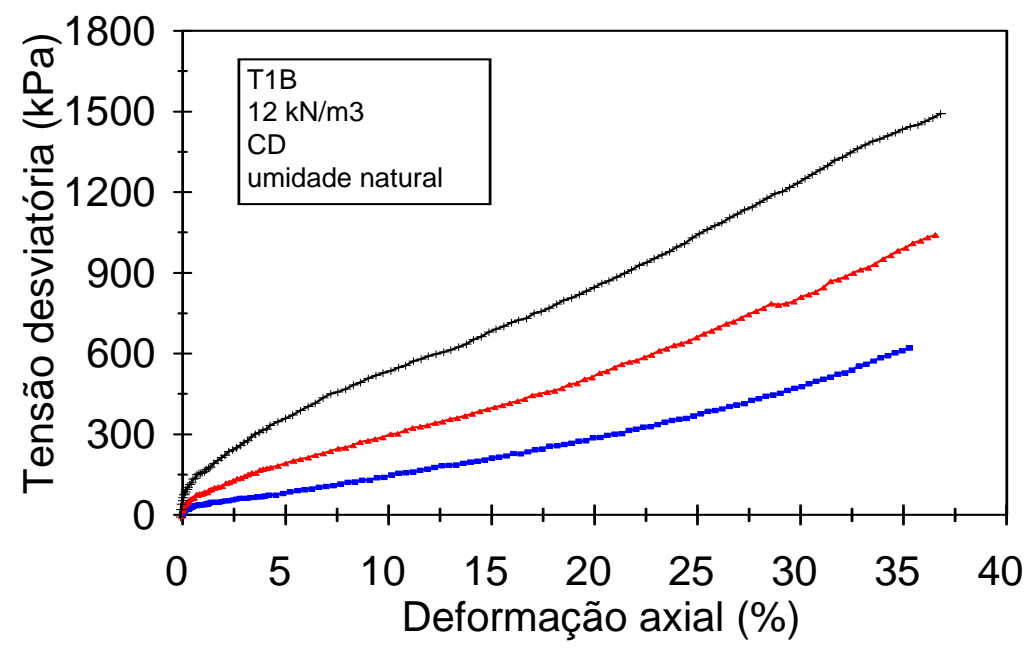

$$
-100 \mathrm{kPa}-200 \mathrm{kPa}+400 \mathrm{kPa}
$$

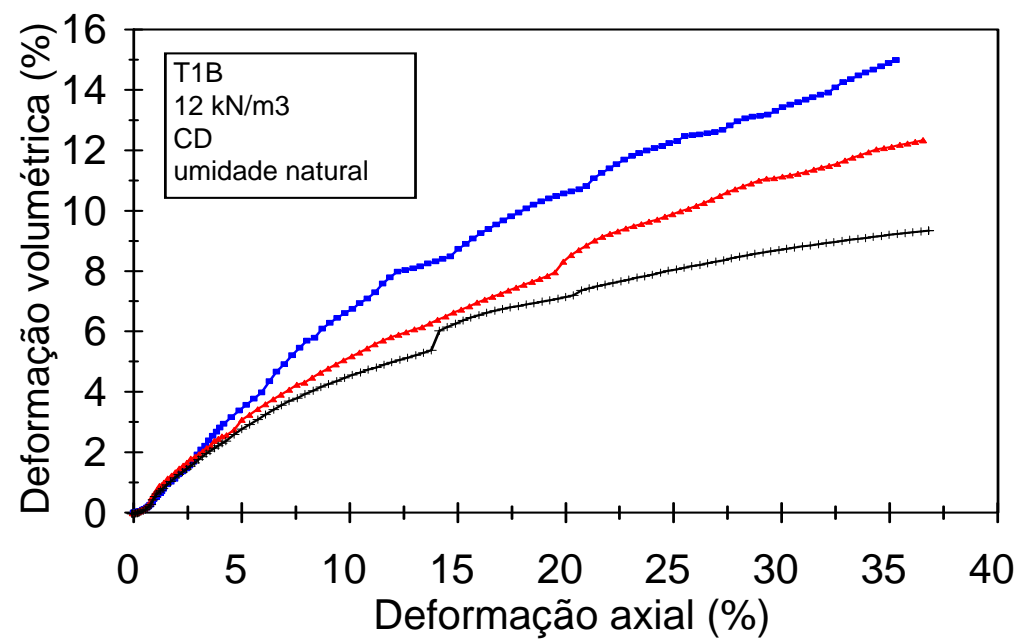

$$
100 \mathrm{kPa}-200 \mathrm{kPa}+400 \mathrm{kPa}
$$

Figura 4.29 - Resultados dos ensaios $C D_{\text {nat }}$ para a amostra $T 1 B$ (T1b12nat), com diâmetro de $150 \mathrm{~mm}$ e altura de $300 \mathrm{~mm}$, com peso específico inicial de $12 \mathrm{kN} / \mathrm{m}^{3}$ e umidade de moldagem de $51,5 \%$. 
A amostra T1B atingiu valores mais altos de deformação volumétrica no cisalhamento que a amostra T2B (ver Fig 4.29 e 4.30), já na compressão isotrópica, apresentaram valores em torno de 16,5\%, para corpos de prova confinados com $100 \mathrm{kPa}$, $23,7 \%$ para os de $200 \mathrm{kPa}$ e $28,2 \%$ para os de $400 \mathrm{kPa}$. Esses resultados foram utilizados nas correções de área do corpo de prova, após adensamento.

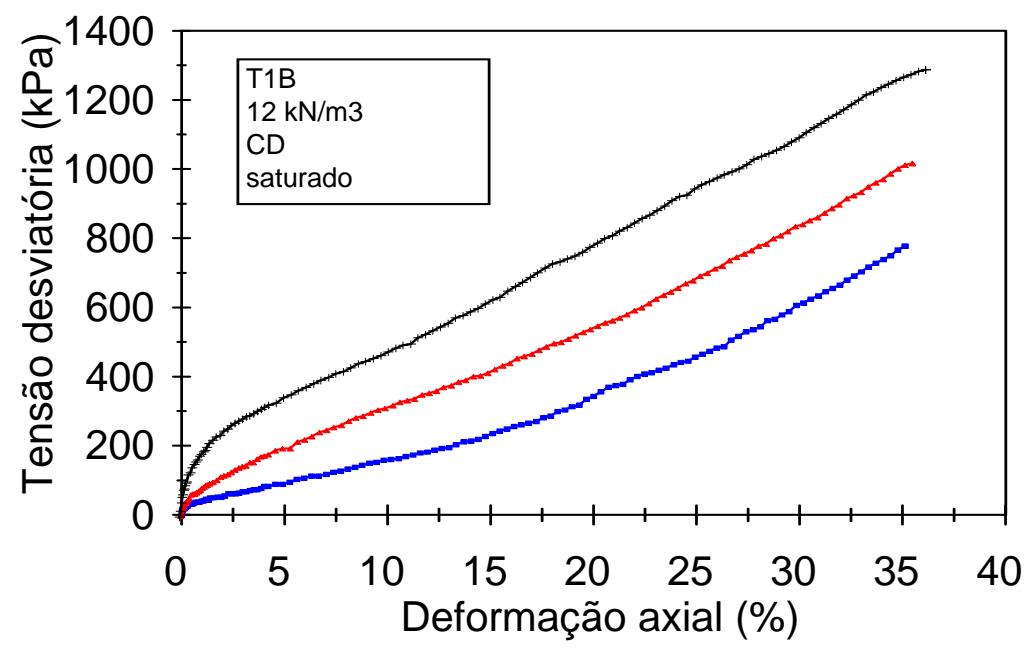

$-100 \mathrm{kPa}-200 \mathrm{kPa}-400 \mathrm{kPa}$

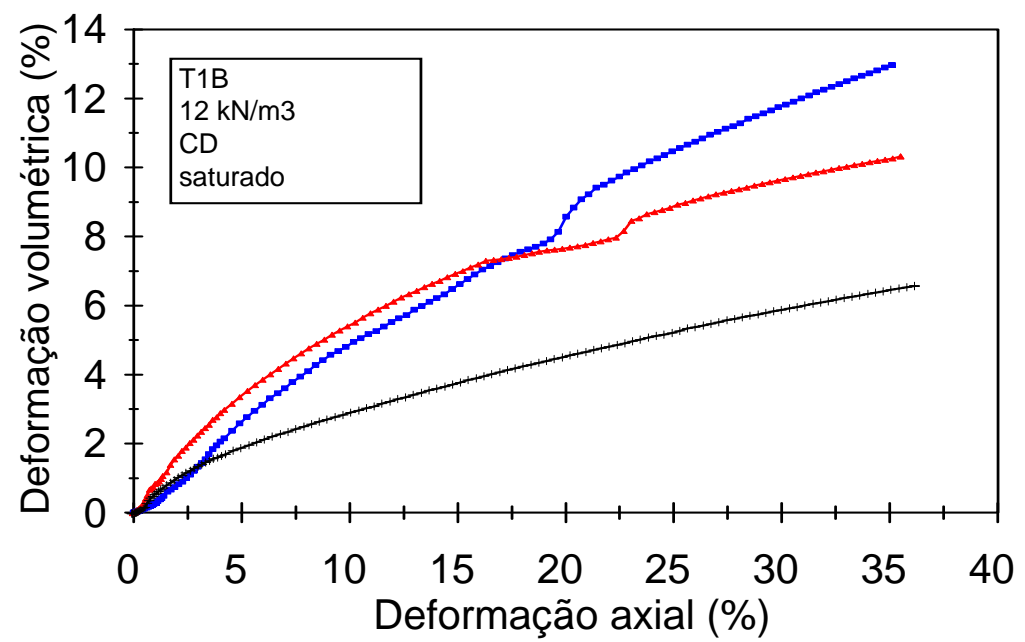

$100 \mathrm{kPa}-200 \mathrm{kPa}+400 \mathrm{kPa}$

Figura 4.30 - Resultados dos ensaios $C D_{\text {sat }}$ para a amostra T1B (T1b12sat), com diâmetro de $150 \mathrm{~mm}$ e altura de $300 \mathrm{~mm}$, com peso específico inicial de $12 \mathrm{kN} / \mathrm{m}^{3}$ e umidade de moldagem de $53,7 \%$. 


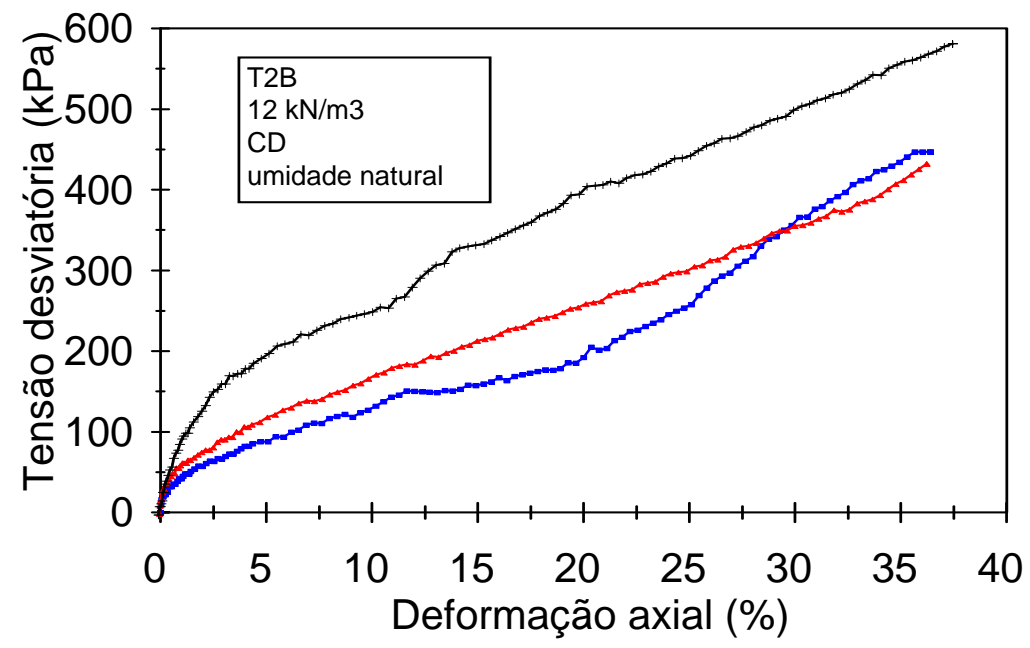

$-100 \mathrm{kPa}-200 \mathrm{kPa}+400 \mathrm{kPa}$

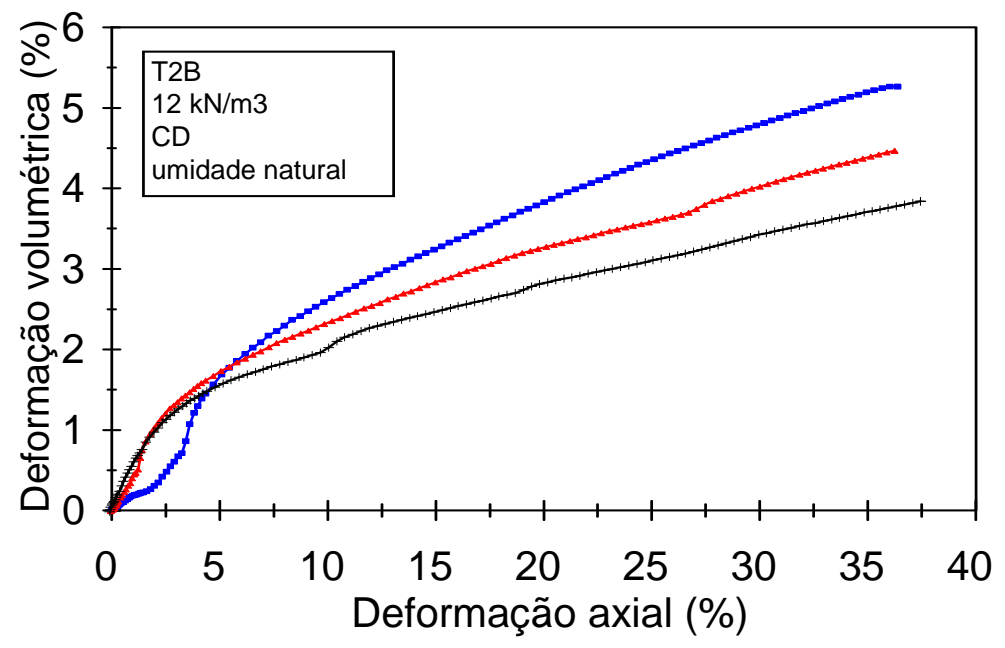

$-100 \mathrm{kPa}-200 \mathrm{kPa}+400 \mathrm{kPa}$

Figura 4.31 - Resultados dos ensaios $C D_{\text {nat }}$ para a amostra T2B (T2b12nat), com diâmetro de $150 \mathrm{~mm}$ e altura de $300 \mathrm{~mm}$, com peso específico inicial de $12 \mathrm{kN} / \mathrm{m}^{3}$ e umidade de moldagem de $44,4 \%$. 


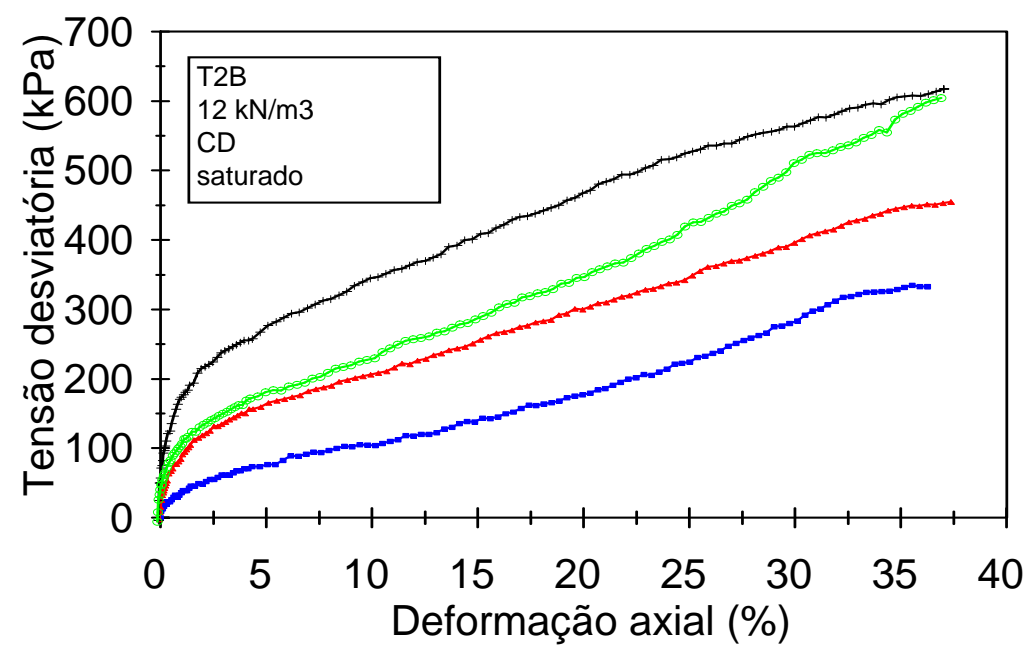

$$
-100 \mathrm{kPa}-200 \mathrm{kPa}+400 \mathrm{kPa}-200 \mathrm{kPa}
$$

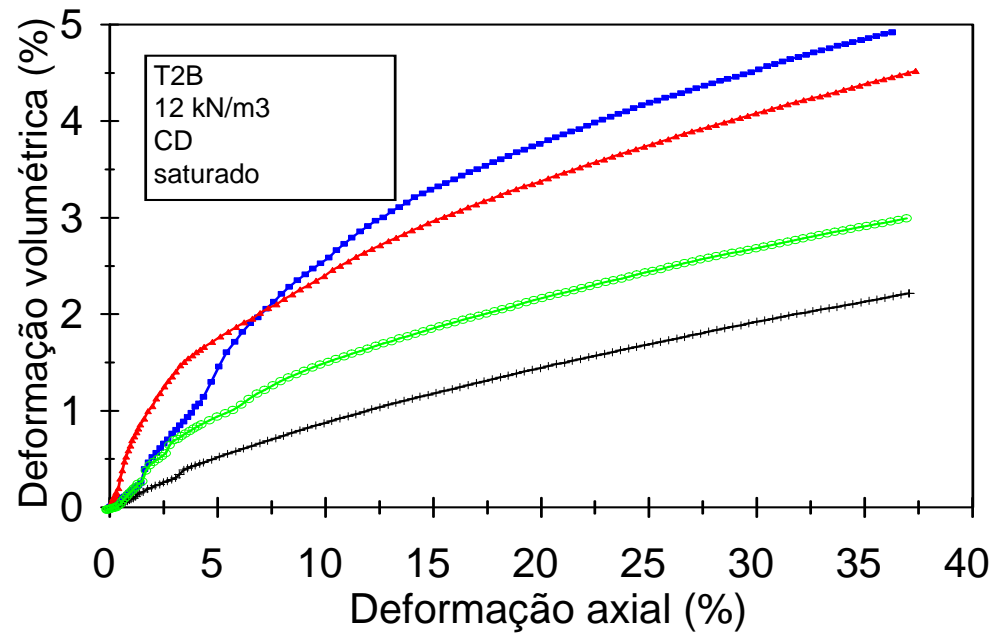

$$
-100 \mathrm{kPa}-200 \mathrm{kPa}+400 \mathrm{kPa}-200 \mathrm{kPa}
$$

Figura 4.32 - Resultados dos ensaios $C D_{\text {sat }}$ para a amostra T2B (T2b12sat), com diâmetro de $150 \mathrm{~mm}$ e altura de $300 \mathrm{~mm}$, com peso específico inicial de $12 \mathrm{kN} / \mathrm{m}^{3}$ e umidade de moldagem de $44,4 \%$.

Foram ensaiados quatro corpos de prova de uma mesma amostra e sob as mesmas condições, para avaliar a reprodutibilidade dos resultados de ensaios triaxiais obtidos com resíduo sólido urbano. Esses ensaios foram executados em corpos de prova da amostra T2A, com 150mm de diâmetro e 300mm de altura, compactados com peso específico em torno de $12 \mathrm{kN} / \mathrm{m}^{3}$ (Tabela 3.1). Foram realizados ensaios tipo consolidado drenado (CD), na umidade natural e com pressão de confinamento de 400kPa. A Figura 4.33 apresenta os resultados obtidos para essa amostra. 


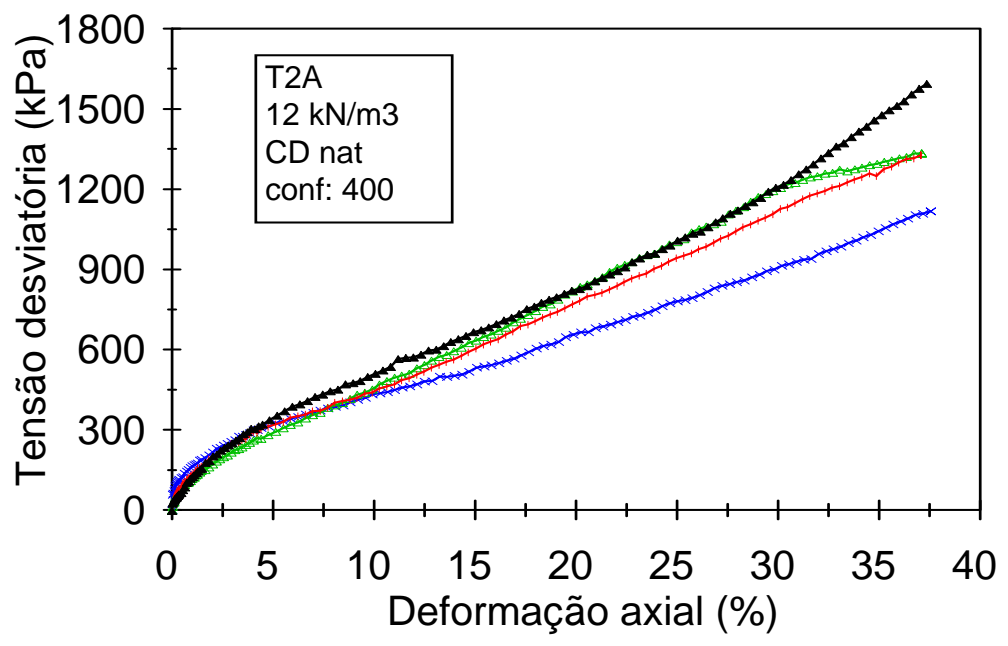

$*$ CP-01 $\rightarrow$ - CP- $02+\mathrm{CP}-03 \rightarrow \mathrm{CP}-04$

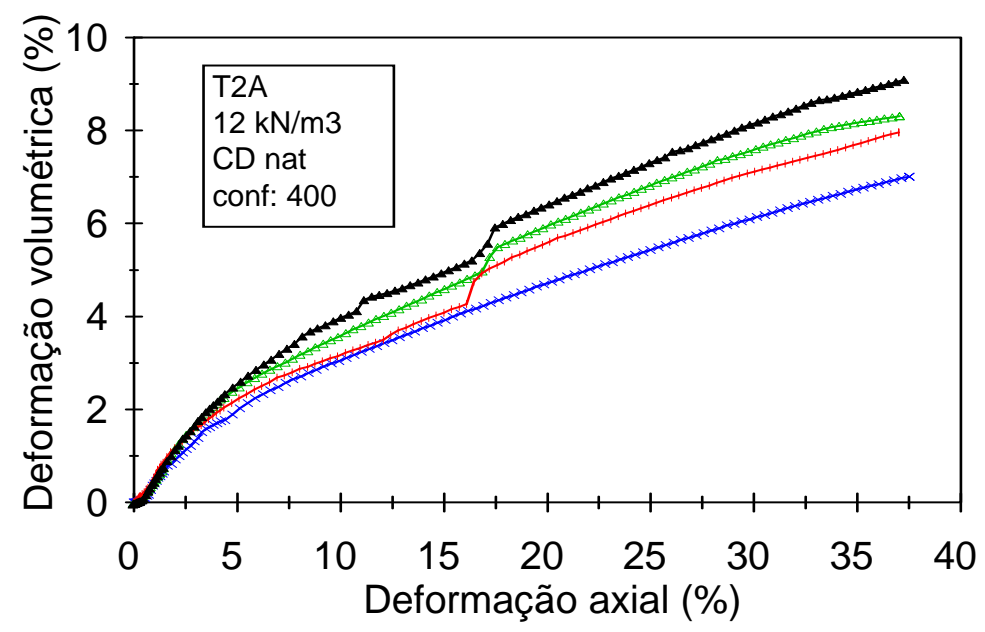

$$
\star \mathrm{CP}-01-\mathrm{CP}-02+\mathrm{CP}-03-\mathrm{CP}-04
$$

Figura 4.33 - Resultados dos ensaios $C D_{\text {nat }}$ para verificação da reprodutibilidade dos resultados triaxiais obtidos. Amostra T2A, com diâmetro de 150 $\mathrm{mm}$ e altura de $300 \mathrm{~mm}$, peso específico inicial de $12 \mathrm{kN} / \mathrm{m}^{3}$ e umidade de $60,7 \%$.

Na Figura 4.34 apresentam-se as curvas tensão-deformação obtidas para a amostra T1B, ensaiada utilizando corpos de prova de $150 \mathrm{~mm}$ de diâmetro, compactados com $12 \mathrm{kN} / \mathrm{m}^{3}$ e submetidos a uma pequena pressão de confinamento $(25 \mathrm{kPa})$ e sem confinamento (compressão simples). É importante ressaltar que os corpos de prova de RSU ensaiados com baixa pressão de confinamento $(25 \mathrm{kPa})$, bem como os ensaiados à compressão simples apresentaram comportamento tensão-deformação semelhante aos obtidos com maiores confinantes, isto é, o RSU enrijece à medida que a deformação aumenta. No Anexo 3 apresentam-se uma seqüência de fotos que ilustram o andamento do ensaio de compressão simples e a variação da área do corpo de prova. Ainda neste anexo 
está apresentado os círculos de Mohr e a envoltória de Mohr-Coulomb, para 20\% de deformação axial, considerando as diferentes condições de confinamento (25, 100, 200 e $400 \mathrm{kPa}$ e sem confinamento).

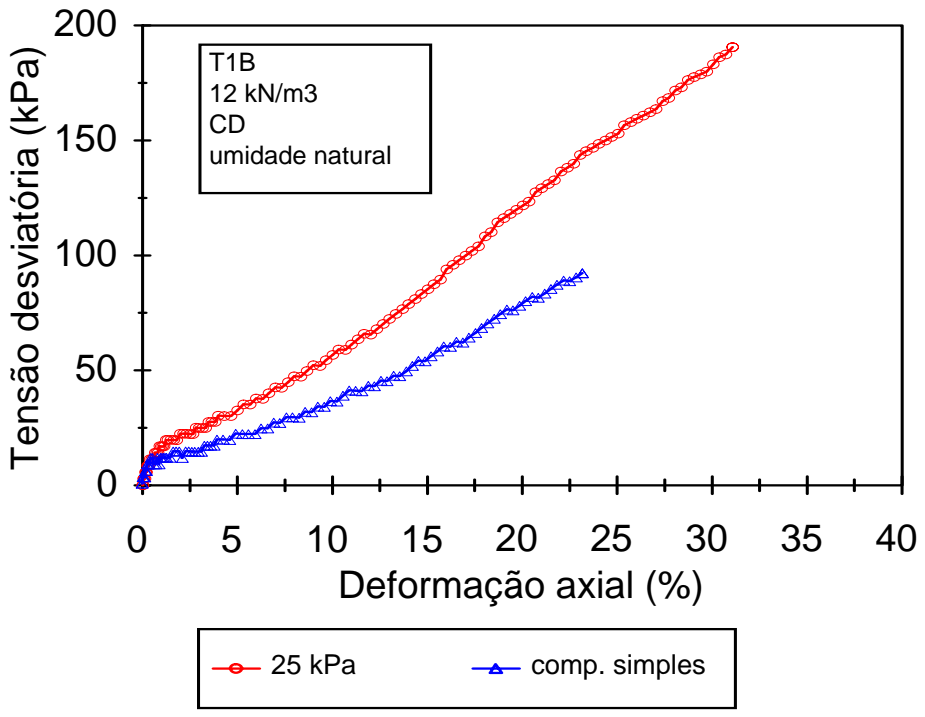

Figura 4.34 - Resultados dos ensaios $C D_{\text {nat }}$ para a amostra $T 1 B$, com diâmetro de $150 \mathrm{~mm}$ e altura de $300 \mathrm{~mm}$, com peso específico inicial de $12 \mathrm{kN} / \mathrm{m}^{3}$.

Os resultados dos ensaios obtidos para determinação do módulo de deformabilidade do RSU em laboratório estão apresentados na Figura 4.35. Estes ensaios foram executados com a amostra T1B, compactada com $12 \mathrm{kN} / \mathrm{m}^{3}$. Obtiveram-se para uma confinante de $50 \mathrm{kPa}$, um valor de $\mathrm{E}$ de $13 \mathrm{MPa}$, para $200 \mathrm{kPa}$ um E de $24 \mathrm{MPa}$ e para confinante de $400 \mathrm{kPa}$, obtiveram-se $\mathrm{E}$ de $37 \mathrm{MPa}$.

Os resultados de ensaios apresentados nas Figuras 4.36 a 4.39, são correspondentes a ensaios consolidados drenados, em corpos de prova com $200 \mathrm{~mm}$ de diâmetro e $400 \mathrm{~mm}$ de altura e com peso específico em torno de $12 \mathrm{kN} / \mathrm{m}^{3}$. Nestas figuras, podem ser observadas as curvas de deformação volumétrica despertadas durante a fase de cisalhamento e as curvas tensão - deformação de cada corpo de prova.

Para a amostra T2A executaram-se ensaios na umidade natural e sob condições saturadas, já com as amostras T2B e T1B executaram-se apenas ensaios com amostra saturada, visto que essas duas amostras foram, inicialmente, secadas ao ar livre para que fosse possível de serem manuseadas. As amostras T2A, na condição de umidade natural e T1B, na condição saturada, apresentaram deformações volumétricas, na fase de compressão isotrópica de $23,5 \%$ para pressão de confinamento de $100 \mathrm{kPa}, 31 \%$ para $200 \mathrm{kPa}$ e $38,5 \%$ para $400 \mathrm{kPa}$. Já a amostra T2A, na condição saturada, apresentou durante a fase de compressão isotrópica, deformação volumétrica um pouco menor que as mencionadas acima, com valores da ordem de $21 \%$ para pressão de confinamento de $100 \mathrm{kPa}, 25 \%$ para $200 \mathrm{kPa}$ e $32 \%$ para $400 \mathrm{kPa}$. Por último, a amostra T2B, na condição saturada, apresentou deformação volumétrica em compressão isotrópica de 22,6\% para 
pressão de confinamento de $100 \mathrm{kPa}, 29,6 \%$ para $200 \mathrm{kPa}$ e $35,4 \%$ para $400 \mathrm{kPa}$. A Tabela 4.5 apresenta as características dos corpos de prova no final do adensamento, para ensaios triaxiais executados em amostras com $200 \mathrm{~mm}$ de diâmetro por $400 \mathrm{~mm}$ de altura.
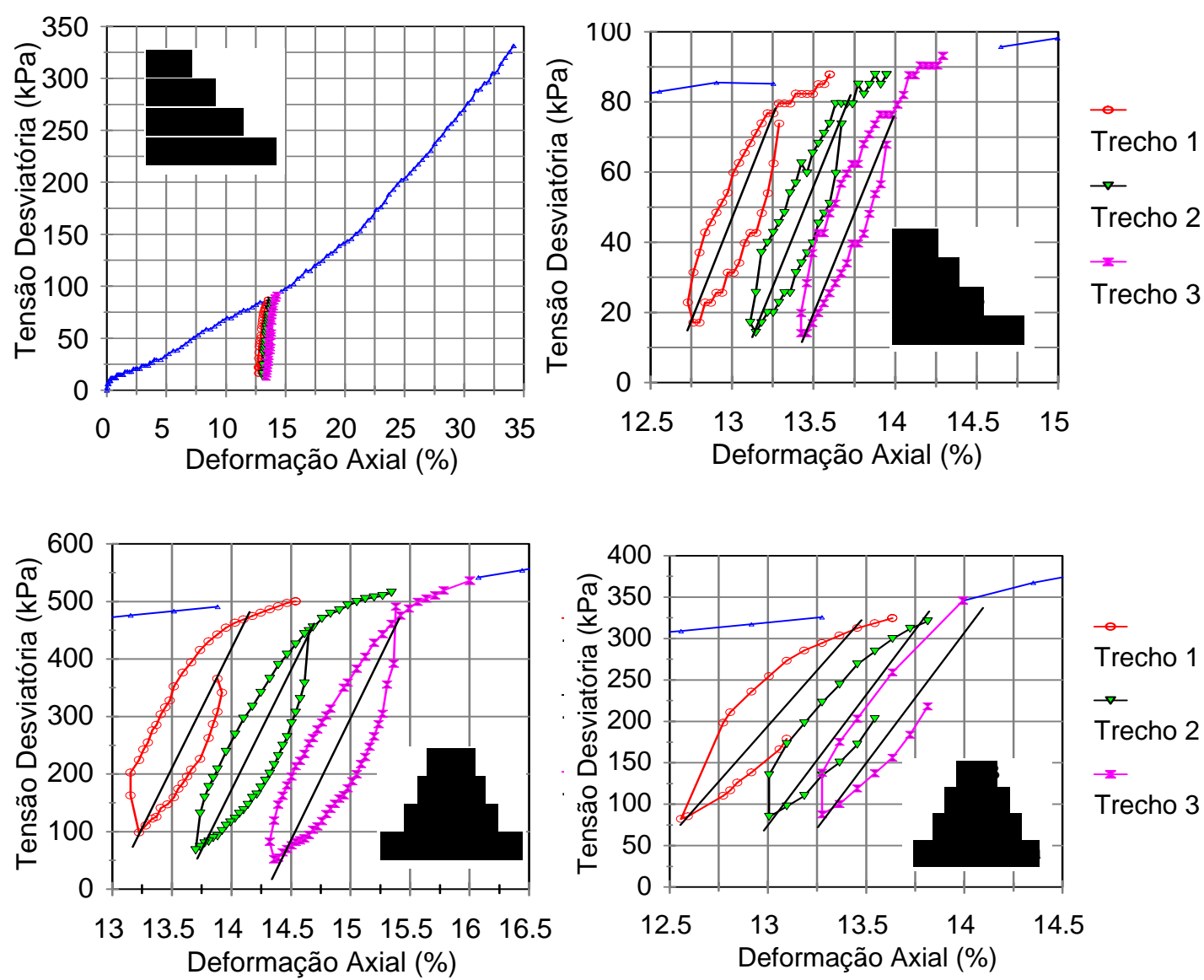

Figura 4.35 - Resultados dos ensaios $C D_{\text {nat }}$ para a amostra $T 1 B$, com diâmetro de $150 \mathrm{~mm}$ e altura de $300 \mathrm{~mm}$, com peso específico inicial de $12 \mathrm{kN} / \mathrm{m}^{3}$, para determinação do módulo de deformabilidade.

Tabela 4.5 - Principais características, dos corpos de prova de $200 \mathrm{~mm}$ de diâmetro e $400 \mathrm{~mm}$ de altura submetidos à ensaios $C D$, após adensamento.

\begin{tabular}{|c|c|c|c|c|c|c|c|c|}
\hline \multirow{2}{*}{ Amostra } & \multirow{2}{*}{ Ensaio } & \multirow{2}{*}{$\mathbf{N}^{\circ}$} & \multirow{2}{*}{$\begin{array}{c}\sigma_{3} \\
(\mathrm{kPa})\end{array}$} & \multirow{2}{*}{$\begin{array}{c}\gamma_{\text {nat }} \\
\left(k N / m^{3}\right)\end{array}$} & \multicolumn{2}{|c|}{ Adensamento } & \multirow{2}{*}{$\begin{array}{l}\gamma_{\mathrm{d} \text { adens }} \\
\left(\mathrm{kN} / \mathrm{m}^{3}\right)\end{array}$} & \multirow{2}{*}{$\mathbf{e}_{\text {aden }}$} \\
\hline & & & & & h (cm) & $D(\mathrm{~cm})$ & & \\
\hline \multirow{6}{*}{$\mathrm{T} 2 \mathrm{~A}$} & $\mathrm{CD}_{\text {nat }}$ & 1 & 100 & 7,57 & 37,24 & 18,37 & 9,67 & 1,316 \\
\hline & & 2 & 200 & 7,65 & 36,09 & 17,81 & 10,62 & 1,110 \\
\hline & T2a40CDnat & 3 & 400 & 7,61 & 34,78 & 17,40 & 11,51 & 0,947 \\
\hline & $\mathrm{CD}_{\text {sat }}$ & 1 & 100 & 7,16 & 37,13 & 18,48 & 8,94 & 1,507 \\
\hline & & 2 & 200 & 7,70 & 36,74 & 18,19 & 10,01 & 1,238 \\
\hline & T2a40CDsat & 3 & 400 & 7,69 & 35,72 & 17,74 & 10,79 & 1,076 \\
\hline \multirow{3}{*}{ T1B } & $\mathrm{CD}_{\text {sat }}$ & 1 & 100 & 7,32 & 36,93 & 18,43 & 9,34 & 1,500 \\
\hline & & 2 & 200 & 7,41 & 35,95 & 17,82 & 10,28 & 1,272 \\
\hline & T1b40CDsat & 3 & 400 & 7,418 & 34,90 & 17,33 & 10,80 & 1,161 \\
\hline \multirow{3}{*}{ T2B } & $\mathrm{CD}_{\text {sat }}$ & 1 & 100 & 8,19 & 36,88 & 18,46 & 10,35 & 1,421 \\
\hline & & 2 & 200 & 8,14 & 36,05 & 18,02 & 11,13 & 1,253 \\
\hline & T2b40CDsat & 3 & 400 & 8,23 & 35,33 & 17,54 & 11,99 & 1,091 \\
\hline
\end{tabular}




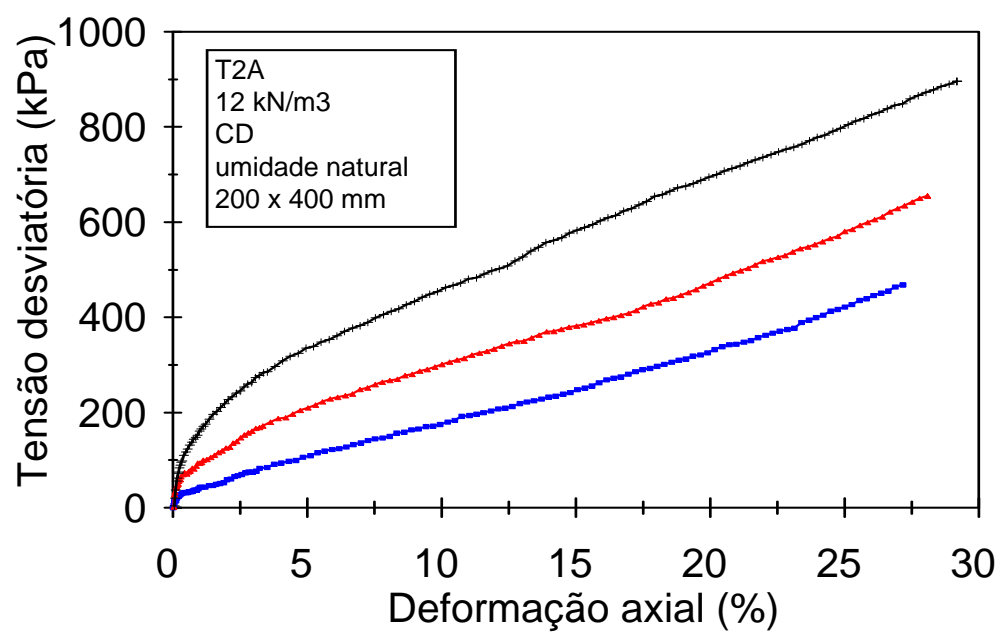

$\rightarrow-100 \mathrm{kPa}-200 \mathrm{kPa} \rightarrow 400 \mathrm{kPa}$

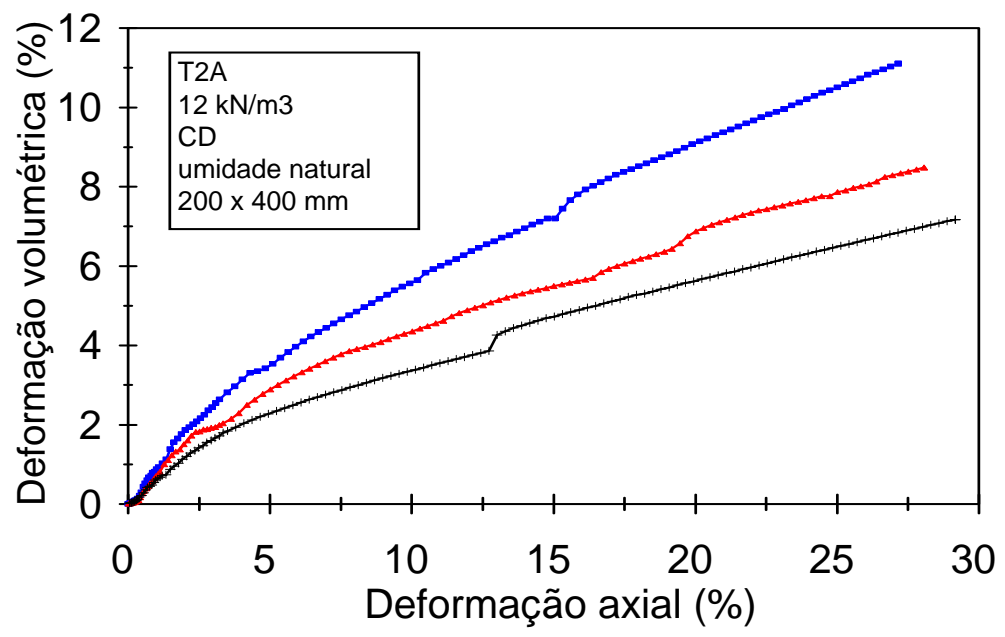

$100 \mathrm{kPa} \rightarrow 200 \mathrm{kPa}+400 \mathrm{kPa}$

Figura 4.36 - Resultados dos ensaios $C D_{\text {nat }}$ para a amostra T2A (T2a40CDnat), com diâmetro de $200 \mathrm{~mm}$ e altura de $400 \mathrm{~mm}$, peso específico inicial de $12 \mathrm{kN} / \mathrm{m}^{3}$ e umidade de moldagem de $58,0 \%$. 


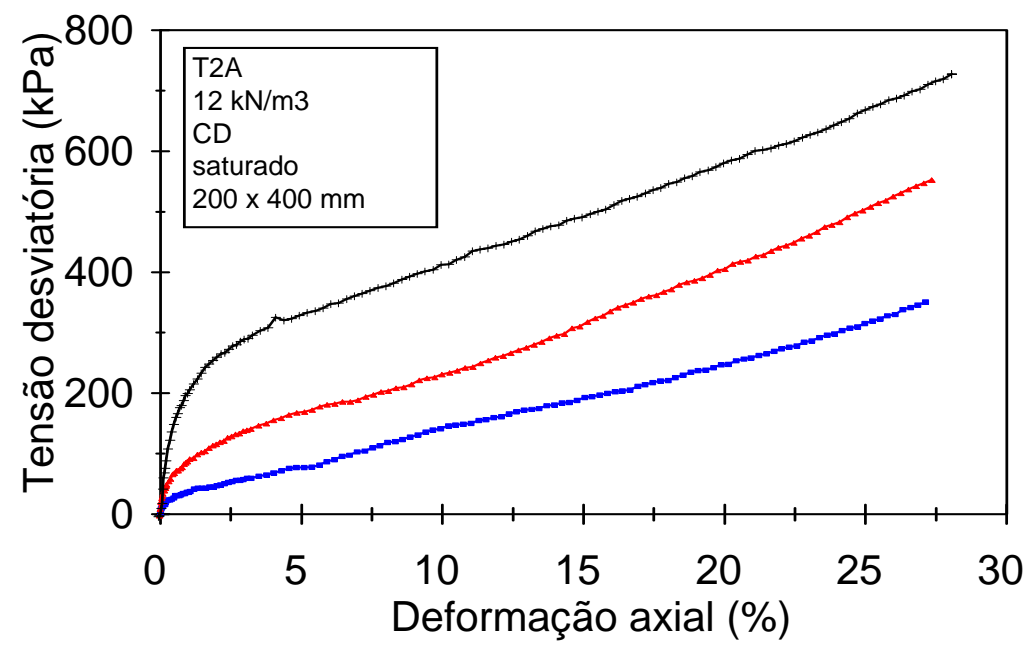

$\rightarrow 100 \mathrm{kPa} \rightarrow 200 \mathrm{kPa}+400 \mathrm{kPa}$

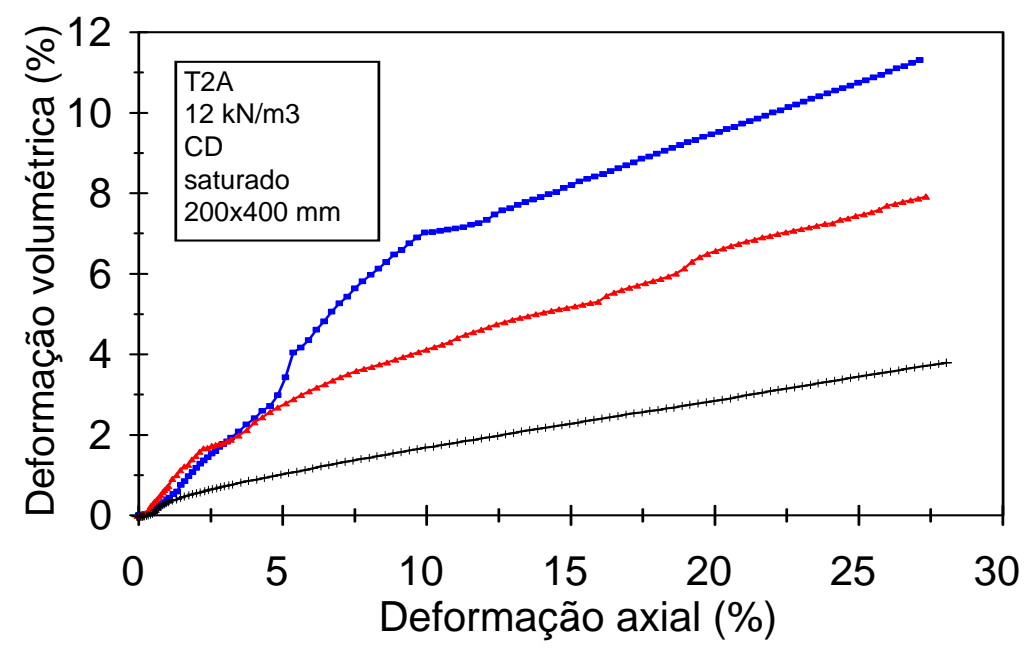

$-100 \mathrm{kPa} \rightarrow 200 \mathrm{kPa}+400 \mathrm{kPa}$

Figura 4.37 - Resultados dos ensaios $C D_{\text {sat }}$ para a amostra T2A (T2a40CDsat), com diâmetro de $200 \mathrm{~mm}$ e altura de $400 \mathrm{~mm}$, peso específico inicial de $12 \mathrm{kN} / \mathrm{m}^{3}$ e umidade de moldagem de $\mathbf{5 8 , 8 \%}$ para corpos de prova com pressão de confinamento de 200 e $400 \mathrm{kPa}$ e umidade de $67,7 \%$ para o de $100 \mathrm{kPa}$. 


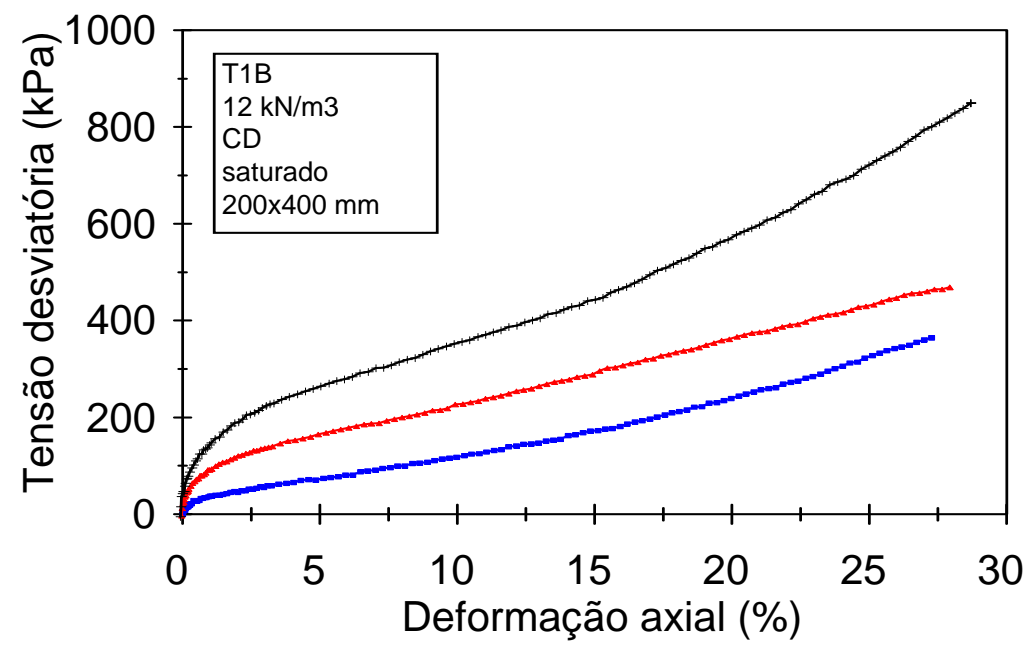

$$
\rightarrow 100 \mathrm{kPa}-200 \mathrm{kPa}+400 \mathrm{kPa}
$$

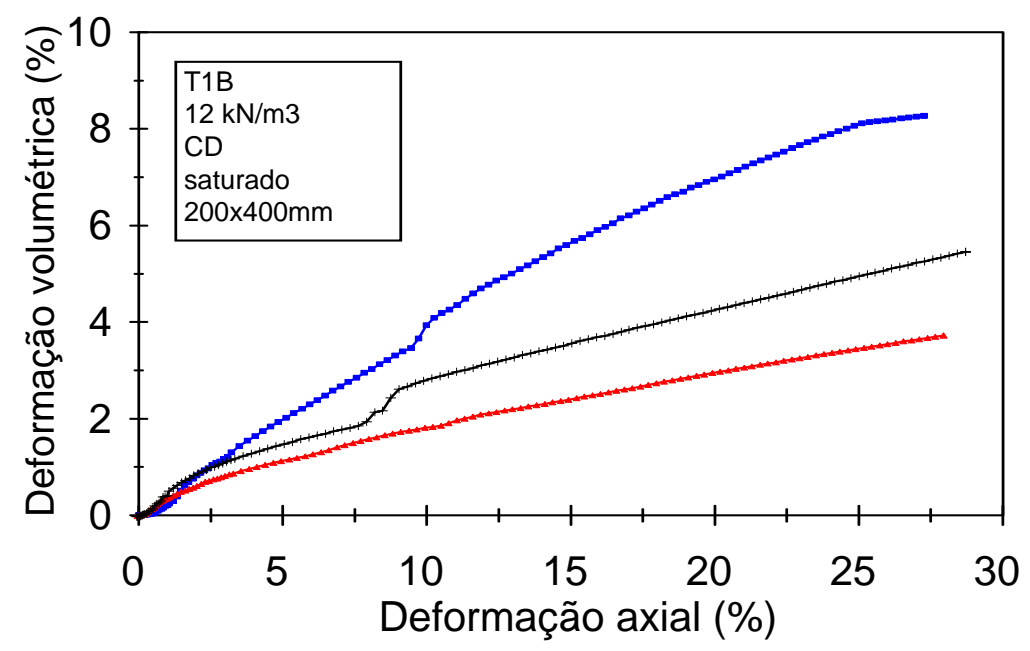

$\rightarrow 100 \mathrm{kPa} \rightarrow 200 \mathrm{kPa}+400 \mathrm{kPa}$

Figura 4.38 - Resultados dos ensaios $C D_{\text {sat }}$ para a amostra T1B (T1b40CDsat), com diâmetro de $200 \mathrm{~mm}$ e altura de $400 \mathrm{~mm}$, peso específico inicial de $12 \mathrm{kN} / \mathrm{m}^{3}$ e umidade de moldagem de $64 \%$. 


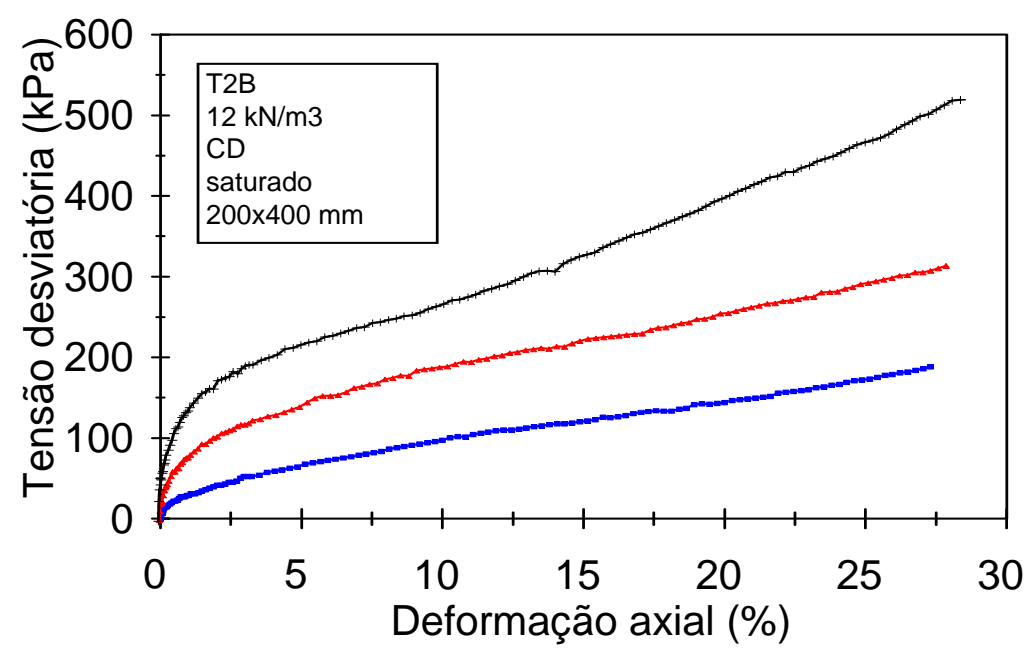

$$
-100 \mathrm{kPa}-200 \mathrm{kPa}+400 \mathrm{kPa}
$$

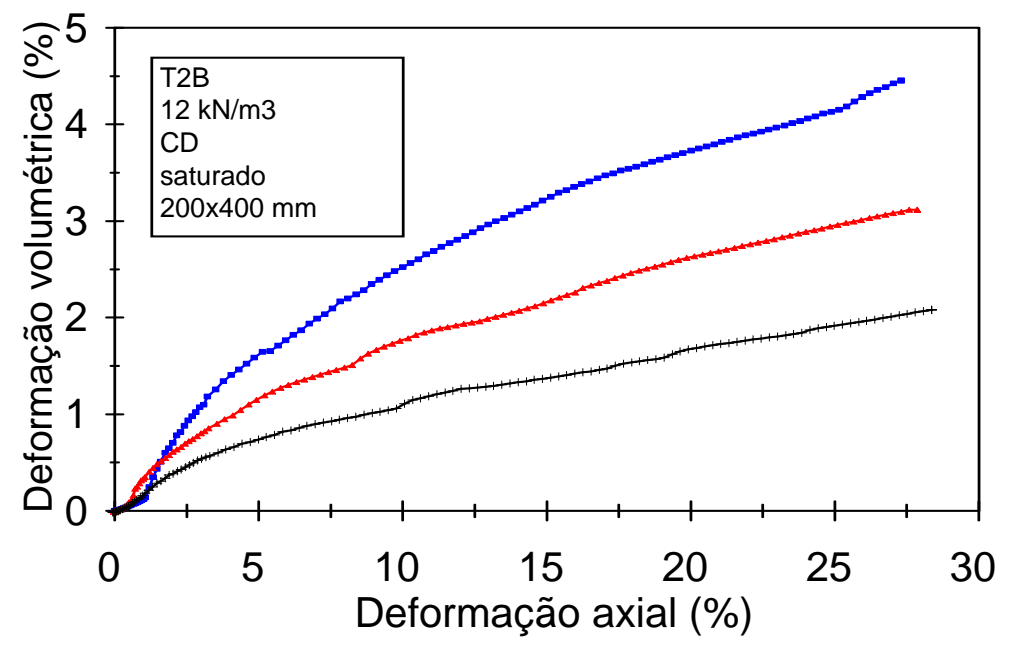

$$
-100 \mathrm{kPa}-200 \mathrm{kPa}+400 \mathrm{kPa}
$$

Figura 4.39 - Resultados dos ensaios $C D_{\text {sat }}$ para a amostra T2B com diâmetro de $200 \mathrm{~mm}$ e altura de $400 \mathrm{~mm}$, com peso específico inicial de $12 \mathrm{kN} / \mathrm{m}^{3}$ e umidade de moldagem de $47,3 \%$.

As Figuras 4.40 a 4.42 apresentam os resultados de ensaios consolidados drenados, saturados, obtidos de corpos de prova de $100 \mathrm{~mm}$ de diâmetro e $200 \mathrm{~mm}$ de altura, executados com a matriz básica das amostras representativas T2A, T2B e T1B compactadas com peso específico em torno de $16 \mathrm{kN} / \mathrm{m}^{3}$. Esses ensaios foram executados 
com a matriz do resíduo, isto é, material resultante da exclusão de materiais plásticos e componentes com dimensões maiores que $2 \mathrm{~cm}$. Mesmo após essa separação, a matriz ensaiada apresentou grande concentração de pequenos fragmentos de plásticos e outros materiais, somente perceptíveis após lavagem do material na peneira $\mathrm{N}^{0}$. \# 200.

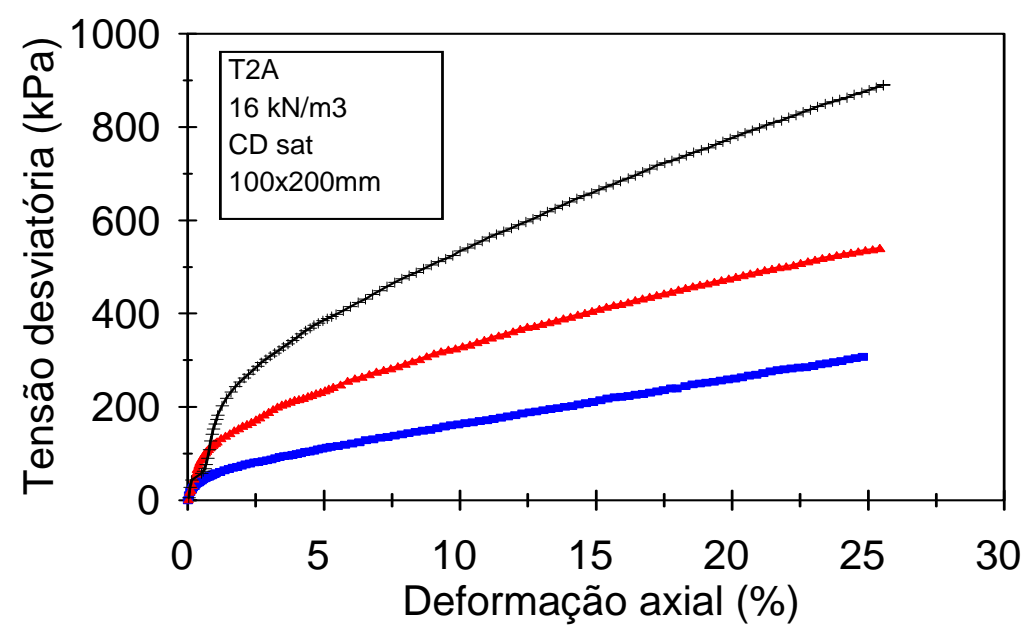

$$
-100 \mathrm{kPa}-200 \mathrm{kPa}+400 \mathrm{kPa}
$$

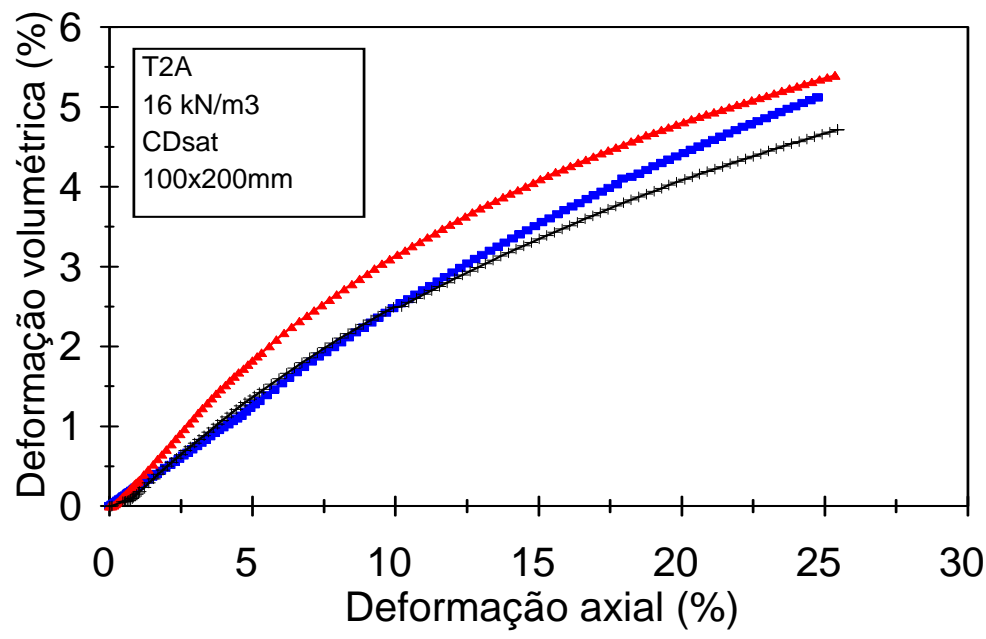

$$
100 \mathrm{kPa} \rightarrow-200 \mathrm{kPa} \leftarrow 400 \mathrm{kPa}
$$

Figura 4.40 - Resultados dos ensaios $C D_{\text {sat }}$ para a matriz da amostra T2A com diâmetro de $100 \mathrm{~mm}$ e altura de $200 \mathrm{~mm}$, peso específico inicial em torno de $16 \mathrm{kN} / \mathrm{m}^{3}$ e umidade de moldagem de $48,2 \%$. 


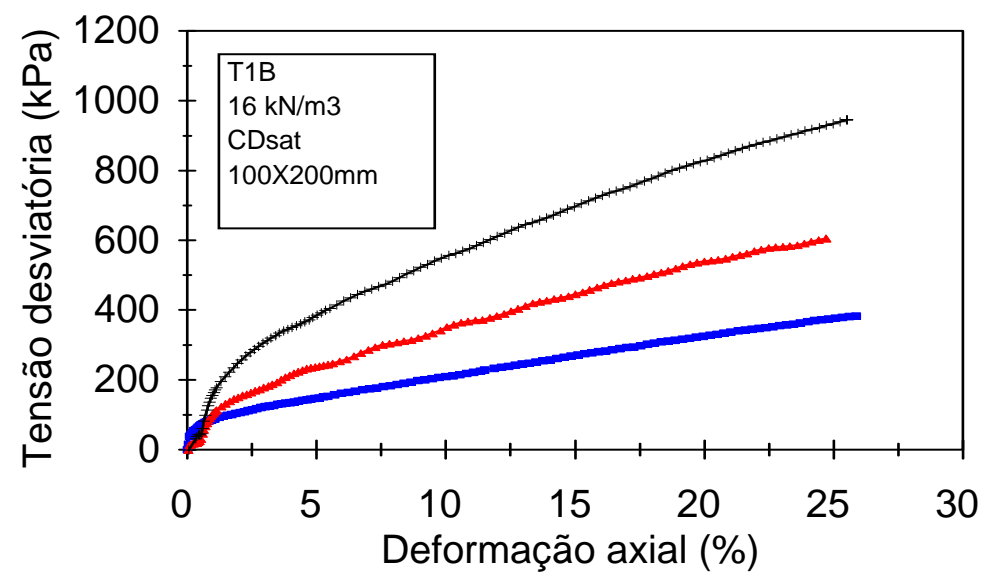

$=100 \mathrm{kPa} \rightarrow 200 \mathrm{kPa}+400 \mathrm{kPa}$

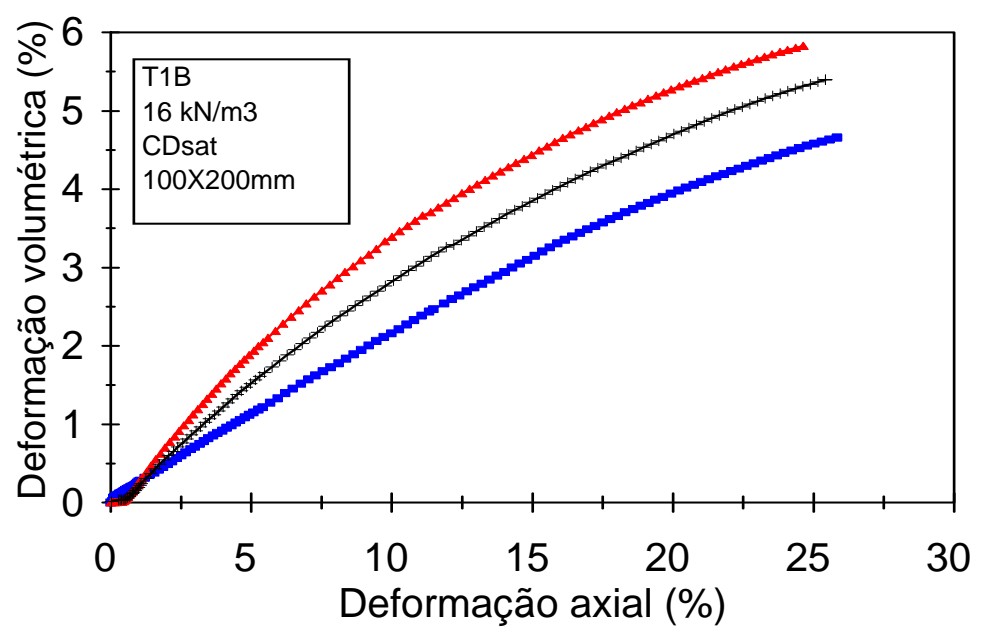

$100 \mathrm{kPa}=200 \mathrm{kPa}+400 \mathrm{kPa}$

Figura 4.41 - Resultados dos ensaios $C D_{\text {sat }}$ para a matriz da amostra $T 1 B$ com diâmetro de $100 \mathrm{~mm}$ e altura de $200 \mathrm{~mm}$, peso específico inicial em torno de $16 \mathrm{kN} / \mathrm{m}^{3}$ e umidade de moldagem de $58,6 \%$. 

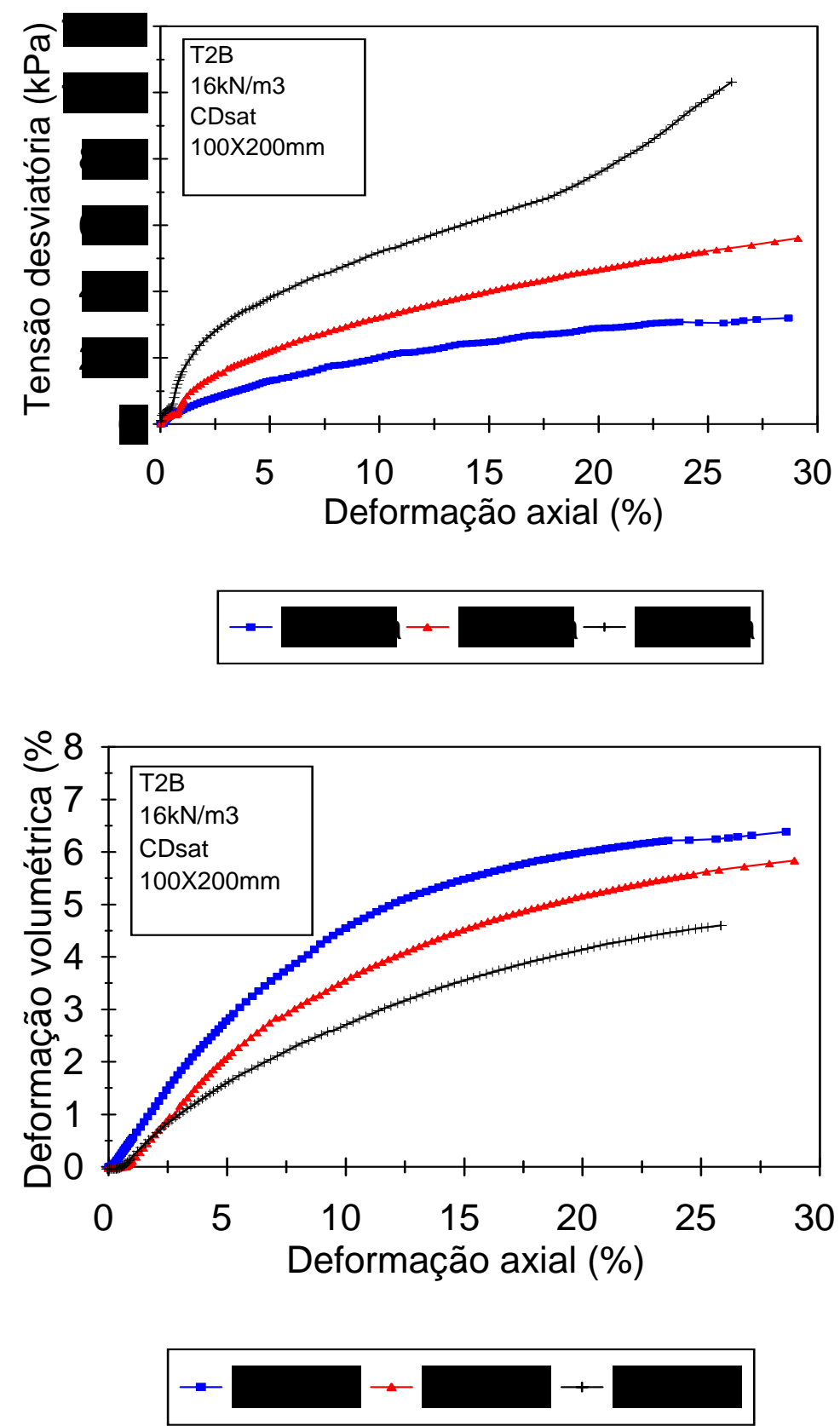

Figura 4.42 - Resultados dos ensaios $C D_{\text {sat }}$ para a matriz da amostra T2B com diâmetro de $100 \mathrm{~mm}$ e altura de $200 \mathrm{~mm}$, peso específico inicial em torno de $16 \mathrm{kN} / \mathrm{m}^{3}$ e umidade de moldagem em torno de $40,5 \%$.

\subsection{2 - Ensaios consolidados não drenados (CU)}

As Figuras 4.43 e 4.44 apresentam os resultados dos ensaios consolidados não drenados (CU), com medida de pressão neutra executados para a amostra T2A, na umidade natural e saturada, respectivamente. Nestas figuras apresentam-se as curvas de tensão, pressão neutra e do parâmetro A de Skempton versus a deformação axial da amostra. 


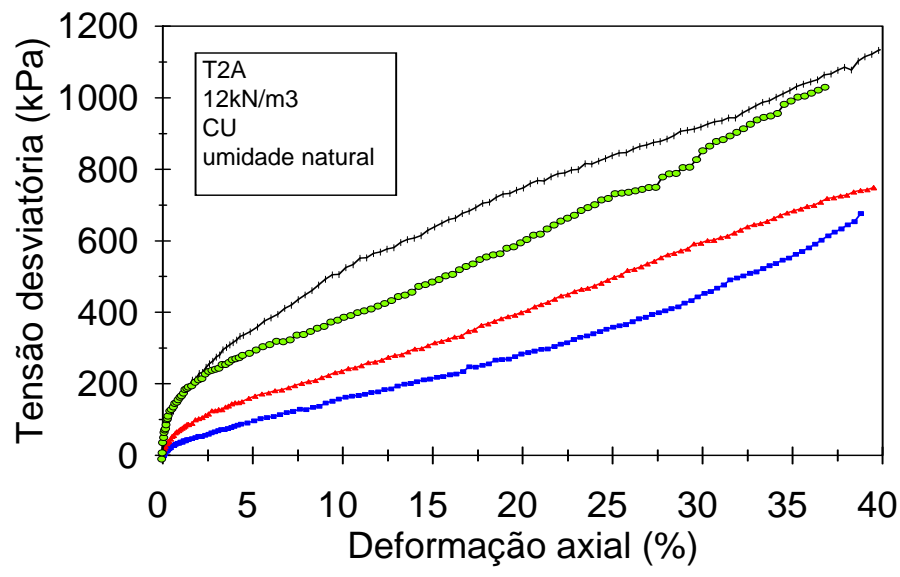

$-92 \mathrm{kPa}-208 \mathrm{kPa}+416 \mathrm{kPa}-408 \mathrm{kPa}$

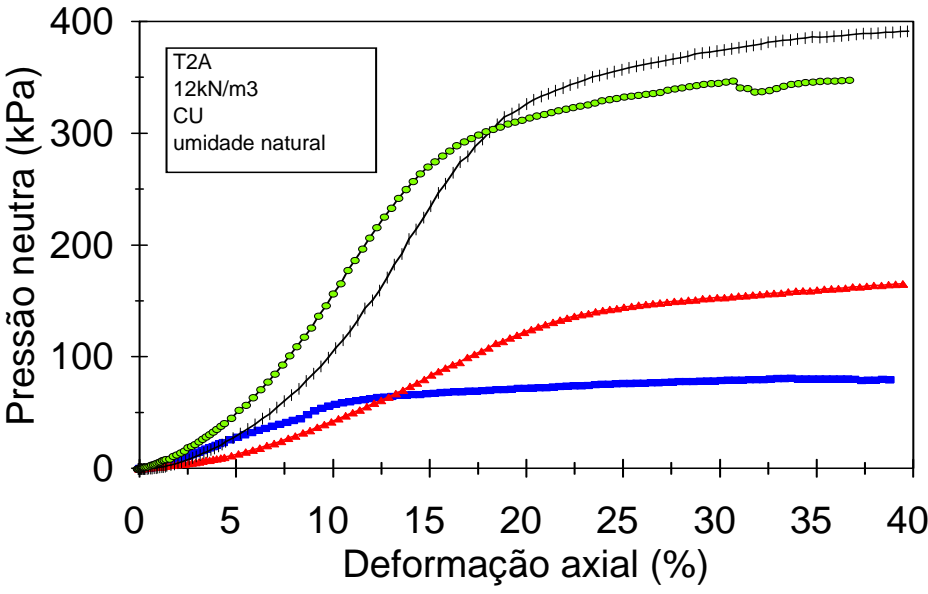

$\rightarrow-92 \mathrm{kPa} \rightarrow 208 \mathrm{kPa}+416 \mathrm{kPa} \multimap 408 \mathrm{kPa}$

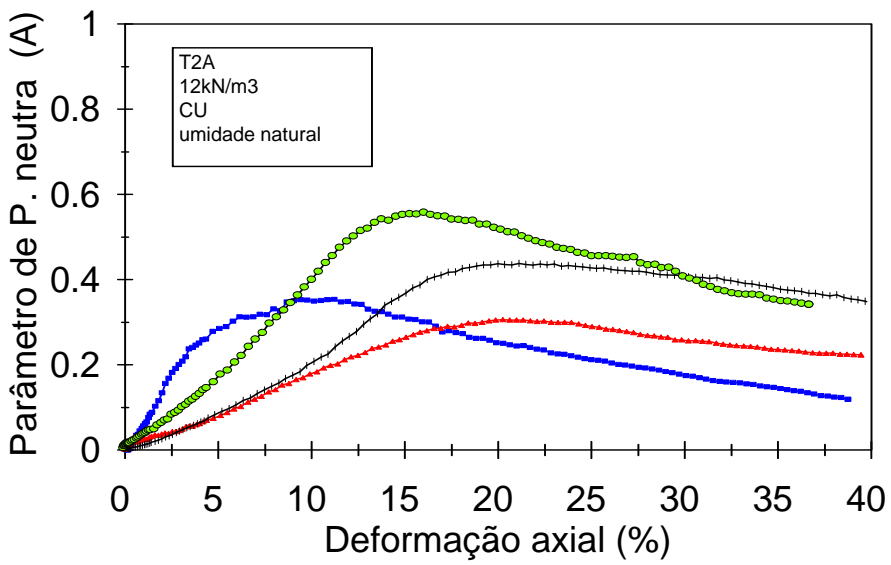

$-92 \mathrm{kPa}-208 \mathrm{kPa}+416 \mathrm{kPa}-408 \mathrm{kPa}$

Figura 4.43 - Resultados dos ensaios $C U_{\text {nat }}$ para a amostra T2A (T2a12CUnat), com diâmetro de $150 \mathrm{~mm}$ e altura $300 \mathrm{~mm}$, na umidade natural e peso esp. de $12 \mathrm{kN} / \mathrm{m}^{3}$. 


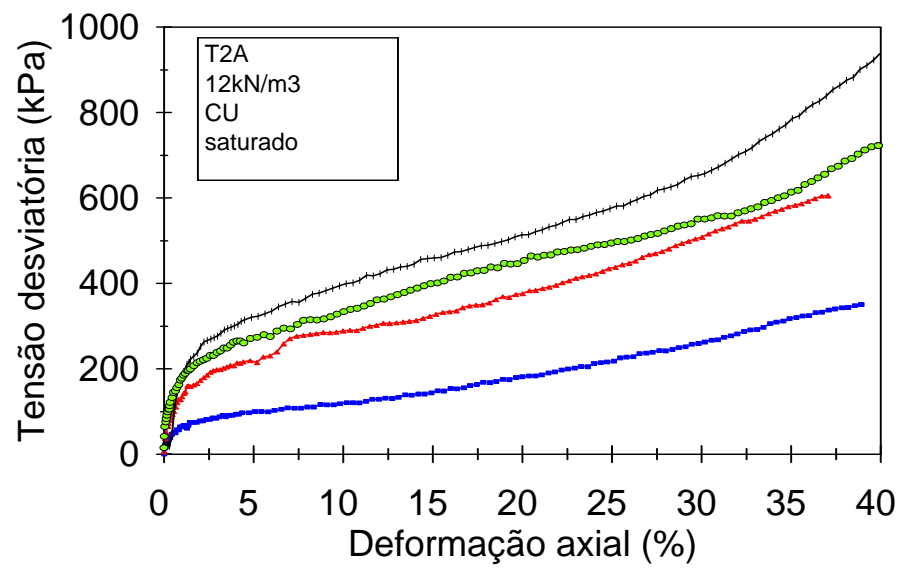

$-108 \mathrm{kPa}-216 \mathrm{kPa}+308 \mathrm{kPa}-226 \mathrm{kPa}$

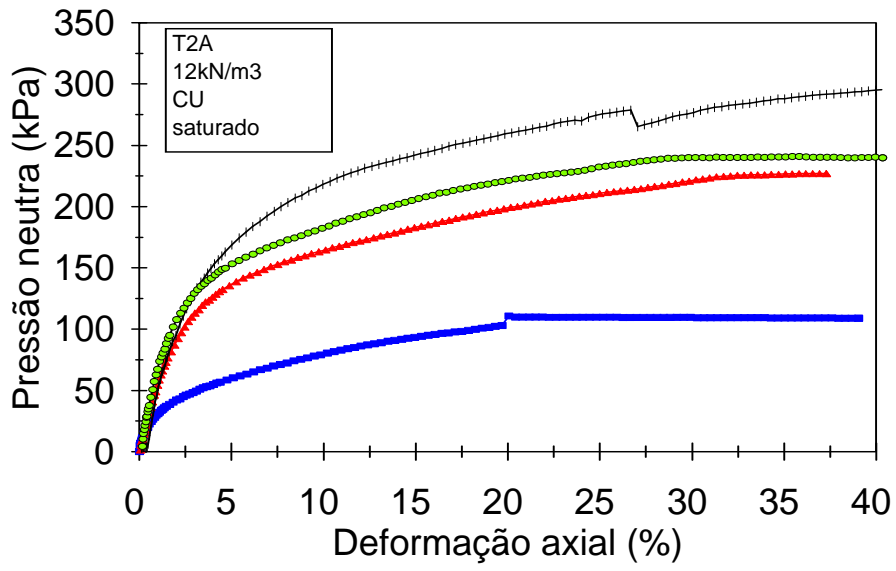

$\rightarrow 102 \mathrm{kPa} \rightarrow 216 \mathrm{kPa} \rightarrow 308 \mathrm{kPa} \multimap 226 \mathrm{kPa}$

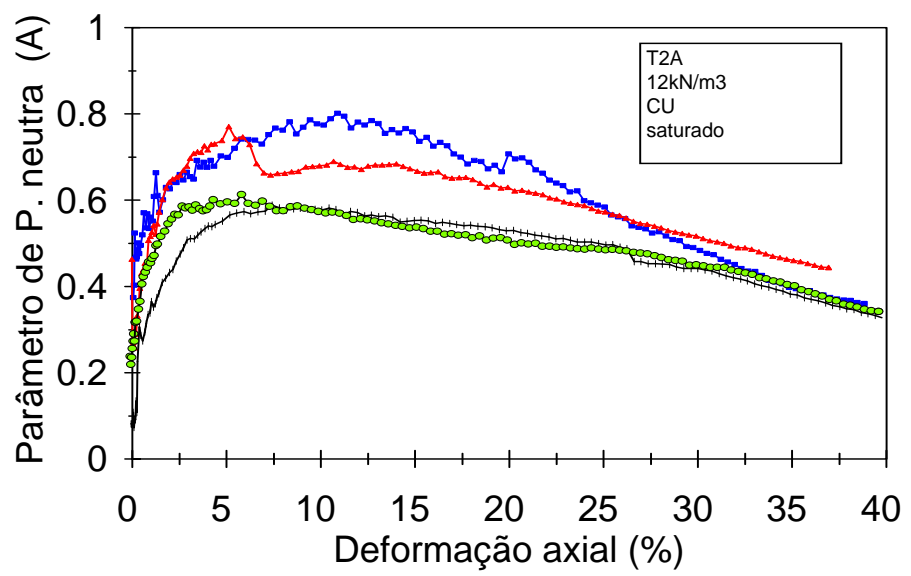

$-102 \mathrm{kPa}-216 \mathrm{kPa}+308 \mathrm{kPa}-226 \mathrm{kPa}$

Figura 4.44 - Resultados dos ensaios $\mathrm{CU}_{\text {sat }}$ para a amostra T2A (T2a12Cusat), saturada, com diâmetro de $150 \mathrm{~mm}$ e altura $300 \mathrm{~mm}$ e peso específico de $12 \mathrm{kN} / \mathrm{m}^{3}$. 
Os corpos de prova da amostra T2A compactados com peso específico de $12 \mathrm{kN} / \mathrm{m}^{3}$ e ensaiados na umidade natural, apresentaram durante o cisalhamento deformações volumétricas variando entre 2 a 6\%. Essa variação é devido à alta compressibilidade do ar presente nos vazios do corpo de prova. Já os corpos de prova saturados apresentaram comportamento dentro do esperado, isto é, variações volumétricas praticamente desprezíveis, com valores inferiores a 1\%. Essas variações são resultantes da presença de ar nos vazios do solo, uma vez que obtiveram-se alguns valores de parâmetro B relativamente baixos.

As deformações volumétricas resultantes do processo de consolidação isotrópica para a amostra T2A, tanto na condição saturada como na umidade natural, variaram em torno de $21 \%$ para os corpos de prova confinados com $100 \mathrm{kPa}, 29 \%$ para os com $200 \mathrm{kPa}$ e, em torno de $35 \%$, para os confinados com 300 e $400 \mathrm{kPa}$. Estes valores foram utilizados na correção da área transversal dos corpos de prova, após processo de consolidação isotrópica.

A Tabela 4.6 apresenta, para os ensaios não drenados executados com as amostras T1B, T2B e T2A, as características dos corpos de prova no final do adensamento e o parâmetro B de Skempton. Para obtenção desses índices físicos considerou-se que o teor de umidade no final do ensaio, após ruptura do corpo de prova, é igual ao teor de umidade no final do adensamento.

Tabela 4.6 - Principais características dos corpos de prova de $150 \mathrm{~mm}$ de diâmetro e $300 \mathrm{~mm}$ de altura, submetidos à ensaios CU, após adensamento.

\begin{tabular}{|c|c|c|c|c|c|c|c|c|c|}
\hline \multirow[b]{2}{*}{ Amostra } & \multirow[b]{2}{*}{ Ensaio } & \multirow[b]{2}{*}{$\mathbf{N}^{\circ}$} & \multirow{2}{*}{$\begin{array}{c}\sigma_{3} \\
(\mathrm{kPa})\end{array}$} & \multirow{2}{*}{$\begin{array}{c}\gamma_{\text {nat }} \\
\left(\mathrm{kN} / \mathrm{m}^{3}\right)\end{array}$} & \multirow[b]{2}{*}{ B } & \multicolumn{2}{|c|}{ Adens. (cm) } & \multirow{2}{*}{$\begin{array}{l}\gamma_{\mathrm{d} \text { adens }} \\
\left(\mathrm{kN} / \mathrm{m}^{3}\right)\end{array}$} & \multirow[b]{2}{*}{$\mathbf{e}_{\text {aden }}$} \\
\hline & & & & & & $\mathbf{h}$ & D & & \\
\hline \multirow{8}{*}{ T2A } & & 1 & 92 & 12,22 & - & 27,54 & 14,00 & 9,69 & 1,312 \\
\hline & $\mathrm{CU}_{\text {nat }}$ & 2 & 208 & 12,21 & - & 27,01 & 13,69 & 10,37 & 1,161 \\
\hline & & 3 & 408 & 12,38 & - & 26,50 & 13,34 & 9,61 & 1,333 \\
\hline & T2a12CUnat & 4 & 416 & 12,50 & - & 26,29 & 13,14 & 11,52 & 0,945 \\
\hline & & 1 & 102 & 12,40 & 0,87 & 27,48 & 13,88 & 9,34 & 1,399 \\
\hline & $\mathrm{CU}_{\text {sat }}$ & 2 & 216 & 12,35 & 0,86 & 26,95 & 13,43 & 9,89 & 1,263 \\
\hline & & 3 & 308 & 12,33 & 0,98 & 26,47 & 13,28 & 10,61 & 1,112 \\
\hline & T2a12CUsat & 4 & 226 & 12,35 & 0.99 & 26,80 & 13,45 & 10,23 & 1,190 \\
\hline \multirow{4}{*}{ T1B } & & 1 & 108 & 12,24 & 0,98 & 28,03 & 13,93 & 9,46 & 1,468 \\
\hline & $\mathrm{CU}_{\text {sat }}$ & 2 & 208 & 12,12 & 0,86 & 27,62 & 13,74 & 9,80 & 1,380 \\
\hline & & 3 & 408 & 11,99 & 0,87 & 27,24 & 13,75 & 9,99 & 1,337 \\
\hline & T1b12CUsat & 4 & 408 & 12,25 & 0,98 & 27,17 & 13,69 & 10,10 & 1,310 \\
\hline \multirow{4}{*}{ T2B } & & 1 & 108 & 12,12 & 0,92 & 27,50 & 13,75 & 10,97 & 1,285 \\
\hline & $\mathrm{CU}_{\text {sat }}$ & 2 & 208 & 12,26 & 0,88 & 27,64 & 13,91 & 10,69 & 1,343 \\
\hline & & 3 & 308 & 12,25 & 0,98 & 27,38 & 13,60 & 11,26 & 1,226 \\
\hline & T2b12CUsat & 4 & 408 & 12,26 & 0,90 & 27,33 & 13,58 & 11,33 & 1,212 \\
\hline
\end{tabular}

As Figuras 4.45 a 4.46 mostram os resultados dos ensaios CU com medida de pressão neutra, obtidos para a amostra T1B e T2B, sob condições saturadas, respectivamente. 


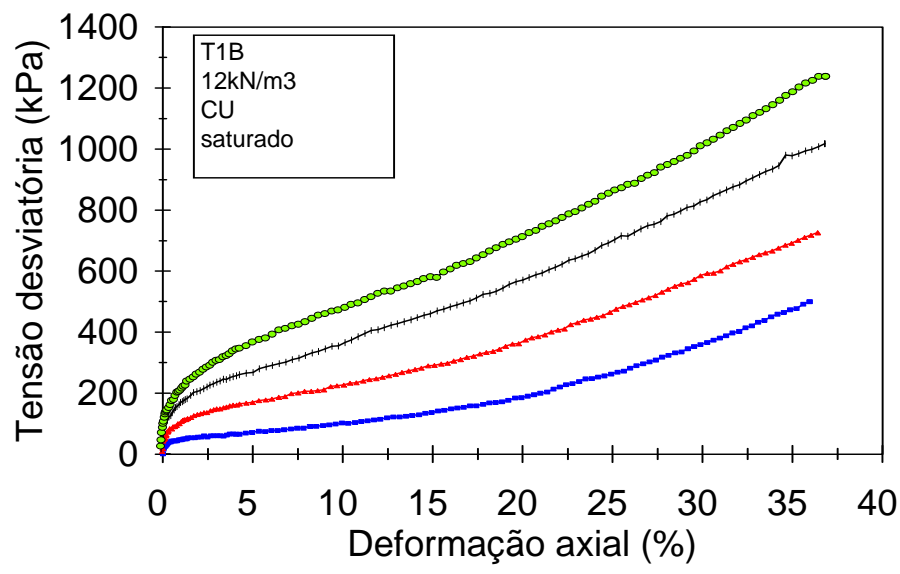

$-108 \mathrm{kPa}-208 \mathrm{kPa}+408 \mathrm{kPa}-408 \mathrm{kPa}$

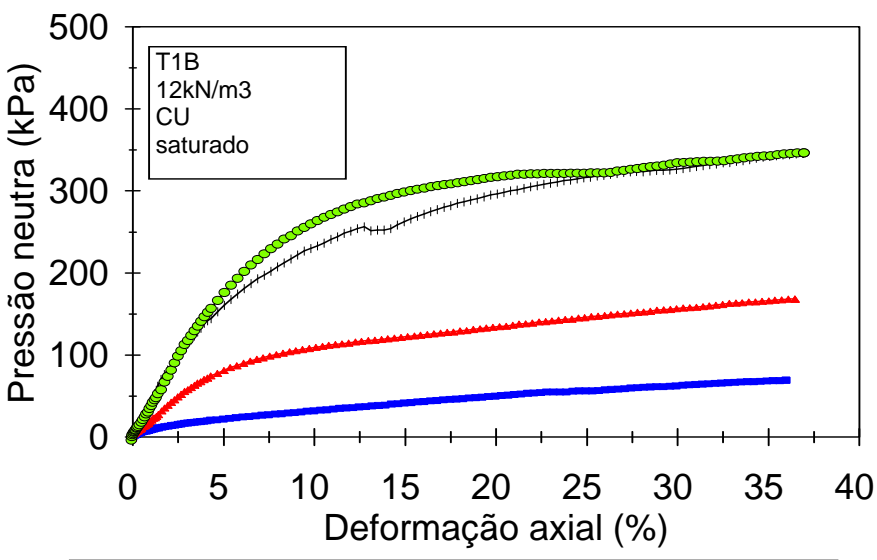

$108 \mathrm{kPa} \multimap 208 \mathrm{kPa}+408 \mathrm{kPa} \multimap 408 \mathrm{kPa}$

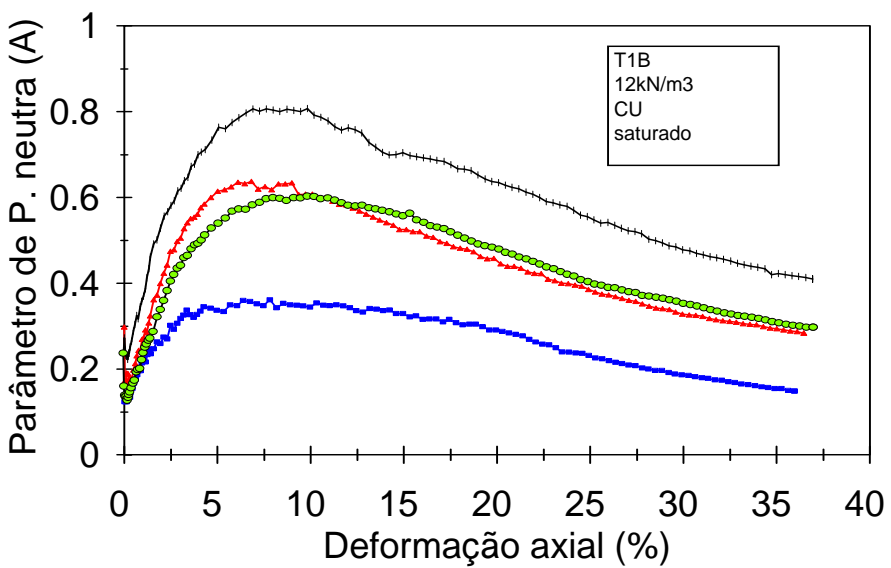

$--108 \mathrm{kPa}-208 \mathrm{kPa}+408 \mathrm{kPa}-\circ-408 \mathrm{kPa}$

Figura 4.45 - Resultados dos ensaios $C U_{\text {sat }}$ para a amostra T1B (T1b12CUsat), saturada, com diâmetro de $150 \mathrm{~mm}$ e altura $300 \mathrm{~mm}$ e peso específico de $12 \mathrm{kN} / \mathrm{m}^{3}$. 


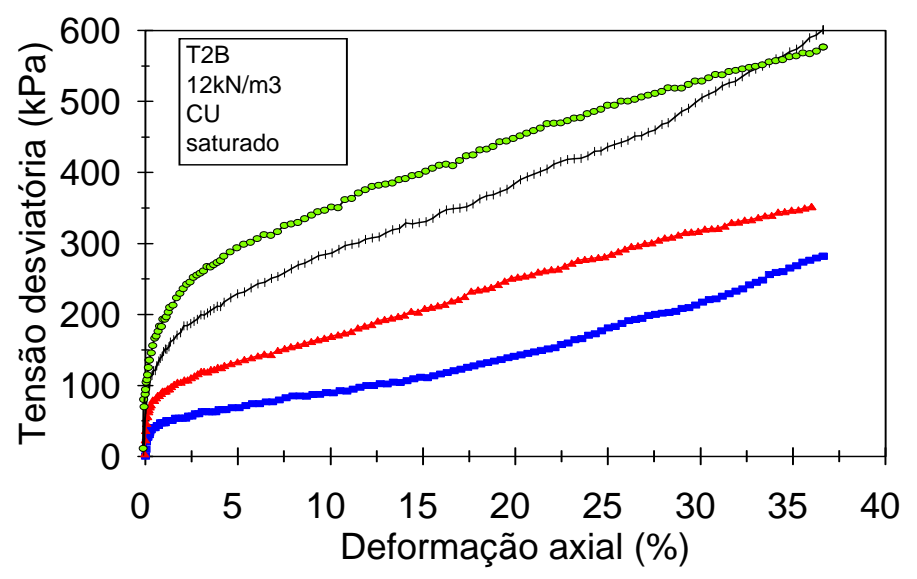

$-108 \mathrm{kPa}+208 \mathrm{kPa}+308 \mathrm{kPa}-408 \mathrm{kPa}$
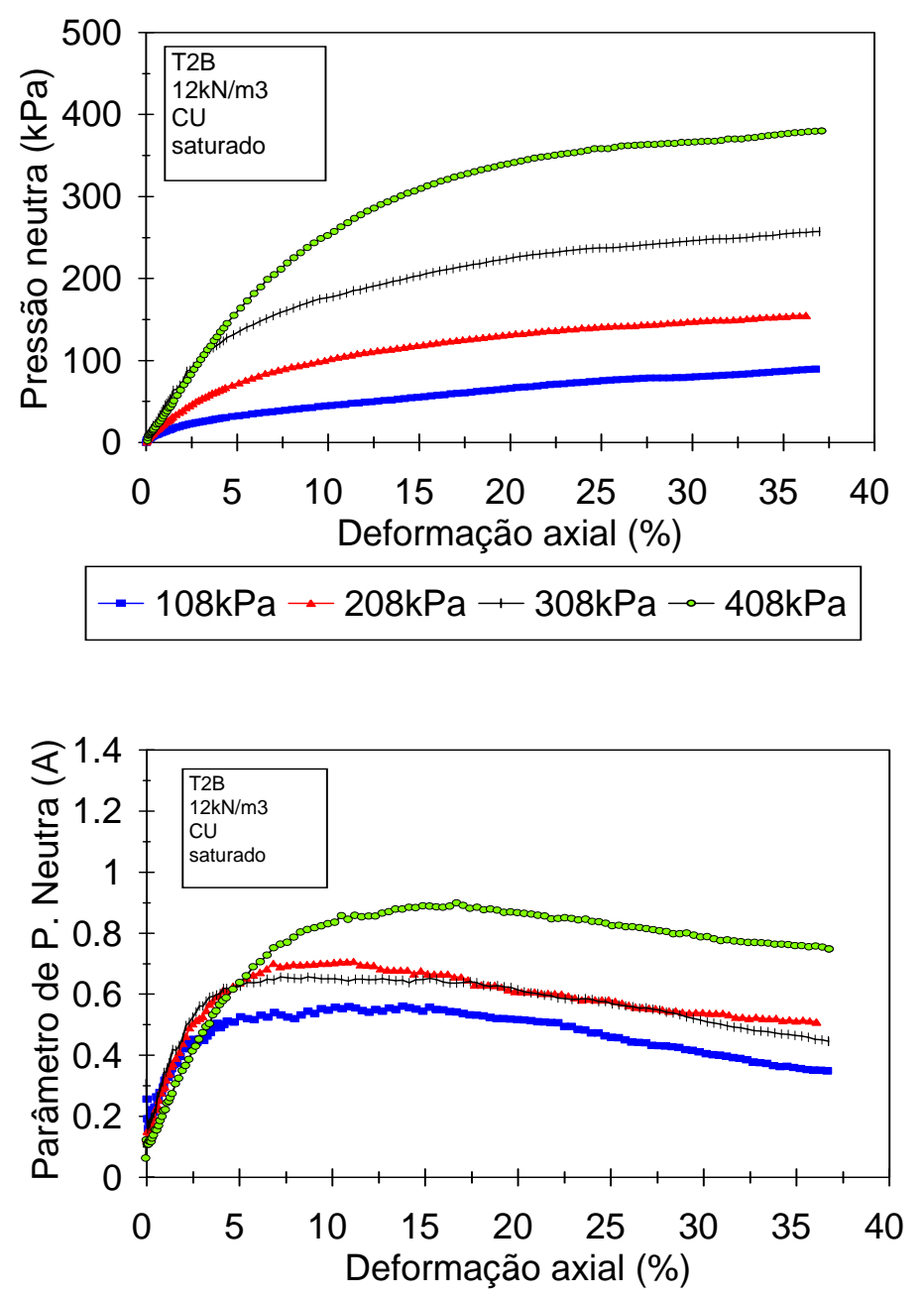

$-108 \mathrm{kPa}+208 \mathrm{kPa}+308 \mathrm{kPa} \rightarrow 408 \mathrm{kPa}$

Figura 4.46 - Resultados dos ensaios $C U_{\text {sat }}$ para a amostra T2B (T2b12CUsat), saturada, com diâmetro de $150 \mathrm{~mm}$ e altura $300 \mathrm{~mm}$ e peso específico de $12 \mathrm{kN} / \mathrm{m}^{3}$. 
Em termos de compressão isotrópica, a amostra T1B apresentou deformações volumétricas em torno de $20 \%$, para o corpo de prova submetido à pressão de confinamento de $100 \mathrm{kPa}, 24 \%$ para o de $200 \mathrm{kPa}$ e $26 \%$ para os de $400 \mathrm{kPa}$. Já a amostra T2B apresentou valores de $24 \%$, para o corpo de prova confinado com $100 \mathrm{kPa}, 21,3 \%$, para o de $200 \mathrm{kPa}$ e $26,5 \%$, para os corpos de prova submetidos a pressões de confinamento de 300 e $400 \mathrm{kPa}$. As características dos corpos de prova no final do adensamento, para essas amostras, foram apresentadas na Tabela 4.6.

\section{5 - ENSAIOS DE COMPRESSÃO CONFINADA}

As curvas índices de vazios - logaritmo da pressão vertical obtidas para todas as amostras estudadas estão apresentadas nas Figuras 4.47 a 4.52.

As Figuras 4.47 a 4.49 apresentam os resultados obtidos para a amostra T2A, ensaiada na umidade natural, com pesos específicos de 8,10 e $14 \mathrm{kN} / \mathrm{m}^{3}$, respectivamente.

Os resultados dos ensaios de compressão confinada obtidos para a amostra T1B com peso específico em torno de $10 \mathrm{kN} / \mathrm{m}^{3}$ e na umidade de moldagem de $95,4 \%$ estão apresentados na Figura 4.50. Na Figura 4.51 apresenta-se os resultados obtidos para a amostra T1B, com peso específico em torno de $10 \mathrm{kN} / \mathrm{m}^{3}$ e vazios saturados com água. Já a Figura 4.52 mostra a curva e $x \log \sigma$ para a amostra T2B, ensaiada na umidade de moldagem de $67,8 \%$ e peso específico de $12 \mathrm{kN} / \mathrm{m}^{3}$.

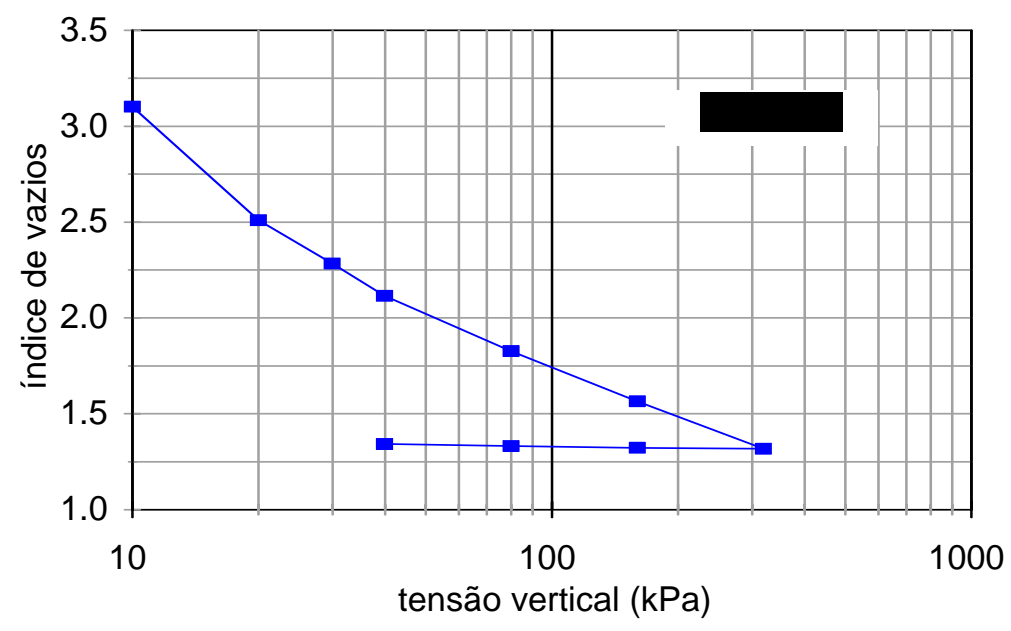

Figura 4.47 - Curva índice de vazios - log da tensão vertical, obtida para a amostra $T 2 A$, com peso específico de $8 \mathrm{kN} / \mathrm{m}^{3}$ e umidade de $63,1 \%$. 


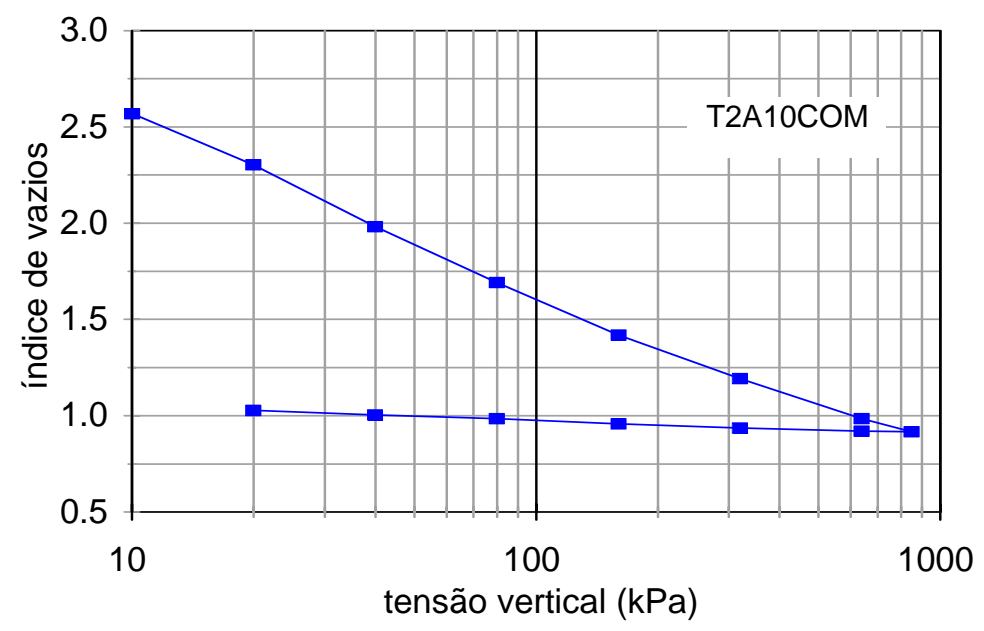

Figura 4.48 - Curva índice de vazios - log da tensão vertical, obtida para a amostra T2A, com peso específico de $10 \mathrm{kN} / \mathrm{m}^{3}$ e umidade de $59,2 \%$.

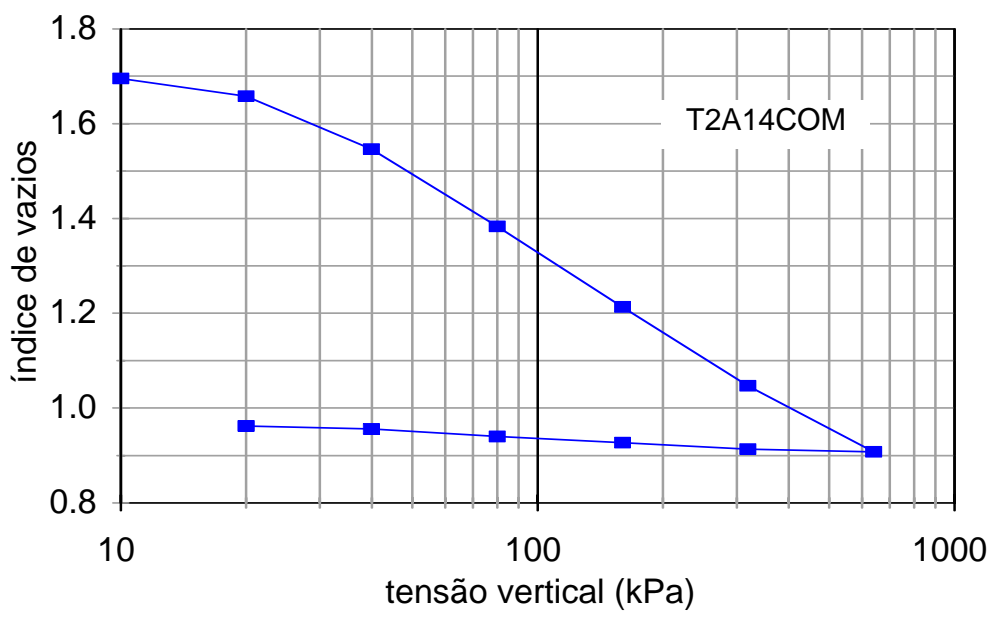

Figura 4.49 - Curva índice de vazios - log da tensão vertical, obtida para a amostra $T 2 A$, com peso específico de $14 \mathrm{kN} / \mathrm{m}^{3}$ e umidade de $62,4 \%$.

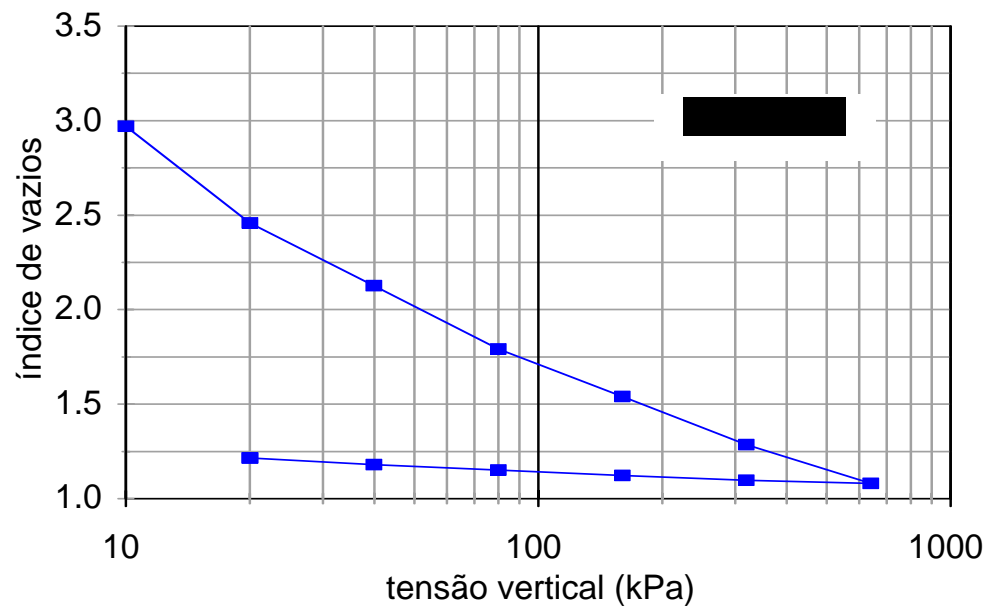

Figura 4.50 - Curva índice de vazios - log da tensão vertical, obtida para a amostra T1B, com peso específico de $10 \mathrm{kN} / \mathrm{m}^{3}$ e umidade de $95,4 \%$. 


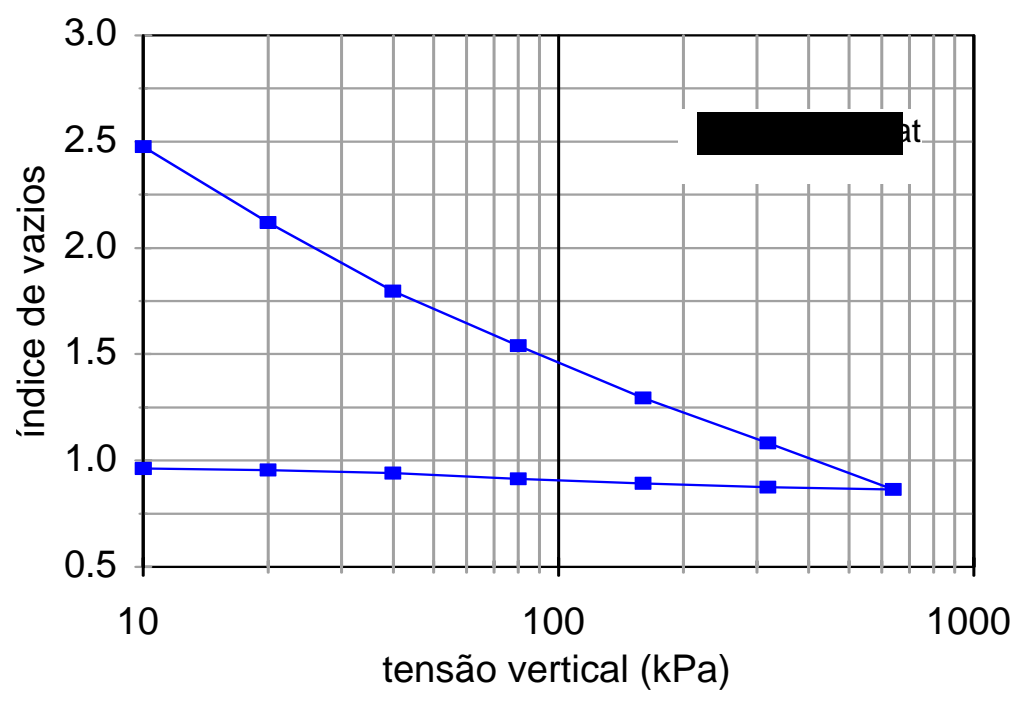

Figura 4.51 - Curva índice de vazios - log da tensão vertical, obtida para a amostra T1B, com peso específico de $10 \mathrm{kN} / \mathrm{m}^{3}$ e na condição saturada.

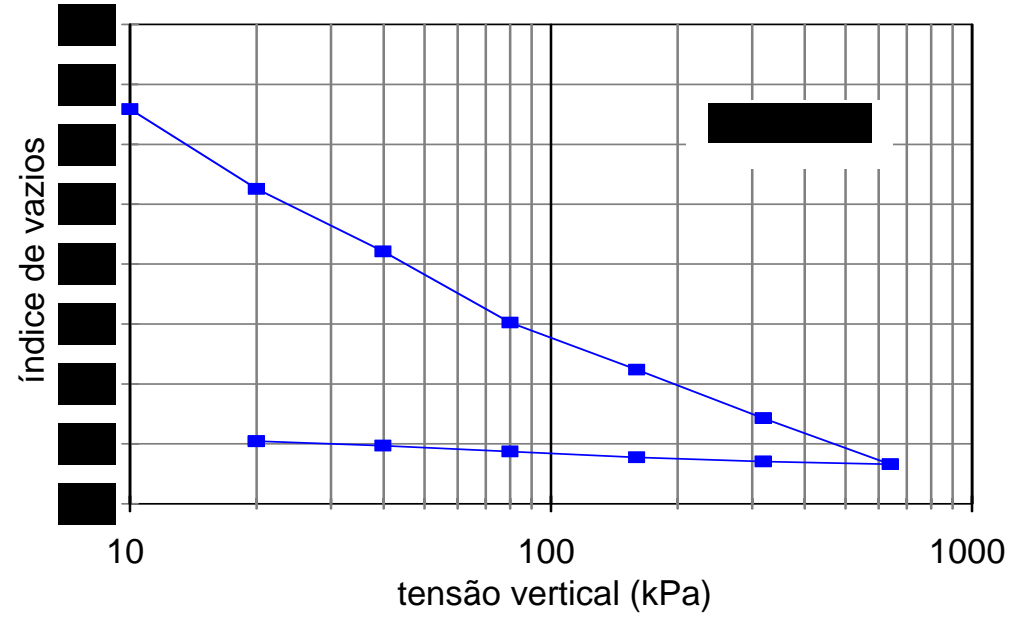

Figura 4.52 - Curva índice de vazios - log da tensão vertical, obtida para a amostra T2B, com peso específico de $12 \mathrm{kN} / \mathrm{m}^{3}$ e umidade de $67,8 \%$.

É importante observar que no ensaio executado para amostra T1B com os vazios saturados com água (T1B10COMsat) ocorreu uma rápida expulsão de grande parte da lixívia com a aplicação do pré carregamento de $10 \mathrm{kPa}$, ocasionando uma brusca redução do índice de vazios inicial de 3,157 para 2,476.

As Figuras 4.53 a 4.64 apresentam as curvas de leitura do extensômetro $x$ raiz do tempo e leitura do extensômetro $\mathrm{x} \log \mathrm{t}$, para todas as amostras ensaiadas nos distintos estágios de carregamento. 

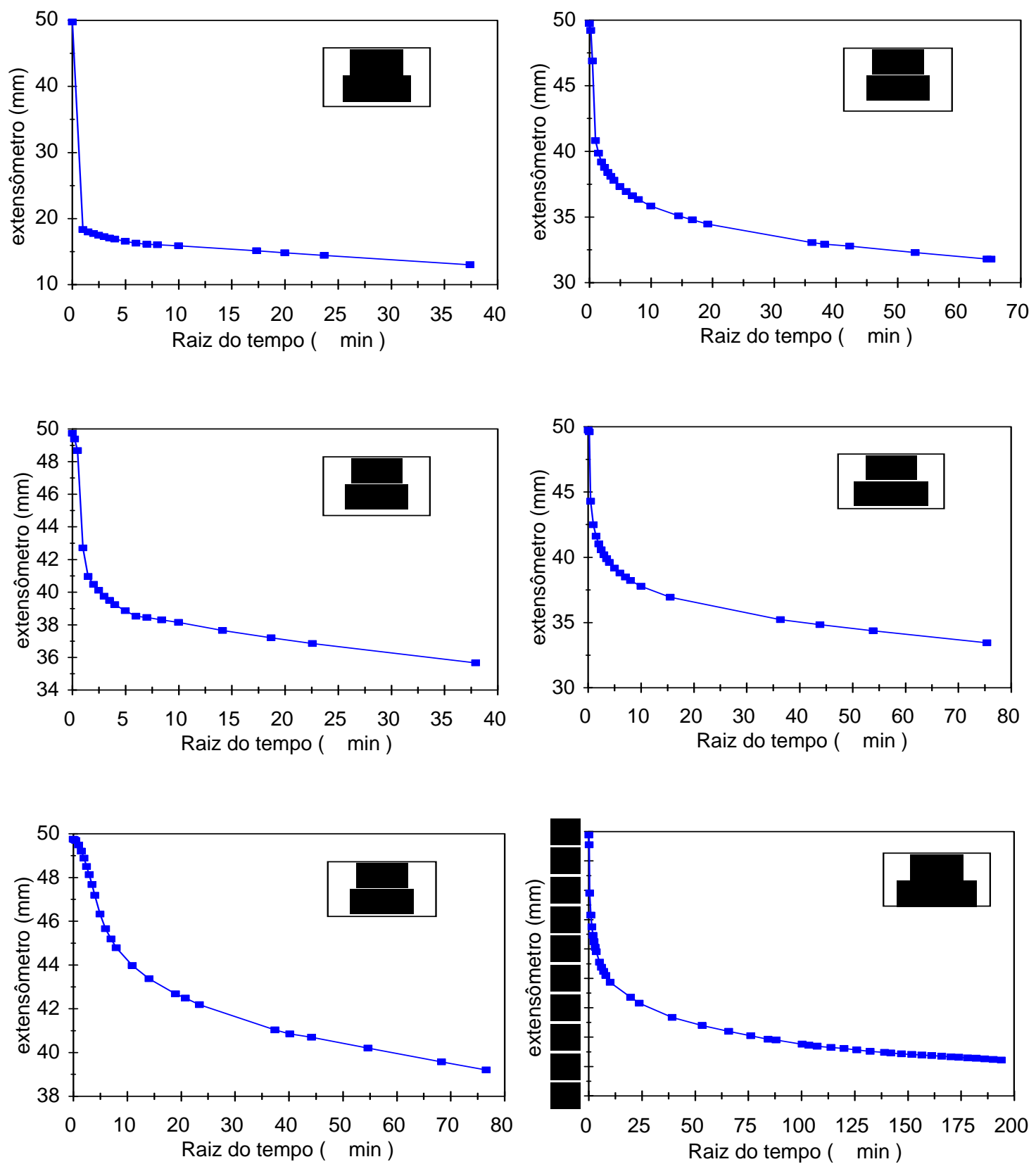

Figura 4.53 - Curvas de leitura do extensômetro x raiz do tempo obtida para a amostra T2A8COM. Peso específico inicial de $8 \mathrm{kN} / \mathrm{m}^{3}$ e umidade inicial de $63,1 \%$. 

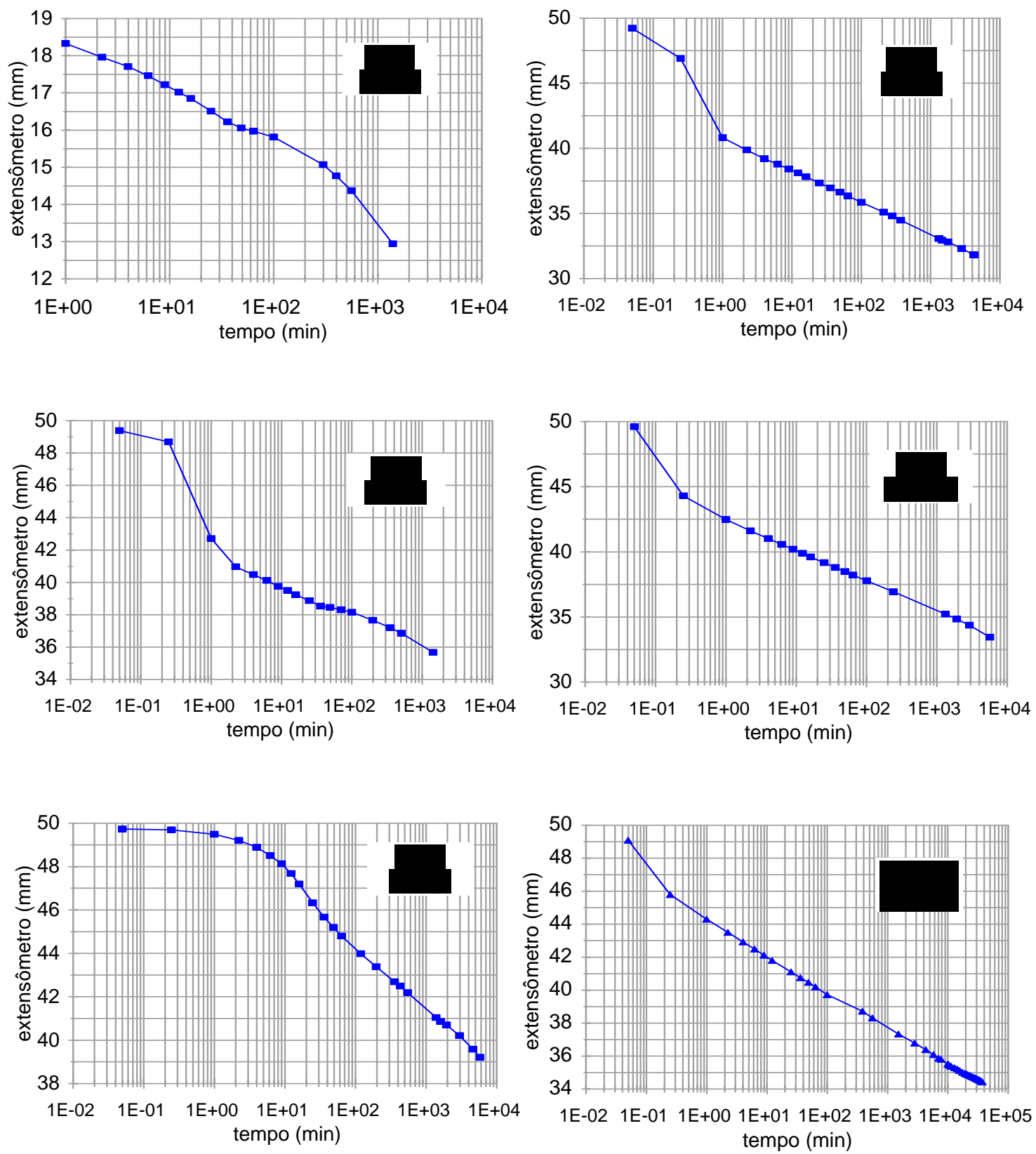

Figura 4.54 - Curvas de leitura do extensômetro x log t obtida para a amostra T2A8COM. Peso específico inicial de $8 \mathrm{kN} / \mathrm{m}^{3}$ e umidade inicial de $63,1 \%$. 

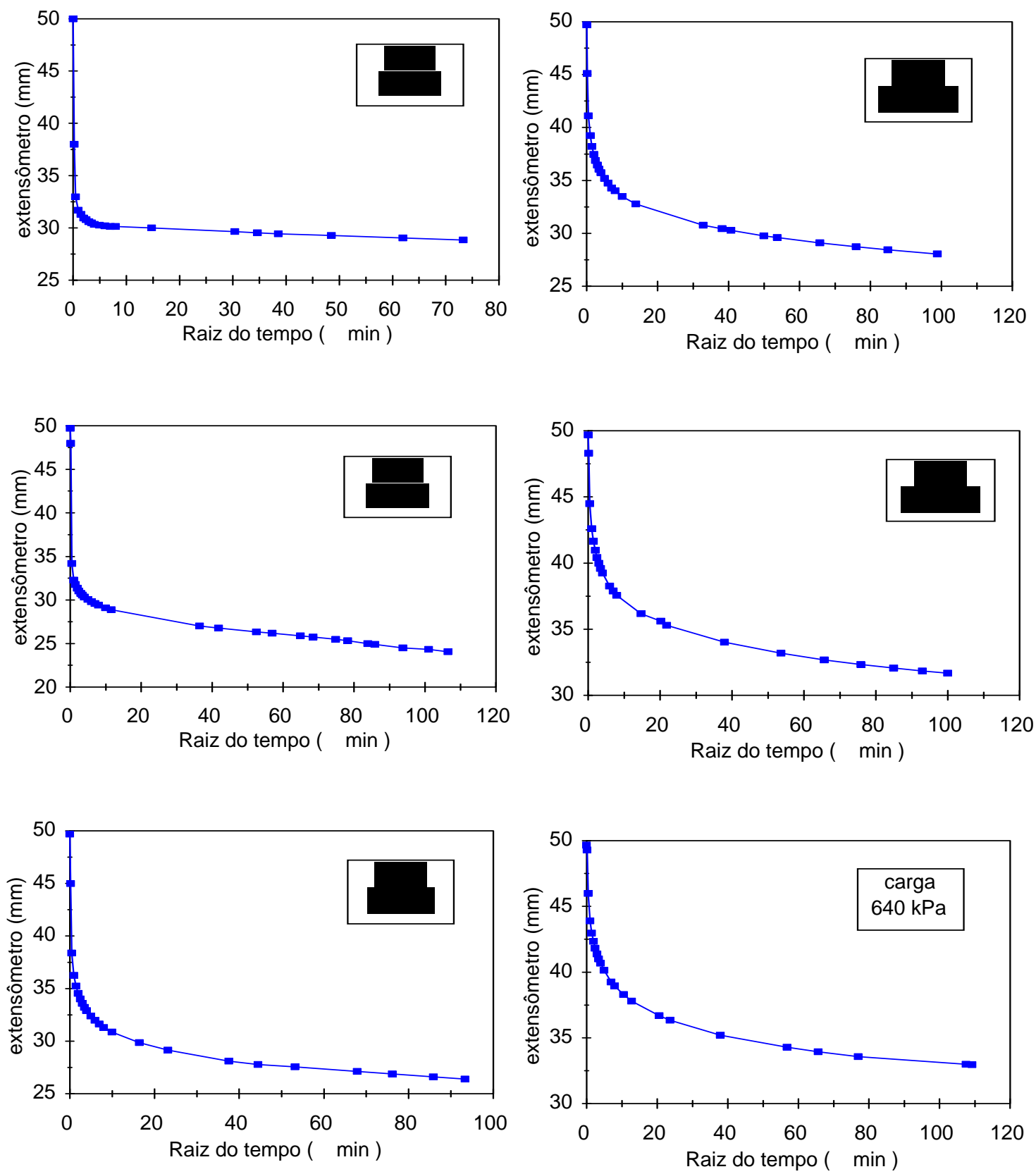

Figura 4.55 - Curvas de leitura do extensômetro x raiz do tempo obtida para a amostra T2A10COM. Peso específico inicial de $10 \mathrm{kN} / \mathrm{m}^{3}$ e umidade inicial de 59,2\%. 

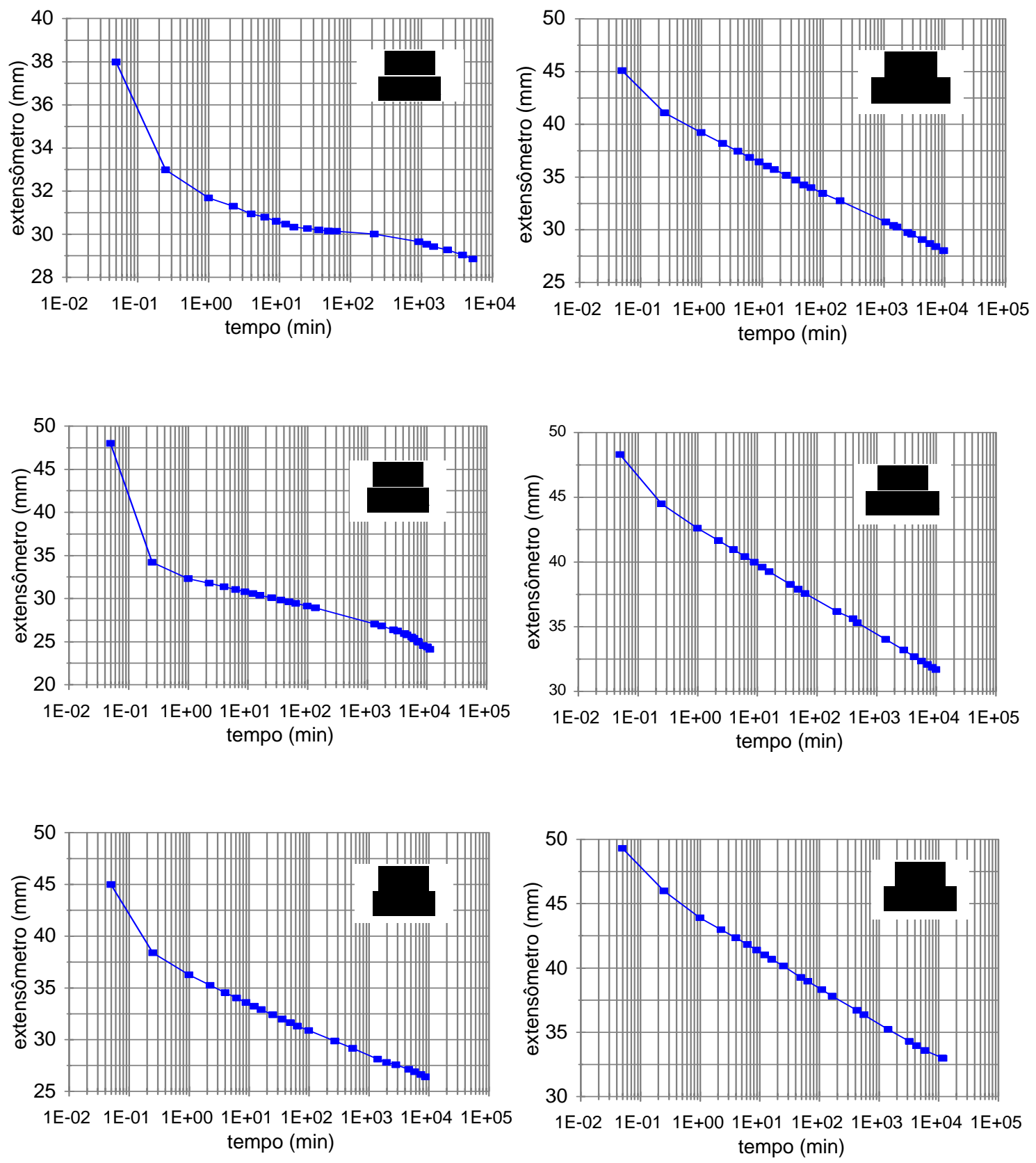

Figura 4.56 - Curvas de leitura do extensômetro x log t obtida para a amostra T2A10COM. Peso específico inicial de $10 \mathrm{kN} / \mathrm{m}^{3}$ e umidade inicial de $59,2 \%$. 

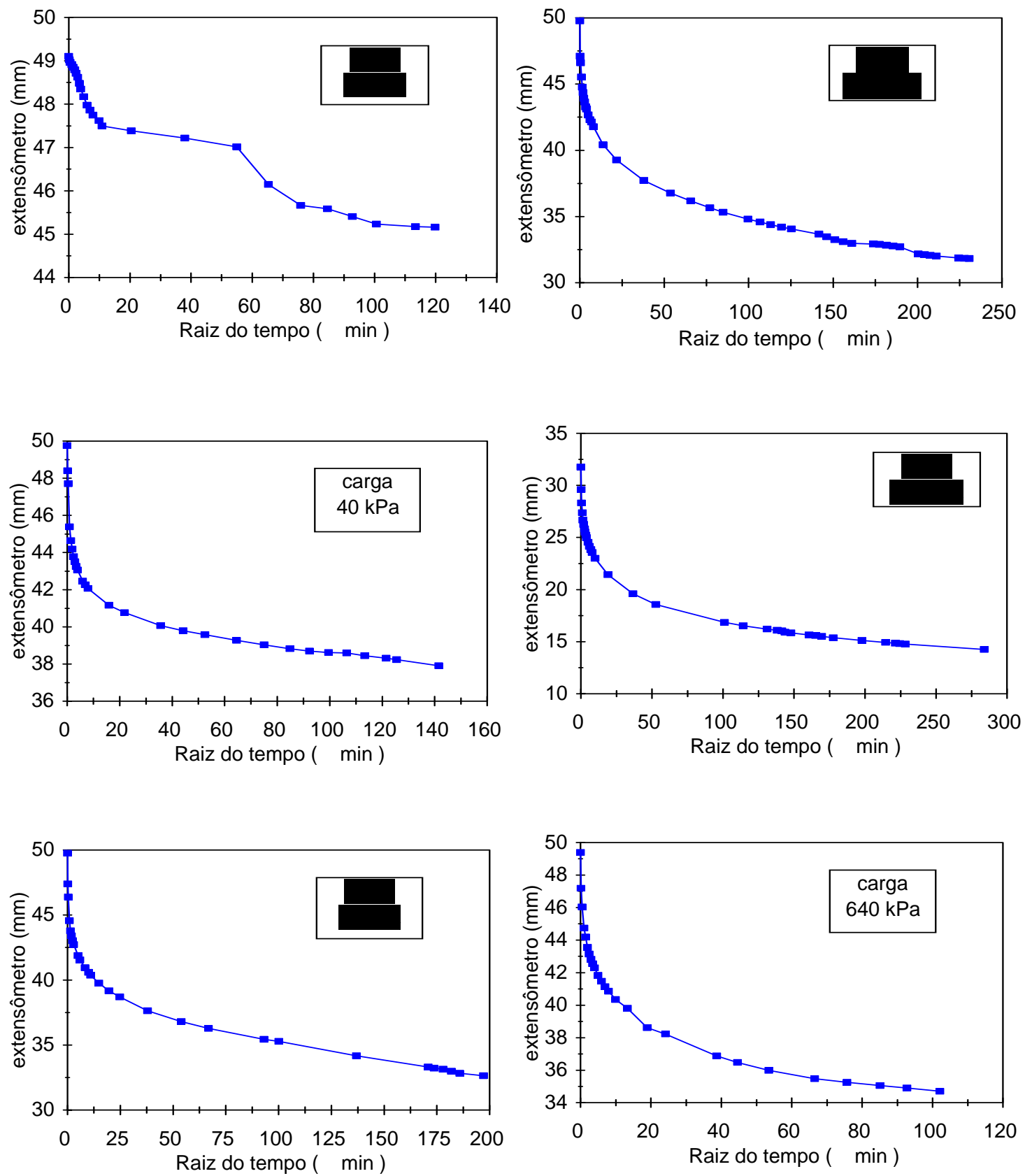

Figura 4.57 - Curvas de leitura do extensômetro x raiz do tempo obtida para a amostra T2A14COM. Peso específico inicial de $14 \mathrm{kN} / \mathrm{m}^{3}$ e umidade inicial de $62,4 \%$. 

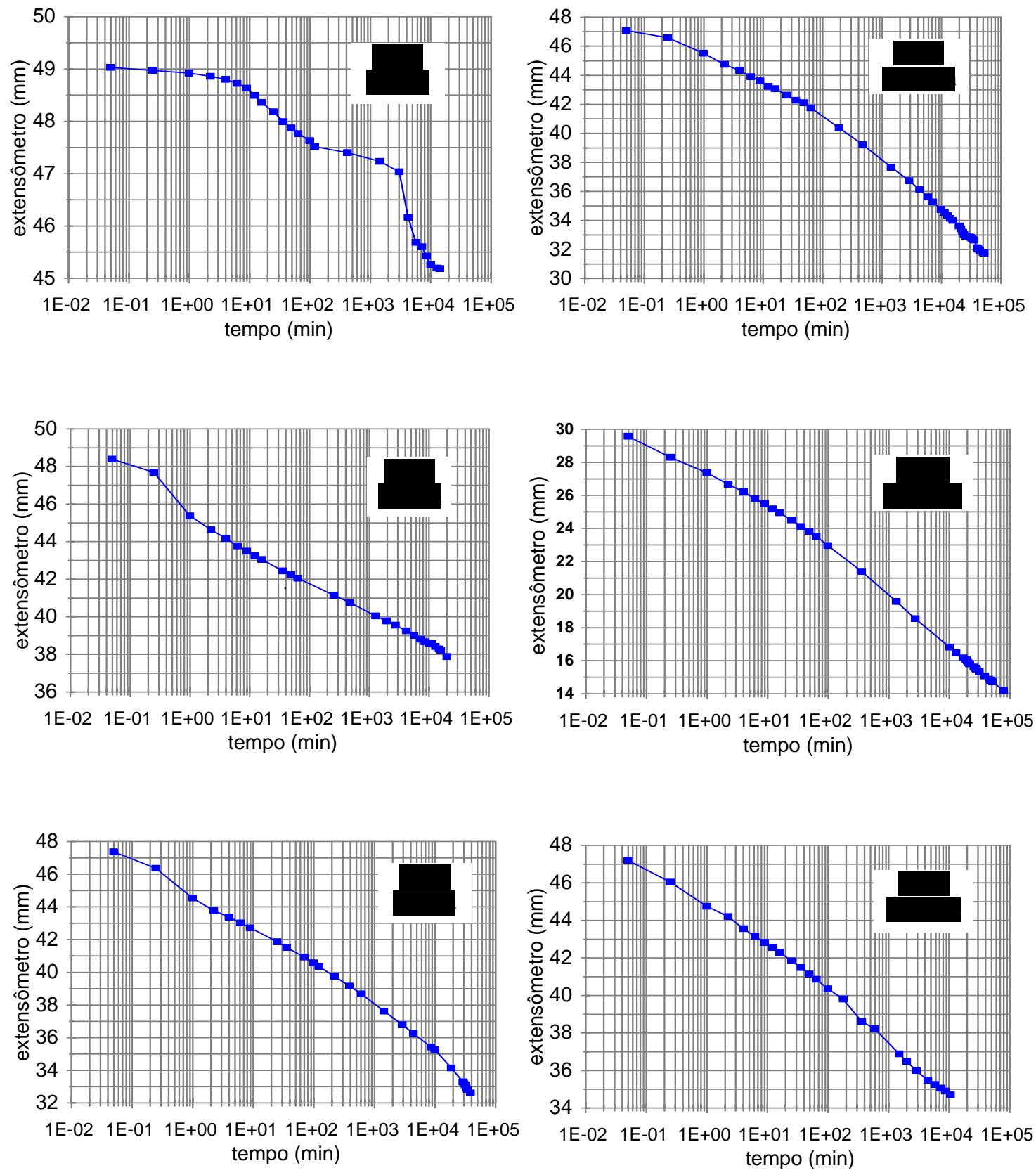

Figura 4.58 - Curvas de leitura do extensômetro x log t obtida para a amostra T2A14COM. Peso específico inicial de $14 \mathrm{kN} / \mathrm{m}^{3}$ e umidade inicial de $62,4 \%$. 

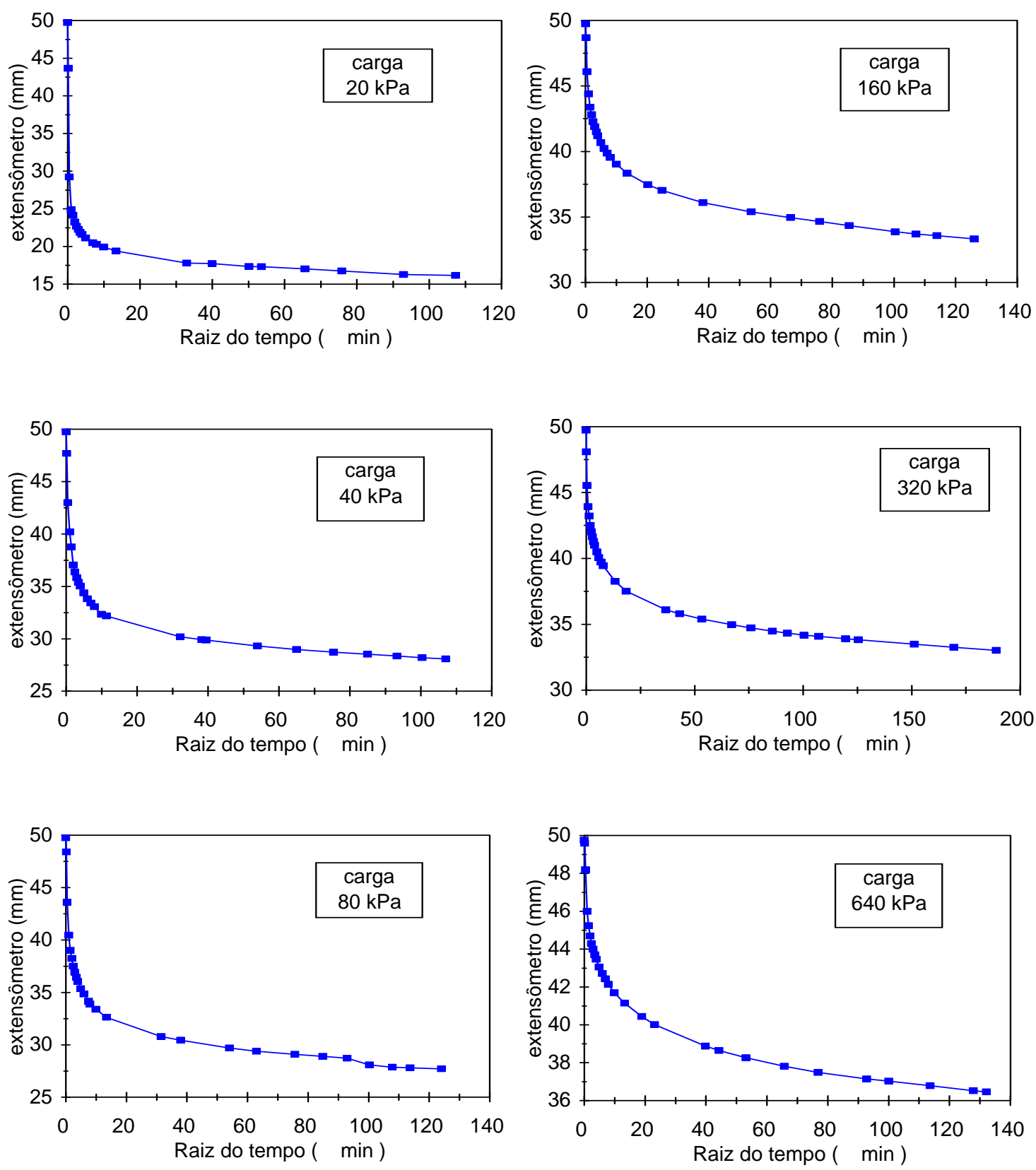

Figura 4.59 - Curvas leitura do extensômetro $x$ raiz do tempo obtida para a amostra T1B10COM. Peso específico inicial de $10 \mathrm{kN} / \mathrm{m}^{3}$ e umidade inicial de 95,4\%. 


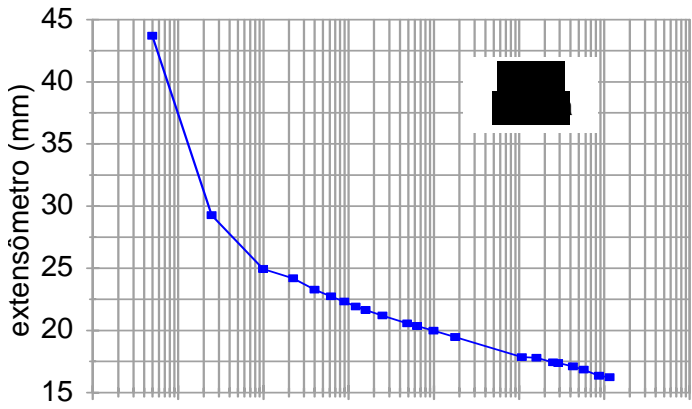

1E-02 1E-01 1E+00 1E+01 1E+02 1E+03 1E+04 1E+05 tempo ( $\mathrm{min})$

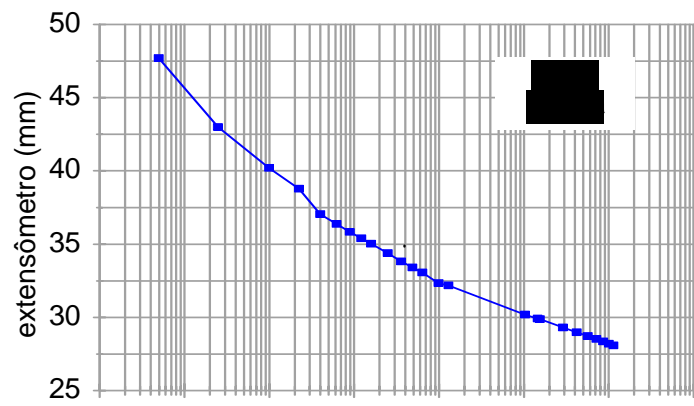

1E-02 1E-01 1E+00 1E+01 1E+02 1E+03 1E+04 1E+05 tempo (min)

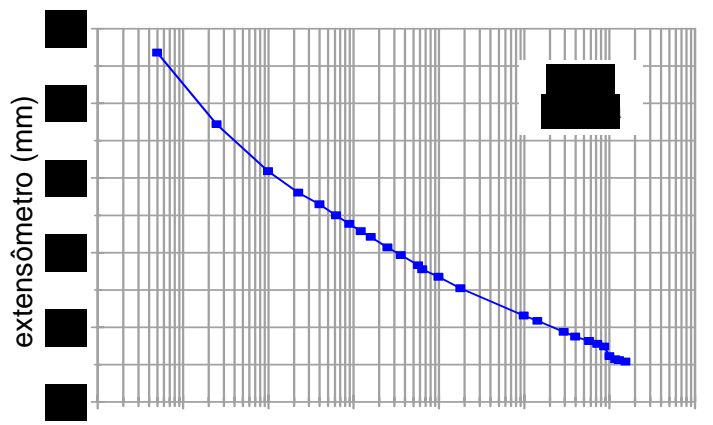

1E-02 1E-01 1E+00 1E+01 1E+02 1E+03 1E+04 1E+05 tempo ( $\mathrm{min})$
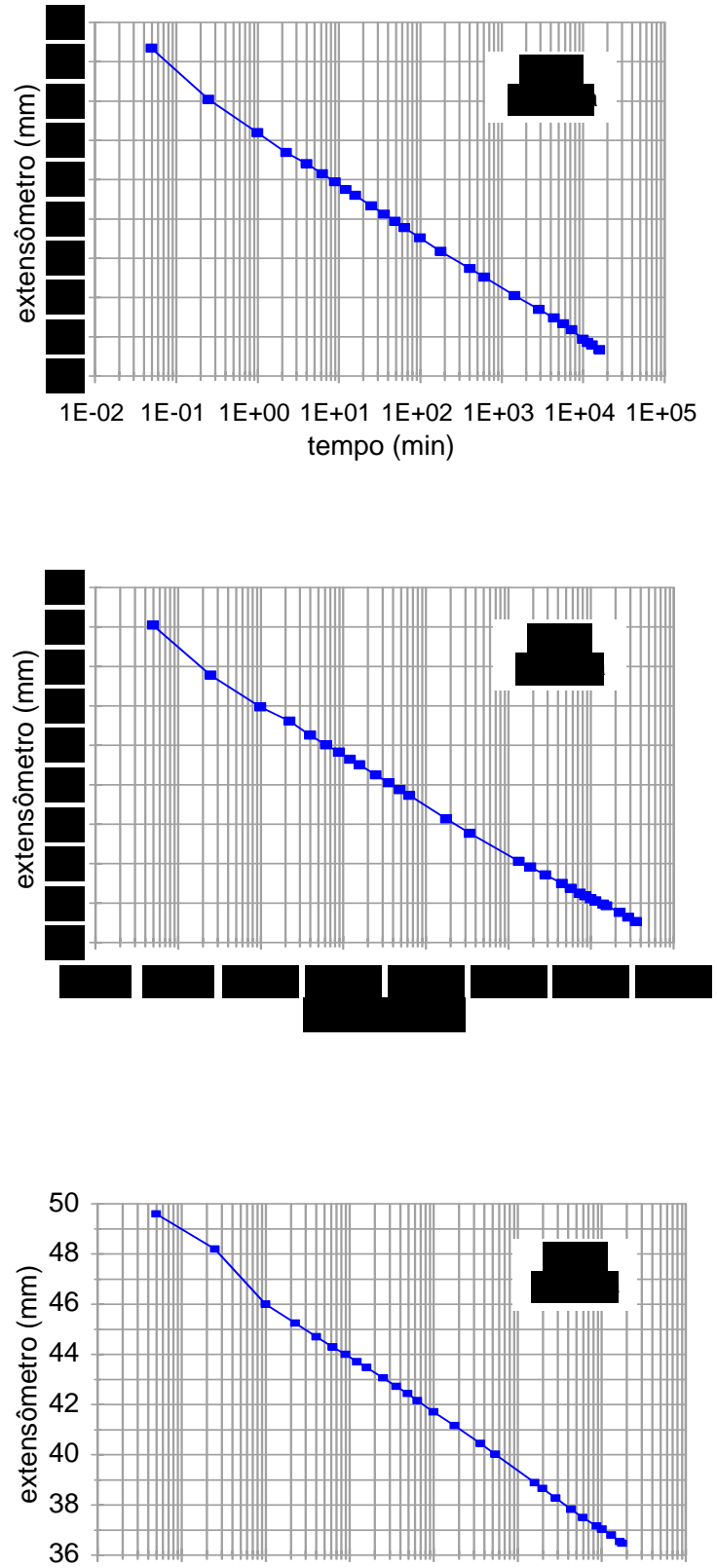

1E-02 1E-01 1E+00 1E+01 1E+02 1E+03 1E+04 1E+05 tempo (min)

Figura 4.60- Curvas leitura do extensômetro $x \log t$ obtida para a amostra T1B10COM. Peso específico inicial de $10 \mathrm{kN} / \mathrm{m}^{3}$ e umidade inicial de $95,4 \%$. 

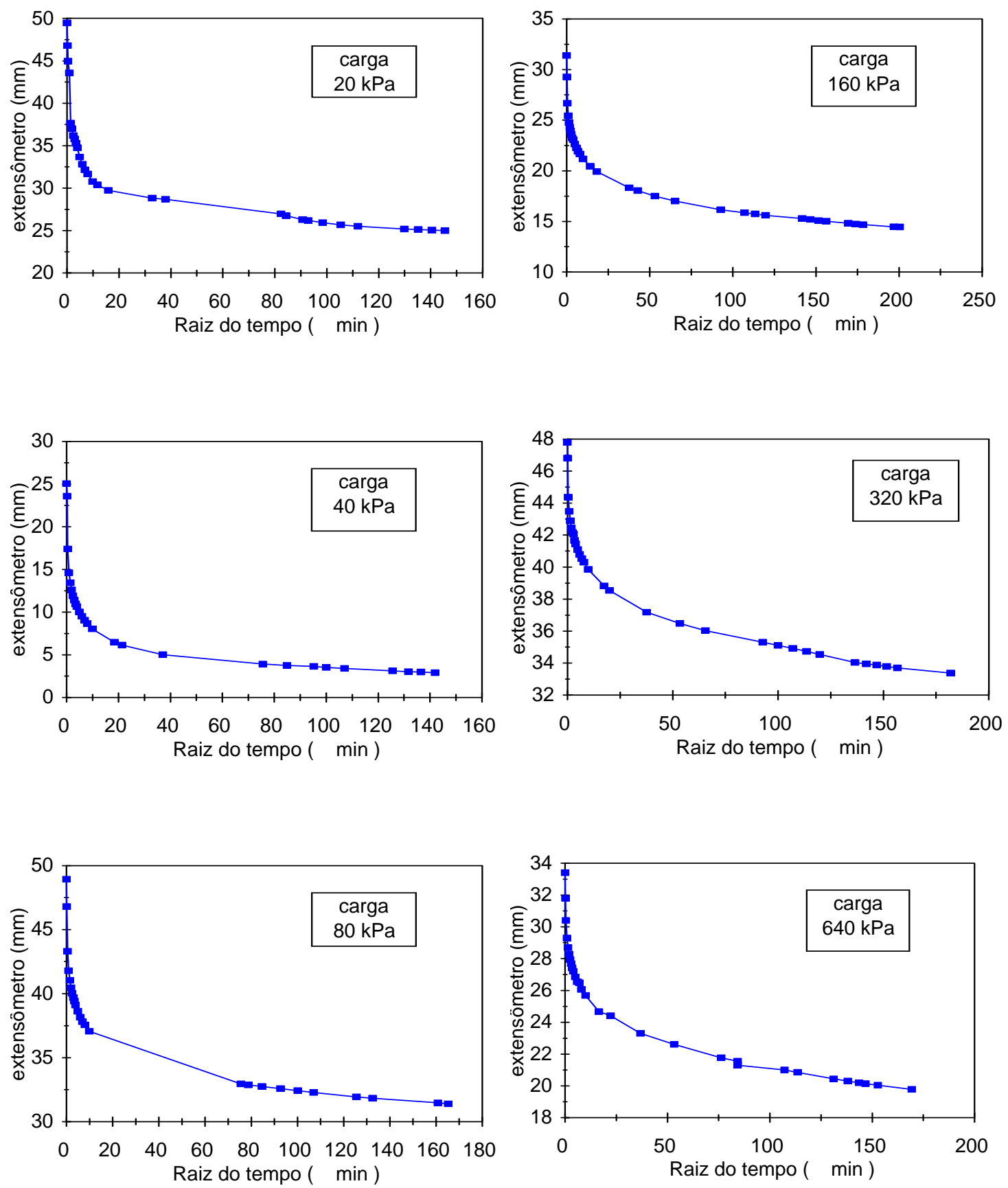

Figura 4.61 - Curvas leitura do extensômetro $x$ raiz do tempo obtida para a amostra T1B10COMsat. Peso específico inicial de $10 \mathrm{kN} / \mathrm{m}^{3}$ e com os vazios saturados com água. 

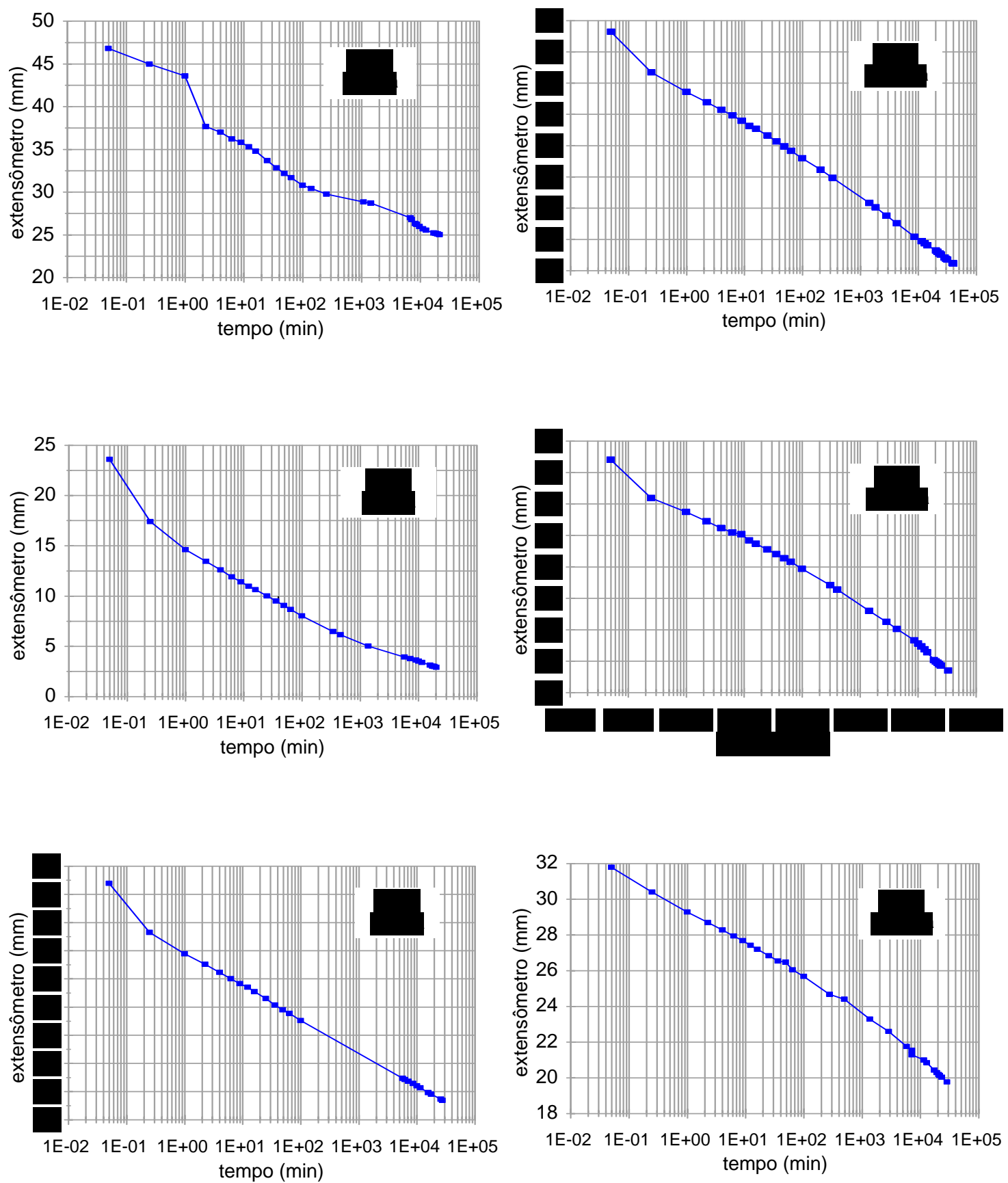

Figura 4.62 - Curvas leitura do extensômetro $x \log t$ obtida para a amostra T1B10COMsat. Peso específico inicial de $10 \mathrm{kN} / \mathrm{m}^{3}$ e com os vazios saturados com água. 

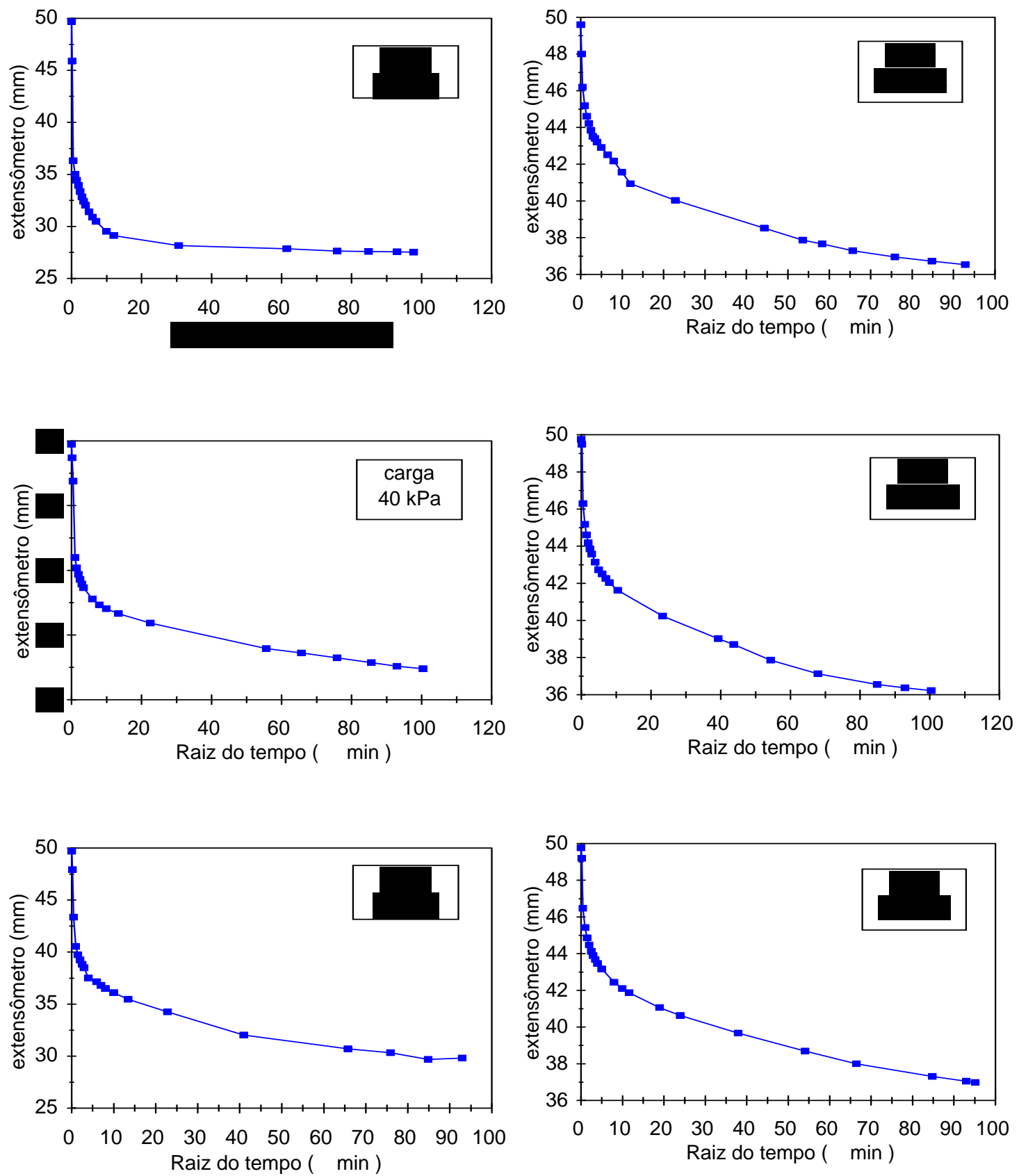

Figura 4.63- Curvas leitura do extensômetro $x$ raiz do tempo obtida para a amostra T2B12COM. Peso específico inicial de $12 \mathrm{kN} / \mathrm{m}^{3}$ e umidade inicial de $67,8 \%$. 

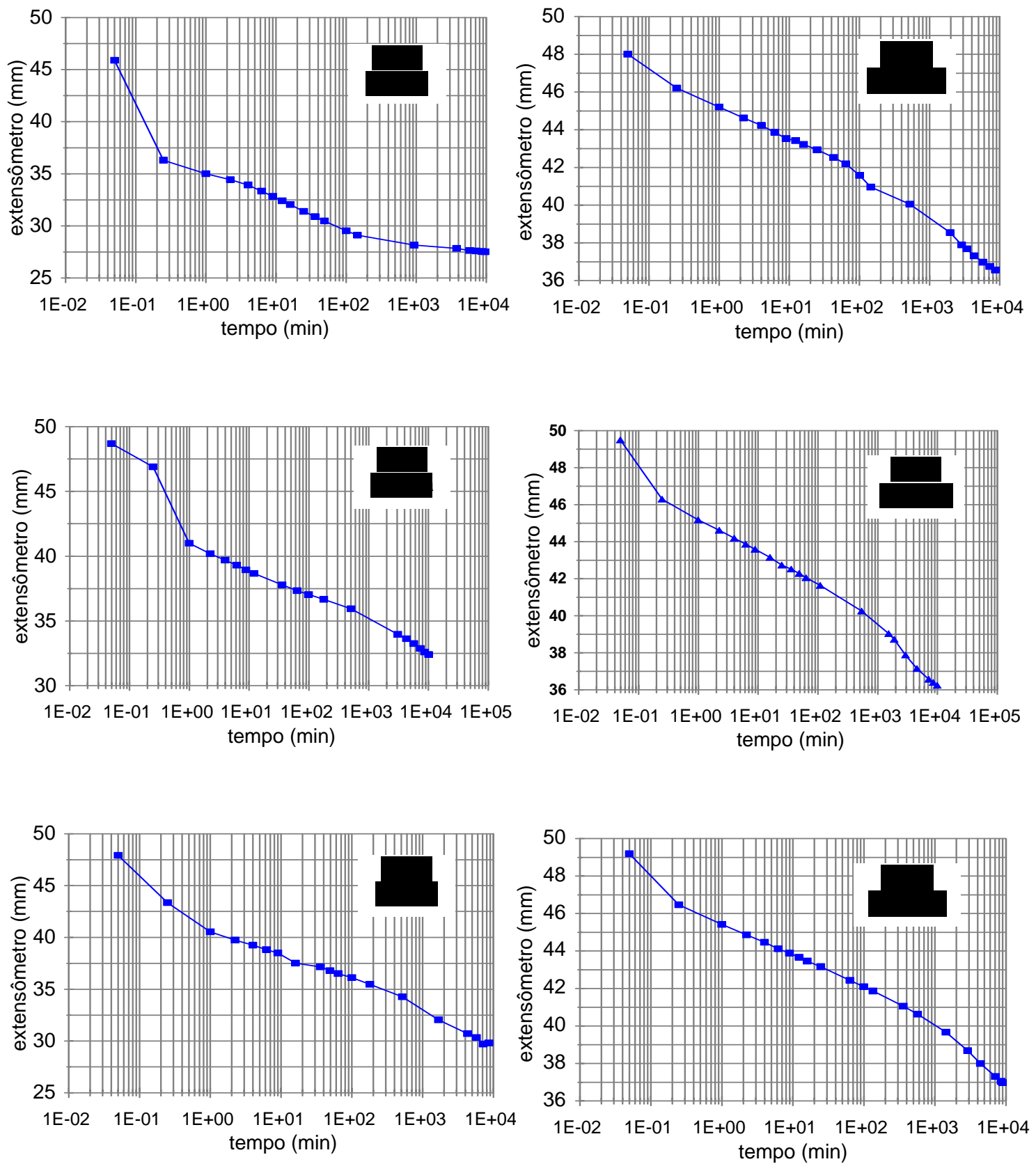

Figura 4.64 - Curvas de leitura do extensômetro x log t obtida para a amostra T2B12COM. Peso específico inicial de $12 \mathrm{kN} / \mathrm{m}^{3}$ e umidade inicial de $67,8 \%$. 


\section{5 - ANÁLISE DOS RESULTADOS}

\section{1 - INTRODUÇÃO}

Neste capítulo serão feitas análises e interpretações dos resultados apresentados no capítulo anterior. As análises serão apresentadas em quatro etapas, as quais compreendem as investigações in situ desenvolvidas, a caracterização físico-química do resíduo coletado, ensaios de resistência ao cisalhamento e ensaios de compressibilidade.

A grande dificuldade no estudo e na interpretação de resultados de ensaios com resíduos sólidos urbanos está associada com a heterogeneidade do material, o qual apresenta diferentes tipos e dimensões de constituintes, presença de componentes que podem degradar com o tempo, etc. Além disso, a adoção de modelos teóricos e técnicas de ensaios de campo e de laboratório, desenvolvidos para solos podem não dar resultados confiáveis quando aplicados para resíduos sólidos urbanos.

As investigações in situ podem ser afetadas pela presença de materiais muito resistentes existentes na massa de RSU, bem como pela presença das camadas de solo de cobertura das células, as quais são difíceis de serem adequadamente definidas devido aos recalques diferenciais. Já as investigações de laboratório, além das dificuldades citadas, podem ser afetadas pela representatividade das amostras, dimensões dos corpos de prova e tipo de ensaio mais adequado, etc.

Até o presente, as propriedades físicas e mecânicas dos RSU estão sendo estudadas estendendo-se para esses materiais os mesmos conceitos da Engenharia Geotécnica desenvolvidos para solos. Existem várias limitações no uso dessa aproximação, pois o RSU possui como citado, diferenças importantes em relação aos solos.

Isto aponta para a necessidade de desenvolvimento de novas teorias ou adaptação das teorias existentes de sorte a ter-se modelos realistas que possam traduzir o complexo comportamento dos resíduos sólidos urbanos. 


\section{2 - ENSAIOS IN SITU}

\subsection{1 - Sondagens de simples reconhecimento com medida de SPT e do torque}

Observa-se, para as camadas de resíduo sólido urbano (RSU), uma tendência de aumento da resistência à penetração média com a profundidade (Figuras 4.1 a 4.5). Excluindo os valores maiores que 20 golpes, os quais correspondem ao esforço para ultrapassar os materiais mais resistentes como pedra, borracha e madeira, o SPT médio é cerca de 7 golpes para as camadas mais superficiais. O SPT alcança 12 golpes para as camadas mais profundas de resíduo (10 - 30m de profundidade). Os valores medidos estão de acordo com os encontrados na literatura (SOWERS, 1968; SINGH \& MURPHY, 1990; SÁNCHEZ- ALCITURRI, 1993; VELLOSO, 1994 e JUCÁ et al. 1997).

Os torques medidos apresentam alguns valores altos (acima de $400 \mathrm{~N} . \mathrm{m}$ ), os quais correspondem igualmente ao cisalhamento de regiões com materiais mais resistentes (madeira e cascalho). Os torques aumentam com a profundidade da mesma forma que os valores de SPT.

De acordo com QUARESMA et al. (1996) a relação entre os valores do torque (T) medidos em kgf.m e os valores de penetração $(\mathrm{N})$ permitem classificar os solos de acordo com um novo sistema de classificação, onde a estrutura do solo desempenha um papel fundamental. Quanto mais estruturado é o solo, maior é o índice de torque (T/N). QUARESMA et al. (1996) apresentam valores de T/N da ordem de 1,2 para solos sedimentares da bacia terciaria de São Paulo e para solos colapsíveis essa relação varia entre 2,5 a 5,0 .

No presente caso, descartando-se os valores de $\mathrm{N}$ maior que 20 golpes, T maior que $300 \mathrm{~N}$.m e os valores correspondentes aos trechos de solo de cobertura do RSU, obtiveram-se a relação $\mathrm{T} / \mathrm{N}$ variando de 0,4 a 2,7. A Figura 5.1 apresenta um histograma de freqüência para os valores de $T / N$ obtidos. A média dos valores $T / N$ para o resíduo estudado é de 1,58.

Considerando os valores médios da resistência à penetração do amostrador $(\mathrm{N})$, obtidos para o resíduo sólido urbano e empregando as correlações existentes entre valores de $\mathrm{N}$ e $\phi$ propostos para solos arenosos, obtiveram-se uma faixa de variação de $26^{\circ}-32^{\circ}$ para o ângulo de atrito efetivo. Já considerando o material puramente coesivo $(\phi=0)$, obtiveram-se valores de resistência ao cisalhamento não-drenada (su) variando entre $90 \mathrm{a}$ $150 \mathrm{kPa}$.

Os valores de resistência à penetração $\mathrm{N}$ obtidos não apresentam nenhum tipo de correlação com a velocidade de propagação das ondas obtidas do ensaio cross-hole. Por outro lado, foi possível correlacionar a resistência à penetração do SPT com a penetração do cone (ver item 5.2.2), porém obtiveram-se baixo coeficiente de determinação. 


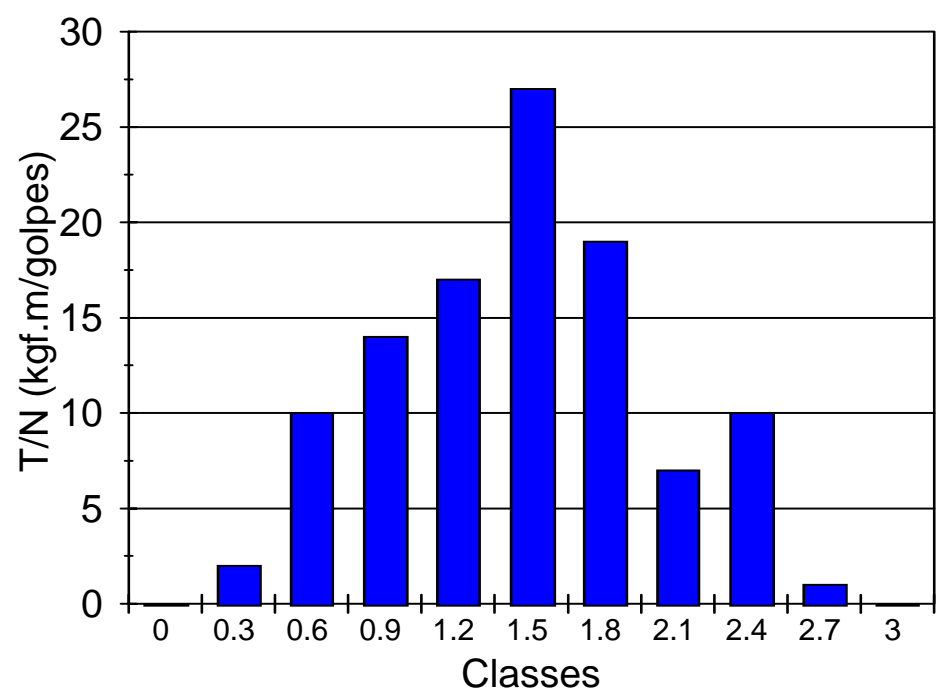

Figura 5.1 - Histograma de freqüência dos valores T/N.

\subsection{2 - Ensaio de penetração contínua - CPT}

Os resultados dos ensaios de CPT indicam que o cone encontra freqüentemente objetos rígidos, os quais produzem picos na resistência de ponta medida. Os resultados obtidos são altamente variáveis como pode ser visto nas Figuras 4.6 e 4.7, onde a resistência lateral varia entre 56 a 1056 kPa e a resistência de ponta entre 1200 a 18000 $\mathrm{kPa}$. Em ambos os casos, uma envoltória para os valores mínimos mostra uma tendência de aumento dos valores de resistência com a profundidade. Para o CPT-02 (Fig. 4.7) a partir dos 17 metros de profundidade ocorreu uma deflexão das hastes do equipamento, assim a partir dessa profundidade os valores foram considerados não representativos.

A resistência de ponta típica é cerca de 2500 - 7500 kPa e a razão de atrito (atrito lateral/ resistência de ponta) de 2,5 - 5\%. Estes valores plotados na carta de Schmertmann (1978) caem na região de areia argilosa a silte e argila siltosa a arenosa (Figura 5.2). Nesta análise, os valores maiores que $10.000 \mathrm{kPa}$, para a resistência de ponta e $400 \mathrm{kPa}$, para a resistência lateral foram considerados não representativos para o resíduo em estudo, portanto foram excluídos. Os valores de resistência obtidos para o resíduo em questão apresentam-se de acordo com os reportados na literatura por HINKLE (1990), SÁNCHEZALCITURRI et al. (1993) e KÖNIG \& JESSBERGER (1997), porém apresentam uma maior faixa de variação.

Correlações existentes com a resistência do cone, para solos arenosos, permitiram estimar valores de ângulo de atrito efetivo entre $29^{\circ}-33^{\circ}$ para resíduo sólido urbano estudado. Para esse caso, bem como para o do SPT, os ângulos de atrito estimados apresentam-se maiores que aqueles obtidos por meio de ensaios triaxiais consolidados drenados para $20 \%$ de deformação axial. Os resultados típicos do cone também permitiram estimar para o RSU valores de coesão não drenada (su) variando entre 45 a $120 \mathrm{kPa}$. 


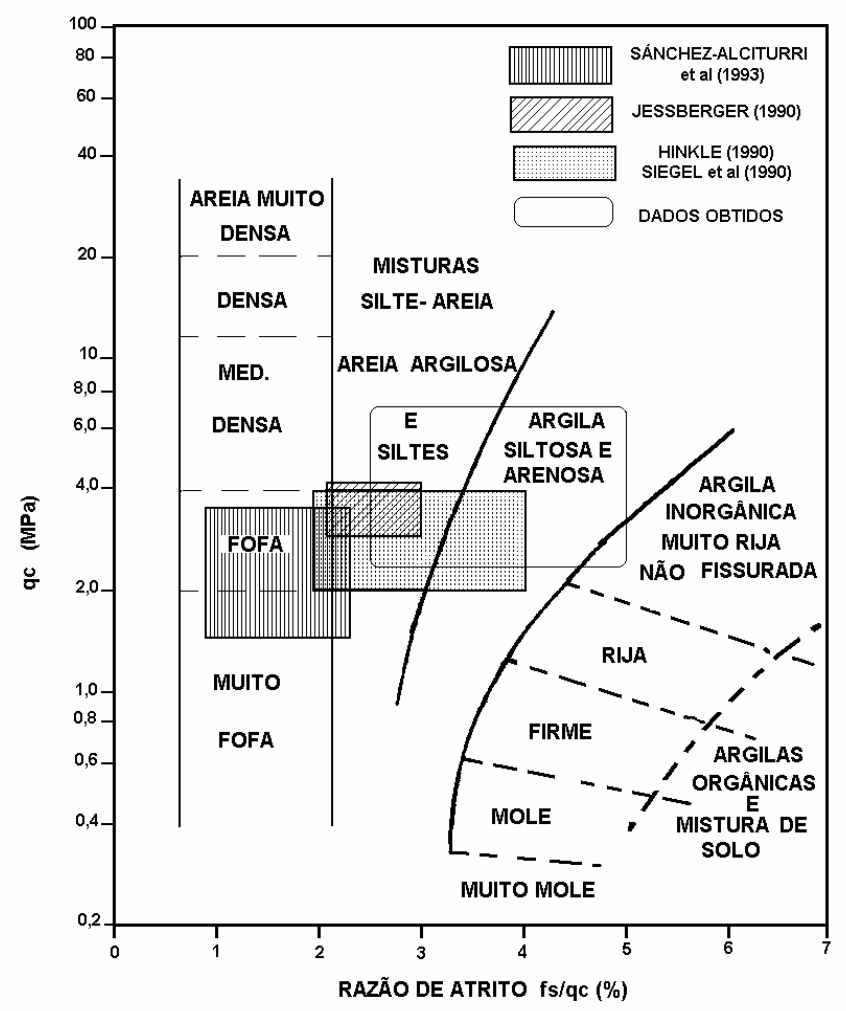

Figura 5.2 - Carta de Schmertmann.

A Figura 5.3 apresenta a correlação obtida entre a resistência de ponta (qc) e a resistência à penetração $(\mathrm{N})$. Nas análises, para os dois locais investigados, foram excluídos os valores de $\mathrm{N}$ maior que 20 golpes e de qc maior que $10.000 \mathrm{kPa}$, bem como os valores correspondentes aos trechos de cobertura de solo. Os valores de qc utilizados são valores médios, obtidos das medidas do cone de $30 \mathrm{em} 30 \mathrm{~cm}$, para o mesmo intervalo de profundidade de determinação do SPT. Obtiveram-se para o resíduo estudado uma relação do tipo qc $=0,53 \mathrm{~N}$ (qc em MPa), com coeficiente de determinação de 0,66. Nesta figura também está apresentado a faixa correspondente a 90\% de confiança dos valores médios obtidos.

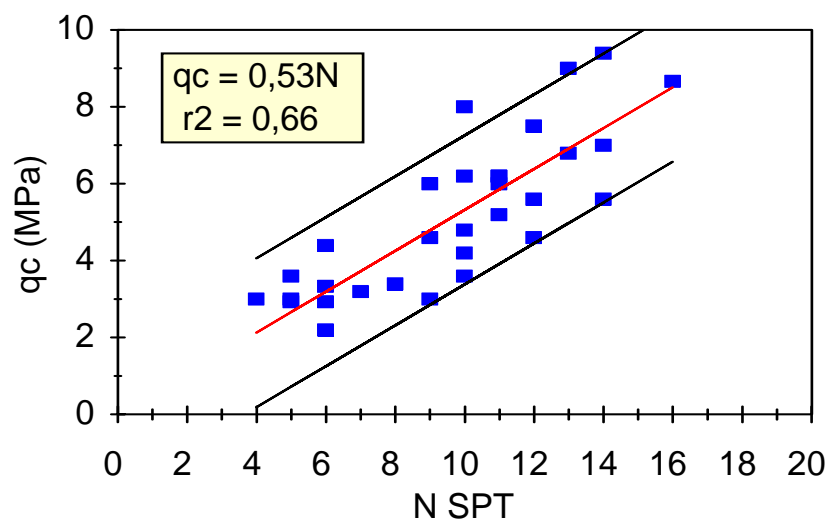

Pontos medidos — Regressão

Figura 5.3 - Correlação entre qc x N para o resíduo sólido urbano estudado. 
Correlações obtidas entre a resistência de ponta do cone com a velocidade de propagação das ondas de cisalhamento e de compressão do ensaio cross-hole são apresentadas nas Figuras 5.4 e 5.5, respectivamente. Obtiveram-se para a velocidade de propagação da onda de cisalhamento $\left(v_{s}\right)$ a relação $q c=0,124 v_{s}-9,2$ (qc em MPa), com coeficiente de determinação $\left(r^{2}\right)$ igual 0,83 , já para a velocidade de propagação da onda de compressão $\left(v_{p}\right)$ obtiveram-se $q c=0,045 v_{p}-5,5$ (qc em MPa) e coeficiente de determinação igual a 0,92.

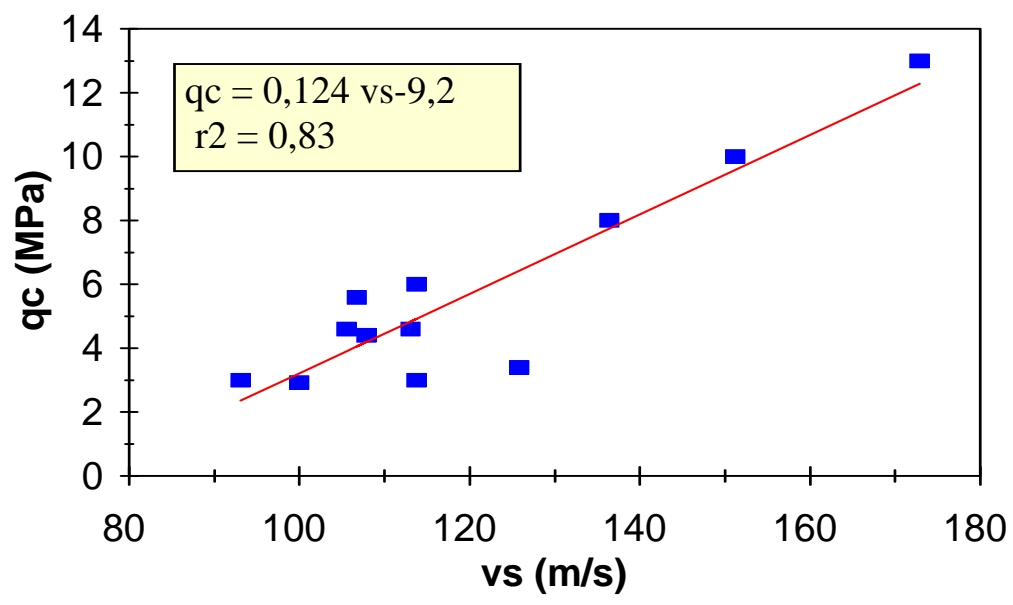

- Pontos medidos - Regressão

Figura 5.4 - Correlação obtida entre $q c \times v_{s}$ para o resíduo sólido urbano estudado.

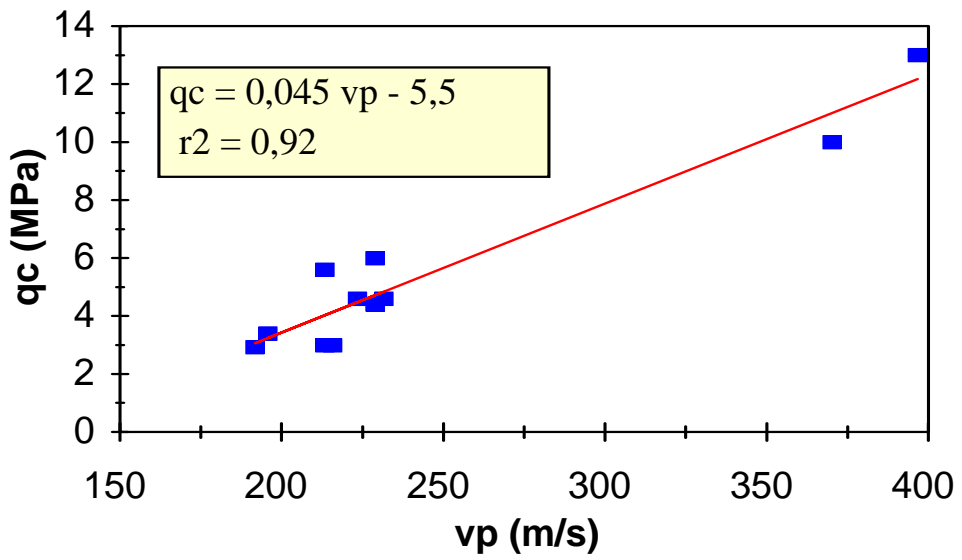

- Pontos medidos — Regressão

Figura 5.5 - Correlação obtida entre $q c \times v_{p}$ para o resíduo sólido urbano estudado. 
Embora os coeficientes de determinação entre qc e as velocidades de propagação das ondas de cisalhamento e compressão sejam melhores que aquele obtido de correlação com valores de $\mathrm{N}$, é importante observar que o número de dados utilizados nas análises é bastante reduzido, o que pode condicionar o resultado. Os dados utilizados para essa análise foram obtidos do ensaio cross-hole (na berma superior) e do CPT-02, o qual foi executado até a profundidade de 17 metros, a partir daí o ensaio teve que ser finalizado, pois ocorreu a deflexão das hastes do equipamento.

\subsection{3 - Ensaios de infiltração em furos de sondagens}

Os coeficientes de permeabilidade obtidos para o resíduo estudado variaram entre $10^{-4}$ a $10^{-6} \mathrm{~cm} / \mathrm{seg}$ (Figura 4.8). Nesta figura observa-se uma tendência do coeficiente de permeabilidade reduzir com a profundidade em virtude do efeito da consolidação do RSU, resultante das camadas sobrejacentes.

Devido ao resíduo sólido urbano apresentar partículas de grandes dimensões, em geral, isso leva a associar para este material elevadas permeabilidades. No entanto, não é o que se tem observado, a partir de ensaios de campo, para resíduos com algum tempo de aterramento. Em geral, obtém-se valores de permeabilidade relativamente baixos indicando a influência do processo de consolidação, quer seja devido ao adensamento do maciço quer seja devido à processos de degradação.

CEPOLLINA et al. (1994) obtiveram, a partir de testes de rebaixamento em poço de grande diâmetro $(50 \mathrm{~cm})$ e profundidade (30 metros) e de abertura de valas de investigações de grandes dimensões, coeficiente de permeabilidade médio da ordem de $10^{-5} \mathrm{~cm} / \mathrm{seg}$ para resíduo urbano do Aterro Bandeirantes, com cerca de 12 anos de disposição.

Os coeficientes de permeabilidade apresentados na literatura são muito variáveis, indo desde valores de $10^{-3}$ a $10^{-2} \mathrm{~cm} / \mathrm{seg}$, para aterros do Canadá (LANDVA \& CLARK, 1990) até valores de $10^{-5} \mathrm{~cm} / \mathrm{seg}$, para aterros de Recife, Brasil (JUCÁ et al. $1997 \mathrm{e}$ SANTOS et al. 1998).

\subsection{4 - Estimativa do peso específico in situ do resíduo}

A estimativa do peso específico in situ obtida através da pesagem dos resíduos coletados dos furos de trado foi problemática, devido a processos de relaxação do furo e seu respectivo fechamento. Assim uma maior quantidade de material foi extraída do furo, o que resultou em medidas de pesos e volumes errôneos. O uso de pasta de bentonita para medida do volume, em uma das perfurações permitiu certificar da ocorrência do processo de fechamento do furo de sondagem. Assim, após algumas correções e considerações 
foram apresentadas estimativas imprecisas de pesos específicos in situ para o resíduo em estudo (Figura 4.11), que apontaram, como limite inferior, um peso específico de $8 \mathrm{kN} / \mathrm{m}^{3} \mathrm{e}$ como limite superior de $15 \mathrm{kN} / \mathrm{m}^{3}$. Os valores obtidos por meio de medições do RSU acondicionado em tambores metálicos (ver figura 4.11) sugerem um aumento do peso específico com a profundidade.

É importante frisar que vários fatores influenciam nos valores de peso específico. Dentre eles pode-se destacar: umidade e composição do RSU, presença de solo de cobertura das células, uso de compactação durante o lançamento e idade do resíduo, dentre outros.

A literatura apresenta uma grande faixa de variação para pesos específicos úmidos de resíduo sólido urbano, a qual pode estar compreendida entre $3 \mathrm{kN} / \mathrm{m}^{3}$, para resíduos não compactados ou pobremente compactados a $17 \mathrm{kN} / \mathrm{m}^{3}$, para resíduos com alto grau de compactação e após adensamento do maciço (KÖNIG \& JESSBERGER, 1997 e STULGIS et al. 1995). Valores de até $18,5 \mathrm{kN} / \mathrm{m}^{3}$ foram apresentados por GOTTELAND et al. (1995) para resíduos domésticos da França. SANTOS et al. (1998) apresentaram valores de pesos específicos variando entre $14-19 \mathrm{kN} / \mathrm{m}^{3}$ para o aterro da Muribeca, na cidade de Recife (Brasil), os quais foram obtidos de ensaios em valas escavadas, impermeabilizadas e preenchidas com água.

\subsection{5 - Ensaio cross-hole}

Pode-se supor que materiais heterogêneos como o RSU, aterrados em células separadas por solos, com grandes vazios e sujeitos a consolidação por peso próprio, por efeito de creep e por degradação dos componentes, podem apresentar alterações substanciais no peso específico ao longo do perfil. Assim, a interpretação dos resultados dos ensaios cross-hole são certamente influenciados por esses fatores, pois os módulos de cisalhamento e de deformação são dependentes do peso específico e da velocidade de propagação da onda no meio (ver item 3.2.5).

Valores constantes para o peso específico com a profundidade tem sido assumidos por muitos autores (SHARMA et al. (1990), SINGH \& MURPHY (1990). KAVAZANJIAN et al. (1995) argumentam que o peso específico aumenta com o aumento da sobrecarga e com o tempo, consequentemente, aumenta com a profundidade. Valores médios, comumente usados para análises sísmicas em aterros de resíduos municipais, estão entre 8,8 a 10 $\mathrm{kN} / \mathrm{m}^{3}$, para o peso específico, e entre 175 e $225 \mathrm{~m} / \mathrm{s}$, para a velocidade da onda de cisalhamento (SINGH \& MURPHY 1990). KAVAZANJIAN et al. (1995), KAVAZANJIAN \& MATASOVIC (1995), MATASOVIC \& KAVAZANJIAN (1998) e MOROCHNICK et al. (1998), mostraram que o perfil de velocidade da onda de cisalhamento no lixo municipal varia com a profundidade e com a idade do resíduo. Velocidade da onda de cisalhamento obtida em 
aterros novos, próximo da superfície, está abaixo de $90 \mathrm{~m} / \mathrm{s}$. Já para aterros antigos, pode atingir valor superior a $170 \mathrm{~m} / \mathrm{s}$. Para profundidade superior a 20 metros e em aterros novos tem-se $v_{s}$ tipicamente entre 140 a $170 \mathrm{~m} / \mathrm{s}$ e, no caso de aterros antigos, pode-se obter valores de $v_{s}$ entre 290 a $350 \mathrm{~m} / \mathrm{s}$.

A velocidade de propagação da onda de cisalhamento no resíduo municipal estudado variou entre 93 a 228m/s (Figura 4.12), a qual encontra-se de acordo com valores apresentados por SINGH \& MURPHY (1990) e por MATASOVIC \& KAVAZANJIAN (1998). Até os 10 metros de profundidade, onde as medidas foram feitas com geofone e martelo na mesma posição, tanto a velocidade da onda de compressão $\left(v_{p}\right)$ como a de cisalhamento $\left(v_{s}\right)$ sofreram pequenas variações, sendo que $v_{s}$ variou entre 93 a $120 \mathrm{~m} / \mathrm{s}$ e $v_{p}$ de $190 \mathrm{a}$ $230 \mathrm{~m} / \mathrm{s}$. A partir dos 10 metros, obteve-se valores bem maiores que os indicados anteriormente. É importante mencionar que o primeiro ponto refere-se à camada de solo de cobertura.

Os coeficientes de Poisson ( $v$ ), obtidos a partir das velocidades das ondas, apresentaram alguns resultados erráticos, mas a maioria dos valores obtidos encontram-se entre 0,27 a 0,38, obtendo-se valores médios de 0,33 (Figura 4.13). MATASOVIC \& KAVAZANJIAN (1998) também encontraram para o Aterro de Oll (Califórnia) valores de $v$ altamente dispersos ao longo do perfil e adotaram $v=0,33$ como valor apropriado para este aterro. Já SHARMA et al. (1990) apresentam valores de $v=0,46$ para o aterro de Richmond (Califórnia).

Os módulos cisalhante $(G)$ e de deformação $(E)$ obtidos para valores máximos e mínimos de peso específico estimados para a área em estudo apresentaram uma leve tendência de aumentar com a profundidade (Figura 4.14). Nesta Figura, o primeiro ponto corresponde à camada de solo de cobertura, portanto deve ser excluído. Os valores de G e $\mathrm{E}$ calculados para o ensaio cross-hole são menores que aqueles apresentados por SHARMA et al. (1990) para resíduo disposto no Aterro de Richmond (Califórnia). Estes autores encontraram valores de $28,9 \mathrm{MPa}$ e de $84,4 \mathrm{MPa}$ para o módulo cisalhante e de deformação, respectivamente, considerando um peso específico de $7,37 \mathrm{kN} / \mathrm{m}^{3}$. Os valores correspondentes para o resíduo urbano de São Paulo foram da ordem de $8 \mathrm{MPa}$ e $25 \mathrm{MPa}$, para peso específico do RSU de $8 \mathrm{kN} / \mathrm{m}^{3}$. Para peso específico de $12 \mathrm{kN} / \mathrm{m}^{3}$, os valores médios obtidos para o módulo de cisalhamento e de deformabilidade são de 14,5 e 40MPa, respectivamente.

\subsection{6 - Ensaio de resistividade elétrica}

Na Figura 4.16, apresentada no capítulo anterior, pôde-se observar que os baixos valores de resistividade, até 4ohm.m, referem-se à massa de RSU e valores acima referem- 
se à base do aterro. Assim, pela diferença de resistividade pôde-se estimar a localização da base do aterro e a profundidade ocupada pelos resíduos.

A técnica de caminhamento elétrico dipolo-dipolo mostrou ser uma ferramenta bastante útil na investigação de áreas de disposição de resíduos urbanos. Os resultados mostram que pode-se obter informações a respeito do mapeamento da contaminação por líquidos percolados e da presença de RSU, através do contraste de resistividade. O nível de detalhe ficou um pouco comprometido, uma vez que o arranjo utilizado foi bastante aberto para permitir o levantamento da resistividade de toda profundidade desejada. Esses ensaios além de serem de baixo custo operacional são de fácil aplicação, pois não há a necessidade de coleta de amostras. Por fim, convém salientar que esses ensaios tiveram o objetivo principal de ser um primeiro teste, para avaliar o desempenho de um equipamento convencional de eletroresistividade em aterros de grandes dimensões.

\section{3 - ENSAIOS DE CARACTERIZAÇÃO DOS RESÍDUOS SÓLIDOS URBANOS COLETADOS}

\subsection{1 - Teor de umidade}

Na Figura 4.17 observa-se que os perfis de umidade global encontrado para as duas tradagens apresentam-se altamente variáveis, com valores que vão desde 50\% até mais de 100\%. Em geral, as amostras da tradagem T1 apresentaram maiores valores de umidade que os da tradagem T2. Observam-se, também, alguns pontos de queda brusca na umidade, os quais podem estar relacionados com a presença de solo de cobertura, próximos a essas posições.

COUMOULOS et al. (1995) também encontraram para resíduo urbano de um aterro em Atenas, valores de umidade tão alto e variável quanto os encontrados para o resíduo aterrado de São Paulo.

Pode-se observar na Tabela 4.1 que o resíduo sólido urbano é constituído por diversos componentes (matéria orgânica, plásticos, papéis, metais, vidros, têxteis, madeira, pedra, borracha e outros), sendo que cada um deles apresenta diferente capacidade de retenção de fluido em seus vazios, tornando a umidade extremamente variável para cada constituinte (Tabela 4.1). Nesta tabela pode-se observar diferenças marcantes entre os diversos constituintes, como por exemplo, papel, madeira, têxteis e pasta orgânica apresentam altos valores de umidade, em geral, acima de 50\% e componentes como vidro (6\%) e pedra (12,6\%) apresentam valores menores de umidade. 


\subsection{2 - Composição gravimétrica}

Nas Figuras 4.18 e 4.19, apresentadas no capítulo anterior, não se observou nenhuma tendência de variação da composição do resíduo com a profundidade, mas pôdese observar a ocorrência de grande quantidade de fração pastosa e uma considerável quantidade de plástico, madeira e pedra.

A partir da execução dos ensaios de STV realizados (ver item 5.3.4) foi possível dividir a fração pastosa em materiais inertes (sólidos totais fixos) e matéria orgânica passível de sofrer decomposição (expressa como STV). As figuras 4.18 e 4.19 apresentam um reduzido valor de STV em relação STF, mostrando que RSU está num estágio avançado de degradação, mas ainda com presença de materiais de grandes dimensões como plásticos, madeiras, metais, etc.

A composição média obtida para os resíduos domiciliares aterrados estudados é de $55 \%$ de fração pastosa (12\% de matéria orgânica e 43\% de cinzas), 4\% de madeira, 10\% de pedra, $3 \%$ de têxteis, $2 \%$ de borracha, $17 \%$ de plástico, $2 \%$ de vidro, $2 \%$ de papel e $5 \%$ de metal (Figura 4.20). Os valores obtidos estão próximos daqueles encontrados por SANTOS et al. (1998) para resíduo do lixão da Muribeca (Recife), sendo que para este caso encontrou-se maior porcentagem de papel (15\%) e menor porcentagem de plástico (8\%) em relação aos encontrados no Aterro Bandeirantes.

\subsection{3 - Tamanho e distribuição dos componentes dos resíduos}

Na Figura 4.21 observa-se que as curvas de distribuição dos tamanhos dos componentes para as amostras T1-1 a T1-7 (até aproximadamente 18 metros) apresentam em média cerca de $30 \%$ dos componentes com tamanhos dos grãos maiores que 20mm e aproximadamente 50\% entre 20 e 2mm. Já para as amostras T1-9 a T1-11 (abaixo 18m) cerca de $50 \%$ dos componentes apresentam tamanhos dos grãos maiores que 20mm e $45 \%$ entre 20 e 2mm. Para as amostras T2-1 a T2-5, cerca de 35\% dos componentes apresentam tamanhos de grãos maiores que $20 \mathrm{~mm}$ e aproximadamente $50 \%$ entre 20 e $2 \mathrm{~mm}$ (Figura 4.22), para as amostras T2-6 a T2-9 esses valores são 20\% e 60\%, respectivamente.

JESSBERGER (1994) apresenta uma faixa de variação típica para a distribuição dos componentes do resíduo sólido urbano (Figura 5.6). Nesta figura, também, estão plotadas as curvas obtidas para os resíduos coletados das tradagens T1 e T2, do Aterro Sanitário Bandeirantes. Observa-se através das curvas obtidas, que o resíduo sólido urbano estudado é composto por partículas mais finas que as apresentadas por JESSBERGER (1994), para resíduo sólido da Alemanha. Isso pode ser em virtude do resíduo estudado já ter cerca de 15 anos de aterramento e consequentemente já passou por um processo de redução e degradação dos seus constituintes. 


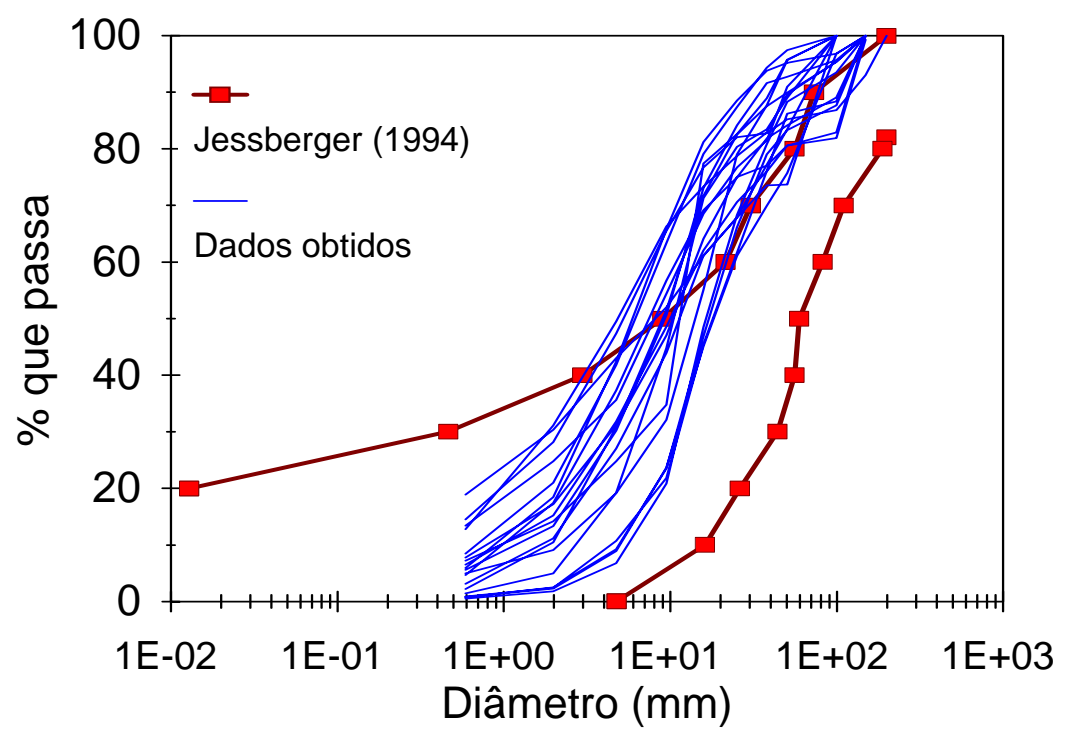

Figura 5.6 - Faixa de variação granulométrica para RSU.

\subsection{4 - Sólidos totais voláteis}

As amostras das duas tradagens apresentaram valores de STV muito próximos, os quais variam entre 120 e 270mg/g (Fig. 4.23). Nas profundidades de 16 e 22 metros observam-se algumas variações nos valores do STV, tal fato pode ser devido à ocorrência de uma camada de cobertura nestas profundidades.

O STV médio, em porcentagem está em torno de 22\% para os dois perfis. Assim, para uma composição média de fração pastosa de 55\% (ver item 5.3.2), obtiveram-se um teor de matéria orgânica de $12 \%$ e inertes de $43 \%$. Como se pode observar, pelos baixos valores de STV, o resíduo já se encontra em um estágio avançado de decomposição.

\subsection{5. - Demanda química de oxigênio - DQO}

Os valores de demanda química de oxigênio refletem a quantidade total de substâncias quimicamente oxidáveis (orgânicos e inorgânicos) presente no RSU. Segundo TCHOBANOGLOUS et al. (1993) os valores de DQO e pH dos líquidos percolados de aterros sanitários podem ser usados como indicadores da idade e da degradação do resíduo. No presente trabalho, ponderação análoga foi adotada partindo-se dos valores de DQO obtidos para as amostras sólidas. Considerou-se que a DQO de amostras sólidas seja proporcional à quantidade de matéria orgânica presente no resíduo e consequentemente proporcional à idade de aterramento dos mesmos.

A Figura 4.24 mostra que foram medidos baixos valores de DQO para as duas tradagens, os quais ficaram em torno de $100-175 \mathrm{mg} / \mathrm{g}$. A DQO média encontrada, em 
porcentagem é da ordem de 13\%. Não se observou nenhuma tendência de variação deste parâmetro com a profundidade. Os teores de DQO acompanharam as variações dos teores de sólidos totais voláteis, podendo ser este utilizado como um parâmetro alternativo no monitoramento do processo de degradação dos resíduos em aterros sanitários.

Os valores de $\mathrm{pH}$ próximos da neutralidade (Tabela 4.2) associados aos baixos valores de DQO e STV indicam que o resíduo já passou pelo pico da fase de decomposição (fase ácida). Assim, os resultados químicos obtidos mostram que grande parte da fração biodegradável do resíduo já alcançou um avançado processo de degradação, o que é consistente com o tempo de aterramento (15 anos).

\subsection{6 - Lixiviação e solubilização}

Os resíduos estudados apresentam concentrações de ferro, manganês e cromo acima dos padrões indicados pela norma NBR 10.004/87, além de propriedades como combustibilidade, degradabilidade e solubilidade em água (Tabela 4.2). Dessa forma são classificados de acordo com a NBR 10.004/87 (Classificação de resíduos) como classe II (não inertes).

\section{4 - ENSAIOS DE COMPRESSÃO TRIAXIAL}

\subsection{1 - Ensaios consolidados drenados (CD)}

As curvas tensão - deformação apresentadas no capítulo anterior (Figuras 4.25 a 4.39) permitem identificar um comportamento típico para o resíduo sólido urbano onde, as tensões aumentam continuamente com o aumento das deformações axiais, sem atingir qualquer pico na curva tensão - deformação ou alcançar um valor último. Ensaios executados por GRISOLIA et al. (1995b), em amostras deformadas de RSU, e por JESSBERGER \& KOCKEL (1993) e JESSBERGER et al. (1995), em RSU triturado, confirmam esse comportamento.

Como não é possível identificar as condições de ruptura para o resíduo urbano, a determinação dos parâmetros de resistência empregando os princípios da mecânica dos solos clássica (critério de ruptura de Mohr-Coulomb) fica comprometida. Dessa forma, os parâmetros de resistência, coesão e ângulo de atrito, devem ser determinados segundo um critério de deformação.

Com os dados apresentados nas Figuras 4.25 a 4.27, obtidos a partir dos ensaios tipo $\mathrm{CD}_{\text {nat }}$, com amostra T2A compactada com peso específico de 10 , 12 e $14 \mathrm{kN} / \mathrm{m}^{3}$, em corpos de prova de $150 \mathrm{~mm}$ de diâmetro por $300 \mathrm{~mm}$ altura, foram traçadas as trajetórias de tensões que estão apresentadas nas Figuras 5.7 a 5.9, respectivamente. Como cada ponto 
da trajetória está relacionado a um nível de deformação axial, pode-se obter, em cada trajetória, um ponto que represente os valores de t e s' para o nível de deformação considerado. Ajustando-se uma reta por esses pontos, pode-se obter envoltórias das trajetórias que fornecem as resistências mobilizadas para dados níveis de deformação. As Figuras 5.7 a 5.9 apresentam as envoltórias para os níveis de deformação axial de 10, 20 e $30 \%$.

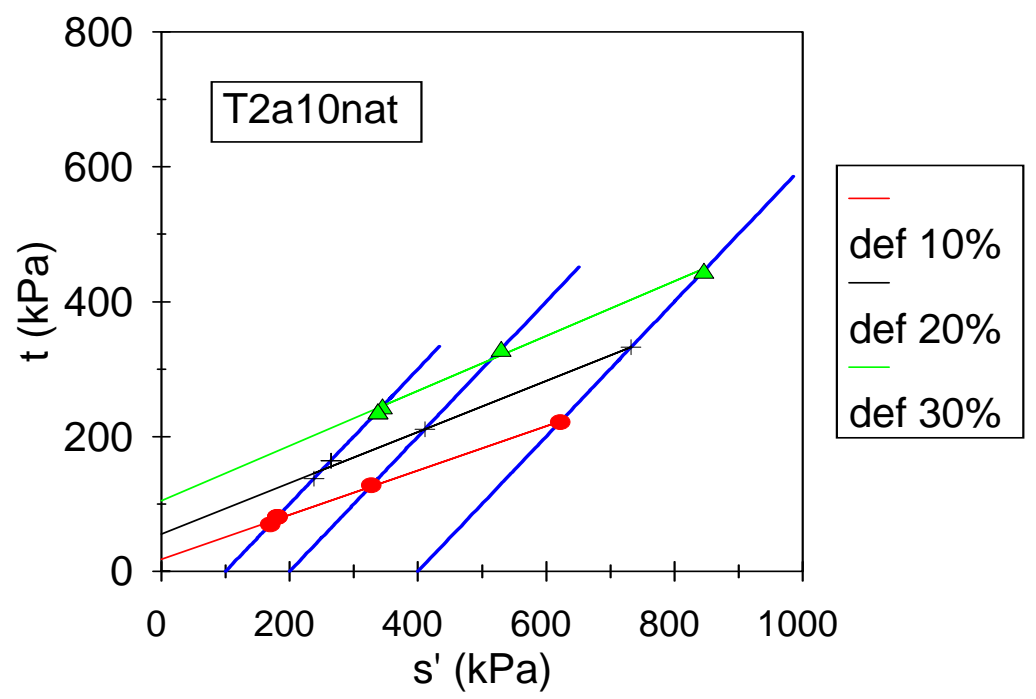

Figura 5.7 - Trajetórias de tensões e envoltórias de resistência num diagrama t-s' obtidas para a amostra T2A, na umidade natural, compactada com peso específico de $10 \mathrm{kN} / \mathrm{m}^{3}$, em corpos de prova de $150 \mathrm{~mm}$ de diâmetro por $300 \mathrm{~mm}$ de altura.

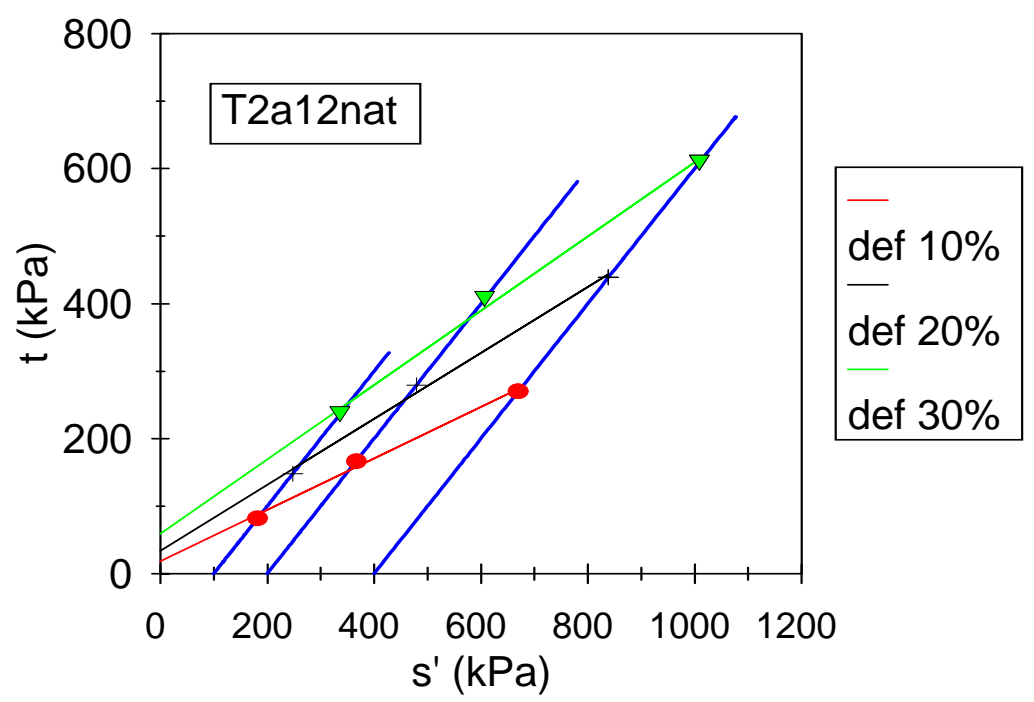

Figura 5.8 - Trajetórias de tensões e envoltórias de resistência num diagrama t-s' obtidas para a amostra T2A, na umidade natural, compactada com peso específico de $12 \mathrm{kN} / \mathrm{m}^{3}$, em corpos de prova de $150 \mathrm{~mm}$ de diâmetro por $300 \mathrm{~mm}$ de altura. 


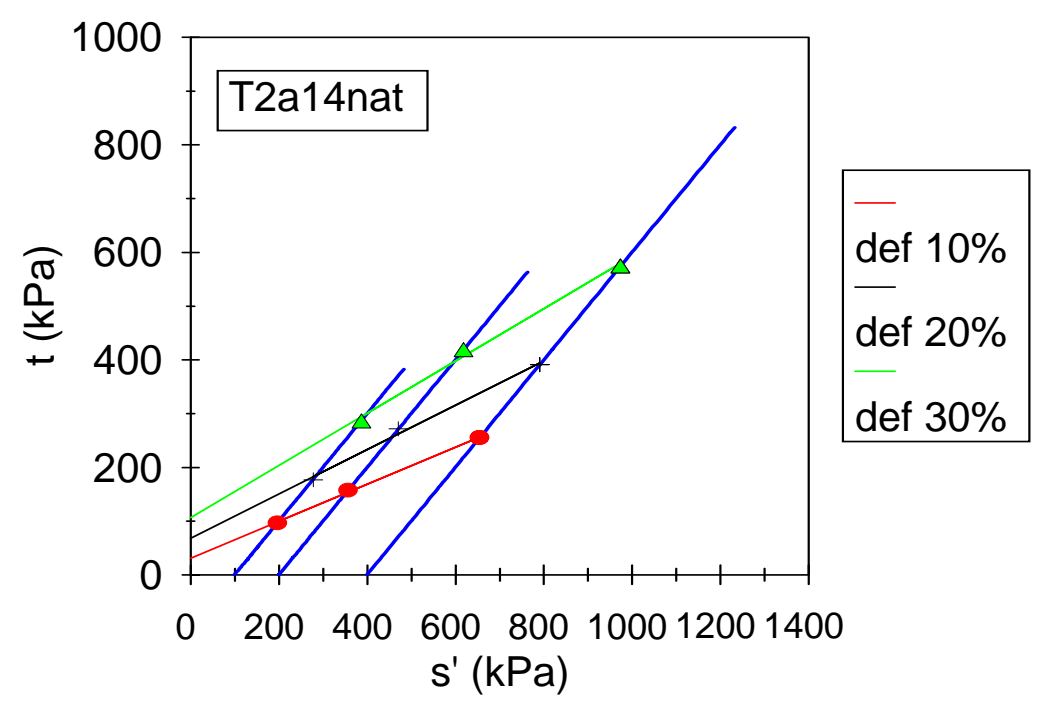

Figura 5.9 - Trajetórias de tensões e envoltórias de resistência num diagrama t-s' obtidas para a amostra T2A, na umidade natural, compactada com peso específico de $14 \mathrm{kN} / \mathrm{m}^{3}$, em corpos de prova de $150 \mathrm{~mm}$ de diâmetro por $300 \mathrm{~mm}$ de altura.

A Tabela 5.1 apresenta, os valores de coesão e de ângulo de atrito, bem como a equação e o coeficiente de determinação, obtidos a partir das trajetórias das Figuras 5.7 a 5.9, para diferentes níveis de deformação axial. Nesta tabela pode-se observar, para uma mesma amostra, a tendência dos parâmetros de resistência aumentarem com o aumento das deformações.

Para a amostra T2A, compactada com diferentes pesos específicos $(10,12$ e $14 \mathrm{kN} / \mathrm{m}^{3}$ ), observa-se, para um mesmo nível de deformação, uma variação nos parâmetros de resistência. Para $20 \%$ de deformação axial, a série de ensaios com peso específico de $10 \mathrm{kN} / \mathrm{m}^{3}$ (T2a10nat) apresentou uma coesão efetiva de $60,2 \mathrm{kPa}$ e ângulo de atrito de $22^{\circ}$, para corpos de prova compactados com 12 (T2a12nat) e 14kN/m³ (T2a14nat) obtiveram-se coesão de 39,2 e $74,9 \mathrm{kPa}$ e ângulo de atrito de 29 e $24,3^{\circ}$, respectivamente. Com os dados disponíveis, não foi possível estabelecer uma clara tendência de variação dos parâmetros de resistência com o peso específico. Além disso, pode-se observar que as três séries de ensaios apresentam valores razoavelmente próximos de resistência, embora se verifiquem variações nos parâmetros de coesão e ângulo de atrito, que são resultantes de ajustes matemáticos. Para ilustrar, no Anexo 4 apresentam-se gráficos de comparação entre as resistências finais obtidas para as diferentes amostras e condições de ensaio. 
Tabela 5.1 - Parâmetros de resistência obtidos para a amostra T2A, em corpos de prova com 150x300 mm, compactados com peso específico de 10, 12 e $14 \mathrm{kN} / \mathrm{m}^{3}$.

\begin{tabular}{|c|c|c|c|c|c|}
\hline \multirow[b]{2}{*}{ Amostra } & \multirow{2}{*}{$\begin{array}{c}\text { Def. axial } \\
\text { (\%) }\end{array}$} & \multirow[b]{2}{*}{ Equação (kPa) } & \multirow{2}{*}{$\begin{array}{c}\text { Coef. } \\
\text { Det. }\left(R^{2}\right)\end{array}$} & \multicolumn{2}{|c|}{ Parâmetros } \\
\hline & & & & $C^{\prime}(k P a)$ & $\phi^{\prime}(9)$ \\
\hline \multirow{7}{*}{ T2a10nat } & 5 & $t=0,288 s^{\prime}+4,5$ & 0,997 & 4,7 & 16,7 \\
\hline & 10 & $t=0,328 s^{\prime}+18,5$ & 0,997 & 19,5 & 19 \\
\hline & 15 & $t=0,360 s^{\prime}+35,4$ & 0,994 & 37,9 & 21 \\
\hline & 20 & $t=0,380 s^{\prime}+55,9$ & 0,993 & 60,2 & 22 \\
\hline & 25 & $t=0,370 s^{\prime}+94,4$ & 0,980 & 101,6 & 21,7 \\
\hline & 30 & $t=0,41 s^{\prime}+105,5$ & 0,996 & 115,4 & 24 \\
\hline & 35 & $t=0,41 s^{\prime}+158,3$ & 0,960 & 173,2 & 24 \\
\hline \multirow{7}{*}{ T2a12nat } & 5 & $t=0,310 s^{\prime}+8,2$ & 0,993 & 8,6 & 18 \\
\hline & 10 & $t=0,380 s^{\prime}+18,5$ & 0,993 & 20,0 & 22 \\
\hline & 15 & $t=0,435 s^{\prime}+27,3$ & 0,995 & 30,2 & 25,7 \\
\hline & 20 & $t=0,487 s^{\prime}+34,3$ & 0,995 & 39,2 & 29 \\
\hline & 25 & $t=0,520 s^{\prime}+46,5$ & 0,995 & 54,2 & 31 \\
\hline & 30 & $t=0,550 s^{\prime}+59,8$ & 0,995 & 71,5 & 33,3 \\
\hline & 35 & $t=0,548 s^{\prime}+93,8$ & 0,988 & 111,80 & 33 \\
\hline \multirow{7}{*}{ T2a14nat } & 5 & $t=0,292 s^{\prime}+13,8$ & 0,999 & 14,5 & 17 \\
\hline & 10 & $t=0,343 s^{\prime}+31,3$ & 0,998 & 33,3 & 20 \\
\hline & 15 & $t=0,378 s^{\prime}+47,1$ & 0,996 & 50,9 & 22,2 \\
\hline & 20 & $t=0,412 s^{\prime}+68,3$ & 0,995 & 74,9 & 24,3 \\
\hline & 25 & $t=0,459 s^{\prime}+81,3$ & 0,997 & 91,5 & 27,3 \\
\hline & 30 & $t=0,485 s^{\prime}+106,4$ & 0,994 & 121,7 & 29,0 \\
\hline & 35 & $t=0,529 s^{\prime}+119,3$ & 0,992 & 140,6 & 32 \\
\hline
\end{tabular}

A Figura 5.10 apresenta, para cada nível de deformação, gráficos txs', para a amostra T2A compactada com os três pesos específicos. Pode-se observar que embora se verifique uma pequena dispersão nos valores de txs', para os corpos de prova compactados com pesos específicos diferentes, foi possível ajustar uma reta por esses pontos e obter envoltórias médias (Figura 5.10). Obtiveram-se razoáveis níveis de correlação entre os valores de txs', os quais estão entre 0,96 a 0,98. Acredita-se que a proximidade entre os resultados de txs' obtidos seja em virtude dos corpos de prova adquirirem, no final do adensamento, pesos específicos razoavelmente próximos (ver Tabela 4.4). O fato é que, durante o adensamento, os corpos de prova compactados com maiores pesos específicos apresentaram, em geral, uma menor compressão que aqueles compactados com menores pesos específicos. 

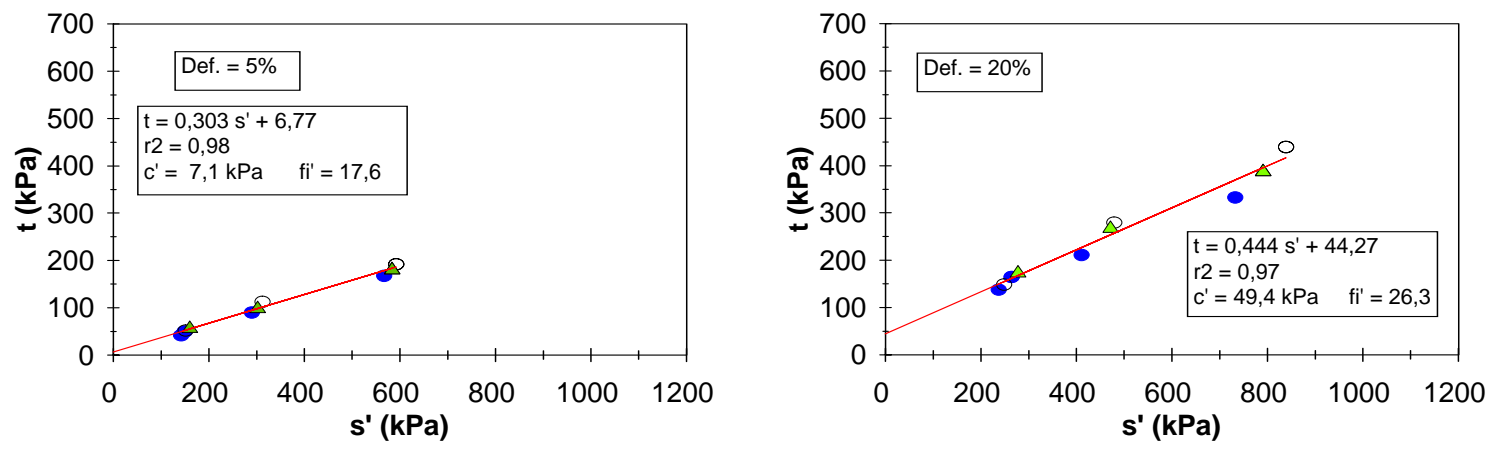

- T2a10nat $\circ$ T2a12nat $\Delta$ T2a14nat - Regressão

- T2a10nat $\circ$ T2a12nat $\triangle$ T2a14nat - Regressão
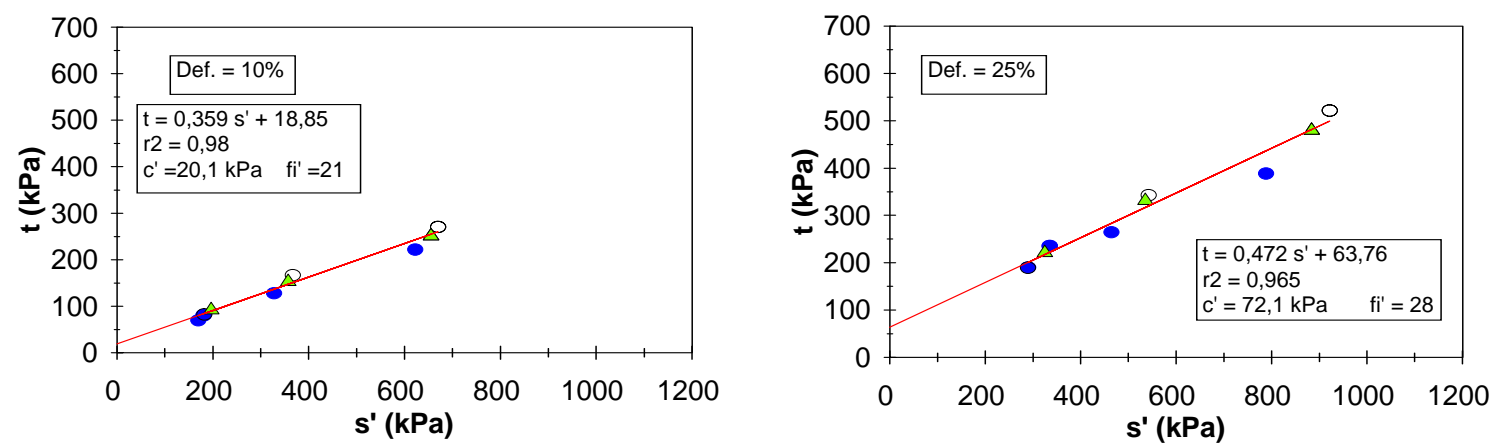

- T2a10nat $\circ$ T2a12nat $\triangle$ T2a14nat - Regressão

- T2a10nat $\circ$ T2a12nat $\triangle$ T2a14nat - Regressão
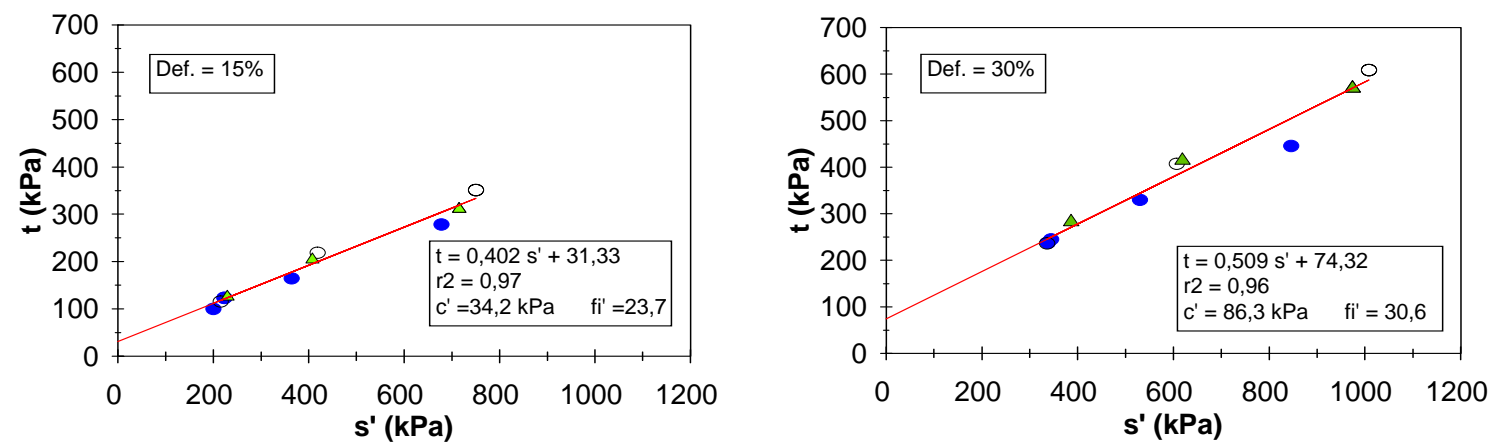

- T2a10nat $\circ$ T2a12nat $\Delta$ T2a14nat - Regressão

- T2a10nat o T2a12nat $\Delta$ T2a14nat - Regressão

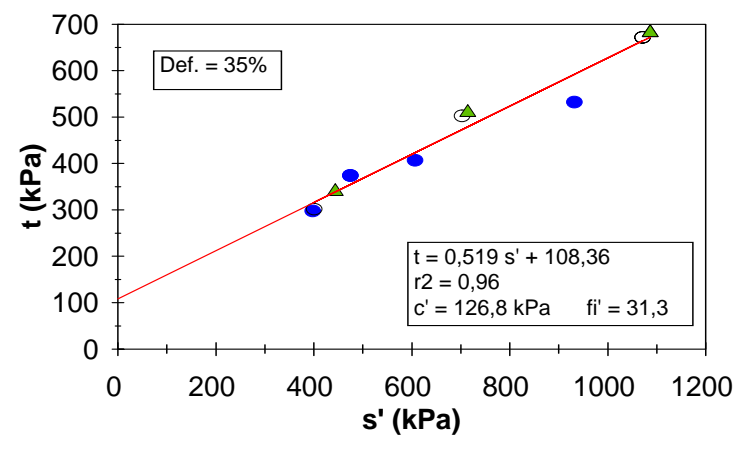

T2a10nat $\circ$ T2a12nat $\Delta$ T2a14nat - Regressão

Figura 5.10 - Envoltórias num diagrama t-s' para a amostra T2A, na umidade natural e peso específico de $10 \mathrm{kN} / \mathrm{m}^{3}$ (T2a10nat), 12 (T2a12nat) e 14 (T2a14nat). 
Com os dados apresentados na Figura 4.28 , obtidos a partir dos ensaios $C D_{\text {sat }}$ realizados em corpos de prova da amostra T2A saturada e com peso específico de $12 \mathrm{kN} / \mathrm{m}^{3}$, foram traçadas trajetórias de tensões e envoltórias de resistência para níveis de deformação axial de 10, 20 e 30\%, as quais são apresentadas na Figura 5.11. Na Tabela 5.2 são apresentadas as equações das envoltórias, coeficiente de determinação, bem como, os parâmetros c' e ф' obtidos para essa amostra.

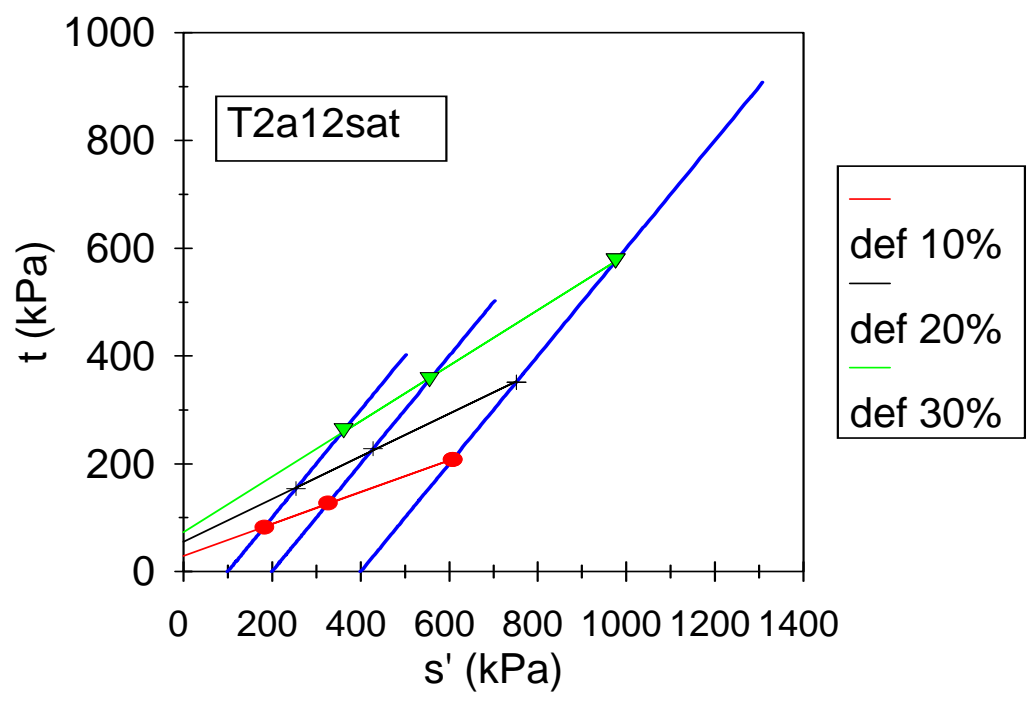

Figura 5.11 - Trajetórias de tensões e envoltórias de resistência num diagrama $t$-s' obtidas para a amostra T2A, saturada e compactada com peso específico de $12 \mathrm{kN} / \mathrm{m}^{3}$, em corpos de prova de $150 \mathrm{~mm}$ de diâmetro por $300 \mathrm{~mm}$ de altura.

Tabela 5.2 - Parâmetros de resistência obtidos para a amostra T2A, saturada compactada com peso específico de $12 \mathrm{kN} / \mathrm{m}^{3}$, em corpos de prova de $150 \mathrm{~mm}$ de diâmetro por $300 \mathrm{~mm}$ de altura.

\begin{tabular}{|c|c|c|c|c|c|}
\hline \multirow[b]{2}{*}{ Amostra } & \multirow{2}{*}{$\begin{array}{c}\text { Def. axial } \\
\text { (\%) }\end{array}$} & \multirow[b]{2}{*}{ Equação (kPa) } & \multirow{2}{*}{$\begin{array}{c}\text { Coef. } \\
\text { Det. }\left(R^{2}\right)\end{array}$} & \multicolumn{2}{|c|}{ Parâmetros } \\
\hline & & & & $C^{\prime}(k P a)$ & $\phi^{\prime}(9)$ \\
\hline \multirow{7}{*}{ T2a12sat } & 5 & $t=0,250 s^{\prime}+14,5$ & 0,999 & 15,0 & 14,5 \\
\hline & 10 & $t=0,294 s^{\prime}+30,0$ & 0,999 & 31,4 & 17 \\
\hline & 15 & $t=0,334 s^{\prime}+44,4$ & 0,999 & 47,1 & 19,5 \\
\hline & 20 & $t=0,395 s^{\prime}+55,8$ & 0,999 & 60,7 & 23 \\
\hline & 25 & $t=0,453 s^{\prime}+65,1$ & 0,998 & 73,0 & 27 \\
\hline & 30 & $t=0,510 s^{\prime}+73,7$ & 0,999 & 85,6 & 30,6 \\
\hline & 35 & $t=0,569 s^{\prime}+80,1$ & 0,995 & 97,4 & 34,7 \\
\hline
\end{tabular}


Comparando os resultados obtidos para a amostra T2A, compactada com peso específico de $12 \mathrm{kN} / \mathrm{m}^{3}$ e ensaiada na condição saturada (T2a12sat) com os resultados obtidos para a amostra ensaiada com o mesmo peso específico e na umidade natural (T2a12nat) (Tabelas 5.1 e 5.2), observa-se pouca variação nos parâmetros de resistência.

Para ilustrar esse fato, envoltórias de resistências de Mohr-Coulomb, para 20\% de deformação axial, são apresentadas nas Figuras 5.12 e 5.13, para amostras ensaiadas na umidade natural e saturada, respectivamente.

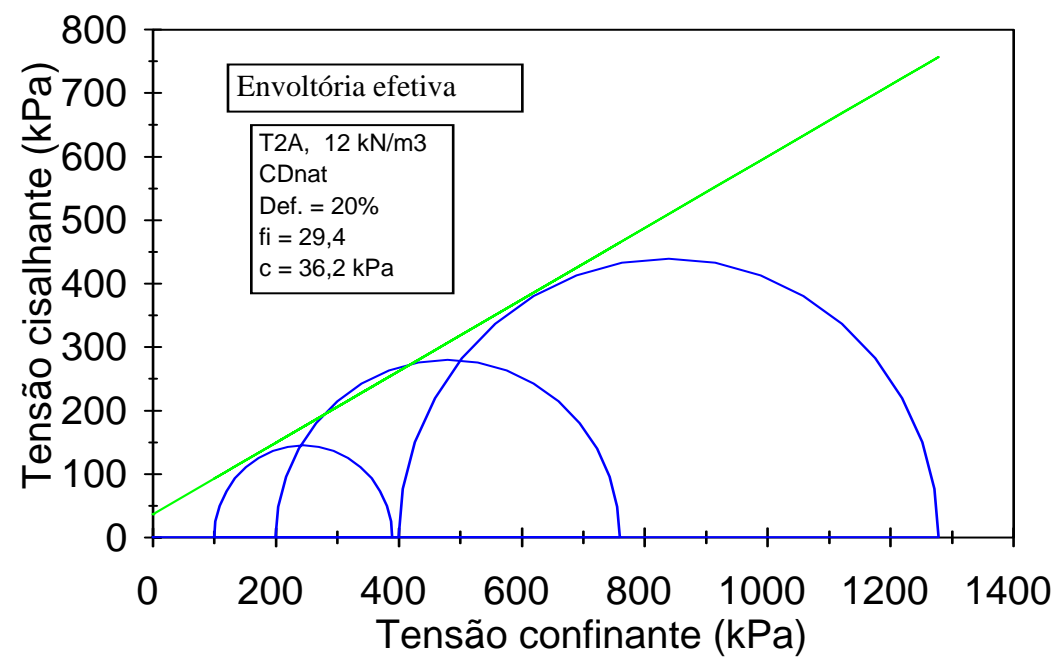

Figura 5.12 - Envoltória de resistência para $20 \%$ de deformação obtida de ensaio $C D_{\text {nat, }}$ para a amostra $T 2 A$, no teor de umidade de moldagem e compactada com peso específico de $12 \mathrm{kN} / \mathrm{m}^{3}$.

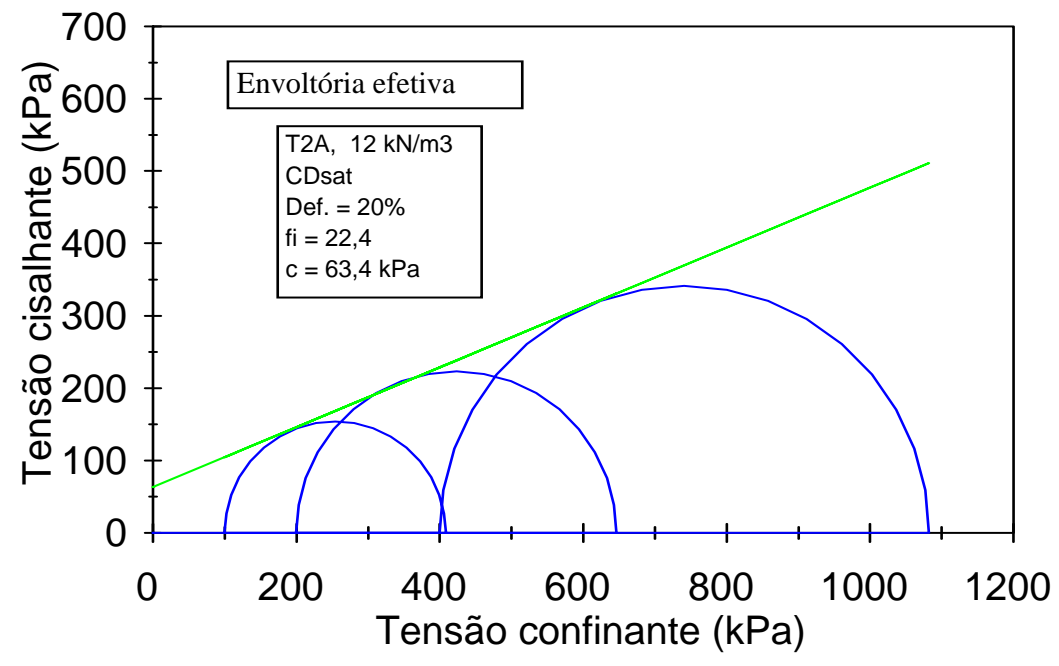

Figura 5.13 - Envoltórias de resistência para 20\% de deformação obtida de ensaio $C D_{\text {sat, }}$ para amostra $T 2 A$, saturada e compactada com peso específico de $12 \mathrm{kN} / \mathrm{m}^{3}$. 
Para a amostra no teor de umidade natural, o intercepto de coesão foi de $36 \mathrm{kPa}$ e ângulo de atrito de $29^{\circ}$, enquanto que para a amostra saturada os valores foram de $63 \mathrm{kPa}$ e $22^{\circ}$, respectivamente.

A amostra saturada mostra um decréscimo no ângulo de atrito e um aumento de coesão quando comparado com a amostra ensaiada no teor de umidade natural. Isso é diferente do que acontece em muitos solos finos e ativos, onde a saturação produz uma redução na sucção e consequentemente na coesão. Essa variação pode ser creditada à heterogeneidade da amostra, mas é possível especular que a saturação possa reduzir a resistência ao cisalhamento entre muitos componentes do RSU e consequentemente reduzir o ângulo de atrito. Por outro lado, acredita-se que a influência da sucção na coesão do RSU seja desprezível, pois esta é originada pela presença de componentes fibrosos e planos (plástico, papel, têxtil, etc), os quais produzem um reforço no material. Daí ocorre uma compensação de valores, isto é, o ângulo de atrito diminui e em contrapartida, a coesão aumenta de modo que as resistências finais não apresentam grandes modificações (ver Anexo 4). Desse modo, é possível obter uma envoltória única $(t=t a n \alpha ' . s '+a)$ para a amostra e é o que se mostra na Figura 5.14. Nesta figura apresenta-se, para cada nível de deformação, gráficos txs', para a amostra T2A, compactada com peso específico $12 \mathrm{kN} / \mathrm{m}^{3} \mathrm{e}$ submetida a ensaios do tipo $\mathrm{CD}_{\text {nat }}$ e $\mathrm{CD}_{\text {sat }}$, bem como, os valores obtidos para c' e $\phi$ ' e os coeficientes de determinação. Os valores de intercepto de coesão e de ângulo de atrito encontrados na Figura 5.14 são próximos dos valores médios encontrados para a amostra T2A compactada com diferentes pesos específicos (Figura 5.10).

A partir dos resultados apresentados da Figura 4.29 e 4.30 foram traçadas as trajetórias de tensões e as envoltórias de resistência para deformações axiais de 10, 20 e $30 \%$, da amostra T1B, na umidade natural e saturada, compactada com peso específico de $12 \mathrm{kN} / \mathrm{m}^{3}$ e em corpos de prova de $150 \mathrm{~mm}$ de diâmetro por 300mm de altura. Esses resultados estão apresentados nas Figuras 5.15 e 5.16, para a amostra na condição de umidade natural e saturada, respectivamente. A Tabela 5.3 apresenta as equações das envoltórias, os coeficientes de determinação e os parâmetros de resistência ao cisalhamento obtidos para essa amostra nas duas condições ensaiadas.

A amostra T1B apresentou o mesmo comportamento mostrado pela amostra T2A, isto é, a coesão da amostra saturada é maior que a da amostra ensaiada na umidade natural, por outro lado, o ângulo de atrito apresenta-se menor. A Figura 5.17 apresenta os gráficos t x s' para a amostra T1B, na umidade natural e saturada, bem como as envoltórias médias das trajetórias e os parâmetros de resistência. 


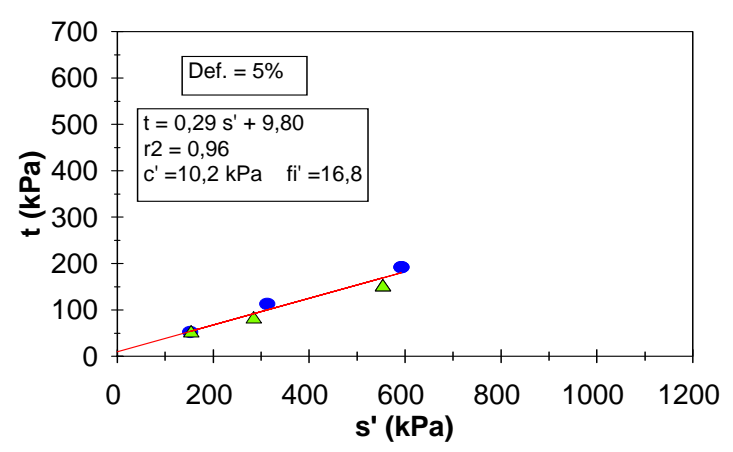

- T2a12nat $\triangle$ T2a12sat - regressão

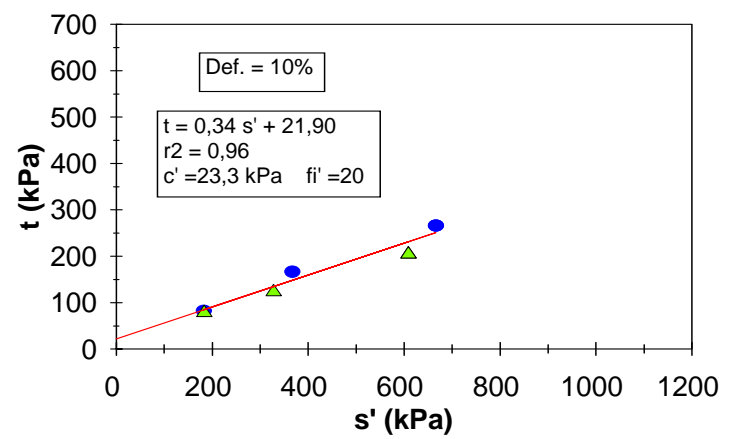

- T2a12nat $\triangle$ T2a12sat - regressão

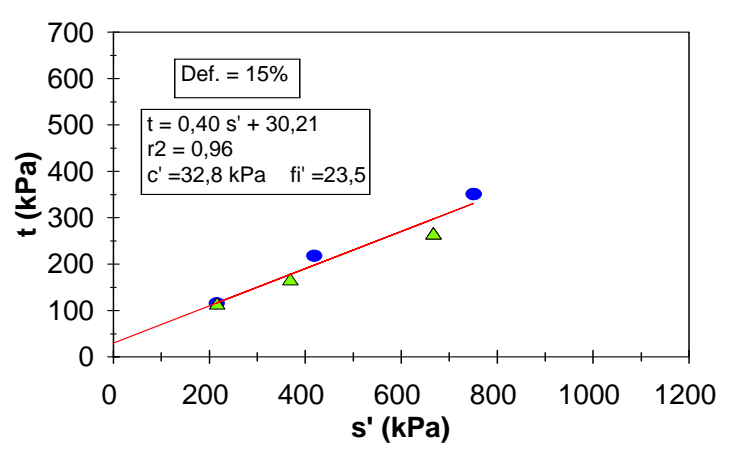

- T2a12nat $\triangle$ T2a12sat - regressão

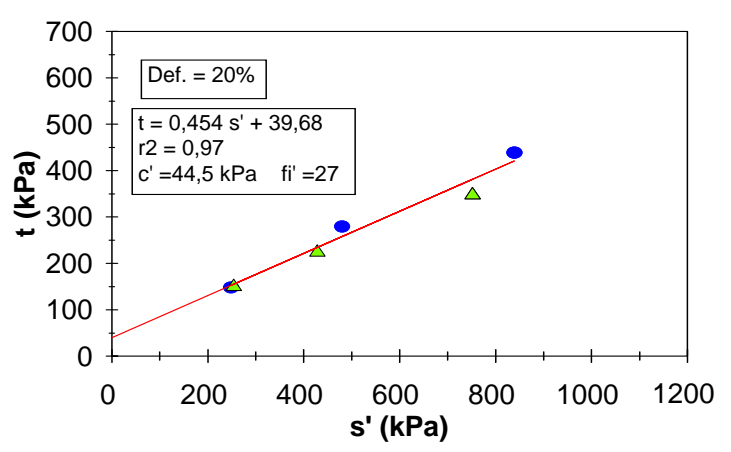

- T2a12nat $\triangle$ T2a12sat - regressão

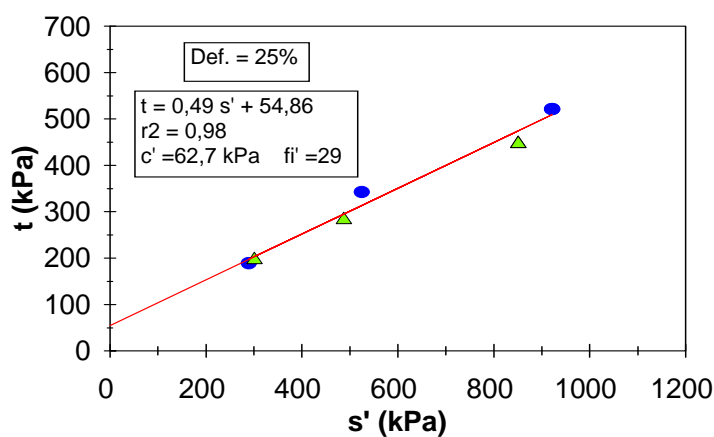

- T2a12nat $\triangle$ T2a12sat - regressão

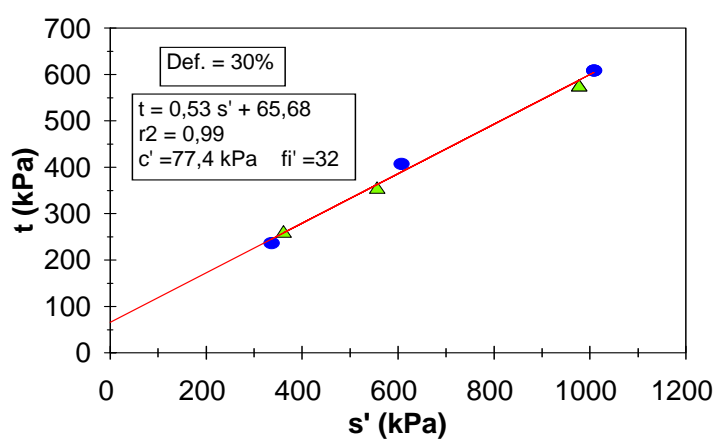

T2a12nat $\triangle$ T2a12sat - regressão

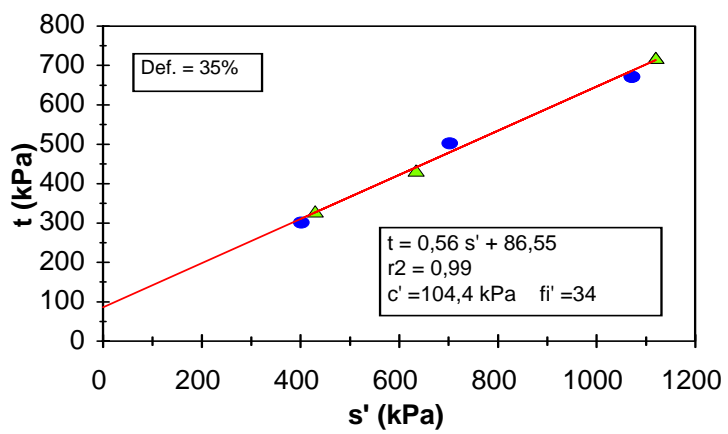

T2a12nat $\Delta$ T2a12sat — regressão

Figura 5.14 - Envoltórias num diagrama t-s' obtidas para a amostra T2A, compactada com $12 \mathrm{kN} / \mathrm{m}^{3}$ e submetida a ensaios $C D_{\text {nat }}$ (T2a12nat) e $C D_{\text {sat }}$ (T2a12sat). 


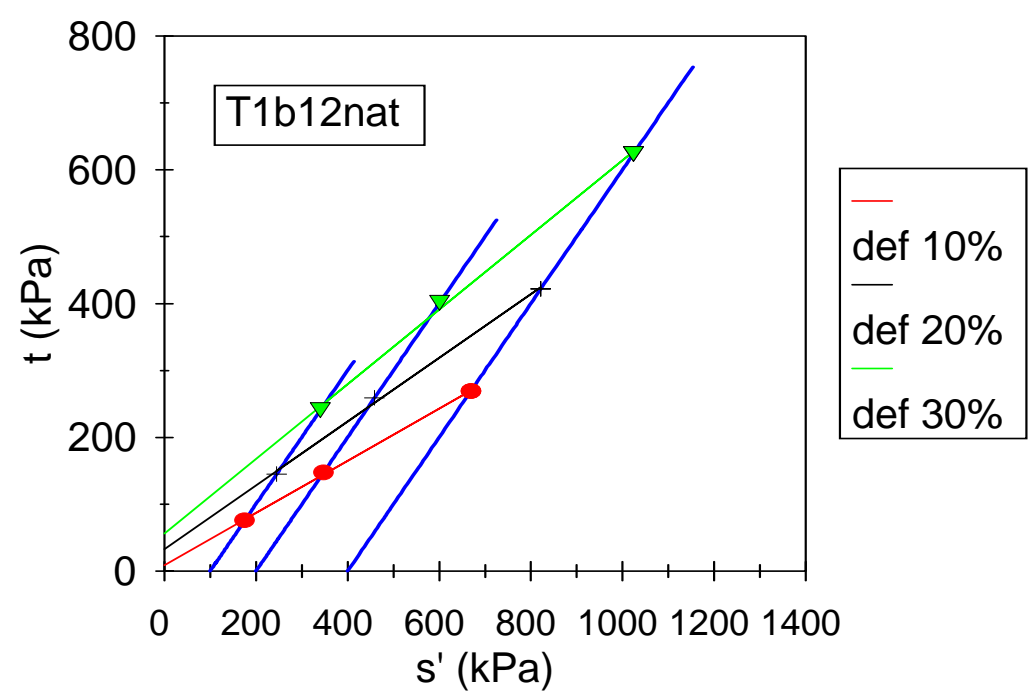

Figura 5.15 - Trajetórias de tensões e envoltórias de resistência num diagrama $t$-s' obtidas para a amostra T1B, na umidade natural, compactada com peso específico de $12 \mathrm{kN} / \mathrm{m}^{3}$, em corpos de prova de $150 \mathrm{~mm}$ de diâmetro e $300 \mathrm{~mm}$ de altura.

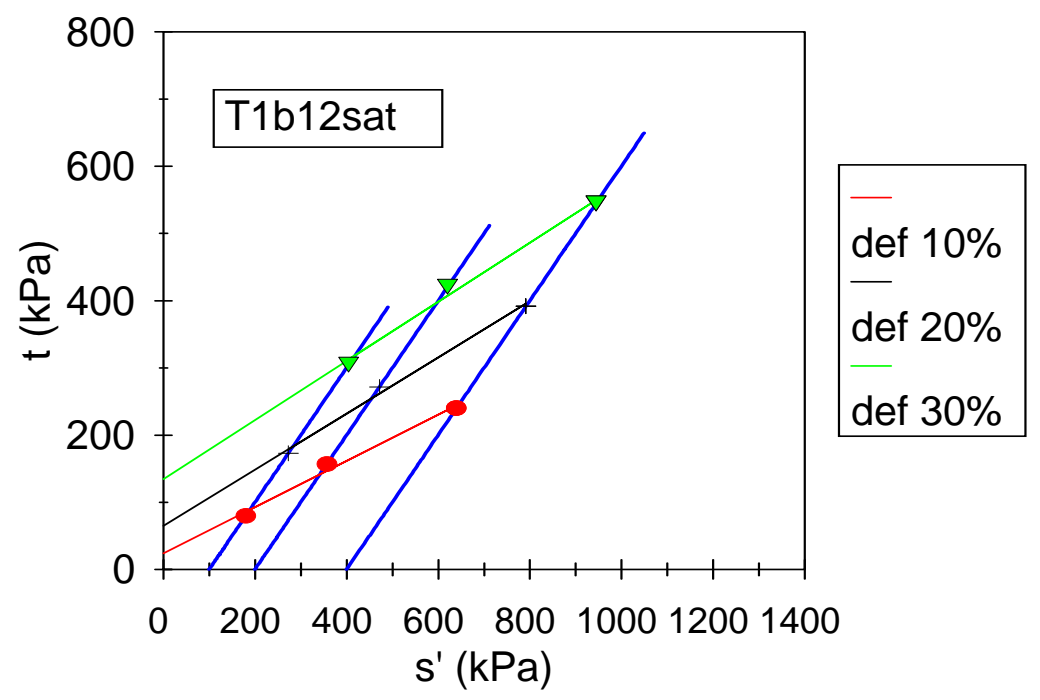

Figura 5.16 - Trajetórias de tensões e envoltórias de resistência num diagrama $t$-s' obtidas para a amostra T1B, saturada, compactada com peso específico de $12 \mathrm{kN} / \mathrm{m}^{3}$, em corpos de prova de $150 \mathrm{~mm}$ de diâmetro e $300 \mathrm{~mm}$ de altura.

É importante observar que no final do adensamento, tanto a amostra saturada (T1b12sat) como a amostra na umidade natural (T1b12nat), apresentaram valores de peso específico seco muito próximos (ver tabela 4.4). Acredita-se que devido a isso as duas amostras apresentaram resistências tão próximas. 

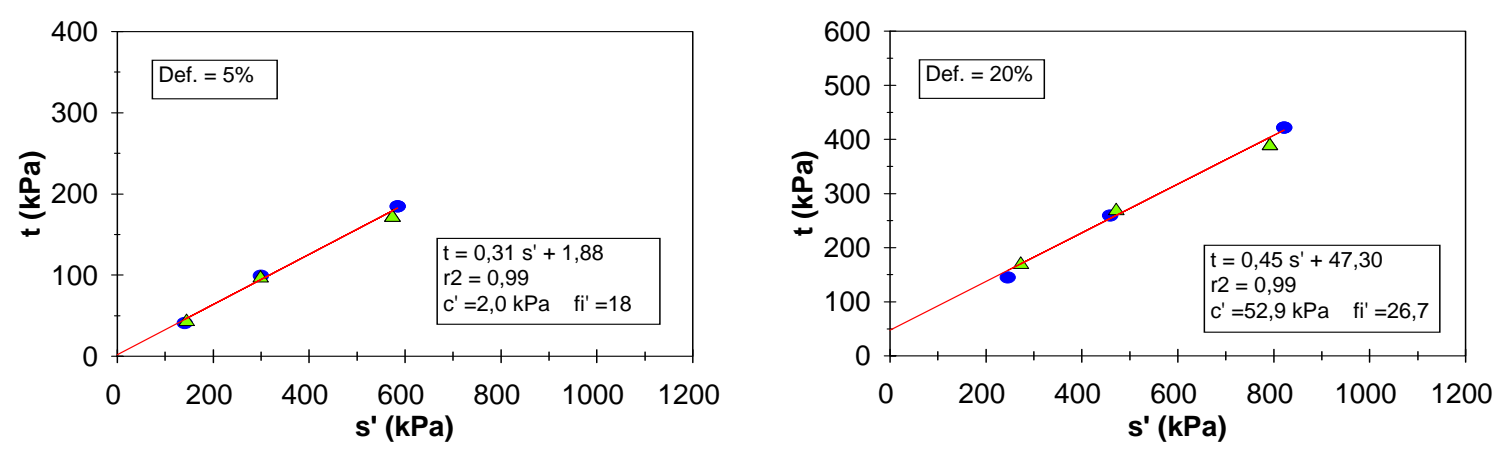

T1b12nat $\triangle$ T1b12sat - regressão

- T1b12nat $\triangle$ T1b12sat - regressão
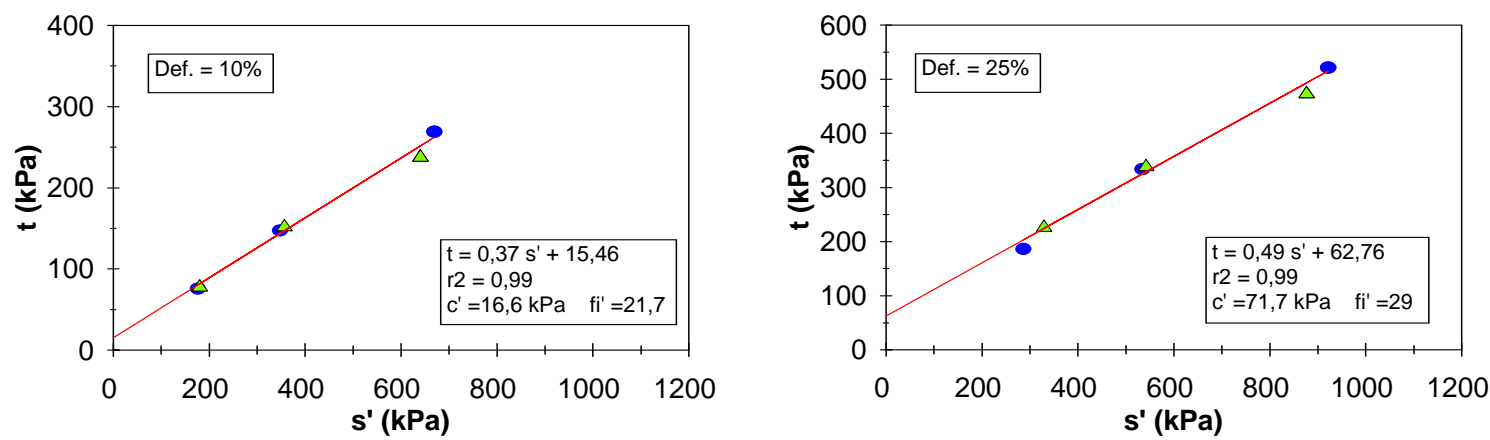

- T1b12nat $\Delta$ T1b12sat - regressão

- T1b12nat $\triangle$ T1b12sat - regressão
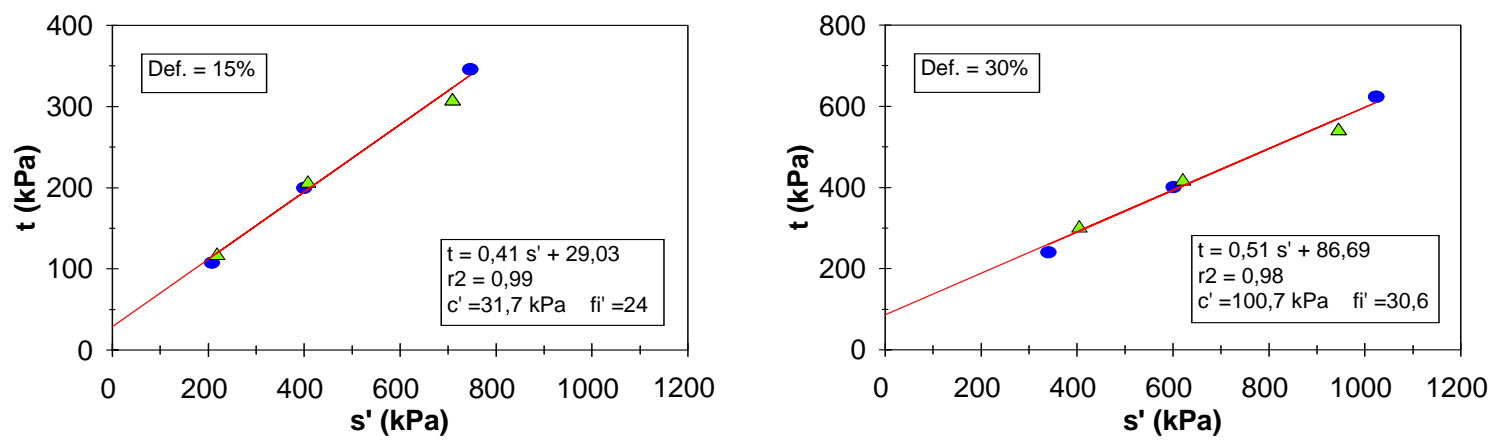

- T1b12nat $\Delta$ T1b12sat - regressão

- T1b12nat $\triangle$ T1b12sat - regressão

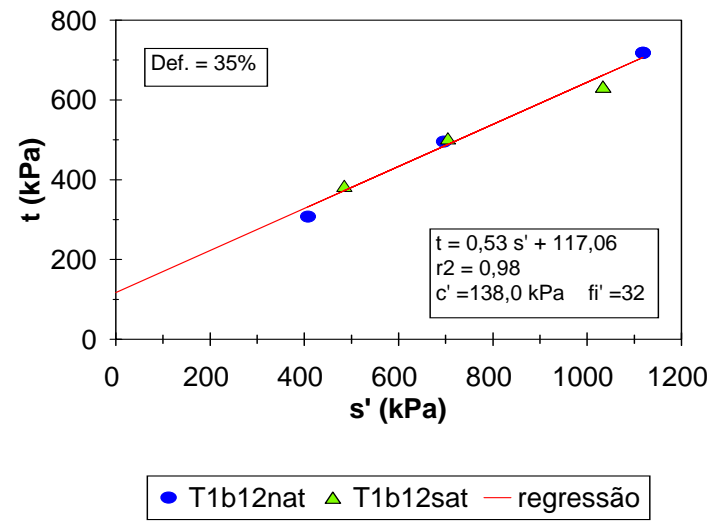

Figura 5.17 - Envoltórias num diagrama t-s' obtidas para a amostra T1B, compactada com $12 \mathrm{kN} / \mathrm{m}^{3}$ e submetida a ensaios $C D_{\text {nat }}$ (T1b12nat) e $C D_{\text {sat }}(T 1 \mathrm{~b} 12 \mathrm{sat}$ ). 
Tabela 5.3 - Parâmetros de resistência obtidos para a amostra T1B na umidade natural e saturada, compactada com peso específico de $12 \mathrm{kN} / \mathrm{m}^{3}$, em corpos de prova $150 \mathrm{~mm}$ de diâmetro por $300 \mathrm{~mm}$ de altura.

\begin{tabular}{|c|c|c|c|c|c|}
\hline \multirow[b]{2}{*}{ Amostra } & \multirow{2}{*}{$\begin{array}{c}\text { Def. axial } \\
\text { (\%) }\end{array}$} & \multirow{2}{*}{$\begin{array}{c}\text { Equação } \\
\text { (kPa) }\end{array}$} & \multirow{2}{*}{$\begin{array}{c}\text { Coef. } \\
\text { Det. }\left(R^{2}\right)\end{array}$} & \multicolumn{2}{|c|}{ Parâmetros } \\
\hline & & & & $C^{\prime}(k P a)$ & $\phi^{\prime}(9)$ \\
\hline \multirow{7}{*}{ T1b12nat } & 5 & $\mathrm{t}=0,320 \mathrm{~s}^{\prime}$ & 0,996 & 0 & 18,7 \\
\hline & 10 & $t=0,390 s^{\prime}+9,1$ & 0,999 & 9,9 & 23 \\
\hline & 15 & $t=0,440 s+19,3$ & 0,998 & 21,5 & 26 \\
\hline & 20 & $t=0,476 s^{\prime}+33,0$ & 0,997 & 37,6 & 28,4 \\
\hline & 25 & $t=0,523 s^{\prime}+43,2$ & 0,996 & 50,6 & 31,5 \\
\hline & 30 & $t=0,557 s^{\prime}+56,6$ & 0,998 & 68,1 & 33,8 \\
\hline & 35 & $t=0,574 s^{\prime}+82,3$ & 0,996 & 100,9 & 35 \\
\hline \multirow{7}{*}{ T1b12sat } & 5 & $t=0,296 s^{\prime}+5,3$ & 0,995 & 5,5 & 17 \\
\hline & 10 & $t=0,343 s^{\prime}+24,4$ & 0,987 & 26 & 20 \\
\hline & 15 & $t=0,383 s^{\prime}+41,1$ & 0,991 & 44,5 & 22,5 \\
\hline & 20 & $t=0,417 s^{\prime}+64,8$ & 0,993 & 71,2 & 24,6 \\
\hline & 25 & $t=0,446 s^{\prime}+89,0$ & 0,994 & 99,5 & 26,5 \\
\hline & 30 & $t=0,440 s^{\prime}+135,0$ & 0,990 & 150,2 & 26 \\
\hline & 35 & $t=0,448 s^{\prime}+175,3$ & 0,991 & 196,0 & 26,6 \\
\hline
\end{tabular}

Os resultados das Figuras 4.31 e 4.32 foram utilizados para traçar as trajetórias de tensões para a amostra $\mathrm{T} 2 \mathrm{~B}$, na umidade natural e na condição saturada, compactada com peso específico de $12 \mathrm{kN} / \mathrm{m}^{3}$ e umidade de moldagem de $44,4 \%$, utilizando corpos de prova de $150 \mathrm{~mm}$ de diâmetro e $300 \mathrm{~mm}$ de altura. As trajetórias de tensões, para pressão de confinamento de 100, 200 e 400kPa e as envoltórias de resistência, para deformação axial de 10, 20 e 30\%, obtidas do ensaio $C D_{\text {nat }}$ (T2b12nat) e $C D_{\text {sat }}$ (T2b12sat) estão apresentadas na Figura 5.18 e 5.19, respectivamente. A Tabela 5.4 apresenta, para vários níveis de deformação, as equações das trajetórias e os coeficientes de determinação, bem como, os parâmetros de resistência ao cisalhamento obtidos para a amostra T2B.

É interessante observar que a amostra T2B apresenta, quanto à saturação, um comportamento contrário aos obtidos para as outras duas amostras (T1B e T2A). A amostra T2B, saturada (T2b12sat) mostrou um decréscimo de coesão e um aumento do ângulo de atrito quando comparado com a amostra ensaiada no teor de umidade natural e com mesmo peso específico (T2b12nat). Acredita-se que essas variações no comportamento seja em virtude da maior ocorrência de solo na composição da amostra T2B.

A Figura 5.20 apresenta os gráficos txs' e as envoltórias médias de resistência para vários níveis de deformação, obtidos dos ensaios $C D$, executados na condição de umidade 
natural e saturada para a amostra T2B. Nesta figura, também estão apresentadas as equações das trajetórias, os valores obtidos para c' e $\phi$ ' e os coeficientes de determinação.

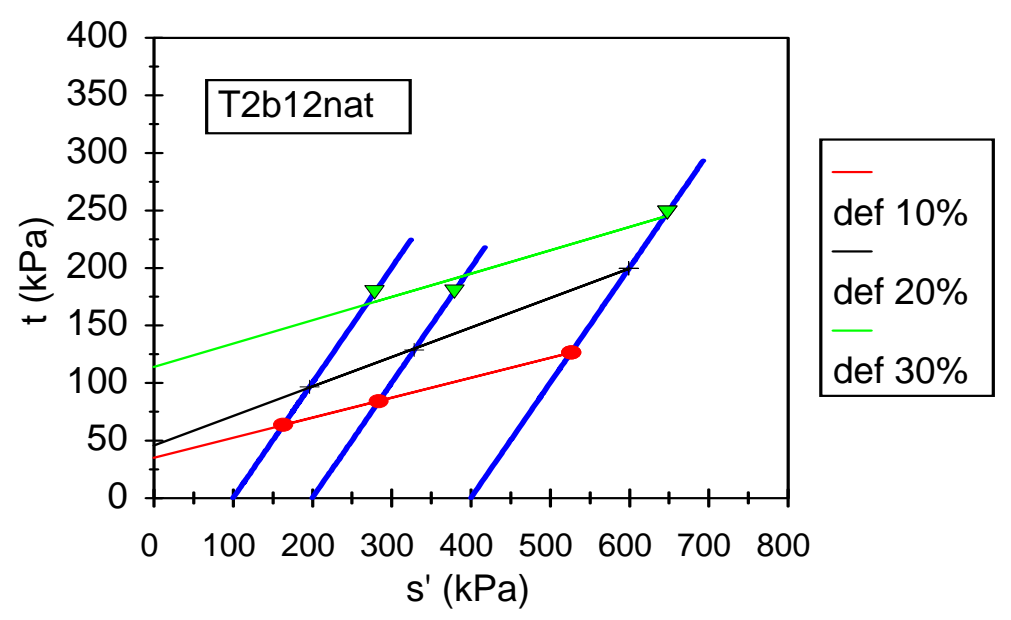

Figura 5.18 - Trajetórias de tensões e envoltórias de resistência num diagrama $t$-s' obtidas para amostra $\mathrm{T2B}$, na umidade natural, compactada com peso específico de $12 \mathrm{kN} / \mathrm{m}^{3}$, em corpos de prova de $150 \mathrm{~mm}$ de diâmetro e $300 \mathrm{~mm}$ de altura.

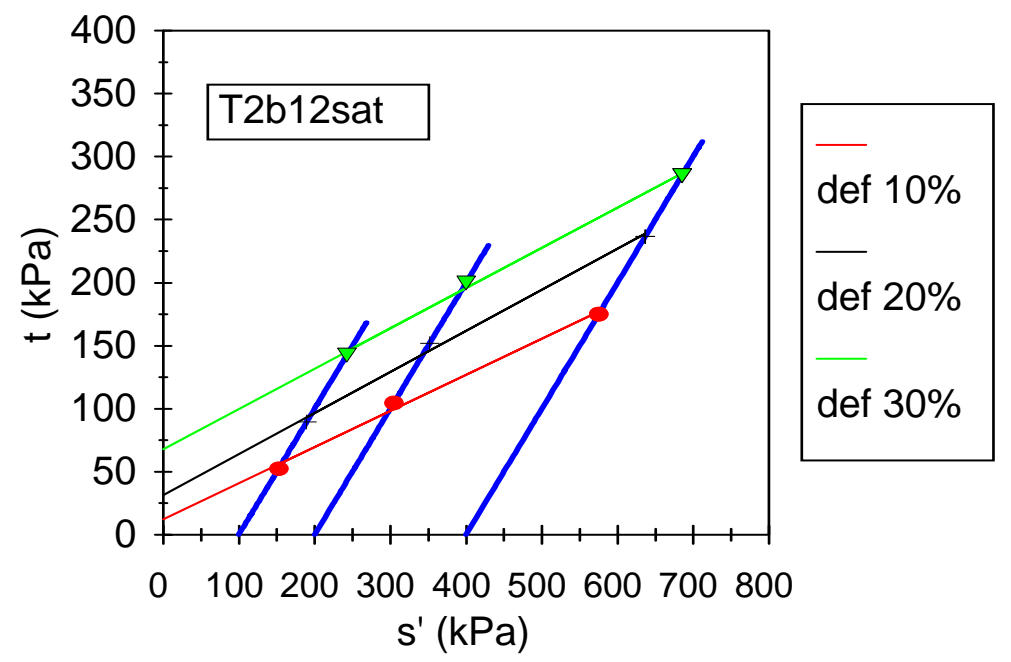

Figura 5.19 - Trajetórias de tensões e envoltórias de resistência num diagrama t-s' obtidas para amostra T2B, saturada, compactada com peso específico de $12 \mathrm{kN} / \mathrm{m}^{3}$, em corpos de prova com $150 \mathrm{~mm}$ de diâmetro e $300 \mathrm{~mm}$ de altura.

Os resultados de quatro ensaios triaxiais $C D_{\text {nat }}$, para avaliação da reprodutibilidade dos resultados obtidos (Figura 4.33), executados com a amostra T2A, com peso específico de $12 \mathrm{kN} / \mathrm{m}^{3}$ e pressão de confinamento de $400 \mathrm{kPa}$, revelaram uma boa concordância entre as curvas, exceto para o corpo de prova 01. O CP-01 apresentou, para deformação axial de 
20\%, valor de tensão desviatória de no máximo $21 \%$ menor em relação as outras curvas. Assim, acredita-se que mesmo para materiais como resíduos sólidos urbanos, os quais são constituídos por diferentes tipos de componentes, com diferentes formas e tamanhos, foi possível obter resultados de ensaios reprodutíveis.

Tabela 5.4 - Parâmetros de resistência obtidos para a amostra T2B, na umidade natural e saturada, compactada com peso específico de $12 \mathrm{kN} / \mathrm{m}^{3}$, em corpos de prova de $150 \mathrm{~mm}$ de diâmetro por $300 \mathrm{~mm}$ de altura.

\begin{tabular}{|c|c|c|c|c|c|}
\hline \multirow[b]{2}{*}{ Amostra } & \multirow{2}{*}{$\begin{array}{c}\text { Def. axial } \\
\text { (\%) }\end{array}$} & \multirow{2}{*}{$\begin{array}{c}\text { Equação } \\
\text { (kPa) }\end{array}$} & \multirow{2}{*}{$\begin{array}{c}\text { Coef. } \\
\text { Det. }\left(R^{2}\right)\end{array}$} & \multicolumn{2}{|c|}{ Parâmetros } \\
\hline & & & & $C^{\prime}(k P a)$ & $\phi^{\prime}(9)$ \\
\hline \multirow{7}{*}{ T2b12nat } & 5 & $t=0,151 s^{\prime}+21,8$ & 0,999 & 22,1 & 8,7 \\
\hline & 10 & $t=0,173 s^{\prime}+35,1$ & 0,999 & 35,7 & 10 \\
\hline & 15 & $t=0,228 s^{\prime}+37,9$ & 0,999 & 38,9 & 13 \\
\hline & 20 & $t=0,256 s^{\prime}+45,6$ & 0,999 & 47,1 & 14,8 \\
\hline & 25 & $t=0,240 s^{\prime}+71,3$ & 0,992 & 73,4 & 13,9 \\
\hline & 30 & $t=0,202 s^{\prime}+114,0$ & 0,934 & 116,4 & 11,6 \\
\hline & 35 & $t=0,196 s^{\prime}+142,9$ & 0,850 & 145,8 & 11,3 \\
\hline \multirow{7}{*}{ T2b12sat } & 5 & $t=0,241 s^{\prime}+8,4$ & 0,992 & 8,7 & 14 \\
\hline & 10 & $t=0,286 s^{\prime}+12,3$ & 0,994 & 12,9 & 16,6 \\
\hline & 15 & $t=0,304 s^{\prime}+21,6$ & 0,994 & 22,7 & 17,7 \\
\hline & 20 & $t=0,325 s^{\prime}+31,5$ & 0,995 & 33,3 & 19 \\
\hline & 25 & $t=0,334 s^{\prime}+44,5$ & 0,997 & 47,2 & 19,5 \\
\hline & 30 & $t=0,319 s^{\prime}+68,1$ & 0,997 & 71,9 & 18,6 \\
\hline & 35 & $t=0,315 s^{\prime}+85,3$ & 0,995 & 89,9 & 18,4 \\
\hline
\end{tabular}

Como comentado anteriormente, foram ensaiadas amostras de RSU com maiores dimensões (200mm de diâmetro e 400mm de altura) com o objetivo de avaliar a influência do tamanho da amostra na resistência medida.

Os resultados de ensaios CD em amostras de 200mm de diâmetro (Figuras 4.36 a 4.39) mostraram um comportamento tensão - deformação, onde a diferença de tensões principais é crescente com o aumento das deformações axiais. Somente foi possível levar o ensaio até $25 \%$ de deformação axial em virtude da maior dimensão da amostra e da altura limitada de subida do prato da prensa de cisalhamento. 


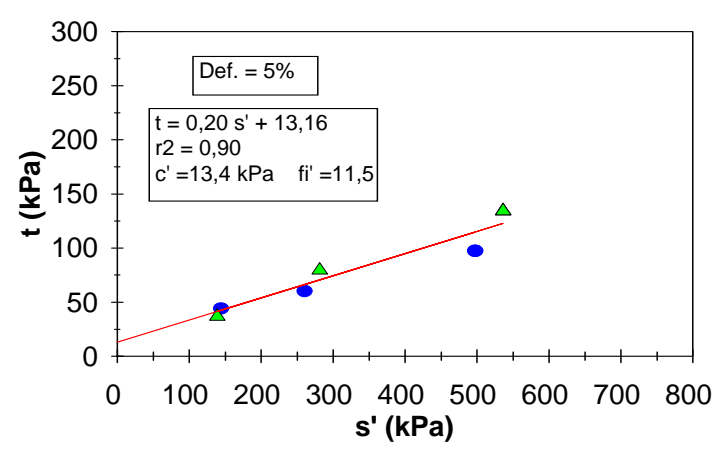

- T2b12nat $\Delta$ T2b12sat - regressão

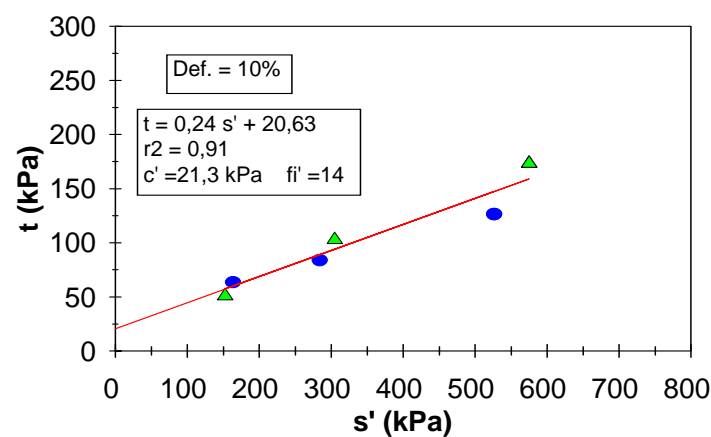

- T2b12nat $\triangle$ T2b12sat - regressão

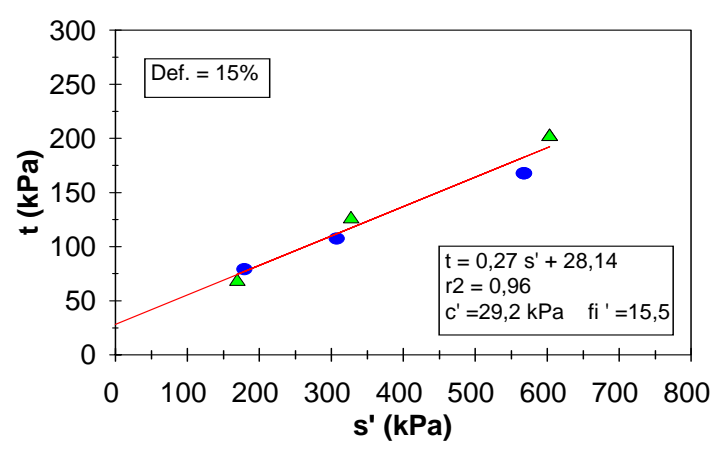

- T2b12nat $\triangle$ T2b12sat - regressão

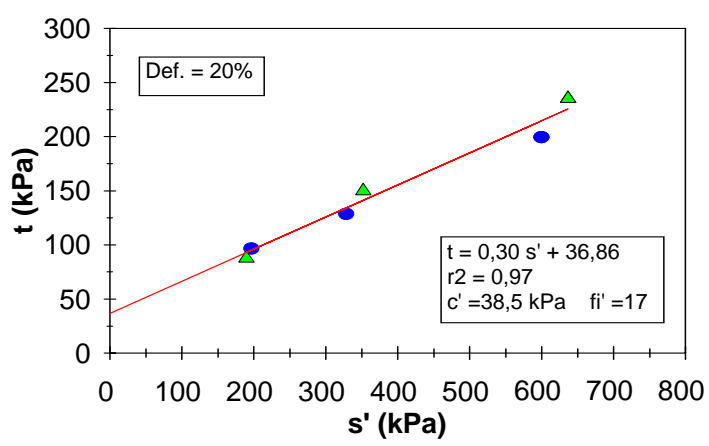

- T2b12nat $\triangle$ T2b12sat - regressão

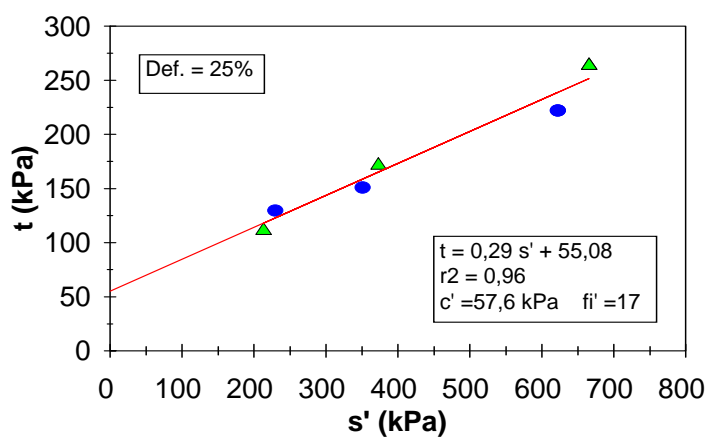

- T2b12nat $\triangle$ T2b12sat - regressão

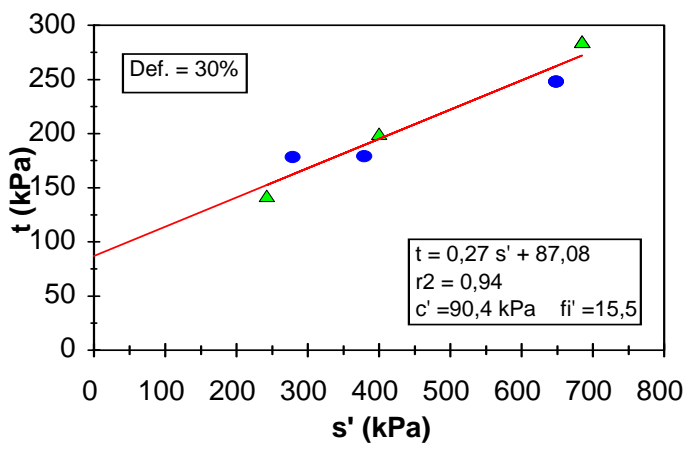

- T2b12nat $\Delta$ T2b12sat — regressão

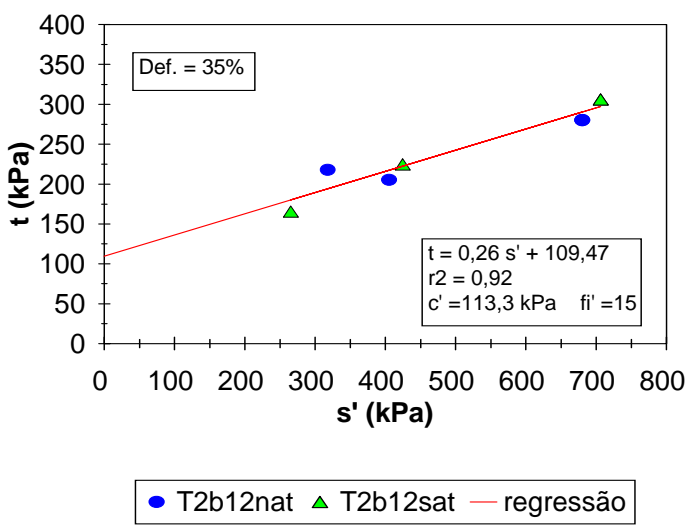

Figura 5.20 - Envoltórias num diagrama $t$-s' obtidas para a amostra T2B, compactada com $12 \mathrm{kN} / \mathrm{m}^{3}$ e submetida a ensaios $C D_{\text {nat }}$ (T2b12nat) e $C D_{\text {sat }}$ (T2b12sat). 
As Figuras 5.21 a 5.24 apresentam as trajetórias de tensões e envoltórias para 10, 20 e 25\% de deformação axial obtidas de ensaios com 200mm de diâmetro por 400mm de altura, para as amostras T2A, na umidade natural e saturada, T1B e T2B sob condição saturada, respectivamente. Na Tabela 5.5 estão apresentados os parâmetros de resistência resultantes das envoltórias, equações e coeficientes de determinação para as quatro amostras ensaiadas.

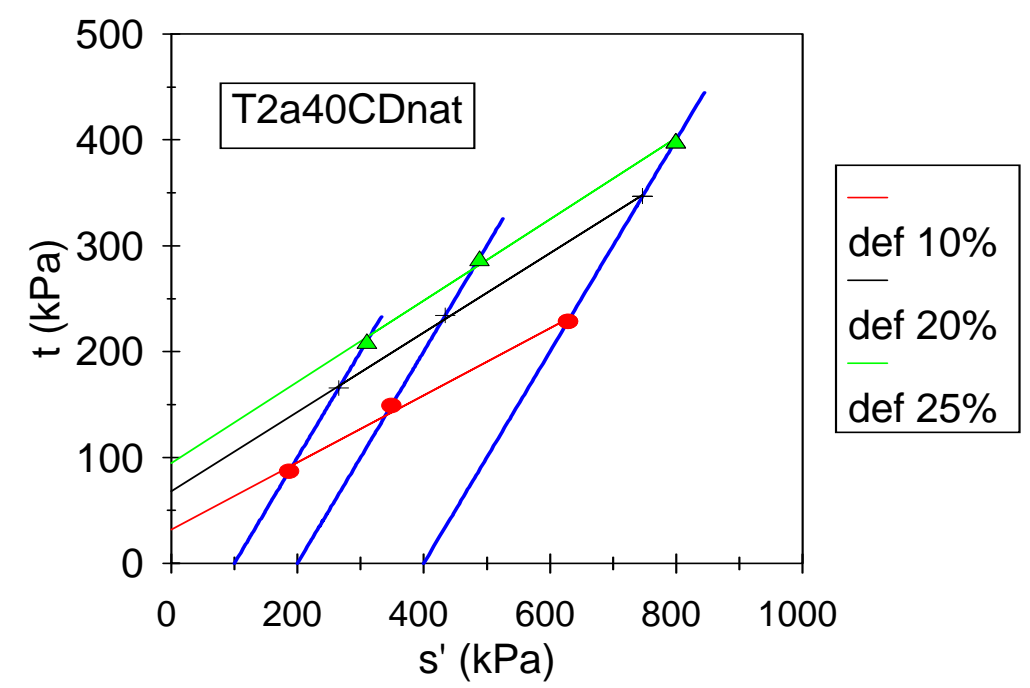

Figura 5.21 - Trajetórias de tensões e envoltórias de resistência num diagrama $t-s$ ' obtidas de ensaio $C D$ com amostra $T 2 A$, na umidade natural, compactada com peso específico de $12 \mathrm{kN} / \mathrm{m}^{3}$, em corpos de prova de 200mm de diâmetro e 400mm de altura.

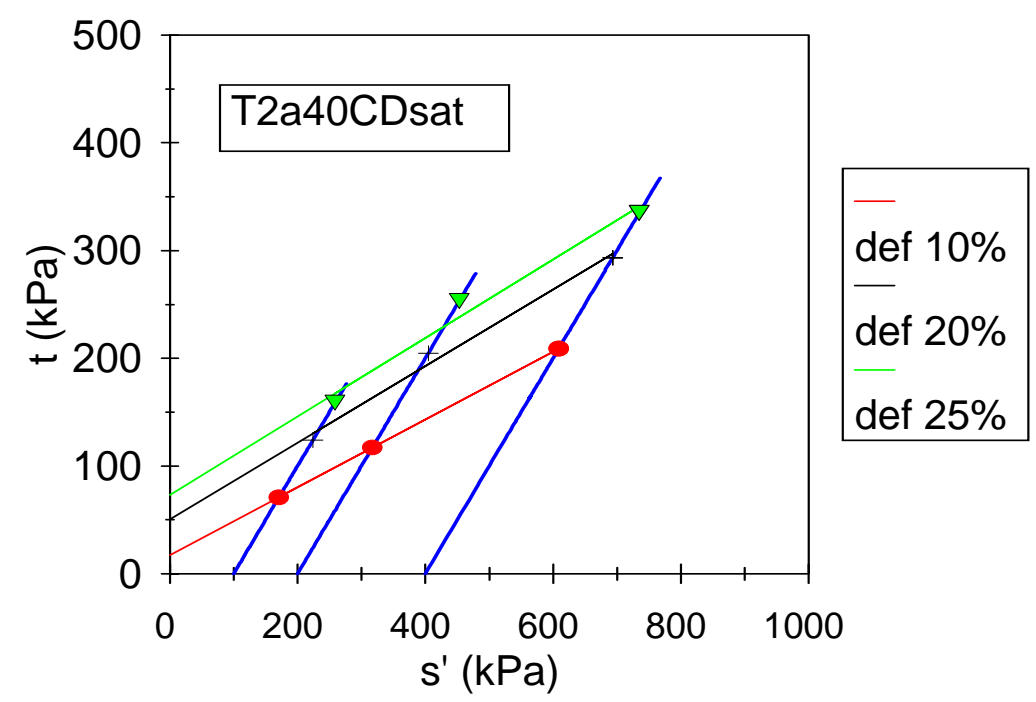

Figura 5.22 - Trajetórias de tensões e envoltórias de resistência num diagrama t-s' obtidas de ensaio CD com amostra T2A, saturada, compactada com peso específico de $12 \mathrm{kN} / \mathrm{m}^{3}$, em corpos de prova de $200 \mathrm{~mm}$ de diâmetro e $400 \mathrm{~mm}$ de altura. 


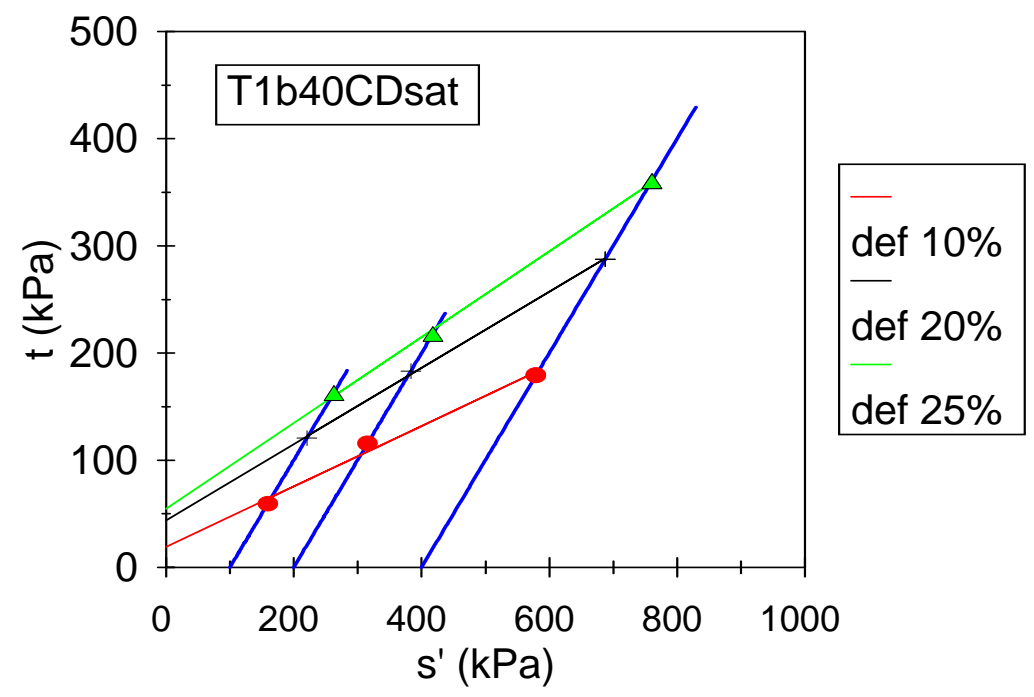

Figura 5.23 - Trajetórias de tensões e envoltórias de resistência num diagrama $t$-s' obtidas de ensaio $C D$ com amostra $T 1 B$, saturada, compactada com peso específico de $12 \mathrm{kN} / \mathrm{m}^{3}$, em corpos de prova de $200 \mathrm{~mm}$ de diâmetro e $400 \mathrm{~mm}$ de altura.

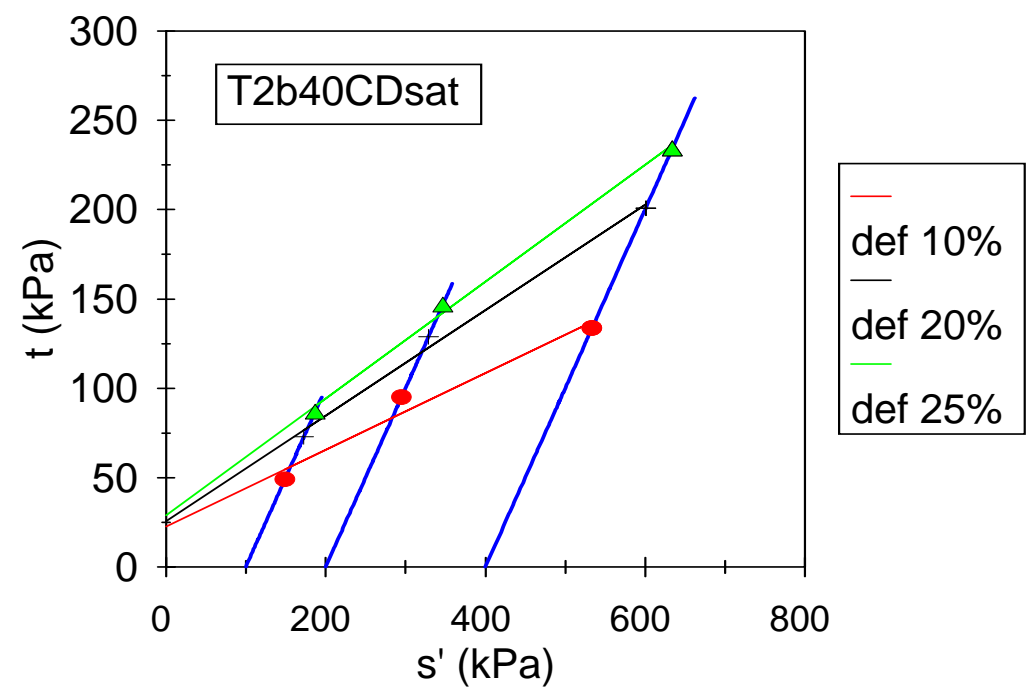

Figura 5.24 - Trajetórias de tensões e envoltórias de resistência num diagrama $t$-s' obtidas de ensaio CD com amostra T2B, saturada, compactada com peso específico de $12 \mathrm{kN} / \mathrm{m}^{3}$, em corpos de prova de $200 \mathrm{~mm}$ de diâmetro e $400 \mathrm{~mm}$ de altura. 
Tabela 5.5 - Parâmetros de resistência obtidos de ensaios CD em amostra T2A, T2B e T1B, com peso específico de $12 \mathrm{kN} / \mathrm{m}^{3}$ e em corpos de prova de $200 \mathrm{~mm}$ de diâmetro por $400 \mathrm{~mm}$ de altura.

\begin{tabular}{|c|c|c|c|c|c|}
\hline \multirow[b]{2}{*}{ Amostra } & \multirow{2}{*}{$\begin{array}{c}\text { Def. axial } \\
\text { (\%) }\end{array}$} & \multirow{2}{*}{$\begin{array}{c}\text { Equação } \\
\text { (kPa) }\end{array}$} & \multirow{2}{*}{$\begin{array}{c}\text { Coef. } \\
\text { Det. }\left(R^{2}\right)\end{array}$} & \multicolumn{2}{|c|}{ Parâmetros } \\
\hline & & & & $C^{\prime}(\mathrm{kPa})$ & $\phi^{\prime}(9)$ \\
\hline \multirow{3}{*}{ T2a40CDnat } & 10 & $t=0,317 s^{\prime}+32,0$ & 0,993 & 33,8 & 18,5 \\
\hline & 20 & $t=0,374 s^{\prime}+68,4$ & 0,998 & 73,8 & 22 \\
\hline & 25 & $t=0,383 s^{\prime}+95,1$ & 0,996 & 103,0 & 22,5 \\
\hline \multirow{3}{*}{ T2a40CDsat } & 10 & $t=0,314 s^{\prime}+17,4$ & 0,999 & 18,3 & 18,3 \\
\hline & 20 & $t=0,355 s^{\prime}+50,8$ & 0,989 & 54,4 & 20,8 \\
\hline & 25 & $t=0,364 s^{\prime}+73,3$ & 0,978 & 78,7 & 21,3 \\
\hline \multirow{3}{*}{ T1b40CDsat } & 10 & $t=0,280 s^{\prime}+19,5$ & 0,988 & 20,4 & 16,3 \\
\hline & 20 & $\mathrm{t}=0,355 \mathrm{~s}^{\prime}+44,2$ & 0,999 & 47,3 & 20,8 \\
\hline & 25 & $t=0,400 s^{\prime}+54,8$ & 0,998 & 59,7 & 23,5 \\
\hline \multirow{3}{*}{ T2b40CDsat } & 10 & $t=0,214 s^{\prime}+22,8$ & 0,964 & 23,3 & 12,3 \\
\hline & 20 & $\mathrm{t}=0,295 \mathrm{~s}^{\prime}+25,7$ & 0,993 & 26,9 & 17 \\
\hline & 25 & $t=0,326 s^{\prime}+28,9$ & 0,997 & 30,7 & 19 \\
\hline
\end{tabular}

As Figuras 5.25 a 5.27 mostram uma comparação entre as curvas tensãodeformação obtidas para os corpos de prova com 150 e 200mm de diâmetros. Observam-se que as curvas tensão - deformação obtidas para os corpos de prova compactados com 150mm de diâmetro e 300mm de altura apresentam, em geral, para uma mesma deformação e pressão de confinamento, maiores diferenças de tensões principais que as dos corpos de prova de $200 \mathrm{~mm}$ de diâmetro. Isso mostra, que existe uma tendência de variação nas resistências obtidas quando se consideram dimensões diferentes das amostras. Para ilustrar, no Anexo 5 apresentam-se uma comparação entre as envoltórias de resistência num diagrama t-s`, considerando $20 \%$ de deformação axial para as duas dimensões de corpos de prova.

A diferença de resistência pode ser melhor observada nas Figuras 5.28 a 5.30. Nestas figuras apresentam-se as relações $\left(\mathrm{s}_{15} / \mathrm{s}_{20}\right)$, obtidas entre as resistências ( $\mathrm{s}=\mathrm{c}$ '+ $\left.\sigma^{`} \operatorname{tg} \phi\right)$ dos corpos de prova de $15 \times 30$, pelas resistências dos corpos de prova de $20 \times 40$, considerando-se tensões normais de 100, 200 e 400kPa, mesma amostra e mesma condição de ensaio.

Para as amostras T2A e T2B, na faixa de deformações axiais entre 10 a 25\%, as resistências $\left(\mathrm{s}_{15}\right)$, obtidas para os corpos de prova de $15 \mathrm{~cm}$ de diâmetro, apresentaram um acréscimo de até $25 \%$ em relação à resistência $\left(\mathrm{s}_{20}\right)$, obtida para os corpos de prova de $20 \mathrm{~cm}$ de diâmetro. Já a amostra T1B apresentou valores bem maiores, acima de 40\% maior, para deformação axial de 25\% (Figuras 5.28 a 5.30). Não se conseguiu com os 
dados disponíveis, estabelecer uma tendência clara de variação da relação $\mathrm{s}_{15} / \mathrm{s}_{20}$, quer com a tensão normal quer com a deformação axial. Registre-se apenas que os corpos de prova da amostra T2A, submetidos à ensaios CDnat (Figura 5.28) mostraram uma tendência da relação $s_{15} / s_{20}$ crescer com a tensão normal.

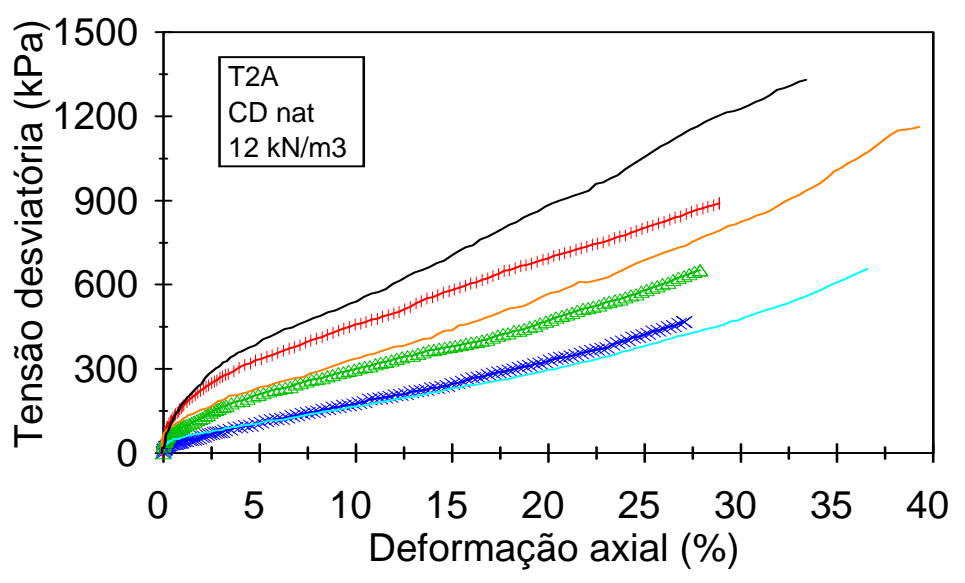

$$
\begin{array}{r}
\leftarrow 20 \times 40(100 \mathrm{kPa}) \triangle 20 \times 40(200 \mathrm{kPa}) \leftarrow 20 \times 40(400 \mathrm{kPa}) \\
-15 \times 30(100 \mathrm{kPa})-15 \times 30(200 \mathrm{kPa})-15 \times 30(400 \mathrm{kPa})
\end{array}
$$

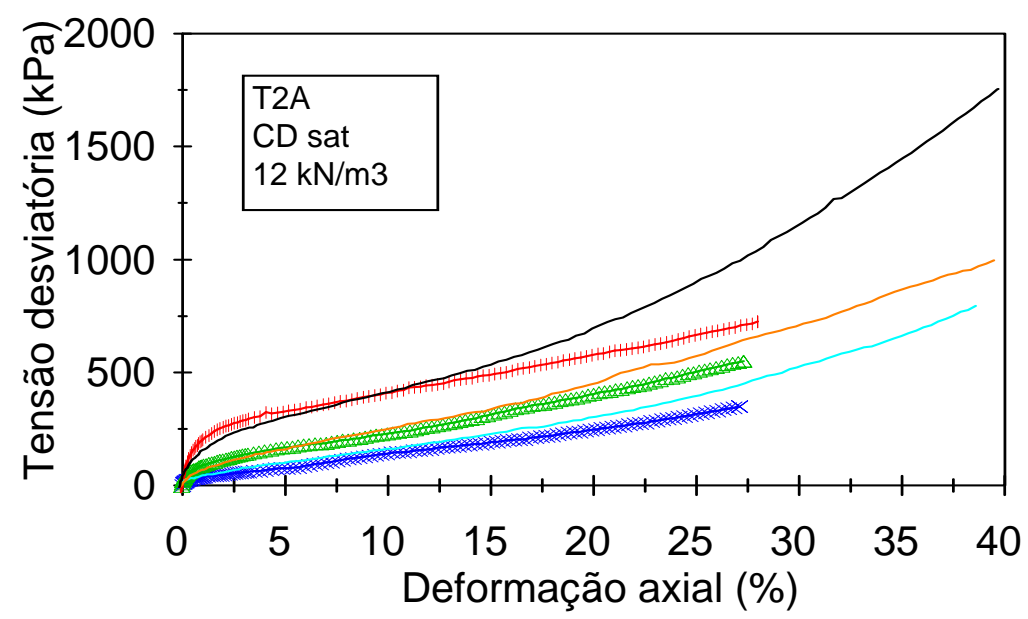

$$
\begin{array}{r}
\leftarrow 20 \times 40(100 \mathrm{kPa}) \triangle 20 \times 40(200 \mathrm{kPa})+20 \times 40(400 \mathrm{kPa}) \\
-15 \times 30(100 \mathrm{kPa})-15 \times 30(200 \mathrm{kPa})-15 \times 30(400 \mathrm{kPa})
\end{array}
$$

Figura 5.25 - Curvas tensão - deformação obtidas de ensaios CD para amostra T2A, na umidade natural e na condição saturada utilizando corpos de prova com diâmetros de 150 e $200 \mathrm{~mm}$. 


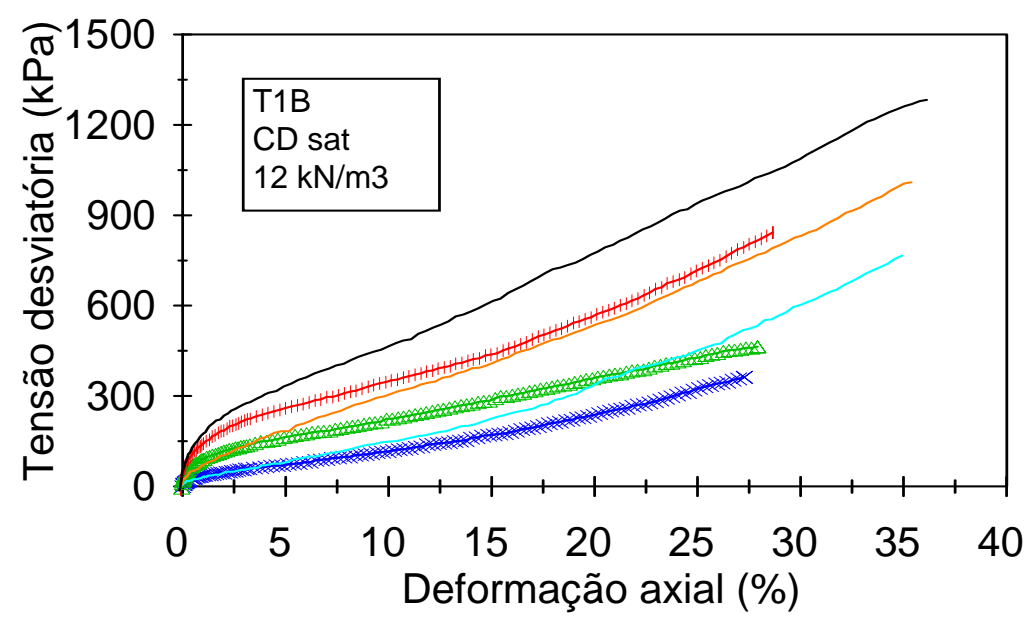

$$
\begin{aligned}
& \star 20 \times 40(100 \mathrm{kPa}) \triangle 20 \times 40(200 \mathrm{kPa})+20 \times 40(400 \mathrm{kPa}) \\
& -15 \times 30(100 \mathrm{kPa})-15 \times 30(200 \mathrm{kPa})-15 \times 30(400 \mathrm{kPa})
\end{aligned}
$$

Figura 5.26 - Curvas tensão - deformação obtidas de ensaios $C D_{\text {sat }}$ para amostra T1B, em corpos de prova com diâmetros de $150 \mathrm{~mm}$ e $200 \mathrm{~mm}$.

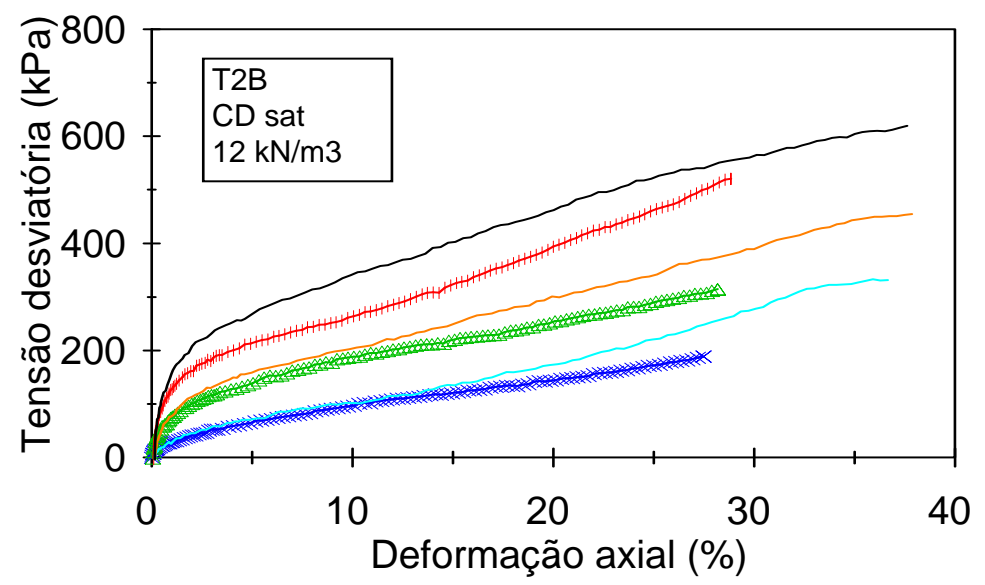

Figura 5.27 - Curvas tensão - deformação obtidas de ensaios $C D_{\text {sat }}$ para amostra T2B, em corpos de prova com diâmetros de $150 \mathrm{~mm}$ e $200 \mathrm{~mm}$.

O acréscimo de resistência ao cisalhamento obtida por meio de ensaios com corpos de prova de menor dimensão $(15 \times 30)$ pode em parte ser creditada à heterogeneidade das amostras, mas acredita-se que o efeito reforço dado pelos materiais fibrosos desempenha um papel importante nesse comportamento. 

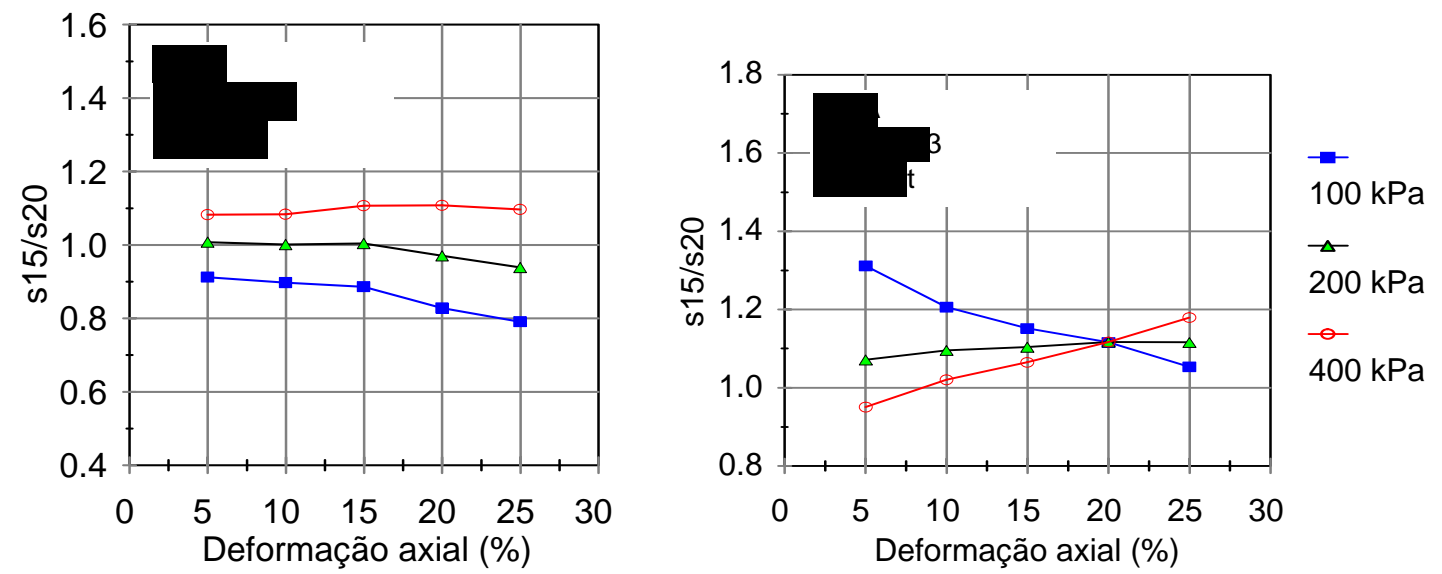

Figura 5.28 - Relação entre as resistências $\left(s_{15} / s_{20}\right)$ obtidas de ensaios $C D$ com amostra T2A, na umidade natural e saturada, compactada com peso específico de $12 \mathrm{kN} / \mathrm{m}^{3}$.

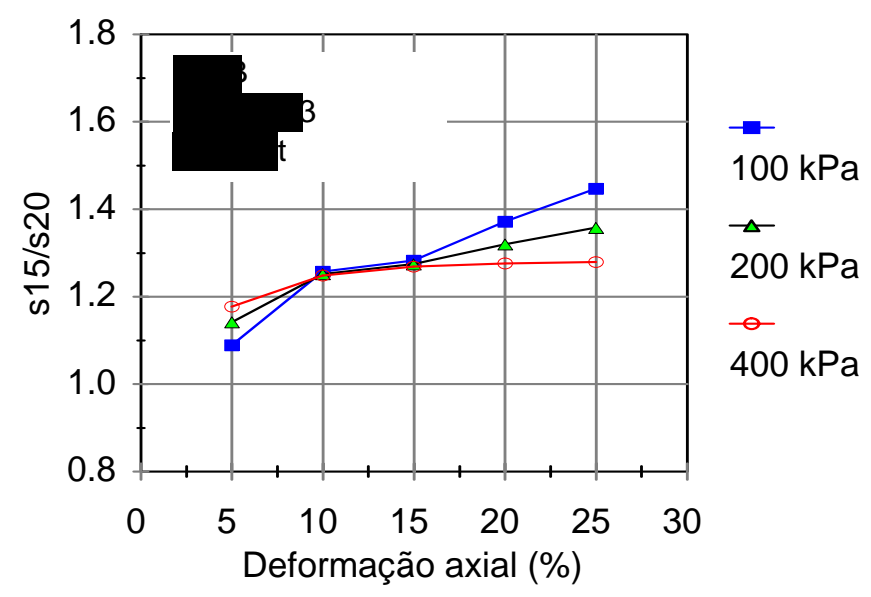

Figura 5.29 - Relação entre as resistências $\left(s_{15} / s_{20}\right)$ obtidas de ensaios $C D$ com amostra T1B, saturada, compactada com peso específico de $12 \mathrm{kN} / \mathrm{m}^{3}$.

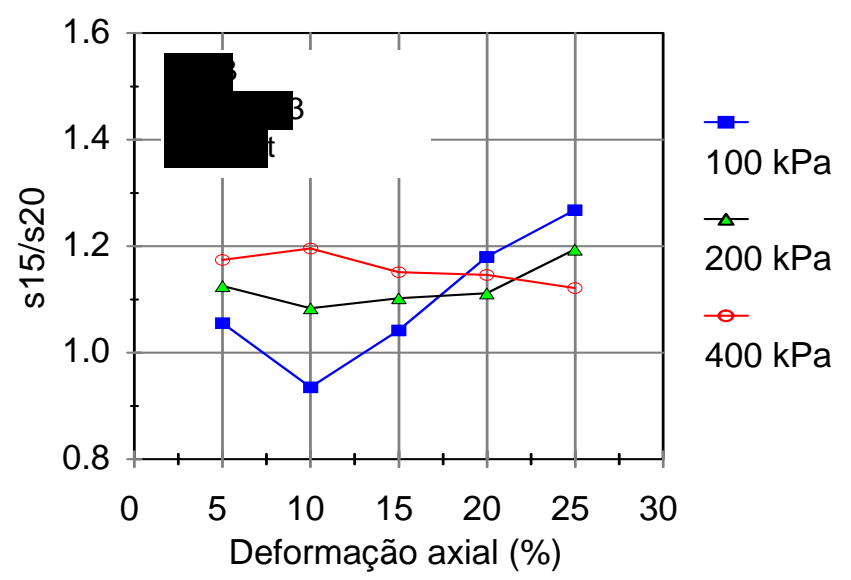

Figura 5.30 - Relação entre as resistências $\left(s_{15} / s_{20}\right)$ obtidas de ensaios $C D$ com amostra T2B, saturada, compactada com peso específico de $12 \mathrm{kN} / \mathrm{m}^{3}$. 
Várias pesquisas com misturas solo - fibra têm demostrado que as fibras impõem ao solo, por vezes, um aumento da parcela de atrito e, de um modo geral, um adicional na parcela coesiva responsáveis por grandes aumentos da resistência à tração (TEODORO \& BUENO, 1998). TEODORO \& BUENO (1998) encontraram, para um solo arenoso da cidade de São Carlos, um aumento da resistência com o aumento do comprimento e do teor das fibras. No entanto, existe um teor de fibras e um chamado índice aspecto (relação entre o comprimento e o diâmetro da fibra) que proporcionam melhores resultados. Quando esses dois parâmetros são altos, as fibras podem deixar de permanecer esticadas reduzindo o comprimento disponível para mobilizar a resistência ao cisalhamento. O conhecimento do mecanismo de interação solo - fibra é de grande importância na compreensão da resposta da mistura, no que refere-se ao seu comportamento mecânico. Este mecanismo depende de vários fatores, entre os quais destacam-se: o tipo de solo e as características das fibras, tais como, teor, comprimento, diâmetro e deformabilidade. No caso de solo reforçado, procuram-se controlar as características das fibras. Já para o RSU, deve-se ter em mente que essas "fibras" são de diferentes tamanhos e de diferentes propriedades tensão deformação, dificultando a compreensão dos resultados e fazendo com que o RSU não apresente uma envoltória de ruptura significativamente bilinear como aquelas obtidas para solos reforçados (ver Anexo 6).

Como o resíduo sólido urbano apresenta, de certa forma, um efeito "reforço" como em solo reforçado, pode-se especular que se se considerar que os materiais utilizados na preparação dos corpos de prova de dimensões diferentes (150x300mm e 200x400mm) apresentam constituição semelhante, ao utilizar-se um corpo de prova de menor dimensão, obter-se-ia uma maior relação entre o comprimento de fibras/ diâmetro do corpo de prova. Talvez isso possa explicar o acréscimo da resistência obtida para as amostras com diâmetro de $150 \mathrm{~mm}$ e altura de $300 \mathrm{~mm}$. É importante deixar claro, no entanto, que resultados dessa natureza com solo reforçado (mesmo comprimento de fibras e variando as dimensões dos corpos de prova), são muito escassos e o único resultado encontrado apresentou-se não conclusivo. Esse ponto, necessita de ser melhor investigado.

Os parâmetros de resistência médios obtidos para as três amostras em estudo (T2A, T1B e T2B), utilizando tanto corpos de prova de 150mm de diâmetro como os de 200mm de diâmetro são plotados versus a deformação axial na Figura 5.31.

$\mathrm{Na}$ Figura 5.31 observa-se que os parâmetros de resistência obtidos para as amostras estudadas aumentaram com as deformações. O ângulo de atrito, para $20 \%$ de deformação, variou entre 17 a $27^{\circ}$ e a coesão entre 39 a 60kPa. A amostra T2B apresentou valores de ângulo de atrito bem destoantes das demais, acredita-se que este fato seja em virtude dessa amostra apresentar razoável quantidade de solo em sua composição. Excluindo os resultados da amostra T2B, pode-se observar que tanto os valores de ângulo de atrito como os de coesão, para as amostras T2A e T1B, estão bem próximos, especialmente no intervalo de deformações entre 15 a $25 \%$ e considerando o mesmo 
diâmetro de corpo de prova. Os valores de resistência obtidos nesta pesquisa, por meio de ensaios triaxiais, apresentaram-se, em geral, superiores àqueles obtidos por BENVENUTO et al (1994), através de estudos de retro - análise de um escorregamento ocorrido em 1991 no sub aterro AS-1 do Aterro Bandeirantes, que forneceram $c^{`}=13,5 \mathrm{kPa}$ e $\phi^{\prime}=22^{\circ}$.
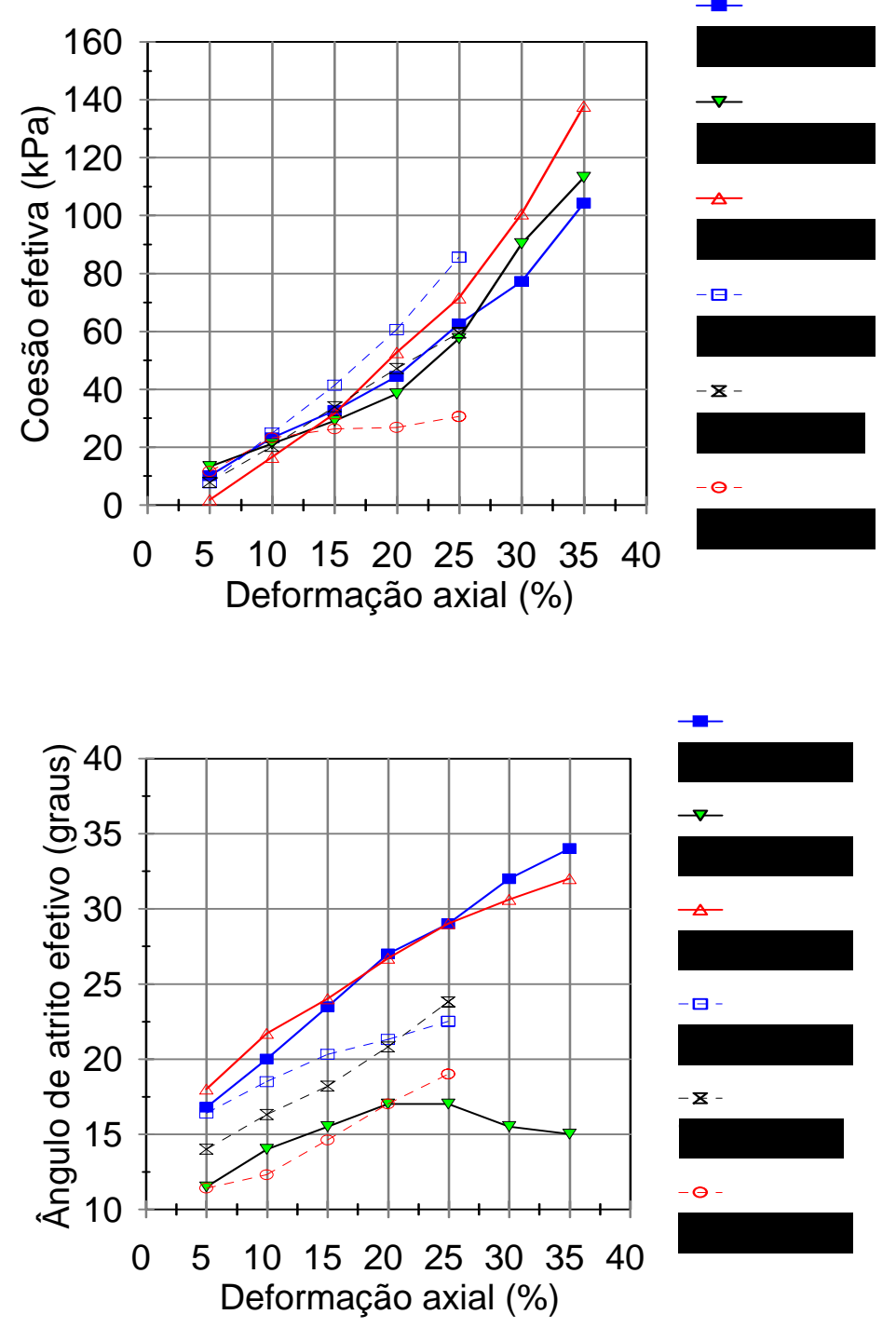

Figura 5.31 - Parâmetros de resistência ao cisalhamento do resíduo sólido urbano estudado, para diferentes deformações, obtidos de ensaios triaxiais CD em corpos de prova de 150 e $200 \mathrm{~mm}$ de diâmetro por 300 e $400 \mathrm{~mm}$ de altura.

Embora tenha-se verificado uma diferença visual no estado de alteração dos resíduos dos dois horizontes $\mathrm{A}$ (superficial e visualmente menos degradado) e $\mathrm{B}$ (profundo e visualmente mais degradado), não se observaram, a partir dos resultados de ensaios triaxiais consolidados drenados disponíveis, nenhuma alteração significativa no comportamento mecânico das amostras no que se refere à redução da resistência em função da degradação. 
As menores resistências obtidas para a amostra T2B, possivelmente, sejam em função da grande quantidade de solo presente na composição dessa amostra, e não em função de alguma variação no estado de degradação. É importante destacar que, assim como a amostra T2B, a amostra T1B também pertence ao horizonte (B), mais profundo e, no entanto, apresentou parâmetros de resistência muito próximos aos da amostra T2A. Além disso, os resultados dos ensaios químicos executados não permitiram observar nenhuma alteração significativa, em termos da degradação para os dois horizontes, ou seja a diferença de degradação, observada visualmente, entre os dois horizontes não foi confirmada pelos testes realizados.

Resultados de ensaios de compressão triaxial apresentados por JESSBERGER \& KOCKEL (1993), para resíduo sólido urbano com diferentes idades, também não apresentaram redução da resistência ao cisalhamento em função da idade do material depositado.

Mesmo reconhecendo que os ensaios realizados apresentam uma série de limitações no que se refere à obtenção de parâmetros de deformabilidade, resolveu-se calcular o módulo de elasticidade (E), a partir das curvas tensão - deformação obtidas para as amostras de RSU estudadas e apresentadas no capítulo anterior, sendo os resultados apresentados nas Figuras 5.32 a 5.34 .

O módulo calculado trata-se do módulo de elasticidade secante às várias deformações, a partir da origem. Nestas figuras, observam-se que o módulo diminui ao aumentar a tensão axial ou a deformação axial. Para grandes deformações, acima de 25\%, o módulo de elasticidade atinge valores bem pequenos, em geral inferiores a 4,0MPa. módulo de elasticidade calculado cresce com o aumento das pressões de confinamento da amostra. Além disso, para a amostraT2A que foi ensaiada com pesos específicos de 10, 12 e $14 \mathrm{kN} / \mathrm{m}^{3}$ (Figuras 5.32), observam-se que o peso específico de compactação da amostra parece influenciar levemente nos valores obtidos para o módulo. Isto é, para as amostras compactadas com maiores pesos específicos, os módulos tendem a ser ligeiramente maiores.

Valores de módulos de elasticidade iniciais (Eo) calculados para as várias amostras estudadas, por meio de ensaios triaxiais, considerando os primeiros valores de deformações medidas, são da ordem de 35 a 40MPa e esses estão próximos dos valores obtidos dos ensaios cross-hole de campo, os quais são calculados a partir das velocidades das ondas longitudinais.

Os resultados de ensaios triaxiais consolidados drenados com ciclo de carga descarga, executados para a amostra T1B, compactada com $12 \mathrm{kN} / \mathrm{m}^{3}$ e umidade de moldagem de 73,5\% (Figura 4.35 do capítulo anterior) mostraram que o módulo de elasticidade aumenta com a pressão de confinamento da amostra. Obtiveram-se valores de módulos de elasticidade de $13 \mathrm{MPa}$ para pressão de confinamento de $50 \mathrm{kPa}, 24 \mathrm{MPa}$ para pressão de confinamento de $200 \mathrm{kPa}$ e $37 \mathrm{MPa}$ para $400 \mathrm{kPa}$. Esses resultados mostraram 
uma relação linear entre as tensões de confinamento e o módulo, dada pela equação $E(M P a)=0,068 \sigma_{3}+9,85$ com r $^{2}=0,998$ e $\sigma_{3}$ em kPa.

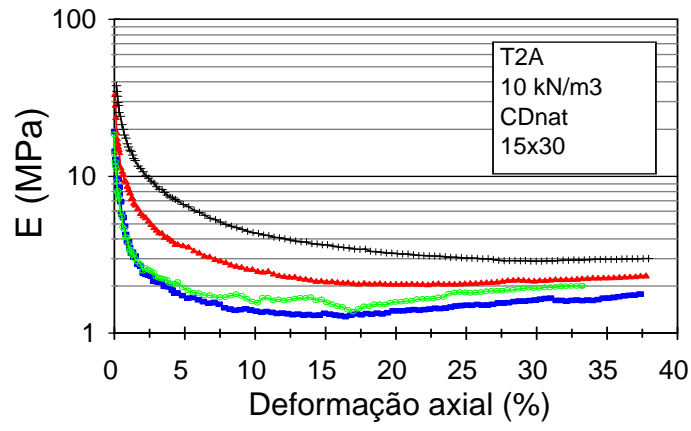

$-100 \mathrm{kPa} \rightarrow 200 \mathrm{kPa}+400 \mathrm{kPa} \multimap 100 \mathrm{kPa}$

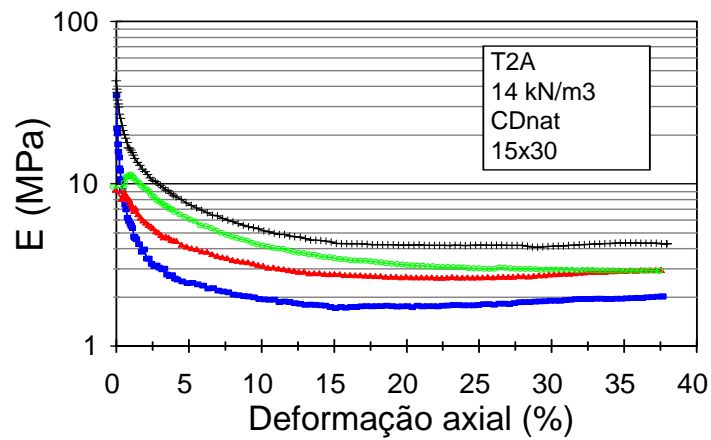

$-100 \mathrm{kPa} \rightleftharpoons 200 \mathrm{kPa}+400 \mathrm{kPa} \multimap 400 \mathrm{kPa}$

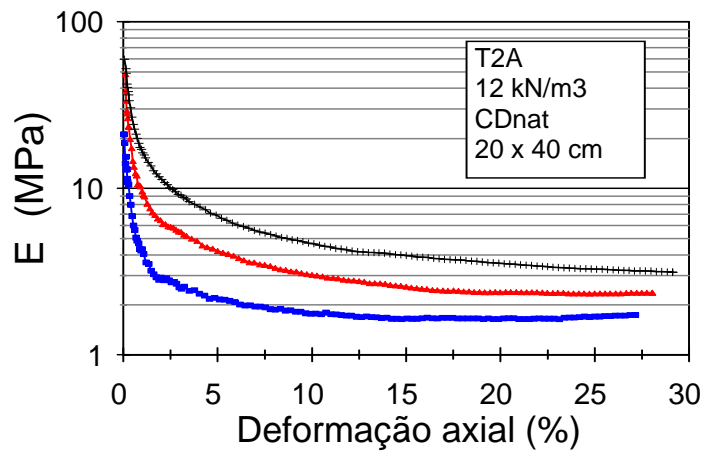

$-100 \mathrm{kPa}=200 \mathrm{kPa}+400 \mathrm{kPa}$

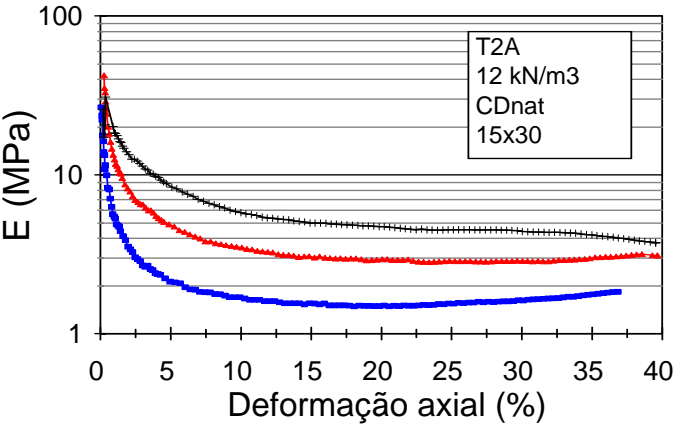

$-100 \mathrm{kPa}=200 \mathrm{kPa}+400 \mathrm{kPa}$

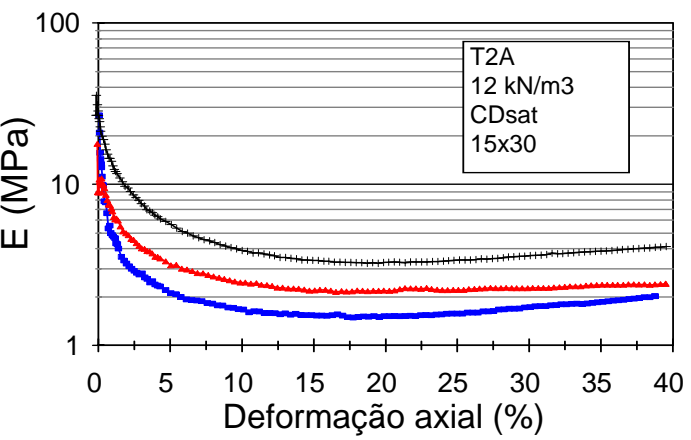

$=100 \mathrm{kPa} \rightarrow-200 \mathrm{kPa}+400 \mathrm{kPa}$

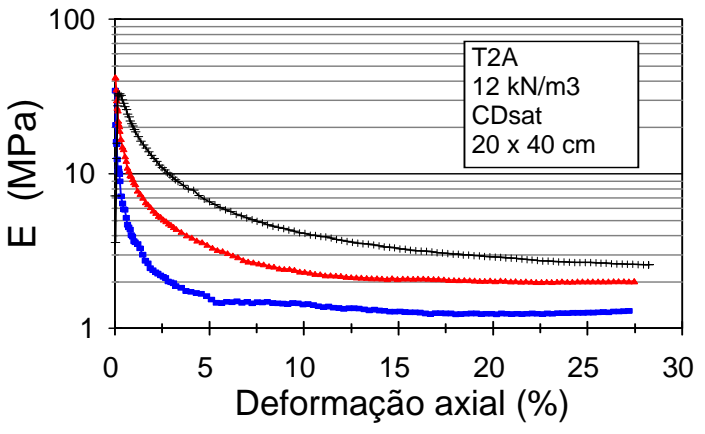

$-100 \mathrm{kPa} \rightarrow 200 \mathrm{kPa}+400 \mathrm{kPa}$

Figura 5.32 - Módulos de elasticidade tangente à origem e secantes, obtidos de ensaios $C D$, em corpos de prova de $150 \mathrm{~mm}$ e $200 \mathrm{~mm}$ de diâmetro para amostra T2A, sob diferentes condições de saturação e peso específico inicial. 

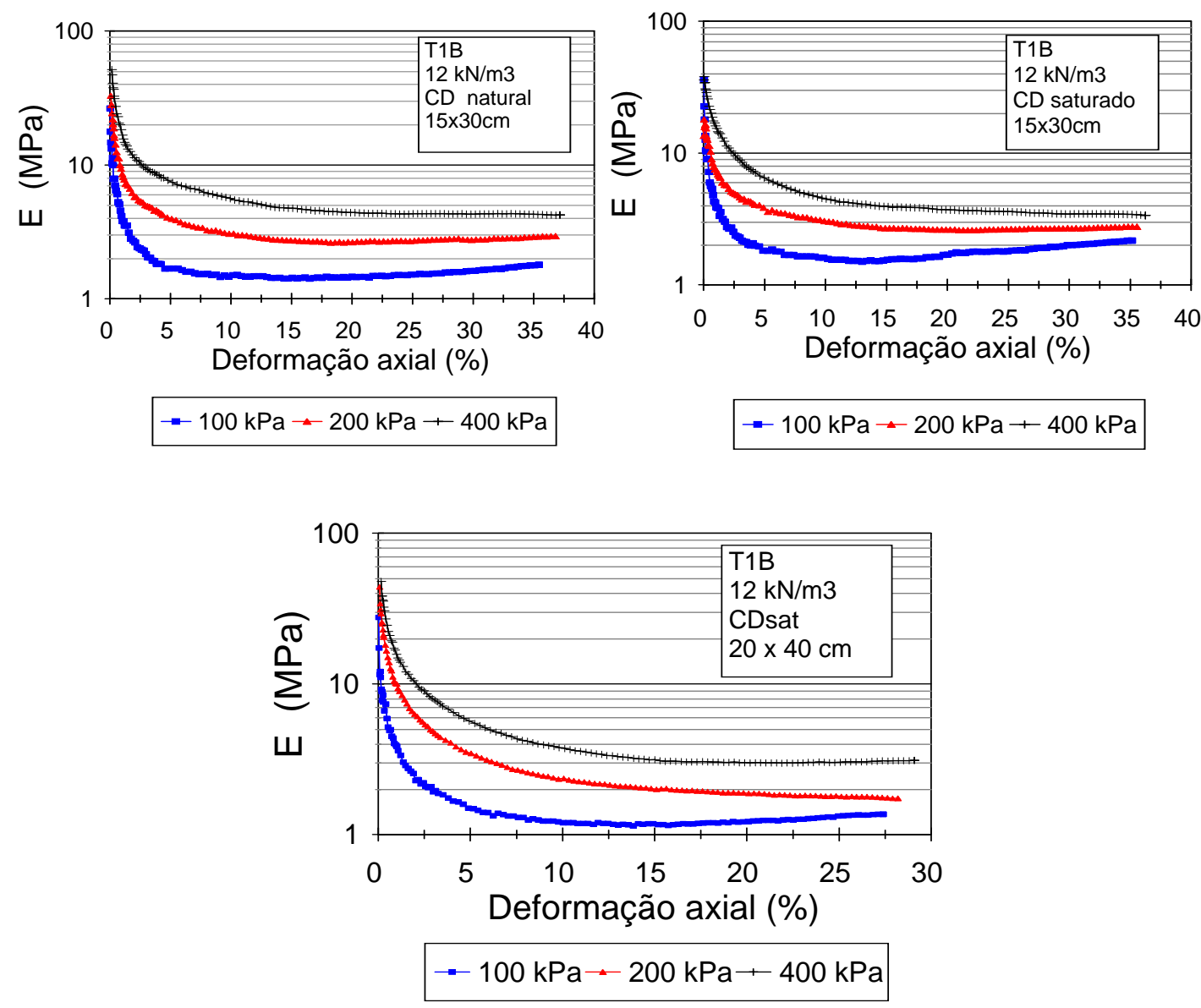

Figura 5.33 - Módulos de elasticidade tangente à origem e secantes, obtidos de ensaios $C D$, em corpos de prova de 150 e 200mm de diâmetro, para amostra T1B, compactada com peso específico de $12 \mathrm{kN} / \mathrm{m}^{3}$, ensaiada na umidade natural e saturada.

As Figuras 5.35 e 5.36 mostram os gráficos dos coeficientes de Poisson, calculados para as três amostras estudadas, considerando todas as condições de ensaios e dimensões dos corpos de prova. O coeficiente de Poisson $(v)$ foi calculado através da fórmula:

$$
v=\frac{\varepsilon_{1}-\varepsilon_{V}}{2 \varepsilon_{1}}
$$

onde,

$\varepsilon_{1}$ corresponde às deformações axiais e $\varepsilon_{\mathrm{V}}$ às deformações volumétricas medidas

Nesses gráficos, desprezando-se os valores iniciais do coeficiente de Poisson, correspondentes à níveis de deformação axial de até $3 \%$, observam-se que $v$ aumenta 
ligeiramente com o aumento das deformações axiais e com o aumento das tensões de confinamento.
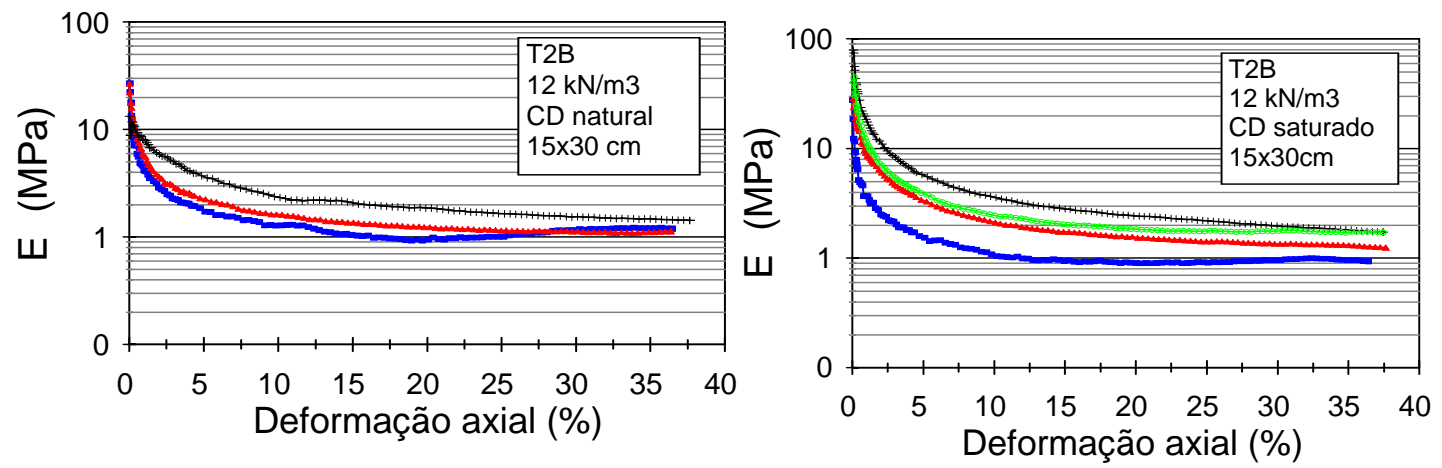

$$
\rightarrow-100 \mathrm{kPa} \rightarrow 200 \mathrm{kPa}+400 \mathrm{kPa} \quad \rightarrow-100 \mathrm{kPa}-200 \mathrm{kPa}+400 \mathrm{kPa} \multimap 200 \mathrm{kPa}
$$

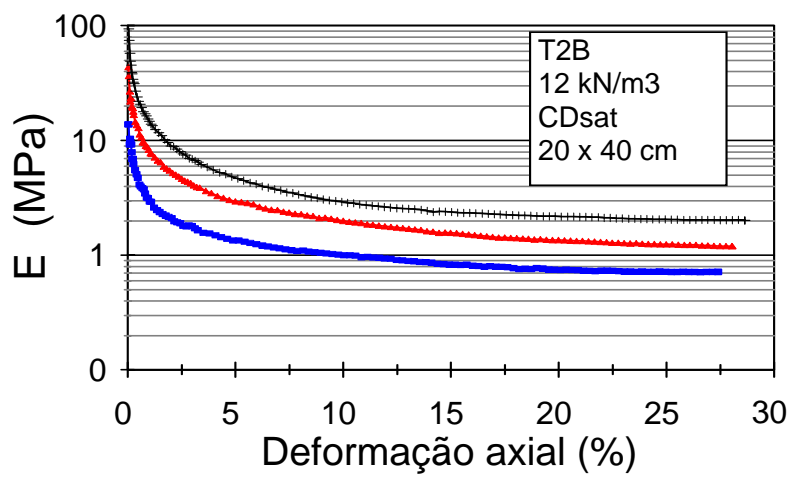

Figura 5.34 - Módulos de elasticidade tangente à origem e secantes, obtidos de ensaios $C D$, em corpos de prova de 150 e 200mm de diâmetro, para amostra T2B, compactada com peso específico de $12 \mathrm{kN} / \mathrm{m}^{3}$ e ensaiada na umidade natural e saturada. 


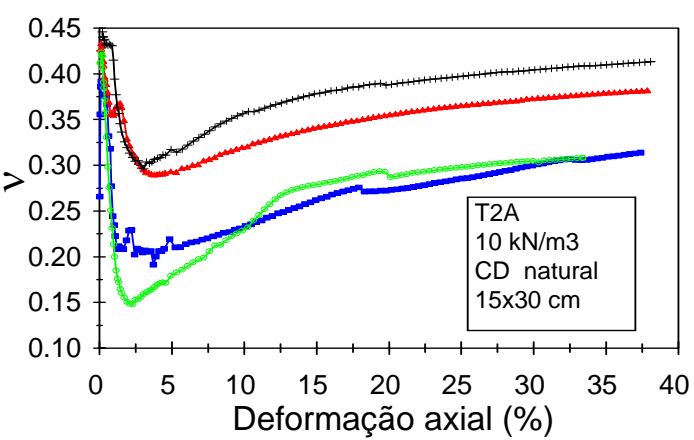

$-100 \mathrm{kPa}=200 \mathrm{kPa}+400 \mathrm{kPa} \multimap 100 \mathrm{kPa}$
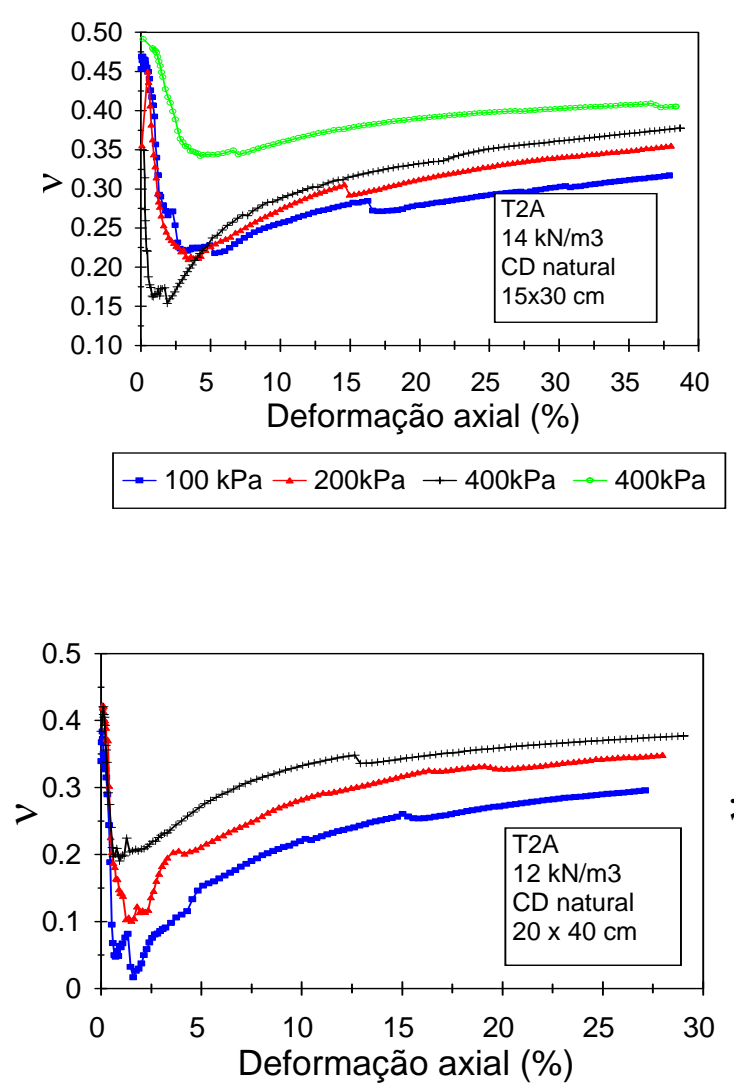

$-100 \mathrm{kPa}-200 \mathrm{kPa}+400 \mathrm{kPa}$

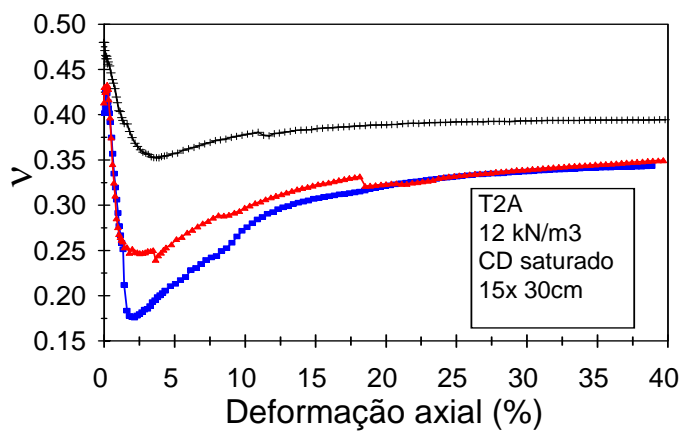

$-100 \mathrm{kPa}-200 \mathrm{kPa}+400 \mathrm{kPa}$

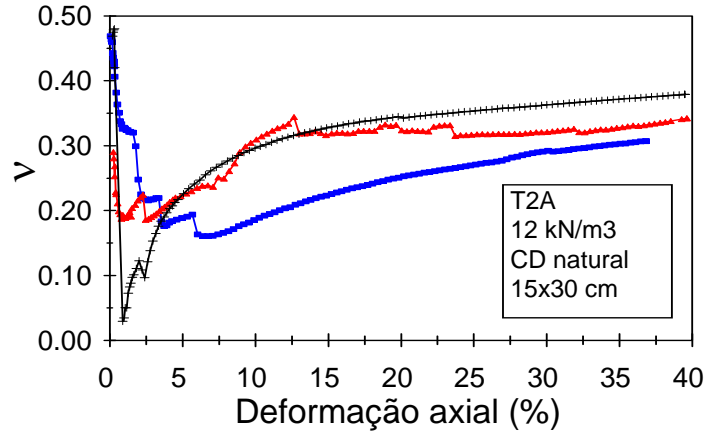

$-100 \mathrm{kPa}=200 \mathrm{kPa}+400 \mathrm{kPa}$

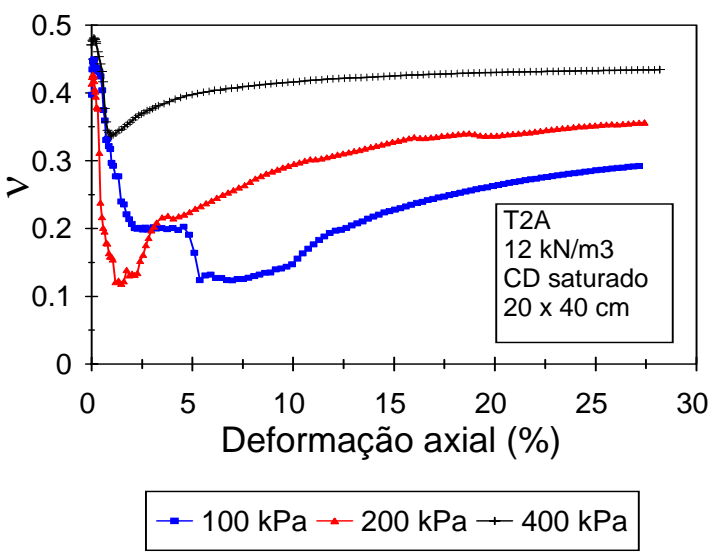

Figura 5.35 - Valores de coeficiente de Poisson obtidos de ensaios $C D$, em corpos de prova de 150 e $200 \mathrm{~mm}$ de diâmetro, para amostra T2A sob diferentes condições de ensaio. 

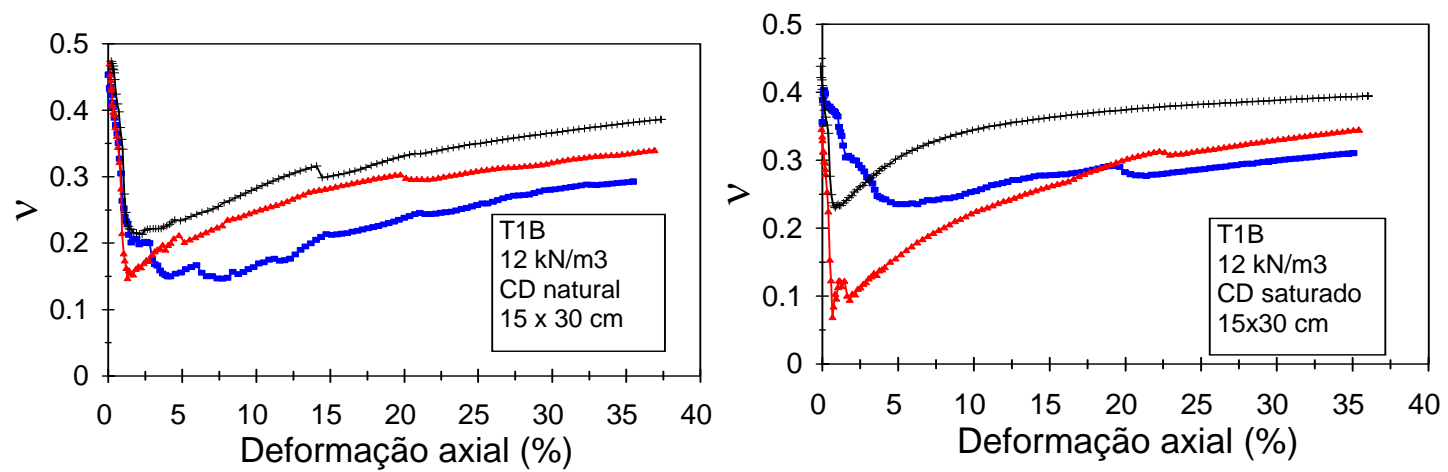

$-100 \mathrm{kPa} \rightarrow 200 \mathrm{kPa}+400 \mathrm{kPa}$

$-100 \mathrm{kPa}=200 \mathrm{kPa}+400 \mathrm{kPa}$
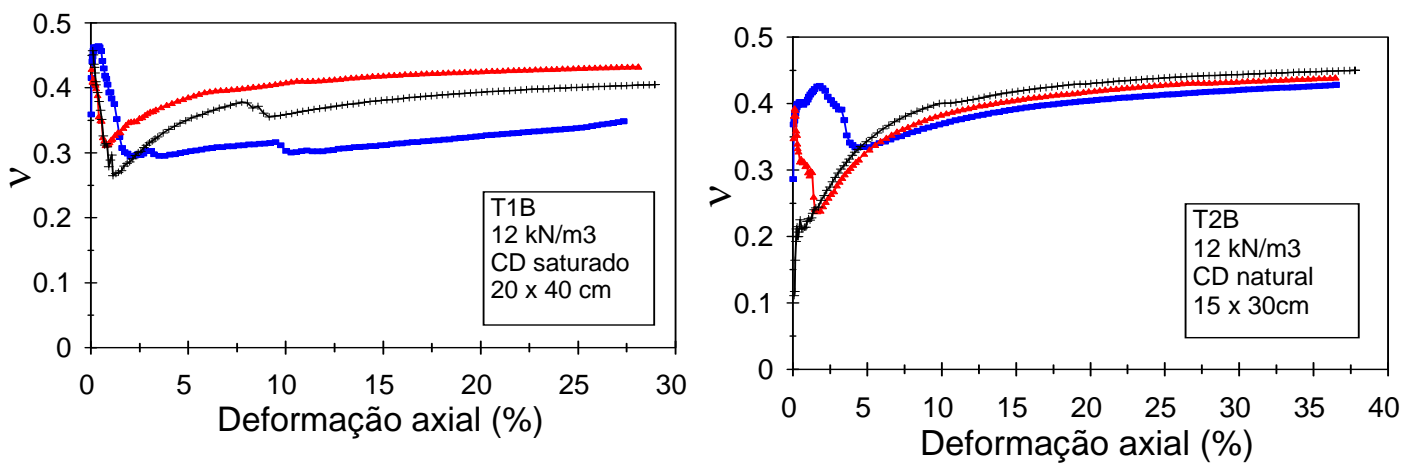

$\rightarrow 100 \mathrm{kPa}=200 \mathrm{kPa} \rightarrow 400 \mathrm{kPa}$
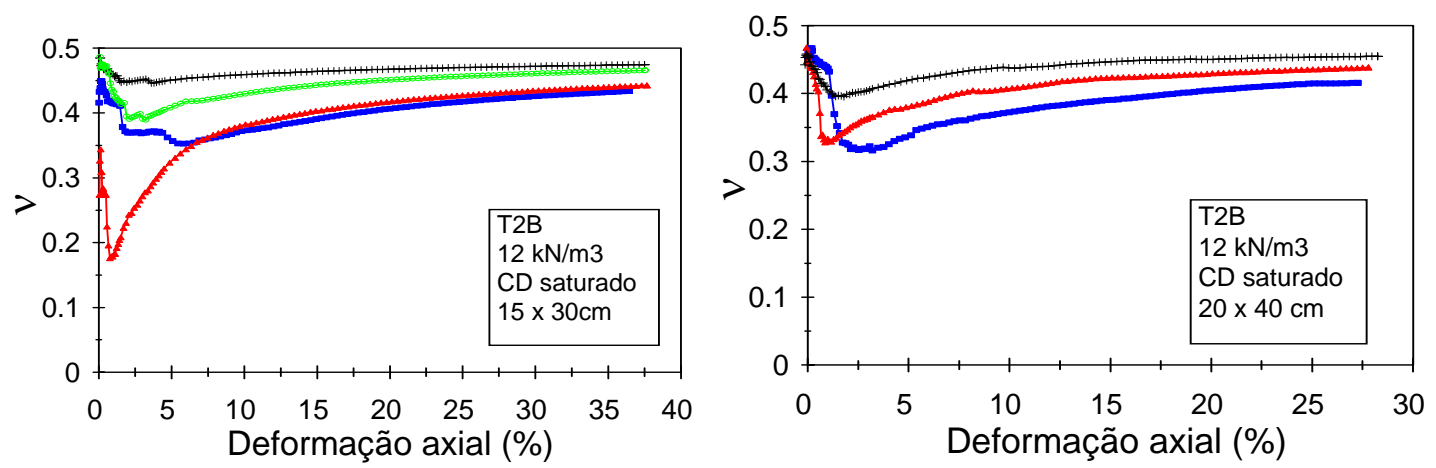

$=100 \mathrm{kPa}=200 \mathrm{kPa}+400 \mathrm{kPa} \rightarrow 200 \mathrm{kPa}$

$\rightarrow 100 \mathrm{kPa} \rightarrow 200 \mathrm{kPa}+400 \mathrm{kPa}$

Figura 5.36 - Valores de coeficiente de Poisson obtidos de ensaios $C D$, em corpos de prova de 150 e $200 \mathrm{~mm}$ de diâmetro, para as amostras T1B e T2B, compactadas com peso específico de $12 \mathrm{kN} / \mathrm{m}^{3}$ e ensaiadas na umidade natural e saturadas.

\subsubsection{1 - Ensaios consolidados drenados com a matriz do resíduo}

As Figuras 5.37 a 5.39 apresentam as trajetórias de tensões e as envoltórias de resistência obtidas para a matriz do resíduo (RSU menos os plásticos e materiais com partículas maiores que $20 \mathrm{~mm}$ ) por meio de ensaios $C D_{\text {sat }}$, executados em corpos de prova 
com $100 \mathrm{~mm}$ de diâmetro e $200 \mathrm{~mm}$ de altura, compactados com peso específico em torno de $16 \mathrm{kN} / \mathrm{m}^{3}$ e traçadas a partir dos resultados apresentados nas figuras 4.40 a 4.42 . As equações das envoltórias e os parâmetros de resistência obtidos para as deformações axiais de 10 e $20 \%$ estão apresentados na Tabela 5.6. Para esses ensaios, utilizou-se a matriz básica de cada amostra representativa, obtida por meio de separação manual dos componentes fibrosos.

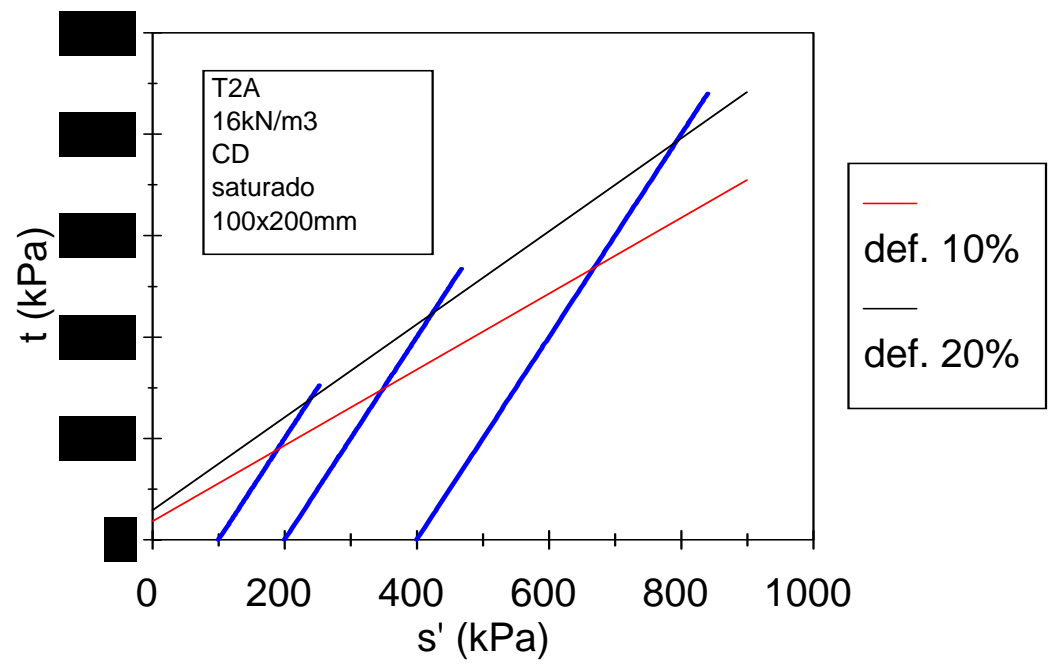

Figura 5.37 - Trajetórias de tensões e envoltórias de resistência num diagrama t-s' obtidas de ensaio $C D$, com a matriz da amostra $T 2 A$, saturada $e$ compactada com peso específico em torno de $16 \mathrm{kN} / \mathrm{m}^{3}$, em corpos de prova de $100 \mathrm{~mm}$ de diâmetro e $200 \mathrm{~mm}$ de altura.

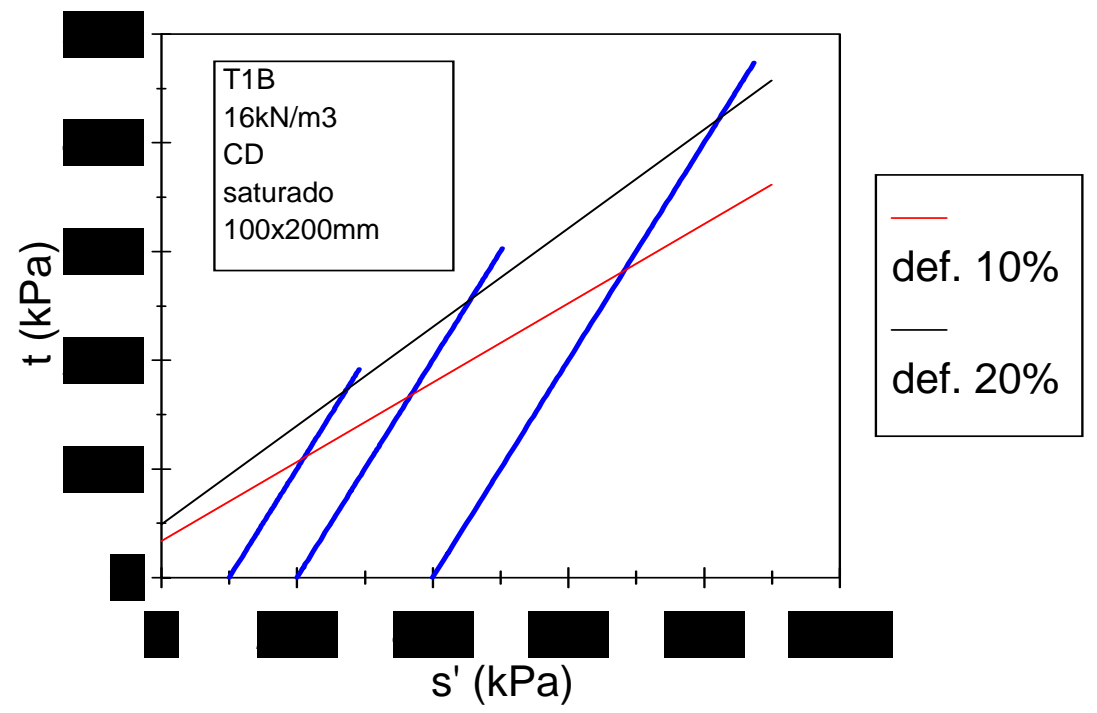

Figura 5.38 - Trajetórias de tensões e envoltórias de resistência num diagrama t-s' obtidas de ensaio $C D$, com a matriz da amostra $T 1 B$, saturada $e$ compactada com peso específico em torno de $16 \mathrm{kN} / \mathrm{m}^{3}$, em corpos de prova de $100 \mathrm{~mm}$ de diâmetro e $200 \mathrm{~mm}$ de altura. 


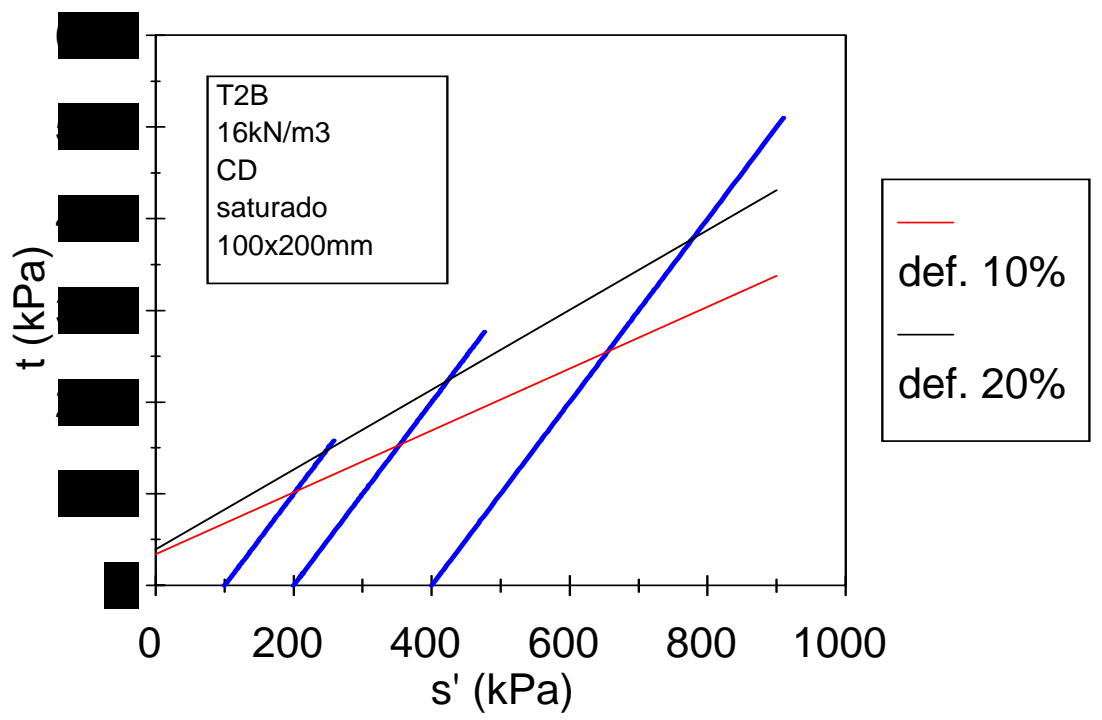

Figura 5.39 - Trajetórias de tensões e envoltórias de resistência num diagrama $t$ - $s$ ' obtidas de ensaio $C D$, com a matriz da amostra $T 2 B$, saturada, compactada com peso específico em torno de $16 \mathrm{kN} / \mathrm{m}^{3}$, em corpos de prova de $100 \mathrm{~mm}$ de diâmetro e $200 \mathrm{~mm}$ de altura.

Tabela 5.6 - Parâmetros de resistência obtidos de ensaios $C D_{\text {sat, }}$ com a matriz das amostras T2A, T2B e T1B, compactada com peso específico em torno de $16 \mathrm{kN} / \mathrm{m}^{3}$ e em corpos de prova de $100 \mathrm{~mm}$ de diâmetro por $200 \mathrm{~mm}$ de altura.

\begin{tabular}{|c|c|c|c|c|c|}
\hline \multirow[b]{2}{*}{ Amostra } & \multirow{2}{*}{$\begin{array}{c}\text { Def. axial } \\
\text { (\%) }\end{array}$} & \multirow{2}{*}{$\begin{array}{c}\text { Equação } \\
\text { (kPa) }\end{array}$} & \multirow{2}{*}{$\begin{array}{c}\text { Coef. } \\
\text { Det. }\left(R^{2}\right)\end{array}$} & \multicolumn{2}{|c|}{ Parâmetros } \\
\hline & & & & $C^{\prime}(\mathrm{kPa})$ & $\phi^{\prime}(9)$ \\
\hline & 10 & $\mathrm{t}=0,374 \mathrm{~s}^{\prime}+18,5$ & 0,993 & 20,0 & 22,0 \\
\hline Matriz T2A & 20 & $t=0,458 s^{\prime}+29,4$ & 0,997 & 33,1 & 27,3 \\
\hline & 10 & $t=0,364 s^{\prime}+34,0$ & 0,997 & 36,5 & 21,3 \\
\hline Matriz T1B & 20 & $t=0,454 s^{\prime}+48,9$ & 0,997 & 54,9 & 27,0 \\
\hline & 10 & $t=0,337 s^{\prime}+34,8$ & 0,998 & 37,0 & 19,7 \\
\hline Matriz T2B & 20 & $t=0,435 s^{\prime}+39,7$ & 0,999 & 44,1 & 25,8 \\
\hline
\end{tabular}

Vale ressaltar que esses ensaios foram executados em amostras compactadas com $16 \mathrm{kN} / \mathrm{m}^{3}$, pois não foi possível obter corpos de prova íntegros com menor peso específico, após a retirada dos materiais fibrosos da amostra de lixo. Além disso, conforme exposto no capítulo 3, mesmo após a retirada manual dos materiais fibrosos, a matriz apresentou significante quantidade de pequenas tiras de plásticos aderidas à massa de solo, as quais tornaram-se perceptíveis somente durante a lavagem do material na peneira \#200, após a execução do ensaio triaxial. Esses dois fatores, com certeza, influenciaram os resultados 
obtidos com a matriz básica, inviabilizando a comparação destes resultados com aqueles obtidos com o RSU propriamente dito.

Por fim, convém salientar que os ensaios com matriz básica do RSU tiveram o objetivo principal de ser um primeiro teste, para avaliar a influência das fibras na resistência ao cisalhamento do RSU. Como visto, isso não foi possível de ser realizado e os resultados apresentados apenas ilustram a condição ensaiada.

\subsection{2 - Ensaios consolidados não drenados (CU)}

As Figuras 4.43 a 4.46 mostram que a curva tensão - deformação típica obtida para o resíduo sólido urbano não exibe pico de ruptura. As tensões seguem a mesma tendência geral apresentada no item anterior, isto é, aumentam continuamente com o aumento das deformações axiais. Nestas figuras, observa-se também o desenvolvimento de pressões neutras positivas durante o cisalhamento, que tendem a aumentar com as deformações e depois tendem à estabilização. As pressões neutras geradas são altas, sendo que, em alguns casos, o valor máximo atingido está próximo ao da tensão de confinamento da amostra. Assim, à medida que se processa o ensaio e com o aumento do carregamento, obtém-se altas pressões neutras positivas e consequentemente baixos valores de tensões efetivas de confinamento.

Os gráficos obtidos para o parâmetro $A$ de pressão neutra, $\left[\mathrm{A}=\frac{\Delta \mathrm{u}}{\mathrm{B}\left(\Delta \sigma_{1}-\Delta \sigma_{3}\right)}\right]$, versus a deformação axial mostram um comportamento típico de materiais muito compressíveis, onde o parâmetro A é positivo.

Com os resultados dos ensaios CU apresentados nas Figuras 4.43 a 4.46 foram traçadas as trajetórias de tensões totais e efetivas para as três amostras estudadas. Nas Figuras 5.40 e 5.41 apresentam-se as trajetórias totais e efetivas num diagrama t-s,s' obtidas para a amostra T2A, compactada com $12 \mathrm{kN} / \mathrm{m}^{3}$, em corpos de prova de $150 \mathrm{~mm}$ de diâmetro por 300mm de altura e submetidos à ensaios na condição de umidade natural e saturada, respectivamente. Já as Figuras 5.42 e 5.43 apresentam as trajetórias obtidas para as amostras T1B e T2B, na condição saturada. Nestas figuras também estão traçadas as envoltórias de resistência, para cada amostra, obtidas para deformações axiais de 10, 20 e $30 \%$. As equações das envoltórias e os coeficientes de determinação, bem como, os parâmetros de resistência obtidos dos ensaios $\mathrm{CU}$, em termos de tensões totais e efetivas, estão apresentados na Tabela 5.7. Em alguns casos, obtiveram-se da regressão linear coesão efetiva menor que zero $(C<0)$. Para evitar isso, foram feitos ajustes obrigando a envoltória passar pela origem dos eixos de coordenadas. 

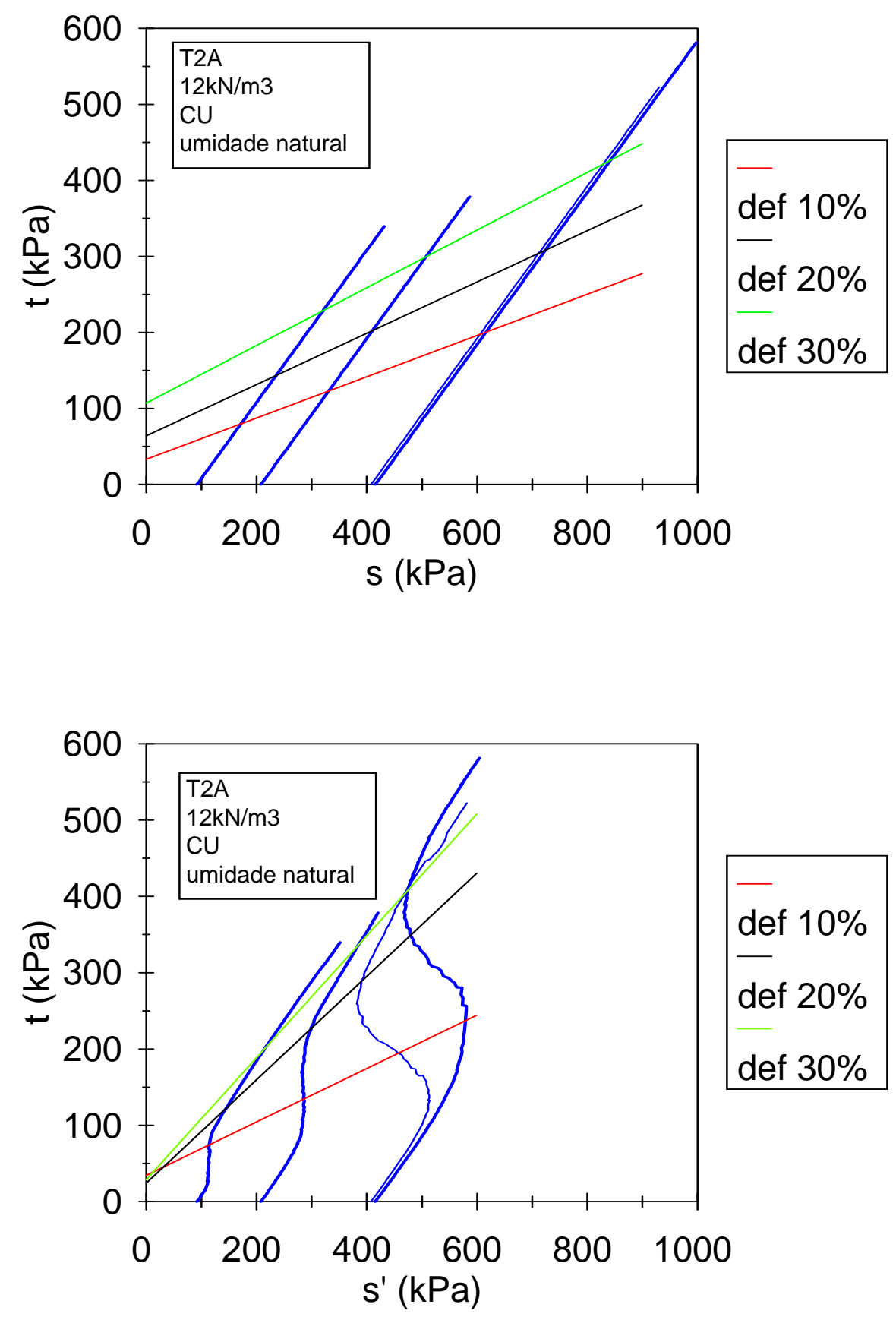

Figura 5.40 - Trajetórias de tensões totais e efetivas e envoltórias de resistência num diagrama $t-s, s^{\prime}$ obtidas de ensaio $C U$, com amostra $T 2 A$, na umidade natural, compactada com peso específico de $12 \mathrm{kN} / \mathrm{m}^{3}$, em corpos de prova de $150 \mathrm{~mm}$ de diâmetro e 300mm de altura. 

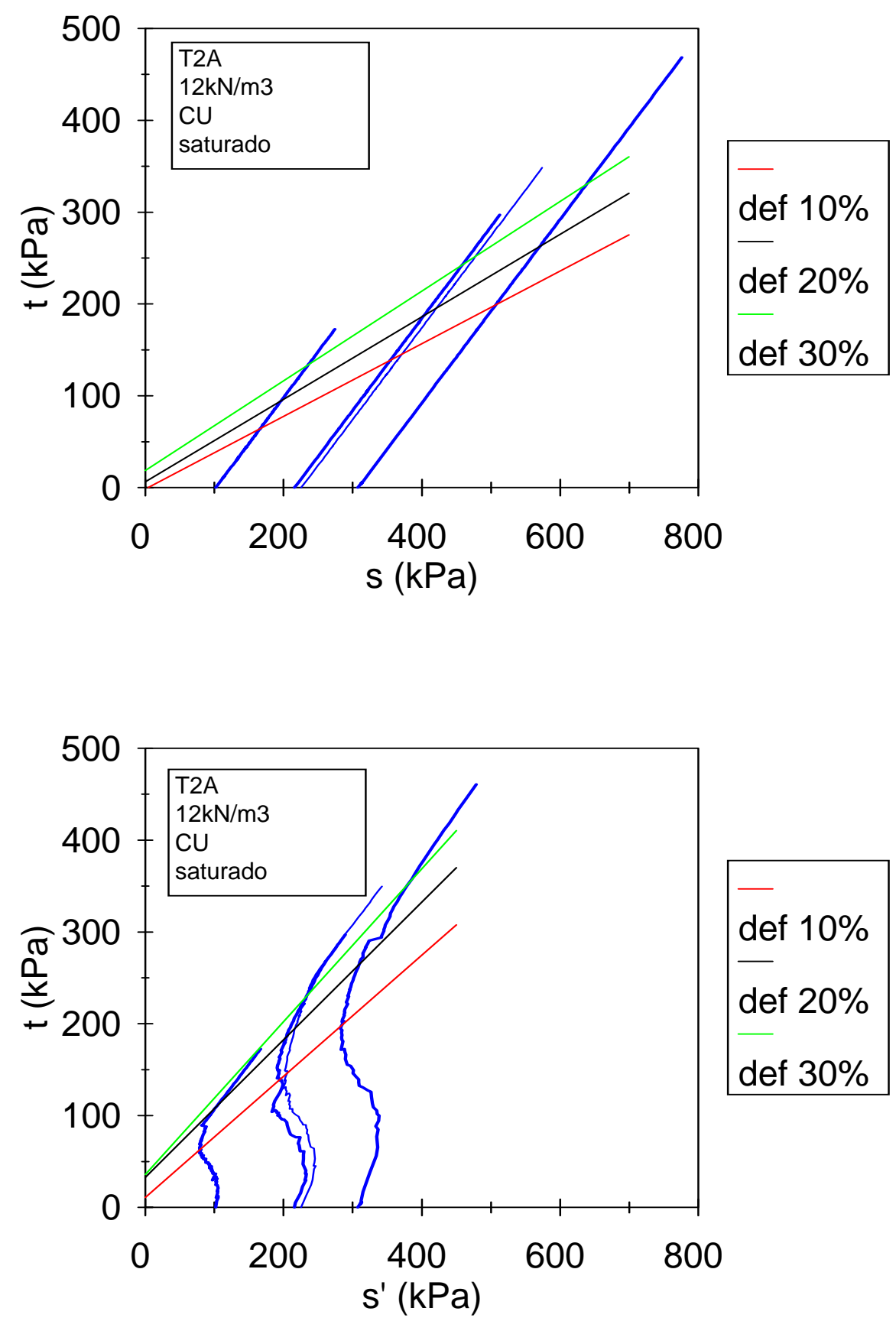

Figura 5.41 - Trajetórias de tensões totais e efetivas e envoltórias de resistência num diagrama $t-s, s^{\prime}$ obtidas de ensaio $C U$, com amostra $T 2 A$, saturada, compactada com peso específico de $12 \mathrm{kN} / \mathrm{m}^{3}$, em corpos de prova de $150 \mathrm{~mm}$ de diâmetro e $300 \mathrm{~mm}$ de altura. 

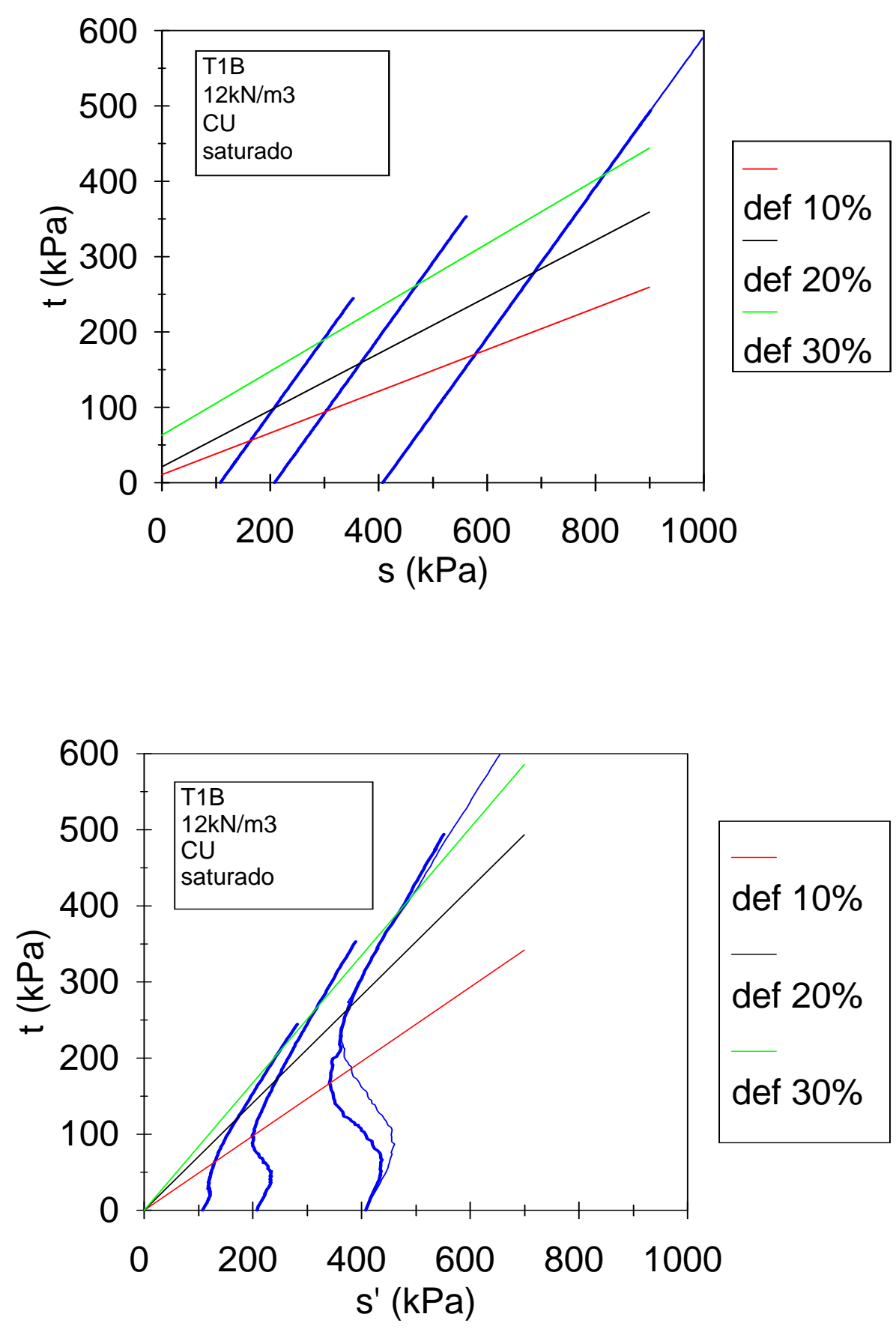

Figura 5.42 - Trajetórias de tensões totais e efetivas e envoltórias de resistência num diagrama $t-s, s^{\prime}$ obtidas de ensaio $C U$, com amostra $T 1 B$, saturada, compactada com peso específico de $12 \mathrm{kN} / \mathrm{m}^{3}$, em corpos de prova de $150 \mathrm{~mm}$ de diâmetro e $300 \mathrm{~mm}$ de altura. 

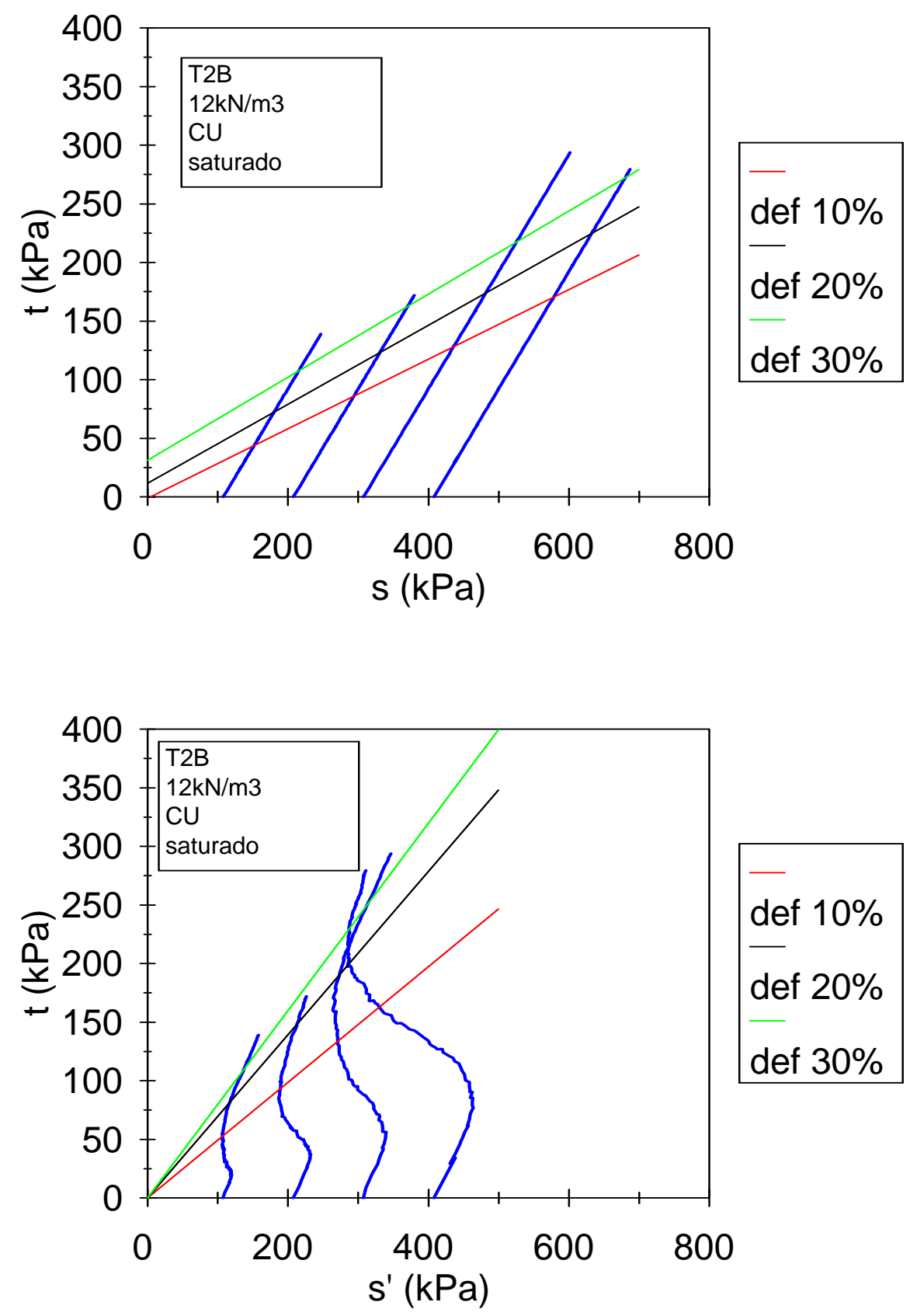

Figura 5.43 - Trajetórias de tensões totais e efetivas e envoltórias de resistência num diagrama $t-s, s^{\prime}$ obtidas de ensaio $C U$, com amostra $T 2 B$, saturada, compactada com peso específico de $12 \mathrm{kN} / \mathrm{m}^{3}$, em corpos de prova de $150 \mathrm{~mm}$ de diâmetro e $300 \mathrm{~mm}$ de altura.

A partir dos resultados dos ensaios não drenados apresentados, observou-se que o comportamento do RSU, em termos de tensões efetivas, é bastante influenciado pelo desenvolvimento de altas pressões neutras positivas. Na Figura 5.44 apresentam-se conjuntamente, para cada amostra ensaiada, as trajetórias de tensões efetivas do ensaio 
não drenado e os correspondentes pontos t-s` para deformação axial de $20 \%$, bem como a envoltória de resistência drenada obtida também para $20 \%$ de deformação axial. Pode-se verificar que os pontos t-s`' a $20 \%$ de deformação axial, da trajetória efetiva do ensaio não drenado posicionam-se, em geral, acima da envoltória drenada. Comportamento semelhante é também observado para alguns solos porosos e muito compressíveis do estado de São Paulo (PINTO, 1996). Para ilustrar, no Anexo 07 apresentam-se- uma comparação entre as envoltórias não drenadas e drenadas, para cada amostra representativa estudada, compactada com mesmo peso específico e mesma condição de ensaio.

Tabela 5.7 - Parâmetros de resistência obtidos de ensaios CU, em amostras T2A, T2B e T1B, compactadas com peso específico de $12 \mathrm{kN} / \mathrm{m}^{3}$ em corpos de prova $150 \mathrm{~mm}$ de diâmetro $\times 300 \mathrm{~mm}$ de altura.

\begin{tabular}{|c|c|c|c|c|c|c|}
\hline \multirow[b]{2}{*}{ Amostra } & \multirow[b]{2}{*}{ Trajetória } & \multirow{2}{*}{$\begin{array}{c}\text { Def. axial } \\
\text { (\%) }\end{array}$} & \multirow{2}{*}{$\begin{array}{c}\text { Equação } \\
\text { (kPa) }\end{array}$} & \multirow{2}{*}{$\begin{array}{l}\text { Coef. } \\
\text { Det.. }\end{array}$} & \multicolumn{2}{|c|}{ Parâmetros } \\
\hline & & & & & $C^{\prime}(\mathrm{kPa})$ & $\phi^{\prime}(9)$ \\
\hline \multirow{6}{*}{ T2a12CUnat } & \multirow{3}{*}{ Total } & 10 & $\mathrm{t}=0,271 \mathrm{~s}^{\prime}+33,6$ & 0,998 & 34,9 & 15,7 \\
\hline & & 20 & $t=0,337 s^{\prime}+64,1$ & 0,999 & 68,07 & 19,7 \\
\hline & & 30 & $t=0,379 s^{\prime}+107,5$ & 0,999 & 116,11 & 22,3 \\
\hline & \multirow{3}{*}{ Efetiva } & 10 & $\mathrm{t}=0,35 \mathrm{~s}^{\prime}+34,6$ & 0,956 & 37,0 & 20,5 \\
\hline & & 20 & $t=0,677 s^{\prime}+24,6$ & 0,967 & 33,4 & 42,6 \\
\hline & & 30 & $t=0,798 s^{\prime}+29,2$ & 0,988 & $48,5,0$ & 53,0 \\
\hline \multirow{6}{*}{ T2a12CUsat } & \multirow{3}{*}{ Total } & 10 & $\mathrm{t}=0,396 \mathrm{~s}^{\prime}$ & 0,990 & - & 23,2 \\
\hline & & 20 & $t=0,449 s^{\prime}+6,2$ & 0,986 & 7,0 & 26,7 \\
\hline & & 30 & $t=0,488 s^{\prime}+18,9$ & 0,994 & 21,8 & 29,2 \\
\hline & \multirow{3}{*}{ Efetiva } & 10 & $\mathrm{t}=0,659 \mathrm{~s}^{\prime}+11,1$ & 0,976 & 14,9 & 41,3 \\
\hline & & 20 & $t=0,749 s^{\prime}+32,9$ & 0,977 & 49,7 & 48,5 \\
\hline & & 30 & $t=0,832 s^{\prime}+36,2$ & 0,973 & 65,3 & 56,3 \\
\hline \multirow{6}{*}{ T1b12CUsat } & \multirow{3}{*}{ Total } & 10 & $t=0,276 s^{\prime}+11,0$ & 0,982 & 11,5 & 16,0 \\
\hline & & 20 & $t=0,375 s^{\prime}+21,5$ & 0,992 & 23,2 & 22,0 \\
\hline & & 30 & $t=0,423 s^{\prime}+63,2$ & 0,9990 & 69,8 & 25,0 \\
\hline & \multirow{3}{*}{ Efetiva } & 10 & $t=0,489 s^{\prime}$ & 0,972 & - & 29,3 \\
\hline & & 20 & $\mathrm{t}=0,705 \mathrm{~s}^{\prime}$ & 0,987 & - & 44,8 \\
\hline & & 30 & $t=0,837 \mathrm{~s}^{\prime}$ & 0,996 & - & 56,8 \\
\hline \multirow{6}{*}{ T2b12CUsat } & \multirow{3}{*}{ Total } & 10 & $\mathrm{t}=0,297 \mathrm{~s}^{\prime}+(-1,4)$ & 0,993 & - & 17,3 \\
\hline & & 20 & $t=0,337 s^{\prime}+11,5$ & 0,992 & 12,2 & 19,7 \\
\hline & & 30 & $t=0,354 s^{\prime}+31,4$ & 0,973 & 33,6 & 20,7 \\
\hline & \multirow{3}{*}{ Efetiva } & 10 & $t=0,493 s^{\prime}$ & 0,972 & - & 29,5 \\
\hline & & 20 & $\mathrm{t}=0,696 \mathrm{~s}^{\prime}$ & 0,950 & - & 44,1 \\
\hline & & 30 & $t=0,799 \mathrm{~s}^{\prime}$ & 0,962 & - & 53,1 \\
\hline
\end{tabular}




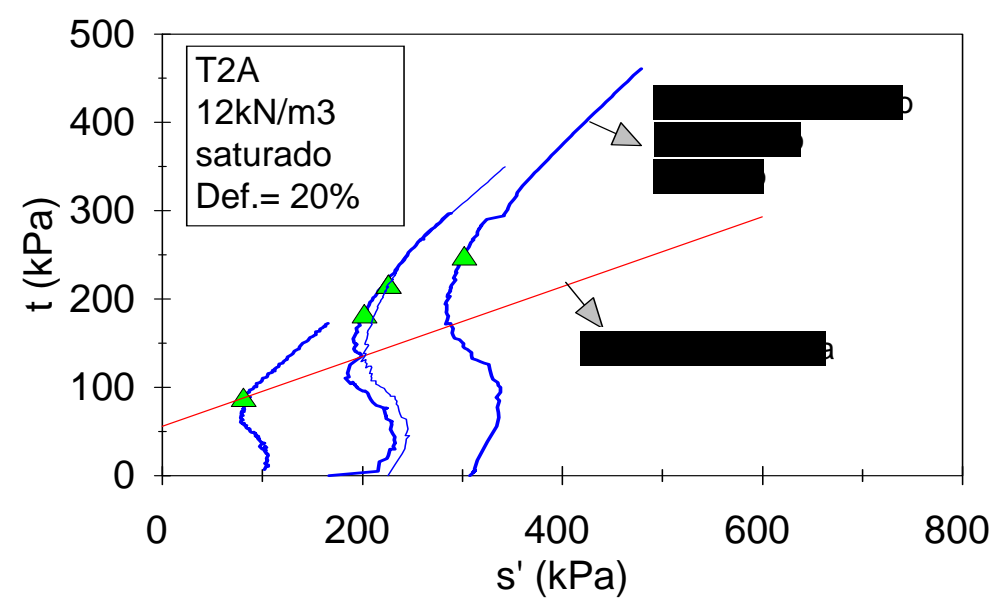

$\triangle$ Ensaio CU ( $20 \%$ def.) — Ensaio CD (20\% def.)
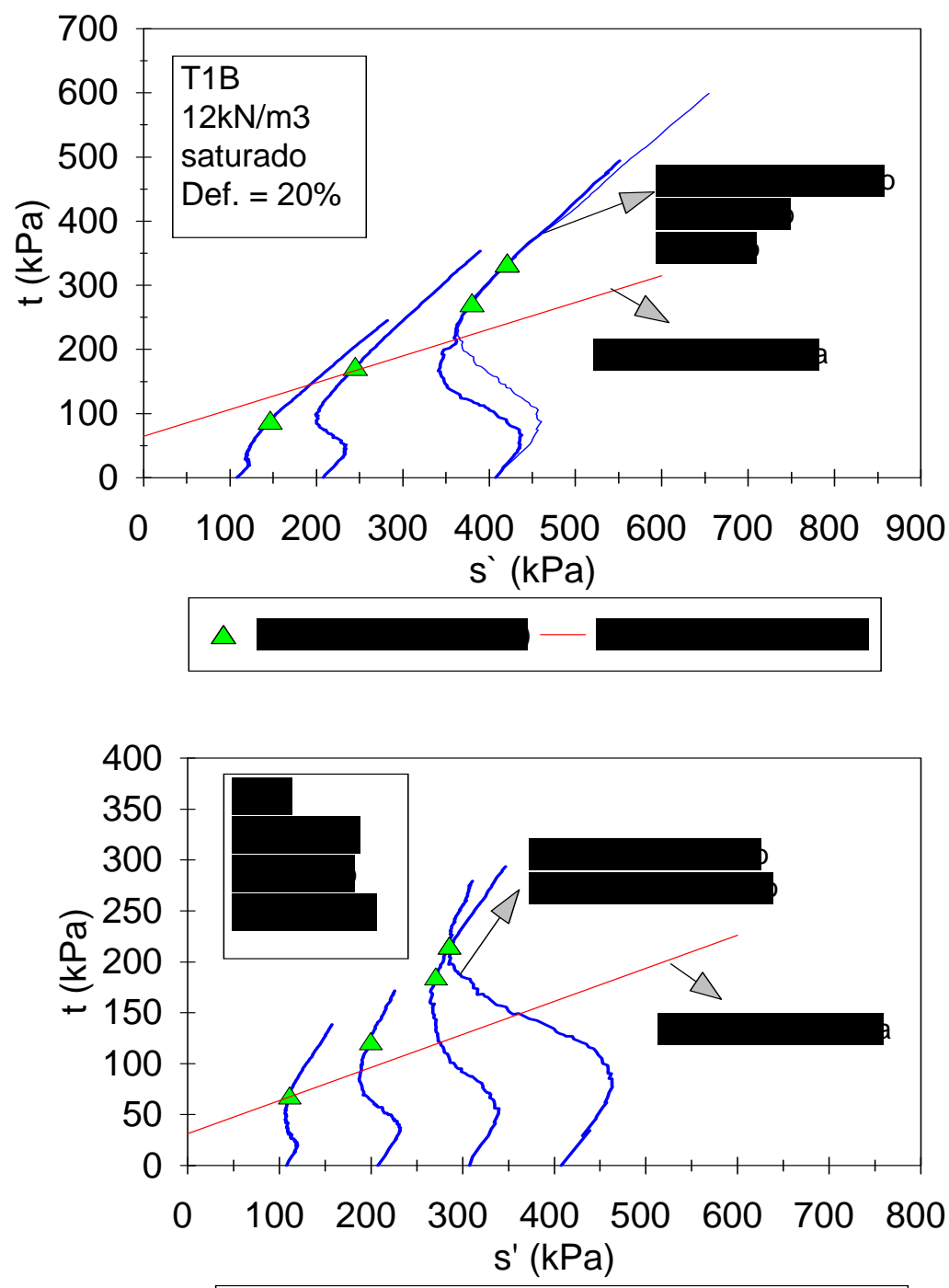

$\triangle \square-\square$

Figura 5.44 - Comparação entre os resultados obtidos de ensaios CU e $C D$ para as amostras T1B, T2A e T2B, compactadas com $12 \mathrm{kN} / \mathrm{m}^{3}$ e saturadas. 
Na Figura 5.45 apresenta-se a resistência não drenada, definida como su $=\left(\sigma_{1^{-}}\right.$ $\left.\sigma_{3}\right) / 2$, em função da tensão efetiva de confinamento atuante no corpo de prova no inicio do cisalhamento de ensaios CU. Obtiveram-se que su é proporcional a $\sigma_{3 c}{ }_{3 c}$, definindo-se uma relação constante para cada amostra estudada. Os resultados apresentados referem-se à deformação de $20 \%$.

\subsection{3 - Uma avaliação da resistência ao cisalhamento do resíduo sólido urbano estudado}

Ao longo dos itens 5.4 .1 e 5.4.2 deste capítulo, tem-se mostrado que o resíduo sólido urbano não apresentou pico de ruptura definido e, portanto, os parâmetros de resistência ao cisalhamento para esse material foram determinados para vários níveis de deformação axial. Quanto a esse comportamento, é importante lembrar que os resultados dos ensaios têm sido obtidos utilizando corpos de prova de maiores dimensões que os convencionalmente utilizados para solos (150×300mm e 200×400mm), mas é possível que utilizando uma escala ainda maior, a ruptura seja definida. No campo, esses materiais além de apresentarem grandes constituintes e heterogeneidade acentuada, são separados por camadas de solo de cobertura que, segundo os levantamentos bibliográficos, influenciam em muito na estabilidade dos maciços de resíduos sólidos domésticos.

Em geral, a instabilidade em aterros sanitários, como a que ocorreu no próprio Aterro Bandeirantes em 1991 (KAIMOTO \& CEPOLLINA, 1996), está mais associada a instabilidade de planos preferenciais constituídos por camadas de solo de separação de células e/ou solo de fundação aliado à geração de elevadas pressões neutras, quer por infiltrações pluviais nas camadas superficiais de cobertura quer por ineficiência dos drenos, do que a problemas de baixa resistência do material de RSU.

Os valores relativamente altos obtidos para a resistência do resíduo sólido urbano são coerentes com algumas observações de campo, onde pôde-se observar cortes em taludes sem nenhuma indicação de ruptura.

Na Figura 5.46 apresentam-se uma comparação entre os parâmetros de resistência obtidos de ensaios consolidados drenados (CD), executados para as três amostras estudadas nesta pesquisa, com alguns encontrados na literatura.

Os resultados apresentados nesta figura e obtidos nesta pesquisa são de ensaios triaxiais consolidados drenados, para $20 \%$ de deformação axial, utilizando tanto ensaios em corpos de prova de $150 \mathrm{~mm}$ de diâmetro por $300 \mathrm{~mm}$ de altura como $200 \mathrm{~mm}$ de diâmetro e $400 \mathrm{~mm}$ de altura. Também foram incluídos, neste gráfico, os resultados de ângulo de atrito e de coesão não drenada estimados através de correlações existentes entre qc e $N$ para areias e solos argilosos, respectivamente. 


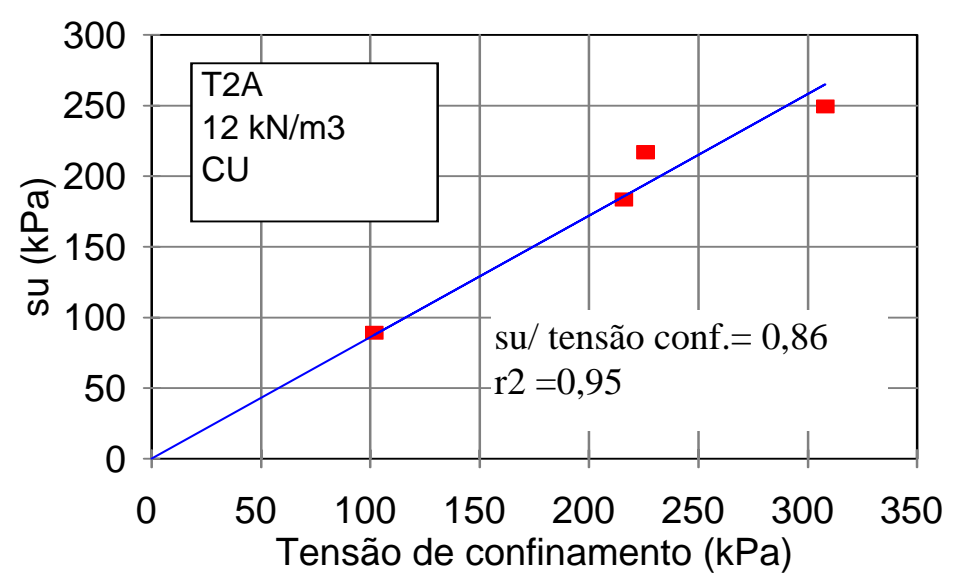

- Pontos medidos - Regressão

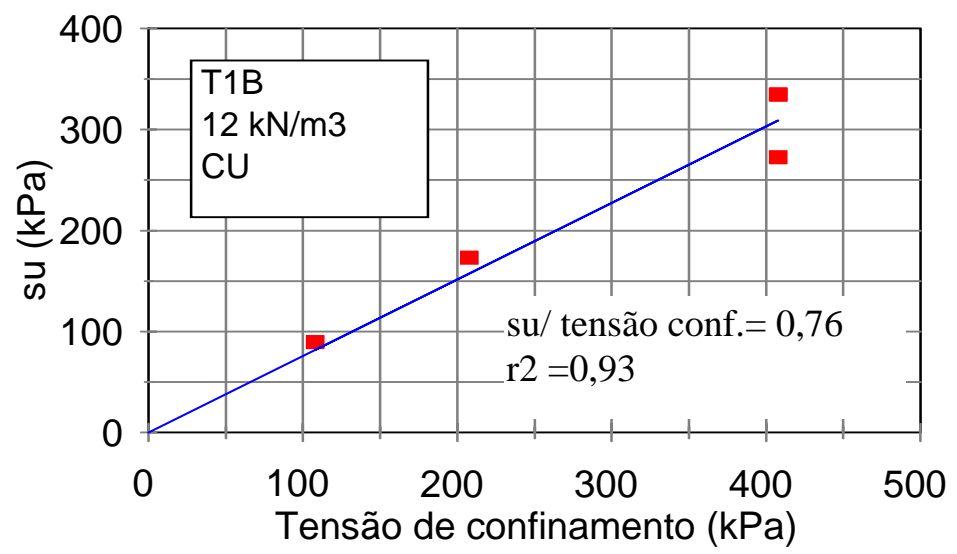

- Pontos medidos - Regressão

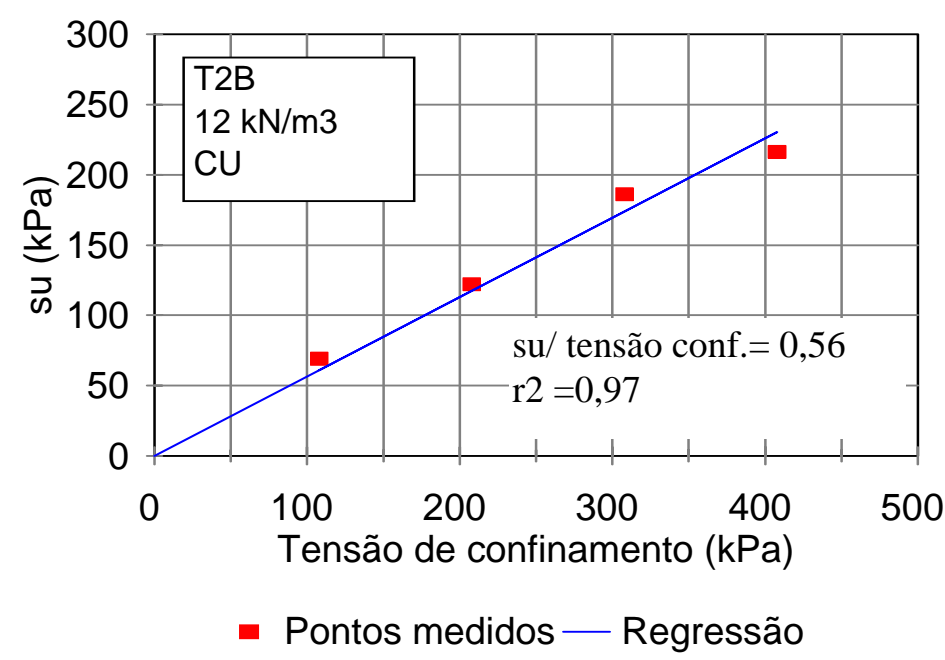

Figura 5.45 - Resistência não drenada (su) em função de $\sigma_{3 c}{ }_{3 c}$ em ensaio CU. 

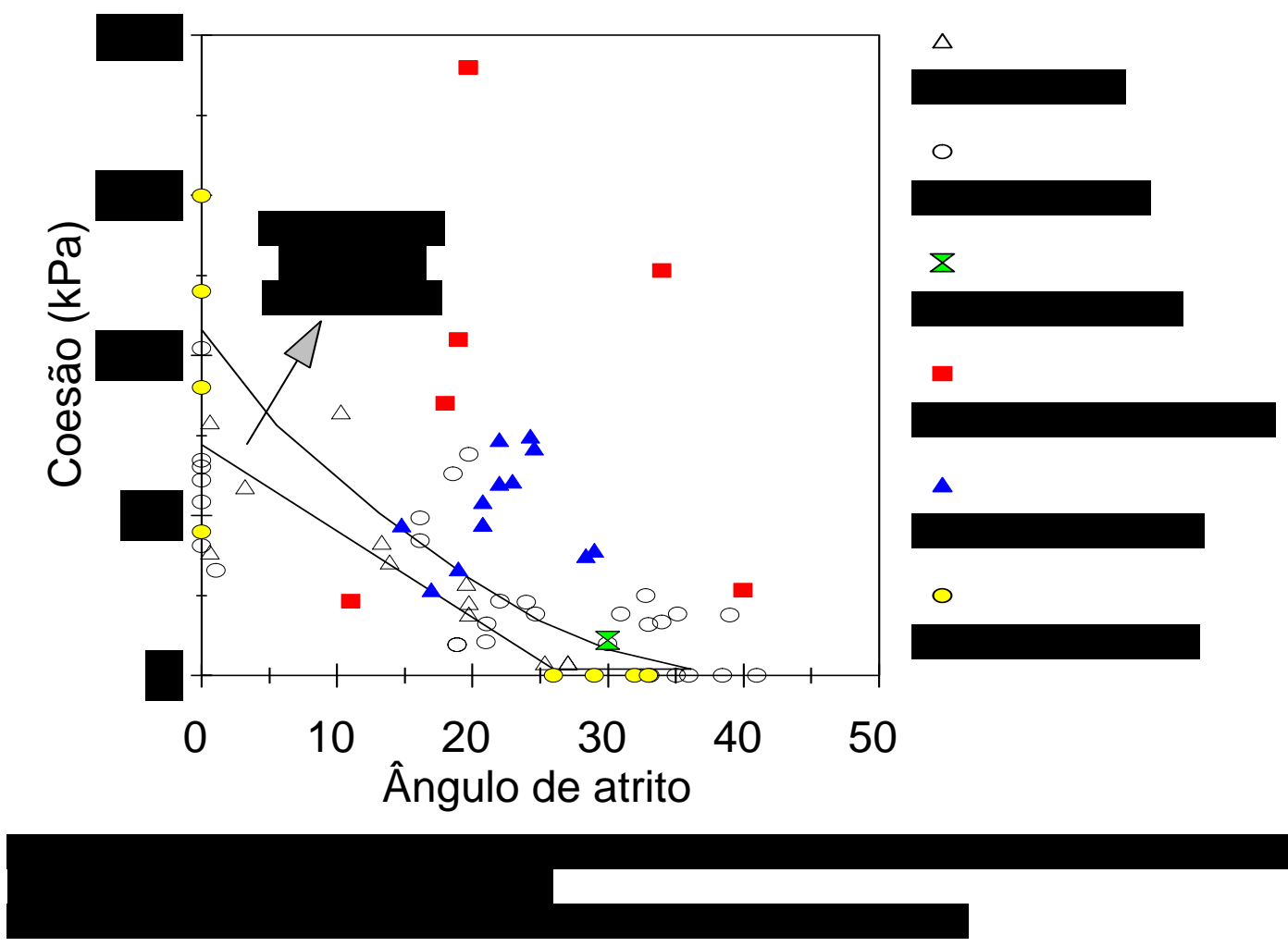

Figura 5.46 - Parâmetros de resistência ao cisalhamento de resíduo sólido urbano obtidos de ensaios de laboratório, campo e de retro - análise.

Os dados provenientes da literatura incluem resultados de ensaios de laboratório (cisalhamento direto e triaxial), ensaios de campo e de retro - análise de rupturas observadas. Esses resultados foram compilados de SINGH \& MURPHY (1990), LANDVA \& CLARK (1990), WITHIAM et al. (1995), GABR \& VALERO (1995), GRISOLIA et al. (1995b) e KÖNIG \& JESSBERGER (1997).

Esse diagrama deve ser analisado com muito cuidado, pois contém informações de resíduos com idades e composições diferentes, bem como resultados de vários tipos de ensaios (laboratório, campo e retro - análise).

Pode-se observar que existe uma grande dispersão nos resultados da Figura 5.46, tornando-se difícil estimar com segurança uma faixa de resistência para o resíduo sólido domiciliar. O ângulo de atrito varia de $10^{\circ}$ a $40^{\circ}$ e a coesão de 25 a próximo de $200 \mathrm{kPa}$. Apesar dessa dispersão algumas tendências podem ser observadas:

- Os resultados obtidos para os ensaios de laboratório tendem a ser maiores que os obtidos por retro - análise. Em geral, os resultados de laboratório caem à direita da faixa sugerida para projetos de aterros por SINGH \& MURPHY (1990).

- Pode-se considerar, para ensaios de laboratório, que os valores de ângulo de atrito variam entre $20^{\circ}$ a $35^{\circ}$ e a coesão de 25 a $80 \mathrm{kPa}$. Em geral, não tem sido 
medido, conforme comenta SÁNCHEZ-ALCITURRI et al. (1993), valores de ângulo de atrito abaixo de $17^{\circ}$. Na Figura 5.46, os valores de $\phi=0^{\circ}$ apresentados por GABR \& VALERO (1995) são correspondentes à ensaios não consolidados não drenados (UU).

- Os resultados de ensaios triaxiais obtidos para $20 \%$ de deformação, exceto os de GRISOLIA et al. (1995b), apresentaram valores de coesão bem superiores à maioria dos ensaios de laboratório. É importante frisar que os valores de coesão são particularmente dependentes dos componentes de reforço do RSU e a mobilização da coesão cresce à medida que aumenta as deformações. Além disso, é importante ressaltar que os resultados de GRISOLIA et al. (1995b) são de ensaios em amostras de RSU fabricadas em laboratório.

- Os resultados produzidos nesta pesquisa, para as amostras T2A e T1B caíram na faixa de laboratório, fora da faixa sugerida por SINGH \& MURPHY (1990). Já as três séries de ensaios executados com a amostra T2B (ver tabela 5.4 e 5.5), posicionaram-se na faixa sugerida por SINGH \& MURPHY (1990). Acrescentase aqui, que os resultados obtidos para a amostra T2B foram afetados por uma considerável quantidade de solo proveniente das camadas de cobertura das células na composição desta amostra.

\section{5 - ENSAIOS DE COMPRESSÃO CONFINADA}

Os resultados dos ensaios de compressão confinada apresentados no capítulo anterior (Figuras 4.47 a 4.52) mostram que o resíduo sólido urbano estudado não apresenta curvas deformação $x$ tempo semelhante àquelas obtidas para solos argilosos, pois o trecho de compressão primária é de pequena monta. O processo de compressão primária para o resíduo é relativamente rápido e termina em poucos minutos. Em seguida, tem-se o aumento linear das deformações com o logaritmo do tempo, caracterizando a compressão secundária. Isso pode estar associado à alta permeabilidade do RSU e, portanto, à rápida dissipação do excesso de pressão neutra gerado pelo carregamento. Esse comportamento é também observado em turfas (SOWERS, 1973; DHOWIAN \& EDIL ,1981), porém tem-se diferenças em termos de compressão secundária. No caso do RSU, a compressão secundária inclui a parcela de decomposição biológica do material.

Tendo em conta as apreciáveis compressões secundárias exibidas nos ensaios, resolveu-se traçar curvas de compressão confinada (índice de vazios $x \log \sigma$ ) para intervalos de tempos distintos (1min, 10min, 1dia e 5dias), conforme mostram-se nas Figuras 5.47 a 5.49, para cada amostra ensaiada. 

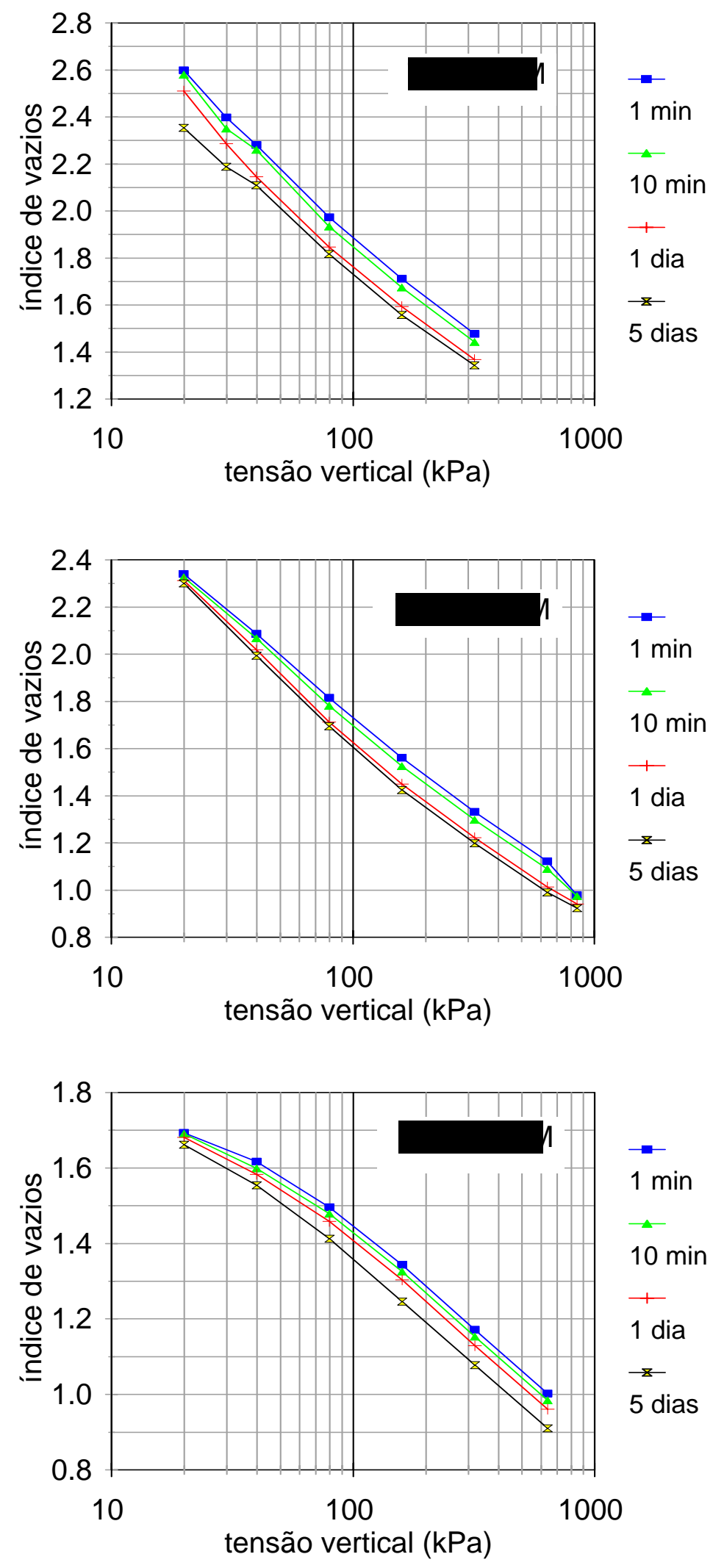

Figura 5.47 - Relação e $x \log \sigma$ nos tempos especificados, para a amostra T2A, ensaiada com pesos específicos de 8,10 e $14 \mathrm{kN} / \mathrm{m}^{3}$. 

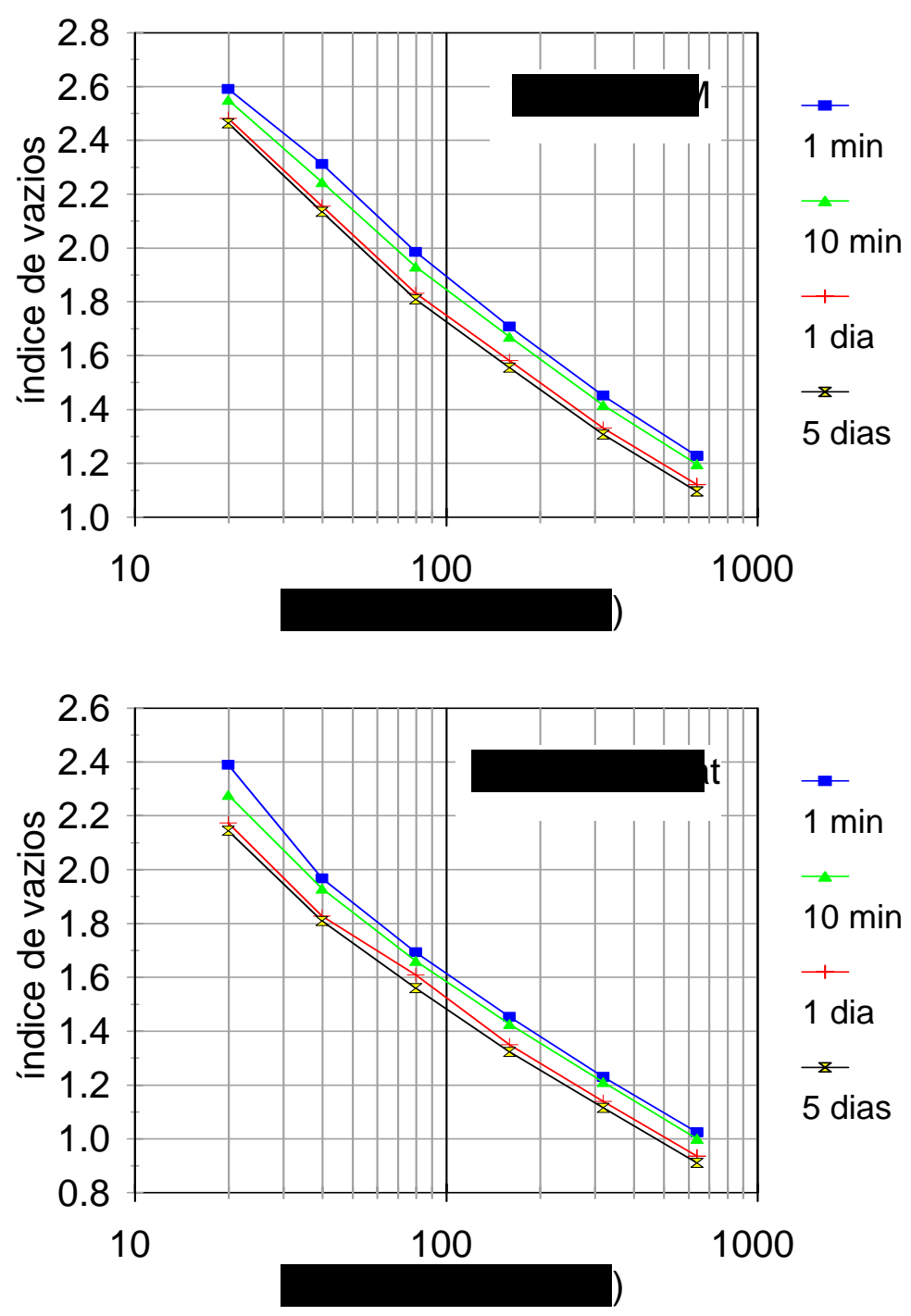

Figura 5.48 - Relação e $x \log \sigma$ nos tempos especificados, para a amostra T1B, ensaiada com pesos específicos de $10 \mathrm{kN} / \mathrm{m}^{3}$.

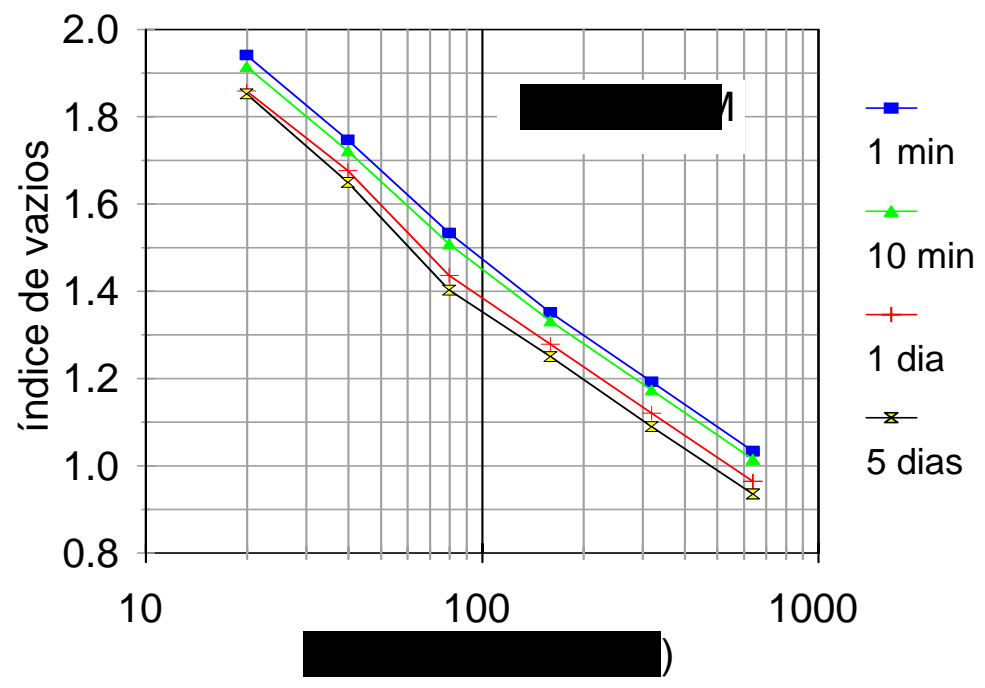

Figura 5.49 - Relação e x log $\sigma$ nos tempos especificados, para a amostra T2B, ensaiada com pesos específicos de $12 \mathrm{kN} / \mathrm{m}^{3}$. 
Por meio dessas curvas, as quais encontram-se mais ou menos paralelas, e através do ajuste de retas para um intervalo de tensão vertical entre 40 a $640 \mathrm{kPa}$, pôde-se determinar o índice de compressão primária $\left(\mathrm{C}_{\mathrm{c}}=\Delta \mathrm{e} / \Delta \log \sigma\right)$, para o resíduo nos tempos especificados. A Tabela 5.8 apresenta os valores médios do índice de compressão primária bem como, os valores dos coeficientes de compressão primária, dado por $C_{c}^{\prime}=\left[C_{c} /(1+e o)\right]$.

Tabela 5.8 - Valores médios de $C_{c}$ e $C^{\prime}{ }_{c}$ para todas as amostras ensaiadas.

\begin{tabular}{|c|c|c|c|}
\hline Amostra & Ensaio & $\begin{array}{c}\text { Índice de compressão } \\
\text { primária } \\
\mathrm{C}_{\mathrm{c}}=\frac{\Delta e}{\log \sigma}\end{array}$ & $\begin{array}{c}\text { Coeficiente de } \\
\text { compressão primária } \\
\mathrm{C}_{\mathrm{c}}=\frac{\mathrm{C}_{\mathrm{c}}}{1+e \mathrm{O}}\end{array}$ \\
\hline \multirow{2}{*}{ T2A } & T2A8COM & 0,92 & 0,20 \\
& T2A10COM & 0,82 & 0,23 \\
& T2A14COM & 0,56 & 0,21 \\
\hline T1B & T1B10COM & 0,89 & 0,20 \\
& T1B10COMsat & 0,76 & 0,18 \\
\hline T2B & T2B12COM & 0,60 & 0,17 \\
\hline
\end{tabular}

Como pode ser observado na Tabela 5.8, obtiveram-se para a amostra T2A, índice de compressão primária variando de 0,92 até 0,56. Esses resultados expressam a dependência do $\mathrm{C}_{\mathrm{c}}$ com o índice de vazios inicial da amostra, isto é, quanto menor é o índice de vazios, menor é o valor do $C_{c}$. Para a amostra T1B, ensaiada na condição de umidade natural (T1B10COM), obtiveram-se um $\mathrm{C}_{\mathrm{c}}$ de 0,89 e, para a amostra ensaiada na condição saturada (T1B10COMsat), obtiveram-se $C_{c}$ de 0,76 . Já para a amostra T2B (T2B12COM) foi encontrado $\mathrm{C}_{\mathrm{c}}$ da ordem de 0,6.

Os ensaios T2A8COM, T2A10COM, T2A14COM e T1B10COM apresentaram valores de coeficiente de compressão primária $\left(C_{C}^{\prime}\right)$ muito próximos, com valor médio da ordem de 0,21. No entanto, registre-se que o ensaio T2B12COM mostrou ser menos compressível, em virtude da maior quantidade de solo presente em sua composição. O ensaio de compressão confinada para a amostra T1B executado saturando os vazios do corpo de prova com água mostrou-se levemente menos compressível que o ensaio executado na condição de umidade natural. Obtiveram-se para a amostra ensaiada na umidade natural valor de coeficiente de compressão primária de 11\% maior que aquele obtido para a amostra saturada. Deve ser registrado que essas duas amostras apresentaram índice de vazios inicial aproximadamente iguais, porém, após a aplicação do pré carregamento de $10 \mathrm{kPa}$, o índice de vazios da amostra saturada reduziu bruscamente de 3,157 para 2,47 (ver Tabela 3.4).

Os valores do coeficiente de compressão primária encontrados para o resíduo sólido urbano estudado estão próximos do limite inferior apresentado por LANDVA \& CLARK (1990), para resíduos sólidos do Canadá ensaiados num equipamento de grandes 
dimensões. LANDVA \& CLARK (1990) apresentaram, para esses resíduos, valores de C'${ }_{c}$ entre 0,2 a 0,5 .

Na Figura 5.50 apresenta-se uma comparação entre os índices de compressão primária $\left(\mathrm{C}_{\mathrm{c}}\right)$ obtidos para os resíduos do Aterro Sanitário Bandeirantes com os encontrados na literatura. Para efeito de comparação, os resultados obtidos para o RSU estudado são plotados conjuntamente com os obtidos por SOWERS (1973) e com a faixa de variação do $\mathrm{C}_{\mathrm{c}}\left(0,55 . \mathrm{e}_{\mathrm{o}}\right.$ a $\left.0,15 . \mathrm{e}_{\mathrm{o}}\right)$ sugerida por esse autor a partir de estudos de retro-análise de dados campo. Nesta figura, também estão apresentados os resultados obtidos por GABR \& VALERO (1995), para resíduo da Pensilvania (com idade entre 15 a 30 anos) ensaiados em célula edométrica convencional e os obtidos por WALL \& ZEISS (1995), provenientes de células experimentais in situ. Obtiveram-se valores de $\mathrm{C}_{\mathrm{c}}$ semelhantes aos divulgados por esses autores, na faixa de índice de vazios ensaiada.

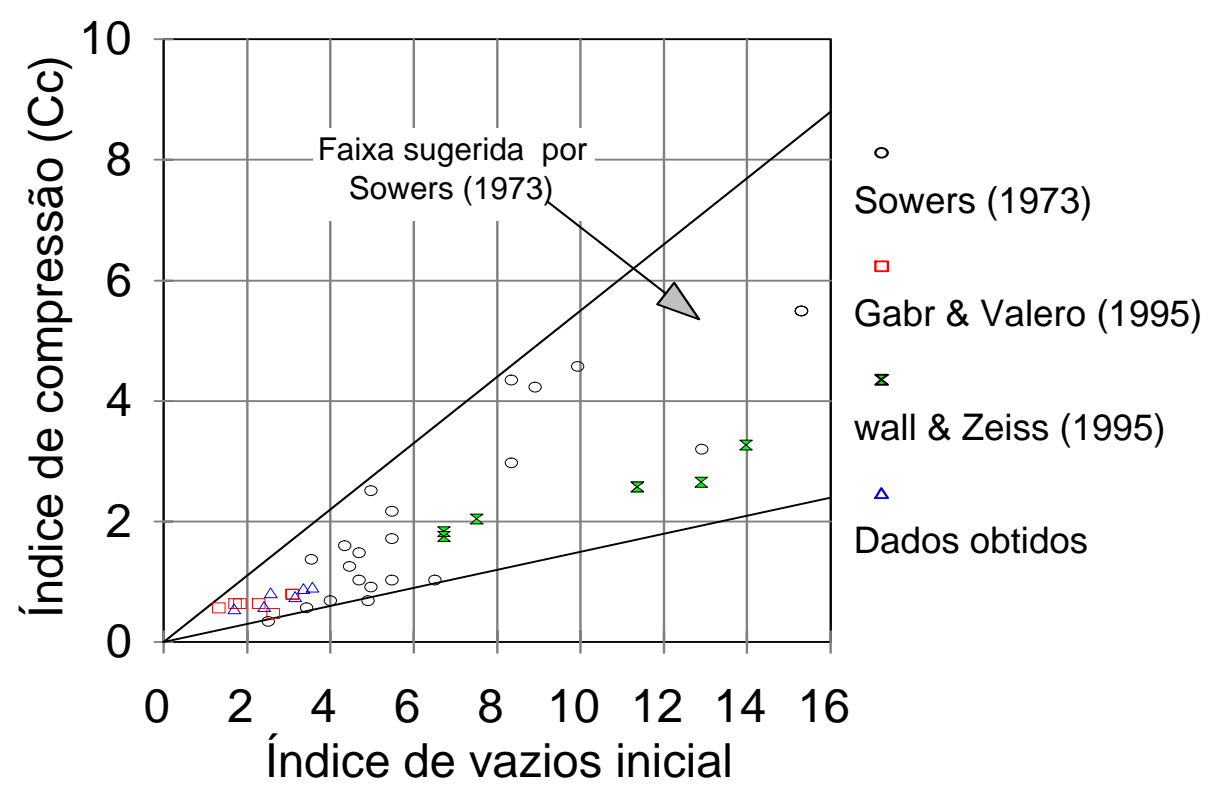

Figura 5.50 - Comparação do índice de compressão primária em função do índice de vazios para resíduos sólidos urbanos.

A alta compressibilidade do RSU é evidente nas curvas deformação $x$ raiz de tempo e deformação $x \log t$, obtidas para os seis ensaios executados, para estágios distintos de carregamento (Figuras 4.53 a 4.64). Nestas figuras, pode-se observar uma acentuada compressão secundária, a qual segue uma relação linear com logaritmo do tempo. A partir destes gráficos foi possível determinar os índices de compressão secundária $\left(C_{\alpha}=\Delta \mathrm{e} / \Delta \mathrm{logt}\right)$ e os coeficientes de compressão secundária $\left[\mathrm{C}_{\alpha}^{\prime}=\mathrm{C}_{\alpha} /(1+\mathrm{eo})\right]$ para cada estágio de carregamento.

A Tabela 5.9 apresenta os resultados de $\mathrm{C}_{\alpha}$ e $\mathrm{C}_{\alpha}^{\prime}$ para todas as amostras ensaiadas. 
Tabela 5.9- Valores de $C_{\alpha}$ e $C_{\alpha}^{\prime}$ para todos as amostras estudadas.

\begin{tabular}{|c|c|c|c|c|c|c|}
\hline \multirow{3}{*}{$\begin{array}{c}\text { Estágio } \\
\text { Carga } \\
(\mathrm{kPa})\end{array}$} & \multicolumn{6}{|c|}{ Amostras } \\
\hline & \multicolumn{2}{|c|}{ T2A8COM } & \multicolumn{2}{|c|}{ T2A10COM } & \multicolumn{2}{|c|}{ T2A14COM } \\
\hline & $\mathrm{C}_{\alpha}$ & $\mathrm{C}_{\alpha}^{\prime}$ & $\mathrm{C}_{\alpha}$ & $C_{\alpha}^{\prime}$ & $\mathrm{C}_{\alpha}$ & $C_{\alpha}^{\prime}$ \\
\hline 20 & 0,0281 & 0,0069 & 0,0041 & 0,0016 & 0,0099 & 0,0038 \\
\hline 40 & 0,0434 & 0,0132 & 0,0213 & 0,0064 & 0,0154 & 0,0058 \\
\hline 80 & 0,0394 & 0,0126 & 0,0313 & 0,0105 & 0,0285 & 0,0112 \\
\hline 160 & 0,0387 & 0,0137 & 0,0344 & 0,0128 & 0,0333 & 0,0140 \\
\hline 320 & 0,0323 & 0,0126 & 0,0345 & 0,0142 & 0,0287 & 0,0130 \\
\hline 640 & - & - & 0,0351 & 0,0160 & 0,0262 & 0,0128 \\
\hline
\end{tabular}

\begin{tabular}{|c|c|c|c|c|c|c|}
\hline \multirow{2}{*}{\begin{tabular}{c} 
Estágio $\begin{array}{c}\text { Carga } \\
(\mathrm{kPa})\end{array}$ \\
\cline { 2 - 7 }
\end{tabular}} & \multicolumn{2}{|c|}{ T1B10COM } & \multicolumn{2}{|c|}{ T1B10COMsat } & \multicolumn{2}{c|}{ T2B12COM } \\
\hline & $\mathrm{C}_{\alpha}$ & $\mathrm{C}_{\alpha}^{\prime}$ & $\mathrm{C}_{\alpha}$ & $\mathrm{C}_{\alpha}^{\prime}$ & $\mathrm{C}_{\alpha}$ & $\mathrm{C}_{\alpha}^{\prime}$ \\
\hline 20 & 0,0282 & 0,0071 & 0,0471 & 0,0135 & 0,0313 & 0,0100 \\
\hline 40 & 0,0382 & 0,0110 & 0,0375 & 0,0120 & 0,0442 & 0,0155 \\
\hline 80 & 0,0303 & 0,0097 & 0,0343 & 0,0123 & 0,0338 & 0,0128 \\
\hline 160 & 0,0364 & 0,0131 & 0,0369 & 0,0145 & 0,0300 & 0,0125 \\
\hline 320 & 0,0371 & 0,0146 & 0,0351 & 0,0153 & 0,0261 & 0,0116 \\
\hline 640 & 0,0343 & 0,0150 & 0,0324 & 0,0156 & 0,0236 & 0,0113 \\
\hline & & & & & & \\
\hline
\end{tabular}

Descartando-se os valores mais baixos de $\mathrm{C}_{\alpha}$ e $\mathrm{C}_{\alpha}{ }_{\alpha}$, obtidos para 20 e $40 \mathrm{kPa}$, provocados provavelmente por acomodações tanto do equipamento como do próprio resíduo, verificam-se que os índices de compressão secundária $\left(C_{\alpha}\right)$ variam entre 0,0213 a 0,0442, podendo-se adotar um valor médio de 0,032 e que os coeficientes de compressão secundária $\left(C_{\alpha}^{\prime}\right)$ variam entre 0,0105 a 0,016, com valor médio de 0,013.

SOWERS (1973) e GABR \& VALERO (1995) apresentaram valores de índice de compressão secundária $\left(C_{\alpha}\right)$ variando de 0,03.e $e_{o}$ a 0,09. $e_{0}$. Já LANDVA \& CLARK (1990) apresentaram para os resíduos sólidos do Canadá, valores $C_{\alpha}^{\prime}$ entre 0,002 a 0,03. Conforme pode ser visto na Figura 5.51, os valores obtidos para o resíduo do Aterro Sanitário Bandeirantes são inferiores aos apresentados por SOWERS (1973) e GABR \& VALERO (1995) e estão coerentes com as indicações de LANDVA \& CLARK (1990).

Foram executados ensaios de compressão para amostra T2A, variando o peso específico inicial do resíduo, a fim de verificar a influência deste parâmetro nos valores de $\mathrm{C}_{\alpha}$ e $\mathrm{C}_{\alpha}^{\prime}$.

Na Tabela 5.9 pode-se observar que, para todas as amostras ensaiadas, os valores $\mathrm{C}_{\alpha}$ e $\mathrm{C}_{\alpha}^{\prime}$. são da mesma ordem de grandeza, qualquer que seja o peso específico inicial das amostras e a sobrecarga. Registre-se apenas que as amostras ensaiadas com peso específico de $10 \mathrm{kN} / \mathrm{m}^{3}$ mostraram uma tendência de crescimento de $C_{\alpha}^{\prime}$, com as sobrecargas. Na faixa de tensões entre 80 e $640 \mathrm{kPa}$, esse acréscimo não superou $50 \%$. De qualquer forma, descartando-se os valores correspondentes a sobrecargas inferiores a 
$80 \mathrm{kPa}$, observa-se que os valores são, no máximo, $25 \%$ maiores ou menores que o valor médio medido de 0,013.

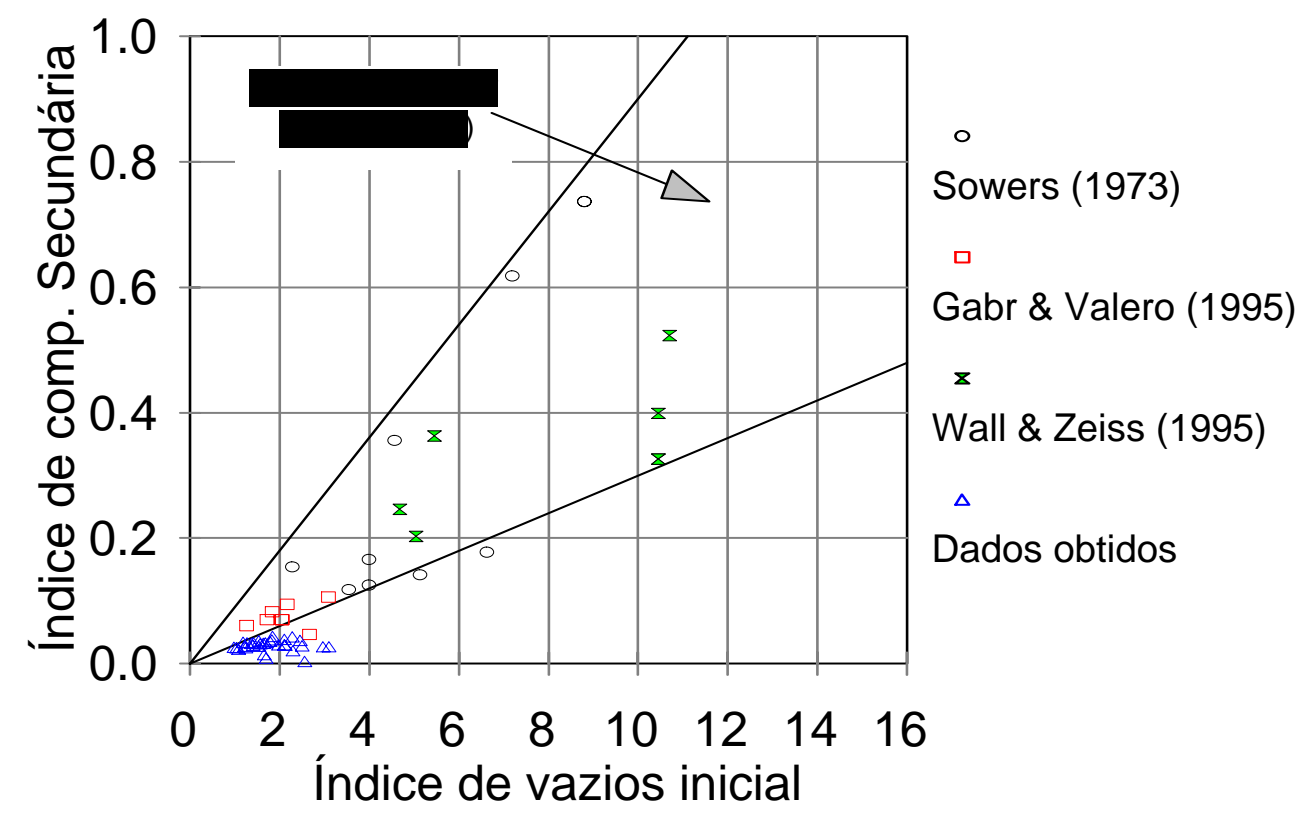

Figura 5.51 - Comparação do índice de compressão secundária em função do índice de vazios para resíduos sólidos urbanos.

Conforme exposto anteriormente, a compressibilidade do RSU envolve variáveis, como, a degradação dos componentes com tempo e a grande compressão secundária, que não são contempladas pelas teorias convencionais de adensamento. Assim faz-se necessário, o desenvolvimento de novas teorias ou a adaptação das teorias existentes de sorte a ter-se modelos realistas que possam traduzir o complexo comportamento dos resíduos sólidos urbanos. Também é importante chamar a atenção para o fato de que, até o presente, os ensaios de compressibilidade do resíduo em laboratório não quantificam os recalques devidos à perda de massa resultante do processo de degradação.

Nas Figuras 5.52 a 5.54 apresentam-se os resultados obtidos para os módulos de compressão confinada (D) em função da pressão vertical aplicada, para as amostras T2A, T1B e T2B, respectivamente. Este módulo é dado pela relação entre a tensão vertical e a deformação axial, que no caso do ensaio de compressão confinada é igual à deformação volumétrica $\left(D=\sigma_{v} / \varepsilon_{v}\right)$. Os módulos revelaram-se crescentes com a tensão vertical, como se pode mostrar nas Figuras 5.52 a 5.54. Com os resultados disponíveis para a amostra T2A (figura 5.52), não foi possível identificar qualquer variação do módulo quer seja com o peso específico inicial, índice de vazios ou grau de saturação da amostra, sendo os resultados da mesma ordem de grandeza. Para todas as amostras ensaiadas obtiveram-se, após ajuste 
matemático, uma relação linear entre o módulo (D) e a tensão vertical ( $\sigma)$, expressa pela seguinte equação: $D=9,93 . \sigma-122,4$ com $r^{2}=0,97$, $D$ e $\sigma$ em $\mathrm{kPa}$.

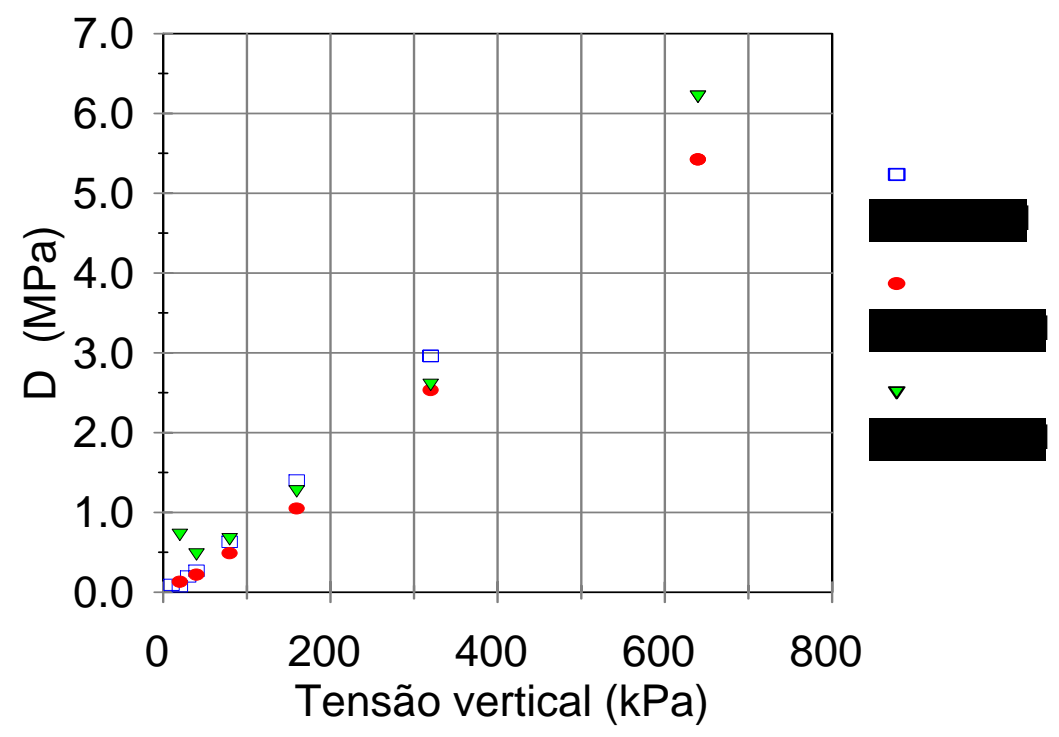

Figura 5.52 - Módulos em compressão confinada (D) em função da tensão vertical obtidos para a amostra T2A, ensaiada com pesos específicos iniciais de 8 (T2A8COM), 10 (T2A10COM) e $14 \mathrm{kN} / \mathrm{m}^{3}$ (T2A14COM).

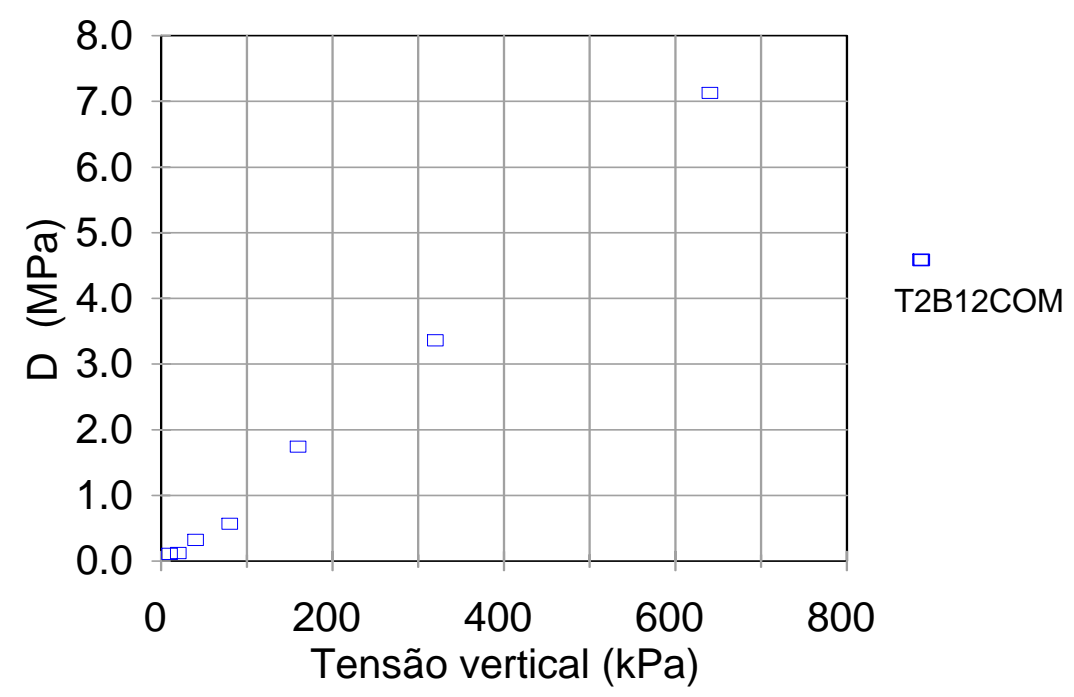

Figura 5.53 - Módulos em compressão confinada (D) em função da tensão vertical obtidos para a amostra T2B, ensaiada com peso específico inicial de $12 \mathrm{kN} / \mathrm{m}^{3}$.

Para efeito de comparação dos módulos obtidos em compressão confinada com aqueles obtidos por meio de ensaios triaxiais, transformaram-se os módulos em compressão confinada (D) em módulos de elasticidade (E) através da fórmula: 


$$
E=\frac{D \cdot(1+v) \cdot(1-2 v)}{(1-v)}
$$

onde: $\mathrm{D}=$ módulo de compressão confinada, $\mathrm{E}=$ módulo de deformabilidade do ensaio triaxial, $v=$ coeficiente de Poisson

Para os cálculos, utilizaram-se o coeficiente de Poisson $(v)$ de 0,33 , valor médio obtido dos ensaios de cross-hole executados (ver item 5.2.5).

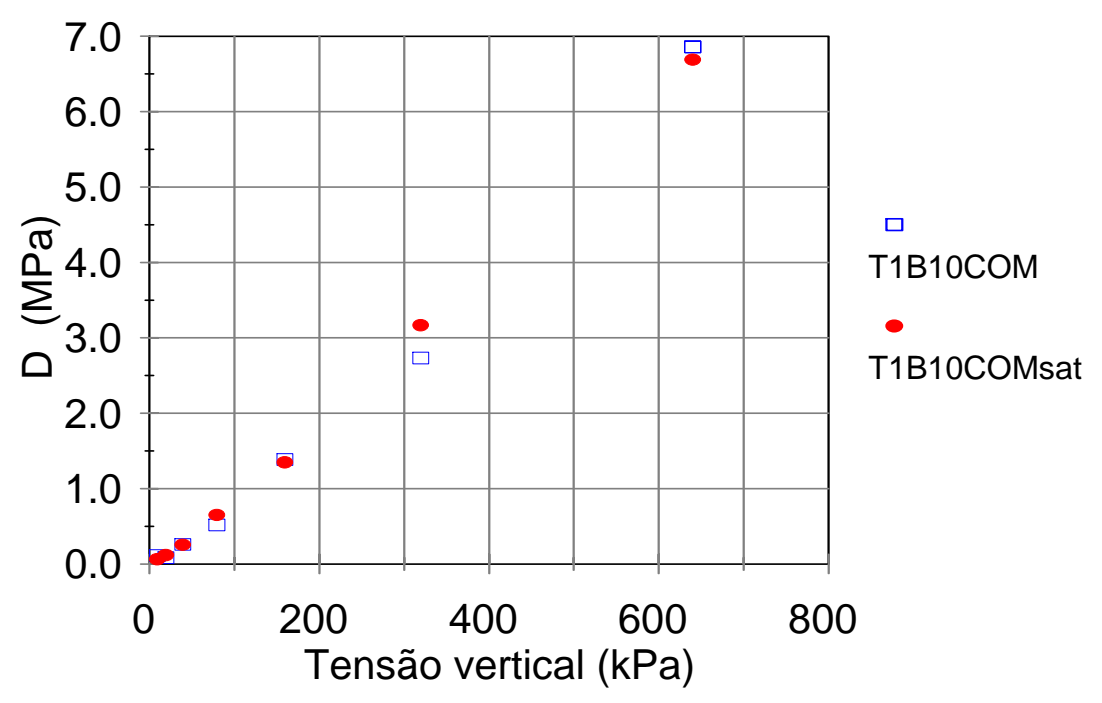

Figura 5.54 - Módulos em compressão confinada (D) em função da tensão vertical obtidos para a amostra T1B, ensaiada com peso específico inicial de $10 \mathrm{kN} / \mathrm{m}^{3}$, na condição de umidade natural e com os vazios saturados com água.

Também para efeito de comparação as tensões verticais do ensaio de compressão confinada tiveram que ser transformadas em octaédricas através da fórmula:

$$
\sigma_{\text {oct }}=\frac{\sigma_{\mathrm{v}} \cdot\left(1+2 \mathrm{k}_{\mathrm{o}}\right)}{3} \quad \mathrm{k}_{\mathrm{o}}=\frac{v}{1-v}
$$

onde:

$\mathrm{k}_{\mathrm{o}}$ é o coeficiente de empuxo em repouso

$\sigma_{v}$ é a pressão vertical de carregamento

Assim, pôde-se comparar os resultados dos módulos de elasticidade, função das tensões octaédricas, obtidos por meio de ensaios em compressão confinada com os módulos de elasticidade função da tensão confinante $\left(\sigma_{3}=\sigma_{o c t}\right)$, obtidos por meio dos ensaios triaxiais, (Figuras 5.55 a 5.57). Para os ensaios triaxiais utilizaram-se os módulos de elasticidade a $20 \%$ de deformação axial. Pôde-se notar nessas figuras, que os valores obtidos estão relativamente próximos, sendo que as amostras T2A e T1B, em geral, apresentaram uma tendência do módulo de elasticidade proveniente do triaxial, alcançar 
valores maiores que os obtidos em compressão confinada, especialmente para tensões octaédricas de até $200 \mathrm{kPa}$. Para tensões octaédricas superiores a $200 \mathrm{kPa}$, obtiveram-se valores próximos da unidade (Figura 5.58). No entanto, a amostra T2B apresentou valores inferiores a unidade, talvez isso seja em virtude dessa amostra apresentar uma maior quantidade de solo em sua composição.

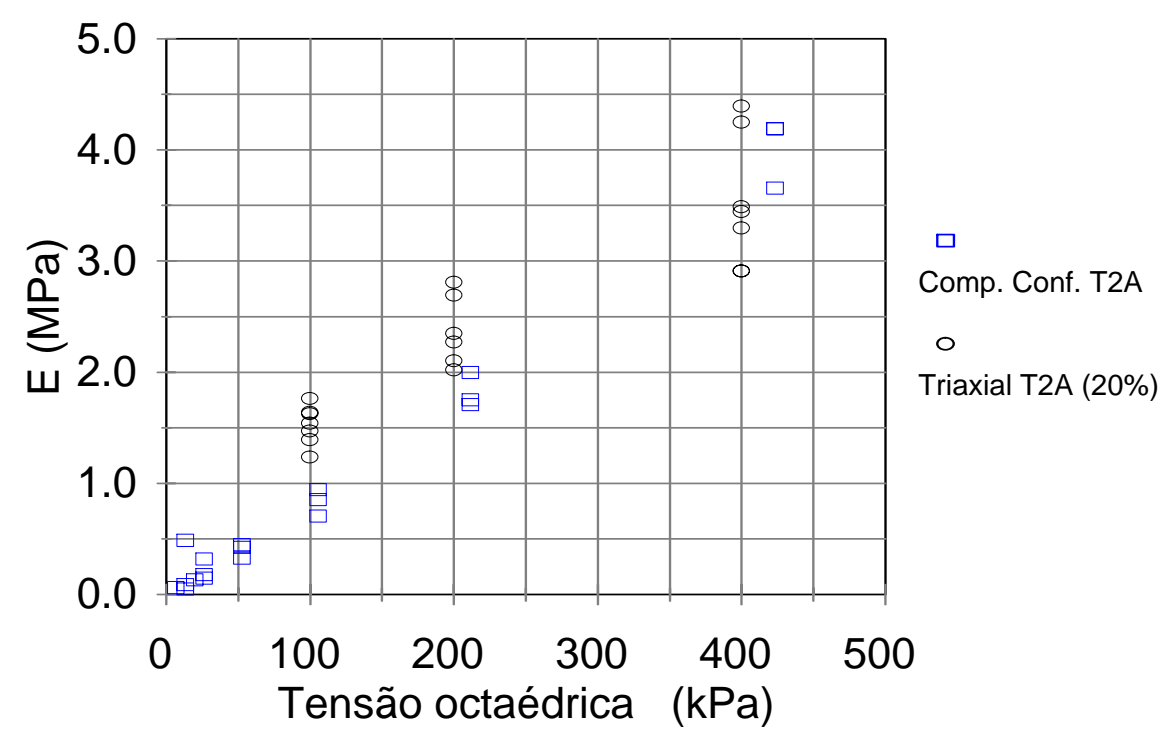

Figura 5.55 - Comparação entre os módulos de elasticidade obtidos de ensaios em compressão confinada e de ensaios triaxiais a $20 \%$ de deformação axial para a amostra T2A.

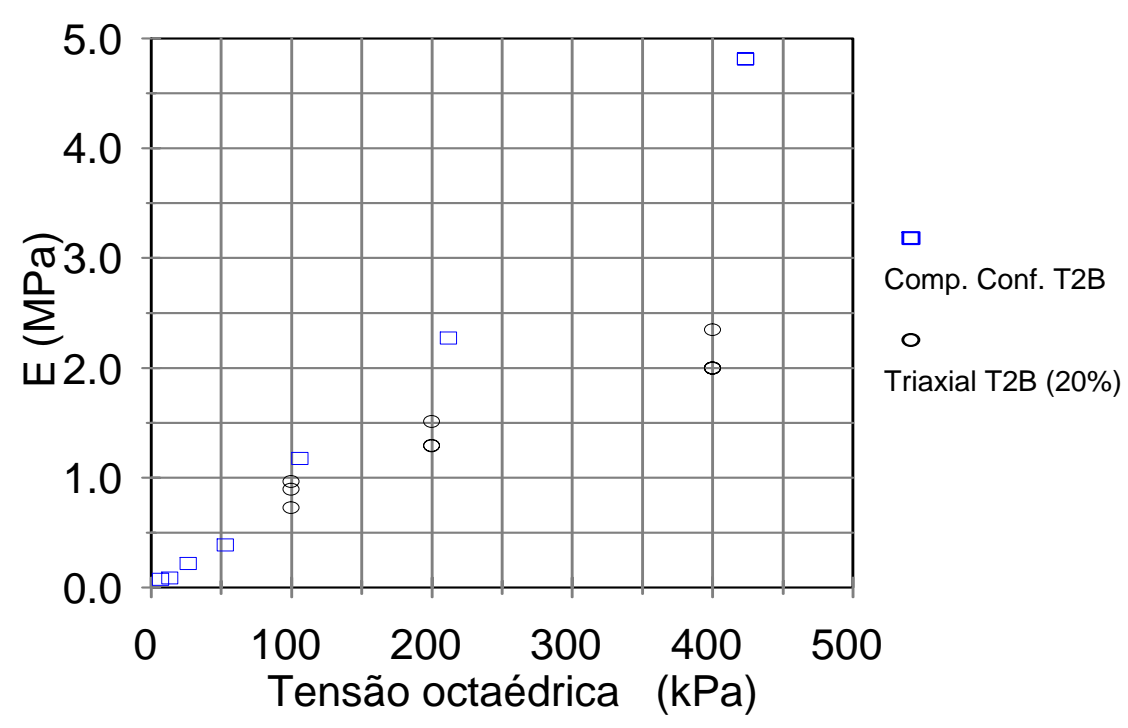

Figura 5.56- Comparação entre os módulos de elasticidade obtidos de ensaios em compressão confinada e de ensaios triaxiais a $20 \%$ de deformação axial para a amostra T2B. 


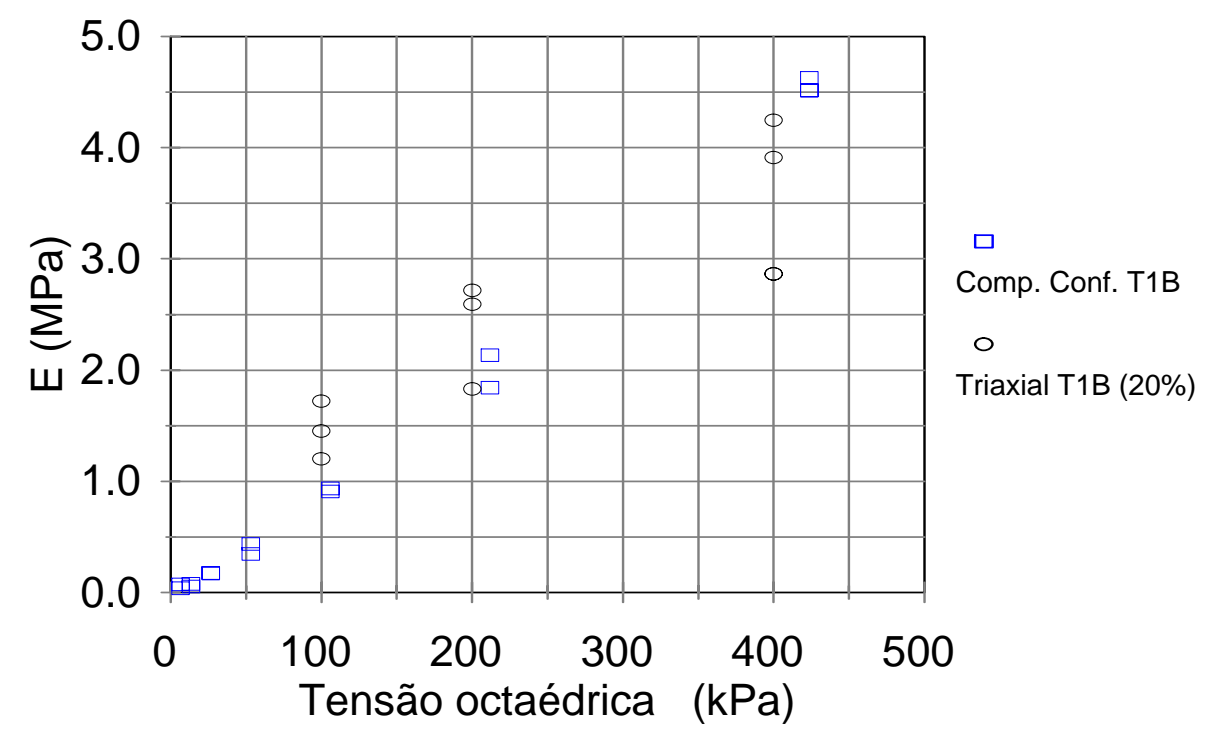

Figura 5.57- Comparação entre os módulos de elasticidade obtidos de ensaios em compressão confinada e de ensaios triaxiais a $20 \%$ de deformação axial para a amostra T1B.

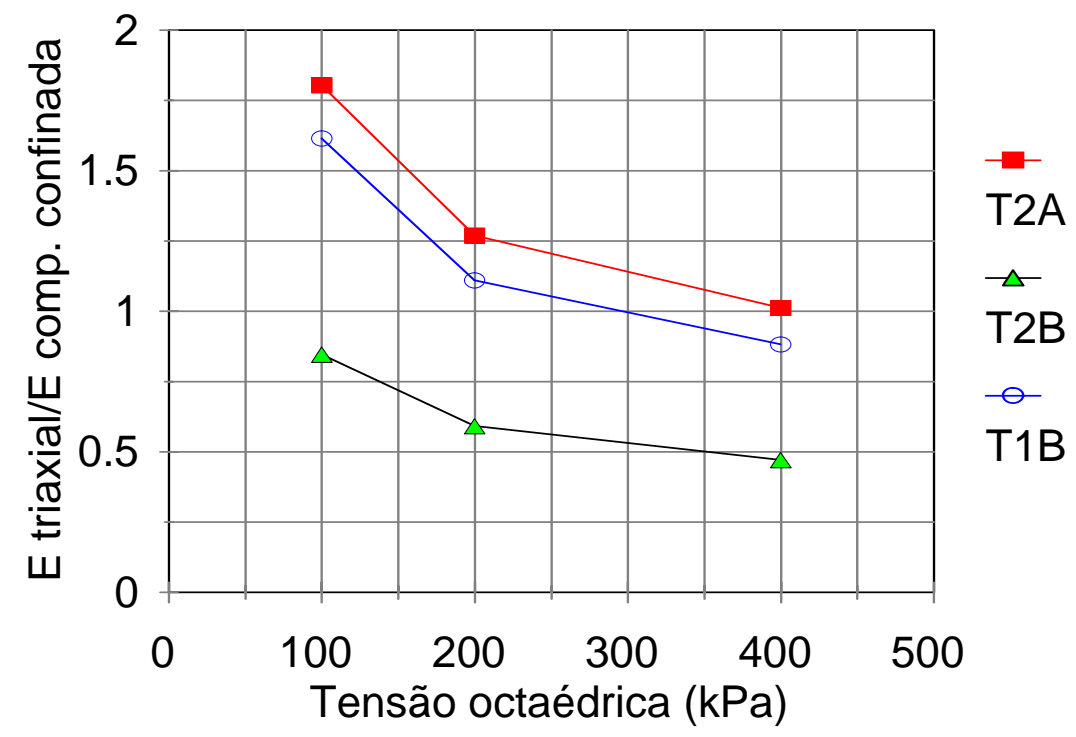

Figura 5.58 - Relação entre os módulos de elasticidade obtidos de ensaios em compressão confinada com os obtidos de ensaios triaxiais a $20 \%$ de deformação axial, para todas as amostras estudadas. 


\section{6 - MONITORAMENTO IN SITU DOS RECALQUES}

\section{1 - INTRODUÇÃO}

Conforme apresentado no capítulo anterior, a compressibilidade do resíduo sólido urbano é um processo complexo devido à heterogeneidade do material, à deformabilidade das partículas e à presença de grandes vazios. Além disso, muitos componentes do RSU podem variar de forma e volume devido às transformações resultantes do processo de degradação bioquímica que ocorre nos aterros. Assim, ocorre uma redução no volume dos componentes sólidos, os quais são transformados, com o passar do tempo, em gases e líquidos (chorume).

O processo de degradação é fortemente influenciado pela composição e umidade do resíduo, detalhes de projeto e de operação do aterro (existência de cobertura diária, compactação, drenagem), condições climáticas favoráveis e aspectos quantitativos e qualitativos de nutrientes (VAN MEERTEN et al. 1995).

Em laboratório, o processo de compressão do resíduo resultante da degradação dos componentes com o tempo é difícil de ser reproduzido, visto que é governado por fatores biológicos e físico-químicos que, para ocorrerem, necessitam de condições ideais e propicias, além de um tempo longo (GRISOLIA \& NAPOLEONI 1996). Dessa forma, o monitoramento in situ do recalque torna-se a maneira mais realista e mais representativa para estudar o processo de compressibilidade dos resíduos sólidos urbanos, pois as medidas em campo incluem todos os fatores e interações dominantes nesse comportamento.

Assim, além dos ensaios de compressibilidade executados em laboratório para os resíduos coletados (ver item 5.5) fez-se um estudo da compressibilidade utilizando dados de monitoramento in situ dos recalques. Esses resultados são apresentados e analisados a seguir.

\section{2 - MONITORAMENTO IN SITU DOS RECALQUES}

Dados de monitoramento de recalques de quatro marcos superficiais, existentes na sub-área AS-2 do Aterro Sanitário Bandeirantes (SP), foram utilizados nesse estudo. Esses 
dados foram coletados por Cepollina Engenheiros Consultores S/C e Heleno Fonseca S/C e nos foram gentilmente cedidos para este estudo.

O monitoramento dos recalques estendeu-se por um período de 7 anos, indo de outubro de 1991 a agosto de 1998. Inicialmente, as leituras foram feitas duas vezes por semana; após o primeiro mês de observação, passaram a ser feitas semanalmente, depois quinzenalmente e, após um ano de observação, mensalmente.

A disposição dos quatro marcos superficiais na área de estudo (MS-11, MS-12, MS13 e MS-21) pode ser vista na Figura 3.1 (capítulo 3, pag.90).

Para o estudo dos recalques considerou-se o tempo zero como sendo a data de início do monitoramento (outubro de 1991) e a altura inicial do RSU em cada marco superficial $\left(\mathrm{H}_{0}\right)$ como sendo a diferença entre a cota de fundação e cota de posicionamento do marco. Como o aterro foi construído numa região de vale os marcos possuem diferentes alturas iniciais de RSU, que são:

$$
\begin{array}{ll}
\text { MS-11: } & H_{0}=28 \text { metros } \\
\text { MS-12: } & H_{0}=37,3 \text { metros } \\
\text { MS-13: } H_{0}=26,3 \text { metros } \\
\text { MS-21: } H_{0}=58,6 \text { metros }
\end{array}
$$

As Figuras 6.1 a 6.4 mostram curvas de recalques normalizados (razão $\Delta \mathrm{H} / \mathrm{H}_{0}$ ), medidos em cada marco superficial, versus o tempo de monitoramento em escala logarítmica.

Nesses gráficos, observa-se um valor de recalque normalizado médio de $12 \%$. É importante ressaltar que, antes da instalação dos marcos, os resíduos, provavelmente, já experimentaram algum processo de compressão inicial devido a operação do aterro e peso próprio das camadas sobrejacentes, os quais não foram contabilizados nas medidas feitas. Segundo dados da literatura, os valores de recalques observados em aterros se situam entre 10 a 30\% da altura inicial do aterro e a maioria deles ocorrem nos primeiros anos após a disposição, diminuindo a velocidade de andamento nos anos subsequentes (SOWERS 1968, EDIL et al. 1990, GRISOLIA \& NAPOLEONI 1996 e KÖING \& JESSBERGER 1997).

Os dados de variação de altura obtidos para os marcos analisados mostram que a taxa de recalques decresce progressivamente ao longo do tempo de monitoramento do aterro. Esse comportamento é melhor observado na Figura 6.5, onde apresenta-se um gráfico típico de taxa de recalques com o tempo, representativo dos pontos observados. Neste gráfico verifica-se que a velocidade vai de $14 \mathrm{~mm} /$ dia, para os primeiros estágios de observação, até $3 \mathrm{~mm} /$ dia para os últimos estágios. A redução da velocidade das deformações com o tempo também foi observada nos resultados obtidos de ensaios de compressão confinada em laboratório. 


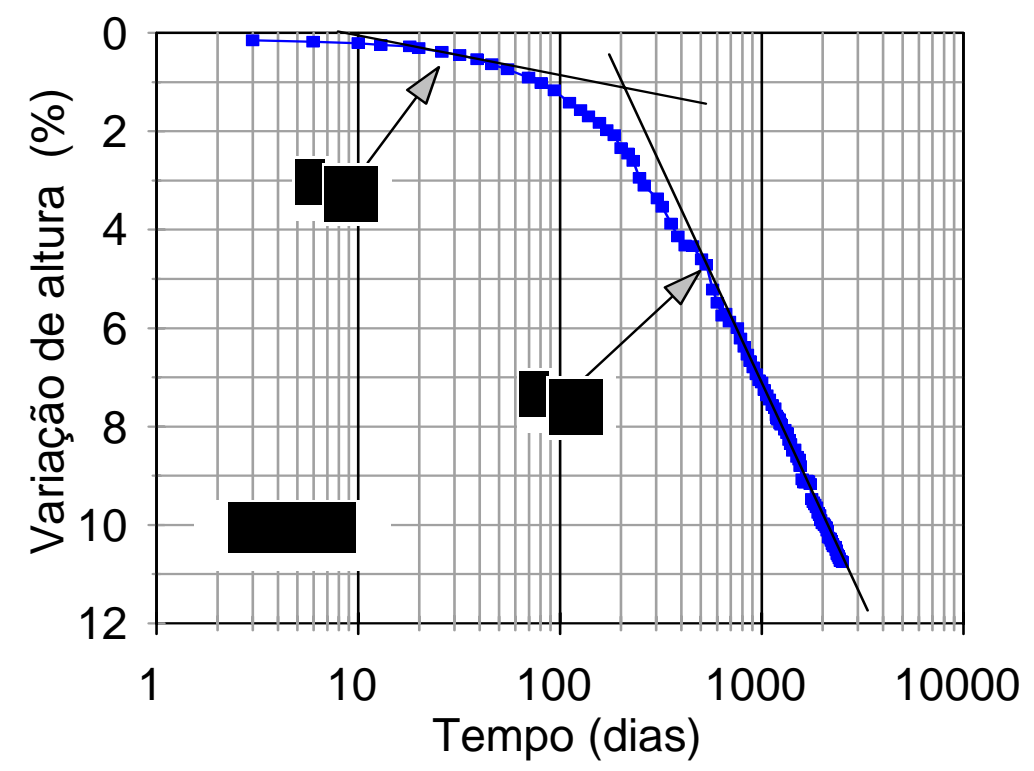

Figura 6.1 - Medidas de recalque normalizado obtidas para 0 marco superficial MS-11. Altura inicial de RSU: 28 metros

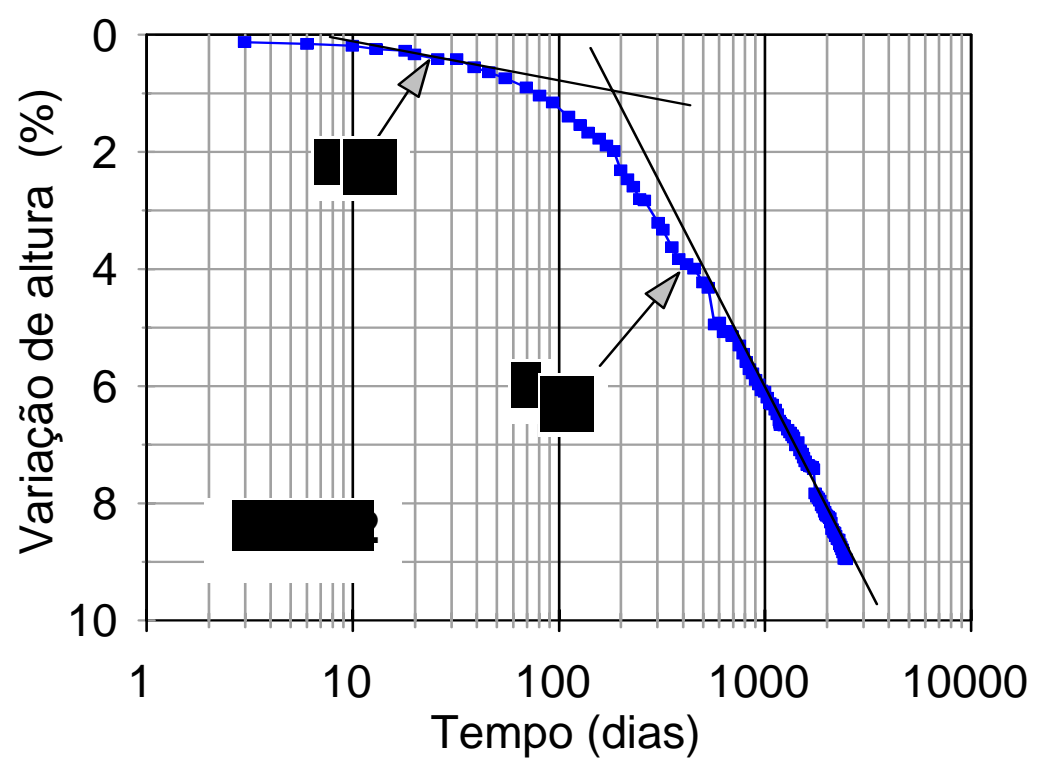

Figura 6.2 - Medidas de recalque normalizado obtidas para o marco superficial MS-12. Altura inicial de RSU: 37,3 metros 


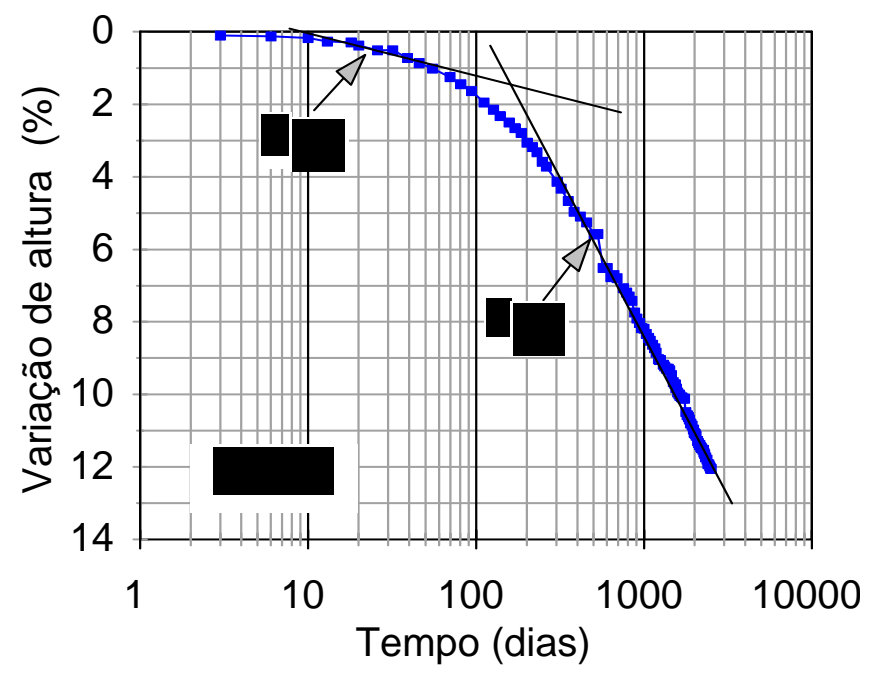

Figura 6.3 - Medidas de recalque normalizado obtidas para o marco superficial MS-13. Altura inicial de RSU: 26,3 metros

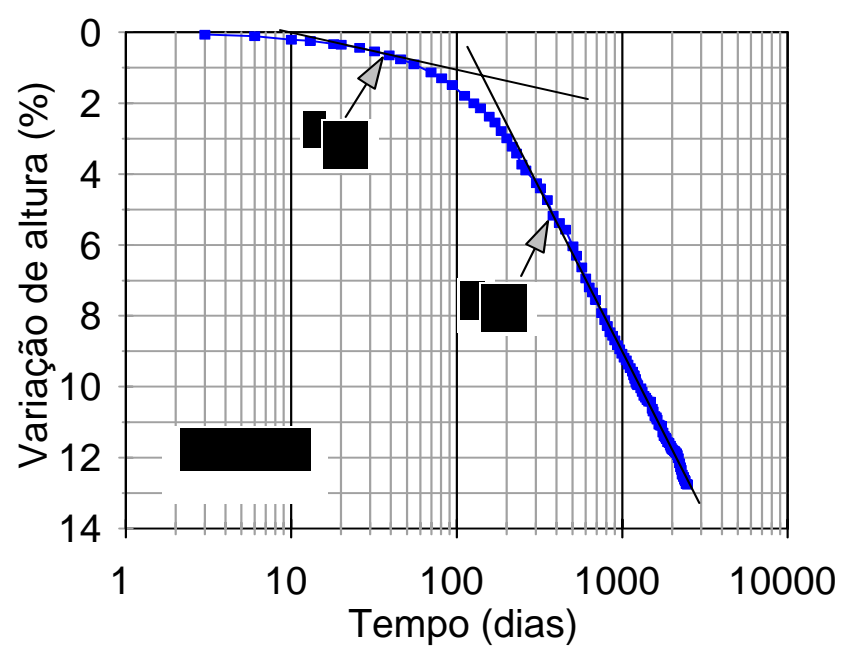

Figura 6.4 - Medidas de recalque normalizado obtidas para o marco superficial MS-21. Altura inicial de RSU: 58,6 metros

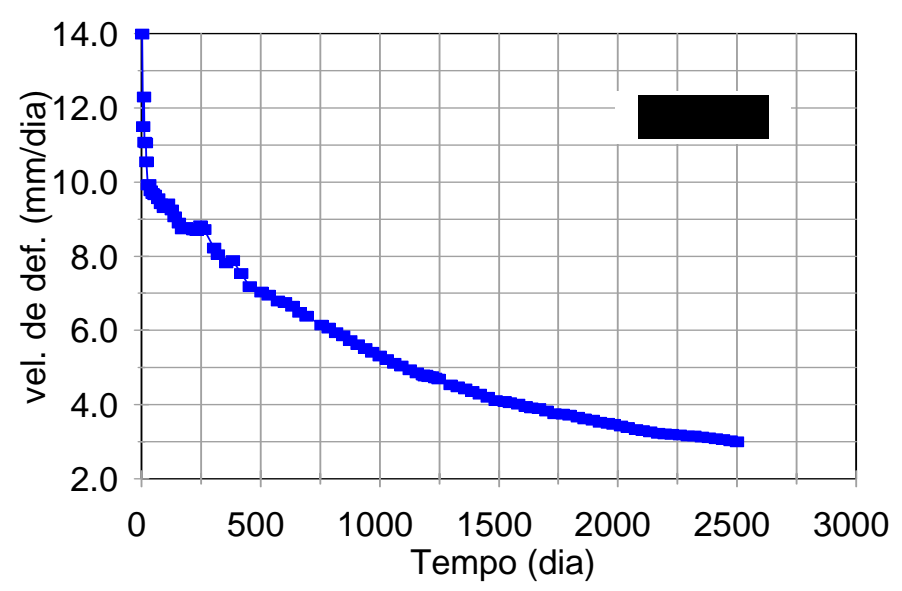

Figura 6.5 - Curva típica de velocidade de deformação $x$ tempo de monitoramento do aterro. 
As curvas de variação de altura em função de log $t$ apresentadas nas figuras $6.1 \mathrm{a}$ 6.4, diferentemente das obtidas de ensaios em laboratório (ver fig.4.53 a 4.64), apresentaram duas partes aproximadamente lineares e com inclinações diferentes. $O$ primeiro trecho da curva vai do início do monitoramento até cerca de 100 dias, o qual é formado por um trecho grosseiramente linear caracterizado por pequena inclinação. Após um período de transição, estas curvas passam a apresentar um novo trecho linear, com maior inclinação.

O comportamento das deformações encontrado para os dados de monitoramento de campo está coerente com as citações de EDGERS et al. (1992), STULGIS et al. (1995), BOUTWELL \& FIORE (1995) e MANASSERO et al. (1996). Segundo esses autores a relação recalque $x$ logaritmo do tempo obtida de aterros de RSU monitorados indica a existência de duas componentes que exibem comportamento linear com $\log t$, mas com inclinações diferentes ( $\left(\alpha_{\text {min. }}\right.$ e $\left.\mathrm{C} \alpha_{\text {máx. }}\right)$. A mudança das deformações com o logaritmo do tempo pode ser atribuída à processos de degradação físico-química e biodegradação dos resíduos, os quais começam a ocorrer após algum tempo de aterramento.

Os parâmetros de compressão secundária ( $\left(C^{\prime} \alpha_{1}\right.$ e C' $\left.\alpha_{2}\right)$ do RSU em estudo foram determinados por meio do ajustes de retas através das leituras de campo obtidas para os marcos superficiais analisados (Figura 6.1 a 6.4). Para esse caso, na impossibilidade de determinação do índice de vazios para o aterro, trabalhou-se com o coeficiente de compressão secundária $\left(C^{\prime} \alpha=C \alpha /(1+e o)\right.$, no lugar de índice de compressão secundária $[(C \alpha=(\Delta \mathrm{e} / \Delta \log \mathrm{t})]$. O valor médio do coeficiente de compressão secundária do primeiro trecho $\left(C^{\prime} \alpha_{1}\right)$ é cerca de 0,010 e o do segundo trecho $\left(C^{\prime} \alpha_{2}\right), 0,083$, sendo $C^{\prime} \alpha_{1}$ apenas $12 \%$ do valor obtido para $C^{\prime} \alpha_{2}$.

O C' $\alpha_{1}$ é atribuído prioritariamente à compressão secundária devido ao fenômeno de creep ou deformação lenta. Já o C' $\alpha_{2}$, envolve os fenômenos de creep e a degradação do resíduo ao longo do tempo. É importante argumentar que transição de C' $\alpha_{1}$ para C' $\alpha_{2}$ após algum tempo, está de acordo com o fato de que, na prática, a degradação dos resíduos aterrados só começa efetivamente a ocorrer após algum tempo de disposição, o qual é necessário para iniciar a transformação dos componentes sólidos do RSU em líquidos e gases (fase anaeróbia). Assim, o C' $\alpha_{2}$ apresenta-se bem superior ao C' $\alpha_{1}$, pois envolve além de deformações de creep, as resultantes do processo de degradação físicoquímico e biológico do resíduo.

Como para o resíduo sólido urbano estudado o valor obtido para o $C^{\prime} \alpha_{1}$ foi de apenas $12 \%$ do valor obtido para $C^{\prime} \alpha_{2}$, pode-se dizer que as deformações devidas à decomposição do resíduo foram muito mais significativas que as de creep. É importante destacar que os valores obtidos dependem das condições específicas de composição e umidade do resíduo e das condições propícias à degradação atuantes neste aterro. Assim, possivelmente, em outros locais poderão ser encontrados valores diferentes, pois a taxa de compressão secundária geralmente depende da quantidade de água disponível no aterro, a 
qual é necessária para facilitar o processo de decomposição (MANASSERO et al. 1996). Deve-se, portanto, tomar cuidado na extrapolação dos resultados obtidos para resíduos de outros locais, que apresentam composição e característica de decomposição muito diferentes dos estudados.

O valor de $C^{\prime} \alpha_{1}$ obtido dos dados de monitoramento de campo é aproximadamente igual àquele obtido dos ensaios de laboratório, cujo valor médio é de 0,013. Isso é uma constatação muito interessante pois tanto para os primeiros períodos de operação do aterro como para os ensaios de laboratório apenas as deformações de creep são medidas. Para o caso dos ensaios de laboratório, os recalques devidos aos processos de degradação não são possíveis de serem previstos, a menos que se utilize um tempo de ensaio excessivamente grande e se forneçam condições ideais para que o processo de degradação ocorra.

Pesquisas de laboratório e de campo deverão ser intensificadas procurando verificar a influência dos efeitos da biodegradação dos RSU nos recalques dos aterros ao longo do tempo. Em laboratório, ensaios conduzidos por períodos mais longos poderiam ser utilizados. No entanto, os longos períodos de ensaio necessários são um empecilho, de sorte que deve-se buscar alternativas que permitam acelerar os processos de degradação durante os ensaios de compressão, para ter-se resultados em tempos mais curtos e compatíveis com as necessidades de projeto. Nesse sentido, ensaios com temperatura, umidade e nutrientes controlados (células reatoras), poderiam ser uma alternativa para estudar o efeito da degradação sobre a compressão secundária e sobre outras características de interesse.

\section{3 - CALIBRAÇÃO DE ALGUNS MODELOS DE RECALQUES DA LITERATURA A PARTIR DE DADOS OBTIDOS EM CAMPO}

Neste item faz-se uma comparação entre os resultados dos recalques in situ obtidos nesse estudo com aqueles publicados por outros pesquisadores, objetivando estabelecer a tendência geral das relações recalque - tempo. Os "métodos" de análise e previsão de recalques em aterros sanitários foram apresentados no capítulo 2 e a maioria deles são simplesmente fórmulas ajustadas a dados de campo, as quais em geral estabelecem uma lei de variação da velocidade de recalques decrescendo com logaritmo do tempo.

Um desses procedimentos é o de YEN \& SCANLON (1975), que a partir de dados de recalques de três aterros da Califórnia, num período de observação de cerca de 10 anos, sugeriram que a taxa de recalque diminui linearmente com $\log t\left(d h / d t=a ` b^{`} \log t\right)$. Os autores apresentam valores de $a$ `e $b$ `variando com a profundidade.

As taxas de recalques $(\mathrm{v}=\mathrm{dh} / \mathrm{dt})$ obtidas para os marcos estudados (MS-11, MS12, MS-13 e MS-21) empregando as proposições de YEN \& SCANLON (1975) estão apresentadas nas Figuras 6.6 a 6.9. Embora o coeficiente de determinação encontrado para 
o ajuste linear ( $a^{`}$ - $\left.b^{`} \log t\right)$ seja baixo, a taxa de recalque apresentou uma tendência de decrescer com a idade média do aterro, dando suporte as conclusões do autor citado acima. Porém, os parâmetros a` e b` obtidos para o RSU estudado são mais de 4,5 vezes maior que os apresentados por YEN \& SCANLON (1975). Isso não é surpreendente, uma vez que os resíduos brasileiros apresentam altos teores de componentes orgânicos (acima de 50\%) bem como condições climáticas ideais para propiciar os processos de degradação e decomposição do RSU. Além disso, grandes variações em relação à reta média pode ser devido as variações nas leituras topográficas dos marcos em campo. Os parâmetros de ajuste a partir dos dados observados e os apresentados por YEN \& SCANLON (1975) podem ser encontrados na Tabela 6.1.

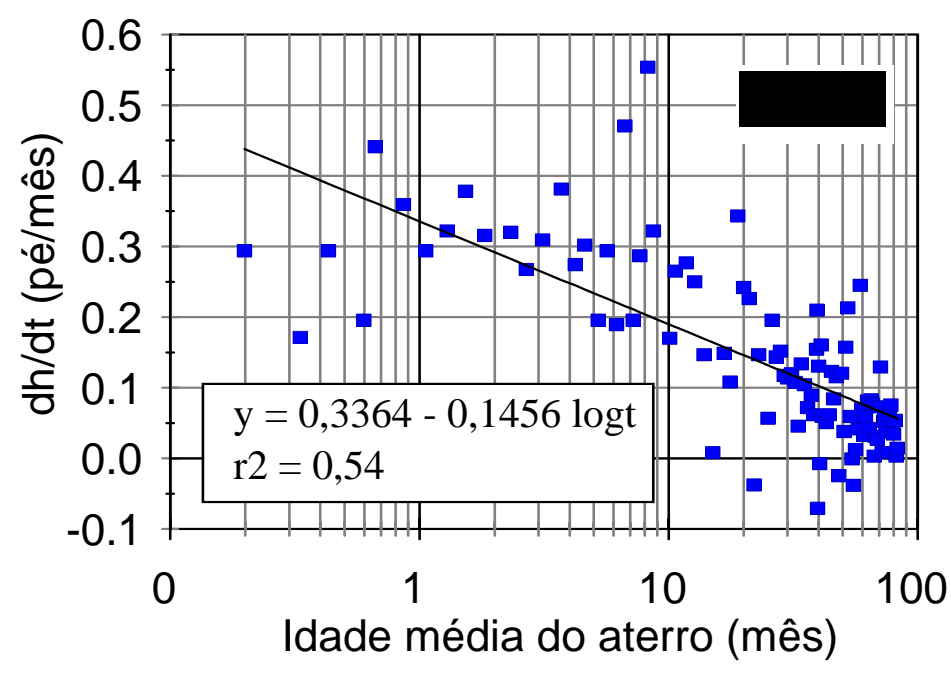

- Pontos observados - Regressão

Figura 6.6 - Taxa de recalque $x$ idade do aterro para o marco MS-11, com altura inicial de RSU de 28,0 metros.

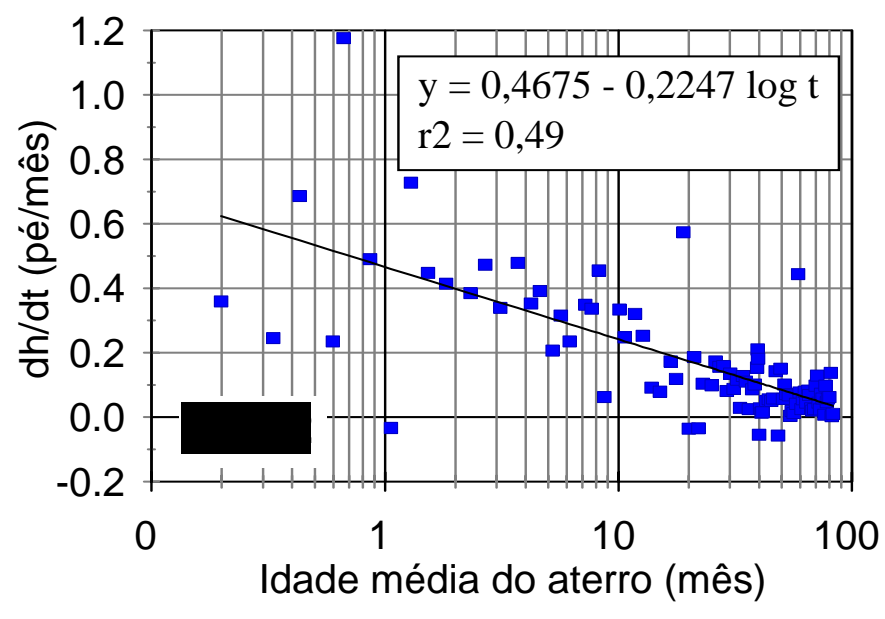

- Pontos observados-Regressão

Figura 6.7 - Taxa de recalque $x$ idade do aterro para o marco MS-12, com altura inicial de RSU de 37,3 metros. 


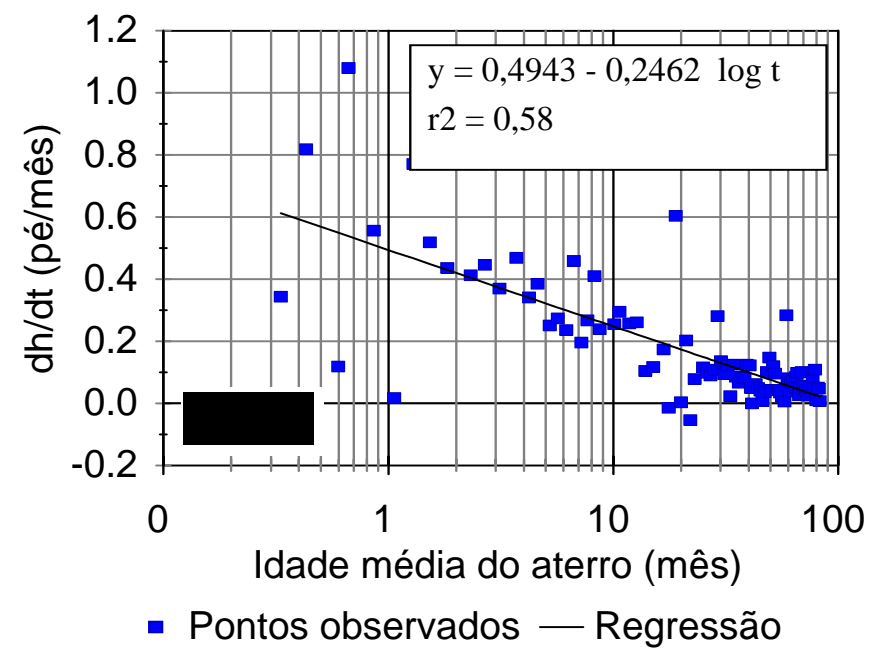

Figura 6.8 - Taxa de recalque $x$ idade do aterro para o marco MS-13, com altura inicial de RSU de 26,3 metros.

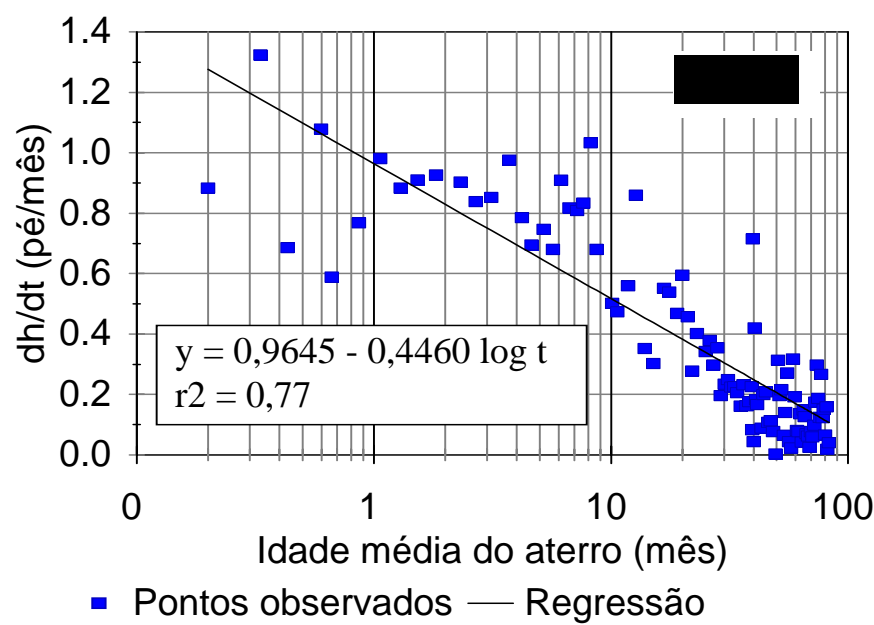

Figura 6.9 - Taxa de recalque $x$ idade do aterro para o marco MS-21, com altura inicial de RSU de 58,6 metros.

Tabela 6.1 - Resultados obtidos do ajuste proposto por YEN \& SCANLON (1975).

\begin{tabular}{|l|c|c|c|c|c|}
\hline \multirow{2}{*}{ Marco } & \multirow{2}{*}{$\begin{array}{c}\mathrm{H}_{0} \\
(\mathrm{pé})\end{array}$} & \multicolumn{2}{|c|}{ Parâmetros ajustados } & \multicolumn{2}{|c|}{ YEN \& SCANLON (1975) } \\
\cline { 3 - 6 } & $\mathrm{a}^{`}$ & $\mathrm{~b}^{`}$ & $\mathrm{a}^{`}=0,00095 \mathrm{H}+0,00985$ & $\mathrm{~b}^{`}=0,00035 \mathrm{H}+0,00509$ \\
\hline MS -11 & 91,80 & 0,336 & 0,146 & 0,097 & 0,037 \\
\hline MS - 12 & 122,29 & 0,467 & 0,225 & 0,126 & 0,048 \\
\hline MS - 13 & 86,22 & 0,494 & 0,246 & 0,0918 & 0,0352 \\
\hline MS - 21 & 192,13 & 0,965 & 0,446 & 0,1923 & 0,0723 \\
\hline
\end{tabular}


SOWERS (1973) adotou um comportamento de recalques, a longo prazo, em aterros sanitários similar à compressão secundária de solo, onde o recalque varia linearmente com o logaritmo do tempo e pode ser expresso por:

$$
\Delta \mathrm{H}=\frac{\mathrm{H}_{\mathrm{o}}}{1+\mathrm{e}_{\mathrm{o}}} \mathrm{C} \alpha \cdot \log \frac{t_{1}+\Delta \mathrm{t}}{t_{1}}
$$

Derivando a equação 6.1, apresentada pelo autor, em função do tempo, obtém -se:

$$
\frac{d h}{d t}=\frac{C \alpha \cdot H}{1+e_{0}} \cdot \frac{0,434}{t}
$$

Incorporando a expressão do coeficiente de compressão secundária $(\mathrm{C} \alpha)$ para as condições sugeridas por SOWERS (1973) como, condição favorável à decomposição (C $\alpha=$ $\left.0,09 \mathrm{e}_{0}\right)$ e condição desfavorável à decomposição $\left(\mathrm{C} \alpha=0,03 \mathrm{e}_{0}\right)$, obtém-se, para cada condição, uma expressão $\{[(\mathrm{dh} / \mathrm{H}) / \mathrm{dt}] . t\}$ em função do índice de vazios inicial do aterro $\left(\mathrm{e}_{0}\right)$ :

a) condição favorável à decomposição:

$$
\frac{d h / H}{d t} \cdot t=0,434 \cdot \frac{0,09 \cdot e_{0}}{1+e_{0}}=\text { cons tan te }
$$

b) Condição desfavorável à decomposição:

$$
\frac{d h / H}{d t} \cdot t=0,434 \cdot \frac{0,03 \cdot e_{0}}{1+e_{0}}=\text { cons tan te }
$$

onde:

$\mathrm{dh}=$ variação da altura do aterro no marco referido $(\mathrm{m}), \mathrm{dt}=$ variação do tempo de medida (dias), $\mathrm{t}=$ tempo médio, $\mathrm{e}_{0}=$ índice de vazios inicial, $\mathrm{H}=$ altura inicial da camada de RSU.

O índice de vazios de cada marco foi estimado a partir das curvas e $x \log \sigma$ obtidas dos ensaios de compressão confinada em laboratório (Fig 4.47 a 4.52), considerando-se a tensão vertical atuando na meia altura da camada de RSU do marco correspondente. No cálculo da tensão vertical foi considerado um peso específico médio para o RSU de $15 \mathrm{kN} / \mathrm{m}^{3}$ (conforme apresenta a figura 4.11). Dessa forma, os valores médios encontrados para o índice de vazios de cada marco foi de:

$$
\begin{aligned}
& \text { MS }-11:(\mathrm{Ho}=28,0) \Rightarrow \sigma_{v}=210 \mathrm{kPa} \Rightarrow \mathrm{e}_{\text {médio }}=1,28 \\
& \mathrm{MS}-12:(\mathrm{Ho}=37,3) \Rightarrow \sigma_{\mathrm{v}}=278 \mathrm{kPa} \Rightarrow \mathrm{e}_{\text {médio }}=1,16 \\
& \mathrm{MS}-13:(\mathrm{Ho}=26,3) \Rightarrow \sigma_{\mathrm{v}}=197 \mathrm{kPa} \Rightarrow \mathrm{e}_{\text {médio }}=1,28 \\
& \mathrm{MS}-21:(\mathrm{Ho}=58,6) \Rightarrow \sigma_{\mathrm{v}}=440 \mathrm{kPa} \Rightarrow \mathrm{e}_{\text {médio }}=1,06
\end{aligned}
$$


A Figura 6.10 apresenta as comparações entre os resultados obtidos dos dados observados e as constantes calculadas segundo as proposições de SOWERS (1973) para as condições favoráveis e desfavoráveis à degradação.

Acima de 1 ano, os valores médios calculados para as constantes $\{[(\mathrm{dh} / \mathrm{H}) / \mathrm{dt}] . t\}$, a partir dos dados observados, estão próximos ou acima do limite superior obtido pela expressão de SOWERS (1973), considerando as condições favoráveis à degradação. Isso mostra que os aterros brasileiros apresentam uma condição mais favorável em termos de decomposição do que aquela apresentada por SOWERS (1973). Possivelmente isso está associado às condições climáticas, que propiciam uma maior degradação, bem como aos altos teores de matéria orgânica presente no resíduo brasileiro. A grande dispersão dos dados apresentada na figura 6.10 é provavelmente em função do processo de leituras em campo.

Outro procedimento para determinação de recalques em aterros sanitários é o procedimento de ajuste empírico proposto por Bjarngard \& Edgers (1990), a partir de dados de monitoramento de recalques em campo (eq. 2.3). As figuras 6.11 a 6.14 apresentam os resultados obtidos desses ajustes matemáticos e a Tabela 6.2 resume estes resultados. Os valores de C' $\alpha_{1}$, e C' $\alpha_{2}$, bem como, o tempo onde ocorre a mudança da inclinação da reta, isto é, o tempo a partir do qual começam efetivamente a atuar os processos de decomposição do RSU, foram obtidos por ajustes matemáticos utilizando o processo dos mínimos quadrados. Nestas figuras também está apresentado o ajuste obtido utilizando o C' $\alpha$ médio, de 0,013 obtido de laboratório. Esse ajuste só é possível para o primeiro trecho da curva, onde tem-se $C^{\prime} \alpha_{1}$ resultante da compressão secundária devido ao fenômeno de creep ou deformação lenta. O segundo trecho, correspondente ao $C^{\prime} \alpha_{2}$, conforme exposto anteriormente, não pode ser determinado em laboratório, pois este além dos fenômenos de creep envolvem os de decomposição físico-química e biológica do resíduo ao longo do tempo, os quais não são contemplados nas medidas de laboratório. Pode-se observar dessas figuras que, os recalques previstos utilizando o $C^{\prime} \alpha_{\text {médio }}$ de laboratório, em geral, ajustaram-se bem aos pontos experimentais.

É importante ressaltar que o efeito da degradação não pode ser ainda medido em laboratório. No entanto, justamente pelas condições de controle que o laboratório oferece, é possível antever ensaios capazes de reproduzir, em um espaço de tempo menor, os processos de degradação e verificar como eles interferem na compressibilidade e em outras características dos resíduos sólidos urbanos.

Por sua vez, a retro- análise de resultados de campo constitui-se, obviamente, em elemento essencial para aferição de hipóteses de projeto e de ensaios de laboratório, pois as medidas em campo incluem todos os fatores e interações presentes no comportamento dos maciços de resíduos. 

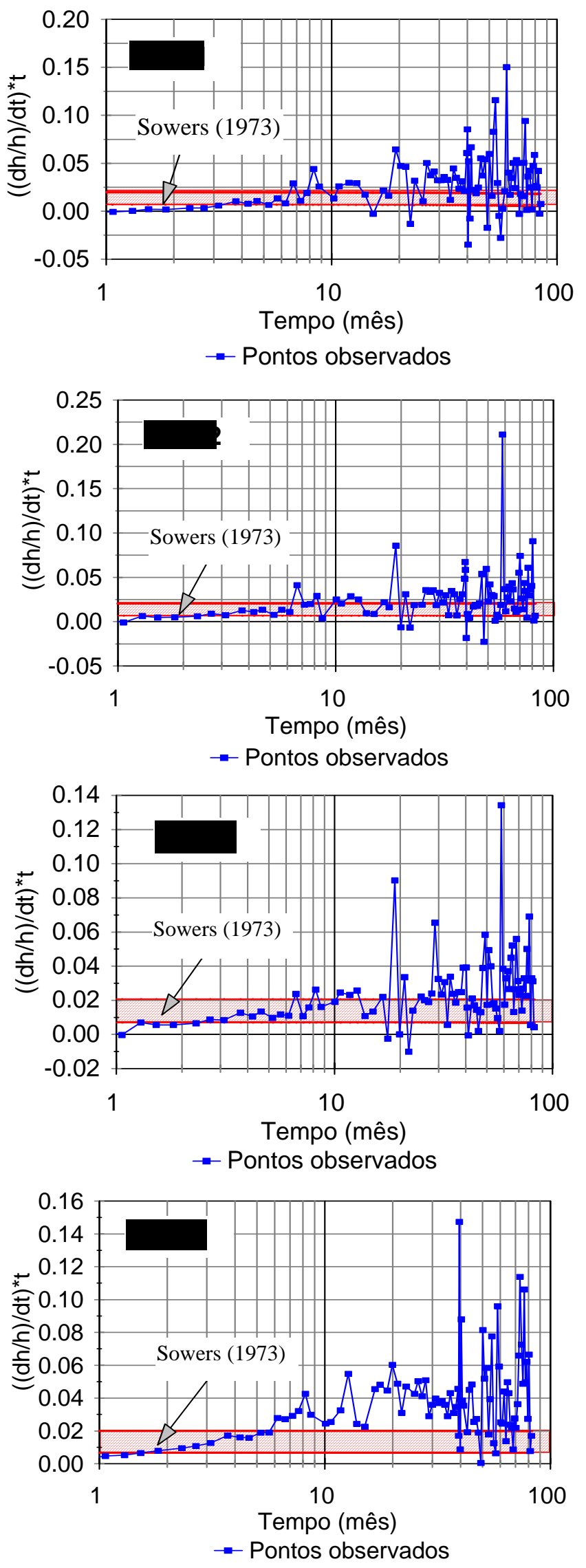

Figura 6.10 - Comparação dos dados observados segundo as propostas de SOWERS (1973). 


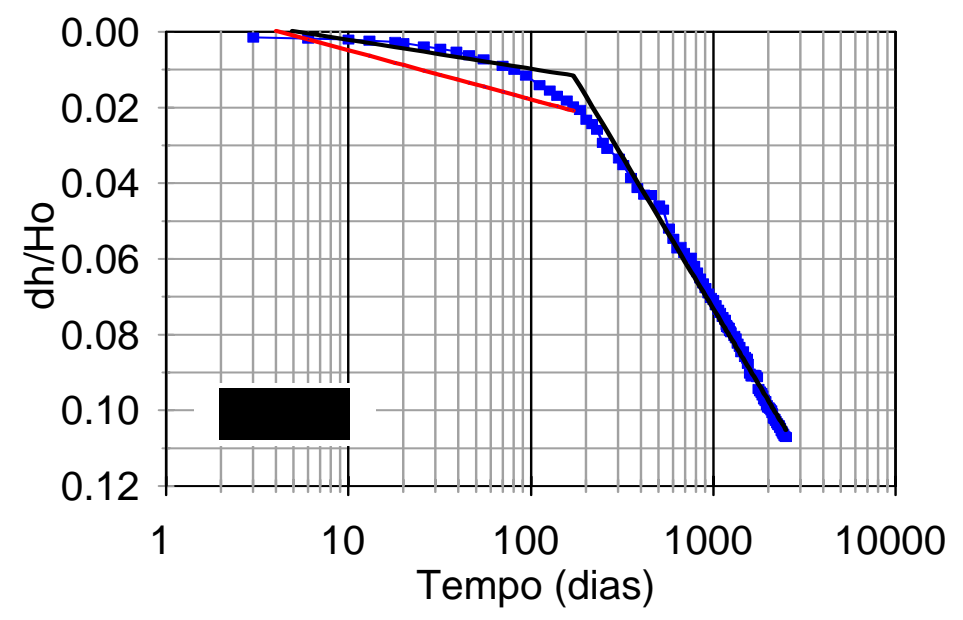

-- Pts. exp. —Pts. ajust. - Pts. prev. Lab.

Figura 6.11 - Ajustes matemáticos a partir de dados de monitoramento de recalques em campo. Marco superficial: MS-11.

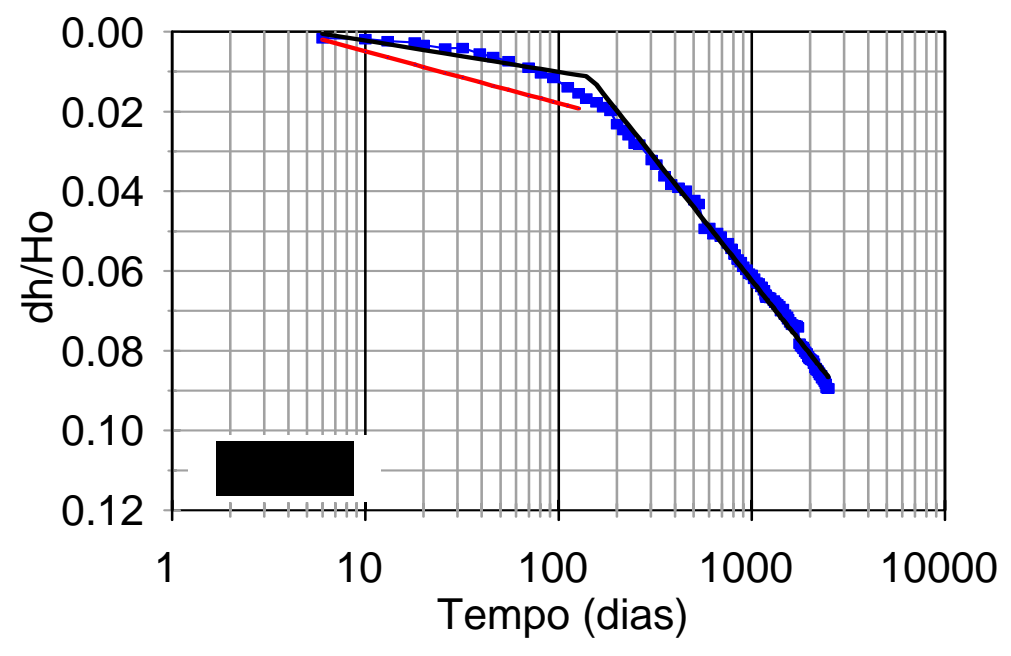

$\rightarrow$ Pts. exp. —Pts. ajust. —Pts. prev. Lab.

Figura 6.12 - Ajustes matemáticos a partir de dados de monitoramento de recalques em campo. Marco superficial: MS-12.

Tabela 6.2 - Parâmetros obtidos do ajuste de dados de campo, procedimento de Bjarngard \& Edgers (1990).

\begin{tabular}{|c|c|c|c|}
\hline \multirow{2}{*}{ Marco } & \multicolumn{3}{|c|}{ Parâmetros ajustados } \\
\cline { 2 - 4 } & $C^{\prime} \alpha_{1}$ & $C^{\prime} \alpha_{2}$ & Tempo crítico (dias) \\
\hline MS - 11 & 0,0085 & 0,0865 & 171,60 \\
\hline$M S-12$ & 0,0079 & 0,0670 & 146,19 \\
\hline$M S-13$ & 0,0117 & 0,0859 & 160,52 \\
\hline$M S-21$ & 0,0109 & 0,0910 & 147,34 \\
\hline
\end{tabular}




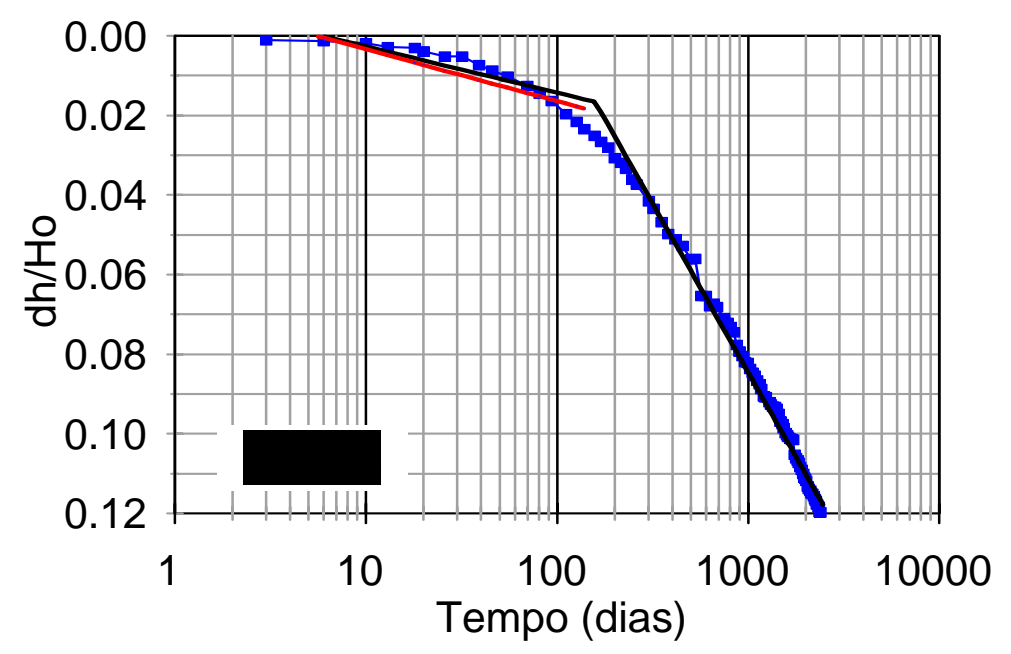

- Pts. exp. - Pts. ajust. - Pts. prev. Lab.

Figura 6.13 - Ajustes matemáticos a partir de dados de monitoramento de recalques em campo. Marco superficial: MS-13.

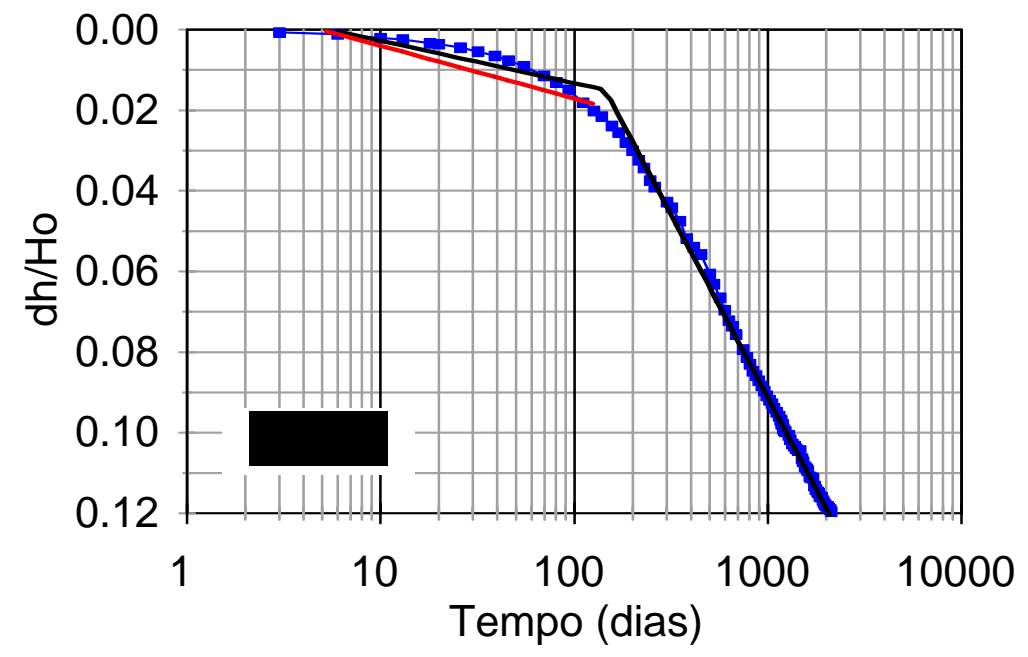

-- Pts. exp. — Pts. ajust. —Pts. prev. Lab.

Figura 6.14 - Ajustes matemáticos a partir de dados de monitoramento de recalques em campo. Marco superficial: MS-21.

Segundo Gibson \& LO e conforme já apresentado nesta revisão bibliográfica, a equação (6.5) pode ser utilizada para representar o comportamento dos recalques diferidos no tempo do RSU. Na equação 6.5, o comportamento do RSU é suposto atender a três parâmetros $(a, b$ e $\lambda)$, os quais podem ser estimados utilizando-se resultados de campo ou de laboratório. A equação 6.6 representa a equação 6.5 escrita de modo a explicitar a razão $(\lambda / b)$, facilitando o seu ajuste e utilizando-se o método dos mínimos quadrados. 


$$
\begin{aligned}
& S_{(t)}=H \varepsilon_{(t)}=H \Delta \sigma\left[\mathrm{a}+\mathrm{b}\left(1-\mathrm{e}^{-\frac{\lambda}{\mathrm{b}} \cdot \mathrm{t}}\right)\right] \\
& \ln \left(1-\frac{\mathrm{S}_{(\mathrm{t})}-H \cdot \Delta \sigma \cdot a}{H \cdot \Delta \sigma \cdot b}\right)=-\frac{\lambda}{\mathrm{b}} \cdot \mathrm{t}
\end{aligned}
$$

onde: $S_{(t)}=$ recalque, $H=$ altura inicial do resíduo, $\varepsilon=$ deformação $(S / H), \Delta \sigma=$ tensão compressiva, a e b = parâmetro de compressibilidade primária e secundária respectivamente, $\lambda / b=$ taxa de compressão secundária, $t=$ tempo decorrido desde $o$ início da aplicação da carga.

Conforme já relatado anteriormente, admite-se que quando da efetuação das medidas de recalque em campo, os recalques advindos da compressão primária do RSU já tinham ocorrido, de sorte que estas medidas incorporam a parcela (H. $\Delta \sigma . \mathrm{a})$, proveniente da compressão primária. O parâmetro de compressibilidade primária (a), não pôde portanto ser determinado a partir das medidas de recalques efetuadas. Por outro lado, conforme se pode observar na equação 6.6, o parâmetro b não pôde ser explicitado, de modo que o ajuste da equação 6.6 aos dados experimentais foi feito por meio de iterações sucessivas, até obtenção do melhor coeficiente de determinação. Para determinação da tensão compressiva foi considerado um peso específico médio para o RSU de $15 \mathrm{kN} / \mathrm{m}^{3}$. Os resultados obtidos desses ajustes estão apresentados visualmente na Figura 6.15 enquanto que a Tabela 6.3 apresenta um resumo desses resultados. Observa-se dos resultados apresentados, que o recalque do resíduo sólido urbano, ao longo do tempo, pôde ser modelado satisfatoriamente pelo modelo de Gibson \& Lo (EDIL et al. 1990).

Tabela 6.3 - Parâmetros empíricos obtidos do ajuste de dados de campo, procedimento de Gibson \& Lo.

\begin{tabular}{|c|c|c|c|}
\hline \multirow{2}{*}{$\begin{array}{c}\text { Marco } \\
\text { Superficial }\end{array}$} & \multicolumn{3}{|c|}{ Parâmetros ajustados } \\
\cline { 2 - 4 } & $\begin{array}{c}\lambda / \mathbf{b} \\
\mathbf{( 1 / d i a )}\end{array}$ & $\begin{array}{c}\mathbf{b} \\
\mathbf{( 1 / k P a )}\end{array}$ & $\mathbf{R}^{\mathbf{2}}$ \\
\hline MS-11 & $9,91 \times 10^{-4}$ & $5,5 \times 10^{-4}$ & 0,996 \\
\hline MS-12 & $1,23 \times 10^{-3}$ & $3,3 \times 10^{-4}$ & 0,987 \\
\hline MS-13 & $1,12 \times 10^{-3}$ & $6,5 \times 10^{-4}$ & 0,991 \\
\hline MS-21 & $1,30 \times 10^{-3}$ & $3,0 \times 10^{-4}$ & 0,995 \\
\hline
\end{tabular}




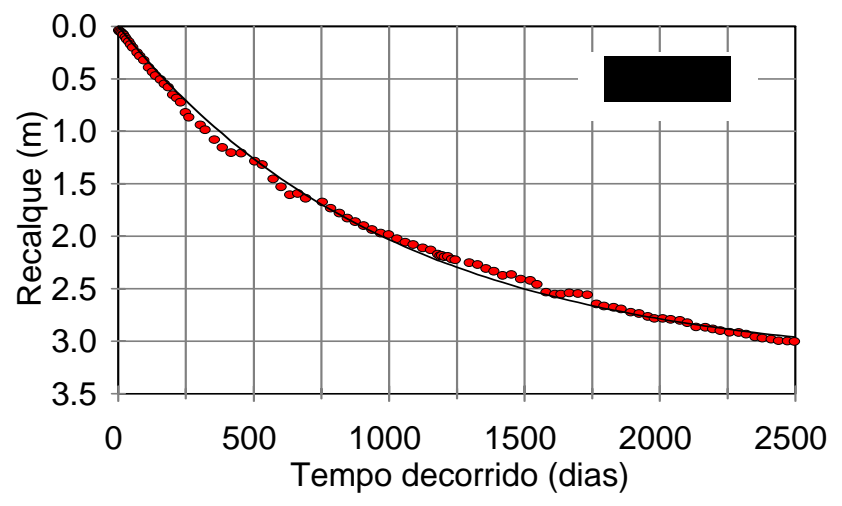

- Pontos experimentais — Pontos ajustados

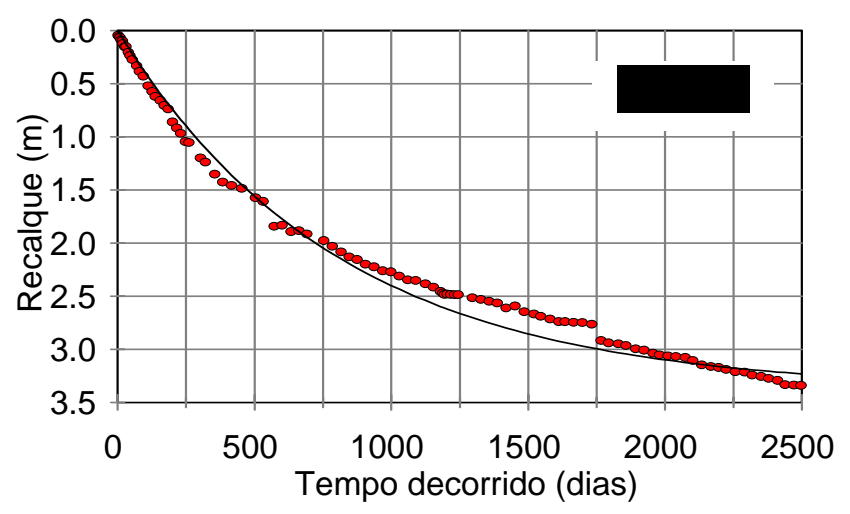

- Pontos experimentais - Pontos ajustados

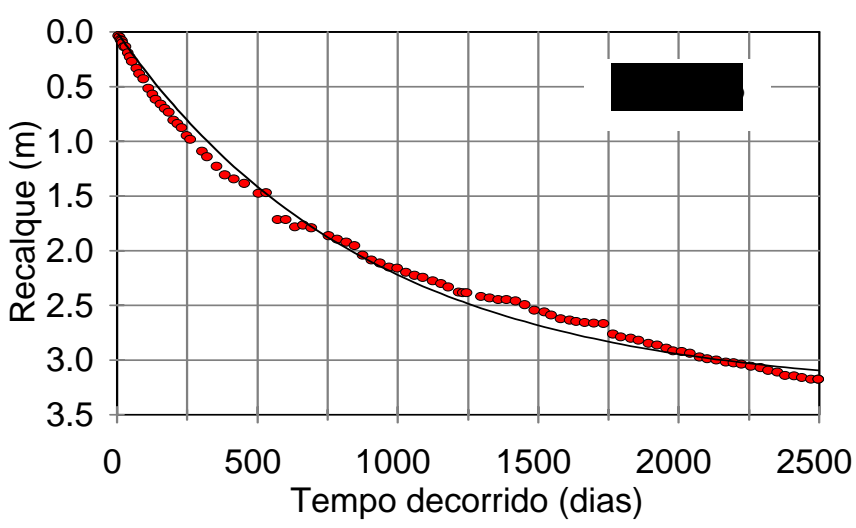

- Pontos experimentais — Pontos ajustados

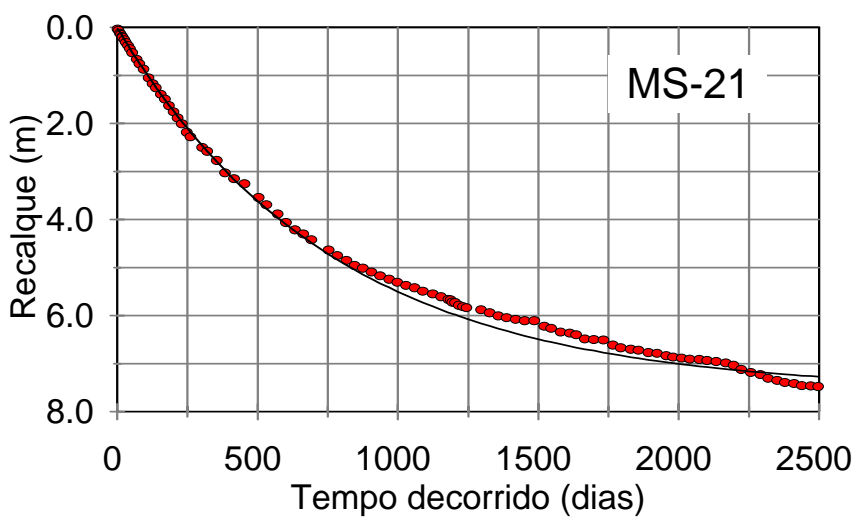

- Pontos experimentais — Pontos ajustados

Figura 6.15 - Resultados obtidos do modelo de Gibson \& Lo. 


\section{7 - CONCLUSÕES}

\section{1 - INVESTIGAÇÕES IN SITU}

As investigações em maciços de resíduos sólidos urbanos são extremamente dependentes do tipo de aterro e materiais a serem investigados. Para o aterro estudado, apesar das dificuldades na ultrapassagem de materiais mais resistentes e deflexão das hastes do equipamento, bem como, pelo baixo rendimento da perfuração, foi possível executar, com sucesso, os trabalhos de investigações no maciço de resíduos sólidos urbanos empregando-se as técnicas consagradas pela mecânica dos solos. Das investigações in situ realizadas no Aterro Sanitário Bandeirantes verificou-se que a resistência à penetração $(\mathrm{N})$ do amostrador SPT aumenta com a profundidade. O SPT médio é cerca de 7 golpes para as camadas mais superficiais e alcança 12 golpes para as camadas mais profundas $(10-30 \mathrm{~m})$. Esses valores permitiram estimar, uma faixa de variação de $26^{\circ}-32^{\circ}$ para o ângulo de atrito, empregando correlações propostas para solos arenosos ou coesão entre $90-150 \mathrm{kPa}$, empregando correlações para solos argilosos. O coeficiente de permeabilidade a água medido no ensaio de infiltração em furo de sondagem variou entre $10^{-4}$ a $10^{-6} \mathrm{~cm} / \mathrm{seg}$ e apresentou uma tendência a diminuir com a profundidade.

As resistências de ponta (qc) e lateral (q $\ell$ ), medidas no ensaio de penetração do cone, apresentaram valores típicos entre 2500 - $7500 \mathrm{kPa}$ e entre $100-400 \mathrm{kPa}$, respectivamente. Os valores típicos obtidos permitiram estimar uma faixa de variação de $29^{\circ}$ - $33^{\circ}$ para o ângulo de atrito efetivo, utilizando correlações existentes para solos arenosos ou coesão entre $45-120 \mathrm{kPa}$, empregando correlações para solos argilosos.

Das investigações in situ realizadas, a mais problemática foi a estimativa do peso específico através da pesagem dos resíduos coletados dos furos de trado, devido aos processos de relaxação do furo e seu respectivo fechamento, o que resultou em medidas errôneas de pesos e volumes. Após algumas correções, obteve-se uma estimativa imprecisa da variação do peso específico do RSU, sendo que o limite inferior encontrado foi de $8 \mathrm{kN} / \mathrm{m}^{3}$ e o limite superior de $15 \mathrm{kN} / \mathrm{m}^{3}$.

Obtiveram-se do ensaio cross-hole, velocidades de propagação da onda de cisalhamento variando entre 93 a $120 \mathrm{~m} / \mathrm{seg}$ e da onda de compressão entre 190 $230 \mathrm{~m} / \mathrm{seg}$. Os módulos de deformação e de cisalhamento, calculados a partir das velocidades dessas ondas, apresentaram um ligeiro aumento com a profundidade e com o peso específico considerado para o resíduo. Para peso específico de $12 \mathrm{kN} / \mathrm{m}^{3}$, os valores 
médios obtidos para G e E são da ordem de 14,5 e 40MPa, respectivamente. O módulo de deformação obtido do cross-hole, para peso específico de $12 \mathrm{kN} / \mathrm{m}^{3}$, está muito próximo do valor $E_{0}$ obtido por meio de ensaios triaxiais. O coeficiente de Poisson médio obtido para o RSU estudado foi de 0,33 .

\section{2 - ENSAIOS DE CARACTERIZAÇÃO DOS RESÍDUOS SÓLIDOS URBANOS COLETADOS}

O resíduo estudado apresentou uma composição média, obtida da segregação manual, de $55 \%$ de fração pastosa (12\% de matéria orgânica e $43 \%$ de inertes), $4 \%$ de madeira, $10 \%$ de pedra, $3 \%$ de têxteis, $2 \%$ de borracha, $17 \%$ de plásticos, $2 \%$ de vidro, $2 \%$ de papel e $5 \%$ de metal. A umidade in situ do RSU, determinada em termos de base seca e empregando o método da estufa $\left(70^{\circ} \mathrm{C}\right)$, é bastante variável, apresentando valores desde $50 \%$ até mais de 100\%. Os baixos valores de STV (120 - $270 \mathrm{mg} / \mathrm{g})$, DQO $(100-175 \mathrm{mg} / \mathrm{g})$ e pH próximo da neutralidade indicaram que o resíduo já atingiu um avançado processo de degradação, o qual é coerente com a idade do material (15 anos de aterramento). O resíduo foi classificado como resíduo classe II (não - inerte), com concentrações de ferro, manganês e cromo acima dos padrões indicados pela norma.

Obtiveram-se para as amostras representativas de RSU coletado, pesos específicos das partículas sólidas, segundo o método empregado para solos, de $23,35 \mathrm{kN} / \mathrm{m}^{3}$ para a amostra T1B, de $22,41 \mathrm{kN} / \mathrm{m}^{3}$ para amostra T2A e de $25,07 \mathrm{kN} / \mathrm{m}^{3}$ para a T2B.

\section{3 - ENSAIOS DE COMPRESSÃO TRIAXIAL}

As curvas tensão - deformação, obtidas a partir de ensaios triaxiais, mostraram um comportamento típico de aumento das tensões com o aumento das deformações axiais, sem atingir um pico de ruptura. O RSU enrijece com o aumento das deformações. Assim os parâmetros de resistência ao cisalhamento do RSU (c e $\phi$ ) são dependentes das deformações axiais e tendem a aumentar com o aumento destas. Descartando-se os resultados da amostra T2B, contaminada com solo de cobertura das células, obtiveram-se de corpos de prova de $15 \times 30 \mathrm{~cm}$ e considerando deformações axiais de $20 \%$, ângulo de atrito de cerca de $27^{\circ}$ e coesão variando de 42 a $55 \mathrm{kPa}$. Já para corpos de prova de $20 \times 40 \mathrm{~cm}$, o ângulo de atrito é da ordem de $21^{\circ}$ e a coesão de 45 a $60 \mathrm{kPa}$.

As dimensões dos corpos de prova parecem influenciar os resultados de resistência ao cisalhamento obtidos para o resíduo estudado. Os corpos de prova de menor dimensão, no caso $15 \times 30 \mathrm{~cm}$, apresentaram maior resistência que os corpos de prova de $20 \times 40 \mathrm{~cm}$. Registre-se que para as amostras T2A e T2B, os valores obtidos são de até $25 \%$ maiores, 
já a amostra T1B atinge valores superiores a 40\%. Acredita-se que o acréscimo na resistência para corpos de prova de menor dimensão pode, em parte, ser creditada à heterogeneidade das amostras, mas o efeito reforço, dado pelos materiais fibrosos, tem um papel importante neste comportamento.

Não se conseguiu com os resultados disponíveis identificar a redução da resistência ao cisalhamento em função da degradação do resíduo, a partir dos resultados de ensaios triaxiais $C D$, executados em amostras pertencentes a horizontes diferentes. Embora as amostras T1B (horizonte B, visualmente mais degradado) e T2A (horizonte A, menos degradado) pertençam a horizontes diferentes, estas amostras apresentaram, considerando a mesmo diâmetro de corpo de prova, coesão e ângulo de atrito bem próximos, especialmente no intervalo de deformações entre 15 e $25 \%$.

Os módulos de elasticidade determinados de ensaios triaxiais fazendo ciclos de carga e descarga, apresentaram um aumento com as pressões de confinamento da amostra, expresso pela equação $E(\mathrm{MPa})=0,068 \sigma_{3}+9,85$ com $r^{2}=0,998$ e $\sigma_{3}$ em $\mathrm{kPa}$. Os módulos de elasticidade iniciais $\left(E_{0}\right)$, calculados a partir de resultados dos ensaios triaxiais, são da ordem de 35 a 40MPa e estes tendem a reduzir com as deformações, atingindo valores entre 1 a $4 \mathrm{MPa}$, a partir de 10\% de deformação axial.

Dos ensaios CU executados, verificou-se que o comportamento de resistência do RSU é bastante influenciado pelo desenvolvimento de altas pressões neutras positivas, cujos valores máximos estão próximos ao da tensão de confinamento da amostra. Os valores de t-s` obtidos do ensaio não-drenado posicionaram-se, em geral, acima da envoltória drenada, dificultando a interpretação dos resultados em termos de tensão efetiva.

Os parâmetros de resistência obtidos para o RSU estudados são relativamente altos e são coerentes com algumas observações de campo, onde pôde-se verificar cortes em taludes sem nenhuma evidência de ruptura. Da comparação da resistência obtida para o resíduo estudado com a resistência apresentada pela literatura especializada, verificou-se que os resultados obtidos para as amostras T2A e T1B caíram na faixa indicada para dados de laboratório e acima da faixa sugerida para projetos por SINGH \& MURPHY (1990). Por outro lado, os resultados da amostra T2B, que se apresentou bastante contaminada com solo de cobertura das células, posicionaram-se na faixa de SINGH \& MURPHY (1990). Ressalta-se a necessidade de verificação da resistência em cada caso, pois os resultados são influenciados por fatores como composição e estado de alteração do RSU e até mesmo tipo de ensaio executado.

\section{4 - ENSAIOS DE COMPRESSÃO CONFINADA}

O resíduo sólido domiciliar estudado apresentou elevada compressibilidade, sendo a compressão secundária bastante pronunciada, apresentando uma relação linear com o logaritmo do tempo. 
Obtiveram-se, para os ensaios de compressão confinada em laboratório, valores médios de 0,032 para o índice de compressão secundária $\left(C_{\alpha}\right)$, de 0,013 para o coeficiente de compressão secundária $\left[C_{\alpha}^{\prime}=C_{\alpha} /\left(1+e_{o}\right)\right]$ e de 0,21 para o coeficiente de compressão primária ( $\mathrm{Cc}^{\prime}$ ), necessários no estudo de recalques. Com os dados disponíveis, não foi possível estabelecer uma clara tendência de variação de $\mathrm{C}_{\alpha}^{\prime}$ com a sobrecarga ou com o peso específico, embora pareça haver um crescimento desse parâmetro com o aumento da sobrecarga.

Para os dados de monitoramento dos recalques no Aterro Sanitário Bandeirantes, obtiveram-se coeficientes de compressão secundária $\left[C_{\alpha}^{\prime}=C_{\alpha} /\left(1+e_{o}\right)\right]$ variáveis em função do logaritmo do tempo, sendo que este aumenta após um certo tempo crítico, possivelmente associado aos processos de degradação do resíduo. Para a primeira etapa, associada essencialmente a fenômenos de fluência lenta, obteve-se para $C_{\alpha 1}^{\prime}$, um valor médio em torno de 0,010 , muito próximo ao valor de laboratório. Já o valor médio do coeficiente de compressão secundária do segundo trecho $\left(\mathrm{C}_{\alpha_{2}}^{\prime}\right)$ é de 0,083 , sendo que este possivelmente é associado tanto aos fenômenos de creep como aos de degradação do RSU com o tempo. O $C_{\alpha 1}^{\prime}$ obtido foi de apenas $12 \%$ do valor obtido para $C_{\alpha 2,}^{\prime}$ o que realça a importância da decomposição do resíduo no estudo da compressibilidade.

Os conceitos da mecânica dos solos, embora talvez não totalmente apropriados, têm sido os pontos de partida para estudo e interpretação do comportamento mecânico do RSU. Ressalta-se a necessidade de desenvolver modelos mais avançados, que contemplem as particularidades do material em análise.

O efeito da degradação não pode ser ainda medido em laboratório. No entanto, justamente pelas condições de controle que o laboratório oferece, é possível antever ensaios capazes de reproduzir, em um espaço de tempo menor, os processos de degradação e verificar como eles interferem na compressibilidade e em outras características dos resíduos sólidos urbanos. Por sua vez, a retro-análise de resultados de campo constitui-se, obviamente, em elemento essencial para aferição de hipóteses de projeto e de ensaios de laboratório, pois as medidas em campo incluem todos os fatores e interações presentes no comportamento dos maciços de resíduos.

\section{5 - SUGESTÕES PARA TRABALHOS FUTUROS}

- Determinar o peso específico in situ do resíduo, através do uso de sonda de raios gama ou através de pesagem do resíduo ao longo da profundidade, utilizando o furo de sondagem revestido, com todo cuidado possível.

- Estudar mais detalhadamente as correlações entre as velocidades de propagação das ondas de cisalhamento e compressão com os valores de resistência de ponta (qc), 
ensaiando até maiores profundidades do aterro e adotando martelo e geofone na mesma posição.

- Verificar a influência das fibras na resistência do resíduo sólido urbano. Poderiam ser executados ensaios triaxiais com diferentes teores de fibras, isto é, utilizar o mesmo resíduo mas em estado de alteração diferente. Isso implica o desenvolvimento de processos de aceleração da degradação do resíduo no laboratório.

- Tentar identificar o fator que influência a resistência do resíduo quando consideram-se amostras com dimensões diferentes. Um caminho seria tentar associar o comportamento dos resíduos com os de solos reforçados, mas tendo-se em mente as diferenças quanto à heterogeneidade dos materiais de reforço do RSU em termos de composição e propriedades tensão - deformação.

- Verificar a influência dos efeitos da biodegradação dos RSU nos recalques dos aterros ao longo do tempo. No laboratório poderiam ser executados ensaios com temperatura, umidade e nutrientes controlados (células reatores) para acelerar os recalques.

- Executar ensaios triaxiais e de compressão confinada em laboratório com o resíduo triturado e com resíduo mais novo.

- Verificar a influência da pressão neutra gerada pelo biogás do aterro no comportamento mecânico dos resíduos sólidos urbanos.

- Estudar a permeabilidade do resíduo à água como também à líquidos percolados executando ensaios em laboratório em amostras de maior dimensão. 


\section{8 - REFERÊNCIAS BIBLIOGRÁFICAS}

\section{NORMAS TÉCNICAS}

ABNT - 1987. Amostragem de Resíduos - Procedimento - NBR 10007/87.

ABNT - 1987. Lixiviação de Resíduos - Procedimento - NBR 10005/87.

ABNT - 1987. Resíduos Sólidos: Classificação - NBR 10004/87.

ABNT - 1987. Solubilização de Resíduos - Procedimento - NBR 10006/87.

ABNT - Apresentação de Projetos de Aterros de Resíduos Sólidos urbanos. - NBR 8419.

ABNT - 1984. Determinação da Massa Específica. Método de Ensaio. - NBR 6508/84.

ABNT - 1980. Execução de Sondagens de Simples Reconhecimento dos Solos. Método de Ensaio. - NBR 6484/80.

ABNT - 1991. Solo. Ensaio de Penetração do Cone "in situ" (CPT). NBR 3406/91.

\section{REFERÊNCIAS BIBLIOGRÁFICAS}

ABARZUA, R. E.; NAREA, M. S. (1992). La Geotecnia en la Construccion Y Diseño de Vertederos Sanitarios. Resíduos Urbano e Industrial, nํㅜ, nov - dez 1992, BilbaoEspanha, p.33-36.

ABGE (1981). Ensaios de Permeabilidade em Solos - Orientações para sua execução no campo. Associação Brasileira de Geologia de Engenharia, Boletim 04, janeiro de 1981.

ABRAMENTO, M. (1995). Durabilidade e Comportamento a Longo Prazo de Geossíntéticos. Parte II: Durabilidade dos Materiais. $2^{\underline{0}}$ SIMPÓSIO BRASILEIRO SOBRE APLICAÇÕES DE GEOSSINTÉTICOS, São Paulo, junho de 1995, p.227 - 235. 
ANTONIUTTI NETTO, L.; VAL, E. C. \& ABREU, R. C. (1995). Desempenho de Piezômetros Vector em Aterros Sanitários. III SIMPÓSIO SOBRE BARRAGENS DE REJEITOS E DISPOSIÇÃO DE RESÍDUOS - REGEO'95, v.II, Ouro Preto/ MG, p.593-601.

AREIAS, L.; VAN IMPE, W. F.; KNIGHT, M. A; OTHMAN, M. A. (1998). Liner System Regulations for MSW Landfills in Belgium, Canadá. In: Proc. of the Third International Congress on Environmental Geotechnics, Lisboa-Portugal, 7-11 September 1998, vol.1, p. 3 - 8.

BENSON, C. H.; BOSSCHER, P. J.; LANE, D. T. \& PLISKA, R. J. (1994). Monitoring System for Hydrologic Evaluation of Landfill Covers. Geotechnical Testing Journal, GTJODJ, ASTM, vol.17, n.2, June 1994, p.138-149.

BENVENUTO, C. \& CUNHA, M. A. (1991). Escorregamento em Massa de Lixo no Aterro Sanitário Bandeirantes em São Paulo. II SIMPÓSIO SOBRE BARRAGENS DE REJEITO E DISPOSIÇÃO DE RESÍDUOS - REGEO’91 - V.2, p.55-66.

BENVENUTO, C. (1995). A Concepção e a Construção de Aterros Sanitários. III SIMPÓSIO SOBRE BARRAGENS DE REJEITOS E DISPOSIÇÃO DE RESÍDUOS REGEO'95, v.II, Ouro Preto/MG, p.551-561.

BENVENUTO, C., CRUZ, P. T. \& MIRANDA, I. C. S. B (1994). A Metodologia Geotécnica Aplicada à Disposição dos Resíduos Sólidos. In: SEMINÁRIO SOBRE GEOTECNIA DE ATERROS PARA DISPOSIÇÃO DE RESÍDUOS - GEOAMBIENTAL'94. Rio de janeiro, abril, 1994, p.1.33-1.48.

BIDONE, F. R. A. \& POVINELLI, J. (1999). Conceitos Básicos de Resíduos Sólidos. São Carlos: EESC /USP, 120p.

BIENER, E.; SASSE, T.; WEMHOFF, T. \& BIESIADA, W. (1995). Stability and Settlement Problems in Old Landfill Remediation. Proceedings Sardinia 95, Fifth International Landfill Symposium, S. Margherita di Pula, Cagliari, Italy, October 1995, p.843-853.

BLENGINO, A. M.; VEGGI, S.; MANASSERO, M.; ROSSELLO, A. \& SPANNA, C. (1996). Investigation, Monitoring System and Stability Analysis of an Old Canyon. In: Proc. Of The Second International Congress on Environmental Geotechnics, ISBN 90 5410848 7, Osaka, Japan, A.A.Balkema, v.2, p. 629-634.

BONAPARTE, R. (1995). Long-Term Performance of Landfills. Geoenviromental 2000. Geotechnical Special Publication n 46, ASCE, vol.1, p.514 - 553. Ed. Yalcin B. Acar and David E. Daniel, New Orleans. 
BOUAZZA, A.; VAN IMPE, W. F. \& HAEGEMAN, W. (1996). Quality Control of Dynamic Compaction in Municipal Solid Waste Fills. In: Proc. Of The Second International Congress on Environmental Geotechnics, ISBN 905410848 7, Osaka, Japan, A.A.Balkema, v.2, p. 635-640.

BOUTWELL, G. P.; FIORE, V. A (1995). Settlement of Clay Cover on Saturated Garbage. In: Geonviromental 2000. Geotechnical Special Publication n 46, ASCE, Ed. Yalcin B. Acar and David E. Daniel, New Orleans, p.964-979.

BROOKTER, T. J. \& HAM, R. K. (1982). Stabilization of Solid Waste in Landfills. In: Proc. Journal of the Environmental Engineering Division, ASCE, v.108(6), Dec.1982, p.1089- 1100 .

CARROLL Jr., R. G. \& CHOUERY-CURTIS, V. (1991). Geogrid Reinforcement in Landfill Closures. Geotextiles and Geomembranes, n.10, p.471-486.

CARTIER, G. \& BALDIT, R. (1983). Comportement Géotechnique des Décharges de Résidus Urbains. Bulletin de Liaison des Laboratoires des Ponts et Chaussés, n. 128, p.55-64, Paris-França.

CEPOLLINA, M.; KAIMOTO, L. S. A. \& LUDEMANN, S. M. (1994). Investigações de Condicionantes Geotécnicos de Maciços Sanitários. X CONGRESSO BRASILEIRO DE MECÂNICA DOS SOLOS E ENGENHARIA DE FUNDAÇÕES, v.3. Foz do Iguaçu, novembro, 1994, p.979-986.

CETESB (1993). Resíduos Sólidos Industriais - 2a edição.

CODUTO, D. P. \& HUITRIC, R. (1990). Monitoring Landfill Movements Using Precise Instruments. Geotechnics of Waste Fills - Theory and Practice, ASTM STP 1070, Arvid Landva and G. David Knowles, Eds., American Society for Testing and Materials, Philadelphia, 1990, p.358-370.

coumoulos, D. G.; KORYAlOS, T. P.; METAXAS, I. L. \& GIOKA, D. A. (1995). Geotechnical Investigation at the Main Landfill of Athens. Proceedings Sardinia 95, Fifth International Landfill Symposium, S. Margherita di Pula, Cagliari, Italy, October 1995, p.885 - 895.

COWLAND, J. W. \& KOOR, N. P. (1995). Stability Considerations for Steep Valley Landfills. Proceedings Sardinia 95, Fifth International Landfill Symposium, S. Margherita di Pula, Cagliari, Italy, October 1995, p.790 - 800. 
COWLAND, J. W.; TANG, K. Y.\& GABAY, J. (1993). Density and Strength Properties of Hong Kong Refuse. Proceedings Sardinia 93, Fourth International Landfill Symposium, S. Margherita di Pula, Cagliari, Italy, October 1993, p.1433 - 1446.

DANIEL, D. E. \& BOWDERS, J. J. (1996). Waste Containment Systems by Geosynthetics. In: Proc. of the Second International Congress on Environmental Geotechnics, Preprint of special lectures, Osaka, Japan, A.A.Balkema, v.3, p. 1275-1291.

DANIEL, D. E. (1993). "Clays Liners". Chapter 7, In: Geotechnical Practice for Waste Disposal, Chapman \& Hall, London.

DANIEL, D. E. (1998). Landfills for Solid and Liquid wastes. In: Proc. of the Third International Congress on Environmental Geotechnics, Lisboa, Portugal, Sêco e Pinto (ed.), Balkema, Rotterdam, ISBN 905809 006x, p. 1231-1246.

DEL-GRECO, O.; OGGERI, C. (1993). Geotechnical Parameters of Sanitary Wastes. In: IV INTERNATIONAL LANDFILL SYMPOSIUM - SARDINIA'93. S. Margherita di Pula, Italy, october, 1993, 12p.

DEZEEUVW, R. E.; HANEY, E. B. \& WENGER, R. (1976). Instalações para Trituração de Resíduos Sólidos nos Estados Unidos e Canadá. Revista Limpeza Pública, nº 7 (trancrição de Solid Wastes Management, abril de 1976), p.16-23.

DHOWIAN, A . W.; EDIL, T. B. (1981). Consolidation Behavior of Peats. Geotechnical Testing Journal, GTJODJ, vol. 3, No. 3, sept. 1981, p. 105- 114.

DUNN, R. J. (1995). Design and Construction of Foundations Compatible with Solid Waste. Landfill Closures - Environmental Protection and Land Recovery, Geotechnical special publication No. 53, ASCE, p.139-159.

EDGERS, L.; NOBLE, J. J.; WILlIAMS, E. (1992). A Biologic Model for Long Term Settlement in Landfills. In: Proc. of the Mediterranean Conference on Environmental Geotechnology, Usmen \& Acar (eds), Balkema, ISBN 905410 0559, p.177 - 184.

EDIL, T. B.; RANGuette, V. J. e WUELlNer, W. W. (1990) Settlement of Municipal Refuse. Geotechnics of Waste Fills - Theory and Practice, ASTM STP 1070, Arvid Landva and G. David Knowles, Eds., American Society for Testing and Materials, Philadelphia, 1990, p.225-239.

EL-FADEL, M. \& AL-RASHED, H. (1997). Settlement in Municipal Solid Waste landfills. In: Proc. the Thirteenth International Conference on Solid Waste Technology and Management, v.2, Philadelphia. 
ELIS, V. R. \& ZUQUETTE, L. V. (1996). Caminhamento Elétrico na Investigação de Depósitos de Resíduos. 8‥ CONGRESSO BRASILEIRO DE GEOLOGIA DE ENGENHARIA, Rio de Janeiro, Setembro de 1996, v.1, p.39-48.

ELIS, V. R. (1998). Avaliação da Aplicabilidade de Métodos Elétricos de Prospeção Geofísica no Estudo de Áreas Utilizadas para Disposição de Resíduos. São Paulo, 1998, 264p. Tese (Doutoramento). IGCE/ Unesp/ Rio Claro.

ENGECORPS-Corpo de Engenheiros Consultores (1996). Rel: 064-SSO-NOD-B173. Estado da Arte dos Aterros Sanitários- Partell, 26/04/96 - São Paulo, 233p.

FANG, H. Y. (1993). Engineering Behavior of Urban Refuse, Compaction Control and Slope stability Analysis of Landfills. In: Proc. International conference Green'93, Waste Disposal by Landfill - GREEN'93, Sarsby (ed), Balkema, Rotterdam, ISBN 905410 3566 , p. $47-72$.

FARQUHAR, G. J.(1989). Leachate: Production and Characterization. Canadian. Journal. Civ. Eng., v.16, p. $317-257$.

GABR, M. A. \& VALERO, S. N. (1995). Geotechnical Properties of Municipal Solid Waste. Geotechnical Testing Journal, GTJODJ, v.18, nํ2, June 1995, p.241-251.

GANDOLLA, M.; DUGNANI, L.; BRESSI, G. \& ACAIA, C. (1994). Determinação dos Efeitos do Recalque Sobre os Depósitos de Lixo Sólido Municipal. SIMPÓSIO INTERNACIONAL DE DESTINAÇÃO DO LIXO, novembro de 1994, Salvador, p.191-211.

GIACHETI, H. L. (1991). Estudo Experimental de Parâmetros Dinâmicos de Alguns Solos Tropicais do Estado de São Paulo. São Paulo, 1991, v.1, 232p. Tese (Doutoramento) - Escola de Engenharia de São Carlos, Universidade de São Paulo.

GIFFORD, G. P.; LANDVA, A. O. \& HOFFMAN, V. C. (1990). Geotechnical Considerations When Planning Construction on a Landfill. Geotechnics of Waste Fills - Theory and Practice, ASTM STP 1070, Arvid Landva and G. David Knowles, Eds., American Society for Testing and Materials, Philadelphia, 1990, p.41-55.

GOMES, L. P. Estudo da Caracterização Física e da Biodegradabilidade dos Resíduos Sólidos Urbanos em Aterros Sanitários. São Paulo, 1989. 167p. Dissertação (Mestrado) - Escola de Engenharia de São Carlos, Universidade de São Paulo.

GOMES, L. P.; FLECK, A. \& CONCEIÇÃO, D. C. (1998). Avaliação dos Recalques em Sistemas - Piloto de Aterramento de Resíduos Sólidos Urbanos. II SIMPÓSIO 
INTERNACIONAL DE QUALIDADE AMBIENTAL - GERENCIAMENTO DE RESÍDUOS E CERTIFICAÇÃO AMBIENTAL, outubro, Porto Alegre, p. 393 - 399.

GOTTELAND, P.; LEMARÉCHAL, D. \& RICHARD, P. (1995). Analysis and Monitoring of the Stability of a Domestic Waste Landfill. Proceedings Sardinia 95, Fifth International Landfill Symposium, S. Margherita di Pula, Cagliari, Italy, october 1995, p.777-787.

GOURC, J. P., THOMAS, S. \& VUILLEMIN, M. (1998b). Proposal of a waste Settlement survey Methodology. In: Proc. of the Third International Congress on Environmental Geotechnics, Lisboa, Portugal, Sêco e Pinto (ed.), Balkema, Rotterdam, ISBN 90 5809 006x, p. 195-200.

GOURC, J. P.; VILLARD, P. \& THOMAS, S. (1998). Geomechanical Aspects of the Use of Geosynthetics in Landfill. In: Proc. of the Third International Congress on Environmental Geotechnics, Lisboa, Portugal, Sêco e Pinto (ed.), Balkema, Rotterdam, ISBN 905809 006x, p. 1371-1374.

GRAY, D. H. (1995). Containment Strategies for Landfilled Wastes. Geoenviromental 2000. Geotechnical Special Publication n 46, ASCE, vol.1, p.484 - 498. Ed. Yalcin B. Acar and David E. Daniel, New Orleans.

GRISOLIA, M. \& NOPOLEONI. (1996). Geotechnical Characterization of Municipal Solid Waste: Choice of Design Parameters. Proc. Of The Second International Congress on Environmental Geotechnics, Osaka, Japan, A.A.Balkema,5- 8 november 1996, v.2, p. 641-646.

GRISOLIA, M.; GASPARINI, A. \& SAETTI, G. F (1993). Survey on Waste Compressibility. Proceedings Sardinia 93, Fourth International Landfill Symposium, S. Margherita di Pula, Cagliari, Italy, october 1993, p.1447-1456.

GRISOLIA, M.; NOPOLEONI, Q. \& TANCREDI, G. (1995). Contribution to a Technical Classification of MSW. Proceedings Sardinia 95, Fifth International Landfill Symposium, S. Margherita di Pula, Cagliari, Italy, october 1995, p.705-710.

GRISOLIA, M.; NOPOLEONI, Q. \& TANCREDI, G. (1995b). The Use of Triaxial Tests for the Mechanical Characterization of MSW. Proceedings Sardinia 95, Fifth International Landfill Symposium, S. Margherita di Pula, Cagliari, Italy, october 1995, p.761-768.

HEAD, K. H. - Manual of Soil Laboratory Testing, Vol 3: Effective Stress Tests. ELE International Limited, 1984, 1238p.

HINKLE, R. D. (1990). Landfill Site Reclaimed for Commercial Use as Container Storage Facility. Geotechnics of Waste Fills - Theory and Practice, ASTM STP 1070, Arvid 
Landva and G. David Knowles, Eds., American Society for Testing and Materials, Philadelphia, 1990, p.331-344.

JESSBERGER, H. L. \& KOCKEL, R. (1993). Determination and Assessment of the Mechanical Properties of Waste Materials. Proceedings Sardinia 93, Fourth International Landfill Symposium, S. Margherita di Pula, Cagliari, Italy, october 1993, p.1383-1392.

JESSBERGER, H. L. (1992). Technical Guidance on Geotechnics of Landfills and Contaminated land. Geotechnical and Environmental, v.23, p.47-52.

JeSSBERGER, H. L. (1994). Geotechnical Aspects of Landfill Design and Construction. Part 1: Principles and Requirements. Proc. Instn Civ. Engrs Geotechnical. Engineering, v.107, Apr. 99 - 104.

JESSBERGER, H. L. (1994b). Geotechnical Aspects of Landfill Design and Construction. Part 2: Material Parameters and Test Methods. Proc. Instn Civ. Engrs Geotechnical. Engineering, v.107, Apr. 105 - 113.

JESSBERGER, H. L. (1995). Waste Containment With Compacted Clay Liners. Geoenviromental 2000. Geotechnical Special Publication n 46, ASCE, vol.1, p.463 483. Ed. Yalcin B. Acar and David E. Daniel, New Orleans.

JESSBERGER, H. L.; SYLLWASSCHY, O. \& KOCKEL, R. (1995). Investigation of Waste Body- Behavior and Waste-Structure-Interaction. Proceedings Sardinia 95, Fifth International Landfill Symposium, S. Margherita di Pula, Cagliari, Italy, october 1995, p.731-743.

JUCÁ, J. F. T.; CABRAL, J. J. P. S; MONTEIRO, V. E. D; SANTOS, S. M. \& PERRIER Jr, G. S. (1997). Geotechnics of a Municipal Solid waste Landfill in Recife, Brazil. Recent Developments in Soil and Pavement Mechanics, Almeida (ed), Balkema, Rotterdam, ISBN9054108851, p.429- 436.

KAIMOTO, L.S.A \& CEPOLLINA, M. (1996). Considerações Sobre Alguns Condicionantes e Critérios Geotécnicos de Projeto e Executivos de Aterros Sanitários. In: SIMPÓSIO INTERNACIONAL DA QUALIDADE AMBIENTAL, Porto Alegre. p. 51-54.

KAVAZANJIAN, E.; MATASOVIC, N. (1995). Seismic Analysis of Solid Waste Landfills. Geoenviromental 2000. Geotechnical Special Publication n 46, ASCE, vol.2, Ed. Yalcin B. Acar and David E. Daniel, New Orleans, p.1066 - 1080.

KAVAZANJIAN, E.; MATASOVIC, N.; BONAPARTE, R. \& SCHMERTMAM, G. R. (1995). Evaluation of MSW Properties for Seismic Analysis. Geoenviromental 2000. Carvalho, Miriam de Fátima. Tese de Doutorado, EESC/USP (1999) 
Geotechnical Special Publication $n^{\circ}$ 46, ASCE, vol.2, p.1126 - 1142. Ed. Yalcin B. Acar and David E. Daniel, New Orleans.

KNOCHENMUS, G.; WOJNAROWICZ, M. \& VAN IMPE (1998). Stability of Municipal Solid Wastes. In: Proc. of the Third International Congress on Environmental Geotechnics, Lisboa, Portugal, Sêco e Pinto (ed.), Balkema, Rotterdam, ISBN 905809 006x, p. 977-1000.

KÖLSCH, F. (1995). Material Values for Some Mechanical Properties of Domestic Waste. Proceedings Sardinia 95, Fifth International Landfill Symposium, S. Margherita di Pula, Cagliari, Italy, october 1995, p.711-729.

KÖNIG, D. \& JESSBERGER, H.L. (1997). Waste Mechanics. In: ISSMFE Technical Committee TC5 on Environmental Geotechnics pg. $35-76$.

LANDVA, A, O.; PELKEY, S. G. \& VALSANGKAR, A. J. (1998). Coefficient of Permeability of Municipal Refuse. In: Proc. of the Third International Congress on Environmental Geotechnics, v.1, Lisboa, Portugal, Sêco e Pinto (ed.), Balkema, Rotterdam, ISBN 905809 006x, p. 63-67.

LANDVA, A. O. \& CLARK, J. I. (1990). Geotechnics of Waste Fill. Geotechnics of Waste Fills - Theory and Practice, ASTM STP 1070, Arvid Landva, G. David Knowles, editors, American Society for Testing and Materials, Philadelphia, 1990, p.86-103.

LEITE, J. C. (1995). Metodologia para Elaboração da Carta de Susceptibilidade à Contaminação e Poluição das águas Subsuperficiais. São Paulo, 1995, v.1, 219p. Dissertação (Mestrado) - Escola de Engenharia de São Carlos, Universidade de São Paulo.

LEITE, W. C. A.(1991). Estudo do Comportamento da Temperatura, pH e Teor de Umidade na Decomposição de Resíduos Sólidos Urbanos em Aterros Sanitários. São Paulo, 1991. 180p. Dissertação (Mestrado) - Escola de Engenharia de São Carlos, Universidade de São Paulo.

LEMA, J. M.; MENDEZ, R. \& BLAZQUEZ, R. (1988). Characteristics of Landfill Leachates and Alternatives for Their Treatment: A Review. Water, Air, and Soil Pollution, v 40, p.223-250.

LING, H. I.; LESHCHINSKY, D.; MOHRI, Y. \& KAWABATA, T. (1998). Estimation of Municipal Solid Waste landfill Settlement. Journal of Geotechnical and Geoenvironmental Engineering, v.124, no. 1, january, 1998, ASCE, p. 21-28. 
MANASSERO, C. M. (1997). Controlled Landfill Design. ISSMFE Technical Committee TC5 on Environmental Geotechnics, TC5 Report. P.77-111.

MANASSERO, M.; PARKER, R.; PASQUALINI, E.; SZABÓ, I.; ALMEIDA, M. S. S.; BOUAZZA, A.; DANIEL, D. E. \& ROWE, R. K. (1998). Controlled Landfill Design (Geotechnical aspects). In: Proc. of the Third International Congress on Environmental Geotechnics, Lisboa, Portugal, Sêco e Pinto (ed.), Balkema, Rotterdam, ISBN 905809 006x, p. 1001-1038.

MANASSERO, M.; VAN IMPE, W.F. \& BOUAZZA, A. (1996). Waste Disposal and Containment. In: Proc. of the Second International Congress on Environmental Geotechnics, Preprint of special lectures, Osaka, Japan, A.A.Balkema, v.3, p. 14251474.

MANUAL DE GERENCIAMENTO INTEGRADO DO LIXO MUNICIPAL (1995). 1a Edição São Paulo: Instituto de Pesquisas Tecnológicas, CEMPRE, 1995, 278p.

MARIANO, M. O. H. \& JUCÁ, J. F. T.(1998). Monitoramento de Recalques no Aterro de Resíduos Sólidos da Muribeca. XI CONGRESSO BRASILEIRO DE MECÂNICA DOS SOLOS E ENGENHARIA DE GEOTÉCNICA, V.3, novembro de 1988, Brasília, p. 1671-1678.

MARQUES, A. C. M.; VILAR, O. M. \& KAIMOTO, L. S. A.. (1998). Urban Solid Waste Conception and Design of a Test Fill. In: Proc. of the Third International Congress on Environmental Geotechnics, v.1, Lisboa, Portugal, Sêco e Pinto (ed.), Balkema, Rotterdam, ISBN 905809 006x, p. 127-132.

MASADA, T.; MITCHELL, G. F.; SARGAND, S. M. \& SHASHIKUMAR, B. (1994). Modified Direct Shear Study of Clay Liner-Geomembrane Interfaces Exposed to Landfill Leachate. Geotextiles and Geomembranes, v.13, 1994, p.165-179.

MASSACCI, G.; MOTZO, G.M.; PILIA, M. \& COSSU, R. (1993). Analysis and Monitoring of Geotechnical Parameters in Sanitary Landfill. Proceedings Sardinia 93, Fourth International Landfill Symposium, S. Margherita di Pula, Cagliari, Italy, october 1993, p.1356-1369.

MATASOVIC, N. \& KAVAZANJIAN, E. (1998). Cyclic Characterization of OII Landfill Solid Waste. Journal of Geotechnical and Geoenvironmental Engineering, v.124, no. 3, March, 1998, ASCE, p. 197-210.

McCREANOR, P. T. \& REINHART, D. R. (1997). Mathematical Modeling of Waste Heterogeneities in Leachate Recirculating Landfills. In: Proc. the Thirteenth 
International Conference on Solid Waste Technology and Management, v.2, Philadelphia.

MELLO. L. G.; VAL, E. C. (1994). Considerações Sobre o Revestimento de Fundo de Áreas de Disposição de Resíduos à Luz das Recomendações Internacionais Atuais. SEMINÁRIO SOBRE GEOTECNIA DE ATERROS PARA DISPOSIÇÃO DE RESÍDUOS, GEOAMBIENTAL'94. Rio de Janeiro, abril, p.3.1-3.13.

MESRI, G. \& GODLEWSKI, P.M. (1977). Time - and Stress- Compressibility Interrelationship. In: Journal of Geotechnical Engineering Division, ASCE, v.103, No. GT5, May, 1977, p.417-430.

MILLER, W.L.; EARLE, J. F. K.; TOWNSEND, T. G.; BARTLETT, C. W.; LEE, H. J. (1991). Leachate Recycle and the Augmentation of Biological Decomposition at Municipal Solid waste Landfills. Report no. 91-3, The College of Engineering, University of Florida, Departments of Environmental Engineering and Agricultural Engineering, $181 p$.

MITCHELL, J. K.; BRAY, J. D. \& MITCHELL, R. A. (1995). Material Interactions in Solid Waste Landfills. Geoenviromental 2000. Geotechnical Special Publication $n^{\circ} 46$, ASCE, vol.1, p.568 - 590. Ed. Yalcin B. Acar and David E. Daniel, New Orleans.

MOROCHNICK, V., BARDET, J. P. \& HUSHMAND, B. (1998). Identification of Dynamic Properties of OIl Landfill. In: Journal of Geotechnical and Geoenvironmental Engineering, v.124, no. 3, march, 1998, ASCE, p. 186-196.

MORRIS, D. V. \& WOODS, C. E. (1990). Settlement and Engineering Considerations in Landfill and Final Cover Design. Geotechnics of Waste Fills - Theory and Practice, ASTM STP 1070, Arvid Landva and G. David Knowles, Eds., American Society for Testing and Materials, Philadelphia, 1990, p.9-21.

OWEIS, I. S. (1993). Stability of Landfill Geotechnical Practice for Waste Disposal. Ed. David \& Daniel, p.244-268.

PASQUALINI, E.; ROCCATO, M. \& SANI, D. (1993). Shear Resistance at the Interfaces of Composite Liners. Proceedings Sardinia 93, Fourth International Landfill Symposium, S. Margherita di Pula, Cagliari, Italy, october 1993, p.1457-1471.

PEGGS, I. D. (1992). Whither PVC. (tradução: Qual o destino do PVC). PGI: PVC Geomembrane Institute, Pennsylvania, USA.

PINTO, C. S. (1996). Cap. 2: Propriedades dos solos. In: Fundações: Teoria e Prática 
PORTEOUS, A. (1993). Developments in, and Environmental Impacts of, Electricity Generation from Municipal Solid Waste and Landfill Gas Combustion. In: IEE Proceedings-A, v. 140, n.1, january, 1993. p.86-93.

PRESA, E. P. (1982). La Compressibilidad de los Vertederos Sanitários Controlados. Espanha, 1982. Seminário - Escuela Técnica Superior de Ingenieros de Caminos, Canales y Puertos, Universidad Politecnica de Madrid, 74p.

QuARESMA, A. R., DÉCOURT L., QUARESMA FILHO, A. R., ALMEIDA, M. S. S., DANZIGER, F. (1996). Investigações Geotécnicas, (cap. 3) - Fundações Teoria e Prática. ABMS/ABEF

QUERIO, A. J. \& LUNDELL, C. M. (1992). Geosynthetic Use as Daily Cover. Geotextiles and Geomembranes, v.11, 1992, p.621-627.

RANZINI, S. M. T (1988). SPTT. Solos e Rochas, ABMS, v. 11, n.5, 1988.

RANZINI, S. M. T (1994). SPTT: Parte II. Solos e Rochas, ABMS, v. 17, n.3, dezembro, 1994.

RAO, S. K., MOULTON, L..K. \& SEALS, R. K. (1987). Settlement of Refuse Landfills. Geotechnical Practice Waste Disposal `87, ASCE, GSP n. 13, Ann Arbor, Michigan, USA, p.574-598.

SÁNCHEZ-ALCITURRI, J. M.; PALMA, J. H.; CAÑIZAL, J \& SAGASETA, C. (1994). Capacidad Portante de un Vertedero Controlado. Resíduos Urbano e Industrial, nํㅜ 1 , janeiro - fev 1994, Bilbao-Espanha, p.44-48.

SÁNCHEZ-ALCITURRI, J. M.; PALMA, J. H.; SAGASETA, C \& CAÑIZAL, J. (1993c). Geotecnia en Vertederos Sanitarios Controlados. Resíduos Urbano e Industrial, $\mathrm{n}^{\underline{0}}$ 2, março - abril 1993, Bilbao-Espanha, p.42-51.

SÁNCHEZ-ALCITURRI, J.M.; PALMA, J.; SAGASETA, C. \& CANIZAL, J. (1993). Mechanical Properties of Wastes in a Sanitary Landfill. In: Proc. International conference Green'93, Waste Disposal by Landfill - GREEN'93, Sarsby (ed), Balkema, Rotterdam, ISBN 905410356 6, p. 357 - 363.

SÁNCHEZ-ALCITURRI, J.M.; PALMA, J.; SAGASETA, C. \& CANIZAL, J. (1993b). Three Years of the Deformation monitoring at Meruelo Landfill. In: Proc. International conference Green'93, Waste Disposal by Landfill - GREEN'93, Sarsby (ed), Balkema, Rotterdam, ISBN 905410356 6, p. 365 - 371. 
SANTOS, L. A. O. \& PRESA, E. P. (1995). Compressibilidade de Aterros Sanitários Controlados. III SIMPÓSIO SOBRE BARRAGENS DE REJEITOS E DISPOSIÇÃO DE RESÍDUOS - REGEO'95, v.II, Ouro Preto/ MG, p.577-591.

SANTOS, S. M.; JUCÁ, J. F. T. \& ARAGÃO, J. M. S. (1998). Geotechnical Properties of a Solid Waste Landfill: Muribeca`s Case. In: Proc. of the Third International Congress on Environmental Geotechnics, v.1, Lisboa, Portugal, Sêco e Pinto (ed.), Balkema, Rotterdam, ISBN 905809 006x, p. 181-184.

SANTOS, S. M.; PONTES, FILHO, I.; JUCÁ, J. F. T.; \& SANTOS, E. A. (1998b). Simulação Numérica de Provas de Carga Realizadas em um Aterro de Resíduos Sólidos. In: XI CONGRESSO BRASILEIRO DE MECÂNICA DOS SOLOS E ENGENHARIA GEOTÉCNICA. Vol.I, Brasília, 5 - 10 de Novembro de 1998. p. 269-276.

SCHALCH, V. (1984). Produção e Caracterização do Chorume em Processo de Decomposição de Lixo Urbano. São Paulo, 1984, v.1, 134p. Dissertação (Mestrado) - Escola de Engenharia de São Carlos, Universidade de São Paulo.

SCHALCH, V.(1992). Análise Comparativa do Comportamento de Dois Aterros Sanitários e Correlações dos Parâmetros do Processo de Digestão Anaeróbia. São Paulo, 1992. 220p. Tese (Doutorado) - Escola de Engenharia de São Carlos, Universidade de São Paulo.

SCHALCH, V.; LEITE, W. C. A.; FANTINI JÚNIOR, W.; de AGUIAR, E. M. (1990). Aterro Sanitário: Considerações do Sítio, Projeto, Implantação, Operação, e Monitoramento. $7^{0}$ CONGRESSO BRASILEIRO DE ÁGUAS SUBTERRÂNEAS, p.123-126.

SHARMA, H. D.; DUKES, M. T. \& OLSEN, D. M. (1990). Field Measurements of Dynamic Moduli and Poisson's Ratios of Refuse and Underlying Soils at a Landfill Site. Geotechnics of Waste Fills - Theory and Practice, ASTM STP 1070, Arvid Landva and G. David Knowles, Eds., American Society for Testing and Materials, Philadelphia, 1990, p.57-70.

SIEGEL, R. A.; ROBERTSON, R. J. \& ANDERSON, D. G. (1990). Slope Stability Investigations at a Landfill in Southern California. Geotechnics of Waste Fills Theory and Practice, ASTM STP 1070, Arvid Landva and G. David Knowles, Eds., American Society for Testing and Materials, Philadelphia, 1990, p.259-284.

SILVA, A .R.; PESSIN, N. \& CARVALHO, M. F.(1998). Degradação da Fração Orgânica de Resíduos Sólidos urbanos em Aterro Sanitário. II SIMPÓSIO INTERNACIONAL DE 
QUALIDADE AMBIENTAL - GERENCIAMENTO DE RESÍDUOS E CERTIFICAÇÃO AMBIENTAL, outubro, Porto Alegre, p. $381-386$.

SIMÕES, G. F. \& CAMPOS, T. M. P. (1998). Modelos de Previsão de Recalques em Aterros Sanitários. XI CONGRESSO BRASILEIRO DE MECÂNICA DOS SOLOS E ENGENHARIA DE GEOTÉCNICA, V.3, novembro de 1988, Brasília, p. 1679-1686.

SIMÕES, G. F.; CAMPOS, T. M. P.; GALVÃO, T. C. B. e VARGAS JR, E. A. (1996). Considerações Sobre o Fenômeno de Adensamento em Aterro Sanitários. In: SIMPÓSIO INTERNACIONAL DA QUALIDADE AMBIENTAL, Porto Alegre. p. 131135.

SIMPSON, B. E. (1995). Five Factors Influencing the Clay/ Geomembrane Interface. Geoenviromental 2000. Geotechnical Special Publication n 46, ASCE, vol.2, p.9951004. Ed. Yalcin B. Acar and David E. Daniel, New Orleans.

SINGH, S. \& MURPHY, B. J. (1990). Evaluation of the Stability of Sanitary Landfills. Geotechnics of Waste Fills - Theory and Practice, ASTM STP 1070, Arvid Landva and G. David Knowles, Eds., American Society for Testing and Materials, Philadelphia, 1990, p.240-258.

SOLER, N. D.; MAHER, A; CHAE, Y. S. \& HAMIDI (1995). A conceptual Model for Transient Settlements in Waste Fills. In: Proc.UNSAT'95, Paris, Alonso \& Delage (ed), p.411416.

SOWERS, G. F. (1968). Foundation Problems in Sanitary Landfills. Journal of the Sanitary Engineering Division, ASCE, v.4, p.103-116.

SOWERS, G. F. (1973). Settlement of Waste Disposal Fills. In: Eighth International Conference on Soil Mechanics and Foundation Engineering's, v.2, parte 2, MoscowURSS, 1973; p.207-210.

STANCATI, G. (1990). Estudo Experimental do Comportamento Tensão - Deformação de uma Argila Adensada Unidirecionalmente. São Paulo, 1990, v.1, 244p. Tese (Doutoramento) - Escola de Engenharia de São Carlos, Universidade de São Paulo.

STULGIS, R. P.; SOYDEMIR, C.; TELGENER, R. J. (1995). Predicting Landfill Settlement. In: Geonviromental 2000. Geotechnical Special Publication n46, ASCE, vol.2, Ed. Yalcin B. Acar and David E. Daniel, New Orleans, p.980-993.

TCHOBANOGLOUS, G.; THEISEN, H.; VIGIL, S. (1993). Integrated Solid Waste Management Engineering Principles and Management Issues. McGraw-Hill, Inc, 1993, 978p.

Carvalho, Miriam de Fátima. Tese de Doutorado, EESC/USP (1999) 
TEODORO, J. M. \& BUENO, B. S. (1998). Estudo do Comportamento dos Solos Reforçados com Fibras Plásticas de Polipropileno. XI CONGRESSO BRASILEIRO DE MECÂNICA DOS SOLOS E ENGENHARIA GEOTÉCNICA - XI COBRANSEG, V.II, Brasília, p.1093 1100.

TIVERON, V. P. M.; MARQUES, A. C. M.; NAHAS, C. M.; FRANÇOSO, N. C. T. \& GODOI, M. O. (1995). Disposição de Resíduos Sólidos no Município de São Paulo: Aterros Sanitários. I SEMINÁRIO LUSO-BRASILEIRO DE GEOTECNIA AMBIENTAL, Lisboa, 1995, 15p.

VAL, E. C.; ANTONIUTTI NETO, L.; MELLO, L. G. (1994). Um Novo Piezômetro para Aterro Sanitários. Seminário sabre Geotecnia de Aterros para Disposição de Resíduos, Geoambiental'94. Rio de Janeiro, abril, p.2.1-2.5.

VAN IMPE, W. F. \& BOUAZZA, A. (1996). Densification of Domestic Waste Fills by Dynamic Compaction. In: Canadian Geotechnical Journal, v.33, p.879-887.

VAN IMPE, W. F. (1998). Environmental Geotechnics - ITC5 - Reports and Future Goals. Geotechnical Hazards, Maric, Lisac \& Szavits-Nossan (eds), Balkema, Rotterdam, ISBN 905410 9572, p. 127 - 156.

VAN IMPE, W. F. (1998b). Environmental Geotechnics: ITC5 activities - State of the art. In: Proc. of the Third International Congress on Environmental Geotechnics, Lisboa, Portugal, Sêco e Pinto (ed.), Balkema, Rotterdam, ISBN 905809 006x, p. 11631187.

VAN IMPE, W. P. (1995). ISSMPE - Policy and the Challenges of Environmental Geotechnics. Report Environment 2000 Meeting, Separata, 29p.

VAN MEeRTEN, J. J.; SELlMEIJER, J. B. \& PEREBOOM, D. (1995). Prediction of Landfill Settlements. Proceedings Sardinia 95, Fifth International Landfill Symposium, S. Margherita di Pula, Cagliari, Italy, october 1995, p.823-831.

VELLOSO, D. A.; FONSECA, H. M. B.; MONROI, J. C. (1994). Fundações da Usina de Reciclagem e Compostagem de Lixo do Caju, Rio de Janeiro. SEMINÁRIO SOBRE GEOTECNIA DE ATERROS PARA DISPOSIÇÃO DE RESÍDUOS, GEOAMBIENTAL'94. Rio de Janeiro, abril, p.1.7-1.16.

VIDAL, D.; GOURC, J. P.; PIERSON, P. (1994). Sistemas de Impermeabilização com Geossintéticos. X CONGRESSO BRASILEIRO DE MECÂNICA DOS SOLOS E ENGENHARIA DE FUNDAÇÕES, v.3. Foz do Iguaçu, novembro, 1994, p.10111018. 
WALL, D. K.; ZEISS, C. (1995). Municipal Landfill Biodegradation and Settlement. Journal of Environmental Engineering, ASCE, vol. 121, No. 3, March, p. 214- 224.

WATTS, K. S. \& CHARLES, J. A. (1990). Settlement of Recently Placed Domestic Refuse Landfills. In: Proc. Institution of Civil Engineering, London, part 1 , v.88, p.971-993.

WITHIAM, J. L.; TARVIN, P. A.; BUSHELL, T. D.; SNOW, R. E.; GERMAM, H. W. (1995). Prediction and Performance of Municipal Landfill Slope. Geoenviromental 2000. Geotechnical Special Publication n 46, ASCE, vol.2, p.1005-1019. Ed. Yalcin B. Acar and David E. Daniel, New Orleans.

WOJNAROWICZ, M., KNOCHENMUS, G \& VAN IMPE, W (1998). Géotechnique de L'environnement - Activités de L'ICSMFE (TC5). In: Revue Française de Géotechnique, No. 83, 2․ Semestre 1998, p.1-16.

YEN, B. C. e SCANLON. B. (1975). Sanitary Landfill Settlement Rates. Jourmal of Geotechnical Division, ASCE, v.101, GT5, p.475-487.

YOSHIDA, H.; HOZUMI, H. \& TANAKA, N. (1996). Theoretical Study on Temperature Distribution in a Sanitary Landfill. In: Proc. Of The Second International Congress on Environmental Geotechnics, ISBN 905410848 7, Osaka, Japan, A.A.Balkema, v.1 p. 323-328.

ZUQUETTE, L. V; PEJON, O. J.; SINELLI, O. GANDOLFI, N. (1995). Carta de Zoneamento Específico para Disposição de Resíduos da Região de Ribeirão Preto - SP. III SIMPÓSIO SOBRE BARRAGENS DE REJEITOS E DISPOSIÇÃO DE RESÍDUOS - 'REGEO'95, v.II, Ouro Preto/ MG, p.535-548. 


\section{ANEXO 1}

Seção transversal através dos furos de sondagens 
ANEXO 2

\section{Descrição das características dos resíduos sólidos urbanos coletados dos furos de trado}

Tabela 01 - TRADAGEM - FURO T1 (AS - 2)

Data de execução: 08/07/1996 (segunda feira)

Condições do tempo: Bom

\begin{tabular}{|c|c|}
\hline $\begin{array}{c}\text { TRECHO } \\
\text { PERFURADO (m) } \\
\text { E HORÁRIO (h) }\end{array}$ & $\begin{array}{c}\text { CLASSIFICAÇÃO DAS AMOSTRAS DE LIXO E } \\
\text { OBSERVAÇÕES }\end{array}$ \\
\hline $10: 00 \mathrm{~h}$ & - Início da perfuração \\
\hline $0,00-1,00$ & - Selo de cc \\
\hline $\begin{array}{l}\text { Amostragem deste trecho foi } \\
\text { descartada devido a grande } \\
\text { quantidade de solo de } \\
\text { cobertura existente no lixo }\end{array}$ & $\begin{array}{l}\text { - lixo com muito solo } \\
\text { - } \text { UMIDADE: seco } \\
\text { - } \text { GOR: preto } \\
\text { - } \text { GRAU DE DEGRADAČÃO: degradado } \\
\text { - } \text { GÁS: ausente } \\
\text { - } \text { ODOR: pouco } \\
\text { - } \text { CHORUME: ausente } \\
\text { - } \text { MATERIAIS COMPONENTES: tiras e pedaços de plásticos (duro e mole), } \\
\text { tecidos (pedaços e tiras), rolo de plástico de etiqueta de garrafa da Coca- } \\
\text { cola, correias de automóvel, pedra no }{ }^{\circ} .4 \text {, pedaço de metal não oxidado, } \\
\text { matéria orgânica. }\end{array}$ \\
\hline $\begin{array}{l}\text { Tempo. Amb.: } 22^{\circ} \mathrm{C} \\
\text { Temp. Furo: } 26^{\circ} \mathrm{C}\end{array}$ & 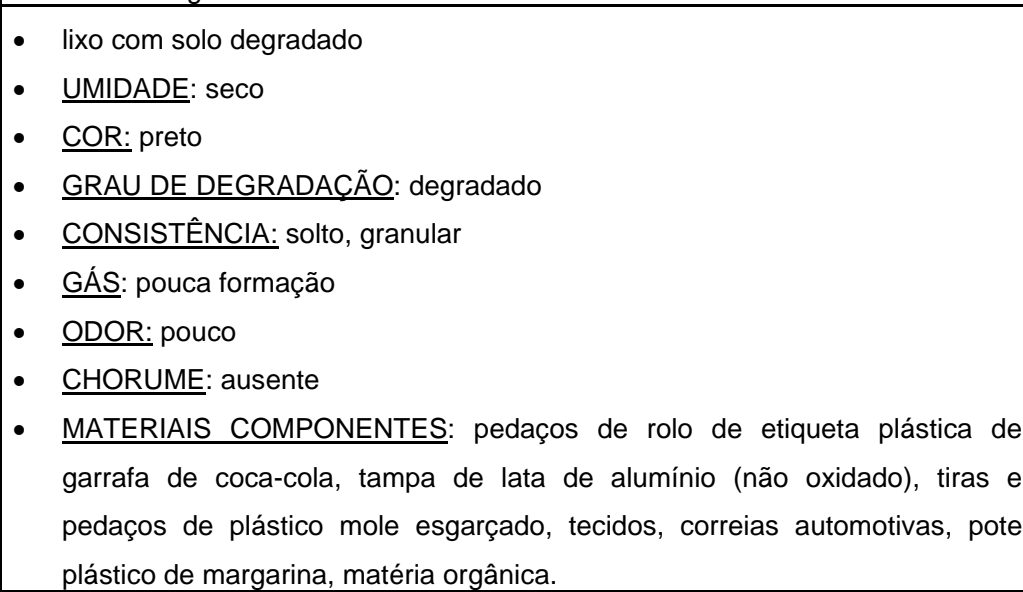 \\
\hline $\begin{array}{c}2,99-6,00 \\
\text { T1-2 } \\
\text { Temp. Amb.: } 22^{\circ} \mathrm{C} \\
\text { Temp.Furo: } 31^{\circ} \mathrm{C}(4,12 \mathrm{~m})\end{array}$ & $\begin{array}{l}\text { - lixo com pouco solo degradado } \\
\text { - UMIDADE: umidade aumentando com a profundidade, sem gotejamento } \\
\text { - } \text { COR: preto } \\
\text { - GRAU DE DEGRADAČÃO: bem degradado } \\
\text { - } \text { CONSISTÊNCIA: mais aderente ao trado, aspecto floculado } \\
\text { - GÁS: forte }\end{array}$ \\
\hline
\end{tabular}


Tabela 01 - TRADAGEM - FURO T1 (AS - 2) (continuação)

\begin{tabular}{|c|c|}
\hline $\begin{array}{l}\text { TRECHO } \\
\text { PERFURADO (m) } \\
\text { E HORÁRIO (h) }\end{array}$ & $\begin{array}{c}\text { CLASSIFICAÇÃO DAS AMOSTRAS DE LIXO E } \\
\text { OBSERVAÇÕES } \\
\text { (continuação) }\end{array}$ \\
\hline $\begin{array}{c}2,99-6,00 \\
\text { T1-2 } \\
\text { Temp. Amb.: } 22^{\circ} \mathrm{C} \\
\text { Temp.Furo: } 31^{\circ} \mathrm{C}(4,12 \mathrm{~m})\end{array}$ & $\begin{array}{l}\text { - } \text { ODOR: forte } \\
\text { - } \text { CHORUME: ausente } \\
\text { (pATERIAIS COMPONENTES: pedaços de embalagens de plástico duro } \\
\text { pedaços de plástico mole esgarçado, pedaços de madeira, estopa, pedaço } \\
\text { de arame de metal (bom estado de conservação), solado de borracha de } \\
\text { sapato, pedaço de manta bidim (bem degradado), matéria orgânica. }\end{array}$ \\
\hline $\begin{array}{l}\text { Temp. Amb.: } 22^{\circ} \mathrm{C} \\
\text { Temp. Furo: } 38^{\circ} \mathrm{C}(6,0 \mathrm{~m})\end{array}$ & $\begin{array}{l}\text { - } \text { UMIDADE: muito úmido } \\
\text { - } \text { COR: preto } \\
\text { - } \text { GRAU DE DEGRADAĈ̃̃O: muito degradado } \\
\text { aderente ao trado } \\
\text { - } \text { GÁS: forte } \\
\text { - } \text { ODOR: forte } \\
\text { - } \text { CHORUME: gotejamento } \\
\text { - } \frac{\text { MATERIAIS COMPONENTES: tiras e pedaços pequenos de plásticos, }}{\text { solado de sapato, pedaços grandes de sacos plásticos, tiras de tecido, lata, }} \\
\text { pedaços de arame, } 03 \text { moedas de } 10 \text { cruzados (1988), saco de leite } \\
\text { (Paulista), pedaços de madeira, pedaço de saco de ráfia, rachão (poucos), } \\
\text { embalagem inteira de plástico duro (produto de limpeza), matéria orgânica. }\end{array}$ \\
\hline $12: 00 \mathrm{hs}$ & ( \\
\hline $13: 1$ & - Reinicio \\
\hline $\begin{array}{l}\text { Não foi possível a leitura } \\
\text { da temperatura pois o } \\
\text { termômetro quebrou. }\end{array}$ & $\begin{array}{l}\text { - lixo com solo } \\
\text { - } \text { UMIDADE: saturado } \\
\text { - } \text { COR: preto } \\
\text { - } \text { GRAU DE DEGRADACÃO: muito degradado } \\
\text { - } \text { GÁS: forte } \\
\text { - } \text { ODOR: forte } \\
\text { - } \frac{\text { CHORUME: escorrendo pela massa de lixo }}{\text { - }} \text { MATERIAIS COMPONENTES: pedra no.4, rachão, embalagem de plástico } \\
\text { duro (produto de limpeza), vassoura de piaçaba, pote de margarina, solado } \\
\text { de chinelo de borracha, saco de ráfia, tecidos, pedaços de madeira, tiras de } \\
\text { borracha, matéria orgânica. }\end{array}$ \\
\hline $13: 45$ & - Parada para suplementação com trado de $6,00 \mathrm{~m}$ \\
\hline $13: 55$ hs & - Reinicio \\
\hline $10,00-12,00$ & $\begin{array}{l}\text { - lixo com solo bastante degradado } \\
\text { - UMIDADE: muito úmido } \\
\text { - } \text { COR: preto } \\
\text { - GRAU DE DEGRADAČÃO: muito degradado } \\
\text { - CONSISTÊNCIA: mole, massa de lixo entremeada com tiras de plástico, } \\
\text { aderente ao trado } \\
\text { - } \text { GÁS: forte } \\
\text { - ODOR: forte }\end{array}$ \\
\hline
\end{tabular}


Tabela 01 - TRADAGEM - FURO T1 (AS - 2) (continuação)

\begin{tabular}{|c|c|}
\hline $\begin{array}{c}\text { TRECHO } \\
\text { PERFURADO (m) } \\
\text { E HORÁRIO (h) } \\
\end{array}$ & $\begin{array}{c}\text { CLASSIFICAÇÃO DAS AMOSTRAS DE LIXO E } \\
\text { OBSERVAÇÕES } \\
\text { (continuação) }\end{array}$ \\
\hline $10,00-12,00$ & $\begin{array}{l}\text { - } \text { - } \text { MATERUME: gotejando } \\
\text { plástico esgarçados, pedaços de tecido, pedaços de arame, pedaço de saco } \\
\text { de ráfia, matéria orgânica. } \\
\text { - OBS.: Solo na ponta do trado }\end{array}$ \\
\hline $12,00-14,00$ & $\begin{array}{l}\text { - } \text { UMIDADE: saturado } \\
\text { - } \text { GOR: preto } \\
\text { - } \text { CONSISTÉNCIA: mais mole, massa de lixo entremeada com tiras de plástico, } \\
\text { aderente ao trado } \\
\text { - } \text { GÁS: muito forte } \\
\text { - } \text { ODOR: muito forte } \\
\text { - } \text { MATORUME: escorrendo pela massa de lixo } \\
\text { plástico duro, tiras e pedaços de plástico, moeda de } 10 \text { cruzeiros (1984), } \\
\text { pedaços e tiras de pano, pedaços de saco de ráfia, potes de margarina, } \\
\text { pedra no }{ }^{\circ} \text {, } \text {, cacos de vidro, pilha pequena, embalagem de plástico duro } \\
\text { (produtos de limpeza), pedaços de madeira, faca de aço inoxidável } \\
\text { (Meridional), solado de sapato de borracha, moeda de } 50 \text { cruzeiros (1985), } \\
\text { balde de lata de } 20 \text { litros amassada (bom estado de conservação), arame na } \\
\text { ponta do trado, matéria orgânica. }\end{array}$ \\
\hline $14,00-16,00$ & 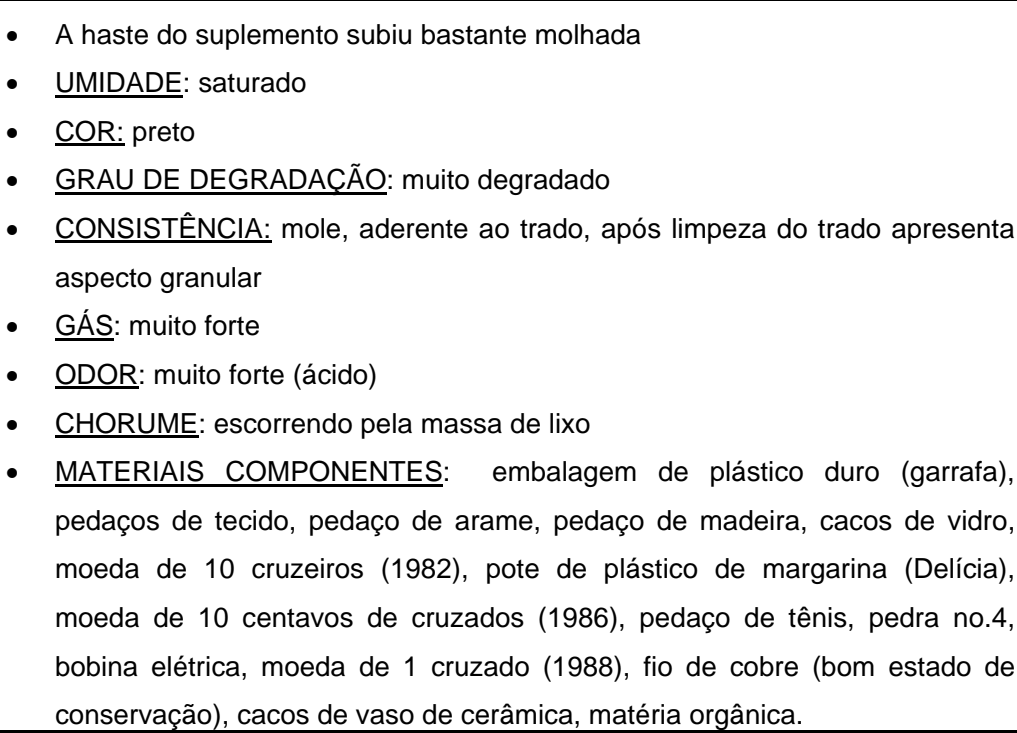 \\
\hline 15:05 hs & - Parada para suplementação com trado de $9,00 \mathrm{~m}$ \\
\hline $15: 14 \mathrm{hs}$ & - Reinicio da perfuração \\
\hline $16,00-18,00$ & $\begin{array}{l}\text { - UMIDADE: úmido } \\
\text { - COR: cinza escuro a preto } \\
\text { - GRAU DE DEGRADAČÃO: muito degradado } \\
\text { - } \frac{\text { CONSISTÊNCIA: mole, aderente ao trado, após limpeza do trado apresenta }}{\text { aspecto granular }} \\
\text { - GÁS: muito forte }\end{array}$ \\
\hline
\end{tabular}


Tabela 01 - TRADAGEM - FURO T1 (AS - 2) (continuacão)

\begin{tabular}{|c|c|}
\hline $\begin{array}{l}\text { TRECHO } \\
\text { PERFURADO (m) } \\
\text { E HORÁRIO (h) } \\
\end{array}$ & $\begin{array}{c}\text { CLASSIFICAÇÃO DAS AMOSTRAS DE LIXO E } \\
\text { OBSERVAÇÕES } \\
\text { (continuação) }\end{array}$ \\
\hline $16,00-18,00$ & $\begin{array}{l}\text { - } \text { ODOR: muito forte (ácido) } \\
\text { - } \text { CHORUME: gotejando pela massa de lixo } \\
\text { MATERIAIS COMPONENTES: pedaços de metal amassado (não oxidado ), } \\
\text { pote de plástico de margarina, pequenos pedaços de plástico mole } \\
\text { esgarçado, embalagens de plástico duro (Alvejante), pedra } n^{\circ} .4 \text {, lata de } \\
\text { alumínio não oxidada (refrigerante), pedaço de garrafa plástica de água, } \\
\text { pedaços de madeira, tênis de lona, matéria orgânica. }\end{array}$ \\
\hline $18,00-20,00$ & $\begin{array}{l}\text { - } \text { UMIDADE: saturado } \\
\text { - } \text { COR: cinza escuro a preto } \\
\text { - } \text { GRAU DE DEGRADAÇÃO: muito degradado } \\
\text { apresenta aspecto granular } \\
\text { - GÁS: muito forte } \\
\text { - } \text { ODOR: muito forte (ácido) } \\
\text { - } \text { CHORUME: escorrendo pela massa de lixo } \\
\text { - } \text { MATERIAIS COMPONENTES: pedra } \mathrm{n}^{\circ} .4 \text {, tiras de plástico mole esgarçado, } \\
\text { tiras de borracha, pedaço de arame, solado de borracha de sapato, pedaço } \\
\text { de madeira, pedaços de tecido, matéria orgânica. }\end{array}$ \\
\hline $20,00-22,00$ & $\begin{array}{l}\text { - } \text { UMIDADE: úmido } \\
\text { - } \text { COR: cinza escuro a preto } \\
\text { - } \text { GRAU DE DEGRADACCÃO: muito degradado } \\
\text { aspecto granular } \\
\text { - } \underline{\text { GÁS: muito forte }} \\
\text { - } \text { ODOR: muito forte } \\
\text { - } \frac{\text { CHORUME: gotejando pela massa de lixo }}{\text { MATERIAIS COMPONENTES:. Pedra } n^{\circ} .4 \text {, tiras de plástico mole esgarçado, }} \\
\text { tiras de borracha, pedaço de madeira, pedaços de tecido, matéria orgânica. }\end{array}$ \\
\hline $22,00-24,00$ & 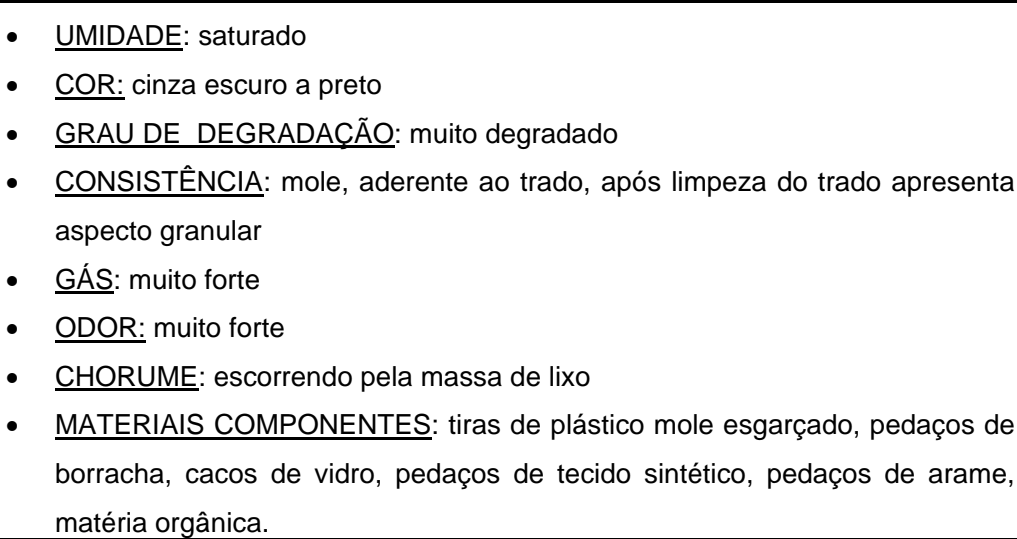 \\
\hline
\end{tabular}


Tabela 01 - TRADAGEM - FURO T1 (AS - 2) (continuacão)

\begin{tabular}{|c|c|}
\hline $\begin{array}{c}\text { TRECHO } \\
\text { PERFURADO (m) } \\
\text { E HORÁRIO (h) }\end{array}$ & $\begin{array}{c}\text { CLASSIFICAÇÃO DAS AMOSTRAS DE LIXO E } \\
\text { OBSERVAÇÕES } \\
\text { (continuação) }\end{array}$ \\
\hline $24,00-26,00$ & 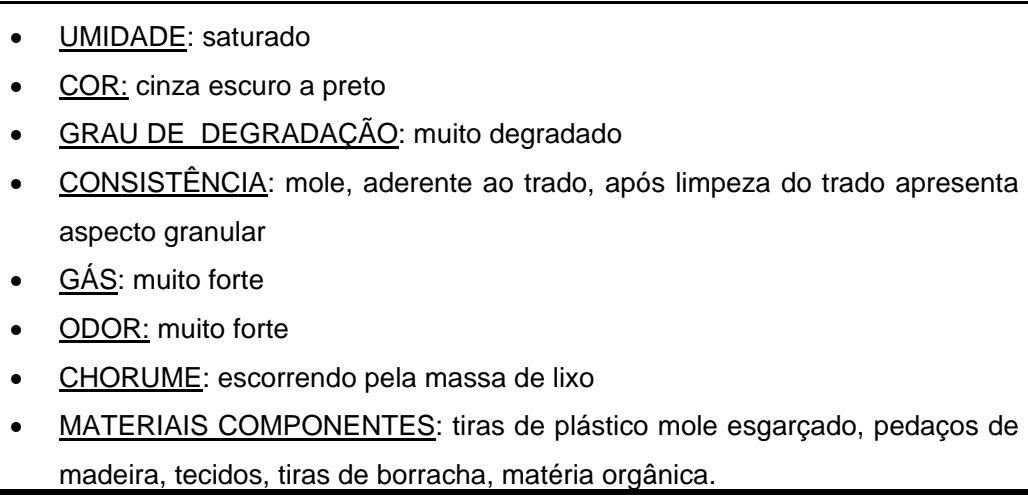 \\
\hline $26,00-29,00$ & $\begin{array}{l}\text { - } \text { UMIDADE: saturado } \\
\text { - } \text { COR: cinza escuro a preto } \\
\text { - } \text { GRAU DE DEGRADACẼ̃O: muito degradado } \\
\text { apresenta aspecto granular } \\
\text { - } \text { GÁS: muito forte } \\
\text { - } \text { ODOR: muito forte } \\
\text { - } \frac{\text { CHORUME: escorrendo pela massa de lixo }}{\text { - }} \text { MATERIAIS COMPONENTES: tiras de plástico esgarçado, muita matéria } \\
\text { - } \text { orgânica. } \\
\text { - } 29,00 m \Rightarrow \text { partir dos } 27,00 m \Rightarrow \text { Solo Natural (avermelhado) } \\
\text { - } 29,0 \text { perfuração }\end{array}$ \\
\hline
\end{tabular}


Tabela 02 - TRADAGEM - FURO T2 (AS - 2)

Data de execução: 09/07/1996 (terça feira)

Condições do tempo: Bom

\begin{tabular}{|c|c|}
\hline $\begin{array}{c}\text { TRECHO } \\
\text { PERFURADO (m) } \\
\text { E HORÁRIO (h) }\end{array}$ & $\begin{array}{c}\text { CLASSIFICAÇÃO DAS AMOSTRAS DE LIXO E } \\
\text { OBSERVAÇÕES }\end{array}$ \\
\hline $10: 40 \mathrm{~h}$ & - Início da perfuração \\
\hline $0,00-2,80$ & - Selo de cobertura com solo \\
\hline $2,80-4,00$ & - Solo com lixo (principalmente plástico) \\
\hline $\begin{array}{l}\text { Amostragem deste trecho foi } \\
\text { descartada devido a grande } \\
\text { quantidade de solo de } \\
\text { cobertura existente no lixo }\end{array}$ & $\begin{array}{l}\text { - lixo com solo } \\
\text { - } \text { UMIDADE: seco } \\
\text { - } \text { COR: lixo preto e solo marrom } \\
\text { - GRAU DE DEGRADAÇÃO: degradado } \\
\text { - } \text { CONSISTÊNCIA: solto, floculado } \\
\text { - } \text { GÁS: pouco } \\
\text { - } \text { ODOR: pouco } \\
\text { - } \text { CHORUME: ausente } \\
\text { - } \text { MATERIAIS COMPONENTES: tiras e pedaços de plásticos (duro e mole), } \\
\text { pedaço de carpete verde, solado de borracha de tênis, placa de circuito } \\
\text { impresso, meia calça de mulher de nylon (inteira), pedaço de borracha, } \\
\text { pedaço de madeira, embalagens de plástico duro de produtos de limpeza, } \\
\text { pedaços de saco de ráfia, cinto de couro, fivela de metal de cinto (bom } \\
\text { estado de conservação), matéria orgânica. }\end{array}$ \\
\hline $6,00-8,00$ & $\begin{array}{l}\text { - lixo com muito solo (marrom) } \\
\text { - UMIDADE: seco } \\
\text { - COR: cinza } \\
\text { - GRAU DE DEGRADAÇÃO: mais degradado } \\
\text { - } \text { CONSISTÊNCIA: solto, floculado } \\
\text { - } \text { GÁS: mais forte } \\
\text { - } \text { ODOR: mais forte } \\
\text { - } \text { CHORUME: ausente } \\
\text { MATERIAIS COMPONENTES: embalagem de plástico duro de desodorante } \\
\text { (Vinólia), pedaços de madeira, pote de plástico duro de margarina, pedaços e } \\
\text { tiras de plástico mole esgarçado, pedaços e tiras de tecido, correia } \\
\text { automotiva, pedaço de cerâmica de peça sanitária, moeda } 10 \text { cruzeiros } \\
\text { (1981), rachão, moeda de } 1 \text { cruzeiros (1981, 1987), moeda de } 1 \text { cruzado } \\
\text { (1988), pilha pequena, miolo de fechadura de automóvel (bom estado de } \\
\text { conservação), moeda de } 50 \text { centavos de cruzado (1986), pedaço de feltro, } \\
\text { solado de sapato, pedaço de saco de ráfia, lata de óleo amassada (sem } \\
\text { oxidação), pedaço de arame, matéria orgânica. }\end{array}$ \\
\hline $8,00-10,00$ & $\begin{array}{l}\text { - lixo com solo } \\
\text { - UMIDADE: seco } \\
\text { - } \text { COR: amarronzado a cinza escuro } \\
\text { - GRAU DE DEGRADAČÃO: mais degradado } \\
\text { - } \frac{\text { CONSISTÊNCIA: aderente ao trado, porém soltando-se com facilidade, }}{\text { entremeado por tiras de plástico }} \\
\text { - GÁS: forte }\end{array}$ \\
\hline
\end{tabular}


Tabela 02 - TRADAGEM - FURO T2 (AS - 2) (continuacão)

\begin{tabular}{|c|c|}
\hline $\begin{array}{c}\text { TRECHO } \\
\text { PERFURADO (m) } \\
\text { E HORÁRIO (h) }\end{array}$ & $\begin{array}{c}\text { CLASSIFICAÇÃO DAS AMOSTRAS DE LIXO E } \\
\text { OBSERVAÇÕES } \\
\text { (continuação) }\end{array}$ \\
\hline $\begin{array}{l}8,00-10,00 \\
\text { T2- } 2\end{array}$ & $\begin{array}{l}\text { - } \text { - } \text { MATERUME: ausente } \\
\text { esgarçado, embalagens de plástico duro (garrafas), pedaços de madeira, lata } \\
\text { amassada (sem oxidação), brita } n^{\circ} .4 \text {, pedaço de feltro, matéria orgânica. }\end{array}$ \\
\hline $11: 50$ hs & - Parada para suplementação da haste de $6,00 \mathrm{~m}$ \\
\hline $12: 00$ hs & - Parada para almoço \\
\hline $13: 30 \mathrm{hs}$ & - Reinicio da perfuração \\
\hline $10,00-12,00$ & $\begin{array}{l}\text { - lixo com solo } \\
\text { - UMIDADE: úmido } \\
\text { - } \text { COR: preto } \\
\text { - } \text { GRAU DE DEGRADAÇÃO: muito degradado } \\
\text { - } \frac{\text { CONSISTÊNCIA: massa mais mole, aderente ao trado }}{\text { - }} \text { GÁS: forte } \\
\text { - } \frac{\text { ODOR: forte }}{\text { - }} \text { CHORUME: escorrendo pela massa de lixo } \\
\text { - } \frac{\text { MATERIAIS COMPONENTES: pedra } n^{\circ} .4 \text {, pedaços e tiras de plástico mole }}{\text { esgarçado, pedaço de arame, pedaço de vassoura de fibras plásticas, pedra }} \\
\mathrm{n}^{0} .2 \text {, tiras de borracha, matéria orgânica. }\end{array}$ \\
\hline $13: 45$ hs & - Parada para suplementação com trado de $6,00 \mathrm{~m}$ \\
\hline $13: 55$ hs & - Reinicio da perfuração \\
\hline $12,00-14,00$ & 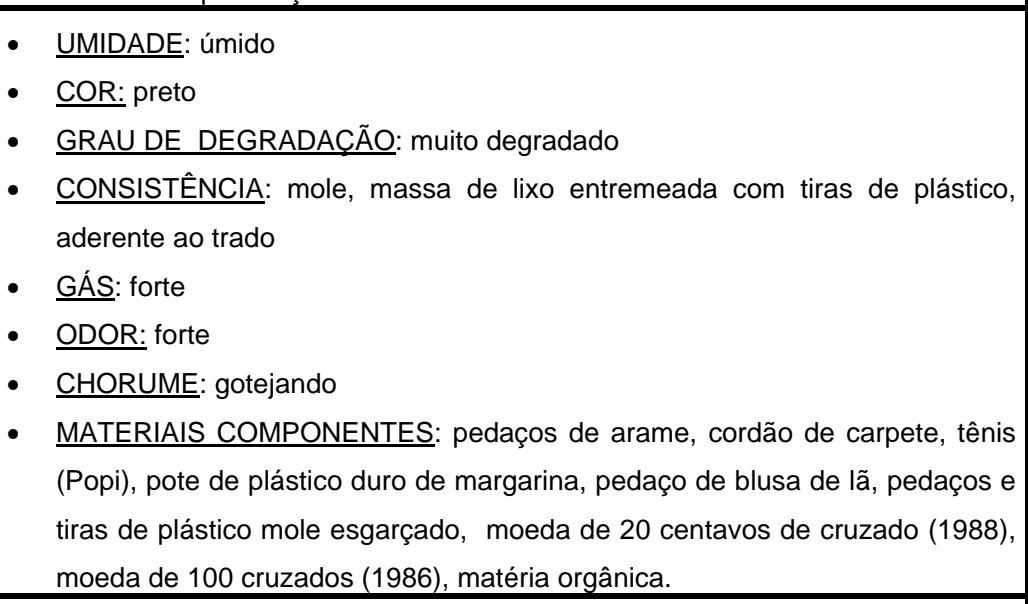 \\
\hline $14,00-15,00$ & $\begin{array}{l}\text { - } \text { UMIDADE: úmido, sem gotejamento } \\
\text { - } \text { GOR: cinza escuro } \\
\text { - } \text { CONSISTÊNCIA: mole, massa de lixo fibrosa, aderente ao trado, porém } \\
\text { destacando-se do trado com facilidade } \\
\text { - } \text { GÁS: muito forte } \\
\text { - } \frac{\text { ODOR: muito forte }}{\text { CHORUME: ausente }} \\
\text { - } \frac{\text { MATERIAIS COMPONENTES: pedaços e tiras de plástico mole esgarçado, }}{\text { pedaço de mangueira de plástico laranja, pedaço de cerâmica, pote de }} \\
\text { plástico duro de margarina, pedaço de metal (bom estado de conservação), } \\
\text { matéria orgânica. }\end{array}$ \\
\hline
\end{tabular}


Tabela 02 - TRADAGEM - FURO T2 (AS - 2) (continuacão)

\begin{tabular}{|c|c|}
\hline $\begin{array}{c}\text { TRECHO } \\
\text { PERFURADO (m) } \\
\text { E HORÁRIO (h) }\end{array}$ & $\begin{array}{c}\text { CLASSIFICAÇÃO DAS AMOSTRAS DE LIXO E } \\
\text { OBSERVAÇÕES } \\
\text { (continuação) }\end{array}$ \\
\hline $15,00-16,00$ & $\begin{array}{l}\text { - } \text { UMIDADE: mais seco } \\
\text { - } \text { GOR: cinza } \\
\text { - } \text { GRAU DE DEGRADAÇÃO: muito degradado } \\
\text { - } \frac{\text { GÁS: menos forte }}{\text { - ODOR: mais fraco }} \\
\text { - } \text { CHORUME: ausente } \\
\text { - } \text { MATERIAIS COMPONENTES: pedaços e tiras de plástico mole esgarçado, } \\
\text { vela de ignição de automóvel (Bosch W8AC), pedaço de calça de brim, pilha } \\
\text { média, cacos de vidro, pedaço de feltro, copinho de plástico duro de água, } \\
\text { pedaço de arame, pedaço de cerâmica de revestimento, saco de ráfia, } \\
\text { matéria orgânica } \\
\text { de } 15,50 \text { a } 16,00 \Rightarrow \text { selo de solo (silte) }\end{array}$ \\
\hline $16,00-18,00$ & 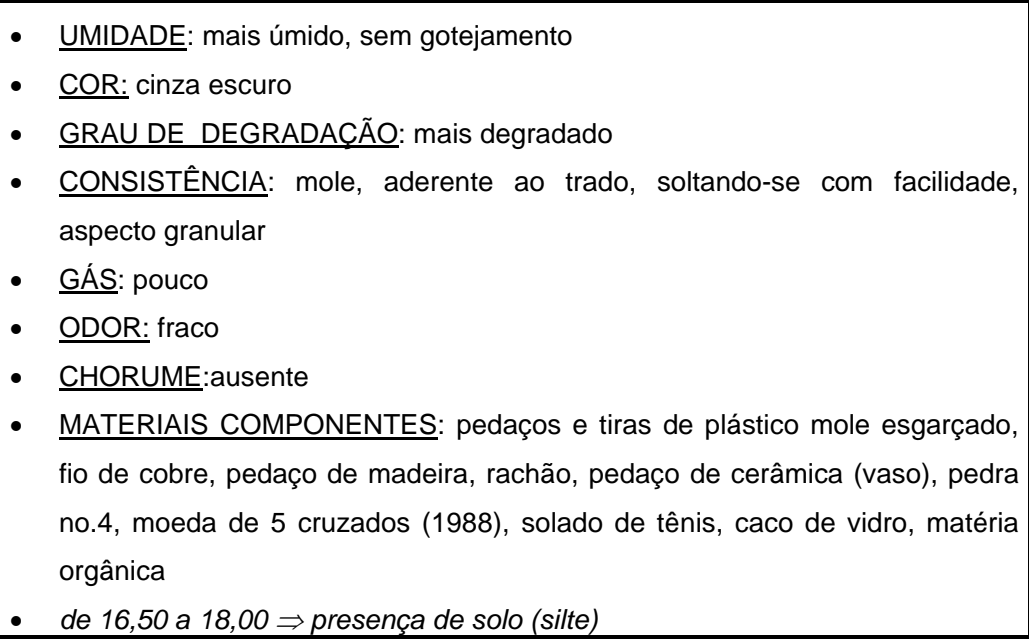 \\
\hline $18,00-20,00$ & $\begin{array}{l}\text { - UMIDADE: pouco úmido a seco } \\
\text { - } \text { COR: cinza } \\
\text { - } \text { GRAU DE DEGRADAÇÃO: muito degradado } \\
\text { - } \text { CONSISTÊNCIA: mole, aderente ao trado, após limpeza do trado apresenta } \\
\text { - } \text { GÁS: pouco } \\
\text { - } \text { ODOR: pouco } \\
\text { - } \frac{\text { CHORUME: ausente }}{\text { MATERIAIS COMPONENTES: pedaços de madeira, pedaços e tiras de }} \\
\text { plástico mole esgarçado, pedaços e tiras de tecido, tiras de elástico, tiras de } \\
\text { - têxtil, rachão, matéria orgânica } \\
\text { Na ponta do trado: pedaço de pneu Goodyear (bom estado de conservação) }\end{array}$ \\
\hline $20,00-22,00$ & $\begin{array}{l}\text { - UMIDADE: pouco úmido } \\
\text { - } \text { COR: cinza escuro } \\
\text { - } \text { GRAU DE DEGRADAÇÃO: muito degradado } \\
\text { - } \frac{\text { CONSISTÊNCIA: mole, aderente ao trado, após limpeza do trado apresenta }}{\text { aspecto granular }}\end{array}$ \\
\hline
\end{tabular}


Tabela 02 - TRADAGEM - FURO T2 (AS - 2) (continuação)

\begin{tabular}{|c|c|}
\hline $\begin{array}{l}\text { TRECHO } \\
\text { PERFURADO (m) } \\
\text { E HORÁRIO (h) }\end{array}$ & $\begin{array}{c}\text { CLASSIFICAÇÃO DAS AMOSTRAS DE LIXO E } \\
\text { OBSERVAÇÕES } \\
\text { (continuação) }\end{array}$ \\
\hline $20,00-22,00$ & $\begin{array}{l}\text { - } \text { - GÁS: médio } \\
\text { - } \text { ODOR: médio } \\
\text { - } \text { MATORUME: ausente } \\
\text { esgarçado, frasco de inseticida, rachão, pedaços de madeira, pote de } \\
\text { plástico duro de margarina, pedaços e tiras de plástico mole esgarçado, } \\
\text { matéria orgânica. }\end{array}$ \\
\hline $22,00-24,00$ & 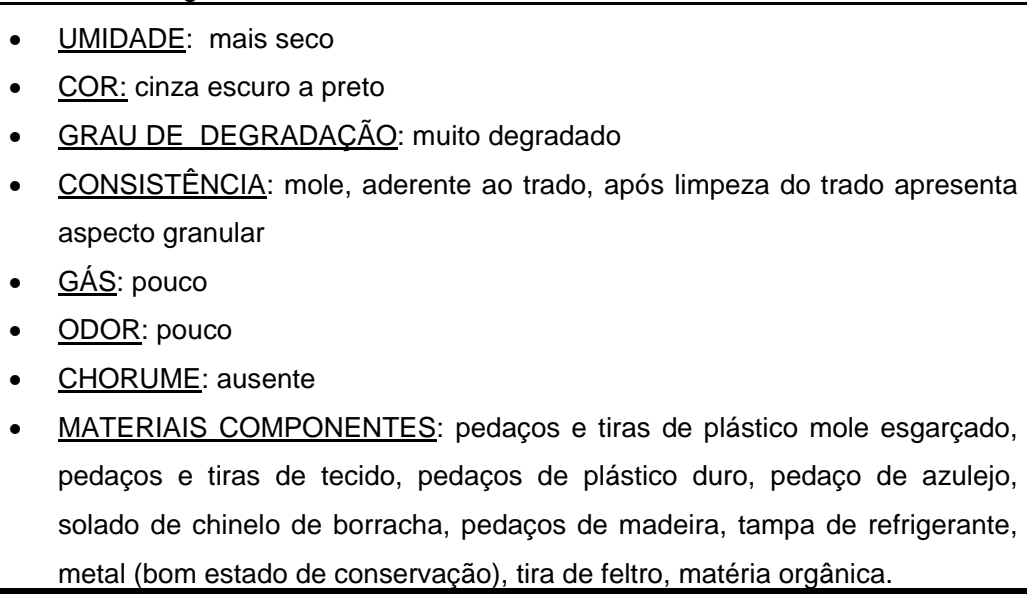 \\
\hline $24,00-27,00$ & 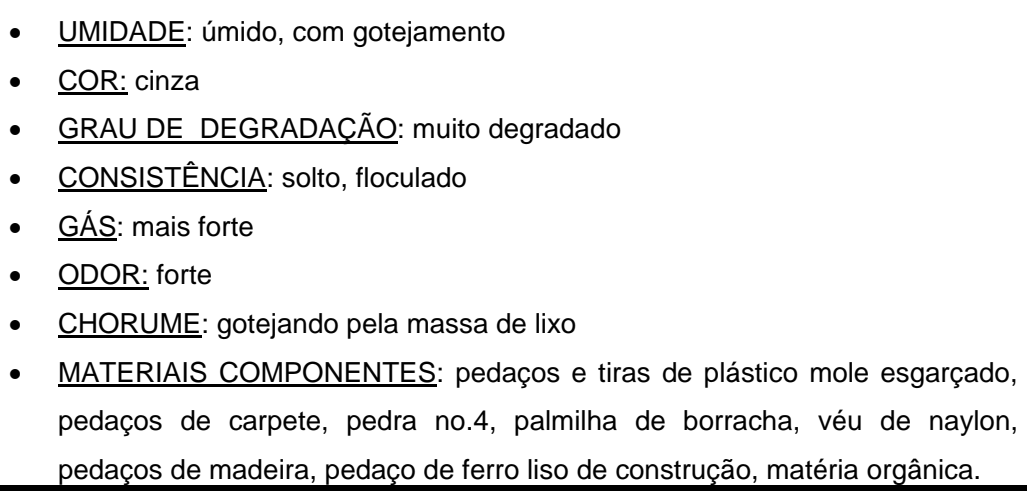 \\
\hline $27,00-30,00$ & 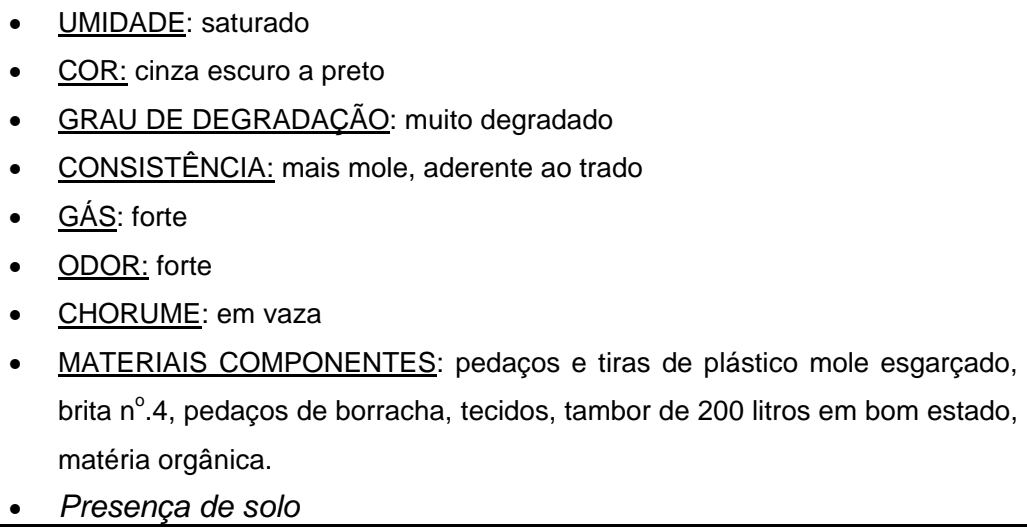 \\
\hline
\end{tabular}


Tabela 02 - TRADAGEM - FURO T2 (AS - 2) (continuacão)

\begin{tabular}{|c|c|}
\hline $\begin{array}{l}\text { TRECHO } \\
\text { PERFURADO (m) } \\
\text { E HORÁRIO (h) }\end{array}$ & $\begin{array}{c}\text { CLASSIFICAÇÃO DAS AMOSTRAS DE LIXO E } \\
\text { OBSERVAÇÕES } \\
\text { (continuação) }\end{array}$ \\
\hline $\begin{array}{l}\text { Obs: Não foi possível coletar } \\
\text { amostra (material em vaza) }\end{array}$ & $\begin{array}{l}\text { - } \text { UMIDADE: saturado } \\
\text { - } \text { COR: cinza escuro a preto } \\
\text { - } \text { GRAU DE DEGRADAČÃO: muito degradado } \\
\text { - } \text { GONSISTÊS: muito forte } \\
\text { - } \text { ODOR: muito forte } \\
\text { - } \text { CHORUME: escorrendo pela massa de lixo } \\
\text { - } \frac{\text { MATERIAIS COMPONENTES: tiras de plástico mole esgarçado, muita }}{\text { matéria orgânica. }} \\
\text { - Devido à presença de chorume em vaza a coleta das amostras fica } \\
\text { - } \text { prejudicada, decidindo-se terminar a tradagem } \\
32,00 \Rightarrow \text { Fim da perfuração }\end{array}$ \\
\hline
\end{tabular}

Tabela 03 - TRADAGEM - FURO T3 (AS - 2)

Data de execução: 10/07/1996 (quarta feira)

Condições do tempo: Nublado

\begin{tabular}{|c|l|}
\hline $\begin{array}{c}\text { TRECHO } \\
\text { PERFURADO (m) } \\
\text { E HORÁRIO (h) }\end{array}$ & \multicolumn{1}{|c|}{ CLASSIFICAÇÃO DAS AMOSTRAS DE LIXO E } \\
OBSERVAÇÕES
\end{tabular}


Tabela 03 - TRADAGEM - FURO T3 (AS - 2) (continuacão)

\begin{tabular}{|c|c|}
\hline $\begin{array}{c}\text { TRECHO } \\
\text { PERFURADO (m) } \\
\text { E HORÁRIO (h) }\end{array}$ & $\begin{array}{c}\text { CLASSIFICAÇÃO DAS AMOSTRAS DE LIXO E } \\
\text { OBSERVAÇÕES } \\
\text { (continuação) }\end{array}$ \\
\hline $10,00-19,00$ & $\begin{array}{l}\text { - MATERIAIS COMPONENTES: pedaços e tiras de tecido, pedaço de carpete, } \\
\text { pedaços e tiras de plástico mole esgarçado, tiras de ferro (sem oxidação), } \\
\text { solado de chinelo de borracha, solado de tênis, pedaços de madeira, tampa } \\
\text { de caneta, frasco de plástico de cândida, tampa plástica de pote de } \\
\text { margarina, moeda } 50 \text { cruzeiros (1984), matéria orgânica. }\end{array}$ \\
\hline $19,00-25,00$ & 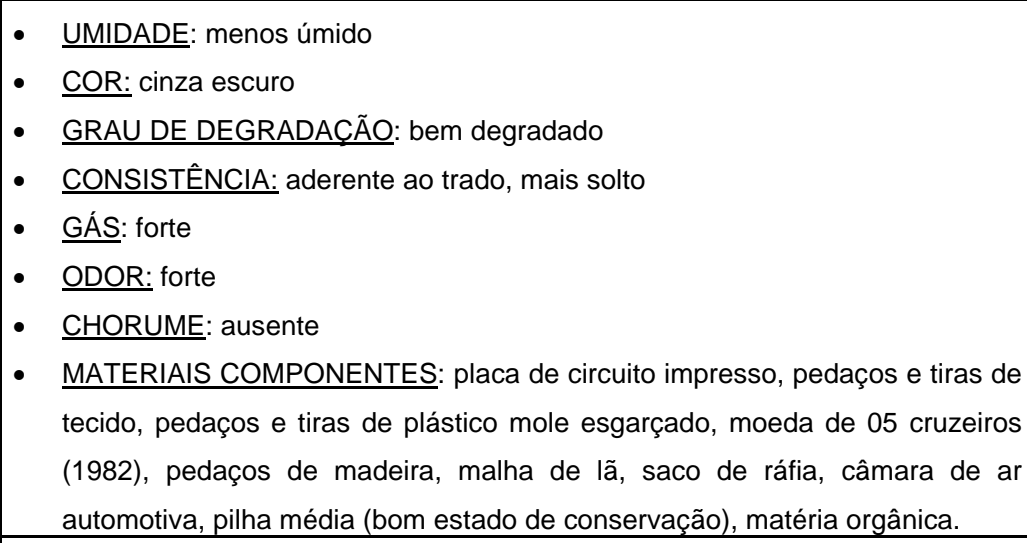 \\
\hline $12: 00$ hs & - Parada para almoço \\
\hline $13: 10 \mathrm{hs}$ & - Reinicio da perfuração \\
\hline $25,00-27,00$ & $\begin{array}{ll}\text { - } & \text { UMIDADE: mais úmido, com chorume em vaza }(26,00 \mathrm{~m}) \\
\text { - } & \text { COR: preto } \\
\text { - } & \text { GRAU DE DEGRADACCÃO: muito degradado } \\
\text { - } & \text { CONSISTÊNCIA: massa mais mole, aderente ao trado, muito mole } \\
\text { - GÁS: forte } \\
\text { - } \frac{\text { ODOR: forte }}{\text { - }} \\
\text { - } \frac{\text { CHORUME: em vaza }(26,00)}{\text { MATERIAIS COMPONENTES: tira plástica para amarração de embalagem }} \\
\text { industrial, tecidos (brim), pedaços de madeira, matéria orgânica. }\end{array}$ \\
\hline $27,00-30,50$ & $\begin{array}{l}\text { - Solo Natural } \\
\text {. } 30,50 \Rightarrow \text { Fim da perfuração }\end{array}$ \\
\hline
\end{tabular}




\section{Andamento do ensaio de compressão simples}

Este ensaio foi excetuado com a amostra T1B, na umidade natural e compactada com peso específico de $12 \mathrm{kN} / \mathrm{m}^{3}$ em corpo de prova de $150 \mathrm{~mm}$ de diâmetro. A velocidade de ruptura deste ensaio foi a mesma velocidade empregada nos ensaios triaxiais $(0,7 \mathrm{~mm} / \mathrm{min})$. As fotos a seguir ilustram o andamento do ensaio. Observar a alteração de área do corpo de prova durante o ensaio e inclinação do cabeçote de aplicação de carga.

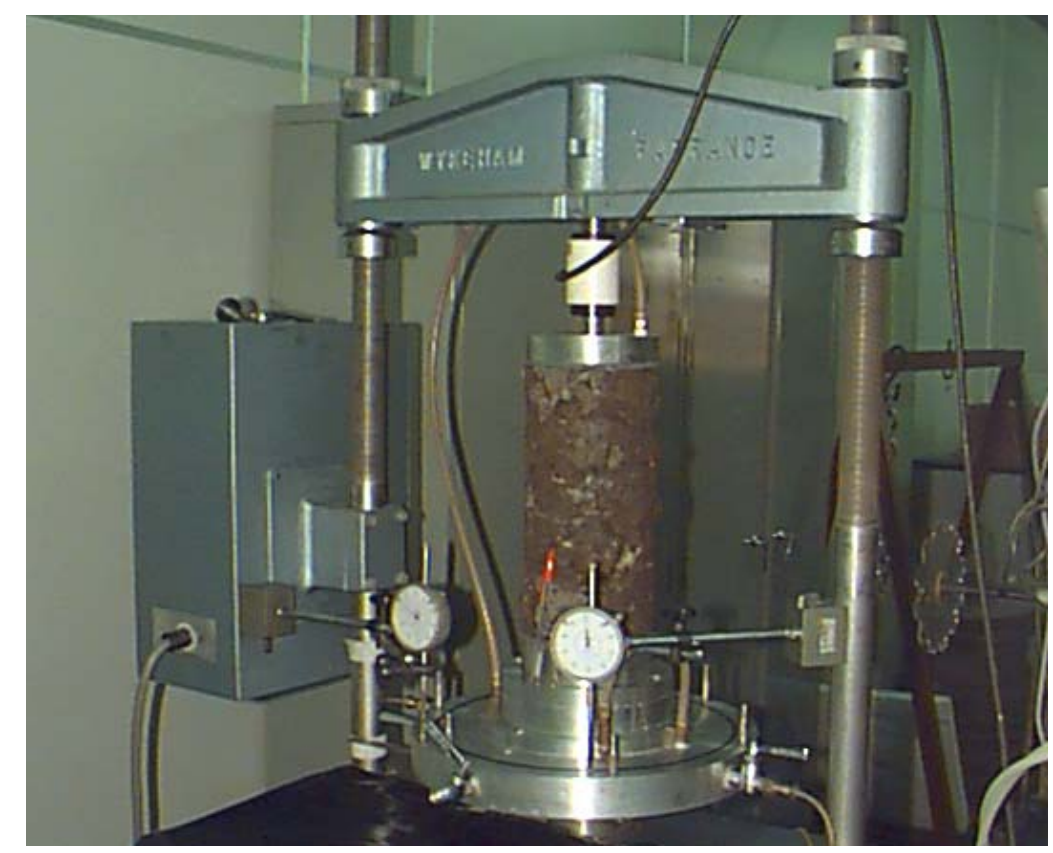

Figura 3a - Vista do corpo de prova da amostra T1B, com peso específico de $12 \mathrm{kN} / \mathrm{m}^{3}$ e umidade de $60,3 \%$, antes do início do ensaio de compressão sem confinamento.

A título de ilustração, este anexo também apresenta os círculos de Mohr e a envoltória de Mohr-Coulomb, para 20\% de deformação axial, obtidos para amostra T1B com diferentes pressões de confinamento $(25,100,200$ e $400 \mathrm{kPa})$ e sem confinamento (compressão simples). Obtiveram-se, para essa amostra, um valor de coesão de 29,6kPa e ângulo de atrito de $24^{\circ}$. 


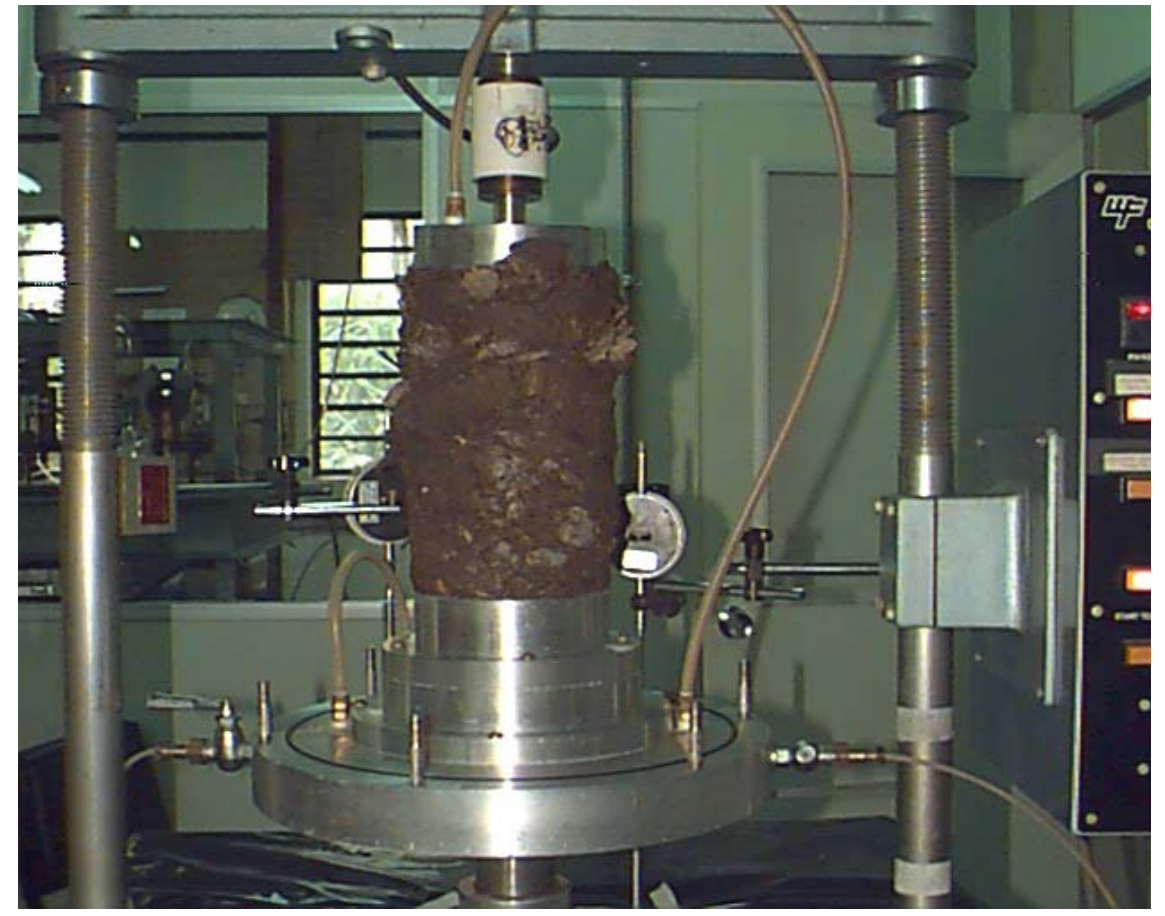

Figura 3b - Vista do corpo de prova da amostra T1B durante o ensaio.

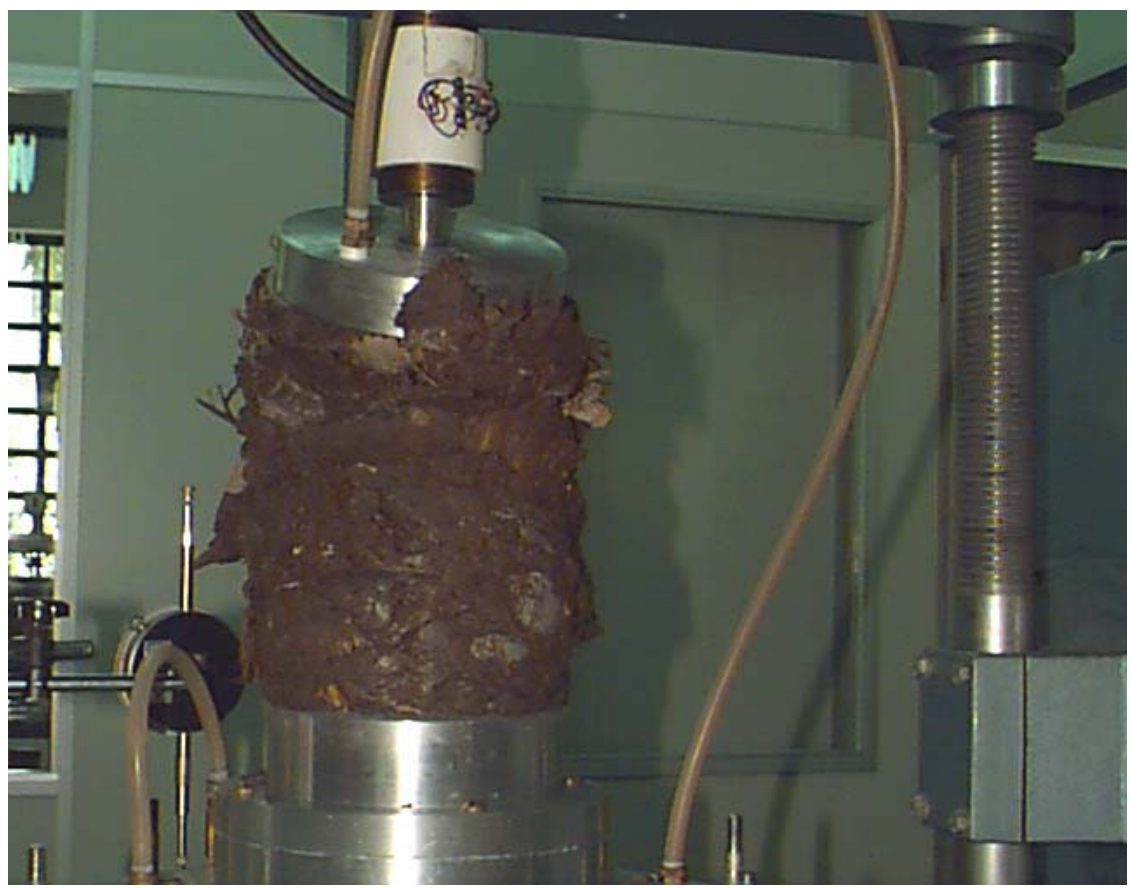

Figura 3c - Detalhe do corpo de prova no final do ensaio, aproximadamente $27 \%$ de deformação axial. 


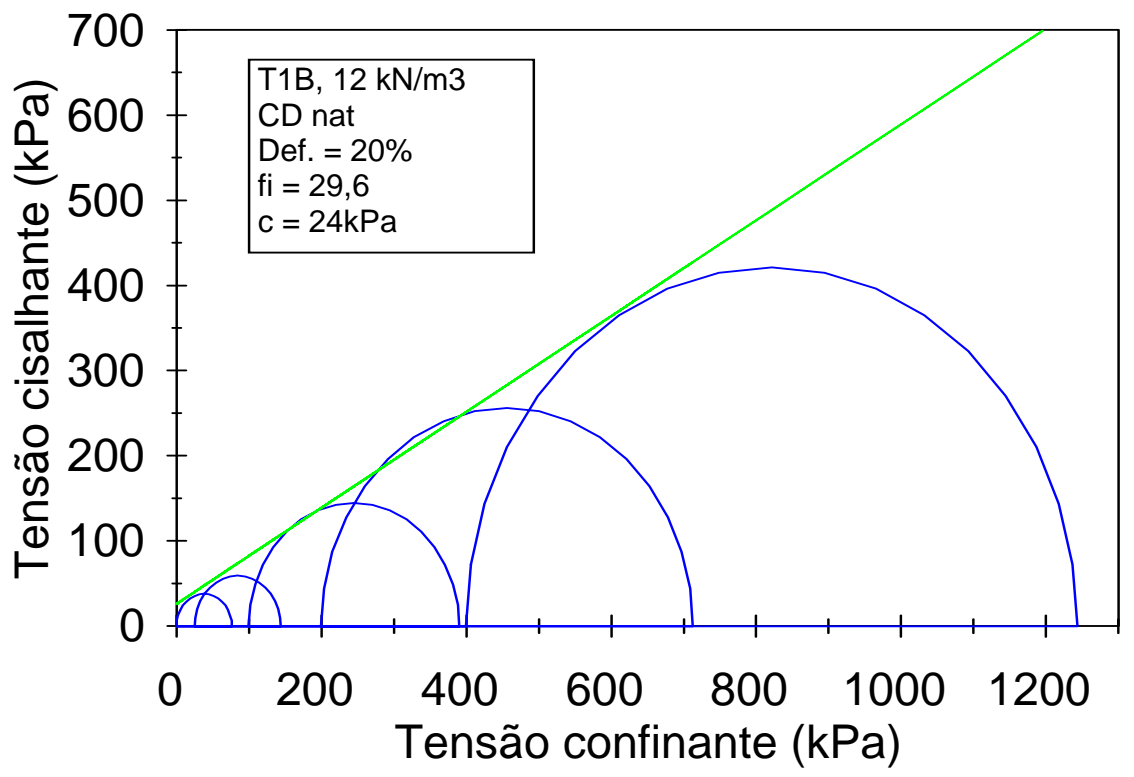

Figura 3d - Envoltória de resistência para $20 \%$ de deformação, obtida de ensaio $C D_{\text {nat }}$ para a amostra $T 1 B$ com $12 \mathrm{kN} / \mathrm{m}^{3}$ e na umidade de moldagem. 


\section{ANEXO 4}

\section{Comparação das resistências obtidas de ensaio $C D$, em corpos} de prova com 150mm de diâmetro e sob diferentes condições de ensaio

Os gráficos da Figura 4a apresentam, para várias deformações, as relações entre as resistências obtidas de ensaios $C D\left(s=c^{\prime}+\sigma^{\prime} \operatorname{tag} \phi\right)$, para os diversos corpos de prova da amostra T2A, compactados com pesos específicos de 10, 12 e $14 \mathrm{kN} / \mathrm{m}^{3}$. Tomou-se como base as resistências obtidas de corpos de prova compactados com $12 \mathrm{kN} / \mathrm{m}^{3}$ e ensaiados na umidade de moldagem. Assim, a figura 4a expressa as relações entre as resistências obtidas de ensaios executados com peso específico de 10 e $14 \mathrm{kN} / \mathrm{m}^{3}$, na umidade de moldagem e $12 \mathrm{kN} / \mathrm{m}^{3}$, na condição saturada, pelas resistências obtidas de ensaios com peso específico de $12 \mathrm{kN} / \mathrm{m}^{3}$ e na umidade de moldagem. Resultados semelhantes, obtidos para as amostras T2B e T1B, estão apresentados na Figura 4b.
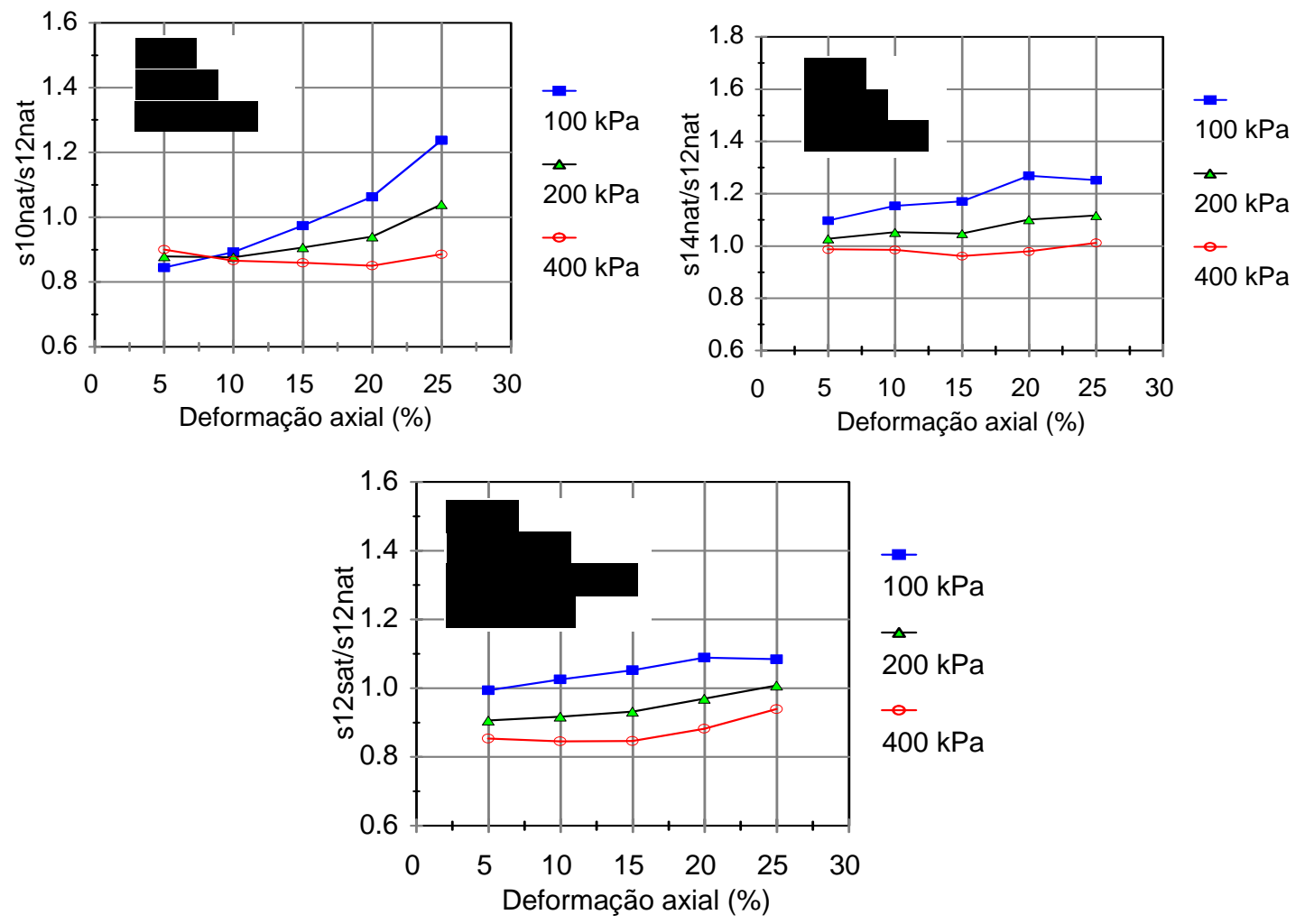

Figura $4 a$ - Relação entre as resistências obtidas de ensaios CD, com amostra T2A, na umidade natural e saturada, compactada com peso específico de 10, 12 e $14 \mathrm{kN} / \mathrm{m}^{3}$. 
As resistências foram calculadas considerando valores de tensões normais de 100, 200 e $400 \mathrm{kPa}$ e utilizando os parâmetros de resistência (c`e $\phi$ ') apresentados nas tabelas 5.1 e 5.2 (amostra T2A), 5.3 (amostra T1B), 5.4 (amostra T2B), as quais foram apresentadas no corpo da tese.

Nestes gráficos, pôde-se observar que as diferenças entre as resistências são relativamente reduzidas, tornando possível a junção dos resultados e obtenção de uma envoltória única, representativa para cada amostra ensaiada. A influência da saturação nos resultados parece, como já foi dito, mais uma questão de ajuste matemático, além disso vale lembrar que mesmo na umidade natural as amostras já apresentavam um grau de saturação (Sr) bem alto, acima de 55\%.
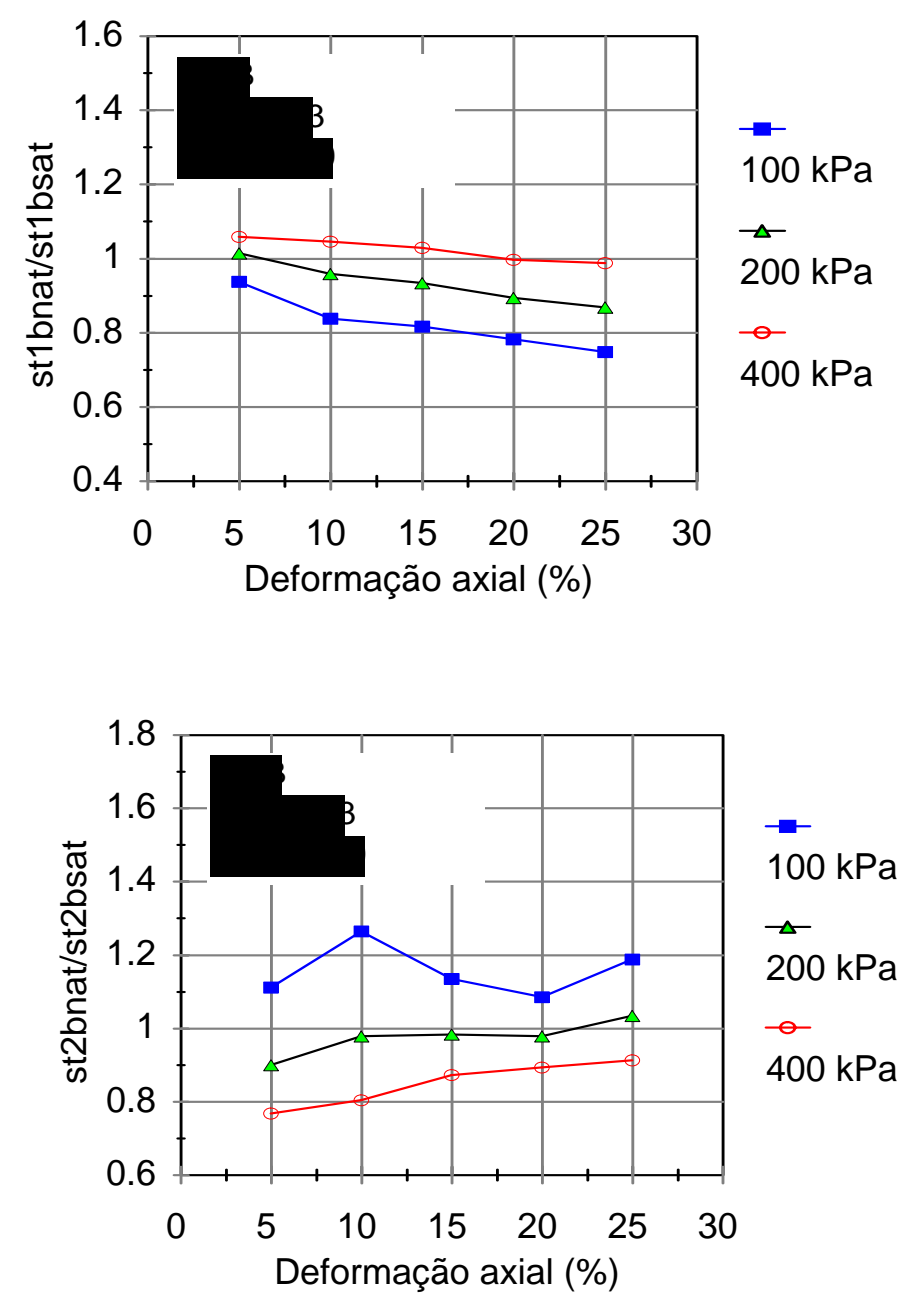

Figura 4a - Relação entre as resistências obtidas de ensaios CD com as amostras T1B e T2B, na umidade natural e saturada, compactadas com peso específico de $12 \mathrm{kN} / \mathrm{m}^{3}$. 
ANEXO 5

Comparação entre as envoltórias de resistência drenadas obtidas de ensaios em corpos de prova com $150 \mathrm{~mm}$ e $200 \mathrm{~mm}$ de diâmetro

As Figuras $5 a$ e $5 b$ apresentam uma comparação entre as envoltórias de resistência drenadas, num diagrama t-s', para 20\% de deformação axial, obtidas de ensaios consolidados drenados, utilizando corpos de prova de 150 e $200 \mathrm{~mm}$ de diâmetro. Pode-se observar que existe uma tendência de variação nas resistências obtidas quando se consideram dimensões diferentes de corpos de prova.
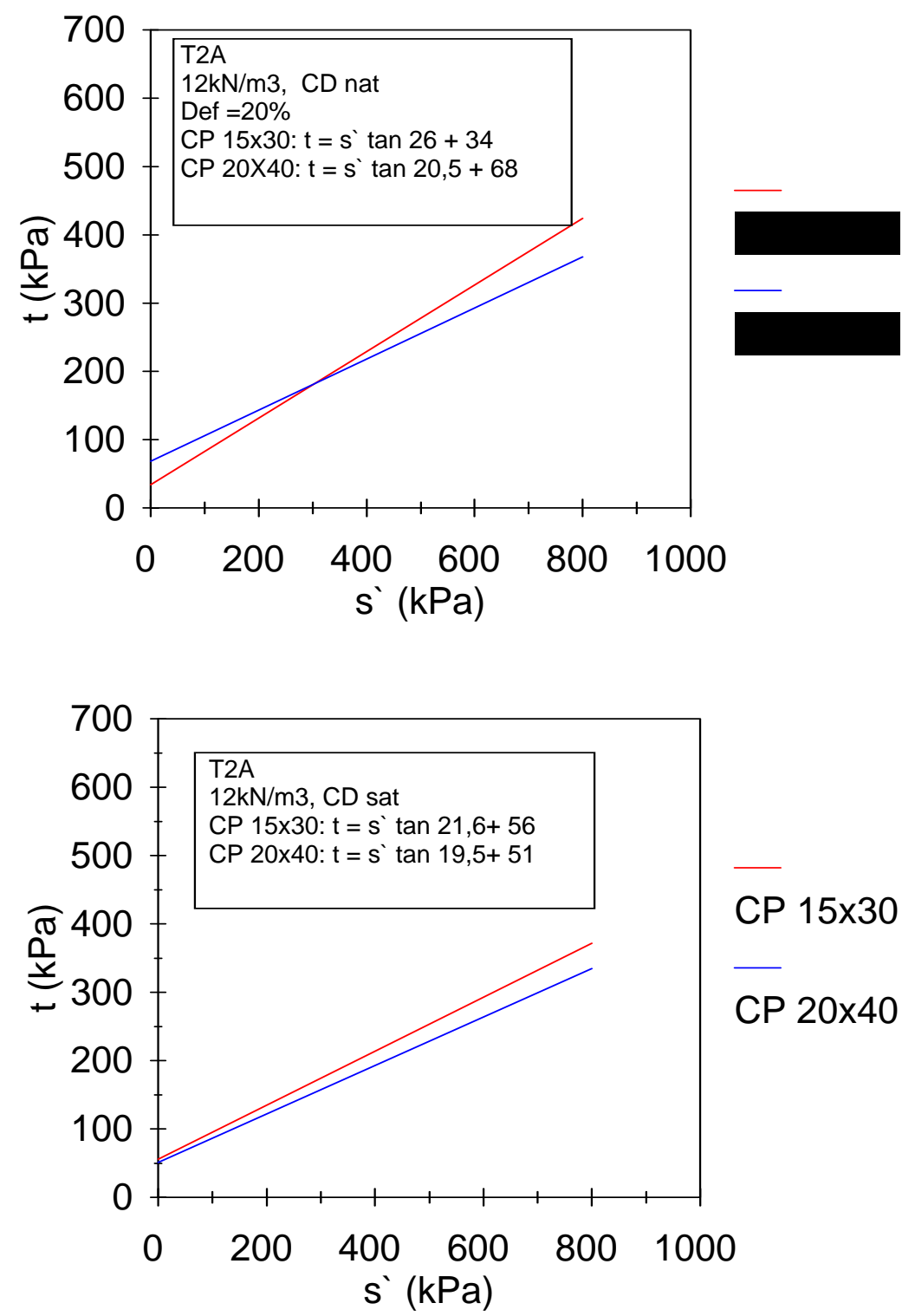

Figura 5a - Comparação das envoltórias de resistência, para $20 \%$ de deformação axial, obtidas de ensaios $C D$ com amostra $T 2 A$, saturada e na umidade natural e compactada com peso específico de $12 \mathrm{kN} / \mathrm{m}^{3}$. 
O acréscimo de resistência ao cisalhamento obtida por meio de ensaios com corpos de prova de menor dimensão $(15 \times 30)$ pode, em parte, ser creditada à heterogeneidade das amostras, mas acredita-se que o efeito reforço, dado pelos materiais fibrosos, desempenha um papel importante nesse comportamento.
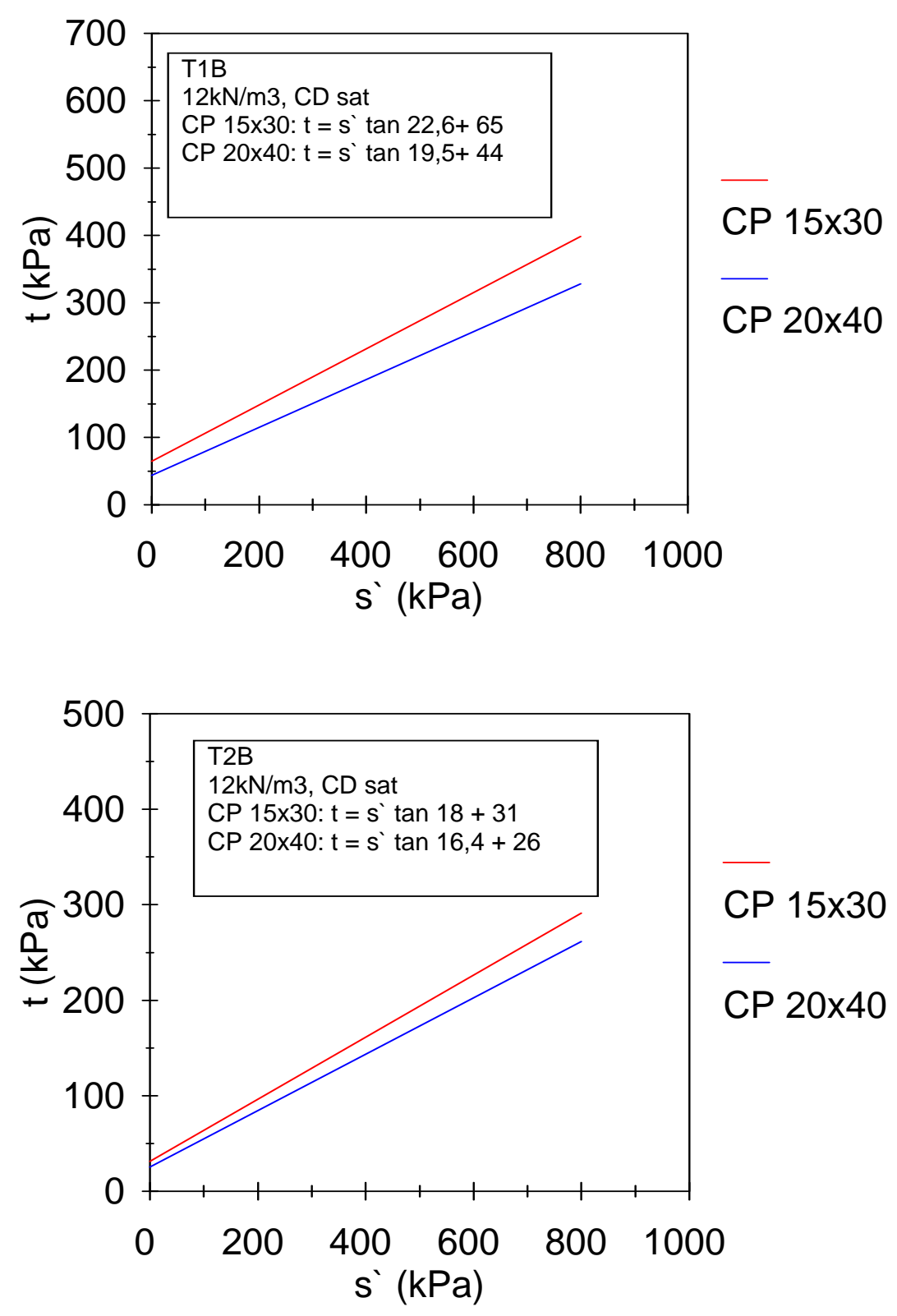

Figura $5 b$ - Comparação das envoltórias de resistência, para $20 \%$ de deformação axial, obtidas de ensaios $C D$, com as amostras T1B e T2B, compactadas com peso específico de $12 \mathrm{kN} / \mathrm{m}^{3}$ e saturadas. 


\section{Envoltória de ruptura, num espaço $\sigma_{1} \times \sigma_{3}$, obtida para o lixo} estudado

Na figura 6a foram plotados os valores de tensão de ruptura máxima $\left(\sigma_{1 r}\right)$ em função da tensão confinante $\left(\sigma_{3}\right)$ para a amostra T1B, ensaiada com peso específico de $12 \mathrm{kN} / \mathrm{m}^{3}$. Esse tipo de representação permite a determinação da tensão de confinamento crítica, correspondente a mudança de inclinação da envoltória de ruptura obtida para materiais reforçados. Sob tensões de confinamento menores que a tensão crítica, as fibras tendem a deslizar durante a deformação e a ação do reforço induz apenas um aumento do ângulo de atrito. Sob tensões maiores do que a tensão crítica, as fibras encontram-se fortemente presas à massa de solo (TEODORO \& BUENO, 1998) predominando a quebra das fibras sobre o deslizamento. Este efeito induz uma pseudo-coesão ao material sem qualquer variação do ângulo de atrito, associadas às fibras que quebram há também aquelas que apenas se estendem ou sofrem deformações plásticas de grande magnitude. Observa-se que o lixo estudado não apresenta, como a maioria dos solos reforçados, uma envoltória de ruptura significativamente bilinear. Isso possivelmente deve-se ao fato do lixo apresentar material de reforço constituído por diferentes tamanhos e propriedades tensão-deformação, dificultando a definição da tensão de confinamento crítica. Da figura 6a, pode-se verificar que a envoltória obtida para o lixo estudado parece tender a bilinearidade, apresentando uma provável tensão de confinamento crítica em torno de 150kPa.

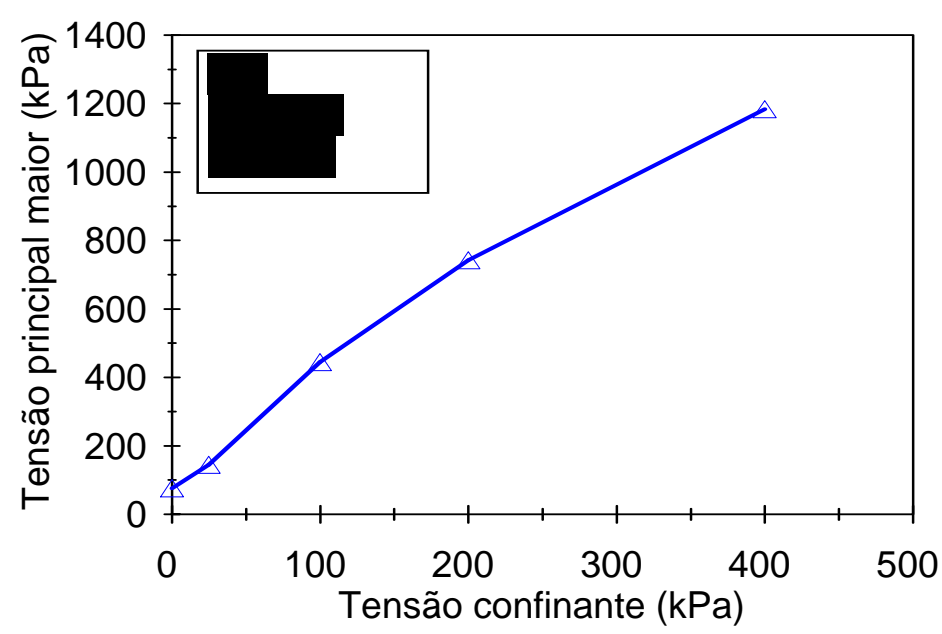

Figura 6a - Envoltória de ruptura para o lixo estudado 
ANEXO 7

Comparação entre as envoltórias de resistência drenada e não drenada, obtidas de amostras de lixo compactadas com $12 \mathrm{kN} / \mathrm{m}^{3}$

Nas Figuras 7a a 7c apresentam-se gráficos de comparação entre as envoltórias de resistência efetiva drenada e não drenada, para 20\% de deformação axial, num diagrama t$\mathrm{s}^{\prime}$, obtidos para as amostras T2A, T1B e T2B, compactadas com peso específico de 12 $\mathrm{kN} / \mathrm{m}^{3}$ e ensaiadas na umidade natural e saturada.
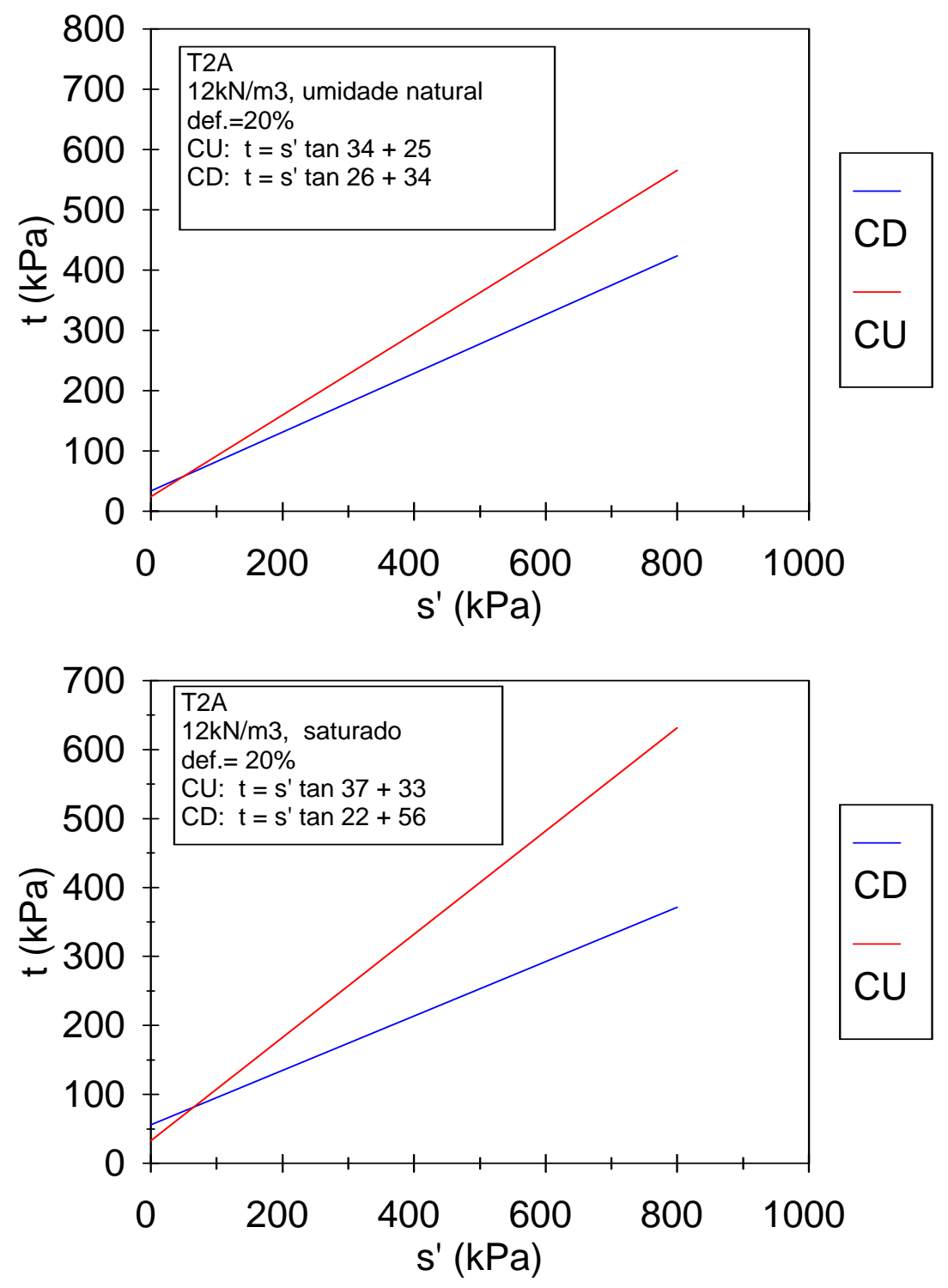

Figura $7 a$ - Envoltórias de resistência num diagrama t-s' obtidas de ensaios não drenados (CU) e drenados (CD), para amostra T2A, na umidade natural e saturada, compactada com peso específico de $12 \mathrm{kN} / \mathrm{m}^{3}$, em corpos de prova de $150 \mathrm{~mm}$ de diâmetro e $300 \mathrm{~mm}$ de altura. 


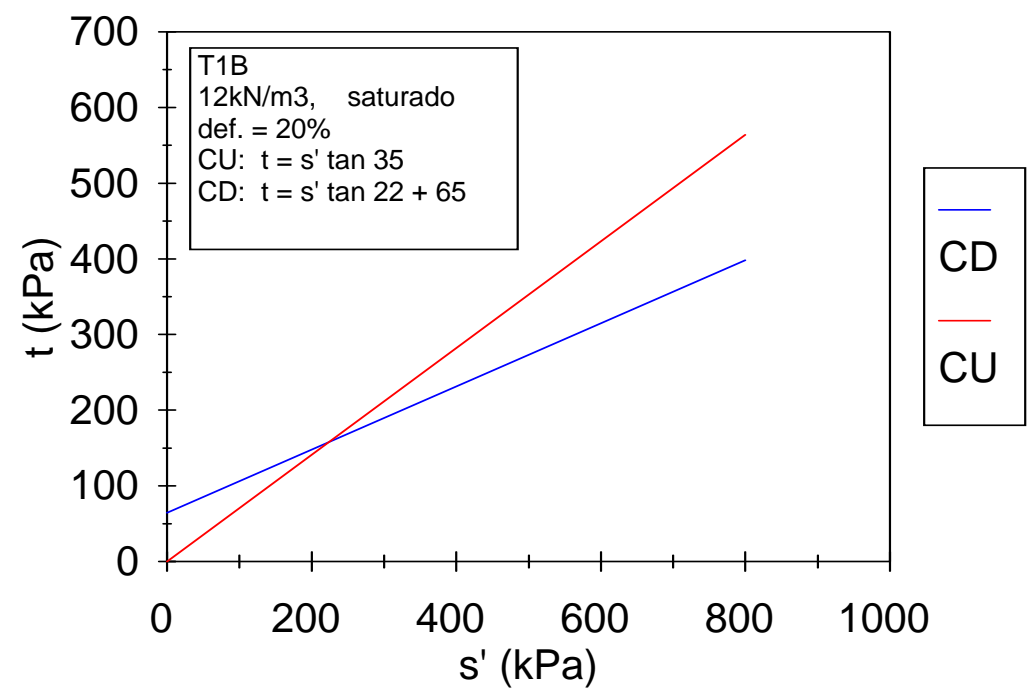

Figura $7 b$ - Envoltórias de resistência num diagrama $t$-s' obtidas de ensaios não drenados (CU) e drenados (CD), para amostra T1B, saturada, compactada com peso específico de $12 \mathrm{kN} / \mathrm{m}^{3}$, em corpos de prova de $150 \mathrm{~mm}$ de diâmetro e $300 \mathrm{~mm}$ de altura.

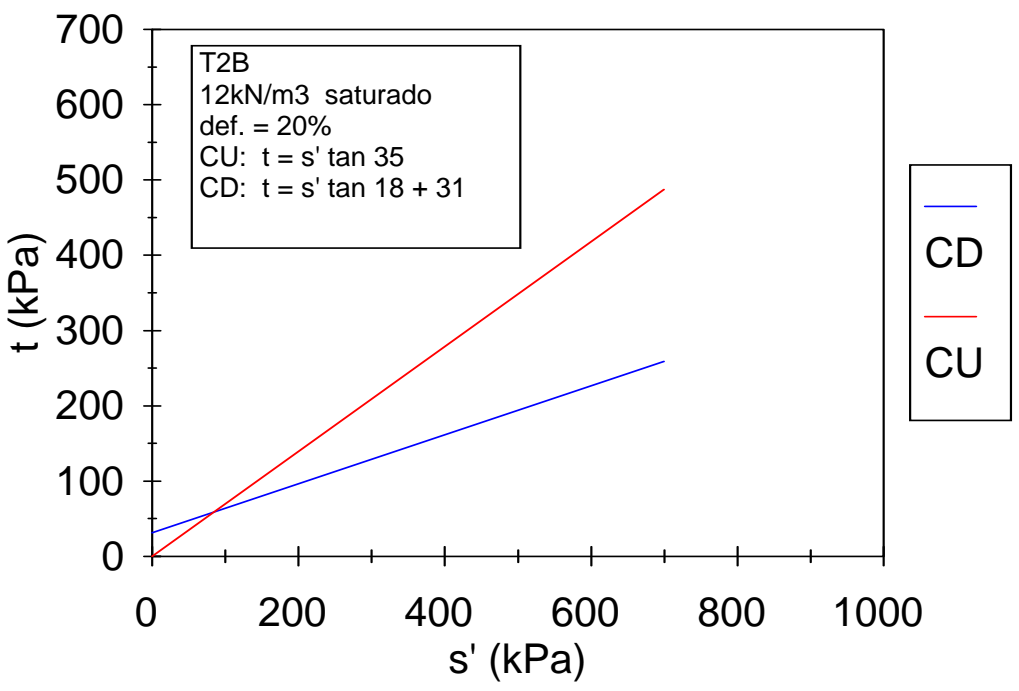

Figura 7c - Envoltória de resistência num diagrama t-s' obtidas de ensaios não drenados (CU) e drenados (CD), para amostra T2B, saturada, compactada com peso específico de $12 \mathrm{kN} / \mathrm{m}^{3}$, em corpos de prova de $150 \mathrm{~mm}$ de diâmetro e $300 \mathrm{~mm}$ de altura.

Para traçar as envoltórias drenadas da amostra T2A utilizaram-se, para os ensaios executados na umidade natural, os resultados obtidos para a amostra T2a12nat (Tabela 5.1) e para ensaios na condição saturada, os da amostra T2a12sat (Tabela 5.2). Para a amostra T1B, a envoltória de resistência drenada foi traçada utilizando os resultados obtidos da amostra T1b12sat (Tabela 5.3) e para amostra T2B, os obtidos da série T2b12sat (Tabela 5.4). Já para a resistências não drenadas os dados utilizados, para as três amostras, estão apresentados na Tabela 5.7. 